\title{
PAMIĘĆ LAT NAZIZMU W NIEMIECKIM FILMIE FABULARNYM LAT 1946-1965
}




\section{REDAKCJA SERII WYDAWNICZEJ \\ „FILMO!ZNAWCY”}

PWSFTviT

prof. dr hab. Jolanta Dylewska (współprzewodnicząca Komitetu Redakcyjnego)

dr Piotr Mikucki, dr Anna Zarychta

\section{UNIWERSYTET ŁÓDZKI}

prof. zw. dr hab. Ryszard W. Kluszczyński (współprzewodniczący Komitetu Redakcyjnego) prof. dr hab. Tomasz Kłys, prof. dr hab. Piotr Sitarski

\section{Szkoła Filmowa w Łodzi}

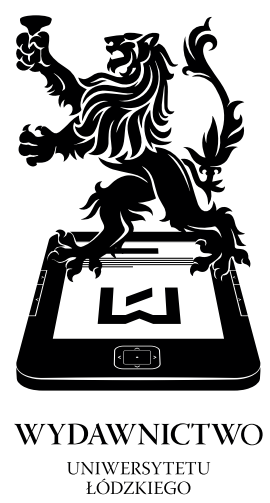


KonRAD KLEJSA

\section{PAMIĘĆ LAT NAZIZMU W NIEMIECKIM FILMIE FABULARNYM LAT 1946-1965}

FILMO!ZNAWCY

Państwowa Wyższa Szkoła Filmowa, Telewizyjna i Teatralna im. Leona Schillera w todzi
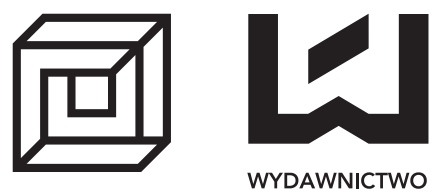

Łódź 2015 
Konrad Klejsa - Uniwersytet Łódzki, Wydział Filologiczny

Katedra Mediów i Kultury Audiowizualnej, Zakład Historii i Teorii Filmu 90-236 Łódź, ul. Pomorska nr 171/173

\author{
RECENZENT \\ Ewelina Nurczyńska-Fidelska \\ REDAKTOR INICJUJĄCY \\ Urszula Dzieciatkowska
}

REDAKTOR WYDAWNICTWA UŁ

Katarzyna Gorzkowska

SKŁAD I ŁAMANIE

Oficyna Wydawnicza Edytor.org

Lidia Ciecierska

\title{
PRZYGOTOWANIE KADRÓW FILMOWYCH
}

Mikołaj Zacharow

\section{PROJEKT OKŁADKI \\ Adrian Dutkowski}

Na okładce wykorzystano kadr z filmu
Przygody Wernera Holta (reż. Joachim Kunert, NRD 1965)

Publikacja powstała w ramach grantu Narodowego Centrum Nauki

przyznanego na podstawie decyzji nr 4298/B/H03/2011/40

(C) Copyright by Uniwersytet Łódzki, Łódź 2015

CC Copyright for this edition by Wydawnictwo Biblioteki PWSFTviT, Łódź 2015

Wydane przez Wydawnictwo Uniwersytetu Łódzkiego

i Wydawnictwo Biblioteki PWSFTviT

Wydanie I. W.06773.14.0.M

Ark. wyd. 27,0; ark. druk. 26,125

Wydawnictwo Uniwersytetu Łódzkiego: ISBN 978-83-7969-559-1

e-ISBN 978-83-7969-560-7

Wydawnictwo Biblioteki PWSFTviT: ISBN 978-83-87870-93-5 


\section{Spis treści}

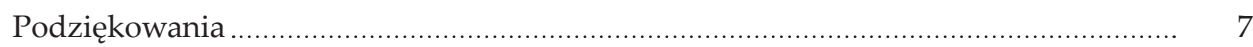

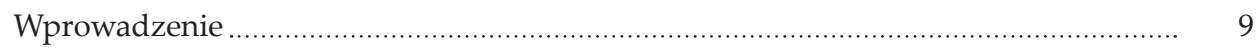

Rozdział I. Okres 1945-1949: kino doby denazyfikacji w strefach okupowanych

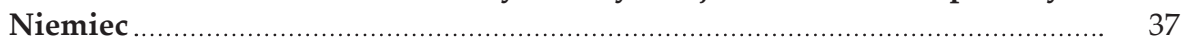

1.1. Mordercy sq wśród nas: traumy pośród ruin ..................................................... 60

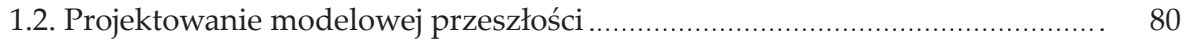

1.3. W kostiumie melodramatu .............................................................................. 87

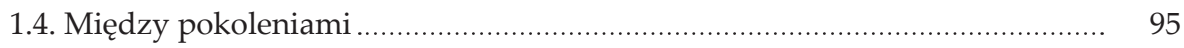

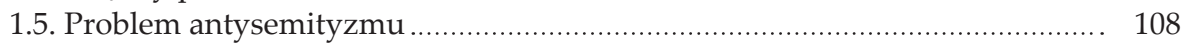

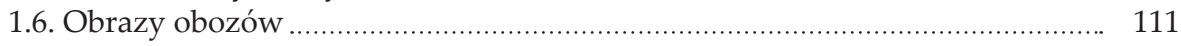

Rozdział II. Kino Niemieckiej Republiki Demokratycznej do 1965 roku: antyfaszyzm jako doktryna .............................................................................. 123

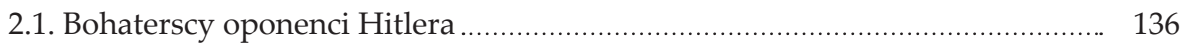

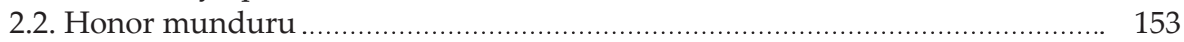

2.3. Nowi sojusznicy: ZSRR ............................................................................... 166

2.4. Wróg zewnętrzny: mordercy są wśród nich ............................................ 171

2.5. Kraj po denazyfikacji: NRD jako alternatywa ................................................. 183

2.6. Problem antysemityzmu ........................................................................... 192

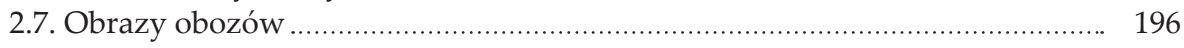

Rozdział III. Kino Republiki Federalnej Niemiec do 1965 roku: przemilczenia

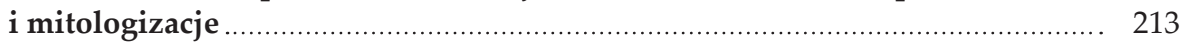

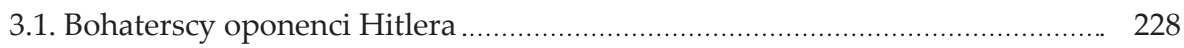

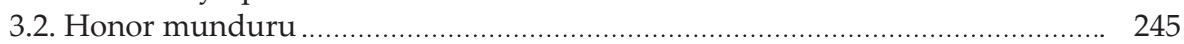

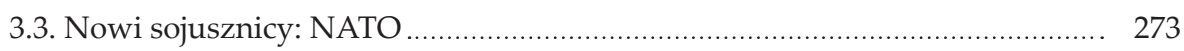

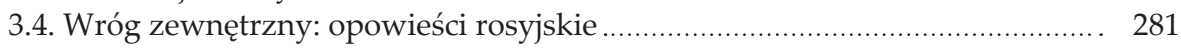

3.5. Kraj po denazyfikacji: mordercy (nadal) są wśród nas ................................ 289

3.6. Problem antysemityzmu ........................................................................... $\quad 310$

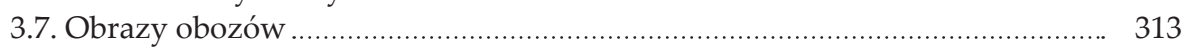

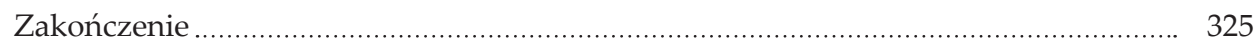

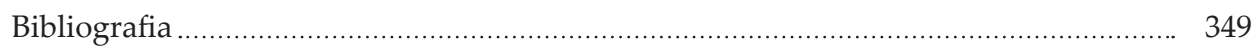


Filmografia . 383

Indeks filmów 389

Indeks osób 401

Summary 415

O autorze 417 


\section{Podziękowania}

Pragnę serdecznie podziękować wszystkim osobom i instytucjom, które zechciały wesprzeć mnie w trudach powstawania niniejszej książki.

Dziękuję za wsparcie Narodowego Centrum Nauki, które umożliwiło mi dwukrotną kwerendę w bibliotece i archiwach Deutsches Filminstitut we Frankfurcie nad Menem. W buszowaniu po bogatych zbiorach tej placówki asystował mi jej kompetentny zespół, któremu pragnę wyrazić wdzięczność za udzieloną pomoc.

W zmaganiach dotyczących enerdowskiego kina asystowali mi pracownicy archiwum łódzkiej Szkoły Filmowej oraz Muzeum Kinematografii, natomiast poszukiwania trudno dostępnych filmów erefenowskich ułatwił mi Pan Rudy Boigs. Interesujące materiały pozyskałem również za pośrednictwem Pana Christiana Nastala oraz dr Magdaleny Saryusz-Wolskiej - do wszystkich tych osób kieruję podziękowania.

Za cenne uwagi, które pozwoliły mi uniknąć wielu błędów w ostatecznej wersji pracy jestem wdzięczny dr Magdalenie Saryusz-Wolskiej oraz prof. Tomaszowi Kłysowi i prof. Tomaszowi Majewskiemu. Inspirujące były dla mnie również pytania zadawane podczas monograficznego konwersatorium Pamięć lat nazizmu w kinie niemieckim, które przeprowadziłem ze studentami Uniwersytetu Łódzkiego w 2014 r. Fakt, że książka ujrzy światło dzienne zawdzięczam też zaangażowaniu pracowników Wydawnictwa Uniwersytetu Łódzkiego, w tym Pani redaktor Katarzyny Gorzkowskiej.

Słowa szczególnej wdzięczności kieruję pod adresem mojej Żony, która przez kilka lat nie tylko cierpliwie znosiła momenty zniechęcenia, jakie towarzyszyły mi przy pisaniu oraz tolerowała $\mathrm{w}$ naszym domu sterty filmów DVD z okładkami upstrzonymi totalitarnymi regaliami, lecz także słowem i czynem wspierała mnie na każdym etapie powstawania tej publikacji. 



\section{Wprowadzenie}

„Można odnieść wrażenie, że niemiecka pamięć jest jak olbrzymi język, poszukujący chorego zęba" - pisał poetycko Ian Buruma w książce porównującej pamięć II wojny światowej w Niemczech i Japonii ${ }^{1}$. Gdyby odnieść to zestawienie do czasów współczesnych, wspomniane poszukiwania miałyby najpewniej charakter bólu fantomowego - odczuwanego bez faktycznej przyczyny, prawem masochistycznego przyzwyczajenia bądź prewencyjnej kontroli. Jeśli jednak wzięlibyśmy pod uwagę tytuł niniejszej książki, ograniczający ramę czasową do lat 1946-1965, sytuacja byłaby inna: będzie bowiem mowa o okresie, w którym III Rzesza wydarzyła się nieledwie „wczoraj”.

Uniwersyteckie kursy i podręczniki akademickie dotyczące historii filmu niemieckiego koncentrują się zazwyczaj na Republice Weimarskiej i III Rzeszy, a następnie na tzw. Nowym Kinie Niemieckim lat 70. Z kolei filmy z Niemieckiej Republiki Demokratycznej - w okresie PRL od czasu do czasu prezentowane w kinie i w telewizji - po $1990 \mathrm{r}$. nie były w Polsce szczególnie chętnie przypominane. I choć trudno mówić o „białej plamie” w badaniach niemieckiej kultury filmowej, okres od zakończenia II wojny światowej do połowy lat 60 . niewątpliwie był do niedawna traktowany po macoszemu. A szkoda, bowiem zaowocował on wieloma fascynującymi filmami - często wtórnymi pod względem ich formalnego ukształtowania, ale intrygującymi z wielu innych powodów, które mam nadzieję naświetlić w niniejszej książce.

\section{Przedmiot pracy - ramy geograficzne i tematyczne}

Przedmiotem mojego zainteresowania będą niemieckie filmy fabularne zrealizowane w latach 1946-1949 w centrach produkcyjnych mieszczących się w różnych strefach okupacyjnych, a także filmy mające swe

\footnotetext{
${ }^{1}$ Ian Buruma, Wages of Guilt: Memories of War in Germany and Japan, London 1995, s. 136 .
} 
premiery w latach 1950-1965 - w obu państwach niemieckich (Niemieckiej Republice Demokratycznej i Republice Federalnej Niemiec). Cezura 1949/1950 jest siłą rzeczy płynna: do pierwszego okresu zaliczam też filmy, które weszły na ekrany kin w II połowie 1949 r., ale już po proklamowaniu osobnych republik (we wrześniu - RFN, w październiku - NRD); decyzja ta wynika z faktu, iż prace preprodukcyjne tych filmów rozpoczęły się jeszcze w strefach okupacyjnych. W rozdziale dotyczącym pierwszych lat powojennych rozróżniam jedynie filmy strefy wschodniej (powstałe w wytwórni Defa - Deutsche Film Aktiengesellschaft) oraz zachodniej - bez wskazania, czy chodziło o strefę amerykańska, brytyjską czy francuską (zreszta, od stycznia 1947 r. dwie pierwsze połączyły się w tzw. Bizonię, do której następnie dołączyła strefa francuska, tworząc Trizonię, zalążek późniejszej RFN).

Podobnie jak autorzy innych publikacji poświęconych kinematografiom narodowym, stoję przed koniecznością wyjaśnienia, jakie fenomeny można włączyć w zbiór określany terminem „kino niemieckie” (i analogicznie: „zachodnioniemieckie” i „wschodnioniemieckie”). Kryterium językowe jest, siłą rzeczy, chybione (z uwagi na nieuwzględniane w pracy kino austriackie i szwajcarskie); niezbyt fortunny byłby także klucz „autorski” - zważywszy, że część twórców realizowała filmy w innych krajach. Za najbardziej zasadne uznaję znaczniki instytucjonalne, tj. akcentujące rolę firmy produkcyjnej - co oznacza, iż nie piszę na przykład o nakręconych w Austrii dwóch, skądinąd interesujących, filmach Georga Wilhelma Pabsta - Pojedynku ze śmiercia (Duel mit dem Tod, reż. Paul May, 1949) i Ostatnim akcie (Der letzte Akt, 1955) czy Ostatnim moście (Die letzte Brücke, Austria-Jugosławia 1953) Helmuta Käutnera.

$\mathrm{Z}$ obszaru mego zainteresowania nie wykluczam natomiast koprodukcji. Tradycyjnie sprawiają one nieco problemów autorom piszącym o kinematografiach narodowych - niekiedy z uwagi na trudną dostępność (związaną z nie zawsze klarownym stanem prawnym dotyczącym praw autorskich producentów i dystrybutorów), ale także ze względu na fakt, iż historycy kina często ignorują "koprodukcyjny” charakter filmu, zaliczając daną produkcję wyłącznie do jednej ze współdziałających kinematografii. W odniesieniu do tematu mej pracy jako przykład można wskazać choćby film Roberta Rosselliniego Niemcy, rok zerowy (Germania, anno zero, 1948) - choć był on formalnie koprodukcją włosko-niemiecką i został zrealizowany nad Szprewą, często uchodzi za film włoski (do czego zapewne przyczyniła się opóźniona o trzy lata niemiecka premiera oraz jego słaba recepcja w Niemczech). Bywa zresztą i odwrotnie - realizacje, które formalnie nie były koprodukcjami, postrzegane są w ten właśnie sposób; tu z kolei można wymienić finansowaną w całości przez hollywoodzkie 
studio produkcję Douglasa Sirka Czas miłości i czas śmierci (A Time to Love and a Time to Die, 1958) - film powstały na podstawie prozy Ericha Marii Remarque'a, nakręcony w RFN z niemiecką obsadą i podejmujący "niemiecką" tematykę.

Termin „film fabularny”, użyty w tytule książki, sygnalizuje główny przedmiot mego zainteresowania - ale nie jest wcale tak oczywisty, jak przyjęło się sądzić. Po pierwsze, należy pamiętać, że "film fabularny" to pojęcie potoczne, niekoniecznie ścisłe w sensie logicznym. Bardziej poprawne wydają się terminy obcojęzyczne, wyróżniane zresztą według różnych kryteriów: angielski fiction film (film fikcjonalny) i niemiecki Spielfilm (film aktorski). Po drugie, rodzajowa specyfika komunikatu filmowego bywa niekiedy trudna do ustalenia - zwłaszcza we współczesnej kulturze audiowizualnej różnica pomiędzy "dokumentem" a „fabułą” często ulega zatarciu. Niemniej jednak, sensowne podejmowanie tematyki „film i historia" - oczywiście, jeśli myślimy o niej nie w kategoriach związku rządu („historia filmu”), lecz zgody („film historyczny”) lub przynależności („historia w filmie”) - wymaga niuansowania pomiędzy formami dokumentalnymi, ",czystą fikcją" osadzoną jedynie w realiach historycznych oraz rozmaitymi wariantami „fabuł opartych na faktach” czy „inspirowanych wydarzeniami autentycznymi".

W przedkładanej pracy sporadycznie używam określenia „film historyczny", mając świadomość jego teoretycznej migotliwości (o czym będzie jeszcze mowa). Wedle najbardziej - jak sądzę - rozpowszechnionego rozumienia tego terminu na miano takie zasługiwać miałyby wyłącznie fikcjonalizacje fabuły historycznej, tj. filmy, których akcja opiera się na rzeczywistych, historycznych faktach; te zaś są centralne i niezbędne dla opowiadania (taka definicja nie wyklucza więc obecności fikcjonalnych wątków pobocznych, ale wskazuje na relacje pomiędzy tym, co „prawdziwe”, i tym, co „wymyślone”). Z drugiej strony możemy mieć do czynienia $z$ uhistorycznieniem fabuły fikcyjnej - opowieści $z$ tzw. łłem epoki, których akcja rozgrywa się w przeszłości, choć nie odwołuje się w istotny sposób do autentycznych wydarzeń (wedle zgrabnej metafory Bolesława Michałka, historia stanowi ich materię, choć nie jest ich bohate$\mathrm{rem}^{2}$ ). Filmy takie niegdyś określane były mianem „kostiumowych” (choć zdarzały się i inne określenia, np. Pierre Sorlin nazywa je filmami quasi-historycznymi³); być może bardziej szczegółowe studium teoretyczne

${ }^{2}$ Bolesław Michałek, Jednostka i mechanizmy historii, „Kino” 1973, nr 10, s. 58. Filmy kostiumowe do „filmów historycznych” zalicza także m.in. Leger Grindon. Zob. idem, Shadows on the Past: Studies in the Historical Fiction Film, Philadelphia 1994.

3 Inna stosowana przez Pierre'a Sorlin nazwa to "dzieła z pretekstem historycznym", ewentualnie "filmy o zabarwieniu historycznym". Autor wymienia tu tzw. dramaty 
przekonałoby do powrotu do tej nomenklatury. Tego rodzaju rozważania nie zostaną $w$ tym miejscu podjęte; dość wspomnieć, że $w$ dalszej części pracy uwzględniam oba wspomniane typy fabuł o tematyce historycznej.

Niemieckie filmy dokumentalne na temat nazistowskiej przeszłości zasługują na odrębne potraktowanie, zatem nie będą stanowić głównego przedmiotu rozprawy; zostaną one przywołane wyłącznie tam, gdzie okaże się to niezbędne. $W$ pierwszym rozdziale pracy wyjątek czynię dla tzw. atrocity films (zrealizowanych przez aliantów pod koniec wojny i w pierwszych miesiącach po jej zakończeniu, przedstawiających skutki zbrodni wojennych popełnionych przez III Rzeszę); tworzą one bowiem istotny kontekst dla głównej linii rozważań, która będzie zogniskowana na filmach fabularnych. Dodać trzeba: filmów kinowych (w rozumieniu: pomyślanych o kinie jako o pierwszym miejscu eksploatacji) - co wydaje się oczywiste $\mathrm{w}$ odniesieniu do pierwszych lat powojennych (w RFN telewizja zaczęła regularnie nadawać sygnał w 1952 r., w NRD - rok później). Filmy telewizyjne o nazistowskiej przeszłości, które powstają w II połowie lat 50. oraz na początku lat 60., mają najczęściej charakter Fernsehspiel, czyli "teatrów telewizji” ${ }^{4}$, nakręconych przy użyciu ograniczonych środków finansowych (a także bez udziału znanych aktorów) i pokazywanych jednorazowo, z ewentualną powtórką. Wkrótce telewizja stanie się - w obu państwach niemieckich - medium ustabilizowanym i przejmie dużą część audiowizualnego dyskursu związanego z reprezentacjami przeszłości - to jeden z powodów (kolejne zostaną przedstawione dalej) obrania połowy lat 60. za limes analizowanego materiału. Kwestia podziału na produkcje kinowe i telewizyjne w pracach filmoznawczych bywa zresztą - można dodać: niemal od zawsze - bardziej kłopotliwa: o ile bowiem większość filmów kinowych trafia ostatecznie na mały ekran, o tyle rzadziej mamy do czynienia z sytuacją odwrotną: gdy filmy produkowane przez telewizję lub mające premierę $\mathrm{w}$ telewizji trafiają ostatecznie do dystrybucji kinowej (w zakresie interesującym mnie w tej książce jest to na przykład przypadek filmu Dom przy Karpfengasse [Haus in der Karpfengasse, reż. Kurt Hoffmann, RFN/Czechosłowacja 1965]).

Przyjęte kryterium tematyczne oznacza, że przedmiotem mej uwagi ( w układzie odmiennym od poniższego wyliczenia - o tym, jakie wiązki

\footnotetext{
kostiumowe spod znaku „płaszcza i szpady”. Pierre Sorlin, Klio na ekranie albo historyk w mroku, tłum. J. Galewska, „Film na Świecie” 1980, nr 4, s. 48-49.

${ }^{4}$ W RFN wyjątkiem były wysokobudżetowe miniseriale w reżyserii Fritza Umgeltera: Jak daleko nogi poniosa (So weit die Füsse tragen, 1959) oraz Na zielonej plaży nad Szprewa (Am grünen Strand der Spree, 1960). Zob. także monografie: Christiane Fritsche, Vergangenheitsbewältigung im Fernsehen. Westdeutsche Filme über den Nationalsozialismus in den 1950er und 60er Jahren, München 2003; Christoph Classen, Bilder der Vergangenheit. Die Zeit des Nationalsozialismus im Fernsehen der Bundesrepublik Deutschland 1955-1965, Köln 1999.
} 
problemowe wyodrębniam w strukturze niniejszej książki, będzie jeszcze mowa) staną się: 1) filmy odnoszące się do okresu ideologicznej krystalizacji nazizmu i jego politycznej dominacji w latach 30 . XX w.; 2) filmy o II wojnie światowej; wśród nich ważne miejsce zajmują - stosunkowo nieliczne - fabuły podejmujące tematykę obozową (nie piszę "filmy o Holocauście”, gdyż dopiero pod koniec lat 70. stał się on centralnym pojęciem „pracy pamięci” w RFN); 3) filmy traktujące o reperkusjach wojny, w tym o denazyfikacji (bądź jej braku). Te trzy tematy wskazane zostały ze względu na okres, w jakim rozgrywa się akcja filmu (lub główny jej wątek); czwarta możliwa kategoria - filmy o powstawaniu ideologii nazistowskiej (a zatem takie, których akcja ulokowana jest przed 1933 r.) zostanie uwzględniona jako odrębna - przede wszystkim z uwagi na specyfikę kinematografii enerdowskiej, w której dorobku jest wiele filmów o "drodze do faszyzmu" (biorącej swój początek nie tylko w latach 20., ale - wedle obowiązującej w NRD marksistowskiej wykładni - integralnie związanej z powstaniem i rozwojem kapitalizmu). Ta arbitralna decyzja nie oznacza, że $w$ toku wywodu nie pojawią się wyjątki - rezerwuję to prawo dla kilku filmów, które zawierają wyraźne wskazanie na okres po 1933 r., chociaż większość przedstawionych w nich wydarzeń rozgrywa się wcześniej.

\section{Kontekst teoretyczny: pamięć kulturowa - polityka historyczna - film fabularny}

Zastanawiając się nad tym, jaki tytuł nadać niniejszej książce, odrzuciłem - wydawałoby się: najprostszy i najbardziej oczywisty - wariant: „Filmowe reprezentacje nazizmu". Decyzja ta nie była spowodowana li tylko niechęcią do prac posługujących się modelem: "obraz czegoś w filmie" (słabości tego rodzaju wywodów wynikają często z nazbyt arbitralnie obranego korpusu przywoływanych tekstów), lecz przede wszystkim z materii przedmiotu niniejszej pracy - a zatem tego, iż część filmów, o których piszę, należałoby określić jako współczesne (w relacji pomiędzy tematyką a czasem produkcji). Inny wariant tytułu - „Filmowy rozrachunek z nazistowską przeszłością" - byłby zapewne bardziej trafny, ale jednocześnie zakładałby swoiste "sfunkcjonalizowanie” filmów (spośród których wiele nie nosi znamion jakkolwiek pojmowanego tropu „rozliczeniowego"). Ostatecznie więc zdecydowałem się na formułę nawiązującą do pojęcia "pamięć", z jednej strony najbardziej pojemną i dającą możliwość uwzględnienia wielu kontekstów, które musiałyby zostać wykluczone w sytuacji wyboru opcji „reprezentacji” lub „rozrachunków”, 
z drugiej jednak - obarczoną ryzykiem uwikłania w mnogość sposobów konceptualizacji tego terminu.

Mglisty i metaforyczny charakter terminu „pamięć" wiódł do rozmaitych sporów interpretacyjnych, ale jednocześnie zapewnił mu wielką karierę $\mathrm{w}$ naukach humanistycznych, począwszy od wczesnego rozumienia „pamięci zbiorowej” (Maurice Halbwachs ${ }^{5}$ ) czy albumu Mnemosyne (Aby Warburg ${ }^{6}$ ), poprzez wpływową koncepcję „miejsc pamięci” (Pierre Nora ${ }^{7}$ ) oraz analiz relacji między pamięcią a narracją (Paul Ricoeur $\left.{ }^{8}\right)$ lub traumą (Dominik La Capra ${ }^{9}$, Frank Ankersmit ${ }^{10}$ ), aż po rozpoznania dotyczące postpamięci (Marianne Hirsch ${ }^{11}$ ) czy ryzykowną, chętnie aplikowaną do prac o filmie, formułę „pamięci protetycznej” (Alison Landsberg ${ }^{12}$ ). Wszystkie te propozycje teoretyczne - dobrze ugruntowane w polskim piśmiennic-

${ }^{5}$ Maurice Halbachs, Społeczne ramy pamięci, tłum. M. Król, Warszawa 1969.

6 Aby Warburg, Atlas Mnemosyne. Wprowadzenie, tłum. K. Pijarski, „Konteksty” 2011, nr 2-3.

7 Pierre Nora, Czas pamięci, tłum. W. Dłuski, „Res Publica Nowa” 2001, nr 7; idem, Między pamięcia a historią: Les Lieux de Mémoire, „Tytuł roboczy: Archiwum” 2009, nr 2.

${ }^{8}$ Paul Ricoeur, Pamięć, historia, zapomnienie, tłum. J. Margański, Kraków 2012. Także jako artykuły w innym przekładzie: idem, Nadużycia pamięci naturalnej: pamięć powstrzymana, pamięć manipulowana, pamięć narzucona, tłum. W. Bońkowski, „Konteksty” 2003, nr 1-2; idem, Między pamięcia a historia, "Znak” 2005, nr 598; idem, Pamięć - zapomnienie - historia, tłum. J. Migasiński, [w:] Tożsamość w czasach zmiany. Rozmowy w Castel Gandolfo, Kraków 1995.

9 Zob. na przykład: Dominick La Capra, Pisanie historii, pisanie traumy, [w:] Pamięć Shoah. Kulturowe reprezentacje i praktyki upamiętnienia, red. Tomasz Majewski, Anna Zeidler-Janiszewska, Łódź 2009; idem, Psychoanaliza, pamięć i zwrot etyczny, tłum. M. Zapędowska, [w:] Pamięć, etyka i historia. Anglo-amerykańska teoria historiografii lat dziewieććdziesiatych. Antologia przekładów, red. Ewa Domańska, Poznań 2006.

${ }_{10}$ Frank Ankersmit, Narracja, reprezentacja, doświadczenie: studia z teorii historiografii, red. Ewa Domańska, Kraków 2004.

${ }^{11}$ Marianne Hirsch, Żałoba i postpamięć, tłum. K. Bojarska, [w:] Teoria wiedzy o przeszłości na tle współczesnej humanistyki, red. Ewa Domańska, Poznań 2011; eadem, Pokolenie postpamięci, tłum. M. Borowski, M. Sugiera, „Didaskalia” 2011, nr 105.

12 Alison Landsberg, Pamięć protetyczna, tłum. M. Szewczyk, [w:] Antropologia kultury wizualnej, red. Iwona Kurz, Paulina Kwiatkowska, Łukasz Zaremba, Warszawa 2012. Pół biedy, gdy Landsberg twierdzi, że ten rodzaj pamięci jest faktycznie formą protezy i wpływa na ciało "pamiętającego", powstając jako rezultat sensualnego kontaktu z obiektem (co można by uznać za prawdziwe na przykład w odniesieniu do muzeów „interaktywnych" czy eksperymentalnych). Uzasadnione wątpliwości pojawiają wówczas, gdy Landsberg sugeruje, że w wyniku percepcji zmediatyzowanej reprezentacji przeszłości ów „pamiętający” niechybnie „identyfikuje się", „,odczuwa emocje” itp. Koncepcja Landsberg została poddana krytyce m.in. przez Johna Bergera, zdaniem którego „pamięć protetyczna" jest metaforą konwencjonalnego procesu czytania znaków, toteż nie można mówić o szczególnych „protetycznych” właściwościach fotografii czy filmu. Zob. John Berger, Which Prosthetic? Mass Media, Narrative, Empathy and Progressive Politics, "Rethinking History" 2007, nr 4. 
twie ${ }^{13}$ - wyliczam w tym miejscu poniekąd z obowiązku; nie będę bowiem $\mathrm{z}$ nich korzystać $\mathrm{w}$ toku wywodu.

Bardziej użyteczne dla podejmowanego w tej książce tematu są koncepcje Aleidy Assmann ${ }^{14}$, w szczególności szeroko rozumiana „pamięć kulturowa”, która - w odróżnieniu od „pamięci komunikacyjnej” (transmitowanej na drodze relacji interpersonalnych) - utrwalona jest $w$ instytucjach i tekstach kultury, a wyrażana przez różnorodne praktyki komemoracyjne, kształtujące wyobrażenia o przeszłości (gesty polityczne, pomniki, wystawy itp.). Ważnym elementem tak rozumianej pamięci kulturowej-którą za innym autorem określić można jako „pamięć upowszechnianą” (tzn. adresowaną do obywateli emanację pamięci „oficjalnej” lub „urzędowej" $)^{15}$ - byłyby także komunikaty audiowizualne (z uwagi na łatwą „przyswajalność" stanowią one dla sporej części społeczeństwa podstawowe źródło wiedzy o przeszłości), ale i same badania historyczne. Rozmaite formy pamięci kulturowej są często (a w niedemokratycznych systemach: zazwyczaj) podatne na procesy instrumentalizacji dla doraźnych celów politycznych. Mogą więc legitymizować porządek społeczny, stabilizować kolektywne tożsamości oraz integrować wspólnotę wokół pewnych idealizowanych tradycji (co z kolei w wielu wypadkach wynika z faktu, że zarówno badania historyczne, jak i twórczość artystyczna bywają finansowane lub współfinansowane przez agendy państwowe $\left.{ }^{16}\right)$. W tym zakresie pole wytwarzania wiedzy różni się w niewielkim stopniu od obszaru produkcji kulturowej (spostrzeżenie to nie odnosi się, rzecz jasna, do wszelkich form twórczości artystycznej i całego piśmiennictwa w zakresie humanistyki).

Nie oznacza to oczywiście, że w danym społeczeństwie mamy do czynienia $\mathrm{z}$ jedna, homogeniczną pamięcią kulturową - przeciwnie, w sferze publicznej współwystępują różne „wspólnoty pamięci”, jak nazywa je Charles Maier ${ }^{17}$. Wspólnoty narodowe nie posiadają jednej „wielkiej narracji”, gdyż są one konstruowane przez wiele opowieści, nierzadko

${ }^{13}$ Zob. zwłaszcza: Modi memorandi. Leksykon kultury pamięci, red. Magdalena Saryusz-Wolska, Robert Traba, Warszawa 2014 (w tomie uwzględnione zostały też koncepcje polskich badaczy, m.in. Barbary Szackiej, Krzysztofa Pomiana, Niny Assorodobraj-Kuli i innych).

14 Aleida Assmann, Między historia a pamięcia, red. Magdalena Saryusz-Wolska, Warszawa 2013; zob. także jej artykuły w tomie: Pamięć zbiorowa i kulturowa. Współczesna perspektywa niemiecka, red. Magdalena Saryusz-Wolska, Kraków 2009.

15 Andrzej Paczkowski, Peerelowska przeszłość w pamięci społecznej, historiografii i polityce, [w:] idem, Od sfatszowanego zwycięstwa do prawdziwej klęski, Warszawa 1999, s. 208-209.

16 Zob. Ewa Domańska, Historie niekonwencjonalne, Poznań 2010, s. 83. O kwestiach tych pisze wielu autorów, m.in.: Georg Iggers, Użycia $i$ nadużycia historii, tłum. A. Pantuchowicz, [w:] Pamięć, etyka i historia...

17 Charles Maier, Goraca pamięć, zimna pamięć, tłum. M. Król, „Res Publica” 2001, nr 7. 
stojących wobec siebie w (faktycznej lub jedynie pozorowanej) opozycji; pamięć kulturowa nie jest zatem monolityczna, lecz mniej lub bardziej pluralistyczna. Zarazem jednak opowieści te rzadko pojawiają się w tym samym "natężeniu" - raczej ścierają się ze sobą i konkurują w walce o dominację, często przeobrażają się w formy pozornie nowe, występują $\mathrm{w}$ nowych kostiumach, umożliwiających powielanie w gruncie rzeczy utartych sposobów myślenia. Jeśli faktycznie naród jest, jak twierdzi Benedict Anderson ${ }^{18}$, „wspólnotą wyobrażoną", budowaną poprzez narracje, których zadaniem jest transformowanie losu w logiczną ciągłość i nadawanie temu, co przypadkowe, uporządkowanego znaczenia, wówczas w filmowych „imaginariach” odnajdziemy ślady pozwalające zrekonstruować procesy ustanawiania państwowotwórczych „mitów założycielskich" oraz społecznie akceptowalnych dyskursów myślenia o minionych dekadach.

Jednym z budulców życia publicznego jest polityka historyczna - termin zaczerpnięty zresztą z języka niemieckiego (Geschichtspolitik ${ }^{19}$ ). Pod tym pojęciem rozumiem, za Lechem Nijakowskim, „intencjonalne działania polityków i urzędników mające formalną legitymizację, których celem jest utrwalenie, usunięcie lub redefinicja określonych treści pamięci społecznej"20. Działania te mogą być podejmowane - zgodnie z dewizac Politik macht Geschichte macht Politik (,Historia tworzy politykę. Polityka tworzy historię") - zarówno na użytek wewnętrzny (z rozmaitych powodów: po to, by identyfikować problemy tożsamościowe wspólnoty politycznej, ale również w celu legitymizacji swej władzy ${ }^{21}$ ), jak i międzynarodowy. Trudno wyobrazić sobie państwo, które polityki historycznej nie prowadzi - jej elementami są przecież także święta narodowe, obchody rocznicowe, nadawanie orderów, programy szkolne czy wspieranie ba-

${ }^{18}$ Benedict Anderson, Wspólnoty wyobrażone: rozważania o źródłach i rozprzestrzenianiu się nacjonalizmu, tłum. S. Amsterdamski, Warszawa 1997.

${ }_{19}$ Inny termin - Vergangenheitspolitik - jest mniej rozpowszechniony, a przez jednego z wpływowych autorów traktowany jako specyficzne określenie pierwszych lat „polityki wobec przeszłości” w RFN (zob. Norbert Frei, Polityka wobec przeszłości. Poczatki Republiki Federalnej i przeszłość nazistowska, tłum. B. Ostrowska, Warszawa 1999).

${ }^{20}$ Lech M. Nijakowski, Polska polityka pamięci: esej socjologiczny, Warszawa 2008, s. 44. Już sam tytuł pracy ujawnia niechętny stosunek autora do terminu „polityka historyczna” (jego zdaniem w Polsce została ona "zawłaszczona” przez środowiska konserwatywne). Z kolei Robert Traba preferuje określenia „polityka wobec historii” lub „wobec pamięci” (Robert Traba, Przeszłość w teraźniejszości, Poznań 2009). Zob. też: Narodowe i europejskie aspekty polityki historycznej, red. Bartosz Korzeniewski, Poznań 2008; Marek Cichocki, Wtadza i pamięć. O politycznej funkcji historii, Warszawa 2003.

${ }_{21}$ Tak rozumiana polityka historyczna jest bliska propagandzie rozumianej jako dążenie do kierowania opinią publiczną i manipulowania wzorami zachowań (zob. Bogusława Dobek-Ostrowska, Janina Fras, Beata Ociepka, Teoria i praktyka propagandy, Wrocław 1997). 
dań naukowych. W rejestrze tym mieści się i film - wówczas, gdy agendy państwa finansują jego produkcję lub wpływają na dystrybucję.

$\mathrm{Z}$ tym ostatnim aspektem związane jest jeszcze inne pojęcie, oscylujące wokół zagadnień pamięci kulturowej, z jednej strony, i polityki historycznej - z drugiej. Chodzi mianowicie o „archiwum”, rozumiane nie jako obiekt czy instytucja służąca do gromadzenia, zabezpieczania i segregowania historycznych artefaktów, lecz jako repozytorium obrazów i wątków, swoista baza danych określająca - by posłużyć się klasyczną już frazą - „warunki możliwości” powstających narracji. Innymi słowy, zaprezentowane tu podejście byłoby bliskie tej tradycji badawczej, która koncentruje się na „reżimach obrazowania”, a komunikaty rozpatruje pod kątem ich funkcji regulacyjnych, czyniących z nich "aksamitne” narzędzie sprawowania władzy politycznej - pojmowanej w sensie Foucaultowskim (jako historycznie zmienny i określony dla danej przestrzeni „ogólny system formowania się i przekształcania wypowiedzi" 22, czyli zinstytucjonalizowane lub nieformalne mechanizmy wyznaczające granice tego, co daje się wyartykułować). Jeśli więc w głównej części książki przywołuję - nawet za cenę pewnej monotonii wywodu - krótkie streszczenia fabuł filmowych, czynię to z uwagi na tak rozumiane powinności „archiwisty”: by unaocznić horyzont fabularnej wyobraźni w odniesieniu do konkretnych tematów.

Użytecznym narzędziem analizy fenomenów kulturowych związanych z zagadnieniami pamięci o latach nazizmu jest zaproponowana przez Assmann typologia „wypierania ze świadomości” niewygodnych wydarzeń. Wymienia ona pięć strategii, jakie może przybrać taki proces: kompensację, eksternalizację, wyłączenie, milczenie i przeinaczenie ${ }^{23}$. Pierwsza z nich ma rodowód psychoanalityczny i polega na swoistej „zamianie ról": sprawcy lub współsprawcy postrzegają siebie jako ofiary. Istotą drugiej z wymienionych strategii jest przypisanie winy innej osobie lub grupie; przykładem eksternalizacji może być zrzucenie odium sprawstwa na elity NSDAP. Wyłączenie i milczenie są do siebie zbliżone - chodzi o pomijanie niewygodnego wydarzenia lub prezentowanie go w formule półprawdy; ilustracją tej strategii mogą być obrazy i narracje o obozach koncentracyjnych, pomijające wątek szczególnej pozycji Żydów wśród ofiar. Wreszcie przeinaczenie polegałoby na wprowadzeniu do narracji mniej lub bardziej istotnej zmiany, rzutującej na ogólną wymowę przekazu (wydaje się, że za osobną strategię mogłaby zostać

${ }^{22}$ Michel Foucault, Archeologia wiedzy, tłum. A. Siemek, Warszawa 2002, s. 165.

${ }^{23}$ Por. Aleida Assmann, Pięć strategii wypierania ze świadomości, tłum. A. Pełka, [w:] Pamięć zbiorowa i kulturowa... 
uznana marginalizacja, sytuująca się na przecięciu porządku „wyłączenia” $\mathrm{i}$ „przeinaczenia”).

Zbliżona do koncepcji Assmann - ale przypominająca bardziej politologiczną analizę dyskursu publicznego - jest typologia autorstwa Helmuta Dubiela, który w swej pracy opartej (przede wszystkim, choć nie wyłącznie) na analizie przemówień w Bundestagu uznał, iż debata o narodowym socjalizmie była modelowana przez kilka strategii retorycznych. Oprócz „przemilczenia” Dubiel wymienia jeszcze: „retuszowanie” (bemänteln), „relatywizację" (szukanie usprawiedliwień poprzez wskazywanie na „winę innych"), „odgraniczenie” (Abspaltung - w myśl tej strategii sprawcy stanowią tylko niewielką garstkę społeczności), „pprzybieranie pozy ofiary" (Opferhaltung - bliskie kompensacji w ujęciu Assmann) i "egzystencjalizację" (Existentialisierung), czyli traktowanie wojny jako „katastrofy naturalnej”, spowodowanej przez metafizyczny Los ${ }^{24}$. Pojęcia zaproponowane przez Assmann i Dubiela można z powodzeniem zastosować do niemieckich filmów o tematyce nawiązującej do lat nazizmu, co w pewnym stopniu uczynię w kolejnych rozdziałach.

Opisywany w wielu miejscach tzw. zwrot pamięciowy, dokonujący się $\mathrm{w}$ humanistyce od połowy lat 70., a związany $\mathrm{z}$ „wywłaszczeniem historyka z jego tradycyjnego monopolu interpretowania przeszłości”25, współtowarzyszył debatom dotyczącym rozpoznania konstrukcyjnego wymiaru historiografii. We wpływowej, wydanej w 1973 r. Metahistory Hayden White dowodził, iż przeszłość jest niedostępna inaczej, niż za pomocą narracji, którą rządzą tropy i figury literackie. Narracja historyczna stanowi bowiem „zapośredniczenie między wydarzeniami, o których opowiada, a strukturami fabularnymi konwencjonalnie wykorzystywanymi w obrębie naszej kultury do nadawania sensu zdarzeniom i sytuacjom nierozpoznanym" ${ }^{26}$. Konsekwencją tego spostrzeżenia było uznanie alternatywnych (wykraczających poza dyskurs języka naturalnego) form opowiadania o przeszłości za równorzędne - przynajmniej teoretycznie - wobec tradycyjnej historiografii. Do sformułowanej przez White'a koncepcji „historiofotii" ${ }^{27}$ („historii w obrazach” - przez analogię do historiografii, czyli "historii w słowach") nawiązywało wielu autorów, m.in. Robert Rosenstone oraz Marc Ferro. Zauważają oni, że praca filmowca i historyka ma zbliżony charakter - polega na budowaniu komunikatu

${ }^{24}$ Helmut Dubiel, Niemand ist frei von der Geschichte. Die nationalsozialistische Herrschaft in den Debatten des Deutschen Bundestages, München 1999.

${ }^{25}$ Pierre Nora, Czas pamięci..., s. 42.

${ }^{26}$ Hayden White, Tekst historiograficzny jako artefakt literacki, [w:] Hayden White. Poetyka pisarstwa historycznego, red. Ewa Domańska, Marek Wilczyński, Kraków 2000, s. 90-91.

${ }^{27}$ Hayden White, Historiografia i historiofotia, tłum. Ł. Zaremba, [w:] Film i historia, red. Iwona Kurz, Warszawa 2009. 
narracyjnego poprzez mechanizmy selekcji, marginalizacji bądź akcentowania poszczególnych wydarzeń, wskazywania relacji przyczynowo-skutkowych, by opowieść nabrała kształtu koherentnego fabularnie („,czyż mając możliwość korzystania z tych samych źródeł wszyscy historycy napisaliby taką samą historię?" 28 - pyta retorycznie Ferro). Zarazem wielokrotnie odżegnują się od poglądu, że "historia i fikcja są tym samym"29; zwracają natomiast uwagę, iż "tak jak każda praca o historii, film musi być osądzany w ramach wiedzy o przeszłości, którą obecnie posiadamy"30. Innymi słowy, konstrukcja materiału fabularnego powinna zostać podporządkowana „prawdzie dyskursu o przeszłości” (opartego na naszej dotychczasowej wiedzy), a osąd musi pojawić się ze skumulowanej wiedzy pochodzącej z historycznych tekstów kultury, do których należy również film.

Przyznam, że w publikacjach poświęconych relacjom filmu i historii zazwyczaj irytuje mnie konkluzja, iż „,każdy film historyczny jest bardziej obrazem epoki, w której powstał, niż tej, o której traktuje". Wrażenie to nie wynika przy tym $\mathrm{z}$ charakteru tego wniosku (jest on bowiem prawdziwy - także wobec innych faktów kulturowych), ale trybu jego prezentacji - jako spostrzeżenia jakoby niesłychanie oryginalnego (być może formułowane bywa ono $\mathrm{w}$ ten sposób $\mathrm{z}$ uwagi na oczekiwania tzw. widzów naiwnych - skłonnych brać filmową reprezentację za faktyczną „relację ze zdarzeń"). Dla porządku powtórzmy jednak: filmowe obrazy dotyczące historii są wyrazem pamięci kulturowej w określonym momencie historycznym, często też - areną sporów o wartości współczesne (jak ujmuje to Marek Hendrykowski, „w filmowych obrazach historii [...] toczy się, prowadzona za pośrednictwem języka ruchomych obrazów, gra, której stawką jest pamięć zbiorowa" ${ }^{31}$ ). Inaczej mówiąc: filmy nie tyle „reprezentują przeszłość" ${ }^{\prime 2}$, ile w większym stopniu modelują legitymizują bądź

${ }_{28}$ Marc Ferro, Historycy i kino, tłum. J. Godzimirski, „Kino” 1989, nr 10, s. 27.

${ }^{29}$ Podobne zarzuty stawiano zresztą White' owi i innym historykom z kręgu "narratywizmu" - zob. na przykład: Chris Lorenz, Czy historia może być prawdziwa? O narratywistycznych koncepcjach filozofii historii Haydena White'a i Franka Ankersmita, [w:] idem, Przekraczanie granic. Eseje z filozofii historii i teorii wiedzy historycznej, tłum. M. Bobako, R. Dziergwa, Poznań 2009.

${ }^{30}$ Robert Rosenstone, The Historical Film: Looking at the Past in a Postliterate Age, [w:] The Historical Film: History and Memory in Media, red. Marcia Landy, New Brunswick 2001, s. 66. Zob. także: idem, Historia w obrazach/historia w słowach: rozważania nad możliwościa przedstawienia historii na taśmie filmowej, [w:] Film i historia...

${ }^{31}$ Marek Hendrykowski, Film jako źródło historyczne, Poznań 2000, s. 74.

32 Niektórzy autorzy słaniają się ku opinii, że jest to po prostu niemożliwe. O sposobach przedstawiania historii w filmie zob.: Piotr Witek, Kultura. Film. Historia. Metodologiczne problemy doświadczenia audiowizualnego, Lublin 2005, Dorota Skotarczak, Historia wizualna, Poznań 2012. 
krytykują pewien tryb myślenia o niej. Zamiast więc czynić zarzuty z niewierności historycznej, warto starać się raczej wniknąć w wewnętrzną logikę dyskursu i próbować odpowiedzieć na pytanie, w jaki sposób i dlaczego historyczna rzetelność zostaje użyta lub nadużyta - a zatem: jaką formę pamięci dany tekst chce wytworzyć.

Podejmując zagadnienia związane z pograniczem humanistyki i nauk społecznych, a zatem także pisząc o relacjach "film i pamięć", należy odróżnić dwa porządki: tekstualności i recepcji. W tym ostatnim przypadku mówimy o pamięci widzów: możemy podjąć próbę formułowania sądów o historycznej widowni (posiłkując się, jak czynię to w niektórych miejscach książki, publikacjami krytycznymi lub innymi zachowanymi świadectwami) lub badać pamięć widzów współczesnych (pytając na przykład, w jaki sposób zapamiętali oni filmy oglądane przed laty; ten rodzaj oglądu jest nieistotny dla niniejszego tomu). Gdy zaś idzie o perspektywę „wewnątrztekstową", analizującą sposoby reprezentacji, nie zaś ich produkcję, kontekst badań pamięciowych może być aplikowany na różnych poziomach interpretacji. Jedna $\mathrm{z}$ autorek opisuje je następująco:

\begin{abstract}
Obrazy filmowe [...] odnoszą się do kategorii pamięci w trojaki sposób: po pierwsze przez fabułę - ich treść zawsze, w mniejszym lub większym stopniu, dotyczy przeszłości (a zatem są rodzajem wspomnienia lub upamiętnienia); po drugie dzięki konstrukcji narracji - ich akcja opiera się w dużej mierze na rozmaitych retrospekcjach [...], a po trzecie dzięki temu, że wykorzystują rozmaite reprezentacje medialne przeszłości - wiele z nich zawiera fragmenty materiałów archiwalnych ${ }^{33}$.
\end{abstract}

Inaczej mówiąc, wśród kryteriów odnoszących się do „wewnątrztekstowej" relacji film - pamięć, można wyróżnić: 1) tematykę historyczną; 2) konstrukcję dramaturgiczna, w tym wykorzystanie retrospekcji; 3) użycie materiałów archiwalnych ${ }^{34}$. W niniejszej książce ten ostatni aspekt będzie podejmowany rzadko - z uwagi na charakter samych filmów, w których zapisy archiwalne wykorzystywane były tylko sporadycznie.

Z kolei pozatekstualna "otulina” filmów - a zatem ten aspekt kultury filmowej, który silniej jest związany z polityką historyczną - będzie uwzględniona tylko w odniesieniu do niektórych tytułów (rekonstrukcja kontekstów produkcyjnych wszystkich pozostałych wymagałaby odrębnych badań oraz innej konstrukcji wywodu). W tym miejscu wystarczy przypomnieć, że obie interesujące mnie kinematografie - enerdowska

${ }^{33}$ Ewa Fiuk, Inicjacje, tożsamość, pamięć. Kino niemieckie na przełomie wieków, Wrocław 2012, s. 74.

${ }^{34}$ Złożoną typologię filmów historycznych przedstawia: Anna Miller-Klejsa, Resistenza we włoskim filmie fabularnym, Łódź 2013. 
i erefenowska - funkcjonowały w zupełnie odmiennych warunkach politycznych i ekonomicznych. Najistotniejsza różnica dotyczy zasad funkcjonowania debaty publicznej: centralizacji w zakresie wytwarzania pamięci historycznej i jej kontrolowania (która obowiązywała w NRD) oraz braku państwowej cenzury (w przypadku RFN) - co jednak nie oznacza, że w odniesieniu do tego ostatniego kraju nie można mówić o mechanizmach umożliwiających wywieranie politycznego wpływu na procesy produkcji i dystrybucji filmów (choćby poprzez obowiązujący od lat 50. - i funkcjonujący do dziś - system tzw. predykatów, uprawniających do ulg podatkowych). W obu krajach mechanizmem polityki historycznej w dziedzinie kultury były też nagrody państwowe: Nationalpreis w NRD (I, II i III stopnia - wprowadzone na wzór Nagród Stalinowskich w 1949 r.) i Deutscher Filmpreis (potocznie: Bundesfilmpreis) w RFN (od 1951 r. przyznawane przez Ministra Spraw Wewnętrznych ${ }^{35}$ ). Wydaje się, że ten aspekt kultury filmowej (nie tylko zresztą niemieckiej) zasługuje na bardziej wnikliwe opracowanie - zbyt często bowiem umyka uwadze historyków.

\section{Stan wiedzy - powojenne kino niemieckie a rozliczenia z nazistowską przeszłością}

Proponowany w niniejszej książce temat nie został dotychczas (co zaskakujące) w wyczerpujący sposób rozpoznany przez humanistykę - $\mathrm{w}$ piśmiennictwie niemieckim, angielskim ani tym bardziej polskim. Generalnie można powiedzieć, że w pracach niemieckojęzycznych na temat „filmowych rozrachunków z nazizmem” dominują bądź nader ogólne, popularyzatorskie omówienia, nierzadko o charakterze eseistycznym, bądź szczegółowe analizy lub „historie produkcyjne” konkretnych filmów. Zarówno w niemieckim, jak i anglojęzycznym piśmiennictwie powstało wiele prac o filmach zrealizowanych w latach 70. i współcześnie; kino lat 50. jest zaś stosunkowo nowym (można powiedzieć: od niedawna dość „modnym”) obszarem badań.

Oczywiście, bardzo liczne są opracowania poświęcone zagadnieniom związanym z niemiecką „kulturą pamięci” (Erinnerungskultur), polityką historyczną (Geschichtspolitik) czy "przezwyciężaniem przeszłości” (Vergangenheitsbewältigung); wiele $\mathrm{z}$ nich będzie przywoływanych $\mathrm{w}$ toku

35 Od 1999 r. nagrody są przyznawane przez Pełnomocnika Rządu Federalnego ds. Kultury i Mediów (w randze ministra). Do 2002 r. w kapitule nagrody zasiadali politycy i przedstawiciele Kościołów, zaś od tego czasu o nominacjach i nagrodach decydują członkowie Niemieckiej Akademii Filmowej. 
wywodu ${ }^{36}$. Spośród tych publikacji trzy książki (autorstwa: Edgara Wolfruma, Aleidy Assmann i Norberta Freia) można uznać za kanoniczne ${ }^{37}$, przy czym większość omówień dotyczy kwestii związanych z RFN, a tylko niektóre prace koncentrują się na różnicach pomiędzy "politykami pamięci" w RFN i NRD ${ }^{38}$. Na osobne wyróżnienie zasługują monografie Petera Reichela, który (zachodnio)niemieckiej pamięci o latach nazizmu poświęcił trzy książki, dotyczące - kolejno - publicznych uroczystości komemoracyjnych, aspektów polityczno-prawnych oraz teatrowi i filmowi (w jednym tomie $)^{39}$. Przekształcenia pamięci podzielonych Niemiec w odniesieniu do lat nazizmu zostały wyczerpująco omówione w opracowaniu Anny Wolff-Powęskiej ${ }^{40}$, zaś polityki historycznej w RFN - w dwóch innych książkach (Kazimierza Wóycickiego i Jana Rydla) ${ }^{41}$. Ich cenne uzupełnienie stanowią dwie antologie przekładów ${ }^{42}$ oraz kilka tłumaczeń wydanych w serii Poznańska Biblioteka Niemiecka ${ }^{43}$.

Monograficzne opracowania historii kina niemieckiego są zbyt liczne, by wymienić je w tym miejscu. W wydanym na początku lat 90 . jednoto-

36 Zob. obszerny słownik Lexikon der "Vergangenheitsbewältigung" in Deutschland: Debatten- und Diskursgeschichte des Nationalsozialismus nach 1945, red. Torben Fischer, Matthias N. Lorenz, Bielefeld 2007. Jako dobre wprowadzenie mogą posłużyć opracowania: Jörn Rüsen, Friedrich Jaeger, Erinnerungskultur, [w:] Deutschland-Trendbuch: Fakten und Orientierungen, red. Karl-Rudolf Korte, Werner Weidenfeld, Opladen 2001; Michael Kohlstruck, Zwischen Geschichte und Erinnerung, Berlin 1997 (część I).

${ }^{37}$ Edgar Wolfrum, Geschichtspolitik in der Bundesrepublik Deutschland. Der Weg zur bundesrepublikanischen Erinnerung 1948-1990, Darmstadt 1999; Aleida Assmann, Ute Frevert, Geschichtsvergessenheit - Geschichtsversessenheit. Vom Umgang mit deutschen Vergangenheiten nach 1945, Stuttgart 1999; Norbert Frei, 1945 und wir. Das Dritte Reich im Bewußtsein der Deutschen, München 2005.

${ }^{38}$ Die geteilte Vergangenheit: Zum Umgang mit Nationalsozialismus und Widerstand in beiden deutschen Staaten, red. Jürgen Danyel, Berlin 1995; także: Jeffrey Herf, Divided Memory: The Nazi Past in the Two Germanys, Cambridge 1997.

39 Peter Reichel, Politik mit der Erinnerung. Gedächtnisorte im Streit um die nationalsozialistische Vergangenheit, Wien 1995; idem, Vergangenheitsbewältigung in Deutschland. Die Auseinandersetzung mit der NS-Diktatur von 1945 bis heute, München 2001; idem, Erfundene Erinnerung: Weltkrieg und Judenmord in Film und Theater, München 2004.

40 Anna Wolff-Powęska, Pamięć - brzemię i uwolnienie. Niemcy wobec nazistowskiej przeszłości (1945-2010), Poznań 2011.

${ }^{41}$ Kazimierz Wóycicki, Niemiecki rachunek sumienia. Niemcy wobec przeszłości 19331945, Wrocław 2004; Jan Rydel, Polityka historyczna w Republice Federalnej Niemiec. Zaszłości, idee, praktyka, Kraków 2011 (zwłaszcza s. 77-200).

${ }^{42}$ Po upadku Trzeciej Rzeszy, red. Jerzy W. Borejsza, Stefan H. Kaszyński, Warszawa 1981; O kondycji Niemiec. Tożsamość niemiecka w debatach intelektualistów po 1945 roku, red. Joanna Jabłkowska, Leszek Żyliński, Poznań 2008.

${ }^{43}$ Na przykład: Mario Rainer Lepsius, O kulturze politycznej w Niemczech, tłum. A. Żychliński, Poznań 2007; Christoph Kleßmann, Sporne problemy współczesnej historii Niemiec, tłum. J. Kałążny, I. Sellmer, M. Tomczak, Poznań 1999. 
mowym opracowaniu zbiorowym Historia kina niemieckiego (o kinie enerdowskim traktuje ledwie jeden z osiemnastu rozdziałów) zagadnienia podejmowane przeze mnie w niniejszej książce zostały omówione naskórkowo ${ }^{44}$. Druga pozycja, która uchodzi za dobre wprowadzenie do dziejów kina niemieckiego, w większym stopniu uwzględnia kinematografię NRD, choć dyskusyjny wydaje się przyjęty przez autorkę (Sabine Hake) pogląd, iż „ukształtowanie dwóch osobnych kultur filmowych dokonało się ostatecznie za sprawą muru berlińskiego" ${ }^{\prime 4}$. Konsekwencją tego przekonania stała się struktura jej książki, w której rozdział IV, obejmujący lata 19451961, omawia łącznie kino wschodnich i zachodnich Niemiec (zarazem dzieląc go na ryzykownie zatytułowane podrozdziały: Upolitycznienie filmu $w$ NRD i Odpolitycznienie filmu w RFN), zaś kolejne dwie części poświęcone są - odpowiednio - filmom z NRD i RFN z lat 1961-1989 (przy czym i tu wprowadzono wewnętrzny podział, tym razem na dekady). Jako dziejowy limes autorka przyjęła rok 1961 - z uwagi na budowę muru berlińskiego przez NRD oraz manifest oberhauseński z 1962 r. Gradację taką, choć na pierwszy rzut oka wydaje się ona sensowna, uznaję jednak za nazbyt "mechaniczną", o czym będzie jeszcze mowa.

Szczególnie chętnie podejmowanym tematem badań jest wczesny okres kina powojennego ${ }^{46}$; na tych zagadnieniach koncentrowali swą uwagę w ostatnich latach także polscy badacze ${ }^{47}$. Sporo napisano - po niemiecku i angielsku - o erefenowskim kinie lat 50.48, najczęściej czytanym przez pryzmat tzw. Heimatfilmów. Publikacje na temat innego ważnego gatunku tej dekady, filmu wojennego, są rozproszone po rozmaitych

${ }^{44}$ Geschichte des deutschen Films, red. Wolfgang Jacobsen, Anton Kaes, Hans Helmut Prinzler, Stuttgart-Weimar 1993. Niewiele miejsca kinu NRD poświęcono także w innych pracach przeglądowych, na przykład w: The BFI Companion to German Cinema, red. Thomas Elsaesser, Michael Wedel, London 1999.

45 Sabine Hake, Film in Deutschland. Geschichte und Geschichten seit 1985, Reinbek 2002, s. 208. Książka Hake ukazała się po raz pierwszy w języku angielskim jako: German National Cinema, New York 2001; niemiecki przekład został poprawiony i uzupełniony.

46 Peter Pleyer, Deutscher Nachkriegsfilm 1946-1948, Münster 1965; Robert R. Shandley, Rubble Films: German Cinema in the Shadow of the Third Reich, Philadelphia 2001 (wyd. niemieckie: Trümmerfilme. Das deutsche Kino der Nachkriegszeit, Berlin 2010); Bettina Greffrath, Gesellschaftsbilder der Nachkriegszeit. Deutsche Spielfilme 1945-1949, Pfaffenweiler 1995.

47 Andrzej Gwóźdź, Obok kanonu. Tropami kina niemieckiego, Wrocław 2011 (rozdział: Niemcy wychodza z mroku, czyli wojna w kinie 1945-1949); Magdalena Saryusz-Wolska, Pierwsze próby rozrachunku. Kino niemieckie 1945-1949, [w:] Konstelacja Szczecin. Aktorzy szczecińscy i kino okresu międzywojennego, red. Radosław Skrycki, Szczecin 2011. Zob. też: eadem, Ikony normalizacji. Kultury wizualne Niemiec 1945-1949, w druku.

${ }_{48}$ Bärbel Westermann, Nationale Identität im Spielfilm der fünfziger Jahre, Frankfurt am Main 1990; Heide Fehrenbach, Cinema in Democratizing Germany: Reconstructing National Identity After Hitler, Chapel Hill 1995. 
antologiach, które będą przywoływane w kolejnych rozdziałach. Z historycznego punktu widzenia ciekawe są prace, w których proponuje się "ogląd wzajemny" - kina NRD opisywanego przez autorów z RFN, i vice versa ${ }^{49}$. W odniesieniu do kina RFN przez wiele lat za kanoniczne uchodziły dwie monografie wydane w latach $70 .{ }^{50} \mathrm{~W}$ enerdowskim piśmiennictwie na temat Defy dominowały natomiast publikacje okolicznościowe; obszerniejszy tom poświęcony najważniejszym twórcom i filmom opublikowano dopiero w latach $80 .^{51}$

Prawdziwy rozkwit badań nad tradycją Defy nastąpił dopiero po zjednoczeniu. Podstawowym opracowaniem o filmach kinowych produkowanych w NRD jest albumowa publikacja pod redakcją Ralfa Schenka ${ }^{52}$. O wczesnym okresie istnienia Defy traktuje monografia Christiane Mückenberger i Güntera Jordana ${ }^{53}$. Użyteczne opracowania na temat „antyfaszystowskich" filmów z wschodnich Niemiec wyszły spod pióra Anne Barnert $^{54}$ i Detlefa Kannapina ${ }^{55}$ - w książkach tego ostatniego, wydanych w wydawnictwach powiązanych z Fundacją Róży Luksemburg, miejscami silnie dają o sobie znać przekonania polityczne autora (niezbyt krytycznego wobec enerdowskich źródeł i mylącego niekiedy fakty z ich propagandowym przedstawieniem). Autorzy dwóch innych prac posta-

49 Erefenowska praca o kinie NRD: Heinz Kersten, Das Filmwesen in der Sowjetischen Besatzungszone Deutschlands, Bonn 1963; Film in der DDR, red. Heiko Blum, Hans-Christoph Blumenberg, München-Wien 1977; enerdowska praca o kinie RFN: Erhard Kranz, Filmkunst in der Agonie. Eine Untersuchung zu den staatsmonopolistischen Machtverhältnissen in der westdeutschen Filmwirtschaft, Berlin 1964.

${ }^{50}$ Film in der Bundesrepublik Deutschland, red. Hans Günther Pflaum, Hans Helmut Prinzler, München-Wien 1979 (wiele późniejszych wydań); Klaus Kreimeier, Kino und Filmindustrie in der BRD, Kronberg 1973. Opublikowana w Kolonii w 1990 r. antologia (Filmland DDR: ein Reader zu Geschichte, Funktion und Wirkung der DEFA, red. Harry Blunk, Dirk Jungnickel, Köln 1990) koncentruje się na okresie po 1965 roku.

51 DEFA-Spielfilm-Regisseure und ihre Kritiker, red. Rolf Richter, Berlin (Ost) 1981 i 1983 (dwa tomy); zob. również ciekawą antologię recenzji: Lissy Zilinski, Spielfilme der DEFA im Urteil der Kritik, Berlin (Ost) 1970.

${ }^{52}$ Das zweite Leben der Filmstadt Babelsberg, DEFA-Spielfilme 1946-1992, red. Ralf Schenk, Berlin 1994. Oprócz tej pozycji można wskazać użyteczne kalendarium (Ralf Schenk, Eine kleine Geschichte der DEFA, Berlin 2006) oraz inne tomy zbiorowe: Der geteilte Himmel. Höhepunkte des DEFA-Kinos 1946-1992, red. Helmut Pflügl, Wien 2001; DEFA-Film als nationales Kulturerbe?, red. Klaus Finke, Berlin 2001 (pomijam w tym miejscu liczne publikacje o poszczególnych twórcach czy gatunkach).

${ }^{53}$ Christiane Mückenberger, Günter Jordan, „Sie sehen selbst, Sie hören selbst...”. Eine Geschichte der DEFA von ihren Anfängen bis 1949, Marburg 1994.

${ }^{54}$ Anne Barnert, Die Antifaschismus-Thematik der DEFA. Eine kultur- und filmhistorische Analyse, Marburg 2012.

${ }_{55}$ Detlef Kannapin, Antifaschismus im Film der DDR: DEFA-Spielfilme 1945 bis 1955, Köln 1997; idem, Dialektik der Bilder: der Nationalsozialismus im deutschen Film; ein Ost-West-Vergleich, Berlin 2005. 
wili sobie za cel zbadanie politycznych związków między Defą a partią komunistyczną ${ }^{56}$. Po 1990 r. w języku angielskim ukazała się jedna autorska monografia kina wschodnich Niemiec, uwzględniająca krótki rozdział o filmach "antyfaszystowskich" ${ }^{27}$, a także kilka tomów zbiorowych o różnych aspektach działalności Defy ${ }^{58}$. Ogólnie rzecz biorąc, w piśmiennictwie ostatnich lat kino NRD coraz rzadziej rozpatrywane jest przez pryzmat związków łączących je z innymi kinematografiami dawnego bloku wschodniego. Trendem dominującym jest natomiast włączanie filmów Defy do „ogólnej” historii kina niemieckiego ${ }^{59}$; w języku polskim czyni tak również Andrzej Gwóźdź w rozdziale krakowskiego cyklu „Historia kina $^{\prime \prime 60}$. Natomiast wcześniejsze - tj. wydane przed 1990 r. - polskie prace na temat kinematografii tak NRD (piśmiennictwo w tym zakresie jest stosunkowo skromne ${ }^{61}$ ), jak i RFN (pojedyncze artykuły w prasie filmowej oraz publikacjach "frontu ideologicznego" ${ }^{2}$ ) pełne są upraszczających, politycznie motywowanych ocen.

O filmach odnoszących się do lat III Rzeszy bądź „przepracowywaniu” nazistowskiej przeszłości w kinie niemieckim traktują nieliczne monografie. Wspomniana książka Reichela omawia te zagadnienia zdawkowo ${ }^{63}$ - tytuł jego pracy brzmi: Odnaleziona pamięć: wojna światowa i zagłada Żydów

56 Thomas Heimann, DEFA, Künstler und SED-Kulturpolitik. Zum Verhältnis von Kulturpolitik und Filmproduktion in der SBZ/DDR 1945 bis 1959, Berlin 1994; Dagmar Schittly, Zwischen Regie und Regime. Die Filmpolitik der SED im Spiegel der DEFA-Produktionen, Berlin 2002.

${ }^{57}$ Daniela Berghahn, Hollywood behind the Wall: the Cinema of East Germany, New York 2005. Interesujące spostrzeżenia zawiera też - niestety, zbyt często grawitująca w stronę ryzykownych interpretacji o proweniencji psychoanalityczno-feministycznej - praca Anke Pinkert, Film and Memory in East Germany, Bloomington 2008.

${ }_{58}$ Na przykład: DEFA: East German Cinema, red. Séan Allan, John Sandford, New York 1999; Moving Images of East Germany. Past and Future of DEFA Film, red. Barton Byg, Betheny Moore, Washington 2002.

59 Zob. na przykład: Michael Wedel, Thomas Elsaesser, Einblicke von aussen? Die DEFA, Konrad Wolf und die international Filmgeschichte, [w:] Michael Wedel, Filmgeschichte als Krisengeschichte. Schnitte und Spuren durch den deutschen Film, Bielefeld 2011 (także jako: Defining DEFAs Historical Imaginary: the Films of Konrad Wolf, „New German Critique” 2001, nr 82).

${ }^{60}$ Andrzej Gwóźdź, Powojenne kino niemieckie, [w:] Kino klasyczne. Historia kina, t. II, red. Tadeusz Lubelski, Iwona Sowińska, Rafał Syska, Kraków 2012.

${ }^{61} \mathrm{~W}$ połowie lat 50. ukazała się, napisana w duchu stalinowskim, broszura na temat „bratniej kinematografii” (Irena Merz, O filmie niemieckim, Warszawa 1954). Kolejną publikację książkową wydano dopiero niemal 40 lat później (Leon Bukowiecki, Film NRD w Polsce, Warszawa 1982) - zawiera ona cenny szkic historyczny i wykaz dystrybuowanych w Polsce filmów Defy wraz ze streszczeniami.

${ }^{62}$ Najobszerniejszą znaną mi publikacją tego rodzaju jest rozdział Miłość do Wehrmachtu z broszury Janusza Skwary Film zachodni a polityka (Warszawa 1970), opublikowanej przez Wydawnictwo Ministerstwa Obrony Narodowej.

${ }^{63}$ Peter Reichel, Erfundene Erinnerung...; podobny charakter ma przeglądowy artykuł: Georg Seeßlen, Faschismus, Krieg und Holocaust im deutschen Nachkriegsfilm, [w:] apropos: Film 2000. Das Jahrbuch der DEFA-Stiftung, red. Ralf Schenk, Erika Richter, Berlin 2000. 
$w$ filmie $i$ teatrze, przy czym autor więcej miejsca poświęca teatrowi oraz słabo operuje narzędziami właściwymi akademickiej refleksji nad filmem (Reichel, podobnie jak wielu historyków, utyskuje na "trywializację" historii przez kino i niezgodność fabuł z faktami historycznymi). Ponadto należy wymienić pracę katalogującą filmy o tematyce nazistowskiej nakręcone do $1955 \mathrm{r}^{64}{ }^{64}$ a także publikacje peryferyjne: dziewięćdziesięciostronicowy katalog, wydany w 1975 r. w RFN ${ }^{65}$ oraz filmografię opublikowaną dziesięć lat później w NRD ${ }^{66}$. Inne, nieco mniej wartościowe omówienia koncentrują się na filmach powstałych w ciągu pierwszych kilku lat od zakończenia wojny ${ }^{67}$. Wydana $\mathrm{w}$ języku angielskim książka katalogująca niemieckojęzyczne (również austriackie) filmy o nazizmie ${ }^{68}$ ma wątpliwą wartość naukową (proponowane w niej zestawienie jest niepełne i zawiera sporo błędów rzeczowych). Kilka prac dotyczy filmowych rozrachunków z przeszłością $\mathrm{w}$ kinie niemieckim lat $70 .{ }^{69}$ Zważywszy na popularność tematyki historycznej we współczesnym kinie niemieckim, nie dziwi istne zatrzęsienie akademickich analiz dotyczących filmów zrealizowanych po $1990 \mathrm{r}^{70}$; opublikowano także kilka tomów o charakterze bliższym krytyce czy eseistyce ${ }^{71}$. Osobną uwagę należy poświęcić wydanej niedawno mo-

${ }^{64}$ Wolfgang Becker, Norbert Schöll, In jenen Tagen... Wie der deutsche Nachkriegsfilm die Vergangenheit bewältigte, Opladen 1995.

${ }^{65}$ Heiko R. Blum, 30 Jahre danach. Dokumentation zur Auseinandersetzung mit dem Nationalsozialismus im Film 1945 bis 1975, Köln 1975.

${ }^{66}$ Das Thema "Antifaschismus" in Filmen der DDR für Kino und Fernsehen. Auswahlfilmographie 1946-1984, Berlin 1985. Po zjednoczeniu w tomie zbiorowym ukazał się krótki rozdział o tematyce antyfaszystowskiej w kinie NRD: Wolfgang Becker, Antifaschismus in den DEFA-Spielfilmen, [w:] Das geteilte Himmel, t. 2, red. Helmut Pflügl, Wien 2001.

${ }^{67}$ Irmgard Wilharm, Bewegte Spuren. Studien zur Zeitgeschichte im Film, Hannover 2006.

${ }^{68}$ Robert C. Reimer, Carol J. Reimer, Nazi-retro Film. How German Narrative Cinema Remembers the Past, New York 1992.

69 Anton Kaes, Deutschlandbilder. Die Wiederkehr der Geschichte als Film, München 1987 (wersja angielska: From Hitler to Heimat. The Return of German History as Film, Harvard 1989); Thomas Elsaesser, New German Cinema: A History, New Jersey 1989 (wydanie niemieckie: Der Neue Deutsche Film, München 1994). Także: Eric L. Santner, Stranded Objects: Mourning, Memory, and Film in Postwar Germany, London-New York 1990.

${ }^{70}$ Na przykład w zbiorach: Der Holocaust im Film: mediale Inszenierung und kulturelles Gedächtnis, red. Waltraud „Wara” Wende, Heidelberg 2007; Das Böse im Blick. Die Gegenwart des Nationalsozialismus im Film, red. Margrit Frölich, Christian Schneider, Karsten Visarius, München 2007.

${ }^{71}$ Myślę na przykład o publikacjach Georga Seeßlena (Das zweite Leben des „Dritten Reichs", Berlin 2013; Faschismus in der populären Kultur, Berlin 1994) czy Dietricha Kuhlbrodta (Deutsches Filmwunder: Nazis immer besser, Hamburg 2006). Ten ostatni - w latach 60. prokurator ścigający zbrodnie nazistowskie, później współpracownik lewackiego pisma "Konkret”, a jako aktor i muzyk związany z wieloma przedsięwzięciami zachodniomieckiego undergroundu - od wielu lat z pasją tropi popkulturowe inkarnacje „fabuł ze swastyką w tle" (zob. http://www.filmzentrale.com/kuhlbrodtkritiken.htm, dostęp: 30.06.2013). 
nografii, której sam tytuł - Narodowy socjalizm w kinie. Od „Triumfu woli” do "Bękartów wojny" - zdradza olbrzymi zakres materiału, jaki zapragnęła omówić autorka ${ }^{72}$. Zamysł ten powiódł się tylko częściowo, co zdradza już kompozycja tomu: połowa monografii dotyczy filmów powstałych po zjednoczeniu Niemiec, natomiast w pierwszych rozdziałach uwzględniono również filmy zrealizowane w okresie III Rzeszy.

Problem reprezentacji nazistowskiej historii $\mathrm{w}$ kinie niemieckim był rzadko analizowany również przez polską humanistykę, przy czym tylko nieliczne publikacje poruszają wybrany aspekt interesujących mnie zagadnien' ${ }^{73}$. Jedyną pracą zwartą jest wydana niedawno monografia autorstwa Joanny Trajman o niemieckim kinie współczesnym ${ }^{74}$; poświęcona mu książka Ewy Fiuk zawiera zaś rozdział o filmach podejmujących temat nazistowskiej przeszłości ${ }^{75}$. Z kolei wątki dotyczące problematyki rozliczeniowej $\mathrm{w}$ kinie niemieckim pierwszych lat po wojnie pojawiają się w pracy Magdaleny Saryusz-Wolskiej ${ }^{76}$. Stan badań w zakresie interesującego mnie okresu kina niemieckiego jest zatem zaskakująco skromny ${ }^{77}$; ambicją niniejszej książki - dla której wymienione pozycje stanowią istotny punkt odniesienia - będzie tę lukę w satysfakcjonujący sposób wypełnić.

\section{Kompozycja książki - periodyzacja i problematyzacja}

Stanąwszy przed dylematem, w jaki sposób podzielić analizowany materiał, posiłkuję się z jednej strony periodyzacją wynikającą z historii politycznej, z drugiej zaś - przemian kultury filmowej. W obu wypadkach konieczne było przy tym uwzględnienie odmiennych trajektorii rozwojowych w obu państwach niemieckich.

Autorzy prac dotyczących przekształceń zachodnioniemieckiej pamięci o narodowym socjalizmie wskazują rozmaite Wendepunkte, które

72 Sonja M. Schultz, Der Nationalsozialismus im Film: Von "Triumph des Willens" bis "Inglorious Bastards", München 2012.

${ }^{73}$ Bartosz Korzeniewski, Filmowe zapośredniczenia niemieckiej pamięci o II wojnie światowej, [w:] Przemiany pamięci społecznej a teoria kultury, red. Bartosz Korzeniewski, Poznań 2007 oraz niektóre artykuły w zbiorze: Kino niemieckie w dialogu pokoleń $i$ kultur, red. Andrzej Gwóźdź, Kraków 2004.

${ }^{74}$ Joanna Trajman, Narodowy socjalizm w kinie zjednoczonych Niemiec, Wrocław 2014. Monografia zawiera wprowadzenie historyczne dotyczące okresu do $1990 \mathrm{r}$.

${ }^{75}$ Ewa Fiuk, Inicjacje, tożsamość, pamięć...

${ }^{76}$ Magdalena Saryusz-Wolska, Ikony normalizacji...

77 Cennym, zawierającym tłumaczenia kilkunastu recenzji niektórych interesujących mnie filmów jest opracowanie okolicznościowe Obrazy Niemiec 1949-1999. Katalog przegladu, red. Grażyna M. Grabowska, Renata Prokurat, Warszawa 1999. 
wpłynęły na jej przemiany (zastrzegając zazwyczaj, iż pamięć ta nie była nigdy homogeniczna; tym samym nie można mówić o radykalnych zmianach - raczej o wzmocnieniu lub słabnięciu istniejących wcześniej dyskursów, ich rozmaitych natężeniach oraz przenikaniach). I tak, Helmut Dubiel wybiera salomonowe rozwiązanie - omawia transformację dyskursów pamięci (na przykładzie debat Bundestagu), obierając za kryterium kompozycyjne po prostu kolejne dekady ${ }^{78}$. Dla Norberta Freia lata 50. najbardziej zasadnie byłoby określić jako czas „polityki wobec przeszłości” (Vergangenheitspolitik ${ }^{79}$, natomiast w odniesieniu do dwóch kolejnych dekad należałoby mówić o „właściwym” Vergangenheitsbewältigung, czyli „przezwyciężaniu przeszłości" ${ }^{80}$. Klaus von Schilling wskazuje cztery fazy, których punkty przełomowe stanowiłyby lata: 1949, 1966 (zmiana koalicji oraz rewolta studencka) oraz 1985 (nowa polityka historyczna gabinetu Helmuta Kohla i tzw. spór historyków) ${ }^{81}$. Helmut König również wyróżnia cztery okresy, ale o nieco innych granicach ${ }^{82}$ : 1) do 1949 r.; 2) lata 50.; 3) długi okres lat 1960-1990; 4) okres po zjednoczeniu. Z kolei Jörn Rüssen, pisząc o pamięci Niemców o Holocauście, wyodrębnia trzy okresy: 1) do końca lat 60. (wyparcie, przemilczenie i „eksterytorializacja”); 2) od końca lat 60. do zjednoczenia; 3) po 1990 r. (uhistorycznienie i przyswojenie) ${ }^{83}$. Podobną formułę wybiera Aleida Assmann ${ }^{84}$, która dzieli powojenną ",historię pamięci” w Niemczech na trzy części: 1) do 1958 r. („,polityczna deklaratywność", ,zmowa milczenia”, polityka amnestii); 2) lata 1958-1984 (za ważne zjawiska tego okresu uważa podjęcie badań naukowych i projekty edukacyjne dotyczące lat nazizmu oraz debaty na temat przedawnienia); 3) od II połowy lat 80. („uniwersalizacja Holocaustu”, ,nacjonalizacja pamięci", polityka pomnikowa, obchody rocznicowe itp). Jeszcze inny autor w swej rekonstrukcji Vergangenheitsbewältigung wskazuje sześć okresów ${ }^{85}$ : 1945-1949, 1949-1959, 1959-1965, 1965-1979, 1979-1985, po 1985.

${ }^{78}$ Helmut Dubiel, Niemand ist frei von der Geschichte...

79 Wyróżnikiem tego okresu byliby jego faktycznie beneficjenci - „to nie ofiary narodowego socjalizmu były jej adresatem, lecz - mówiąc najogólniej - »ofiary « jego przezwyciężania" (Norbert Frei, Polityka wobec przeszłości..., s. 11).

${ }^{80}$ Norbert Frei, 1945 und wir..., s. 26.

${ }^{81}$ Klaus von Schilling, Scheitern an der Vergangenheit, Berlin 2002 (zwłaszcza s. 77-214).

${ }^{82}$ Helmut König, Die Zukunft der Vergangenheit: Der Nationalsozialismus im politischen Bewusstsein der Bundesrepublik, Frankfurt am Main 2003.

${ }^{83}$ Jörn Rüsen, Pamięć o Holokauście a tożsamość niemiecka, tłum. P. Przybyła, M. Saryusz-Wolska, [w:] Pamięć zbiorowa i kulturowa...

${ }^{84}$ Aleida Assmann, Osobiste wspomnienia i pamięć zbiorowa w Niemczech po 1945 roku, tłum. A. Teperek, [w:] eadem, Między historia a pamięcia...

${ }_{85}$ Andreas Wöll, Vergangenheitsbewältigung in der Gesellschaftsgeschichte der Bundesrepublik. Zur Konfliktlogik eines Streitthemas, [w:] Vergangenheitsbewältigung. Modelle der politischen und sozialem Integration in der bundesdeutschen Nachkriegsgeschichte, red. Andreas Wöll, Gary Schaal, Baden-Baden 1997. 
Autorzy większości przywołanych periodyzacji są zgodni co do tego, że zasadne jest wyróżnienie jako osobnego okresu lat 1945-1949, a zatem czasu, gdy terytoria niemieckie (w nowych granicach ustalonych przez konferencje pokojowe) pozostawały pod kuratelą państw alianckich, a pamięć o niedawnych wydarzeniach była zdominowana przez procesy norymberskie oraz prawodawstwo denazyfikacyjne. Propozycja uznania przełomu lat 1958/1959 za punkt demarkacyjny wiąże się z głośnym procesem przeciw członkom tzw. Einsatzgruppen w Ulm, powołaniem instytucji do ścigania zbrodni nazistowskich (tzw. Zentrale Stelle w Ludwigsburgu) oraz ekscesami antysemickimi, w wyniku których wprowadzono przepisy umożliwiające ściganie podobnych wybryków (tzw. Volksverhetzungparagraphen) ${ }^{86}$. Rzetelność naukowa wymaga, by przytoczyć te periodyzacje, jednak zachowanie podobnego podziału wiązałoby się z koniecznością wprowadzenia dodatkowej gradacji do kolejnych rozdziałów, co zaburzyłoby strukturę książki i znacznie zwiększyło jej objętość.

Z kolei w Niemieckiej Republice Demokratycznej, podobnie jak w innych krajach bloku wschodniego, twórczość artystyczna i życie kulturalne były reglamentowane w rytm kolejnych "odwilży” i "przymrozków” (niem. Frostperiode), wywoływanych przez okoliczności zewnętrzne (polityka ZSRR) i wewnętrzne (tarcia pomiędzy frakcjami SED). Kluczowe wydarzenia polityczne tego okresu - stłumienie rebelii robotników we wschodniej części Berlina w czerwcu 1953 r., referat Chruszczowa o zbrodniach stalinowskich trzy lata później czy budowa muru berlińskiego latem 1961 r. - mogłyby zostać uznane za punkty podziału historii NRD, ale dla niniejszej książki mają znaczenie drugorzędne. O kilku ważnych dla kultury filmowej decyzjach SED (Sozialistische Einheitspartei Deutschlands - Niemieckiej Socjalistycznej Partii Jedności) wspominam w rozdziale poświęconym NRD. W tym miejscu trzeba podkreślić znaczenie XI Plenum Komitetu Centralnego SED, kiedy to przypuszczony został atak na rzekomo „niepokornych” twórców - skutkiem czego na półki trafiła niemal cała roczna produkcja Defy ${ }^{87}$.

O ile wskazanie wydarzenia szczególnie istotnego dla periodyzacji historii kina enerdowskiego nie budzi większych wątpliwości (jest nim wspomniane XI plenum z 1965 r.), o tyle nieco problemów nastręcza podobna próba w odniesieniu do kinematografii zachodnioniemieckiej. Dużą rangę nadaje się „manifestowi z Oberhausen”, ogłoszonemu podczas

${ }^{86}$ Peter Reichel, Vergangenheitsbewältigung in Deutschland..., s. 147.

87 Kahlschlag. Das 11. Plenum des ZK der SED 1965. Studien und Dokumente, red. Günther Agde, Berlin 1999. Zob. też: Xavier Carpentier-Tanguy, Die Maske und der Spiegel. Zum XI. Plenum der SED 1965, [w:] DEFA-Film als nationales Kulturerbe?, red. Klaus Finke, Berlin 2001. 
festiwalu filmów krótkometrażowych w lutym 1962 r. i postrzeganemu jako początek formacji Nowego Kina Niemieckiego. Trzeba jednak pamiętać, że pierwsze ważne pełnometrażowe filmy autorów zaliczanych do tej grupy $^{88}$ trafiły do kin dopiero w 1965 i 1966 r. Ponadto, właśnie wtedy w zachodnioniemieckiej kinematografii doszło do zmian instytucjonalnych - za sprawą powołania instytucji wspierających twórców młodszego pokolenia - Kuratorium Młodego Kina Niemieckiego (Kuratorium Junger Deutscher Film). Z tych właśnie powodów uznałem za uzasadnione przesunięcie granicy wskazującej faktyczny przełom z 1962 na 1965 r. Zreszta, podobną decyzję podjęli eksperci z Deutsches Filmmuseum/Deutsches Filminstitut (Frankfurt nad Menem), którzy w zestawieniu zatytułowanym Najważniejsze niemieckie filmy, opublikowanym na - skądinąd bardzo użytecznej - stronie www.filmportal.de, podzielili historię swej narodowej kinematografii w zbliżony sposób: w dziale opatrzonym nagłówkiem „1946-1964” znalazło się dwadzieścia filmów (w tej liczbie: sześć z okresu do 1949 r. i pięć nakręconych w NRD) ${ }^{89}$.

Niniejsza książka składa się z trzech obszernych rozdziałów. Pierwszy z nich poświęcony jest filmom zrealizowanym od zakończenia wojny do powstania dwóch państw niemieckich w 1949 r. Rozdział drugi dotyczy filmów wyprodukowanych w Niemieckiej Republice Demokratycznej; w trzecim zaś omawiam filmy zachodnioniemieckie, powstałe od lat 50. do połowy lat 60 . Każdy z rozdziałów zawiera krótkie wprowadzenie historyczne; jego funkcja będzie polegać przede wszystkim na zarysowaniu kontekstów społecznych i politycznych, decydujących o charakte-

${ }^{88}$ Chodzi o filmy: Niepogodzeni, albo: Tylko przemoc pomaga tam, gdzie rzadzi przemoc (Nicht Versöhnt, oder Es hilft nur Gewalt, wo Gewalt herrscht, reż. Danièle Huillet, Jean-Marie Straub, RFN 1965), Pożegnanie z dniem wczorajszym (Abschied von Gestern, reż. Alexander Kluge, RFN 1966) i Niepokoje wychowanka Törlessa (Der junge Törless, reż. Volker Schlöndorff, RFN 1966).

${ }^{89}$ Zob. http://www.filmportal.de/thema/die-wichtigsten-deutschen-filme-chronologische-uebersicht (dostęp: 30.03.2013). Na liście tej znalazło się trzynaście filmów związanych z tematyką rozliczeniową: Mordercy sa wśród nas (Mörder sind unter uns, reż. Wolfgang Staudte, Niemcy 1946), W tamtych dniach (In jenen Tagen, reż. Helmut Käutner, Niemcy 1947), Małżeństwo w mroku (Ehe im Schatten, reż. Kurt Maetzig, Niemcy 1947), Niemcy, rok zerowy (Germania - anno zero, reż. Roberto Rossellini, Włochy/Niemcy 1948 - prem. we Włoszech/1952 - prem. w RFN), Berlińska ballada (Berliner Ballade, reż. Robert A. Stemmle, Niemcy 1948), Rotacja/Brunatna pajęczyna (Rotation, reż. Wolfgang Staudte, Niemcy 1949), Zagubiony (Der Verlorene, reż. Peter Lorre, RFN 1951), Poddany (Der Untertan, reż. Wolfgang Staudte, NRD 1951), Noca, kiedy przychodzit diabet (Nachts, wenn der Teufel kam, reż. Robert Siodmak, RFN 1957), W czepku urodzeni (Wir Wunderkinder, reż. Kurt Hoffmann, RFN 1958), Gwiazdy (Sterne, reż. Konrad Wolf, NRD 1959), Most (Die Brücke, reż. Bernhard Wicki, RFN 1959) oraz Róże dla prokuratora (Rosen für die Staatsanwald, reż. Wolfgang Staudte, RFN 1959). 
rystycznych dla danego okresu/miejsca formach oficjalnej pamięci (akty prawne, gesty polityczne, praktyki komemoracyjne itd.), jak również na zaprezentowaniu tych fenomenów artystycznych (literackich, teatralnych, plastycznych i muzycznych), które z owymi „aktami pamięci” współgrały bądź się im przeciwstawiały.

Filmy omawiane w kolejnych podrozdziałach pogrupowane zostały według klucza problemowego. Rzut oka na spis treści wystarczy, by dostrzec, że w obrębie rozdziału drugiego i trzeciego znalazły się te same zagadnienia; wykorzystanie identycznej struktury także $\mathrm{w}$ rozdziale pierwszym było jednak niemożliwe (mógłbym to uczynić za cenę retorycznego „nagięcia” interpretacji, co byłoby jednak nadużyciem wobec przedmiotu pracy, czyli samych filmów, które i tak nierzadko wymykają się zaszeregowaniu do jednego, konkretnego porządku). Niemniej jednak, we wszystkich trzech przypadkach te same nagłówki - Problem antysemityzmu oraz Obrazy obozów - mają dwa ostatnie podrozdziały (oddzielenie tych zagadnień w strukturze całości wynika $\mathrm{z}$ materii analizowanego zjawiska, bowiem niemieckie filmy o tematyce obozowej, zresztą stosunkowo nieliczne, tylko niekiedy wiązały ją z Zagładą $\left.{ }^{90}\right)$. Ponadto, w rozdziale drugim i trzecim Czytelnik odnajdzie podrozdziały o niemieckim ruchu oporu i wizerunkach Wehrmachtu (w wypadku kina RFN są to zagadnienia ściśle ze sobą powiązane), problemach związanych z polityką zimnej wojny, a zatem o sposobie rzutowania okresu nazistowskiego na ówczesnych sojuszników i wrogów obu państw niemieckich (ograniczam się przy tym do wskazania "opowieści rosyjskich" w kinie RFN oraz filmów o zachodnim sąsiedzie - w kinie NRD), wreszcie podrozdział zatytułowany „Kraj po denazyfikacji”, w którym przedstawiam wybrane filmy prezentujące swoisty "autoportret" rozliczeń z brunatną przeszłością w NRD i RFN. Taka struktura wywodu umożliwia też lekturę nielinearną (w rozumieniu: wybierającą konkretny temat i jego aktualizacje, omawiane w poszczególnych rozdziałach). W podsumowaniu podejmuję próbę oglądu komparatystycznego, ukierunkowanego problemowo, a także krótko prezentuję dalsze losy zmagań z nazistowską przeszłością w niemieckich filmach fabularnych.

90 Używam pojęć „Zagłada”, „Holocaust” i (rzadziej) „Shoah” synonimicznie, mając świadomość pewnych różnic semantycznych między nimi oraz uwikłania w konteksty religijne i polityczne (na ten temat zob. Monika Adamczyk-Garbowska, Henryk Duda, Terminy "Holokaust”, "Zagłada" i "Szoa" oraz ich konotacje leksykalno-kulturowe w polszczyźnie potocznej i dyskursie naukowym, [w:] Żydzi i judaizm we wspótczesnych badaniach polskich, red. Krzysztof Pilarczyk, Kraków 2003). 


\section{Metodologia wywodu - tekst filmowy i świadectwa recepcji}

Ponieważ uznaję filmy za ważne świadectwa społecznych przemian, modelowanych zarówno przez dyskurs polityczny (debaty, ustawodawstwo, jurysdykcja, praktyki komemoracyjne itp.), jak i teksty kultury (zwłaszcza literaturę i teatr), metodę postępowania badawczego określam jako analizę kontekstualną. W interpretacjach poszczególnych dzieł - lub ich skrótowych omówieniach (ze względu na przyjętą formułę faworyzującą ogląd "panoramiczny”) - szczególną uwagę zwracam na kwestie dramaturgiczne: motywacje postaci pierwszo- i drugoplanowych, fabularne (i dyskursywne) konflikty, funkcje zakończenia itp. W mniejszym stopniu akcentuję zagadnienia związane ze stylem wizualnym omawianych filmów. Owszem, są wśród nich takie, które wyróżniają się pod tym właśnie względem, ale - jak sądzę - w odniesieniu do tematu książki „klucz stylistyczny" nie powinien przesłaniać kontekstualnych uwikłań poszczególnych filmów. Z tego samego powodu niewiele miejsca poświęcam na przykład autorskim idiomom - gdybym przyjął ten model oglądu, najpewniej skomentowałbym obszerniej twórczość Wolfganga Staudtego czy Konrada Wolfa, lecz nie mógłbym wówczas uwzględnić wielu innych ważnych filmów.

Kuszącą perspektywą interpretacji niektórych filmów o tematyce historycznej - biograficznych bądź będących fikcjonalizacjami wydarzeń autentycznych - jest (nazwijmy ją roboczo) "analiza faktograficzna", polegająca na weryfikacji fabuły przez pryzmat wiedzy historycznej w celu sprawdzenia wiarygodności komunikatu (przedmiotem namysłu byłby przede wszystkim stopień zgodności materiału fabularnego ze stanem badań naukowych). W tym przypadku ustalenia dokonywane przez historyków mogą pełnić - zarówno w procesie kreacji, jak i odbioru - funkcję „posiłkową"; podobna relacja zachodzi między utworami literackimi oraz ich ekranizacjami czy remake'ami oraz filmami będącymi ich pierwowzorami.

W odniesieniu do tego rodzaju komunikatów mamy do czynienia ze szczególnym rodzajem relacji pomiędzy nimi a widownią. Można bowiem domniemywać, że przynajmniej pewna część widzów (zależna przede wszystkim od zasobu ich wiedzy, która z kolei warunkowana jest przez poziom wykształcenia, ale też wiek czy kraj pochodzenia) zna „materiał prymarny”, czyli wie, jak „potoczy się" przedstawiona historia, a odstępstwa od tej wyobrażonej narracji będzie odbierać z zaskoczeniem (często bywa ono uzupełniane przez emocje negatywne: rozczarowanie, przeświadczenie o „zdradzie” pierwowzoru itp.). „Faktograficzny” tryb analizy - możliwy i zależny od wiedzy pozafilmowej widza oraz paratekstów (a więc zewnętrznych informacji okalających filmowy tekst) - za- 
demonstrowałem $\mathrm{w}$ innym miejscu (w odniesieniu do filmów o Sophie Scholl z lat $80 .{ }^{91}$ ). Nie zostanie on wykorzystany w niniejszej książce - jeśli wśród omawianych filmów znajdą się takie, które opowiadają o autentycznej postaci lub faktycznych wydarzeniach, kontekst badań faktograficznych (a zatem także zgodność fabuł z ustaleniami historyków) będzie mnie interesował jedynie w ograniczonym stopniu.

Jak już wspomniałem, podzielam opinię, iż film o tematyce historycznej (bez względu na to, czy mamy do czynienia z fabularyzacją autentycznych wydarzeń, czy z „,czystą fikcją" osadzoną w realiach przeszłości) mówi więcej o czasie swego powstania niż o przeszłości, o której traktuje fabuła. Jak każdy komunikat, również film może ujawniać napięcia w dyskursie społecznym właściwym dla czasu jego realizacji. W przypadku fabuł o tematyce historycznej jest to szczególnie ważne $\mathrm{z}$ uwagi na ich częste uwikłanie w bieżącą politykę (historyczną). Dlatego w procesie interpretacyjnym istotne są swego rodzaju "szczeliny” w narracji filmowej, "pęknięcia” i niespójności, mimowolnie odsłaniające motywacje twórców i dostarczające potencjalnych dowodów na to, jak na tekst wpływała współczesna im polityczna rzeczywistość $c^{92}$. Wspominam o tych - wydawałoby się: elementarnych - kwestiach, gdyż niektóre z obserwacji czynionych w dalszej części wywodu mogą wydać się nadinterpretacja, w rozumieniu wniosków ahistorycznych, osadzonych w realiach dzisiejszego dyskursu. Tymczasem $\mathrm{w}$ procesie interpretacji są one w pełni dopuszczalne, by nie rzec: najistotniejsze. Zawsze interpretujemy bowiem „z dzisiejszego punktu widzenia", co nie oznacza, że nie można (twierdzę wręcz, że należy) uwzględnić okoliczności rzutujących na produkcję oraz odczytania tekstu w momencie jego powstania.

Wśród kontekstów instytucjonalnych jedynie w niewielkim stopniu (ograniczonym do podstawowych kwestii związanych ze scenariuszem) uwzględniam zagadnienia produkcyjne. Niewątpliwie monografia tego samego tematu napisana na podstawie zachowanych materiałów produkcyjnych i dystrybucyjnych byłaby niezmiernie interesująca; tego rodzaju analizy szczególnie ważne mogą okazać się zwłaszcza w odniesieniu do systemów kinematograficznych charakteryzujących się wysokim stopniem centralizacji bądź/oraz dużym udziałem publicznych funduszy, które wspierają wytwarzanie tekstów kultury ukierunkowanych na modelowanie opinii publicznej (polityka historyczna). Wypada żywić nadzieję, że wysiłek taki podejmą badacze znad Szprewy, mający stały dostęp do niemieckich archiwów. O tym, jak trudne i żmudne to zadanie,

${ }^{91}$ Konrad Klejsa, Pamięć o rodzeństwie Scholl w filmach Michaela Verhoevena i Percy'ego Adlona-konteksty i interpretacje, „Człowiek i Społeczeństwo” 2012, nr 34.

92 Marc Ferro, Film. Kontranaliza społeczeństwa, tłum. A. Karpowicz, [w:] Film i historia... 
przekonałem się podczas kwerend w Archiwum Artura Braunera we Frankfurcie. Powstałe na tej bazie (oraz na podstawie analiz niemieckich autorów), lecz opublikowane $\mathrm{w}$ innym miejscu ${ }^{93}$ opracowanie dotyczące filmów o Stauffenbergu z lat 50. tylko w pewnym fragmencie, odnoszącym się do zagadnień dramaturgicznych, uwzględniłem w maszynopisie niniejszej książki (pozostawienie obszernej partii tekstu dotyczącej kwestii produkcyjnych zaburzyłoby koherentność wywodu).

Przytaczam natomiast wyimki z recenzji filmowych oraz publikacji krytycznych (jeśli nie zaznaczono inaczej, cytaty z piśmiennictwa angloi niemieckojęzycznego podaję w przekładzie własnym). Nieocenioną pomocą były dla mnie skoroszyty i mikrofilmy ze zbiorów Deutsches Filmmuseum/Deutsches Filminstitut (a także internetowe archiwa niektórych wydawnictw prasowych, zwłaszcza „Der Spiegel” czy „Die Zeit”). Zawierają one materiał daleko bogatszy niż ten, który przedstawiam w przypisach; przywołuję bowiem jedynie teksty zamieszczane w najważniejszych zachodnioniemieckich tygodnikach („Der Spiegel”, „Die Zeit”, "Rhenischer Merkur"), dziennikach („Die Welt”, ,FAZ”, ,Süddeutsche Zeitung”, „Die Tageszeitung”, "Frankfurter Rundschau”) i prasie fachowej („epdFilm", , film-dienst”, ,Filmkritik"). Natomiast w odniesieniu do NRD najczęściej posiłkuję się opiniami z organu prasowego SED („Neues Deutschland" - archiwalne numery dostępne są online); są one szczególnie istotne, ponieważ pokazuja w jaki sposób propaganda profilowała pożądany odbiór filmu. Niekiedy przywołuję także wyimki z innych czasopism - w wypadku NRD: "Film und Fernsehen”, "Neue Film-Welt” (od 1954 r. - „Filmspiegel”) czy pismo o bardziej akademickim profilu: „Deutsche Filmkunst” (wydawane w okresie 1953-1962).

Istotnym kryterium były również rozpoznawalność i renoma krytyka. W RFN uznaniem cieszyli się m.in. Frieda Grafe, Karena Niehoff, Gunter Groll czy Enno Patalas, natomiast w wypadku piśmiennictwa filmowego NRD szczególną uwagę warto poświęcić (mając oczywiście świadomość ograniczeń, jakim poddana była debata publiczna w tym kraju) materiałom sygnowanym przez Horsta Knietzscha, Hartmuta Albrechta czy Freda Gehlera. Sporadycznie wspominam o recepcji filmów enerdowskich w RFN i erefenowskich w NRD - właściwe opracowanie tego tematu wymagałoby osobnej książki. Zresztą, niemieckie filmy o nazistowskiej przeszłości (lub braku jej rozliczeń) rzadko przekraczały granicę pomiędzy NRD i RFN (a jeśli tak się zdarzało, to z istotnym opóźnieniem). Zarazem warto pamiętać, że do powstania muru berlińskiego mieszkańcy

${ }_{93}$ Konrad Klejsa, Co wydarzyło się 40 lipca? Pierwsze filmowe opowieści o Clausie von Stauffenbergu i ich filmowe konteksty, [w:] Historia w kulturze współczesnej. Niekonwencjonalne podejścia do przeszłości, red. Mariusz Mazur, Ewa Solska, Piotr Witek, Lublin 2011. 
tego miasta mieli możliwość oglądania filmów w kinach obu jego części (w zachodnioberlińskiej prasie ukazywały się recenzje produkcji Defy, natomiast $\mathrm{w}$ prasie enerdowskiej tylko niekiedy wspominano o filmach erefenowskich, zazwyczaj bardzo krytycznie). Nie interesuje mnie natomiast recepcja prasowa $\mathrm{w}$ innych krajach (sporadycznie wzmiankuję recenzje filmów dystrybuowanych w polskich kinach ${ }^{94}$ ). Mając świadomość, że publikacje prasowe nie mogą być świadectwem faktycznej recepcji widzów, wspominam (tam, gdzie możliwe było zrekonstruowanie takich danych) o popularności filmu oraz o kulturowych „markerach” obiegu, takich jak festiwale filmowe. Co do zasady, ograniczałem się do informacji o, nielicznych zreszta, nagrodach uzyskanych przez niemieckie filmy na trzech największych festiwalach (Cannes, Wenecja, Berlin), niekiedy tylko napomykając o innych.

Materiał ilustracyjny wybrany dla dopełnienia głównej części wywodu stanowią cytaty wizualne $\mathrm{z}$ omawianych filmów. Z powodów czysto praktycznych (również natury finansowej) zrezygnowano z przedrukowywania programów filmowych, werków, fotosów czy plakatów - zwłaszcza te ostatnie są ważnym świadectwem profilowania recepcji (nie tylko w wymiarze stricte marketingowo-promocyjnym). Na szczęście bez trudu można się z nimi zapoznać na wspomnianym już portalu prowadzonym przez Deutsches Filmmuseum/Deutsches Filminstitut (za którym przy tytułach filmów podaję rok premiery).

W toku wywodu sporadycznie wzmiankuję także losy tych twórców filmowych, którzy byli aktywni zawodowo w okresie III Rzeszy. W odniesieniu do pierwszych lat powojennych chodzi w istocie o zdecydowaną większość reżyserów, autorów zdjęć, muzyki filmowej i scenografii - co nie oznacza, że wszyscy oni pracowali wcześniej przy filmach propagandowych (zreszta, w kinie niemieckim lat 1933-1945 dominowały produkcje stricte rozrywkowe i tylko niektóre z nich można uznać za promujące narodowosocjalistyczny światopogląd). Do biografii twórców nie przykładam jednak szczególnej wagi, choć w niektórych wypadkach (właśnie odnoszących się do produkcji z lat nazistowskiej propagandy) nie są one całkiem bez znaczenia. $W$ każdym razie, jeśli wspominam o tych kontekstach, czynię to raczej na marginesie wywodu lub w przypisach.

Ostatniewyjaśnieniezwiązanejestzużyciemsłów:„,Niemcy”/,naziści” oraz „niemiecki”/,nazistowski”. Poprawność naukowa, nie polityczna, skłania do użycia tego drugiego terminu - zgodnie z wątpliwościami

${ }_{94}$ Oczywiście, przeważały wśród nich filmy enerdowskie - zob. Piotr Zwierzchowski, Recepcja kinematografii NRD w polskim piśmiennictwie filmowym 1949-1990, [w:] W drodze do sasiada. Polsko-niemieckie spotkania filmowe, red. Andrzej Gwóźdź, Andrzej Dębski, Wrocław 2013. 
wyrażonymi wkrótce po zakończeniu wojny przez Hannah Arendt (wskazującą na ryzyko powtórzenia „hitlerowskiej strategii politycznej: że nie ma różnicy między hitlerowcami a Niemcami" ${ }^{95}$ ), ale też z implikacjami logiki, czyli tzw. błędem wielkiego kwantyfikatora. Zarazem jednak - szkoda, że w dzisiejszym dyskursie należy podkreślać tak oczywiste, zdawałoby się, sądy! - kwestią nie ulegającą wątpliwości jest odpowiedzialność, jaką za zbrodnie nazizmu i wybuch wojny ponosi państwo niemieckie, w którym narodowosocjalistyczna polityka była prowadzona przy entuzjastycznej czy choćby milczącej zgodzie większości obywateli. Przyjmuję zatem zdroworozsądkowy tryb doboru pojęć: jeśli piszę „naziści”, nie oznacza to w żadnym razie, że usiłuję "zatrzeć" niemiecki charakter narodowego socjalizmu; jeżeli zaś będę używać kwalifikatorów: „Niemiec", „Niemcy”, „niemiecki” itp. - będzie to uzasadnione bądź jednoznacznymi danymi tekstualnymi (np. charakterystyką postaci w danym filmie), bądź względami czysto stylistycznymi (tj. uniknięciem powtórzeń).

Z powyższą uwagą związana jest konkluzja niniejszego wprowadzenia. Niewątpliwie, na polsko-niemieckich relacjach niekiedy nadal kładą się cieniem wzajemne uprzedzenia i stereotypy, które wynikają z doświadczeń historii - ale także, jak przypuszczam, ze słabości kulturowego transferu. Wyrażam zatem nadzieję, iż przedkładana książka - wyjaśniając fenomeny, które w niektórych interpretacjach potraktowane bywają w sposób uproszczony lub całkiem chybiony - przyczyni się do pogłębionego rozumienia dyskursów modelujących niedawną i współczesną debatę publiczną w Niemczech, a zarazem będzie stanowić zachętę do prowadzenia dalszych badań w zakresie kina niemieckiego.

${ }_{95}$ Hannah Arendt, Zorganizowana wina i powszechna odpowiedzialność, tłum. J. Sieradzki, [w:] O kondycji Niemiec..., s. 83 (przekład wcześniej opublikowany w: „Literatura na Świecie" 1985, nr 6). 


\section{Rozdział I}

\section{Okres 1945-1949: kino doby denazyfikacji w strefach okupowanych Niemiec}

„Jesteśmy tu od dwóch miesięcy, rozmawialiśmy z wieloma osobami, zadawaliśmy setki pytań - i nie znaleźliśmy ani jednego nazisty. Każdy jest przeciwko Hitlerowi. Wszyscy zawsze byli przeciwnikami Hitlera" - te słowa zawarł w swoim raporcie o nastrojach panujących wśród Niemców w pierwszych miesiącach po kapitulacji Saul Padover, amerykański historyk, który wraz z armią Stanów Zjednoczonych trafił do Europy ogarniętej wojenną pożogą ${ }^{1}$. Przytoczony wniosek oparł na protokołach z setek przesłuchań oraz rozmów z Niemcami w różnym wieku i reprezentujących rozmaite zawody. W relacjach przywoływanych przez Padovera ulga spowodowana zakończeniem działań wojennych splata się z poczuciem porażki, wynikającym nie z rozpoznania totalitarnych zbrodni, lecz z przekonania o niekorzystnych decyzjach militarnych po Stalingradzie: „Niemcy chcą odsunąć od siebie winę i odpowiedzialność, przedstawiając światu winnego, którego jeszcze niedawno wychwalali pod niebiosa jako półboga [...]. Hitlerowi zarzuca się nie to, że wojnę rozpętał, ale to, że ją przegrał"2

Polityka aliantów wobec zajętych Niemiec była kształtowana w toku dyplomatycznych debat i międzypaństwowych porozumień w ciagu ostatnich dwóch lat wojny. Po przekreśleniu planu Henry'ego Morgenthaua (amerykańskiego dyplomaty i sekretarza skarbu w gabinecie Roosevelta) z 1944 r., postulującego przekształcenie Niemiec w państwo agrarne, ostateczne decyzje podjęto na konferencji w Poczdamie, gdzie ustalono podział zajętych ziem na strefy okupacyjne - sowiecką oraz trzy strefy zachodnie: amerykańską, brytyjską (od stycznia 1947 r. zostały one połączone w tzw. Bizonię) oraz francuską (później określane wspólnie

${ }^{1}$ Saul Padover, Lügendetektor. Vernehmungen im besiegten Deutschland 1944/45, München 2001, s. 46 (org.: idem, The Experiment in Germany. The Story of an American Intelligence Officer, New York 1946).

2 Saul Padover, Lügendetektor..., s. 93-94. 
jako „Trizonia”). Przyjętą wówczas politykę wobec Niemiec określa się zwyczajowo skrótem ",4D” (demilitaryzacja, denazyfikacja, demokratyzacja, decentralizacja), dołączając niekiedy do tego wyliczenia "demontaż” (tj. konfiskaty urządzeń przemysłowych).

Denazyfikacja przebiegała w odmienny sposób w poszczególnych strefach $^{3}$, przy czym w strefach aliantów zachodnich powierzono ją samym Niemcom, zaś w części administrowanej przez ZSRR - organom bezpieczeństwa zdominowanym przez oficerów sowieckich. Duża liczba ukaranych na tym terenie świadczyła tylko pozornie o konsekwencji polityki denazyfikacyjnej: „,wśród skazanych obok nazistów było też wielu przeciwników dawnego reżimu; władze sowieckie często bardziej interesowały się właśnie tymi drugimi" ${ }^{4}$. W strefach zachodnich każdy pełnoletni obywatel musiał wypełnić szczegółową (składająca się ze 131 pytań) ankietę, ocenianą przez specjalną komisję (tzw. Spruchkammer). Osoby, które wykazały związki z narodowym socjalizmem lub co do których istniały podejrzenia o zatajenie takich relacji, przyporządkowywano do jednej z pięciu kategorii (główni winowajcy - Hauptschuldige, obciążeni - Belastete, mniej obciążeni - Miderbelastete, sympatycy - Mitläufer i nieobciążeni - Entlastete). Następnie wymierzano „środek pokuty” (Sühnemaßnahme), zależny od kategorii. Katalog kar był bogaty i mógł obejmować umieszczenie w obozie pracy, konfiskatę majątku, grzywnę, czasowy zakaz wykonywania zawodu lub utratę praw publicznych.

Denazyfikacja prowadzona w ten sposób najdłużej trwała w strefie amerykańskiej. W części francuskiej, której władze - zapewne z uwagi na kontekst Vichy - nie były szczególnie zainteresowane karaniem osób zaangażowanych w system nazistowski, automatycznie zwalniano od odpowiedzialności osoby urodzone po 1918 r., a wszystkich urzędników niższej rangi zaklasyfikowano jako „sympatyków”. Łącznie spośród $13 \mathrm{mln}$ ankiet podjęto zaledwie 3,2 mln spraw, a ostatecznie rozpatrzono 836 tys. z nich, gdyż pozostałe podlegały różnego rodzaju amnestiom ${ }^{5}$. W praktyce wymierzano kary łagodne - ponad 500 tys. osób zaliczono do czwartej lub piątej kategorii. Sami Niemcy określali denazyfikację jako Persilscheinverfahren (czyli: "postępowanie wybielające” - od nazwy proszku do prania),

3 Zob. m.in.: Entnazifizierung. Politische Säuberung und Rehabilitierung in den vier Besatzungszonen 1945-1949, red. Clemens Vollnhaus, München 1991; Lutz Niethammer, Deutschland danach. Postfaschistische Gesellschaft und nationales Gedächtnis, Bonn 1999 (rozdział: Schule der Anpassung. Die Entnazifizierung in den vier Besatzungszonen).

${ }^{4}$ Kazimierz Wóycicki, Niemiecki rachunek sumienia. Niemcy wobec przeszłości 19331945, Wrocław 2005, s. 30.

${ }^{5}$ Franciszek Ryszka, Norymberga. Prehistoria i ciag dalszy, Warszawa 1982, s. 302. Zob. także: Henryk Sołga, Niemcy. Sądzacy i sądzeni, 1939-2000, Kraków 2000. 
a dokumenty wystawiane przez urzędy ds. denazyfikacji - jako Persilschein (świadectwa oczyszczenia).

Ostatecznie prawną odpowiedzialność za zbrodnie dokonane przez reżim nazistowski przypisano nielicznym. Pierwszy duży proces w powojennych Niemczech - nad komendantem obozu Bergen-Belsen i jego podwładnymi - zorganizowano przed brytyjskim sądem wojskowym (zapadło 11 wyroków śmierci). Uwagę niemieckiej - i światowej - opinii publicznej w o wiele większym stopniu przykuł, rozpoczęty w listopadzie 1945 r., proces w Norymberdze przed Międzynarodowym Trybunałem Wojskowym. W trwającym rok głównym procesie przeciw czołowym przedstawicielom nazistowskiej dyktatury dziewiętnastu oskarżonych uznano za winnych (trzech uniewinniono); w kolejnych procesach norymberskich sądzono lekarzy, przemysłowców, wojskowych i urzędników. Pod koniec 1946 r. w strefie brytyjskiej rozpoczął się proces przeciw nadzorcom obozu Ravensbrück. W I połowie 1947 r. przed amerykańskim trybunałem wojskowym na ławie oskarżonych zasiedli nadzorcy z kacetu Buchenwald, zaś w II połowie tego samego roku w błyskawicznym postępowaniu przeprowadzonym w strefie sowieckiej skazano załogę obozu Sachsenhausen. I choć materiał dowodowy zebrany podczas procesów był szeroko dyskutowany w niemieckojęzycznych mediach, to „ujawnieniu zbrodni nazistowskich przed trybunałami wojskowymi towarzyszył proces komplementarny, skutkujący niemal całkowitą zbiorową amnestią dla reszty Niemców" ${ }^{\prime \prime}$.

Podejmowane $\mathrm{w}$ Niemczech $\mathrm{w}$ pierwszych latach po wojnie debaty o niedawnej historii zogniskowane były na dwóch zagadnieniach ${ }^{7}$ : ciągłości historycznej (a zatem związków między III Rzeszą a wcześniejszym dziedzictwem niemieckiej kultury) oraz kwestii winy. Za sprawą dyskutowanych wówczas esejów, publikowanych na łamach czasopism kulturalnych („Merkur", „Die Wandlung”, „Der Ruf”, „Frankfurter Hefte”), w dyskursie publicznym pojawiły się wówczas określenia Neubeginn (nowy początek) i Zusammenbruch (załamanie). Bywały one krytykowane z uwagi na swą dwuznaczność (czy można ot tak, po prostu, „porzucić przeszłość" ? $\left.{ }^{8}\right)$, ale szybko weszły do potocznego użytku. Nowe Niemcy miały rozpocząć swe powojenne dzieje "od początku”.

${ }^{6}$ Mary Fulbrook, German National Identity after the Holocaust, Cambridge 1999, s. 50-51.

7 Zob.: Anson Rabinbach, In the Shadow of the Catastrophe. German Intellectuals between Apocalypse and Enlightment, Berkeley 1997; Jeffrey Olick, In the House of the Hangman. The Agonies of German Defeat, 1943-1949, Chicago 2005; Barbro Eberan, Luther? Friedrich "der Große"? Wagner? Nietzsche? Wer war an Hitler schuld? Die Debatte um die Schuldfrage 1945-1949, München 1983.

${ }^{8}$ Krytyka formułowana jest również przez autorów współczesnych - przykładowo Norbert Frei określa Zusammenbruch „,wygodną metaforą przysłaniającą indywidualną odpowiedzialność" (Norbert Frei, Polityka wobec przeszłości. Początki Republiki Federalnej i przeszłość nazistowska, tłum. B. Ostrowska, Warszawa 1999, s. 120). 
Spośród żywo komentowanych wówczas książek najbardziej wpływową była praca Friedricha Meineckego o dwuznacznym tytule Niemiecka katastrofa ${ }^{9}$ (czy mowa o katastrofie doświadczanej przez Niemców, czy przez nich spowodowanej?), w której okres nazizmu profilowany był jako swego rodzaju wyrwa w dziejach Niemiec. Autor podkreślał antychrześcijański wymiar narodowego socjalizmu oraz znaczenie wewnątrzsystemowej opozycji wokół „ruchu 20 lipca” (i dokonanej przez Stauffenberga próby puczu), a w zakończeniu swej książki postulował powrót do klasycznych wartości kultury zachodniej („kółka miłośników Goethego", jak ironizowali polemiści). Również Gerhard Ritter w pracy Europa a sprawa niemiecka odrzucał tezę, jakoby III Rzesza była nieuchronną kulminacją całych dziejów Niemiec, argumentując, iż także w odniesieniu do innych krajów europejskich okresu międzywojennego mówić można o kryzysie relacji: państwo - obywatele ${ }^{10}$. O ile książki Meineckego i Rittera rychło zostały uznane - w Niemczech zachodnich - za klasyczne pozycje z pogranicza historii i politologii, o tyle podstawą polityki historycznej w sowieckiej strefie okupacyjnej (a później - w NRD) stała się wydana w 1945 r. (gdy autor przebywał na emigracji w Meksyku) praca Aleksandra Abuscha Naród na manowcach ${ }^{11}$. Analizując niemiecką drogę do faszyzmu, autor podkreśla rolę okresu wilhelmińskiego (pruscy junkrzy jako klasa „rozsadników” imperializmu i militaryzmu). Wskazuje też na historyczne źródła antyfaszyzmu (wojny chłopskie w XVI w., wiosna ludów, rewolta listopadowa w 1918 r.), akcentując zarazem rolę partii komunistycznej i wykluczając z "antyfaszystowskiej wspólnoty” socjaldemokratów (jako ugrupowanie zbyt ugodowe i nieskuteczne w politycznej opozycji wobec zwolenników NSDAP).

Drugie dyskutowane wówczas zagadnienie - kwestia winy (Schuldfrage) - związane było natomiast z pytaniem o charakter i zakres odpowiedzialności za zbrodnie nazizmu ${ }^{12}$. Jak zauważyła Aleida

${ }_{9}$ Friedrich Meinecke, Die deutsche Katastrophe, Wiesbaden 1946.

${ }^{10}$ Gerhard Ritter, Europa und die deutsche Frage. Betrachtungen über die geschichtliche Eigenart des deutschen Staatsdenkens, München 1948.

11 Aleksander Abusch, Naród na manowcach. Przyczynek do poznania dziejów Niemiec, tłum. A. Liebfeld, Warszawa 1950 (data publikacji polskiego przekładu wskazuje na „imprimatur", jaki praca Abuscha uzyskała w kręgach stalinowskich). O znaczeniu pracy Abuscha dla kształtowania enerdowskiej polityki historycznej pisze też Jeffrey Herf (Divided Memory: the Nazi Past in the Two Germanys, Cambridge 1997, s. 61-63).

12 Aleida Assmann, 1945 - der blinde Fleck der deutschen Erinnerungsgeschichte, [w:] Aleida Assmann, Ute Frevert, Geschichtsvergessenheit, Geschichtsversessenheit. Vom Umgang mit deutschen Vergangenheiten nach 1945, Stuttgart 1999, s. 83. Debata pomiędzy zwolennikami tezy o „winie zbiorowej” i „,winie ekskluzywnej” nie zakończyła się bynajmniej w okresie będącym przedmiotem niniejszego rozdziału - powróciła ze szczególną intensywnością najpierw na przełomie lat 60. i 70., a później - już po zjednoczeniu Niemiec. 
Assmann, w debatach prowadzonych w Niemczech w okresie tużpowojennym można wyróżnić dwa dyskursy: dotyczący winy zbiorowej (Kollektiuschuld), odnoszącej się do całego narodu niemieckiego, oraz zawężający zagadnienie winy do Hitlera i jego „kliki” (wina „ekskluzywna" - Exklusivschuld). Głosem na rzecz pierwszego stanowiska było tzw. Schuldbekenntnis - „wyznanie winy”, dokonane przez związek niemieckich kościołów protestanckich w październiku 1945 r. w Stuttgarcie, deklarujące:

Z wielkim bólem mówimy: to za naszą sprawą na narody i kraje spadło bezgraniczne cierpienie, przez nas wiele krajów i społeczeństw doznało nieskończonego cierpienia [...]. Oskarżamy się o to, że nie dawaliśmy świadectwa z dostateczną odwaga, że nie modliliśmy się dość intensywnie, że nie wierzyliśmy silniej i że nie kochaliśmy dość gorąco $^{13}$.

Liczba mnoga zastosowana $\mathrm{w}$ tym orędziu wywołała sprzeciw wielu środowisk, dostrzegających zagrożenie związane z postrzeganiem zbrodni nazistowskich przez pryzmat winy zbiorowej.

W najobszerniejszy sposób przeciw koncepcji „,winy zbiorowej” opowiedział się Karl Jaspers w teoretycznym studium Problem winy ${ }^{14}$, w którym wyróżnił cztery jej rodzaje (kryminalna, polityczna, moralna i metafizyczna), wskazując zarazem instancje o niej rozstrzygające (odpowiednio: sąd, siła zwycięzcy, sumienie i Bóg) ${ }^{15}$. Dzieło Jaspersa nie doczekało się w ówczesnych Niemczech szerszej debaty; ukazało się zresztą w czasie, gdy władze okupacyjne zaczęły odchodzić od polityki „winy zbiorowej”, początkowo implementowanej na różnych poziomach reorganizacji życia społecznego (choć nigdy nie skodyfikowanej w żadnym oficjalnym dokumencie). Eugen Kogon, autor pierwszej w języku niemieckim pracy o nazistowskich obozach koncentracyjnych, fiasko tej polityki komentował w następujący sposób:

13 Dokument dostępny pod adresem: http://www.1000dokumente.de/index (dostęp: 10.09.2014).

${ }_{14}$ Karl Jaspers, Problem winy, tłum. J. Garewicz, Warszawa 1982. Zob. także: idem, Zróżnicowanie niemieckiej winy, tłum. K. Piesowicz, [w:] O kondycji Niemiec. Tożsamość niemiecka w debatach intelektualistów po 1945 roku, red. Leszek Żyliński, Joanna Jabłkowska, Poznań 2008.

${ }^{15}$ Jaspers zaznaczał przy tym, że „poza wszelkimi rozważaniami o winie pozostaje poczucie honoru żołnierskiego" (idem, Zróżnicowanie niemieckiej winy..., s. 64); zob. również komentarz Stephana Hermlina: „Nie możemy pozbyć się uczucia, że w tym momencie etyczna nieugiętość filozofa Karla Jaspersa uległa audytorium, które po prostu niczego innego nie mogło chcieć usłyszeć" (Stephan Hermlin, $O$ „zróżnicowaniu niemieckiej winy” Karla Jaspersa, tłum. L. Żyliński, [w:] O kondycji Niemiec..., s. 97). 
Oskarżenie wszystkich o współwinę miało wywołać szok, który doprowadziłby Niemców do rozpoznania prawdziwych przyczyn ich klęski. Już rok po ogłoszeniu tej tezy można stwierdzić, że nie osiągnęła ona swego celu. Nie przemawia to jedynie na niekorzyść społeczeństwa niemieckiego, ale również przeciw zastosowanym metodom pedagogicznym, ponieważ ocena politycznych środków uzależniona jest również od tego, czy uda się im wypełnić ich założenia. Niestety, polityka szokowa nie obudziła niemieckiego sumienia, a jedynie rozbudziła mechanizmy samoobrony pośród oskarżonych o współodpowiedzialność i potępionych za zbrodnicze czyny narodowego socjalizmu ${ }^{16}$.

Aliancka polityka kulturalna w poszczególnych strefach okupacyjnych ewoluowała ${ }^{17}$ - od tezy o winie zbiorowej do zachęt do przyjęcia indywidualnej odpowiedzialności. Odejście od koncepcji „winy zbiorowej" spowodowane było narastającym konfliktem pomiędzy aliantami zachodnimi a stroną sowiecką - dla obu stron utrwalanie stref wpływów warunkowane było bowiem współpracą z przynajmniej częścią Niemców w poszczególnych strefach okupacyjnych. W konsekwencji - jak pisze Norbert Frei - od 1948 r. "gotowość duchowej refleksji, początkowo istotnie postulowanej i popieranej, słabła, i to mniej więcej w takim samym tempie, w jakim do współpracy nad ekonomiczną i polityczną odbudową Europy Zachodniej alianci angażowali tych, których w 1945 r. pokonali"18.

Początkowo polityka kulturalna aliantów była skupiona na działaniach z zakresu reedukacyjnej propagandy wizualnej ${ }^{19}$. Latem 1945 r. w brytyjskiej i amerykańskiej strefie rozpowszechniano w dużym nakładzie broszurę KZ. Bildbericht aus fünf Konzentrationslagern, zawierającą fotoreportaż dokumentujący zbrodnie popełnione $\mathrm{w}$ obozach koncentracyjnych ${ }^{20}$. Na

${ }^{16}$ Eugen Kogon, SS-Staat. Das System der deutschen Konzentrationslager, München 1998 , s. 409.

17 O polityce kulturalnej w poszczególnych strefach zob.: Ralph Willet, The Americanization of Germany, 1945-1949, London-New York 1989 (w strefie amerykańskiej); David Pike, The Politics of Culture in Soviet-Occupied Germany, 1945-1949, Stanford 1992 oraz Gerd Dietrich, Politik und Kultur in der SBZ 1945-1949, Frankfurt am Main 1993 (w strefie sowieckiej); Gabriele Klemens, Britische Kulturpolitik in Deutschland 1945-1949, Stuttgart 1997 (w strefie brytyjskiej) oraz Daniela Högerle, Propaganda oder Verständigung? Instrumente französischer Kulturpolitik in Südbaden, Frankfurt am Main 2013 (w strefie francuskiej).

${ }^{18}$ Norbert Frei, Polityka wobec przeszłości..., s. 12.

${ }^{19}$ O podejmowanych przez Amerykanów działaniach z zakresu propagandy wizualnej zob.: Cora Sol Goldstein, Capturing the German Eye: American Visual Propaganda in Occupied Germany, Chicago 2009; Jennifer Fay, Theaters of Occupation. Hollywood and the Reeducation of Postwar Germany, Minneapolis 2008.

20 Cornelia Brink, Ikonen der Vernichtung. Öffentlicher Gebrauch von Fotografien aus nationalsozialistischen Konzentrationslagern nach 1945, Berlin 1998, s. 60; Habbo Knoch, Die Tat als Bild. Fotografien des Holocaust in der deutschen Erinnerungskultur, Hamburg 2001, s. 147. Zob. też: Dagmar Barnouw, Konfrontation mit dem Grauen. Alliierte Schuldpolitik 1945, „Merkur. Deutsche Zeitschrift für Europäisches Denken" 1995, nr 5. 
ocalałych z wojennej pożogi budynkach władze okupacyjne rozwieszały plakaty pokazujące zbrodnie nazistowskie. Na najsłynniejszym z nich, wykorzystującym fotografię z Buchenwaldu, umieszczono także palec wymierzony w oglądającego i napis: „To wasza wina” (Eure Schuld). Hannah Arendt, która w 1948 r. przyjechała po piętnastu latach do Niemiec, ironizowała:

Dla większości mieszkańców Niemiec te zdjęcia były pierwszym rzeczywistym zetknięciem się ze zbrodniami, jakie popełniono w ich imieniu. Jak mogli czuć się winni, skoro nawet o tym nie wiedzieli? Wszystko, co z tego zapamiętali, to ten wyciągnięty palec, który wskazywał najwyraźniej niewłaściwą osobę [...]. Zarówno siła reakcji, jak i okoliczność, że ludzie mijają przedstawioną na zdjęciach rzeczywistość z wyraźną obojętnością, są raczej efektem zawartej w plakacie prawdy niż skutkiem ewidentnie popełnionego błędu ${ }^{21}$.

Jak poświadczają zachowane relacje, materiały wizualne dystrybuowane przez aliantów na początku okupacji spotykały się z niechęcią wielu Niemców, którzy traktowali je jako obca, narzuconą im propagandę. Dopiero później, pod koniec analizowanego tu okresu, wizualne świadectwa zbrodni były prezentowane przez instytucje niemieckie, m.in. Związek Prześladowanych przez Reżim Nazistowski (VVN), którego wystawy - Kampf und Opfer (Walka i ofiary) w brytyjskiej strefie okupacyjnej oraz Das andere Deutschland (Inne Niemcy) w części sowieckiej - obejrzało ponad 300 tys. osób ${ }^{22}$.

Do propagandy reedukacyjnej zaprzęgnięto, rzecz jasna, także kino. W krótkich materiałach zamieszczanych w kronikach filmowych ${ }^{23}$ wykorzystywano materiały archiwalne, przedstawiające m.in. liderów NSDAP i filmowe notacje procesów norymberskich, opatrzone stosownym komentarzem. W kinach strefy sowieckiej w 1946 r. rozpowszechniano zaś serię kilkuminutowych filmów Nigdy tego nie zapomnijcie - to oni sa winni (Vergesst es nie - schuld sind sie!) Richarda Brandta (taka „oskarżycielsko-

${ }^{21}$ Hannah Arendt, Wizyta w Niemczech, tłum. A. i A. Klubowie, "Przegląd Polityczny” 2002, nr 55, s. 118. W tym eseju (po raz pierwszy został opublikowany w 1950 r. w USA, zaś w Niemczech ukazał się dopiero w 1993 r.) Arendt mylnie podaje napis na wzmiankowanym plakacie (jako Du bist schuldig - „Ty jesteś winien”). Za wyjaśnienie to dziękuję Magdalenie Saryusz-Wolskiej.

${ }^{22}$ Habbo Knoch, Die Tat als Bild..., s. 251-253; Jürgen Danyel, Bilder vom "anderen Deutschland". Frühe Widerstandsrezeption nach 1945, "Zeitschrift für Geschichtswissenschaft" 1994, nr 1; Manfred Overesch, Buchenwald und die DDR oder die Suche nach Selbstlegitimation, Göttingen 1995, s. 233-260; Magdalena Saryusz-Wolska, Ikony normalizacji. Kultury wizualne Niemiec 1945-1949, w druku (rozdział: Wina i wyparcie).

${ }_{23}$ Były to: Świat w filmie (Welt im Film) - w strefie brytyjskiej i amerykańskiej, Naoczny świadek (Augenzeuge) - w strefie sowieckiej, Spojrzenie na świat (Blick in die Welt) - w strefie francuskiej. Zob. Jutta Gröschl, Die Deutschlandpolitik der vier Großmächte in der Berichterstattung der deutschen Wochenschau 1945-1949, Berlin 1997. 
-demaskatorska" formuła narracji będzie charakterystyczna dla dokumentalnych i oświatowych filmów o tematyce historycznej, realizowanych później w NRD).

Wykorzystywano również materiały dokumentalne zarejestrowane przez operatorów pracujących w strukturach armii alianckich ${ }^{24}$. We wschodniej części Niemiec pokazywano filmy nakręcone przez sowieckich operatorów: Majdanek (Irina Setkina, 1944) i Auschwitz (Elisaweta Swilowa, 1945), a także film zrealizowany przez Czołówkę przy Dywizji im. Tadeusza Kościuszki Majdanek - cmentarzysko Europy (Aleksander Ford, Jerzy Bossak). Film Obóz śmierci Sachsenhaus podpisali już niemieccy twórcy (Todeslager Sachsenhaus, real. Richard Brandt i Karl Schnog, Niemcy 1946) ${ }^{25}$. Szczegóły dotyczące dystrybucji tych filmów w sowieckiej strefie okupacyjnej nie zostały, jak dotąd, wnikliwie zbadane ${ }^{26}$.

O wiele więcej wiemy natomiast o analogicznych przedsięwzięciach podejmowanych przez Amerykanów. Gdy pod koniec wojny służba informacyjna armii amerykańskiej (Information Control Division) zleciła przygotowanie filmu oświatowego o nazistowskich obozach, zadania tego podjął się George Stevens (hollywoodzki weteran i późniejszy reżyser Jeźdźca znikąd). Sześćdziesięciominutowy materiał zatytułowany $K Z$, znany dziś jako Nazi Concentration Camps Footage, zawiera zdjęcia z 11 obozów ${ }^{27}$. Film ten, będący niezmiernie ważną notacją zdarzeń historycznych, poniósł jednak porażkę jako materiał propagandowy służący denazyfikacji - przez niemieckich widzów został odrzucony podczas pierwszych seansów (dla więźniów wojennych w amerykańskiej i brytyjskiej strefie) ${ }^{28}$. W związku z tym władze amerykańskiej strefy okupacyjnej (OMGUS - Of-

${ }^{24}$ Zob. Stewart Liebmann, Obraz obozu w pierwszych filmach dokumentalnych, tłum. A. Zawrzykraj, „Dialog” 2010, nr 1. Zob. także: idem, Cmentarzysko Europy (1944). Pierwszy film o Holokauście?, tłum. G. Dąbkowski, „Zeszyty Majdanka” 2011, t. XXV.

${ }_{25}$ Zob. Thomas Heimann, Bilder von Buchenwald. Die Visualisierung des Antifaschismus in der DDR (1945-1990), Köln 2005, s. 28.

${ }^{26} \mathrm{~W}$ późniejszych latach w kinach strefy sowieckiej dystrybuowano również Ostatni etap Wandy Jakubowskiej (1947). Na temat recepcji Ostatniego etapu w radzieckiej strefie okupacyjnej zob. Thomas Heimann, Bilder von Buchenwald..., s. 23-24, 30-31.

27 Dane za bazą "Cinematografie des Holocausts”, prowadzoną przez Fritz-Bauer-Institut, http://www.fritz-bauer-institut.de/cine-holocaust.html (dostęp: 20.09.2013).

${ }^{28} \mathrm{O}$ wynikach przeprowadzanych wówczas ankiet, zaświadczających jakoby o porażce reedukacyjnego zamysłu tzw. atrocity films, piszą m.in. Susan Carruthers (Compulsory Viewing: Concentration Camp Film and German Re-education, "Millennium. Journal of International Studies" 2001, nr 3) i Brigitte Hahn (Umerziehung durch Dokumentarfilm? Ein Instrument amerikanischer Kulturpolitik im Nachkriegsdeutschland, Münster-Hamburg 1997; Dokumentarfilm in Dienste der Umerziehung. Amerikanische Filmpolitik 1945-1953, [w:] Lernen Sie diskutieren! Re-education durch Film; Strategien der westlichen Alliierten nach 1945, red. Heiner Roß, Berlin 2005). 
fice of Military Government for Germany) podjęły decyzję o konieczności zrealizowania nowego filmu. Dodatkowy materiał - zarejestrowany przez operatorów działających przy oddziałach wyzwalających obóz - posłużył, wraz z ujęciami z KZ ${ }^{29}$ oraz materiałami brytyjskimi ${ }^{30}$ i sowieckimi, do stworzenia dwudziestodwuminutowej krótkometrażówki zatytułowanej Młyny śmierci (Todesmühlen). Jej montaż nadzorowali Hanuš Burger (do 1938 r. pracujący w kinematografii czechosłowackiej, zaś w armii amerykańskiej w oddziale ds. propagandy ${ }^{31}$ oraz Billy Wilder ${ }^{32}$. Ewidentna wartość dokumentacyjna tego filmu nie zmienia faktu, iż był on wówczas adresowany przede wszystkim do widowni niemieckiej, o czym mowa jest na planszy otwierającej anglojęzyczną wersję filmu. W niemieckojęzycznym wariancie natomiast adresata sugeruje zmiana formuły narracji w ponadkadrowym komentarzu - z auktorialnej na pierwszoosobową (Tak, pamiętam. Na zjeździe partyjnym w Norymberdze skandowatem "Heil”. A gdy Gestapo przyszło po mojego sąsiada, odwrócitem się - czemu miałbym się tym przejmować?). Młyny śmierci pokazywane były w niemieckich kinach od października $1945 \mathrm{r}$. do lata $1946 \mathrm{r}^{33}$, przy czym sporadycznie były to seanse obowiązkowe dla

${ }^{29}$ Brewster S. Chamberlin, "Todesmühlen”. Ein früher Versuch zur Massen-Umerziehung im besetzten Deutschland, 1945-1946, „Vierteljahrshefte für Zeitgeschichte” 1981, nr 29, s. 429-430. Zob. także: idem, Kultur auf Trümmern: Berliner Berichte der Information Control Section. Juli-Dezember 1945, München 1979.

${ }_{30}$ Chodzi o niespełna godzinny film Memory of the Camps (jego producentem był Sidney Bernstein, w napisach końcowych jako treatment advisor figuruje Alfred Hitchcock). Film, odnaleziony w 1983 r., pokazano publicznie po raz pierwszy na Berlinale rok później (zob. Elisabeth Sussex, The Fate of F3080, "Sight and Sound” 1984, nr 53. Por. też: Hannah Caven, Horror in Our Time. Images of the Concentration Camps in the British Media, 1945, „Historical Journal of Film, Radio and Television" 2001, nr 21).

31 Zob. Hanuš Burger, Der Frühling war es wert. Erinnerungen, München 1977, s. 232-266.

${ }^{32}$ Tomasz Majewski zwraca uwagę, że w czołówce pierwotnej (niemieckojęzycznej) wersji filmu Burger został podpisany jako reżyser i autor scenariusza, a Wilder jako twórca koncepcji montażowej; z kolei w wersji amerykańskiej Wilderowi przypisano reżyserię (Tomasz Majewski, Berlin/Wilder - reminiscencje, [w:] Billy Wilder. Mistrz kina z Suchej Beskidzkiej, red. Kamila Żyto, Marcin Pieńkowski, Warszawa 2011, s. 28). O Młynach śmierci zob. także: Magdalena Saryusz-Wolska, Ikony normalizacji... (rozdział: Wina i wyparcie).

33 Thomas Heimann podaje, że Młyny śmierci pokazywane były jako dodatki przed „zwykłymi" seansami repertuarowymi (Thomas Heimann, Bilder von Buchenwald...); informację tę prostuje Ulrike Weckel, przekonując, że były one wyświetlane wyłącznie jako osobne pokazy (zob. Beschämende Bilder. Deutsche Reaktionen auf alliierte Dokumentarfilme über befreite Konzentrationslager, Stuttgart 2012 oraz jej artykuły: "Wir ahnten, dass uns Abscheuliches vorgeführt wurde". Alliierte Dokumentarfilme über die Lagerbefreiung und die Reaktionen deutscher Kriegsgefangener, [w:] „Welchen der Steine du hebst”. Filmische Erinnerung an den Holocaust, red. Claudia Bruns, Asal Dardan, Anette Dietrich, Berlin 2012; eadem, Nachsitzen im Kino. Anglo-amerikanische KZ-Filme und deutsche Reaktionen 1945/46 - ̈̈ber Versuche kollektiver Beschämung, „Berliner Debatte Initial” 2006, nr 1-2). 
wybranych grup widzów ${ }^{34}$. Aby zachęcić do oglądania materiałów zarejestrowanych w obozach, stosowano też rozmaite promocje, na przykład obniżone ceny biletów (w niektórych relacjach znaleźć można informację, że w kasach kin stemplowano kartki żywnościowe ${ }^{35}$ ). Trzeci film zrealizowany na zlecenie OMGUS - Norymberga i nauki z niej płynace (Nuremberg: its Lesson for Today / Nürnberg und seine Lehren, 1948, real. Stuart Schulberg) - poświęcony był procesowi w Norymberdze ${ }^{36}$ i jest już wyraźnym świadectwem odejścia od tezy o kolektywnej winie ${ }^{37}$. Jeśli chodzi o wpływ tych filmów na niemiecką widownię, trudno wydawać jednoznaczne osądy. Przeważa pogląd, że był on raczej ograniczony, o czym świadczą zachowane raporty amerykańskiego wywiadu (w lutym $1946 \mathrm{r}$. jeden z oficerów skonstatował: „Niemcy przez dwanaście lat tak bardzo przyzwyczaili się do wszelkiego rodzaju propagandy, że nie robi już ona na nich wrażenia [...] w tej sytuacji cokolwiek przypomina im film propagandowy z zasady jest przeciwskuteczne" ${ }^{\prime 38}$ ). W tej sytuacji stało się jasne, że „reedukacja poprzez film" przyniesie większe efekty, gdy realizowana będzie za pośrednictwem nie dokumentu, lecz filmów fabularnych.

Odbudowa przemysłu filmowego następowała inaczej w każdej ze stref okupacyjnych ${ }^{39}$. Zgodnie z ustawą nr 191 przyjętą przez władze

${ }^{34}$ Informacje o seansach obowiązkowych zawarte są w - przywoływanych w przyp. 28 i 29 - pracach Brewstera S. Chamberlina, Susan Carruthers i Brigitte Hahn. W ostatnich latach z tezami tymi przekonująco polemizuje Ulrike Weckel (zob. przyp. 33).

${ }^{35}$ Billy Wilder wspominał, że był to jego pomysł - zob. "Ich nehm' das alles nicht so ernst... Gespräch mit Billy Wilder, [w:] Billy Wilders Filme, red. Neil Sinyard, Adrian Turner, West Berlin 1980, s. 48. Informację o stemplowaniu kartek żywnościowych kwestionuje jednak Weckel (zob. przyp. 33), która w archiwach nie znalazła żadnych informacji na ten temat.

${ }^{36}$ Do materiału dowodowego zaprezentowanego podczas owego procesu włączono dziesięć filmów, w tym wymieniony KZ Stevensa oraz materiały nakręcone przez operatorów Armii Czerwonej. Zob. Christian Delage, Image as Evidence and Mediation: The Experience of the Nuremberg Trials, [w:] Law and Popular Culture, red. Michael Freeman, Oxford 2005; Lawrence Douglas, Film as Witness: Screening "Nazi Concentration Camps" before the Nuremberg Tribunal, „The Yale Law Journal” 1995, nr 2 (niemieckojęzyczna wersja tekstu ukazała się w: "Niemand zeugt für den Zeugen". Erinnerungskultur nach der Shoah, red. Ulrich Baer, Frankfurt am Main 2000); Ulrike Weckel, The Power of Images: Real and Fictional Roles of Atrocity Film Footage at Nuremberg, [w:] Reassessing the Nuremberg Military Tribunals, red. Kim Priemel, Alexa Stiller, New York 2012; Mirjam Wenzel, Vom Zeugnis zum Tribunal. Zum Status des Dokumentarischen in Filmen, die im Nürnberger Prozess gezeigt oder über diesen gedreht wurden, [w:] „Welchen der Steine du hebst"...

37 O procesie w Norymberdze powstał też film Sąd narodów (Cyд народob, reż. Roman Karmen, ZSRR 1946).

${ }^{38}$ Michael Josselson, German Reactions, "Mills of Death", „Military Government Weekly Information Bulletin", 23.02.1946; podaję za: Cora Sol Goldstein, Capturing the German Eye..., s. 58.

39 Zob. Magdalena Saryusz-Wolska, Ikony normalizacji... (rozdział: Obrazy pod kontrola - polityki wizualne aliantów). 
alianckie jeszcze w listopadzie 1944 r., na terytorium zajętym przez wojska sojusznicze obowiązywał zakaz działalności medialnej, w tym produkcji i dystrybucji filmów oraz prowadzenia kin. Postanowienia te zostały złagodzone przez rozporządzenie o kontroli informacji (Nachrichtenkontrollvorschrift) z maja $1945 \mathrm{r}^{40} \mathrm{~W}$ myśl tego dokumentu podjęcie działalności producenckiej lub dystrybucyjnej wymagało stosownej licencji. W strefach zachodnich otrzymać ją mogły konkretne osoby, natomiast w sowieckiej strefie okupacyjnej licencje przyznawano instytucjom.

Największa i stosunkowo najlepiej zachowana baza produkcyjna - przede wszystkim studia Ufa International w Babelsbergu, a także wytwórnia kopii filmowych - znajdowała się na obszarze sowieckiej strefy okupacyjnej (podług szacunków, około 75 procent potencjału wytwórczego dawnego holdingu Ufi wpadło w ręce Sowietów ${ }^{41}$ ). Jej władze (SMAD - Sowjetische Militäradministration in Deutschland) nie zezwalały niemieckim filmowcom na wstęp do hal w Babelsbergu aż do wiosny 1948 r.; do ich dyspozycji pozostawiono natomiast dawne studia Althoff w Poczdamie i Tobis w Berlinie-Johannisthalu ${ }^{42}$. Wszystkie te instytucje były poddane kontroli przez sowieckich urzędników, wśród których pierwsze skrzypce grali: major Aleksander Dymszyc - kierujący Wydziałem Kultury SMAD, oraz pułkownik Siergiej Tulpanow, odpowiedzialny za Wydział Informacji (a zatem: propagandę i cenzurę). Ośrodkiem bardziej dekoracyjnym niż decyzyjnym był zaś niemiecki Centralny Zarząd Oświecenia Publicznego (Zentralverwaltung für Volksbildung), na czele którego stał funkcjonariusz KPD Paul Wandel.

Wśród pierwszych przedsięwzięć filmowych w strefie sowieckiej było udźwiękowienie (pod kierunkiem Wolfganga Staudtego) i wprowadzenie do dystrybucji Iwana Groźnego (reż. Siergiej Eisenstein, ZSRR 1944), który na ekrany kin trafił jeszcze w sierpniu $1945 \mathrm{r}$. Wtedy też powołano grupę Filmaktiv, skupiającą twórców zainteresowanych odbudową przemysłu filmowego, a zarazem członków KPD. W skład tego kolektywu weszli

${ }^{40} \mathrm{~W}$ odniesieniu do strefy amerykańskiej i polityki USA na tym terenie zob. Larry Hartenian, Controlling Information in US Occupied Germany 1945-1949: Media Manipulation and Propaganda, New York 2003; Ulrich M. Bausch, Die Kulturpolitik der US-amerikanischen Information Control Division in Württemberg-Baden, Stuttgart 1991; Kultur auf Trümmern: Berliner Berichte des amerikanischen Information Control Section, Juli-Dezember 1945, red. Brewster Chamberlin, Stuttgart 1979; USA und Deutschland: amerikanische Kulturpolitik 1942-1949. Bibliographie - Materialien - Dokumente, red. Michael Hoenisch, Klaus Kämpfe, Karl-Heinz Pütz, Berlin 1980.

${ }^{41}$ Klaus Kreimeier, The Ufa Story: A History of Germany's Greatest Film Company, 19181945, trans. R. Kimber, Berkeley 1999, s. 57-58.

42 Więcej na ten temat w: Christiane Mückenberger, Zeit der Hoffnungen. 1946 bis 1949, [w:] Das zweite Leben der Filmstadt Babelsberg. DEFA-Spielfilme 1946-1992, red. Ralf Schenk, Berlin 1994. 
m.in. Kurt Maetzig (wkrótce szef kroniki filmowej) i Hans Klering (aktor, od 1931 r. w Związku Radzieckim) ${ }^{43}$. Ten ostatni kilka miesięcy później został dyrektorem artystycznym Defy (Deutsche Film Aktiengesellschaft), koncernu filmowego powołanego do życia w maju 1946 r., od początku nadzorowanego przez władze sowieckiej strefy okupacyjnej, a w kolejnych latach coraz ściślej kontrolowanego przez partię komunistyczną SED (Sozialistische Einheitspartei Deutschlands) ${ }^{44}$. Początkowo (od listopada 1947 r.) Defa była niemiecko-sowiecką spółką akcyjną w której 55 procent udziałów należało do Ministerstwa Przemysłu Filmowego ZSRR (formalna nacjonalizacja nastąpiła w styczniu 1953 r.). Nieruchomości i wyposażenie należały formalnie (do lipca $1950 \mathrm{roku}$ ) do - mającej siedzibę w Moskwie - sowieckiej spółki Linsa, która jedynie wynajmowała Defie swój teren i sprzęt. Również dystrybucja była - do końca 1948 roku - w gestii sowieckiej (monopol na nią miała spółka Sojusintorgkino, potem przemianowana na Sovexportfilm).

W inicjującym działalność Defy przemówieniu Klering deklarował, iż podstawowym zadaniem nowej instytucji będzie „przezwyciężenie pseudorealizmu ery Goebbelsa" ${ }^{\prime 4}$. Natomiast pułkownik Tulpanow tak oto doprecyzował propagandowe cele wytwórni:

Towarzystwo Defa ma trudną misję do wypełnienia. Do najważniejszych zadań należą: walka o demokratyczną odbudowę Niemiec i wyplenienie resztek nazizmu oraz militaryzmu ze świadomości każdego Niemca, troska o wychowanie niemieckiego narodu, w szczególności młodzieży, w duchu prawdziwej demokracji i humanizmu, a przy tym wezwanie do przebudzenia dla innych narodów i krajów ${ }^{46}$.

${ }^{43}$ A także: operator Werner Krien, aktor Adolf Fischer i kierownik produkcji Alfred Lindemann oraz scenografowie Willy Schiller, Karl Hans Bergmann i Carl Haacker (w grupie tej przeważali dawni pracownicy wytwórni Prometheus-Film, w której powstały tzw. "filmy proletariackie” w czasie Republiki Weimarskiej). W listopadzie tego samego roku odbyło się drugie zebranie, w którym uczestniczyli również inni twórcy, później odgrywający ważną rolę w kulturze NRD (m.in. Boleslaw Barlog, Hans Deppe, Hans Fallada, Werner Hochbaum, Gerhard Lamprecht, Herbert Maisch, Peter Pewas i Günther Weisenborn).

${ }^{44}$ W listopadzie 1947 r. specjalna komórka SED została włączona w strukturę Defy, w partii natomiast powołano odrębną komisję do spraw filmu (Filmkomission, później działającą jako Abteilung Kultur: Sektor Film) - zob. Christiane Mückenberger, Zeit der Hoffnungen..., s. 23-25.

${ }^{45}$ Hans Klering, Rede, „Tägliche Rundschau”, 18.05.1946, za: Thomas Brandlmeier, Und wieder Caligari... Deutsche Nachkriegsfilme 1946-1951, [w:] Der deutsche Film. Aspekte seiner Geschichte von den Anfängen bis zur Gegenwart, red. Uli Jung, Trier 1993, s. 143.

${ }^{46}$ Cyt. za: Ralf Schenk, Eine kleine Geschichte der DEFA, Berlin 2006, s. 20; Christiane Mückenberger, Günter Jordan, „Sie sehen selbst, Sie hören selbst...". Eine Geschichte der DEFA von ihren Anfängen bis 1949, Marburg 1994, s. 38. 
Te „pedagogiczne” cele, formułowane zgodnie z komunistyczną ideologią "tworzenia nowego człowieka", powtarzane były też przez poszczególnych twórców, rozpoczynających współpracę z Defą. Peter Pewas (który wkrótce opuści NRD i będzie realizował filmy w RFN) przekonywał na przykład:

Nowy film podejmie problemy naszych dzieci, dorastających zatrutych młodych ludzi, małżeństw rozbitych przez bezduszność naszych czasów, zniszczonych miast, przestępczości, całej sfery publicznej. Jego motoryczna siła pozwoli stworzyć wolnego człowieka ${ }^{47}$.

Wiele tego rodzaju deklaracji wygłoszono podczas Kongresu Autorów Filmowych, zorganizowanego we wschodniej części Berlina w czerwcu 1947 r. ${ }^{48}$; wydarzenie miało przede wszystkim charakter propagandowy, choć do udziału w dyskusjach zaproszeni zostali także twórcy przebywający w zachodnich strefach okupacyjnych.

Przemysł filmowy na tym obszarze dawnej III Rzeszy był bardzo rozproszony (małe firmy produkcyjne powstawały w Hamburgu, Monachium, Getyndze, a także w zachodniej części Berlina ${ }^{49}$ ) i zapewne również z tego powodu ",manifesty” podobne do tych, które przygotowywano w Defie, należały do rzadkości (krótka debata na temat kształtu powojennej kultury filmowej toczyła się na łamach pisma „Der neue Film”). Nieco dokumentów „programowych” wytworzyli jedynie Hans Abich i Rolf Thiele, założyciele studia w Getyndze, którzy w 1946 r. pisali: „,samooczyszczenie niemieckiego narodu może wyrazić się przez film: okiełznać jego magiczną siłę powinno być zadaniem nowego filmu niemieckiego" ${ }^{\prime 50}$ (opinię tę warto odnotować, gdyż zawiera krytyczny osąd produkcji III Rzeszy i swego rodzaju wskazówkę dla twórców kina powojennego).

Pierwszy powojenny niemiecki film fabularny, Mordercy sq wśród nas (Mörder sind unter uns, reż. Wolfgang Staudte, 1946), pokazano we wschodniej części Berlina w październiku 1946 r. Fakt, iż ten właśnie tytuł zainicjował działalność produkcyjną Defy w zakresie fabuły (jak również to, że materiał Staudtego spotkał się z zainteresowaniem akurat w strefie sowieckiej), był poniekąd dziełem przypadku (o czym będzie jeszcze mowa). Początkowo decydenci z Defy planowali bowiem nakręcić

${ }^{47}$ Peter Pewas, Über das Gesicht des kommenden Films, [w:] Der Filmregisseur Peter Pewas, red. Ulrich Kurowski, Andreas Meyer, Berlin 1981, s. 62.

${ }_{48}$ Zob. Der Deutsche Film. Fragen, Forderungen, Aussichten. Bericht vom Ersten Deutschen Filmautoren-Kongreß, Berlin 1947.

49 Zob. Johannes Hauser, Neuaufbau der westdeutschen Filmwirtschaft 1945-1955 und der Einfluss der US-amerikanischen Filmpolitik, Pfaffenweiler 1989.

${ }^{50}$ Cyt. za: Thomas Brandlmeier, Und wieder Caligari..., s. 144. 
w pierwszej kolejności film Kolonne Strupp - opowiadający o ostatnich miesiącach walki o Berlin. Zarówno autorzy scenariusza (Friedrich Wolf i Ernst Busch), jak i potencjalny reżyser (Slátan Dudow), twórcy znani z komunistycznych poglądów, okres III Rzeszy spędzili na emigracji ${ }^{51}$. Do współpracy pozyskany został także Staudte, który na potrzeby projektu wykonał dokumentalne zdjęcia $\mathrm{w}$ berlińskim metrze, gdzie miała rozgrywać się część scen ${ }^{52}$ (2 maja 1945 r., wskutek wysadzenia w powietrze zapory wodnej przez SS, zalany został tunel, w którym schroniły się setki osób). Ostatecznie, produkcja ta nie doszła do skutku (do motywu zatopionych $\mathrm{w}$ tunelu cywilów powróci Staudte $\mathrm{w}$ jednym $\mathrm{z}$ kolejnych filmów, o czym będzie jeszcze mowa).W sowieckiej strefie zdążyły powstać jeszcze dwie inne fabuły, zanim swą premierę miał pierwszy film nakręcony w zachodniej części Niemiec: Powiedz prawdę (Sag die Wahrheit, reż. Helmut Weiß, 1946) - zrealizowana na licencji brytyjskiej komedia omyłek, której scenariusz napisany został jeszcze przed zakończeniem wojny. Najmniej filmów powstało w strefie francuskiej, gdzie infrastruktura przemysłu kinematograficznego była najsłabiej rozwinięta. Władze amerykańskiej strefy okupacyjnej były natomiast początkowo niechętne podejmowaniu przez Niemców jakichkolwiek przedsięwzięć w zakresie filmu fabularnego - pierwszy niemiecki film z licencją amerykańską: Między dniem wczorajszym a jutrzejszym (Zwischen gestern und morgen, reż. Harald Braun) miał premierę dopiero w grudniu $1947 \mathrm{r}$.

Przyczyną owego opóźnienia w produkcji filmów w strefach zachodnich były nie tylko kwestie stricte produkcyjne (związane $\mathrm{z}$ dostępem do sprzętu i atelier), lecz także polityka kadrowa. Wspominałem już o tym, że w pierwszych miesiącach po zakończeniu działań wojennych denazyfikacja była prowadzona szczególnie skrupulatnie w strefie amerykańskiej. Dotyczyło to również osób związanych z kinematografią - podstawą decyzji o dopuszczeniu do takiej pracy był tajny raport ${ }^{53}$, przygotowany

${ }^{51}$ Jak wspominał Kurt Maetzig, reżyserię chciano początkowo powierzyć Wilhelmowi Dieterle (który w 1945 roku miał przybyć na krótko do Berlina); rozważano ponoć również kandydaturę Rosselliniego (zrealizował on w Berlinie zdjęcia dokumentujące skalę zniszczeń miasta, później wykorzystane w jego filmie Niemcy, rok zerowy) - Kurt Maetzig, Friedrich Wolf und der Film, [w:] Kurt Maetzig: Filmarbeit, Gespräche, Reden, Schriften, red. Günter Agde, Berlin (Ost) 1987, s. 355. Zob. także: Friedrich Wolf, Briefe. Eine Auswahl, Berlin (Ost) 1969, s. 212.

52 Staudte wspominał, że pod koniec 1945 r. spotkał Ernsta Buscha i Friedricha Wolfa, którzy oświadczyli: „My zrobimy pierwszy film” i zapytali, czy nie pomoże im w realizacji (Wolfgang Staudte über die Produktionsbedingungen seiner Filme, [w:] Wolfgang Staudte, red. Eva Orbanz, Berlin 1977, s. 67).

${ }^{53}$ Raport zawierał 150 „,charakterystyk” ważnych postaci życia kulturalnego Niemiec (podzielonych na cztery grupy - w zależności od stopnia popierania polityki narodowosocjalistycznej). Pełna wersja raportu (Carl Zuckmayer, Geheimreport, Göttingen 2002) została 
w 1943 r. na zamówienie biura wywiadu USA (Office of Strategic Services) przez Carla Zuckmayera, wybitnego dramaturga ${ }^{54}$, który w Republice Weimarskiej pracował dla kina (był m.in. współautorem scenariusza Błękitnego anioła [Der blaue Engel, reż. Josef von Sternberg, Niemcy 1930] - na podstawie Profesora Unrata Heinricha Manna). Z raportu korzystał m.in. Erich Pommer (w Republice Weimarskiej stał na czele spółki Decla, wchłoniętej później przez Ufę; był także pierwszym szefem SPIO - Niemieckiej Izby Filmowej), który w 1946 r. objął w OMGUS - w randze pułkownika - nadzór nad kulturą filmową ${ }^{55}$.

Początkowo mogło się wydawać, iż amerykańska polityka względem kina w Niemczech będzie uwzględniać przede wszystkim ekonomiczne interesy hollywoodzkich wytwórni, które w strefach okupowanych odnalazły nową widownię - nie były więc zainteresowane reanimacją dawnego potężnego konkurenta. Innym możliwym wariantem było wykorzystanie infrastruktury z terytoriów okupowanych dla własnych celów produkcyjnych - również dla realizacji filmów adresowanych do niemieckiego czy austriackiego widza, poruszających aktualne tematy i dotyczących obecności aliantów na terenach okupowanych. I tak, w Bawarii Billy Wilder nakręcił znakomity Zagraniczny romans (A Foreign Affair, 1948), gdzie główną rolę kokoty zmuszonej romansować z amerykańskim żołnierzem zagrała Marlena Dietrich ${ }^{56}$, a w tym samym roku Fred Zinnemann zrealizował Poszukiwanie (The Search, 1948) o perypetiach czeskiego chłopca, który przeżywszy Auschwitz, został przygarnięty przez amerykańskiego żołnierza (formalnie to produkcja amerykańsko-szwajcarska, choć zdjęcia kręcono w Bawarii).

Ostatecznie to sam Pommer przyczynił się do korekty amerykańskiej polityki wobec niemieckiej kinematografii. Jednym z czynników

opublikowana w Niemczech już po zjednoczeniu. Zob. także: Zur Diskussion: Zuckmayers »Geheimreport « und andere Beiträge zur Zuckmayer-Forschung, "Zuckmayer-Jahrbuch" 2002, nr 5. Za wskazanie tego tropu dziękuję Tomaszowi Majewskiemu.

${ }_{54}$ Powstały w ostatnich latach wojny dramat Zuckmayera Generat diabła (zekranizowany w latach 50. w RFN - zob. podrozdział 3.1), jedna z pierwszych fabuł ustanawiających mit "dobrych oficerów” Wehrmachtu, należał do najczęściej wystawianych sztuk w amerykańskiej i brytyjskiej strefie okupacyjnej - zob. Katrin Weingran, "Des Teufels General" in der Diskussion: zur Rezeption von Carl Zuckmayers Theaterstück nach 1945, Marburg 2004.

55 Zob. Heide Fehrenbach, Cinema in Democratizing Germany: Reconstructing National Identity After Hitler, Chapel Hill 1995, s. 62-65.

56 Zob. Tomasz Majewski, Berlin/Wilder...; Gerd Gemünden, In the Ruins of Berlin: "A Foreign Affair"; [w:] German Postwar Films, red. Wilfried Wilms, William Rasch, New York 2008; David Bathrick, Billy Wilder's Cold War Berlin, „New German Critique” 2010, nr 110; kontekstowo także: Annette Brauerhoch, Fräuleins und GIs. Geschichte und Filmgeschichte, Frankfurt am Main 2006 (rozdział: Leben in Ruinen). 
zliberalizowania przez aliantów zachodnich w 1947 r. przepisów dotyczących licencji mogło być dostrzeżenie przez nich potencjału produkcyjnego Defy. Wedle słów Pommera,

zreorganizowany niemiecki przemysł filmowy rzeczywiście może stać się najskuteczniejszym środkiem reedukacji narodu niemieckiego ku demokratycznemu życiu, o ile założymy, że jednocześnie zostaną stworzone możliwości, które gwarantują solidną i wieloletnią kontrolę. Prócz perspektywy idealistycznej jest jeszcze praktyczna. Właściwa historia, na podstawie której nakręcony zostanie dobry film rozrywkowy, grany przez niemieckich aktorów, na niemieckim tle, może lepiej przysłużyć się naszemu celowi, niż najlepszy film propagandowy lub dokumentalny ${ }^{57}$.

W konsekwencji, w 1948 r. na obszarze zachodnich stref okupowanych znacząco wzrosła liczba wydanych zezwoleń (z sześciu w 1947 r. do dziewiętnastu w 1948 r.). Do końca 1948 r. powstało łącznie czternaście pełnometrażowych filmów fabularnych w strefie sowieckiej i dwadzieścia sześć w zachodnich ${ }^{58}$, a znaczący przyrost produkcji nastąpił w $1949 \mathrm{r}$. (dane liczbowe mogą być $\mathrm{w}$ tym wypadku mylące, $\mathrm{z}$ uwagi na przyporządkowywanie konkretnych filmów bądź do "kina strefowego", bądź kinematografii RFN lub NRD).

Zdecydowana większość niemieckich filmów z lat 1946-1949 została zrealizowana przez twórców aktywnych zawodowo w czasach nazistowskich (m.in. Wolfganga Staudtego, Helmuta Käutnera, Wolfganga Liebeneinera i Josefa von Báky'ego) - co, po pierwsze, nie oznacza wszakże: „przez byłych nazistów”, i co, po drugie, nie powinno szczególnie dziwić, zważywszy na braki kadrowe $\mathrm{w}$ pierwszych latach powojennych. Można zatem zasadnie mówić o „kontynuacji”, przy czym tendencja ta była szczególnie widoczna na obszarze stref zachodnich, gdzie - według wyliczeń Klausa Kreimeiera - „w latach 1946-1948 niemal wszystkie filmy zostały wyreżyserowane i wyprodukowane przez byłych pracowników Ufy lub innych firm koncernu Ufi" 59 .

Spośród najbardziej znanych reżyserów nazistowskich filmów propagandowych dotkliwszej kary doczekał się w zasadzie tylko Fritz Hippler, internowany i skazany na dwa lata więzienia (później współpracował pod pseudonimem przy realizacji kilku filmów dokumentalnych i szkolenio-

57 Cyt. za: Wolfgang Jacobsen, Erich Pommer. Ein Produzent macht Filmgeschichte, Berlin 1989, s. 144 (dziękuję Magdalenie Saryusz-Wolskiej za wskazanie tego cytatu).

58 Peter Pleyer, Deutscher Nachkriegsfilm 1946-1948, Münster 1965, s. 31-45 i 459-460. Cytowany już Brandlmeier podaje, że do 1948 r. wyprodukowano 40 niemieckich filmów fabularnych. Dane ilościowe zawiera też: Alfred Bauer, Deutscher Spielfilm Almanach, t. 2: 1946-1955, München 1981.

${ }^{59}$ Klaus Kreimeier, The Ufa Story..., s. 376. 
wych). Veit Harlan został dwukrotnie oczyszczony z zarzutów zbrodni przeciw ludzkości (proces w Hamburgu - wiosną 1948 r., a w Berlinie Zachodnim - rok później). Z kolei Leni Riefenstahl, która przechodziła denazyfikację kilkukrotnie, $\mathrm{w}$ różnych strefach okupacyjnych (Niemiec i Austrii), w ten oto sposób relacjonowała przesłuchanie, jakiemu została poddana w sierpniu $1946 \mathrm{r}$.:

- Więc nigdy pani nie słyszała o Buchenwaldzie i Mauthausen? - pokrzykiwał na mnie jeden z Francuzów.

- Nie.

- Kłamie pani. Nie wierzymy pani. Proszę powiedzieć nam prawdę.

- Nie, nie, nie! - wykrzykiwałam w rozpaczy.

- Jeśli pani miłe życie własnej matki, to... - Tego już było za wiele. Nie zdążył posunąć się dalej. Rzuciłam się na niego i tak wczepiłam zębami w gardło, że popłynęła krew $^{60}$.

Spośród nielicznych reżyserów - reemigrantów część pracowała w landach zachodnich (Fritz Kortner, Peter Lorre, Robert Siodmak), część - w Defie (Slátan Dudow, Peter Pewas, Kurt Maetzig). Generalnie w omawianym okresie - z uwagi na „przepuszczalność” granic i zapotrzebowanie na specjalistów - wewnętrze migracje twórców z poszczególnych stref nie należały do rzadkości.

Filmy mogły być początkowo rozpowszechniane tylko w obrębie jednej strefy (wraz z łączeniem stref zachodnich wymóg ten został złagodzony do całego obszaru Trizonii). Wymiana pomiędzy strefami aliantów zachodnich i strefą sowiecką odbywała się na zasadzie "kopia za kopię" - co powodowało niekiedy znaczne przesunięcia czasowe w dystrybucji filmów w poszczególnych strefach (przykładowo, film Mordercy sa wśród nas miał premierę w Berlinie wschodnim w październiku 1946 r., w strefie amerykańskiej - sześć miesięcy później, zaś w strefie brytyjskiej - w lipcu 1948 r. ${ }^{61}$ ). Wymiana była kontynuowana także później, po proklamacji RFN i NRD, ale miała już bardziej ograniczony charakter - do roku 1949 większość filmów z sowieckiej strefy pokazywana była również w Trizonii,

${ }^{60}$ Leni Riefenstahl, Pamiętniki, tłum. J. Łaszcz, Warszawa 2003, s. 283. Interesujące są również opisane w Pamiętnikach, okoliczności związane z publikacją przez magazyn „Wochenende" w 1948 r. rzekomych dzienników Ewy Braun, przekazanych wydawcy przez Luisa Trenkera, niegdysiejszego reżysera „filmów górskich" i aktora, u boku którego Riefenstahl występowała w filmach Fancka. Z uwagi na zawarte w owych „dziennikach" liczne komentarze dotyczące jej bliskich relacji z Hitlerem, autorka Triumfu woli wytoczyła wydawcy proces, zakończony korzystnym dla niej werdyktem, który od tej pory będzie przez nią często przywoływany (ibidem, s. 300-303).

${ }^{61}$ Informacje o datach premier podaję za bazą danych www.filmportal.de, prowadzoną przez Deutsches Filminstitut. 
ale już tylko cztery filmy wyprodukowane w NRD w roku 1950 weszły do dystrybucji kinowej w RFN ${ }^{62}$.

Repertuar filmowy niemieckich kin okresu 1945-1949 zapełniały przede wszystkim filmy rozrywkowe; sporą ich część stanowiły produkcje z krajów danej strefy okupacyjnej oraz filmy dźwiękowe zrealizowane w Republice Weimarskiej. W normalnej dystrybucji były też filmy nakręcone w III Rzeszy (z dystrybucji wyłączono tylko najbardziej propagandowe realizacje) ${ }^{63}$. Wedle ustaleń Pleyera ${ }^{64}$, Amerykanie wydali zgodę na dystrybucję 845 filmów, niemal wszystkich przedstawionych im do oceny (ponad 300 filmów niemieckich, 194 amerykańskich oraz ok. 350 filmów innej produkcji), Brytyjczycy dopuścili większą liczbę tytułów (ponad 500 niemieckich, 130 brytyjskich i ok. 550 innej produkcji), ale zarazem objęli zakazem 300 innych ${ }^{65}$, w strefie francuskiej zaś proporcje te kształtowały się odpowiednio na poziomie: blisko 400, 120 i 380 (odrzucono 39 tytułów $)^{66}$. Analogiczne dane ze strefy sowieckiej nie są znane, ale na podstawie repertuarów kin można zrekonstruować podobne proporcje ${ }^{67}$. Na ekrany weszły również Überläuferfilme - filmy „przechodnie” lub „przejściowe ${ }^{\prime \prime 68}$, czyli takie, które zostały nakręcone pod koniec wojny, lecz nie doczekały się premiery lub zostały zatrzymane przez nazistowską cenzurę

${ }^{62}$ Thomas Brandlmeier, Von Hitler zu Adenauer: Deutsche Trümmerfilme, [w:] Zwischen gestern und morgen: westdeutscher Nachkriegsfilm 1946-1962, red. Hilmar Hoffmann, Walter Schober, Frankfurt am Main 1989, s. 41. Zob. też: Peter Stettner, Der deutsch-deutsche Filmaustausch (1947-1951). Von einer gesamtdeutschen Kooperation zum Kampf um die politische und kulturelle Hegemonie im geteilten Deutschland, [w:] DEFA-Film als nationales Kulturerbe?, red. Klaus Finke, Berlin 2001.

${ }^{63}$ Lista filmów zakazanych dostępna w: John F. Kelson, Catalogue of Forbidden German Feature and Short Film Productions held in Zonal Film Archives of Film Section, Information Services Division, Westport 1996.

${ }^{64}$ Peter Pleyer, Deutscher Nachkriegsfilm..., s. 26-27 (powtórzone w: Robert R. Shandley, Trümmerfilme. Das deutsche Kino der Nachkriegszeit, Berlin 2010, s. 32).

${ }^{65}$ Zob. Gabriele Klemens, Britische Kulturpolitik... (rozdziały 5.2 i 7.2).

${ }^{66}$ Na temat polityki filmowej Francji w jej strefie okupacyjnej zob. Laurence Thaisy, La politique cinématographique de la France en Allemagne occupée: 1945-1949, Villeneuve-d'Ascq 2006; w języku niemieckim - Frank Becker, Kino und Film im französisch besetzten Württemberg-Hohenzollern, Frankfurt am Main 2007.

${ }^{67}$ Michael Hanisch wylicza, że w 1948 r. w sowieckiej strefie pokazano 34 filmy dawnej Ufy, 21 sowieckich, 7 defowskich i 6 z innych stref (Michael Hanisch, „Um 6 Uhr abends nach Kriegsende” bis "High Noon": Kino und Film im Berlin der Nachkriegszeit, 1945-1963, Berlin 2004, s. 19-32, 78-80).

68 Andrzej Gwóźdź proponuje tłumaczenie „filmy dezerterskie” od rzeczownika Überläufer („zbieg, uciekinier”); bardziej sensowne jest może utworzenie polskiego tłumaczenia od czasownika überlaufen („przebiegać, przechodzić”). Termin „dezerterski” wydaje mi się niezbyt fortunny w odniesieniu do, na przykład, Leni Riefenstahl, której Niziny (Tiefland) miały premierę w $1954 \mathrm{r}$. 
w ostatnich miesiącach jej istnienia ${ }^{69}$; łącznie do dystrybucji weszło ponad trzydzieści filmów „przechodnich"70. Ostatecznie, produkcje niemieckie zrealizowane po 1945 r. stanowiły - do proklamacji RFN i NRD - tylko niewielką część repertuaru niemieckich kin, w których dominowały repryzy rodzimej produkcji. To właśnie one cieszyły się największym powodzeniem wśród ówczesnej widowni, która w dużej mierze odrzucała najnowsze niemieckie filmy (co wynika z dwóch badań sondażowych opublikowanych w $1948 \mathrm{r} .{ }^{71}$ ), a zarazem - według ustaleń współczesnych historyków - niezbyt wysoko oceniała produkcje pochodzące z państw alianckich $^{72}$.

Gatunkiem specyficznym dla niemieckiej kinematografii pierwszych lat po wojnie są „filmy ruin” (Trümmerfilme) - najogólniej mówiąc: fabuły osadzone w plenerach zniszczonych miast ${ }^{73}$. Choć Trümmerfilme nie były

${ }^{69}$ Były wśród nich filmy uznanych - zarówno wcześniej, jak i później-reżyserów, na przykład Helmuta Käutnera. Wśród pierwszej kategorii „filmów przechodnich” znajduje się jego Pod mostami (Unter den Brücken, 1944/1946), do drugiej zaś zaliczyć można Große Freiheit Nr. 7 (1944/1946).

${ }^{70}$ Holger Theuerkauf, Goebbels' Filmerbe. Das Geschäft mit unveröffentlichen Ufa-Filmen, Berlin 1998, s. 136-156.

${ }^{71} \mathrm{~W} 1948$ r. wykonano badanie sondażowe, którego wyniki omawiano w prasie (Horst Müting, Deutsche Filme bevorzugt, "National Zeitung”, 8.12.1948); podług tego badania (niestety, w przywołanym artykule brak informacji o jego szczegółach) najnowsze niemieckie filmy miały być odrzucane przez 90 procent widzów. Z kolei z ankiety dotyczącej tzw. „filmów ruin” (zob. dalsza część rozdziału), którą przeprowadziła w tym samym roku gazeta "Die Neue Zeitung”, wynikało, że nie akceptowało ich 56 procent widzów („Die Neue Zeitung”, 29.02.1948; przedruk w: „Als der Krieg zu Ende war”. Literarisch-politische Publizistik 1945-1959, red. Gerhard Hay, Hartmut Rambaldo, Joachim Stork, Marbach 1974, s. 419-420).

72 Jennifer Fay konstatuje, opierając się na wynikach badań sondażowych prowadzonych w strefie amerykańskiej, że filmy hollywoodzkie, choć oglądane chętnie, były często rozumiane inaczej niż przewidywały władze tej strefy, liczące na przeszczepienie za pośrednictwem atrakcyjnych fabuł zasad demokracji i kapitalizmu (Jennifer Fay, Theaters of Occupation. Hollywood and the Reeducation of Postwar Germany, Minneapolis 2008, s. 72). Z kolei Pawel Skopal dowodzi, że w strefie sowieckiej niezbyt popularne były filmy z ZSRR (Pavel Skopal, "It is not enough we have lost the war - now we have to watch it!" Cinemagoer's attitudes in the Soviet occupation zone of Germany - a case study from Leipzig, "Participations. Journal for Audience and Reception Studies" 2011, nr 2).

${ }^{73}$ Poza przywoływaną już książką Shandleya, która uchodzi za podstawową monografię tego zjawiska, można wymienić: Martina Möller, Vom Expressionismus zum Trümmerfilm? Visueller Stil und Nachkriegskrise im Trümmerfilm, [w:] Krisenkino. Filmanalyse als Kulturanalyse: Zur Konstruktion von Normalität und Abweichung im Spielfilm, red. Waltraud Wende, Lars Koch, Bielefeld 2010; Thomas Brandlmeier, Von Hitler zu Adenauer...; Trümmer und Träume: Nachkriegszeit und fünfziger Jahre auf Zelluloid; deutsche Spielfilme als Zeugnisse ihrer Zeit, red. Ursula Bessen, Bochum 1989. W języku polskim zob.: Magdalena Saryusz-Wolska, Ikony normalizacji... (rozdział: Ruiny i odbudowa); Andrzej Gwóźdź, Obok kanonu. Tropami kina niemieckiego, Wrocław 2011. 
nurtem dominującym w ówczesnej niemieckiej produkcji filmowej ${ }^{74}$, ani nie cieszyły się - jak już wspomniałem - szczególnie dużą popularnością, są dziś kanonicznie uwzględniane w opracowaniach historii kina. Co więcej, znaczenie samego terminu wyraźnie się rozszerzyło - coraz częściej odnosi się on bowiem do całej niemieckiej kinematografii pierwszych lat powojennych, wypierając stosowane wcześniej określenie Zonenfilme (filmy strefowe) czy, po prostu, Nachkriegsfilme (filmy powojenne).

Wydaje się zreszta, że "filmy ruin" można uznać za zjawisko emblematyczne nie tylko dla kina niemieckiego - podobne filmy realizowano wówczas bowiem także we Włoszech ${ }^{75}$. W Niemczech Trümmerfilm wykształcił jednak własną specyfikę, przede wszystkim za sprawą wizualnych nawiązań do poetyki Ufy, zarówno „ekspresywistycznych” filmów Republiki Weimarskiej (scenografia wykraczająca poza funkcję uwiarygodniania wydarzeń, niski klucz świetlny, przekrzywione pole widzenia kamery), jak i melodramatów zrealizowanych w okresie III Rzeszy. Pod względem wizualnym wyróżnikiem Trümmerfilme są z pewnością plenerowe ujęcia o dużym walorze dokumentalnym ${ }^{76}$. Gdy zaś idzie o dramaturgię, charakterystyczną cechą "filmów ruin" była specyficzna konstrukcja męskich i kobiecych bohaterów/ek, wzorowanych na typach społecznych właściwych dla tużpowojennych niemieckich realiów: Trümmerfrau (kobieta, która musi zapewnić byt rodzinie pod nieobecność męża lub syna) i Heimkehrer (mężczyzna powracający do Niemiec, najczęściej zdemobilizowany żołnierz zwolniony z obozu jenieckiego). Filmy, w których pojawia się ten ostatni typ bohatera, są dla niniejszej pracy dość kłopotliwe - większość tych fabuł ograniczała się bowiem do przedstawienia procesu jego włączania $\mathrm{w}$ dzieło powojennej odbudowy. W filmach tych przeszłość i wspomnienia bohatera muszą zostać przezwyciężone, oddalone z horyzontu doświadczenia, gdyż paraliżowałyby „produktywność", jakiej od protagonistów doby Neubeginn wymaga nowy czas.

${ }^{74}$ Zdaniem Bettiny Greffrath, motyw ruin był szczególnie częsty w kinie lat 19461948 i pojawiał się tylko w pojedynczych produkcjach z 1949 r. (Bettina Greffrath, Gesellschaftsbilder der Nachkriegszeit. Deutsche Spielfilme 1945-1949, Pfaffenweiler 1995, s. 217).

${ }^{75}$ W szczególności chodzi tu o niektóre filmy zaliczane do nurtu neorealizmu. Ciekawym przypadkiem jest nakręcony w Niemczech przez Roberta Rosselliniego w 1947 r. film Niemcy, rok zerowy - trafił on na niemieckie ekrany dopiero w 1952 r., gdy większość "filmów ruin" wycofano już z repertuarów kin.

${ }^{76}$ Jaimey Fisher określa je mianem rubble shots. Można zgodzić się z autorem, że ujęcia tego rodzaju nie mogą być rozpatrywane wyłącznie jako źródło filmowego realizmu (jeśli będziemy go pojmować tak, jak w wypadku klasycznego filmu fabularnego), bowiem - faktycznie - częstokroć autonomizują przestrzeń, która wyłamuje się ze swej służebności wobec "dziania się" akcji. Niezbyt przekonujące zdają mi się natomiast uwagi Fishera o rzekomym podważaniu przez rubble shots „,skopofilicznych przyjemności widowiska filmowego" (Jaimey Fisher, Who's Watching the Rubble-Kids? Youth, Pedagogy and Politics in Early DEFA Films, „New German Critique” 2001, nr 82, s. 97-98). 
Przykładem takiego filmu jest ... a nad nami niebo (Und über uns der Himmel, reż. Josef von Baký, 1947) ze strefy amerykańskiej, z Hansem Albersem, gwiazdorem kina III Rzeszy, w roli głównej. W fabule tej wykorzystano dramaturgiczny schemat konfliktu pokoleniowego, chętnie stosowany w kinie tego okresu. W filmie von Baký'ego rozgrywa się on pomiędzy Hansem - doświadczonym robotnikiem, który nie mogąc znaleźć legalnej pracy, wiąże się z kryminalnym „półświatkiem” przemytników i paserów - oraz jego synem Walterem. W czasie wojny stracił on wzrok, co w jednej ze scen staje się pretekstem do montażowego zestawienia obrazów zrujnowanego Berlina i archiwalnych ujęć przedstawiających stolicę tętniącą życiem; te ostatnie mają w narracji podwójny status: można je odczytać zarówno jako retrospekcję (Hans wspominający niedzielne wycieczki z rodziną), jak i mind screen (obrazy wyobrażane przez niewidomego Waltera, nieświadomego skali zniszczeń $)^{77}$. Znamienne, że ujęcia te nie są dyskursywnie związane z okresem nazizmu (na ulicach nie ma żadnych flag ani mężczyzn w mundurach), przywołują jedynie "dobre, stare dzieje". O wojnie bohaterowie zresztą nie rozmawiają konflikt dotyczy wyłącznie postaw obieranych przez bohaterów w okresie odbudowy.

W podobny sposób Heimkehrer - zdemobilizowany żołnierz lub mężczyzna zwolniony z obozu tymczasowego ${ }^{78}$ - profilowany był w kilku innych filmach, m.in.: Przed nami życie (Vor uns liegt das Leben, reż. Günther Rittau, 1948), Ludzie w rękach Boga (Menschen in Gottes Hand, reż. Rolf Meyer, 1948), Drogi w mroku (Wege im Zwielicht, reż. Gustav Fröhlich, 1948), Zapomniana twarz (Das verlorene Gesicht, reż. Kurt Hoffmann, 1948), Dokad jada pociagi (Wohin die Züge fahren, reż. Boleslaw Barlog, 1949) ${ }^{79}$. Z faktu, że wszystkie one zostały nakręcone w strefach zachodnich nie należy wyciągać przesadnych wniosków - Heimkehrerfilme powstawały także w Defie, o czym będzie jeszcze mowa.

Wątki związane z nazistowską przeszłością pojawiają się w niektórych tylko „filmach ruin" $\mathrm{i}-\mathrm{w}$ szerszym rozumieniu tego pojęcia - w zrealizowanych w latach 1946-1949 fabułach, których akcja rozgrywa się w okresie powojennym. Owszem, w kilku z nich wprowadzony zostaje bohater, najczęściej drugoplanowy, w jakiś sposób (dramaturgicznie lub

${ }_{77}$ Na tę scenę zwracano uwagę również w ówczesnej krytyce - na przykład: Gunter Groll, In der Schauburg: "Und über uns der Himmel”, "Süddeutsche Zeitung”, 13.01.1948.

${ }^{78}$ Wzorzec Heimkehrerfilme został przejęty z okresu weimarskiego, kiedy powstawały filmy o „powrocie weterana” (na przykład Powrót do domu [Heimkehr] Joe Maya z 1929 r.). Dziękuję Tomaszowi Kłysowi za tę uwagę.

79 Wbrew temu, co może sugerować tytuł, film Dokąd jada pociagi nie dotyczy Holocaustu. Z kolei bohaterką Zapomnianej twarzy jest Luscha, niespełna rozumu dziewczyna, cierpiąca na amnezję i mówiąca niezrozumiałym językiem (dobrotliwa hrabianka podejrzewa, że pochodzi ona... z Tybetu!). 
dyskursywnie) powiązany z narodowym socjalizmem - co jednak nie zawsze pociąga za sobą pogłębioną refleksję nad ponurym dziedzictwem nazizmu. Przykładowo, w filmie Defy ...Gdyby tylko jeden (...und wenn's nur einer wär', reż. Wolfgang Schleif, 1949) taką postacią jest wychowawca berlińskiego domu dziecka, który zastępuje lubianego opiekuna, sam zaś okazuje się bez mała tyranem. Gdy jego podopieczni uciekają z placówki i odnajdują swego poprzedniego wychowawcę (we wschodnim sektorze!), wychodzi na jaw, że „nowy” jest dawnym oficerem SS. Z tej dramaturgicznej wolty niewiele jednak wynika dla dyskursu filmu - poza tym może, iż "dobry wychowawca" skojarzony zostaje ze wschodnią częścią Berlina, a były esesman z sektorem zachodnim.

Brak refleksji nad nieodległą historią jest uderzający również w przypadku dwóch filmów, w których wykorzystano ramę narracyjną a zatem formułę potencjalnie ułatwiającą metadyskursywny namysł nad znaczeniami wytwarzanymi przez fabułę. W zrealizowanym w strefie brytyjskiej Filmie bez tytułu (Film ohne Titel, reż. Rudolf Jugert, 1948) rama ta ma charakter autotematyczny: scenarzysta, reżyser i aktor (Willy Fritsch - gwiazdor z okresu III Rzeszy!) jadą na wieś, by pracować nad scenariuszem. W pierwszej scenie spierają się o to, jaki film powinni zrealizować: Trümmerfilm, Heimkehrerfilm, Antinazifilm, Propagandafilm czy Bombenfilm. Ostatecznie, rama narracyjna okala dość banalną historyjkę miłosną - romans handlarza dziełami sztuki i dziewczyny ze wsi, który komplikuje się po wojnie, gdy mężczyzna, wskutek utraty majątku, musi prosić o pomoc rodziców ukochanej. I choć opowieść ta rozpoczyna się w wojennym anturażu (dom zniszczony przez nalot bombowy), a także zawiera elementy Heimkehrerfilm (bohater nie wraca wprawdzie z obozu dla jeńców, lecz jest raczej dezerterem, gdyż w ostatnich miesiącach wojny został wciągnięty do Volkssturmu), nie ma w niej choćby cienia refleksji nad przyczynami wojny, jej przebiegiem i politycznymi skutkami (innymi niż cierpienie niemieckich cywilów).

Inna fabuła wykorzystująca ramę narracyjną - Berlińska ballada (Berliner Ballade, reż. Robert A. Stemmle, 1948) ze strefy amerykańskiej - jest nawiązującą do tradycji burleski satyryczną parabolą niemieckiego społeczeństwa pierwszych lat powojennych ${ }^{80}$. Film rozpoczyna się panoramą nowoczesnego „Berlina przyszłości”, z połowy XXI wieku - „retrospekcję" wprowadza ironiczna narracja ponadkadrowa: sto lat temu, $w$ do-

${ }^{80}$ Scenariusz Güntera Neumanna był filmową przeróbką jego popularnego kabaretowego programu Schwarzer Jahrmarkt (dosł. "czarny jarmark" - gra słów z pojęciem Schwarzer Markt, czyli „,czarny rynek”). Na temat inspiracji kabaretem w Berlińskiej balladzie por. Claudia Breger, "Kampf gegen den Kampf”: Aesthetic Experimentation and Social Satire in "The Ballad of Berlin", [w:] German Postwar Films... 
brych starych czasach, wygladało to wszystko zupetnie inaczej. Chwilę później - w scenie kręconej z POV - okazuje się, że ów narrator jest postacią diegetyczna, kimś w rodzaju „dziennikarza z przyszłości”, doskonale orientującego się w realiach epoki (gdy wprowadza głównego bohatera, symuluje westchnienie ówczesnych widzów: ach, jeszcze jeden film o Heimkehrerze!).

Protagonistą jest niejaki Otton Przeciętniak (Normalverbraucher - od słowa określającego przeciętne zapotrzebowanie kartek żywnościowych). W kilku retrospektywnych scenkach obyczajowych z życia młodego kawalera przedstawiona zostaje (między 11 a 14 minutą filmu) „historia II wojny w pigułce". W 1940 r. - bohater słucha audycji radiowej o zwycięstwach na froncie; dwa lata później - pojawia się komentarz: $z a$ padły ciemności; na ścianie nadal wisi portret Hitlera (ale - jak głosi komentarz $-z$ powodu dozorcy). W 1943 r. pobliska eksplozja sprawia, że w mieszkaniu szyby wypadają z okien; z półki nad radiem spada książka, o której narrator mówi: Z przodu stał Rosenberg, który przykrywał Thomasa Manna. Słuchać pukanie do drzwi - i ponaddiegetyczny komentarz: Strach przed sasiadami (gdy okazuje się, że to listonosz, narrator poprawia się: Strach przed powotaniem do wojska). Kolejne scenki pokazują próby uniknięcia wojska (łykanie olbrzymiej ilości medykamentów, próby zatrucia pokarmowego, wreszcie - w dniu komisji lekarskiej - bieganie po schodach w górę i dół). Gdy Otto mdleje w czasie badania, zmyślny match-cut "przenosi” jego leżące ciało wprost do koszar, gdzie bohater poddany zostaje wycieńczającej musztrze. Samej wojny w tym „skrócie” - w zasadzie nie ma. Po jej zakończeniu Otto zostaje zwolniony z tymczasowego obozu i powraca do Berlina, gdzie musi ułożyć sobie życie, szukając dachu nad głową oraz źródła utrzymania.

Zakończenie filmu jest $\mathrm{z}$ ducha chaplinowskie: $\mathrm{w}$ jednej $\mathrm{z}$ ostatnich scen pokazana zostaje narada przedstawicieli różnych państw (zamiast wypowiadanych słów słychać fragmenty muzyki klasycznej, jakoby płynące z ust dostojników); spotkanie kończy się przypadkowym podpaleniem globusa. Chwilę potem Otto trafia na tajne spotkanie dwóch - można się domyślać - agentów (lub po prostu: alegorycznych postaci symbolizujących świat zachodni i blok sowiecki), planujących kolejną wojnę. Gdy sprzeciwia się ich zamiarom, zostaje znokautowany i w konsekwencji umiera. W ramowej narracji protagonista "zmartwychwstaje": na pogrzebie staje nad swoją trumna, oznajmia, że czuje się jak nowo narodzony, a następnie deklaruje: tym, co powinniśmy pogrzebać, jest strach: przed ludźmi, przed przyszłościa, przed wojna i przed pokojem.

Wśród pełnometrażowych niemieckich filmów powstałych w strefach okupacyjnych odnajduję tylko kilka takich, które w ewidentny sposób dotyczyły okresu nazistowskiego, tj. umieszczały akcję filmu w latach 1933-1945 lub przedstawiały powojenne reperkusje związane 
z nazizmem w sposób pogłębiony, tj. wykraczający poza pokazanie li tylko zniszczonych miast czy problemów z aprowizacją i czarnym rynkiem. W strefach zachodnich powstało osiem takich filmów: W tamtych dniach (In jenen Tagen, reż. Helmut Käutner, 1947), I kiedyś się znowu odnajdziemy (Und finden dereinst wir uns wieder, reż. Hans Müller, 1947), Między dniem wczorajszym a jutrzejszym (Zwischen gestern und morgen, reż. Harald Braun, 1947), Miłość 47 (Liebe 47, reż. Wolfgang Liebeneiner, 1948), Morituri (reż. Eugen York, 1948), Dtuga jest droga (Lang ist der Weg, reż. Herbert Fredersdorf, Marek Goldstein, 1948), Powołanie (Der Ruf, reż. Josef von Baký, 1949) i Ostatnia noc (Die letzte Nacht, reż. Eugen York, 1949). Gdy zaś idzie o produkcje Defy, wskazać można pięć tytułów: Mordercy sa wśród nas, Małżeństwo w mroku (Ehe im Schatten, reż. Kurt Maetzig, 1947), Gdzieś w Berlinie (Irgendwo in Berlin, reż. Gerhard Lamprecht, 1946), Cztery pokolenia (Die Buntkarrierten, reż. Kurt Maetzig, 1949) oraz Rotacje/Brunatna pajęczyne (Rotation, reż. Wolfgang Staudte, 1949 ${ }^{81}$ ). Więcej filmów dotyczących nazizmu zrealizowano zatem w strefach zachodnich - przy czym statystyka wyglądałaby inaczej, gdyby dane podać w procentach (w odniesieniu do ogólnej liczby filmów wyprodukowanych we wschodniej i zachodniej części Niemiec), bowiem w okresie 1946-1949 w strefach kontrolowanych przez aliantów zachodnich powstało łącznie trzy razy więcej pełnometrażowych fabuł niż w strefie sowieckiej ${ }^{82}$.

\subsection{Mordercy sq wśród nas: traumy pośród ruin}

Pierwszy film fabularny zrealizowany w Niemczech po II wojnie światowej-Mordercy sa wśród nas - zaliczany jest do kanonu kina niemieckiego i był po wielokroć analizowany, najczęściej w perspektywie produkcyjnej (problemy ze zdobyciem licencji, różne wersje scenariusza), femi-

${ }^{81} \mathrm{~W}$ okresie PRL film był dystrybuowany jako Brunatna pajęczyna. Wprawdzie w polskim piśmiennictwie rozpowszechniony jest ten właśnie tytuł, Magdalena Saryusz-Wolska w swej książce (Ikony normalizacji...) proponuje - skądinąd, całkiem zasadnie - rezygnację $\mathrm{z}$ tej, silnie nacechowanej propagandową intencja, wersji tłumaczenia, na rzecz przekładu dosłownego: Rotacja. W związku z tym zdecydowałem się na salomonowe rozstrzygnięcie - i podawanie obu wariantów tytułu.

${ }^{82}$ Na procentową przewagę filmów Defy wskazuje Kirsten Burghardt w swoim zestawieniu filmów z okresu 1946-1949, traktujących o „moralnym odrodzeniu”. Autorka uwzględnia w nim nieco inne tytuły - dołączając do analizowanego korpusu także dwa filmy na licencji amerykańskiej: ... a nad nami niebo i Przed nami życie (Vor uns liegt das Leben, reż. Günther Rittau, Niemcy 1948). Zob. Kirsten Burghardt, Moralische Wiederaufrüstung im frühen deutschen Nachkriegsfilm, [w:] Positionen deutscher Filmgeschichte. 100 Jahre Kinematographie: Strukturen, Diskurse, Kontexte, München 1996, s. 274. 
nistycznej (interpretacje relacji pomiędzy męską i kobiecą postacią) oraz stylistycznej (ekspresywistyczna estetyka wskazująca na pokrewieństwa dzieła Staudtego z ważnymi filmami Republiki Weimarskiej). A jednak Mordercy... wydają się tekstem wciąż „niedopowiedzianym” i zachęcającym do bardziej wnikliwej analizy.

Akcja filmu rozgrywa się w Berlinie kilka miesięcy po zakończeniu wojny. Chirurg Hans Mertens, który służył na froncie wschodnim, otrzymuje kwaterunek w opuszczonym mieszkaniu. Gdy powraca jego właścicielka, Susanne Wallner, Mertens początkowo kwestionuje jej prawo do zajmowania lokalu, ale ostatecznie rodzi się między nimi romans. Hans cierpi z powodu wspomnień z okresu, gdy służył w oddziale dowodzonym przez kapitana Brücknera. Kiedy Mertens dowiaduje się, że jego były przełożony żyje i prowadzi prosperującą firmę, postanawia go zabić. W zakończeniu zostaje powstrzymany przez Susanne, która przekonuje bohatera, że zbrodnie wojenne powinny być osądzone przez wymiar sprawiedliwości.

Pierwsza wersja scenariusza została napisana w ciągu ostatnich dwóch miesięcy wojny. Do swego projektu Staudte bezskutecznie usiłował przekonać najpierw władze strefy brytyjskiej, a następnie Francuzów - nie spotkał się ze zrozumieniem ${ }^{83}$. Scenariusz został odrzucony również przez amerykańskiego oficera (Petera van Eycka, późniejszego gwiazdora kina zachodnioniemieckiego); ostatecznie licencję wydała administracja strefy sowieckiej - pod warunkiem zmiany zakończenia (o którym będzie jeszcze mowa), na co reżyser przystał ${ }^{84}$. Problemu nie stanowiła natomiast praca Staudtego dla kinematografii III Rzeszy, w szczególności zaś - drugoplanowa rola w filmie Veita Harlana Żyd Süss (Jud Süss, 1940) ${ }^{85}$. W żadnej ze znanych mi recenzji, które ukazały się tuż po premierze filmu, nie ma zresztą mowy o tym epizodzie z biografii reżysera - był to fakt bądź

83 Wolfgang Staudte über die Produktionsbedingungen seiner Filme..., s. 66.

${ }^{84}$ Treść rozmowy z urzędnikiem odpowiedzialnym za produkcję filmową w strefie sowieckiej reżyser przytaczał wielokrotnie; poszczególne wersje różnią się szczegółami. Zob. Wolfgang Staudte, red. Eva Orbanz, Hans Helmut Prinzler, Berlin 1991, s. 132-133; także: Spur der Filme. Zeitzeugen über die DEFA, red. Ingrid Poss, Peter Varnecke, Berlin 2006, s. 35.

${ }^{85} \mathrm{~W}$ późniejszych wywiadach Staudte kilkakrotnie wyjaśniał, iż gdyby odmówił zagrania w filmie Harlana, trafiłby na front (zob. Wolfgang Staudte über die Produktionsbedingungen seiner Filme..., s. 35). Oprócz kilku filmów reklamowych przyszły reżyser Morderców... nakręcił w 1943 r. pełnometrażowy film Akrobat Schö-ö-n, którego z pewnością nie można określić jako propagandowy, a następnie otrzymał zakaz wykonywania zawodu (zimą 1944 r. przerwano zdjęcia do jego filmu Frau über Bord, który na ekrany wszedł osiem lat później pod tytułem Das Mädchen Juanita). Zob. też: Magdalena Saryusz-Wolska, Wolfgang Staudte. Sumienie ponad podziałami, [w:] Autorzy kina europejskiego VI, red. Alicja Helman, Andrzej Pitrus, Warszawa 2012. 
nieznany, bądź uważany za niewart wzmianki ${ }^{86}$. Pewne konsekwencje dla promocji filmu miały natomiast problemy, jakie w postępowaniu denazyfikacyjnym dotknęły grającego główną rolę Ernsta Wilhelma Borcherta $^{87}$ (wcześniej wystąpił w filmie U-Booty na Zachód [U-Boot westwärts, reż. Günter Rittau, 1941], jednym z nielicznych filmów wojennych nakręconych w okresie III Rzeszy).

Zachowane recenzje dowodza, że film Staudtego był autentycznym wydarzeniem. W wielu recenzjach (zwłaszcza w opublikowanych w pismach ze strefy sowieckiej) komentowany jest - faktycznie prowokacyjny - tytuł filmu, "rozciągający” wydarzenia fabularne na powojenną niemiecką rzeczywistość. W recenzjach opublikowanych bezpośrednio po premierze nie dostrzeżono, że odwołuje się on do słynnego $M$ Fritza Langa, a dokładnie - pierwotnej wersji tytułu tego dzieła, które miało brzmieć: Mörder unter uns - bez rodzajnika, a zatem z intencją zaakcentowania dwuznaczności: liczby pojedynczej („morderca”) bądź mnogiej („,mordercy wśród nas”) ${ }^{88}$. Tego rodzaju wahania nieobce były zapewne także Staudtemu, gdyż pierwsza wersja scenariusza (przedłożona Amerykanom) opatrzona została nagłówkiem Der Mann, den ich töten werde (Człowiek, którego zabiję). Ostatecznie - w okolicznościach, których nie sposób zrekonstruować - reżyser zdecydował się jednak zasygnalizować w tytule aspekt nie indywidualny, lecz zbiorowy (rezygnując z wykorzystania ambiwalencji wcześniejszego pomysłu Langa poprzez wprowadzenie orzeczenia liczby mnogiej: sind unter uns, czyli „są pośród nas”).

Uderzającą cechą większości recenzji, które ukazały się tuż po premierze, jest pozytywna ocena protagonisty. Profilowano go jako typowego reprezentanta pokolenia ${ }^{89}$ : człowieka mającego za sobą traumatyczne przeżycia wojenne, ale zarazem ufającego w wymiar sprawiedliwości. Tylko $\mathrm{w}$ nielicznych publikacjach zwrócono uwagę na dwuznaczność postaci - i wymowy całego filmu:

${ }^{86}$ Warto wspomnieć przy tej okazji, że współautorem zdjęć był Friedl Behn-Grund, który wcześniej pracował przy Oskarżam (Ich klage an, 1941) Wolfganga Liebeneinera oraz Wuju Krügerze (Ohm Krüger, 1941) Hansa Steinhoffa.

87 Z tego właśnie powodu - jak sugeruje Magdalena Saryusz-Wolska - jego nazwisko zniknęło z materiałów reklamowych, a w napisach początkowych wymienione jest dopiero na ósmym miejscu (Magdalena Saryusz-Wolska, Ikony normalizacji..., rozdział: Ruiny i odbudowa). Co do czołówki, można znaleźć inne wyjaśnienie jej układu: najpierw wymienione są bowiem role kobiece - napis „W. Borchert” (brak pełnego imienia) pojawia się tuż obok nazwiska Arno Paulsena.

${ }^{88}$ Tomasz Kłys, Od Mabusego do Geobbelsa. Weimarskie filmy Fritza Langa i kino niemieckie do roku 1945, Łódź 2013, s. 479.

${ }^{89}$ Ulrike Weckel, The Mitläufer in Two German Postwar Films. Representation and Critical Reception, „History \& Memory” 2003, nr 2. 
To my jesteśmy mordercami. Także doktor Mertens [...], ponieważ zachował się tak samo, jak my wszyscy: skapitulował przed przemocą. Wzruszył ramionami i pozwolił zabić bezbronne kobiety oraz dzieci, nie podejmując żadnego wysiłku, aby je uratować. I takiego właśnie winnego-niewinnego przeciętnego Niemca przedstawia się nam jako zrehabilitowanego bohatera ${ }^{90}$.

Generalnie rzecz biorąc, oceny krytyków ze stref zachodnich były bardziej wstrzemięźliwe - pisano na przykład, że film jest „tendencyjny"91 $\mathrm{i}$ „pogrążony w mroku symboli” ${ }^{92}$. W strefie sowieckiej podkreślano natomiast „bieżący” aspekt filmu, tj. analogie do procesu norymberskiego zbrodniarzy wojennych (zakończonego dwa tygodnie przed premierą filmu) - w „Tägliche Rundschau” pisano na przykład: „kapitan Brückner to krew-z-krwi tych oskarżonych, którzy odmówili przyjęcia odpowiedzialności za swe czyny, i którzy twierdzili, że jedynie wykonywali swój obowiązek" ${ }^{\prime \prime 3}$.

Pod wieloma względami Mordercy... to realizacja paradygmatyczna dla niemieckiej produkcji filmowej pierwszych lat powojennych ${ }^{94}$. Jak w kilku innych fabułach tego czasu (omawianych w kolejnych podrozdziałach książki), bohater - okaleczony emocjonalnie przez wojenne przeżycia - zyskuje szansę na "zintegrowanie" się ze społeczeństwem: poprzez swą pracę (Mertens jest lekarzem) oraz rodzinę. W tym wypadku chodzi raczej o jej namiastkę czy raczej: nowy związek (wątek miłosny jest w Mordercach... niezbyt wiarygodny - Susanne miałaby prawo czuć

90 Wolfdietrich Schnurre, Film-Rundschau, „Deutsche Rundschau”, 5.11.1946. To jedyna recenzja, w której mówi się wprost, iż główny bohater jest mordercą. Warto nadmienić, iż Schnurre kilka miesięcy później znajdzie się w gronie współzałożycieli tzw. Grupy 47 - stowarzyszenia literackiego, które w kolejnych dekadach będzie często zabierało głos w sprawach dotyczących polityki RFN (zob. np. Günter Grass, Wolfdietrich Schnurre, Kto milczy, staje się wspótwinny, tłum. L. Żyliński, [w:] O kondycji Niemiec...).

${ }_{91}$ Martin Rupper, Epilog auf einem Film, "Allgemeine Zeitung”, 20.05.1947.

92 Friedrich Luft, Der erste deutsche Film nach dem Kriege, „Der Tagesspiegel”, 16.10.1946. Autor tej recenzji wyraził opinię, iż twórcom filmu „,nie udało się przezwyciężyć artystycznego smaczku (Beigeschmack des Filmisch-Artistischen), nieco zawadzającego, a niekiedy wręcz obraźliwego”. Dostrzegając swoisty „naddatek symboliczny”, pytał: „Dlaczego na przykład żołnierze wieszają broń akurat na krucyfiksie? [...] I dlaczego dobrotliwy optyk musi umrzeć?". Luft nie próbuje znaleźć odpowiedzi na te pytania - może dlatego, że byłaby ona, istotnie, „zawadzająca” lub „wręcz obraźliwa”...

${ }_{93}$ Hans Ulrich Eylau, Ein neues Kapitel der deutschen Filmgeschichte, "Tägliche Rundschau", 16.10.1946; Hugo Hermann, Der erste deutsche Nachkriegsfilm. „Tägliche Rundschau”, 20.10.1946. Podaję za: Christiane Mückenberger, Günter Jordan, "Sie sehen selbst, Sie hören selbst...", s. 42-43.

94 Za chybioną uważam opinię Roberta Shandleya, iżby Morderców... można było czytać jako "niemiecki western” (Robert Shandley, Rubble Canyons. "The Murderers Are Among Us" and the Western, "German Quaterly" 2001, nr 2). 
się zaskoczona dość niespodziewanym wyznaniem Mertensa: Nadejdzie kiedyś ten dzień, kiedy... Już w to nie wierzyłem... Kiedy będę mógł powiedzieć komuś: kocham cię. I tym kimś będziesz ty).

Wydarzenia z przeszłości ujawniają się natomiast poprzez migawkowe retrospekcje; w filmie Staudtego są one o tyle ciekawe, że mają charakter tłumionej traumy, mimowolnie „wdzierają się" do świadomości bohatera, katalizowane przez sytuacje, których jest świadkiem. Niewątpliwie mamy tu do czynienia z wywodzącą się z ekspresjonizmu „psychologizacją przestrzeni" ${ }^{\prime 25}$, zwłaszcza w scenach rozgrywających się w kamienicy zamieszkanej przez Hansa i Susanne oraz w przedostatniej scenie Morderców..., nawiązującej do analogicznej (także przedostatniej) sceny ze wspomnianego $M$. Inaczej niż Ulrike Weckel, która podobieństwa pomiędzy zakończeniem filmów Langa i Staudtego dostrzega głównie w chwytach wizualnych ${ }^{96}$, analogie widziałbym raczej w samym pomyśle dramaturgicznym. Otóż w obu wypadkach morderca zostaje najpierw "osądzony" przez pozainstytucjonalną "sprawiedliwość ludową" (w $M-$ przez „trybunał” powołany przez przestępczy półświatek miasta, u Staudtego - przez Mertensa), która zamierza samodzielnie wymierzyć karę, lecz ostatecznie tego nie czyni (u Langa - z uwagi na wkroczenie policji na salę "trybunału”, w Mordercach... - dzięki interwencji Susanne). Taka analogia ma swoje dalej idące konsekwencje, jeśli przypomnimy, że "trybunał" u Langa bywa odczytywany jako projekcja nazistowskich tendencji społeczeństwa, które - nieufne wobec legalnego wymiaru sprawiedliwości - postanawia „wziąć sprawy w swoje ręce", nie bacząc na literę stanowionego prawa.

Główni bohaterowie - Hans i Susanne - zostają wprowadzeni, odpowiednio, w pierwszej i drugiej scenie filmu. Są one bliźniaczo do siebie podobne, zarówno $\mathrm{w}$ warstwie przedstawiającej (obie sceny pozbawione są dialogów, a ponadto zajmują mniej więcej tyle samo czasu ekranowego), jak i przedstawionej. Protagoniści umieszczeni zostają mianowicie na tle

${ }^{5}$ Współscenografem filmu został Otto Hunte, który wcześniej pracował przy produkcji monumentalnych arcydzieł Fritza Langa: Doktor Mabuse, gracz (Dr. Mabuse, der Spieler, 1922), Nibelungi (Die Nibelungen, 1925) czy Kobieta na księżycu (Frau im Mond, 1929).

${ }^{96}$ Zdaniem Weckel, zastosowanie w tej scenie ujęcia z POV (Brückner pokazany jest en face, a na ścianie pojawia się cień osądzającego go Mertensa) ma sprawić, by widz przyjął nie tylko optyczna, ale i moralną perspektywę bohatera (Ulrike Weckel, "Die Mörder sind unter uns" oder: Vom Verschwinden der Opfer, "Werkstatt Geschichte” 2000, nr 25, s. 106). Trzeba by w tym miejscu dopowiedzieć, że w przedostatniej scenie $M$ nie ma podobnie skomponowanego ujęcia. Owszem, podczas dramatycznej przemowy oskarżonego pojawia się kilka ujęć przedstawiających go en face, ale żadnego z nich nie można uznać za POV któregoś z oskarżycieli. Ponadto, cień nie odgrywa w scenie „sądu” szczególnej roli - co więcej, cień „zastępujący” protagonistę przypisany jest u Langa postaci zbrodniarza (w scenie pierwszego porwania dziewczynki), a nie "sprawiedliwego". 
zrujnowanej przestrzeni miejskiej - choć w każdej ze scen w nieco inny sposób. Zanim bowiem ujrzymy Mertensa, na pierwszym planie pokazana jest usypana z piasku mogiła, obok której leży hełm i kwiaty w starej puszce po konserwie (fot. 1). Po chwili kamera obejmuje swym polem widzenia aktora zbliżającego się w jej stronę, a także porzucony czołg, bawiące się dzieci, wrak samochodu i kolejny grób. Uwaga widza nakierowana jest raczej na przestrzeń niż samego bohatera (choćby dlatego, że w scenie nie ma zbliżenia na jego twarz). Snuje się on wśród ruin bez widocznego celu, z rękami niedbale wciśniętymi do kieszeni starego płaszcza (na który spada popiół z papierosa, jaki Hans trzyma w ustach); kąt widzenia kamery jest lekko pochylony, co niejako „na wejściu” znakuje bohatera jako postać „niestabilną". Inaczej przedstawiona zostaje Susanne - pierwsze ujęcie pokazuje ją wśród pasażerów wysiadających z pociągu i wychodzących z dworca. Filmowana jest niczym gwiazda Ufy - w wysokim kluczu świetlnym i na zbliżeniu; ubrana jest dość elegancko, w nieskazitelnie biały płaszczyk (widz ma prawo czuć się zaskoczony, gdy niedługo potem dowie się, że Susanne została zwolniona z obozu koncentracyjnego). Sceny te ustanawiaja, prawem klasycznej dramaturgii, wstępną charakterystykę postaci - a zarazem inicjują ten składnik dyskursu Morderców..., który określiłbym jako „postawy wobec nowej rzeczywistości”.

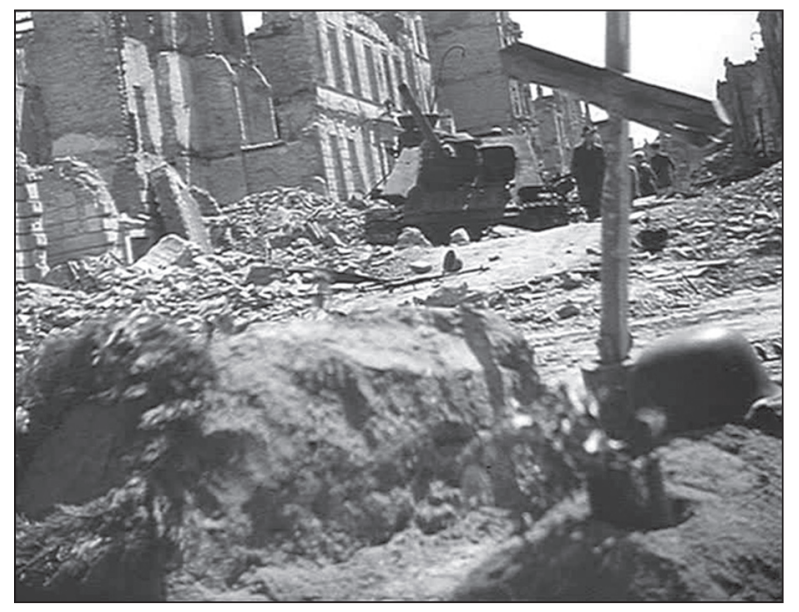

Fot. 1. Mordercy sa wśród nas (reż. Wolfgang Staudte, 1946) Kadr ze sceny otwierającej pierwszy powojenny niemiecki film fabularny

Obie sceny kończą się podobnym ujęciem, zawierającym wewnątrzdiegetyczny napis: Mertens wkracza do przybytku oznaczonego szyldem „Nowoczesny (moderne) kabaret. Taniec, atmosfera, humor”, Susanne 
dochodzi zaś do plakatu z napisem „Piękne Niemcy” (korelacja jej ruchu $\mathrm{z}$ ujęcia poprzedzającego $\mathrm{z}$ powolną jazdą kamery w stronę plakatu pozwala przyjąć, że jest to jej optyczny punkt widzenia). W obu wypadkach treść napisu ma charakter kontrastujący z ruinami otaczającymi bohaterów i ewokuje pojęcie „innego świata”. Znaczenie, jakie nadamy owemu kontrapunktowi, zależy już jednak od tego, jak ów „inny świat” umiejscowimy w wyobrażonym chronotopie tej opowieści. Kabaret oznaczony jest słowem moderne - co można rozumieć jako „współczesny” i „aktualny”, lecz przecież także jako odsyłający do okresu weimarskich tingel-tangli (do czego zachęca synkopująca ścieżka dźwiękowa - z pozoru ilustracyjna, gdyż nie słyszymy żadnych innych dźwięków mogących się wydobywać ze świata przedstawionego, ale może i diegetyczna, jeśli uznać, że dobiega z wnętrza lokalu). Natomiast plakat „Piękne Niemcy”, najpewniej propagandowa (lub po prostu: reklamująca turystyczne atrakcje) pozostałość po III Rzeszy, może być również - nie w diegezie, ale w dyskursie filmu - sygnałem odbudowy. Działania z nią związane w kolejnych scenach przypisane są Susanne, więc nieprzypadkowo to właśnie ona zestawiona zostaje z plakatem. Inaczej mówiąc, już w dwóch pierwszych scenach pojawiają się znaki, które "rozciagają” dyskursywny chronotop filmu: w przeszłość (ku czasom jeśli nie „przed Hitlerem”, to z pewnością „przed wojną”) i w przyszłość (kierując uwagę ku pytaniu: jak odbudować Niemcy - i jaki kształt mają one przyjąć).

O ile przeszłość w filmie Staudtego rozwijana jest głównie poprzez retrospekcje dotyczące Mertensa i Brücknera (z wyłączeniem losów Susanne), a także postać Mondscheina (będzie o nim jeszcze mowa), o tyle ten aspekt dyskursu Morderców..., który odnosi się do odbudowy Niemiec, prowadzony jest przez inną "triadę": Mertensa, Susanne i Brücknera (tym razem z pominięciem Mondscheina). Szczególnie istotny jest tu kontrast między Mertensem (początkowo niezdolnym do jakiegokolwiek konstruktywnego działania, dopiero później postanawiającym powrócić do praktyki lekarskiej) a Brücknerem. Ten ostatni prowadzi rentowne (o czym świadczy jego mieszkanie) przedsiębiorstwo, zatrudniające wielu pracowników (stłoczonych na wigilii), a zajmującą się przetapianiem żołnierskich hełmów na garnki. Inaczej mówiąc, to „Krupp a'rebours”: zarabia na wojnie, choć nie na jej prowadzeniu, a na demobilizacji. Tego rodzaju skojarzenia - kapitalizmu z militaryzmem - będą stanowić ważny element późniejszej enerdowskiej propagandy. W Mordercach... są one podane wprost $\mathrm{w}$ dialogach (Odbudowa, kochanieńki, odbudowa, to nasza dewiza, kompania Brücknera maszeruje znowu). I nie bezzasadne jest chyba dostrzeżenie podobieństwa między fizjonomiami Brücknera (gra go Arno Paul- 
sen) i Heinricha Himmlera ${ }^{97}$ - zarówno bohater Morderców..., jak i jego (domniemany) pierwowzór modelowo ucieleśniają to, co Hannah Arendt określi później jako „banalność zła”. Z kolei Susanne - postać „silna”, zorganizowana, nastawiona na przyszłość (w odróżnieniu od Mertensa, który rozpamiętuje wojnę i topi troski w alkoholu) - przypomina z jednej strony Trümmerfrau (kilkakrotnie powtarza: Musimy pracować, żyć, pomagać sobie), z drugiej zaś zostaje jednoznacznie przyporządkowana przestrzeni domu (opuszcza go tylko dwa razy, w obu przypadkach w sprawach związanych z Hansem $)^{98}$. Z rozmowy wścibskich sąsiadów na ponurej klatce schodowej dowiadujemy się, że kobietę aresztowano w 1942 r. z powodu ojca, a następnie przebywała w obozie koncentracyjnym. Ona sama nie dzieli się swymi przeżyciami - pytana, gdzie była podczas bombardowań (mowa jest o piekle), Susanne odpowiada: Tak, byłam bezpieczna, jeśli chce pan to tak nazwać; w oryginale brzmi to: im Sicherheit, co może sugerować aresztowanie przez SD (Sicherheitsdienst). W każdym razie o przeżyciach bohaterki z czasu wojny wiadomo niewiele; jest ona postacią ",bez historii” - „pustym znakiem”, który można wypełnić dowolną backstory.

Takie niedopowiedzenia - same w sobie sprawiające wrażenie zrepresjonowanej pracy pamięci - nie dotyczą wyłącznie Susanne. Także retrospekcyjne sekwencje filmu nie tworzą pełnego (koherentnego fabularnie) obrazu wydarzeń z przeszłości. Niewiele wiadomo na przykład o losach Mertensa i Brücknera w ostatnich latach wojny (mamy tylko krótką scenę, w której ranny kapitan otrzymuje od Hansa pistolet - $\mathrm{w}$ domyśle: aby popełnić samobójstwo, w razie gdyby został schwytany). Jedną z wersji przedstawia sam Brückner, który pracowicie buduje swoją wojenną legendę - gdy przy rodzinnym obiedzie opowiada, jak to ciężko ranny przetrwał sam w środku lasu. Na podstawie informacji zawartych w narracji nie można jednoznacznie ocenić tej relacji jako nieprawdziwej- przeciwnie, wydaje się ona dość prawdopodobna (bowiem gdy w retrospekcji Brückner pojawia się po raz ostatni, faktycznie widzimy go rannego w środku lasu).

Niejasności dotyczą też kluczowego dla intrygi wydarzenia: rozstrzelania polskich cywilów w wigilię 1942 r. na rozkaz kapitana Brücknera.

${ }_{97}$ Heinz Kersten, Ankläger der Mörder und Untertanen, [w:] Wolfgang Staudte, red. Eva Orbanz [1977], s. 17.

${ }^{98}$ Więcej o postaci Susanne piszą - w optyce feministycznej - cytowane w niniejszym rozdziale: Ulrike Weckel („Die Mörder sind unter uns”...) oraz Magdalena Saryusz-Wolska (Ikony normalizacji..., rozdział: Ruiny i odbudowa). Autorki przypominają również, że Hildegard Knef, grająca rolę Susanne, stała się ikoną Trümmerfrau, zaś jej późniejsze filmowe wcielenia odegrały znaczącą rolę w kulturowej historii kina niemieckiego (zob. Ulrike Sieglohr, Heroines without Heroes. Reconstructing Female and National Identities in European Cinema, 1945-1951, New York 2000; Johannes von Moltke, Hans-Jürgen Wulff, Trümmer-Diva. Hildegard Knef, [w:] Idole des deutsche Films, red. Thomas Koebner, München 1997). 
Informacje na ten temat wprowadzane są - za pośrednictwem narracji subiektywnej przypisanej Mertensowi - w trzech scenach: w szpitalu, w gabinecie Brücknera i w jego firmie, przy czym katalizatorem wspomnień jest w każdym przypadku inny obraz (odpowiednio: chorzy leżący na szpitalnym korytarzu; pistolet, jaki Hans podarował kapitanowi w czasie wojny, oraz choinka dekorowana przez tego ostatniego). Z retrospekcja sensu stricto mamy do czynienia jedynie w ostatnim wypadku; w dwóch pierwszych zaś szczegóły dotyczące wydarzeń z przeszłości podane zostaną wyłącznie na ścieżce dźwiękowej: w szpitalu Mertens wydobywa z siebie zdania, których początkowo nie można przyporządkować żadnemu wcześniej wzmiankowanemu lub pokazanemu wydarzeniu, w gabinecie Brücknera natomiast mamy do czynienia z voice-over bohatera.

Anke Pinkert zwraca uwagę, że Mertens nigdy nie wyjawia werbalnie swych przeżyć wojennych, a w momencie, gdy może to uczynić, potencjalne wyznanie zostaje uniemożliwione przez pojawienie się syna Brücknera ${ }^{99}$. Ponadto, Susanne dowiaduje się o zbrodni kapitana i planach powziętych przez Hansa z prowadzonego przezeń dziennika, zaś w jedynej wymianie zdań pomiędzy Mertensem a Brücknerem, w której mowa o ich wspólnych wojennych przeżyciach, Hans przywołuje jedynie liczby (36 mężczyzn, 54 kobiety, 31 dzieci), nie mówi natomiast nic o osobistych wspomnieniach. Te nie poddają się bowiem werbalizacji - w szpitalu Mertens majaczy: Kapitanie, proszę odwotać rozkaz, chwilę później wydaje z siebie niezidentyfikowane dźwięki przy pominające serię karabinu maszynowego, a następnie krzyczy: Dzieci, co dzieci maja z tym wspólnego? A kobiety? Te krzyki! Ja... ja nie mogę tego zrobić. Lekarz i pielęgniarka komentują zajście tak, jakby często bywali świadkami podobnych sytuacji (To przeżycia wojenne... To musiało być coś strasznego). Pinkert podkreśla też, że załamanie Mertensa nieprzypadkowo rozgrywa się w szpitalu, dzięki temu bowiem bohater zostaje "oznakowany" (tak fabularnie, jak i dyskursywnie) jako człowiek chory, pacjent na krawędzi choroby psychicznej, który potrzebuje pomocy ${ }^{100}$. Scena ta jest istotna $\mathrm{z}$ jeszcze jednego powodu - mianowicie sugeruje ona (ponieważ nie widzimy tego, co przeżywa Mertens), że Hans mógł rozstrzeliwać dzieci. Może to on jest jednym $\mathrm{z}$ „morderców wśród nas"?

Na ten trop może prowadzić również scena wspomnienia wywołanego przez pistolet, jaki Brückner oddaje Mertensowi. Retrospekcja ta ma wyłącznie charakter audialny - ścieżka dźwiękowa podłożona pod długie zbliżenie na twarz Mertensa zbudowana jest z kilku warstw: oprócz huku wystrzałów i wycia syren oraz krzyku i płaczu pojawiają się dwa mo-

\footnotetext{
99 Anke Pinkert, Film and Memory in East Germany, Bloomington 2008, s. 34.

100 Ibidem, s. 29.
} 
tywy, których rozpoznanie wymaga dziś pewnych kompetencji (można jednak z dużym prawdopodobieństwem założyć, że były one znane zdecydowanej większości ówczesnych niemieckich widzów). Są to: fanfary z czołówki nazistowskiej kroniki filmowej, a także kilka taktów z piosenki Lili Marleen. Montaż taki tworzy korelację między oznakami wojny i symbolami III Rzeszy - choć zarazem nie można powiedzieć, że ustanawia jednoznaczną relację przyczynowo-skutkową (w rodzaju „nazistowska propaganda przyczyniła się do wywołania wojny"). Co więcej, po zbliżeniu na twarz Hansa narracja nie powraca do diegetycznego "punktu wyjścia" retrospekcji (gabinetu Brücknera), ale poprzez przenikanie przechodzi w ujęcie plenerowe, przedstawiające ruiny powojennego Berlina, dzięki czemu Hansowi zostają przyporządkowane pojęcia: „zniszczenie”, „wojna”, „cierpienia”. Dopiero ostatnia retrospekcja - w której słowa: co dzieci maja z tym wspólnego? pojawiają się raz jeszcze - ujawnia, że kapitan nie był faktycznym sprawcą ani wykonawcą egzekucji, lecz raczej jej świadkiem, zaś wina Hansa polega przede wszystkim na tym, że nie udało mu się zapobiec tragedii. Niezależnie od tych dramaturgicznych implikacji, scena pokazująca rozstrzeliwanie cywilów jest szczególnie ważna, gdyż - jako pierwsza w powojennym filmie niemieckim, a zarazem jedyna w omawianym tu okresie (na co wskazuje również Saryusz-Wolska) - pokazuje zbrodnie dokonane przez Wehrmacht ${ }^{101}$. W późniejszych latach - zarówno w niemieckich filmach, jak i w szeroko pojętej kulturze pamięci tak RFN, jak i NRD - odpowiedzialnością za nie obciążano zazwyczaj SS (zob. także podrozdziały 2.2 i 3.2).

Zwróćmy uwagę na sposób ukształtowania tej sceny. Zmontowana jest ona zgodnie z zasadą montażu atrakcji: najpierw widzimy grupę żołnierzy śpiewających kolędę, później padające na ziemię ciała i ponownie wnętrze oficerskiego baraku. Ostatnie zbliżenie pokazuje krucyfiks na ścianie; na jego ramionach wisza, zawieszone niczym w szatni, karabin i hełm. Można dyskutować nad potencjalnymi implikacjami tego rekwizytu - przykładowo, Christiane Mückenberger nasunął on intertekstualne skojarzenie z rysunkiem Georga Grosza, przedstawiającym Chrystusa w masce gazowej ${ }^{102}$. Najprostsze wyjaśnienie nakazywałoby chyba jednak widzieć w nim degradację symbolu krzyża, bliską marksistowskiej propagandzie antychrześcijańskiej (a zatem kierującą na asocjacje w rodzaju

${ }^{101}$ Detlef Kannapin wskazuje, że w filmie Staudtego najpewniej (ze względu na kwestię: tylko dlatego, że gdzieś padł strzat) chodzi o tzw. Geiselmordbefehl - rozkaz wydany 16 września 1941 r. przez marszałka Keitla, nakazujący egzekucję „od 50 do 100 komunistów za 1 niemieckiego żołnierza" (Detlef Kannapin, Antifaschismus im Film der DDR, Köln 1997, s. 95).

${ }^{102}$ Christiane Mückenberger, Günter Jordan, „Sie sehen selbst, Sie hören selbst...", s. 45. 
„hipokryzja Kościoła” itp.). Zarazem nie jest to przecież jedyne zestawienie "krzyż i hełm” w filmie - opatrzone tymi znakami są również prowizoryczne groby z pierwszego ujęcia, jednak w odróżnieniu od nich, „konstrukcja” z gabinetu Brücknera nie ewokuje pojęcia „ofiary”, lecz raczej „mordercy”. Symbolika chrześcijańska jest zresztą w filmie obecna kilkakrotnie: poprzez rozwiązania dramaturgiczne (umiejscowienie kluczowego wydarzenia w okresie Bożego Narodzenia) i kompozycję obrazu (krzyże zarówno w otwierającym, jak i zamykającym film ujęciu). W odniesieniu do tych scen można faktycznie mówić raczej o wykorzystaniu tych motywów w funkcji „,uniwersalnej obrzędowości”"103 niż o pogłębionym dyskursie, który nie rozwija (a przecież mógłby) tematu przebaczenia, miłosierdzia czy poniesionej ofiary, a problem winy „metafizycznej” (w ujęciu Jaspersowskim) jedynie muska (w końcowej tyradzie Mertensa), sprowadzając ją ostatecznie do indywidualnej odpowiedzialności prawnej. Jednak „scena à la Grosz” każe spojrzeć na motywy chrześcijańskie z nieco innej perspektywy - tę swoistą "kontaminację" przedmiotów (krzyża, hełmu i karabinu) trudno bowiem uznać za "zwykły” rekwizyt, którego główną funkcją byłoby bądź uwiarygodnienie realizmu wydarzeń, bądź/oraz wyakcentowanie sensów kulturowo przypisanych znakowi krzyża.

Pierwotny pomysł na scenę finałową - zakładający, iż Mertens dokona samosądu na swym byłym dowódcy - został zakwestionowany przez sowieckiego urzędnika Defy (,jeśli film okaże się sukcesem [...] to na ulicy będą strzelaniny, a to oczywiście nie wchodzi w rachubę. Rozumiemy potrzebę zemsty, ale trzeba powiedzieć: nie tędy droga"104). W przygotowanej przez Staudtego drugiej wersji zakończenia Mertens oddaje Brücknera w ręce wymiaru sprawiedliwości ${ }^{105}$, a w jeszcze innej finał rozgrywa się na sali sądowej: to Mertens jest oskarżonym, zaś prokurator wysławia cnoty mężczyzny, który w wigilię został zamordowany. Próbując uzasadnić swe działania, bohater opowiada przed sądem o wydarzeniach z 1942 r. i kończy słowami:

Mordercy sa wśród nas! W maskach skromnych obywateli wznosza głośne okrzyki przeciw wojnie i szowinizmowi, $i$ w swej obłudnej przyzwoitości twierdza, że pracowicie działaja na rzecz spokojnej przyszłości. Nosza dziś cywilne ubrania, ale tak naprawdę pasuja na nich wyłacznie - mundury! Ich budulcem jest wojna, a ich najwyższymi ideałami - rabunek i mord!106

${ }^{103}$ Magdalena Saryusz-Wolska, Ikony normalizacji...

104 Wolfgang Staudte über die Produktionsbedingungen seiner Filme..., s. 36.

105 Heinz Kersten, Ankläger der Mörder..., s. 5.

${ }^{106}$ Film miał się kończyć zbliżeniem na wiszący na ścianie obraz przedstawiający Temidę z zasłoniętymi oczami; Wolfgang Staudte, Arbeitstitel: "Die Mörder sind unter uns", „Film und Fernsehen” 1986, nr 9, s. 12. 


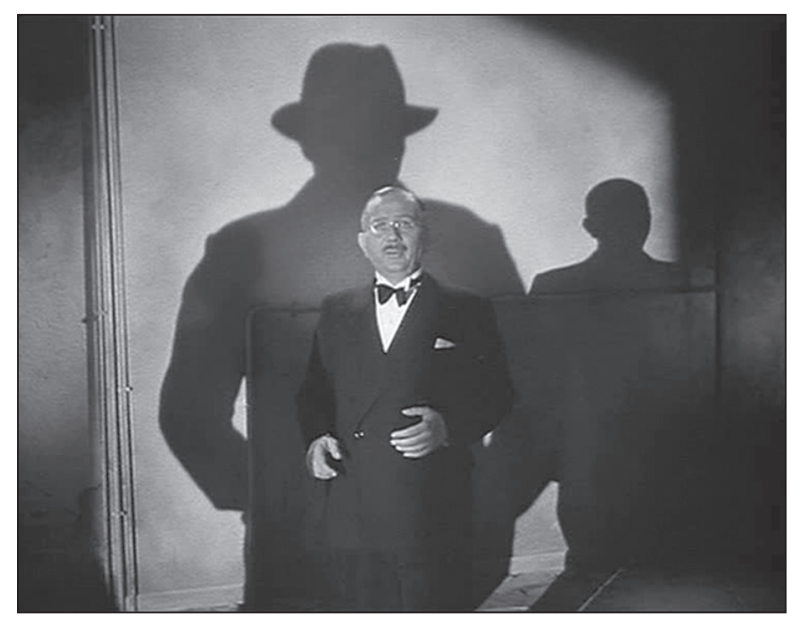

Fot. 2. Mordercy sa wśród nas (reż. Wolfgang Staudte, 1946) „Jestem niewinny" - przekonuje Brückner

Ostatecznie, doszło do swoistej fuzji wcześniejszych pomysłów: gdy Mertens jest o krok od zabicia swego dawnego przełożonego, nadbiega Susanne; jej obecność powstrzymuje Hansa od pociągnięcia za spust. Nie mamy prawa osądzać - mówi Susanne, co Mertens komentuje: Tak, ale mamy prawo oskarżać $i$ żądać sprawiedliwości w imieniu milinów niewinnych zamordowanych. Ostatnia scena filmu rozpoczyna się od półzbliżenia na Brücknera, który - jak się okazuje, gdy wraz z odjazdem kamery ukazane zostają kraty - przebywa w celi, wykrzykując (czterokrotnie) Jestem niewinny (fot. 2). Takie zakończenie w sposób dobitny pozostawało w kontrze do tezy o winie zbiorowej, a zarazem idealnie rezonowało z przyjętą ostatecznie przez aliantów polityką sądzenia indywidualnych sprawców, najczęściej zaprzeczających swej odpowiedzialności za popełnione zbrodnie. Na ten aspekt filmu zwracali uwagę także recenzenci ${ }^{107}$ - trudno zreszta, by było inaczej, skoro realizacja Staudtego miała premierę dzień przed ogłoszeniem wyroku przeciw zbrodniarzom wojennym $\mathrm{w}$ norymberskim procesie.

Scena finałowa nie kończy się jednak na ujęciu przedstawiającym Brücknera. Tuż po nim na przenikaniu pojawiają się następujące obrazy: matka tuląca dziewczynkę i chłopca, dwóch żołnierzy (jeden o lasce, drugi najpewniej ociemniały), wreszcie - krzyże na bezimiennych mogiłach.

107 Walter Lenning, recenzent „Berliner Zeitung”, pisał: „Poza wszelką wątpliwością pozostaje fakt, że film ten ma coś do zakomunikowaniu każdemu Niemcowi. [...] Osądzać nie powinna jednostka [...], ale cały naród. Dopiero, kiedy nastąpi wewnętrzne oswobodzenie, kiedy dokona się rzeczywista pokuta, możliwa będzie też prawdziwa wolność" (Walter Lennig, Ein Film der deutschen Wirklichkeit. Zur Uraufführung des Defa-Films "Die Mörder sind unter uns", „Berliner Zeitung”, 17.10.1946). 
O ile żołnierze "przypisani” są jednoznacznie do Wehrmachtu (noszą niemieckie mundury), o tyle ujęcie prezentujące matkę i dzieci nie precyzuje, czy chodzi o Niemców, czy też o obywateli podbitych przez nich krajów - ewokuje zatem szersze pojęcie "bezbronnych ofiar wojny”. Krzyże natomiast są przyprószone śniegiem - najpewniej mamy więc do czynienia z "poległymi na wschodzie”. Wydaje się, że to mogiły poległych żołnierzy z Wehrmachtu - podobne obrazy ówcześni niemieccy widzowie mogli znać jeszcze $z$ nazistowskich fotografii i kronik ${ }^{108}$. Tak czy inaczej, status tej sekwencji w narracji jest niejasny - można potraktować ją bądź jako subiektywną wizję Mertensa, która stanowiłaby swoiste dopowiedzenie jego argumentacji, bądź jako komentarz odautorski Staudtego. Daniela Berghahn zwraca uwagę również na funkcję kompozycyjną tych ujęć: budują one mianowicie „wizualne nawiązanie do sceny otwierającej film i ujawniają wymiar symboliczny leitmotywu przewijającego się przez cały film: krzyżujących się ram okiennych, cieni rzucanych przez krzyże i przecinających się linii"109. Obserwacji tej towarzyszy próba interpretacji znaczeń - zdaniem autorki, dochodzi tu do „podprogowego (subliminal) odwrócenia relacji pomiędzy ofiarami i sprawcami - sugerującego, iż to powojenni Niemcy muszą »nieść swój krzyż « - ciężar przeszłości"110. Nie jestem przekonany, czy faktycznie mamy do czynienia z tego rodzaju „odwróceniem” (niezależnie od tego, czy miałoby ono być "podprogowe”); z pewnością jednak obrazy te budują wspólnotę wszystkich (czy rzeczywiście?) „ofiar wojny” (wątpliwość wynika z wykorzystanej symboliki krzyża), a zarazem poświadczają to, co i tak wynika już z głównej linii fabularnej, czyli włączenie do tej społeczności także zdemobilizowanych i powracających do Niemiec żołnierzy Wehrmachtu.

Wspomniałem już o choince, którą dekoruje Brückner, nakazując w tym samym czasie rozstrzelanie ponad setki cywilów. Gdy w retrospekcji Hans wchodzi do gabinetu kapitana, aby prosić go o cofnięcie rozkazu, pierwsze zdanie, jakie ten kieruje do podwładnego, brzmi: Przyjrzyj się temu drzewku, Mertens. Czy czegoś brakuje? Otóż Brücknerowi brakuje gwiazdy, którą nakazuje wykonać Hansowi; ten nie zdąży jednak zawiesić jej na drzewku - ostatnie ujęcie przedstawia gwiazdę porzuconą w śniegu. Zapytajmy: dlaczego w scenie pokazującej masowe morderstwo

108 Zob. Dagmar Barnouw, Germany 1945: View of War and Violence, Bloomington 1996, s. 169.

109 Daniela Berghahn, Hollywood behind the Wall: the Cinema of East Germany, New York 2005, s. 67.

110 Ibidem. 
dokonane w Polsce 1942 r. tak dużą rangę nadano temu konkretnemu rekwizytowi? Z jakiego powodu jest to właśnie gwiazda, a nie inna choinkowa ozdoba: bombka, świeczka czy cukierek? I wreszcie - dlaczego jest to gwiazda sześcioramienna (co widać na zbliżeniu - krótkim wprawdzie, ale jakże istotnym dla celów analitycznych!)? Otóż w filmie Staudtego, faktycznie, czegoś brakuje: mianowicie zwraca uwagę brak świadectw Zagłady. Wzmianka na ten temat pojawia się raz, poprzez obecny na ekranie przez ledwie dwie-trzy sekundy nagłówek w gazecie, w którym mowa o zagazowanych $w$ Auschwitz (znamienne, że artykuł ten nie jest w żaden sposób komentowany ${ }^{111}$ ).

Postacia, która w dyskursie filmu mogłaby lokować się w obrębie znaczeń „zbrodnie dokonywane w obozach” jest sąsiad Susanne i Hansa, pan Mondschein. W publikacjach poświęconych filmowi bohater ten określany jest często jako Żyd - choć słowo to $\mathrm{w}$ filmie nie pada ${ }^{112}$. Z czego więc wynika taka charakterystyka postaci? W gruncie rzeczy jedynymi tropami mogącymi posłużyć za uzasadnienie "żydowskości" bohatera są: nazwisko Mondscheina i jego rzemieślnicza profesja - jest on bowiem optykiem (w scenach z jego udziałem kilkakrotnie pojawiają się zbliżenia okularów). To jednak zdecydowanie zbyt mało - szukać trzeba więc dalej. Dyskurs filmu lokuje Mondscheina pośród ofiar - o jego przeżyciach podczas wojny nie ma wprawdzie mowy, lecz słyszymy o jego zaginionym synu. Ponadto, optyk dobrze rozumie się z Susanne (która kieruje doń słowa: Sa rany, których nikt nie widzi). To jednak wciąż niewystarczające przesłanki, by pisać o „żydowskim bohaterze”. Może więc sygnałem kierującym na taki trop byłyby ciągi cyfr, których wprawdzie nie ma wytatuowanych na ramieniu, ale które widnieją na tablicy w jego gabinecie? Nie, to wciąż zbyt słabe i ryzykowne zarazem argumenty.

Otóż sądzę, że przypisanie „żydowskości” Mondscheinowi dokonuje się szczególnie silnie $\mathrm{w}$ dwóch scenach. W obu pojawia się bądź zostaje

111 Magdalena Saryusz-Wolska zweryfikowała informację podaną przez Claudię Fritsch (autorkę obronionej w USA rozprawy doktorskiej o wizerunkach seryjnego mordercy w kinie niemieckim), która przypisała ten nagłówek artykułowi zatytułowanemu Der Mann, der 2 Milionen Menschen vergaste („Człowiek, który zagazował 2 miliony ludzi” - materiał dotyczył Rudolfa Hössa) z pierwszej strony autentycznej gazety („Berliner Zeitung", 19.03.1946). Saryusz-Wolska dodaje, że w wydaniu tym nie było podtytułu, w którym znajdowałyby się słowa Konzentrationslager Auschwitz (a jedynie lid z informacja że Höss był komendantem obozu Zagłady [Vernichtungslager] Auschwitz) i konkluduje: „Wiele wskazuje na to, że scenograf filmu - posługując się autentycznym tytułem artykułu - zaprojektował stronę gazety od nowa, tak by w zbliżeniu można było odczytać tytuł i zmodyfikowany podtytul" (Magdalena Saryusz-Wolska, Ikony normalizacji...).

${ }^{112}$ Frank Stern, Ein Kino subversiver Widersprüche. Juden im Spielfilm der DDR, „Apropos: Film. Das Jahrbuch der DEFA-Stiftung" 2002, nr 3, s. 10. 
przywołana jeszcze inna postać, o której autorzy znanych mi interpretacji niemal w ogóle nie wspominają: Bartlomäus Timm, mieszkający w tej samej kamienicy oszust, rzekomo przepowiadający przyszłośćc ${ }^{13}$. W scenie, w której mami on Mondscheina obietnicą powrotu jego syna (inkasuje zresztą za tę "usługę" honorarium w gotówce), zaprezentowany zostaje jako figura ewidentnie „mabuse'ańska” - siedzi przed wielkim globusem, jak gdyby panował nad światem (fot. 3). Sytuację tę uznaję za prefigurację wielu podobnych scen z później nakręconych filmów, do których wprowadzono wątek starań podejmowanych przez żydowskich bohaterów o „wykupienie bliskich" (lub choćby pozyskanie informacji o ich losie). Próby takie pokazywane były zazwyczaj jako bezowocne - i nie inaczej jest w filmie Staudtego. Gdy narracja po raz ostatni powróci do gabinetu Mondscheina, jest on pusty (ponownie: motyw „porzuconego warsztatu” znany z filmów o Holocauście); na ścieżce dźwiękowej świst wiatru dobiega zza niedomykających się drzwi. Scenę kończy ujęcie, w którym dwóch mężczyzn (ich twarze nie są pokazane) wynosi trumnę; kamera nie podąża jednak za nimi, ale wykonuje zbliżenie na napis reklamowy na murze: Przepowiadam przyszłość za pomoca ściśle naukowych metod - Bartolomäus Timm. W ten sposób ze śmiercią Mondscheina zostaje skorelowany nie tyle jego sąsiad, ale raczej ściśle naukowe metody, którymi ów jakoby się posługiwał.

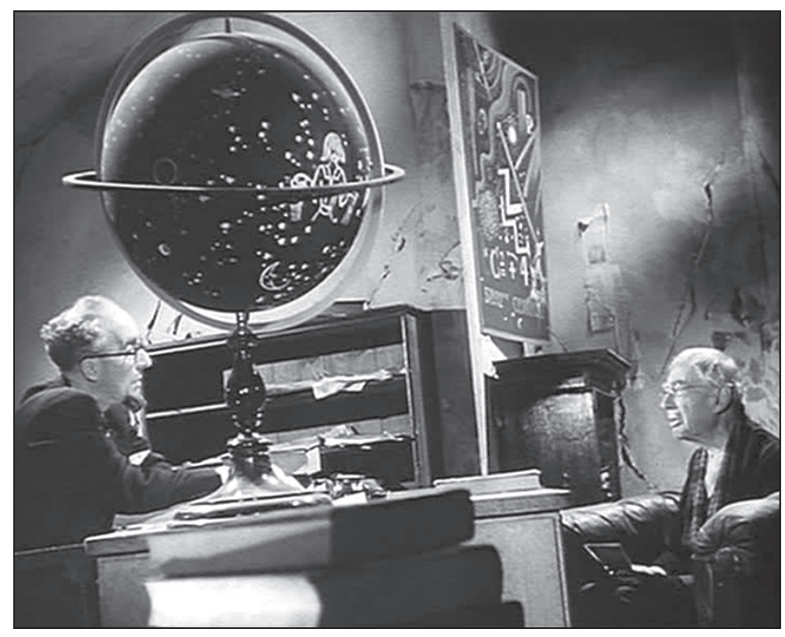

Fot. 3. Mordercy są wśród nas (reż. Wolfgang Staudte, 1946) Mondschein w gabinecie oszusta

${ }^{113}$ Co ciekawe, postaci Mondscheina oraz sąsiada w ogóle nie są wzmiankowane w pierwotnym treatmencie (Wolfgang Staudte, Ein Exposé. Arbeitstitel: Die Mörder sind unter uns, [w:] Wolfgang Staudte, red. Eva Orbanz, Hans Helmut Prinzler). 
Na kilka scen przed „wigilijną” retrospekcją odsyłającą do lat wojny pojawia się $\mathrm{w}$ filmie inna choinka, którą tym razem dekoruje Susanne (na dalszym planie, w drugim pokoju siedzi Mertens). W obu "choinkowych" scenach bohaterowie mówią o śmierci, zawieszając na drzewku ozdobę: Brückner wydaje rozkaz zlikwidować; z kolei Susanne mówi: biedny Mondschein... musiat bardzo kochać swego syna. Pomiędzy tymi scenami istnieje relacja lustrzanej zależności - jak gdyby to syn Mondscheina był wśród grupy pomordowanych "gdzieś w Polsce”. I nawet jeśli dla tak sformułowanej hipotezy nie znajdziemy innego potwierdzenia, zbieżność obu „choinkowych” sytuacji wytwarza związki podobieństwa pomiędzy losem syna Mondscheina i losem cywilów rozstrzelanych w Polsce.

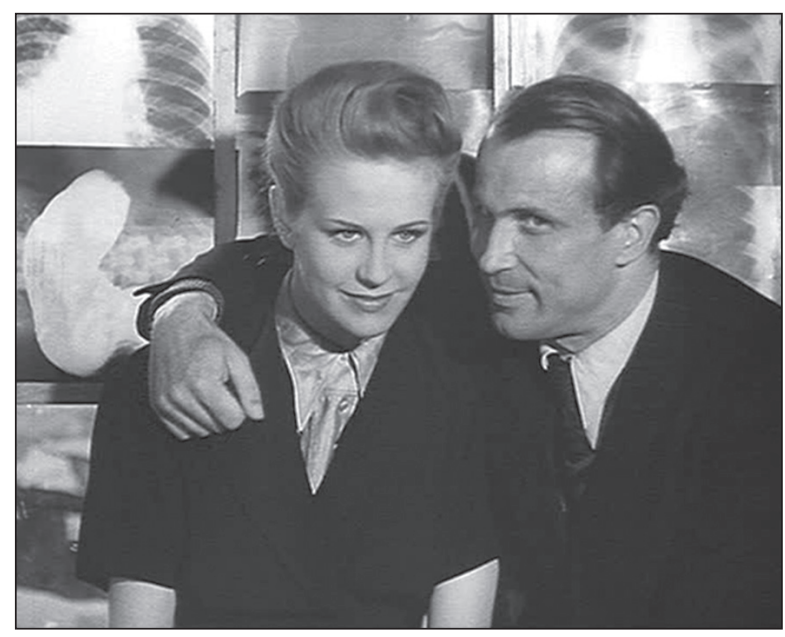

Fot. 4. Mordercy sa wśród nas (reż. Wolfgang Staudte, 1946) Tłem relacji bohaterów jest wizualne świadectwo cielesnego cierpienia

Wniosek ten staje się tym bardziej prawdopodobny, im wnikliwiej przypatrzymy się scenografii wykorzystanej w scenie z Susanne i Hansem. Rozpoczyna się ona w planie ogólnym; w tle widoczne są okna, których szyby pokryte zostały dziwnymi wzorkami - być może szyby są brudne lub zamalowane $\mathrm{z}$ uwagi na procedury przeciwlotnicze z końca wojny? Dopiero po chwili, gdy bohaterowie zostaną ukazani w półzbliżeniu - bezpośrednio na tle okien - stanie się jasne, że w ramach umieszczone są... zdjęcia rentgenowskie (fot. 4). Fabularnie ich obecność wyjaśniona jest powziętym przez Mertensa powrotem do praktyki lekarskiej; nie zmienia to faktu, że mamy do czynienia z niezwykle osobliwym 
obrazem - ścianą pokrytą zdjęciami ludzkich kości ${ }^{114}$. Także monolog Hansa - zaprezentowany jako wspomnienie ryzykownej operacji ze studiów medycznych - wydaje się w rzeczywistości mówić o okropnościach wojny: Błagat, żebym mu pomógł... apelowat do mojego współczucia... [...] a potem poczułem całkowity spokój... jakbym to robit tysiąc razy wcześniej.

W wielu interpretacjach Morderców... dostrzeżono szczególny związek, jaki zachodzi pomiędzy wykorzystanymi w filmie rekwizytami: stłuczonym lustrem (przed którym Susanne staje, gdy wraca do miasta), zepsutymi okularami (w gabinecie optycznym Mondscheina), wybitymi szybami (w domu Susanne i Hansa), zdjęciami rentgenowskimi (należącymi do Mertensa) i aparatem fotograficznym (który Hans zamierza sprzedać na czarnym rynku). Mnogość rozmaitych „przyrządów optycznych”, przedmiotów związanych z technologiami widzenia sprawia, że niewątpliwie można w uzasadniony sposób mówić o wykorzystanych w filmie „metaforach wizualnych". Z konstatacji tej wywieść można jednak rozmaite wnioski ${ }^{115}$. Za pośrednictwem wymienionych rekwizytów tekst Morderców... zapewne wzmacnia ten wymiar swojego dyskursu, który sugeruje wielość punktów widzenia i zachęca do porównywania perspektyw poszczególnych bohaterów. Za uprawniony uważam też wniosek, iż poprzez podkreślenie zasadniczej usterki kilku „przyrządów optycznych” (stłuczone lustro, zepsute okulary, powybijane szyby) sugerowany jest, po prostu, problem ułomności dostępnych sposobów patrzenia na rzeczywistośćc ${ }^{116}$ (fizyczne zniszczenie materii przez wojenną hekatombę powoduje tu konsekwencje natury epistemologicznej). Dla takiej tezy szczególnie istotna byłaby relacja pomiędzy wybitymi szybami a - wprawionymi na ich miejsce w domu Susanne i Hansa - obrazami rentgenowskimi, skutkiem czego bohaterowie mogą chcąc nie chcąc, obserwować świat wyłącznie przez „plamy kości”. Umieszczenie tych „okien grozy” nie w mind-screen bohatera, ale $\mathrm{w}$ diegezie (nawet $\mathrm{z}$ dopowiedzeniem, że chodzi o zdjęcia wykonane przez Mertensa przed wojną - cokolwiek zresztą absurdalnym: skąd bowiem Hans „,wytrzasnął” te fotografie?), w niczym nie zmienia siły ich metaforycznego oddziaływania.

W poszukiwaniu znaczeń, które mogą być ewokowane przez „narzędzia optyczne" wprowadzone do filmu Staudtego, warto zwrócić szcze-

114 Zdjęcia ludzkich kości i stert szkieletów znalezionych w obozach były publikowane w niemieckiej prasie tamtego czasu; zob. na ten temat: Cornelia Brink, Ikonen der Vernichtung..., s. 82-84.

${ }^{115} \mathrm{~W}$ feministycznych interpretacjach filmu tym przedmiotom nadano znaczenia korelujące z dyskursami „zmarginalizowanego mężczyzny" i „udomowionej kobiety” - nie referuję tych rozważań, gdyż nie mają one związku z głównym tematem mojego wywodu.

${ }^{116}$ Na ten aspekt zwraca uwagę Magdalena Saryusz-Wolska, Ikony normalizacji... (rozdział: Ruiny i odbudowa). 
gólną uwagę na jedno $\mathrm{z}$ nich, mianowicie aparat fotograficzny. $\mathrm{W}$ fabule jego znaczenie jest oczywiste: to cenny "łup” (być może nielegalny - rozpowszechnianie zdjęć wymagało bowiem licencji władz alianckich, a aparaty fotograficzne były często rekwirowane), na którego sprzedaży Hans może zarobić. Ostatecznie jednak tego nie czyni - rezygnuje z transakcji, choć zainteresowana kupnem (lub pośrednictwem) jest jedna $\mathrm{z}$ tancerek; o aparacie nie będzie już więcej mowy (co oznacza też, że Hans może mieć go przy sobie!). Przedmiot ten zostanie zatem narracyjnie "porzucony" - czy może raczej: zastąpiony przez rekwizyty poniekąd z nim związane, mianowicie zdjęcia rentgenowskie. Osobliwość „rozegrania” tego motywu - w sposób sprzeczny z klasyczną zasadą „,strzelby Czechowa” - jest cokolwiek zastanawiająca, również z uwagi na kategorialne przesunięcie, które w narracji dokonuje się na linii: aparat - zdjęcia rentgenowskie. Ma ono ważne konsekwencje: owszem, aparat można włączyć do zbioru przedmiotów oznaczanych jako "technologie widzenia", jednak zarazem jego podstawowa funkcja wykracza poza zastosowanie „oglądania przez". I choć w filmie Staudtego nikt żadnych zdjęć nie wykonuje (zaś te, które pojawiają się w domu Hansa i Susanne, są obrazami medycznymi), narracja wyraźnie akcentuje problem rejestrowania rzeczywistości. Prawem licentia poetica można by w tym miejscu rozważyć, jak inaczej skonstruowany mógłby zostać scenariusz - i pożałować, że nie wprowadzono doń dodatkowej intrygi, na przykład związanej ze śladem/świadectwem (nazistowskich zbrodni?), jaki Mertens mógłby znaleźć na kliszy. Takie rozwiązanie zapewne wzmocniłoby konwencję thrillera, a zarazem idealnie wpasowało się $\mathrm{w}$ proponowany tu pomysł interpretacyjny, ukierunkowany na domniemany trop autotematyczny. Kto wie, czy nie warto jednak go uwzględnić - z zastrzeżeniem, że założone przez Staudtego „przesunięcie kategorialne", jak je nazwałem (aparat - zdjęcia rentgenowskie) ma większy "ciężar gatunkowy": nie zachęca do namysłu nad indeksalną naturą obrazów technicznych, lecz sugeruje niemożność rejestracji. Inaczej mówiąc: domniemana ontologia obrazu fotograficznego (i, jak chcieli niektórzy teoretycy, także filmowego) nie może ziścić się wtedy, gdy obiekt, który mógł/miał zostać zarejestrowany, przestaje istnieć.

Funkcję „zastępnika" wydarzeń, o których nie da się opowiedzieć, można nadać innej scenie: operacji, jaką Mertens wykonuje w jednym ze zrujnowanych domów. To długa scena - trwa ponad pięć minut, a czas ekranowy poświęcony na nią nie rozwija w żaden sposób akcji (operowana dziewczyna i jej matka to postaci drugoplanowe) oraz słabo przyczynia się do rozwoju postaci. Przyjmijmy jednak, że zamysłem scenarzysty i reżysera było, aby za sprawą pomyślnie zakończonej operacji, zaimprowizowanej przez Mertensa w polowych warunkach, bohater ten 
zyskał jeszcze więcej cech pozytywnych (tak, by widz mógł przyporządkować mu opis: „prawdziwy profesjonalista, który nawet w niesprzyjających okolicznościach potrafi powściągnąć emocje, aby uratować życie dziecka"). A jednak sposób rozegrania tej sceny sprawia, że zawiera ona w sobie niepokojący naddatek. Mertens zostaje poproszony o pomoc przy nagłym wypadku - ale nie jest to, powiedzmy, wypadek wymagający chirurgicznej interwencji czy krwotok, który może udałoby się zahamować. Dziewczynka z jakichś powodów dusi się (a w zasadzie: oddycha bardzo szybko, lecz płytko) - jej matka sama jest zaskoczona: jeszcze godzine temu czegoś się napita, a teraz... Co jej jest, panie doktorze? Mertens mówi tylko: Tak, rozumiem... Jednym słowem: nie dowiadujemy się, na co cierpi dziewczynka (dla ówczesnych widzów zapewne jasne było, że to dyfteryt, choroba powszechna w pierwszych latach po wojnie ${ }^{117}$ - co wszelako nie powinno wpływać na dociekliwość interpretatora, zaintrygowanego faktem, iż scenarzyści wybrali akurat tę chorobę).

Hans przystępuje do działania: aby odkazić nóż, którym przeprowadzi tracheotomię, wrzuca go do wrzątku. Następnie pyta o jakąś niezbędną mu rurkę; kobieta wręcza mu coś w rodzaju klucza do montażu mebli, Hans ogląda przedmiot i stwierdza, że potrzebuje czegoś innego. Matka dziewczynki, równie zagubiona jak widz, pyta: Panie doktorze, czego właściwie pan szuka? On rozgląda się po pokoju, a następnie zdejmuje ze szczytu szafy ciężkawy przedmiot pokaźnej wielkości; po chwili okazuje się, że jest to żeliwny piecyk. Mertens odłącza zeń gruby przewód, z którego z kolei wyciąga krótszy, metalowy fragment (również ta część trafia do garnka z wrzątkiem). Dziewczynka zostaje położona na stole, a lekarz wydaje kobiecie polecenia: proszę o poduszkę, proszę wlać wodę do miski (Mertens myje ręce), prosze przynieść garnek, proszę zdjać pokrywkę.. W tym miejscu następuje dość długie zbliżenie na wnętrze garnka, w którym leżą odkażone już instrumenty chirurgiczne: nóż i... gazrurka (chwilę później pojawi się jeszcze jedno zbliżenie na ten przedmiot) ${ }^{118}$. Wykorzystane tu rekwizyty wzbudziły moją analityczną czujność nie tylko z uwagi na wyraźną retardację akcji wywołaną „pustym przebiegiem” narracji (osobliwą wymianę zdań między lekarzem a kobietą), ale także dlatego, że w tej scenie mamy do czynienia z niepokojącą redundancją: otóż w pomieszcze-

117 Za tę uwagę dziękuję Magdalenie Saryusz-Wolskiej.

118 Spośród wszystkich znanych mi recenzji Morderców... tylko w jednej wspomniano o tym niecodziennym przecież rekwizycie: „Dłoń lekarza spoczywa najczęściej bądź na szklaneczce sznapsu, bądź na rewolwerze; w jedynej scenie, w której jest aktywna, pomaga duszącemu się dziecku za pomocą gazrurki”. Scenę tę autor recenzji określa jako „bolesną", "niepokojącą" i „wątpliwą z medycznego punktu widzenia” (Werner Fiedler, Der Weg durch die Trümmer, „Neue Zeit”, 17.10.1946). 
niu, w jakim rozgrywają się te wydarzenia, garnki z wodą podgrzewane są na piecyku węglowym (co zostaje wyraźnie pokazane), tymczasem dla przeprowadzenia operacji równie niezbędny okazuje się piecyk gazowy. W ten sposób budowany jest następujący szereg pojęć: „niemiecki lekarz” - "gaz" - „dusząca się dziewczynka". Wszystkie te elementy w omawianej sekwencji niewątpliwie się znajdują i nie są interpretacyjnymi derywatami powstałymi z elementów diegezy. $Z$ tego wnioskuję - być może ryzykownie, ale w sposób, jak sądzę, uprawniony - że w filmie Mordercy sa wśród nas opowieść o Zagładzie zostaje "przeniesiona” na historię o Niemcach w ruinach Berlina. W omawianej scenie w sposób dość niezwykły (by nie rzec: perfidny), gdyż postacią „dobrą” jest w niej właśnie niemiecki lekarz.

W swej Odysei po zniszczonym Berlinie Mertens trafia do jeszcze jednego miejsca - jest bywalcem lokalu, który jako żywo przypomina tingel-tangle z Błękitnego anioła: alkohol, prostytutki, jazz. Przestrzeń ta pokazana została jako świat „moralnego zepsucia”, który „odradza się” wśród ruin; nieprzypadkowo właśnie to miejsce jest tak atrakcyjne dla Brücknera. Pełni ono jednak jeszcze jedną funkcję w dyskursie filmu - oto gdy po raz pierwszy widzimy Mertensa w tym przybytku, bohater jest nietrzeźwy; w pewnej chwili dosiada się do kobiety, która gra w szachy. Mertens wydmuchuje tytoniowy dym wprost na szachownicę i stwierdza, że wygląda ona jak pole bitwy. Następnie wywiązuje się następujący dialog:

\footnotetext{
Mertens: Straci pani dwa pionki.

Kobieta: Ale uratuję króla.

Mertens: Dobro ptynace wprost z serca monarchistki.

Kobieta: Niech pan da spokój, jest pan pijany. To tylko gra, to figurki z drewna.

Mertens: Z drewna, z kości stoniowej [org. Elfenbein], lub z kości [org. Knochen], zawsze chodzi o to samo: ratować króla, pionki moga iść do diabła, ważne, żeby król był bezpieczny... Nie cierpię tej gry [zrzuca szachownicę na ziemię, a po chwili dodaje] Od niewinnej gry ołowianymi żotnierzykami niedaleka droga do karabinów.
}

Przedziwna ta scena - jej obecność w narracji nie jest uzasadniona ani względami dramaturgii (nie znamy imienia rozmówczyni Mertensa, nie pełni ona żadnej funkcji w innych sekwencjach), ani prawdopodobieństwa (szachy w nocnym klubie?) - jest wręcz gęsta od sensów, które nie znalazłszy swego miejsca w fabule filmu, muszą odnaleźć się w jego planie dyskursywnym. Zgryźliwą uwagę o "tendencjach monarchistycznych", które skorelowane zostają z wojną prowadzoną z woli i dla Führera można potraktować jako trybut spłacony mecenasowi (Defie i władzom sowieckiej strefy). Z kolei w szeregu z drewna, z kości słoniowej (Elfenbein) lub z kości (Knochen) zastanawiający jest ostatni wyraz - nawet nie tyle ze względu na swoją redundantność (była już przecież mowa o kości - słoniowej), ale 
wręcz absurdalność (czy „zwykłe” kości mogą posłużyć do produkcji figurek?), która nie znajduje innego uzasadnienia, niż „freudowskie przejęzyczenie". Dodajmy do tego strój, w jakim w omawianej scenie pojawia się Mertens. Otóż na chwilę przed przystąpieniem do gry Hans zakłada na głowę zabawną czapeczkę przypominającą na pierwszy rzut oka dziecięcy berecik. A może jarmułkę? Skojarzenie to wynika z sygnałów rozproszonych $\mathrm{w}$ innych miejscach filmu, ale też ze zdroworozsądkowego domysłu: po pierwsze, $w$ tej scenie bohaterowi nie jest potrzebne nakrycie głowy (znajduje się przecież $\mathrm{w}$ ciepłym pomieszczeniu); po drugie, gdyby uznać, że „odgrywa” przed kobietami rolę żołnierza, wówczas spośród wielu otaczających go przedmiotów powinien wybrać atrybut faktycznie $z$ taką postacią związany, po trzecie: nie mamy raczej prawa uznać, że „czapeczka” jest „zastępnikiem” wojskowej czapki (bohater nie salutuje). Skoro nie znajduję logicznego wytłumaczenia fabularnego, nadaję temu rekwizytowi sens odnoszący się do wyższego poziomu znaczeń i powiązany z innymi „podpowiedziami”, które kierują uwagę na to, co nie zostało pokazane.

Warto przypomnieć $\mathrm{w}$ tym miejscu wszystkie intrygujące aporie filmu Staudtego, przez które przeziera „coś więcej” niż tylko historia o zdemobilizowanym żołnierzu, pragnącym z pomocą wiernie stojącej u jego boku kobiety wyrównać rachunki ze swym dawnym dowódca. Byłyby to: nagłówek gazety (o Auschwitz), zdjęcia rentgenowskie (na ich tle Susanne mówi o synu Mondscheina, a Mertens o pacjencie, który apelowat do jego współczucia), sześcioramienna (!) gwiazda, którą Hans ma znaleźć i którą wyrzuca na śnieg (w retrospekcji wigilii na froncie), śmierć pana Mondscheina zestawiona $\mathrm{z}$ informacją o naukowych metodach, wreszcie - osobliwa czapeczka (jarmułka?) Mertensa, jego wzmianka o „kościach” i zagadkowa "operacja z użyciem gazrurki” w ruinach Berlina. Mnogość tych argumentów pozwala sformułować opinię, iż Mordercy... w planie fabularnym przemilczają wprawdzie Zagładę, lecz jednocześnie sygnalizują ją w serii migotliwych „przebłysków”.

\subsection{Projektowanie modelowej przeszłości}

Oprócz „filmów ruin”, w których dominował wątek współczesny, a lata III Rzeszy wzmiankowane są w krótkich retrospekcjach lub dialogach, w okresie 1946-1949 nakręcono w Niemczech kilka fabuł historycznych bądź bezpośrednio przywołujących czas nazizmu, bądź ewokujących go w sposób pośredni. W tej ostatniej grupie można wskazać - odwołujący się do dramatu Georga Büchnera - film Wozzeck (reż. Georg 
C. Klaren, Niemcy 1947), którego akcja rozgrywa się wprawdzie w okresie I wojny światowej, ale który - poprzez wprowadzenie wątku "skrzywdzonego żołnierza" - może być sytuowany zarówno wśród innych defowskich fabuł piętnujących "militarystyczne tendencje społeczeństw zachodnich", jak i wśród filmów akcentujących konieczność rehabilitacji Heimkeherów i ich włączenia do powojennej rzeczywistości ${ }^{119}$. Z kolei, również wschodnioniemiecka, Sprawa Bluma (Die Affäre Blum, reż. Erich Engel, Niemcy 1948) może być zaliczona do grupy filmów o antysemityzmie - z zastrzeżeniem, że wydarzenia przedstawione w filmie dotyczą Republiki Weimarskiej (kanwą fabuły jest autentyczne zdarzenie z 1926 r.: żydowski właściciel fabryki został oskarżony o zamordowanie księgowego; winą obciążył go prawdziwy sprawca, były żołnierz Freikorpsu).

Wśród fabuł z okresu 1946-1949 niewiele jest takich, których akcja rozgrywa się wyłącznie podczas wojny. W ostatnim roku jej trwania dzieją się wydarzenia przedstawione w filmie I kiedyś się znowu odnajdziemy. Jego bohaterami są młodzi chłopcy z obozu ewakuacyjnego w Westfalii. W pierwszej części filmu ich wychowawcy toczą spór o to, czy pozostawić ich na miejscu (jeden z opiekunów, wcześniej zagorzały nazista, usiłuje przekonać pozostałych, że wojna jest tak czy inaczej przegrana, zaś on sam wstąpił do NSDAP pod przymusem), czy raczej skierować do Berlina, by wesprzeć obronę stolicy (gdzie rozegrają się wydarzenia w dalszej części filmu).

Chłopcy początkowo pokazani są jako całkowicie zindoktrynowani nazistowską propagandą (to pierwszy niemiecki film fabularny poruszający ten problem); ich punkt widzenia zmienia się jednak, gdy w czasie podróży stają się słuchaczami relacji napotkanych żołnierzy i cywilów. Szczególnie interesująca pod względem prezentacji postaw Niemców w czasie wojny jest scena w pociągu, gdzie jeden z głównych bohaterów jest świadkiem następującej wymiany zdań pomiędzy pasażerami (starszym małżeństwem, kobietą i żołnierzem) ${ }^{120}$ :

- Tak jak my postępowaliśmy z innymi, tak oni postapia z nami.

- Dlaczego oni rozpoczęli wojnę? Przecież każdy mógł zobaczyć, że nie wygladało to dobrze.

119 Zob. Anke Pinkert, Film and Memory... (rozdział: Psychotic Breaks and Conjugal Rubble); Jan-Christopher Horak, Postwar Traumas in Klaren's „Wozzeck” (1947), [w:] German Film and Literature: Adaptations and Transformations, red. Eric Rentschler, New York 1986.

${ }^{120}$ Bettina Greffrath określa tę scenę mianem „,kalejdoskopowej”, co dla osoby, która nie widziała filmu, może być mylące (zarówno gdy idzie o wymowę - „kalejdoskopowość” oznaczać może bowiem także różnorodność, której faktycznie tu nie ma, jak i budowę formalną - nie jest to bowiem sekwencja montażowa, zbudowana z dialogów wypowiadanych w różnych czasoprzestrzeniach diegezy). Zob. Bettina Greffrath, Gesellschaftsbilder der Nachkriegszeit..., s. 144. 
- A kiedy nas pytano o zdanie? Gdyby tylko ktoś otworzył usta...

- Wojna była zła, już od pierwszej chwili... To niedobrze, jeśli walczy się o niewłaściwa sprawę.

- Latami trzymano nas w milczeniu, w strachu przed SS, przed obozem koncentracyjnym. Ale teraz powiem, co o tym myślę. Mój mąż poległ w Rosji. Dwóch moich synów zginęło. Cóż mam robić na tym świecie? Ja już się nie boję. Moga mnie równie dobrze zabić.

Proces „dojrzewania” bohaterów dobiega kresu w finale, gdy na własnej skórze doświadczą działań wojennych (fot. 5). Kiedy podczas strzelaniny jeden z chłopców (Uli) chce uratować psa, dosięga go granat; śmiertelnie ranny bohater żegna się z podtrzymującym go kolegą (Wolfgangiem) i jeszcze jednym żołnierzem:

Uli: Powiedz mojej matce, że byłem dzielny.

Wolfgang: Nie chciałem, żeby tak to się skończyło.

Żołnierz: Ty nie, ale tamten [ein anderer] chciat.

Wolfgang: Ma pan rację. I moja matka miała rację. On jest taki, jak wszyscy mówią. On jest morderca.

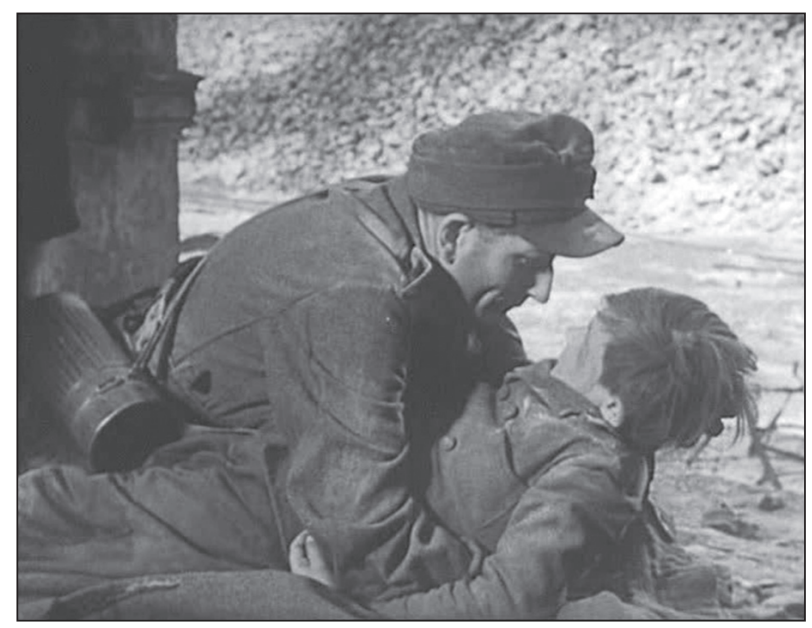

Fot. 5. I kiedyś się znowu odnajdziemy (reż. Hans Müller, 1947)

Ostatnie słowa umierającego chłopca

W scenie tej mamy do czynienia z zaczynem dyskursu, który będzie rozwijany w późniejszych filmach niemieckich (kręconych tak w RFN ${ }^{121}$,

${ }^{121} \mathrm{~W}$ fabułach zrealizowanych w RFN w latach 50. będzie z kolei chętnie wykorzystywana formuła gatunkowa zastosowana w Ostatniej nocy - innej „strefowej” produkcji, której akcja rozgrywa się w czasie wojny. Łączy ona elementy filmu szpiegowskiego (bohaterka z francuskiego ruchu oporu, aresztowana za sabotaż) i melodramatu (niemiecki oficer, który zakochuje się w działaczce résistance i pozwala jej uciec, za co sam staje przed sądem wojskowym). 
jak i w NRD): głównym winowajcą jest "tamten” (w domyśle: Hilter), natomiast wysiłek wojenny "zwykłych żołnierzy" powinien zostać doceniony, a pamięć o ich bohaterstwie - pielęgnowana (Powiedz matce, że bytem dzielny).

Kino niemieckie będzie odwoływać się także do wzorów dramaturgicznych z filmu $W$ tamtych dniach. Jest on zbudowany z siedmiu nowelek, okalanych ramą narracyjną: historie snuje bowiem... samochód, który starają się naprawić dwaj mężczyźni (pod gołym niebem, w ruinach czegoś, co niegdyś mogło być warsztatem). Każda historyjka bierze początek $\mathrm{z}$ przedmiotu znalezionego $\mathrm{w}$ aucie, bohaterami są kolejni właściciele pojazdu ${ }^{122}$, on sam zaś - mimowolnym świadkiem i uczestnikiem zdarzeń. Można by więc zażartować: to film biograficzny (a może nawet - auto-biograficzny?): pierwsza retrospekcja przedstawia „narodziny” bohatera na linii montażowej w fabryce. Sekwencja ta wykorzystuje najpewniej fragmenty z jednego z Unternehmensfilme (reklamówek zamawianych przez duże firmy) lub propagandowych kronik z lat III Rzeszy. Na trop ten naprowadza ironiczny głos ponadkadrowy: Gdy byłem młody, myślałem, że będę żyt tysiac lat, $i \dot{z}$ e będa to wspaniałe czasy (aluzja do "tysiącletniej Rzeszy"), ale moje życie nie było wcale tak wspaniałe, $i$ trwało tylko dwanaście lat (wiemy zatem, że samochód „narodził się" w 1933 r.) ${ }^{123}$.

W kolejnych epizodach filmu przedstawiono egzemplaryczne postawy Niemców w okresie nazistowskiej dyktatury - przy czym "typowość" owych postaw należy rozumieć w kategoriach życzeniowej projekcji, pożądanej przez samych Niemców po wojnie. W pierwszej noweli Sybille musi wybrać między dwoma mężczyznami: Steffen chce wyemigrować do Meksyku, a Peter popiera nowe władze; kobieta ostatecznie decyduje się na wyjazd. Bohaterka drugiego epizodu odkrywa romans swej matki z kompozytorem, oskarżanym o tworzenie sztuki zdegenerowanej,

122 Pomysł zbliżony jest do zrealizowanego w czasie wojny filmu Historia jednego fraka (Tales of Manhattan, reż. Julien Duvivier, 1942), w którym to filmie kolejne nowelki łączone są motywem fraka, przechodzącym z ręki do ręki kolejnych protagonistów. Pomysł użycia pojazdu jako narratora zastosował Käutner już wcześniej, w scenariuszu do filmu Salonka E 417 (Salonwagen E 417, reż. Paul Verhoeven, Niemcy 1939).

${ }^{123}$ Jak twierdzi Paul Dobryden, poprzez wybór samochodu jako „instancji opowiadającej" dyskurs filmu odwołuje się do ważnego elementu niemieckiej tożsamości narodowej, tj. przemysłu motoryzacyjnego i - w szerszym ujęciu - myśli naukowo-technicznej doby nowoczesności (Paul Dobryden, Good Germans, Humane Automobiles: Redeeming Technological Modernity "In Those Days", „Film \& History” 2010, nr 1). Można dodać, że w tej perspektywie mielibyśmy do czynienia ze swoistą subwersją symboliki, którą wcześniej przypisywał sobie nazizm (sukces programu budowy autostrad i „,narodowy samochód”, czyli Volkswagen), a która w filmie Käutnera zestawiona zostaje z postawami moralnie właściwymi. 
ale zataja ten fakt, gdyż w przeciwnym razie muzykowi groziłyby problemy. Akcja trzeciej noweli rozpoczyna się dzień przed „nocą kryształową" - kobieta żydowskiego pochodzenia chce się rozwieść ze swoim mężem dla jego dobra; oboje popełniają samobójstwo. W epizodzie czwartym bohaterka ratuje życie swej siostrze, choć ta jest kochanką jej męża i działa wraz z nim w ruchu oporu. Nowelka piąta rozgrywa się na froncie - szofer zdeklarowanego nazisty zostaje zastrzelony przez partyzantów gdzieś na wschodzie. W szóstym epizodzie służąca ratuje baronową gdyż jej syn jest związany ze spiskowcami z kręgu Stauffenberga. Wreszcie, w siódmej noweli żołnierz naraża życie, aby ratować pochodzącą ze Śląska kobietę z dzieckiem, których ucieczka mogłaby zostać uznana za zdradę (gdyby widz miał problem z dostrzeżeniem nawiązania do opowieści biblijnej o narodzeniu Chrystusa, bohaterowie przedstawią się jako Maria i Józef - fot. 6).

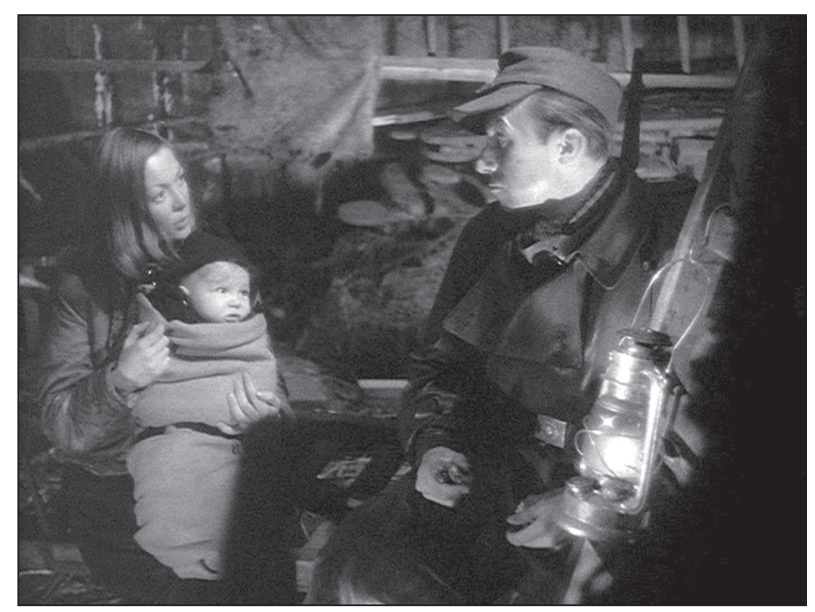

Fot. 6. W tamtych dniach (reż. Helmut Käutner, 1947) Maria (z niemowlęciem) i Józef (żołnierz Wehrmachtu)

Wybór akurat tych tematów jest znamienny co najmniej z kilku powodów. Przede wszystkim, w filmie wskazano kilka "punktów węzłowych" historii politycznej III Rzeszy - dzień powołania Hitlera na kanclerza (w pierwszej noweli), „,noc kryształowa”" (w trzeciej) oraz zamach na Führera (w szóstym epizodzie). Zasygnalizowano też wybrane przykłady prześladowania niemieckich obywateli podczas wojny: brak możliwości działania w legalnej opozycji do NSDAP (w pierwszej nowelce), zakazy wykonywania zawodu (w drugiej) czy ustawy rasowe (w trzeciej). Dwa epizody (czwarty i szósty) traktują o ruchu oporu (przy czym o jego uczestnikach jedynie się mówi, widzimy zaś ich rodziny), natomiast $\mathrm{w}$ dwóch 
innych (piąta i siódma nowelka) podkreślone jest nieposłuszeństwo rozkazom. Większość postaci to niemieckie ofiary nazizmu (są wśród nich także wysiedlone rodziny, a ruiny, wśród których mieści się warsztat z opowieści ramowej, przypominają o ofiarach bombardowań). Wśród bohaterów filmu nie ma natomiast w zasadzie sprawców, czy po prostu „złych Niemców" (jedynie w trzecim epizodzie pojawia się kilku bezimiennych członków SA i Hilterjugend, tłuczących szyby „żydowskich” sklepików). Szczególnie ciekawa jest pod tym względem czwarta nowelka - mężczyzna z ruchu oporu, którego kochają obie bohaterki, jest najprawdopodobniej esesmanem (co sugeruje napis na urzędzie, w jakim spodziewają się go zastać). Z kolei Peter z noweli pierwszej mógłby zostać zaklasyfikowany jako Mitläufer: polityka, która dzieje się za oknami auta, jest czymś zewnętrznym, niezagrażającym kochankom (ten sam aktor pojawi się jeszcze w piątej noweli, w mundurze Wehrmachtu - nie jest jasne, czy w ten sposób pokazano dalsze losy bohatera znanego z pierwszego epizodu).

Poszczególne opowieści prezentowane są jako historie z przeszłości raczej dalszej niż bliższej (na co wskazuje już sam tytuł: W tamtych dniach); w przeciwieństwie do Morderców... brak tu sugestii o bezpośrednim ich oddziaływaniu na teraźniejszość. Sam reżyser deklarował swe intencje w następujący sposób:

wprawdzie akcja filmu rozgrywa się w naszej niedawnej przeszłości, ale mnie interesują jedynie ludzkie losy. Dlatego w moim filmie nie widać żadnych flag i mundurów. Unikałem wszystkiego, co mogłoby przypominać film propagandowy. Ówczesna sytuacja polityczna jest sygnalizowana jedynie przez detale, na przykład widoczne w tle plakaty lub nagłówki z „VB" [Völkischer Beobachter - organ prasowy NSDAP, przyp. K. K.] $]^{124}$.

W każdej z nowel podkreślony został moralny wymiar niełatwych wyborów dokonywanych przez bohaterów (Shandley w lapidarny sposób określa dzieło Käutnera jako „film o dobrych ludziach w złych czasach"125). Ich indywidualne decyzje są bez wyjątku właściwe: protagoniści ryzykują poważnymi konsekwencjami, a w kilku epizodach - swym życiem. Za pośrednictwem swych bohaterów Käutner przedstawia sytuacje, które mogłyby się wydarzyć, lecz czyni to w sposób sugerujący, że miały charakter powszechny (w żadnym punkcie ramy fabularnej nie pojawia się choćby cień wątpliwości, opowieści snute są z pozycji „tak rzeczywiście było"). Jak pisał jeden z recenzentów:

124 Ein Auto als Hauptperson Helmut Käutner erzählt von seinem Film „In jenen Tagen”, „Hannoversche Presse”, 21.01.1947.

125 Robert R. Shandley, Trümmerfilme..., s. 280. 
W tym dziele wyrażono dobitnie to, co wprawdzie czuliśmy, ale nigdy nie odważyliśmy się powiedzieć, gdy wzniósł się przed nami mroczny mur podejrzliwości i zarzutów: że w anonimowej masie, jaką tworzymy dla kogoś z zewnątrz, odpowiedzialnej w całości za to wszystko, czego nie można opowiedzieć (Unsagbare), źródła człowieczeństwa nigdy do końca nie zostały zniszczone ${ }^{126}$.

Ten aspekt filmu jest akcentowany przez ramową historię dwóch mechaników, Willego i Karla. O ich przeszłości nie ma w filmie mowy; skontrastowane zostają jednak ich poglądy na skutki wojennej hekatomby: o ile Karl jest przygnębiony i przeświadczony, iż nie ma już przy$z w o i t y c h ~ l u d z i$, o tyle Willi argumentuje, że można ich było odnaleźć nawet w chaosie wojny. Właśnie do tej rozmowy „włącza się” samochód, który sprzeciwia się mizantropii Karla (instancja narracyjna zdradza więc bezpośrednio intencję filmu - będącą w kontrze do tezy o „winie zbiorowej"). Kolejne scenki mają zatem charakter argumentacyjnej perswazji, która - jak wynika z zakończenia - odnosi skutek: gdy w ostatniej scenie filmu obaj mężczyźni powracają do rozmowy z początku, Karl stwierdza, że dzisiejsze czasy daja tak wiele możliwości. Kropkę nad „i" stawiają ostatnie ujęcia z bawiącymi się dziećmi.

Reakcje krytyki na film były przeważnie pozytywne ${ }^{127}$. We wschodnioberlińskim „Vorwärts" pytano jednak: „Dowiadujemy się, że w tych nieszczęsnych czasach było miejsce dla prawdziwych ludzi. Ale nie uzyskujemy odpowiedzi na pytanie, dlaczego inni ludźmi nie byli i dlaczego tak wielu spośród tych przyzwoitych musiało umrzeć" ${ }^{\prime 28}$. Krytyczną recenzję opublikował także - przy okazji omawiania programu festiwalu w Locarno - dziennikarz szwajcarskiej gazety „Luzerner Neuste Nachrichten”. Charakter zarzutów, jakie postawił filmowi, można zrekonstruować z listu do redakcji, jaki wystosował Käutner. Treść korespondencji jest niezwykle symptomatyczna, toteż warto przytoczyć jej obszerniejszy fragment. Reżyser pisał:

Ani [film] ani autorzy i reżyser w żaden sposób nie negują czynów, które popełnili Niemcy. Film nie ma też na celu spowodować, by czyny te uległy zapomnieniu albo zafałszowaniu. W ogóle o tym nie mówi, bo nie jest polityczny i nie ma być politycznie rozumiany. [...] Ten rodzaj filmów, taki sposób pokazywania rzeczy, które nas poruszaja, wydaje mi się w tej chwili jedynym możliwym dla nas, Niemców. [...] Muszę zatem skrytykować wnioski, które wyciąga recenzent. Nic nie uprawnia go do twierdzenia, że ten film nie dąży do niczego poza „zrzuceniem niemieckiej winy na fantom narodowego socjalizmu”, ani też, że moim lub naszym zdaniem ",nasze obecne gorzkie cierpienie jest niezasłużoną niesprawiedliwością". Myślę, że my, Niemcy, lepiej

126 H. Steffen, In jenen Tagen, „Film-Echo” 1947, nr 5.

127 Zebrane na stronie: http://www.geschichte-projekte-hannover.de/filmundgeschichte (dostęp: 20.04.2014).

${ }^{128}$ Hermann Müller, Anständige Menschen, „Vorwärts”, 18.06.1947. Autor dodaje, że film Staudtego Mordercy... był „zbyt ostry w wymowie, ten zaś jest zbyt łagodny”. 
od innych wiemy, jaka jest nasza sytuacja i nasze cierpienie, które zresztą wcale nie są "gorzkie", ale zasłużone. Uważamy, że [...] puste przyznanie się do winy nikomu nie pomoże, a już najmniej tym, którym wyrządzone zostały krzywdy. I nie uważamy za właściwe, aby każde dzieło artystyczne [...] musiało o tej winie mówić. Sami między sobą też niewiele o tym rozmawiamy. Przyznajemy, że nie mamy na to czasu, bo jesteśmy zajęci pokutowaniem i - jeśli dostaniemy taką szansę - naprawianiem. [...] Usta zamyka nam jednak nie tylko brak czasu, ale też wstyd ${ }^{129}$.

Interesująca jest późniejsza recepcja filmu Käutnera, szczególnie w latach 60. i 70. W 1961 r. przenikliwy Enno Patalas dostrzegł w filmie taka oto gradację bohaterów:

Antyfaszyści pojawiają się gdzieś na marginesie, jako ci, którzy potrzebują pomocy, a nie ci, którzy jako jedyni konsekwentnie troszczą się o jej zapewnienie. „Ludźmi” są jednak właśnie ci apolityczni. Tak więc już w 1947 r. Käutner opracował schemat, na którym opierają się dziś wszystkie filmy nawiązujące do "tamtych dni" - tu faszyści, tam antyfaszyści, a pomiędzy nimi apolityczni, którzy mogą być zadowoleni, że zachowali czyste ręce i w pewnym niewielkim zakresie także miłość bliźniego. Nie nazwana pozostaje jednak najpowszechniejsza forma braku człowieczeństwa - abstynencja polityczna. Jest to alibi dla niezaangażowanych, serwowane tutaj w charakterze kaca po klęsce ${ }^{130}$.

Film Käutnera jako „wyjątkowo nieprawdziwy” określił też Siegfried Zielinski w swym młodzieńczym artykule z 1979 r. ${ }^{131}$ Równie surowo ocenia dziś W tamtych dniach Andrzej Gwóźdź:

fakt, że całą opowieść wyznaczała perspektywa samochodu (co dawało czasami interesujące efekty dramaturgiczne) sprawił, że winni zostali całkowicie wyłączeni z wojennych rozrachunków, ulotniwszy się w przestrzeni pozakadrowej. Wyglądało więc na to, że winę za wojnę i zbrodnię ponosiły tytułowe "tamte dni" pozbawione obecności oprawców, sprowadzone do potoczności „tak było”132.

\subsection{W kostiumie melodramatu}

Wykorzystana w niektórych nowelach $W$ tamtych dniach formuła melodramatu posłużyła także Kurtowi Maetzigowi w opracowaniu fabuły Małżenstwa w mroku. Jest ona inspirowana faktami - losami Joachima

${ }^{129}$ Helmut Käutner, list do red. Stickelbergera. Podaję za: Magdalena Saryusz-Wolska, Ikony normalizacji... (rozdział: Wina i wyparcie).

${ }^{130}$ Cyt. za: Obrazy Niemiec 1949-1999. Katalog przegladu, red. Grażyna M. Grabowska, Renata Prokurat, Warszawa 1999, s. 14.

131 Siegfried Zielinski, Faschismusbewältigungen im frühen deutschen Nachkriegsfilm. Staudtes "Mörder sind unter uns" und Käutners "In jenen Tagen”, "Sammlung. Jahrbuch für antifaschistische Literatur und Kunst" 1979, nr 2.

132 Andrzej Gwóźdź, Obok kanonu..., s. 173. 
Gottschalka, popularnego w latach 30. gwiazdora teatralnego (występującego także w filmach) i jego żony, Mety Wolff, aktorki scen żydowskich, którzy w $1941 \mathrm{r}$. odebrali sobie życie ${ }^{133}$. Ich personalia, zmienione w scenariuszu, ujawnia wieńcząca film plansza z napisem: Ten film jest poświęcony aktorowi Joachimowi Gottschalkowi, który w 1941 roku wraz z rodzina zostat doprowadzony do śmierci - $i$ innym, którzy byli ofiarami (znamienne, że w dedykacji tej wymieniony został z imienia i nazwiska jedynie mężczyzna). Wzmianki o śmierci i pogrzebie Gottschalka zostały zakazane przez Goebbelsowską propagandę; można więc domniemywać, że ówcześni widzowie dowiedzieli się o losie aktora właśnie z filmu Maetziga.

W wyborze przez Kurta Maetziga (Małżeństwo w mroku było fabularnym debiutem) tego akurat tematu dopatrywano się aluzji do losów rodziny reżysera, który pochodził z „małżeństwa mieszanego": matka reżysera była Żydówka, a ojciec rozwiódł się z nia, choć potajemnie spotykali się, póki kobieta nie odebrała sobie życia. Po latach Maetzig utrzymywał, że Małżeństwo... było swoistą polemiką z postawą jego ojca ${ }^{134}$, wcześniej jednak - zgodnie z duchem wschodnioniemieckiej historiografii, akcentującej przede wszystkim rolę komunistycznego ruchu oporu - twierdził, iż „żydowska burżuazja” w Niemczech była pozbawiona właściwego oglądu sytuacji w kraju, a tym samym ponosi „współodpowiedzialność za stanie się ofiarami" (mitschuldig) ze względu na swe słabe zaangażowanie polityczne ${ }^{135}$ ( $w$ filmie Elisabeth łudzi się początkowo, że niemiecka tradycja nie pozwoli na takie bestialstwo).

Trzy części filmu rozgrywają się, odpowiednio, w latach 1933, 1938 i 1943. W części I o względy bohaterki - aktorki żydowskiego pochodzenia - konkuruje dwóch mężczyzn: jej partner z teatru, Hans Wieland oraz doktor Blohm, który wstąpił do NSDAP i piastuje wysokie stanowisko w Ministerstwie Kultury. Elisabeth przyjmuje oświadczyny Wielanda, choć ostrzega, że sprowadzi na niego nieszczęście; sama zaś, po pożarze Reichstagu, musi zrezygnować z kariery. W części II akcent położony zostaje na konflikt między małżonkami: Elisabeth zarzuca Hansowi, że ożenił się z nią z przyzwoitości; Hans niemal zdradza żonę. Część III ma najbardziej dramatyczny przebieg: Elisabeth mieszka sama w Berlinie, z trudem

${ }^{133}$ Scenariusz oparto na opowiadaniu Hansa Schweikerta Es wird schon nicht so schlimm. O losie rodziny Gottschalków zob.: Ulrich Liebe, Verehrt, Verfolgt, Vergessen: Schauspieler als Naziopfer, Berlin 1992.

${ }^{134}$ Kurt Maetzig: Filmarbeit..., s. 35. Zob. też: Bettina Greffrath, Gesellschaftsbilder der Nachkriegszeit..., s. 187-188.

${ }^{135}$ Cyt. za: Die Mörder sind unter uns, Ehe im Schatten, Die Buntkarierten, Rotation: Vier Filmerzählungen nach den bekannten DEFA-Filmen, red. Ellen Blauert, Berlin Ost 1969, s. 144; Kurt Maetzig: Filmarbeit..., s. 54. 
radząc sobie z niedostatkami życia codziennego; Hans został powołany do wojska, skąd powraca chory na tyfus; wydaje mu się, że może nadal chronić żonę - ale Blohm sugeruje, iż powinien postarać się o rozwód. Gdy bohater odmawia, a następnie demonstracyjnie przychodzi z żoną na premierę swego filmu, Blohm zmuszony jest cofnąc Wielandowi zezwolenie na występy. Małżeństwo popełnia samobójstwo.

Film otwiera scena $\mathrm{w}$ teatrze, w którym bohaterowie - Elisabeth i Hans - grają w Intrydze i miłości Friedricha Schillera. Odczytanie intertekstualnego tropu wymaga znajomości dramatu - traktuje on bowiem o nieszczęśliwej miłości arystokraty Ferdynanda do mieszczanki Luizy; ponieważ nie uzyskują oni zgody rodzin na zawarcie małżeństwa, popełniają samobójstwo. Śmierć... Śmierć... Rozwiazuje wszystkie przysięgi. Ferdynandzie! Ziemia i niebo nie zna człowieka nieszczęśliwszego od ciebie. Umieram niewinnie ${ }^{136}$. Paralela między losem Ferdynanda i Luizy ze sztuki oraz Elisabeth i Hansa ujawni się dopiero w finale filmu; w teatrze nic nie zapowiada tragedii. Sekwencja ta ma jeszcze jedną istotną funkcję - zawiera bowiem wzór sytuacyjny, który Maetzig wykorzysta jeszcze w kilku innych scenach zawierających motyw podglądania lub patrzenia $\mathrm{z}$ dystansu ${ }^{137}$. Przez okno bohaterowie śledzą wydarzenia „nocy kryształowej”: Elisabeth w mieszkaniu, zaś Hans na przyjęciu. Dźwięk wybijanej szyby "otrzeźwia" bohatera, który chwilę wcześniej był bliski popełnienia zdrady (paradoksalnie, „noc kryształowa” cementuje związek małżonków).

Małżeństwo w mroku zawiera kilka sekwencji ilustrujących antysemicką politykę nazistów. Pierwszy znak zmieniających się nastrojów społecznych pojawi się podczas wakacji, gdy na plaży pokazany zostanie napis: Żydom wstep wzbroniony. Stopniowe zaostrzanie ustaw rasowych unaocznia natomiast scena poboru kartek żywnościowych - przy okienku z napisem Für Mischehen und Juden („Dla małżeństw mieszanych i Żydów”) dwa ostatnie słowa zostają przekreślone (bohaterka, która sama straciła prawo do poboru kuponów, zostaje zadenuncjowana przez swoją dawną garderobianą). Dotknięci antysemicką polityką są także dwaj bohaterowie drugoplanowi: Louis Silberman, wuj Elisabeth - żydowski lekarz zmuszony zamknąć praktykę, i Kurt Bernstein, przyjaciel głównych bohaterów, który po „nocy kryształowej” emigruje do Wiednia ${ }^{138}$. Gdy pięć lat później Kurt powraca do Berlina i pojawia się w mieszkaniu

136 Friedrich Schiller, Intryga i miłość. Tragedia mieszczańska w pięciu aktach, tłum. A. M. Swinarski, Gdańsk 2000, s. 117 (akt V, scena VII).

137 Thomas Fox, Stated Memory: East Germany and the Holocaust, Rochester 1999, s. 110-111.

${ }^{138} \mathrm{~W}$ postaciach tych krytycy doszukali się odzwierciedlenia biografii grających ich aktorów: Alfreda Balthoffa (grał w berlińskim teatrze żydowskim do jego zamknięcia w 1941 r.) i Willy'ego Pragera (który otrzymał zakaz wykonywania zawodu w 1933 r.). 
Elisabeth, wyznaje jej, że udało mu się uciec z obozu koncentracyjnego. Te informacje nie zostaną jednak zwizualizowane w retrospekcji, lecz pod koniec filmu „przeniesione” na Hansa, który wyobraża sobie przyszłość Elisabeth.

W ostatniej części filmu najbardziej rozbudowana jest sekwencja kinowej premiery, na którą przybywa zwolniony z wojska Hans wraz z żoną. Małżeństwo trafia tam na Blohma w towarzystwie wysokiego urzędnika partyjnego; gdy ten dowiaduje się, że podał rękę Żydówce, nakazuje Blohmowi wyczyścić sprawę. Ten wzywa Hansa, oświadcza mu, iż jego żona zostanie deportowana i zachęca go do rozwodu, dzięki czemu może uratować swoją karierę. Dochodzi do następującej wymiany zdań (w żadnym innym filmie tego okresu nie ma sceny, w której wybrzmiałby równie oskarżycielski ton):

Hans: Niech mi pan powie, czy nie wstyd panu składać mi takiej propozycji? Dziesięć lat temu twierdzit pan, że wstępuje do partii, aby zapobiec niesprawiedliwości. Jakim niesprawiedliwościom pan zapobiegł przez ten czas?

Blohm: Ależ panie Wieland, prosze nie zapominać, że przez cały ten czas ochraniałem pana i kilka innych osób.

Hans: Tyle ma pan do powiedzenia na swoja obronę, że pomógł pan dwóm lub trzem osobom? Panie Blohm, któregoś dnia setki artystów, którym pan i polityka rasowa wszystko zabrała, oskarża pana, pana osobiście, panie Blohm.

Blohm: Ale niech pan sam powie, co ja sam mogę, jako urzędnik...

Hans: Cóż, my sami jesteśmy sobie winni za nasz los. Nie zaprzataliśmy sobie głowy polityka, zawsze wierzyliśmy, że jakoś to będzie, że możemy, jako artyści, zwolnić się z odpowiedzialności, jesteśmy tak samo winni, jak i pan.

Blohm: Jak może pan coś takiego mówić?

Hans: Pan, pan jest narzędziem najgorszych zbrodniarzy i staje się pan winnym śmierci tych, którzy kiedyś byli blisko pana.

W czasie powrotu do domu Hans wyobraża sobie, jak esesmani wyciągają Elisabeth z mieszkania i transportują w przepełnionym wagonie do otoczonego drutem kolczastym obozu. Takie rozwiązanie narracyjne ma ważne konsekwencje dla „rozliczeniowego” dyskursu filmu: sugeruje on bowiem, że jeszcze przed zakończeniem wojny Niemcy mieli świadomość istnienia obozów i warunków w nich panujących.

Wróciwszy do domu, bohater rozpuszcza w kawie truciznę, co Elisabeth dostrzega i komentuje następującym wyznaniem: Dobrze postapiłeś. Dopiero dzisiaj widzę, jak bardzo Cię kocham. Prześladowania, strach i cierpienie zbliżyły nas tak, byśmy byli jedna osobą. Ach Hans, taka jestem szczęśliwa. Samobójstwo - bohaterowie nie są uśmiercani przez Niemców, lecz sami wybierają śmierć - jest wątkiem powracającym w kilku pochodzących $\mathrm{z}$ tamtego okresu filmach, w których poruszony został wątek Mischehen 
(małżeństw mieszanych) ${ }^{139}: \mathrm{w}$ jednej z nowel filmu $W$ tamtych dniach (samobójstwo małżonków ${ }^{140}$ ) oraz we wspomnianym wcześniej filmie Między dniem wczorajszym a jutrzejszym (samobójstwo bohaterki związanej $\mathrm{z}$ Niemcem).

Małżeństwo w mroku uzyskało zróżnicowane recenzje - o ile na przykład jeden z krytyków sugerował, że „na taką fabułę jest jeszcze za wcześnie" ${ }^{141}$, o tyle w innym komentarzu czytamy: „,ważne, że ten film powstał, ważne, że jest właśnie teraz pokazywany, gdy miliony ludzi ze spokojem myśla że litując się sami nad sobą, mogą nie zastanawiać się nad przyczynami swego cierpienia"142. Dostrzeżony w tej ostatniej recenzji „pedagogiczny" wymiar filmu najwyraźniej nie przeszkadzał widowni - Matżenstwo w mroku było jednym z najbardziej kasowych niemieckich filmów pierwszych lat powojennych ${ }^{143}$ (a zarazem jedyną niemiecką produkcja której premiera odbyła się jednocześnie we wszystkich czterech sektorach Berlina ${ }^{144}$ ). Maetzig wspominał, że podczas premiery filmu w Hamburgu doszło do incydentu - w kinie pojawił się Veit Harlan, który został ponoć wyproszony z sali przez wzburzonych widzów ${ }^{145}$. Film pokazywany był także w Stanach Zjednoczonych, gdzie spotkał się z ostrą krytyką Siegfrieda Kracauera ${ }^{146}$; zarzucił on Maetzigowi nazbyt sentymentalną formę oraz obronę „przyzwoitych Niemców”.

Formułę melodramatu przyjmuje także nakręcony w zachodniej części Niemiec film Miłość 47. Reżyser - Wolfgang Liebeneiner - był twórcą aktywnym w okresie III Rzeszy: w latach 1939-1942 piastował kierownicze stanowisko w Izbie Filmowej Rzeszy (Reichsfilmkammer), a między 1942 a 1945 r. był szefem produkcji Ufy; nakręcił m.in. wysokobudżetowy dyptyk o Bismarcku (Bismarck, 1941; Dymisja [Die Entlassung], 1942) oraz

139 Gallwitz zauważa, że motyw ten obecny był również w dwóch filmach austriackich owego czasu: w Aniele z puzonem (Der Engel mit der Posaune, reż. Karl Hartl, 1948) oraz Innym życiu (Das andere Leben, reż. Rudolf Steinboeck, 1948). Zob. Tim Gallwitz, „Wir konnten nach all den Jahren nicht darauf losfilmen, als sei nichts geschehen". Antisemitismus und Judenverfolgung im deutschsprachigen Spielfilm 1946-1950, [w:] Im Bann der Katastrophe. Innovation und Tradition im europäischen Film 1940-1950, red. Johannes Roschlau, München 2010.

140 Zwróciła na to uwagę Bettina Greffrath, Gesellschaftsbilder der Nachkriegszeit..., s. 174.

${ }^{141}$ Wilhelm Ehlers, Ehe im Schatten, „Der Morgen”, 5.10.1947.

${ }_{142}$ Rosemarie Knop, Ehe im Schatten, „Start”, 10.10.1947.

${ }^{143}$ Christiane Mückenberger, Günter Jordan, "Sie sehen selbst, Sie hören selbst...", s. 85.

144 Kurt Maetzig: Filmarbeit..., s. 55.

${ }^{145}$ Neuer Zug auf alten Gleisen. Kurt Maetzig über die Ufa-Tradition und die DEFA-Gründung, dostępne pod adresem: http://www.filmportal.de/material/kurt-maetzig-ueber-die-ufa-tradition-und-die-defa-gruendung (dostęp: 20.01.2014).

146 Siegfried Kracauer, Der anständige Deutsche. Ein Filmportrait, [w:] idem, Kleine Schriften zum Film 1932-1961, Frankfurt am Main 2004. 
Oskarżam (Ich klage an, 1941), produkcję wspierającą eutanazyjną politykę NSDAP. Po wojnie pozytywnie przeszedł postępowanie denazyfikacyjne $^{147}$, by w 1947 r. na deskach hamburskiego teatru wystawić alegoryczną sztukę Wolfganga Borcherta Pod drzwiami (Draußen vor der Tür), na kanwie której kilka miesięcy wcześniej powstało też popularne słuchowisko radiowe, a później - scenariusz Miłości 47. Recenzje filmu Liebeneinera były entuzjastyczne ${ }^{148}$, lecz nie przełożyły się na popularność wśród widzów - być może z uwagi na fakt, iż znana wówczas fabuła autorstwa Borcherta została w filmie w znacznym stopniu zmodyfikowana ${ }^{149}$.

Sztuka opowiada historię niemieckiego repatrianta Fritza Beckmanna, który po Stalingradzie i trzyletniej niewoli na Syberii nie jest w stanie wrócić do normalnego życia. Pomaga mu w tym - podobnie jak w Mordercach... -kobieta. Fritz i Anna poznają się nad rzeką w Hamburgu, gdy oboje postanawiają popełnić samobójstwo. Ona jednak zmienia zdanie, przekonuje również Beckmanna i zabiera go do domu, gdzie snują wspomnienia z czasów wojny. Ostatecznie uczucie rodzące się pomiędzy bohaterami pozwoli im z nadzieją patrzeć w przyszłość i rozpocząć wspólne życie. W odróżnieniu do filmu Mordercy sa wśród nas, przez pryzmat którego czytać można Miłość 47, w filmie Liebeneinera wspomnienia bohaterki, paralelne wobec losów Fritza, zajmują większość czasu ekranowego ${ }^{150}$ - co jest znaczącą zmianą wobec dramatu Borcherta, gdzie pojawia się jedynie bezimienna i drugoplanowa postać kobieca.

147 Magdalena Saryusz-Wolska przywołuje - i ciekawie komentuje - list, jaki w czerwcu 1949 r. Liebeneiner wystosował do redakcji pisma "Sonntag”, którego recenzent wypomniał mu nazistowską przeszłość oraz zarzucił antysemityzm. Reżyser odpierał oskarżenia, powołując się na swą znajomość z Joachimem Gottschalkiem (aktorem, którego losy posłużyły jako kanwa scenariusza Małżeństwa w mroku). Zob. Magdalena Saryusz-Wolska, Ikony normalizacji... (rozdział: Wina i wyparcie).

148 Przykładowo: Walter Panofsky, Liebe 47, „,Der neue Film” 1949, nr 8; Willy H. Thiem, Drinnen im Zimmer: ein neuer Glaube. Wolfgang Liebeneiner ging neue Wege, "Abendpost”, 2.04.1949.

149 Sztuka Borcherta była w Niemczech jeszcze dwukrotnie przenoszona na ekran - tym razem telewizyjny (w RFN w 1957 r. - w reżyserii Rudolfa Noelte, w NRD w 1960 r. - w reżyserii Fritza Bornemanna). Zob. Ulrike Weckel, Spielarten der Vergangenheitsbewältigung - Wolfgang Borcherts Heimkehrer und sein langer Weg durch die westdeutschen Medien, [w:] Medien - Politik - Geschichte, red. Moshe Zuckermann, Tel Aviv 2003; Andreas Kötzing, Dreifacher Beckmann. Wolfgang Borcherts Drama "Draußen vor der Tür" und seine Verfilmungen in der Bundesrepublik und in der DDR, [w:] Der lange Weg nach Hause. Konstruktionen von Heimat im europäischen Spielfilm, red. Lars Karl, Dietmar Müller, Katharina Seibert, Berlin 2014.

${ }^{150}$ Magdalena Saryusz-Wolska przypomina w tym kontekście, że tuż po wojnie opublikowano w Niemczech kilka autobiograficznych relacji pisanych z perspektywy kobiet: Berliner Aufzeichnungen Ursuli von Kardoff, Schauplatz Berlin. Tagebuchaufzeichnungen 19451948 Ruth Andreas-Friedrich oraz Tage des Überlebens. Berlin 1945 Margaret Boveri. Zob. Magdalena Saryusz-Wolska, Ikony normalizacji... (rozdział: Ruiny i odbudowa). 
Struktura filmu budowana jest przez dwie linie narracyjne - dopełniające się (dotyczą bowiem losu i postaw Niemców pod koniec wojny) oraz zarazem konkurujące ze sobą (można odnieść wrażenie, że tak Fritz, jak i Anna chcą wzajemnie się przekonać, kto doświadczył większych cierpień). Znamienne, iż w wędrówce obojga bohaterów głównym zagrożeniem była Armia Czerwona (z pewnością w Defie podobnego filmu nie można byłoby wówczas nakręcić). Beckmann na froncie stał się kaleką, cierpiał z powodu głodu i mrozu, spędził kilka miesięcy w sowieckiej niewoli. Natomiast Anna musiała wraz z maleńką córką uciekać przed bombardowaniami do rodzinnych Prus Wschodnich; gdy z uwagi na nadciągający front zostały zmuszone do powrotu, dziewczynka zginęła pod kołami pociągu. Miłość 47 jest pierwszym niemieckim filmem fabularnym, w którym wprowadzono - rozpowszechnione w ówczesnej prasie i literaturze wspomnieniowej - obrazy tzw. Flucht und Vertreibung („ucieczki i wypędzenia”) $)^{151}$, później - także współcześnie - chętnie eksploatowane w kinie Republiki Federalnej Niemiec. Ponadto, film Liebeneinera lokuje akcję tej części filmu na Mazurach - a właśnie ucieczki z Prus Wschodnich (nie na przykład z Dolnego Śląska) zapisały się w niemieckiej pamięci kulturowej szczególnie silnie, być może za sprawą elementu "egzotycznej przeprawy”, związanego z obrazami „kibitek” sunących po zaśnieżonych duktach ${ }^{152}$.

Bohaterowie Miłości 47 wspominają również swoich małżonków. Żona Beckmanna - sądząc, że zginął on podczas wojny - związała się z innym mężczyzną. Natomiast Jürgen, mąż Anny, był - podobnie jak Fritz - żołnierzem Wehrmachtu. Zarówno w retrospekcjach Beckmanna, jak i w opowieści Anny armia przedstawiana jest jako organizacja bez mała apolityczna - o poglądach politycznych Fritza nie dowiadujemy się niczego, zaś Jürgen o nazistach mówi „oni” (Trzeba przyznać, że znaja się na prowadzeniu wojny!). Do początkowej akceptacji dla narodowego socjalizmu przyznaje się natomiast Anna (Wtedy wierzyłam jeszcze we wszystko, co nam mówiono); wiemy też, że nazistą był ojciec Fritza. Ten wątek został potraktowany w filmie Liebeneinera inaczej niż w dramacie. Gdy w wersji scenicznej Beckmann udaje się do domu rodzinnego, dowiaduje się od nowej lokatorki, że rodzice zabili się (odkręcając kurki z gazem) z powodu

${ }^{151}$ Krótki epizod związany z przesiedleniami pojawia się w Filmie bez tytułu. Wspomniane są one także w defowskim Moście (Die Brücke, reż. Artur Pohl, Niemcy 1949), choć jego akcja w całości rozgrywa się w obozie dla przesiedleńców.

${ }^{152}$ Michaela Ast, Ucieczka i wypędzenie w niemieckim filmie fabularnym lat pięćdziesiatych XX wieku i wspótcześnie, [w:] W drodze do sasiada. Polsko-niemieckie spotkania filmowe, red. Andrzej Dębski, Andrzej Gwóźdź, Wrocław 2013; Bill Niven, On a supposed taboo: flight and refugees from the East in the GDR film and television, "German Life and Letters" 2012, nr 2. 
Żydów. W analogicznej scenie filmu zniwelowano obecną w sztuce aluzję do antysemickich prześladowań: pojawia się wprawdzie informacja o samobójstwie rodziców, a także charakterystyka ojca jako nieprzejednanego nazisty (ein scharfer Nazi), nie ma jednak wzmianki o Żydach ani motywu gazu $^{153}$.

Pokrewieństwo filmu Liebeneinera z Mordercami... wynika nie tylko z wykorzystania schematu "ocalenia depresyjnego Heimkehrera przez kobietę", lecz przede wszystkim z wprowadzenia wątku traumatycznego doświadczenia z przeszłości, z którym musi zmierzyć się bohater. Fritza Beckmanna z Miłości 47 prześladują senne koszmary (fot. 7) i duchy rodzin żołnierzy, za których śmierć czuje się odpowiedzialny (z jednej z retrospekcji dowiadujemy się, iż Fritz prosił nawet, aby postawić go przed sądem wojennym, ale prośba została oddalona, a on sam - uznany za niepoczytalnego).

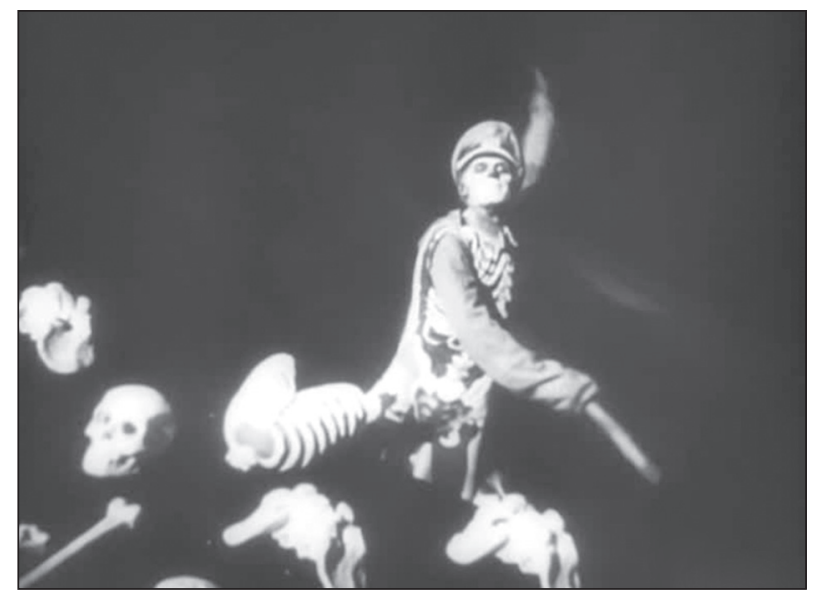

Fot. 7. Miłość 47 (reż. Wolfgang Liebeneiner, 1948)

Wizja ubranej w nazistowski mundur Śmierci grającej na kościach

Podobnie jak u Staudtego, protagonista skonfrontowany zostaje także ze swoim przełożonym z okresu wojny - byłym pułkownikiem, radzącym sobie w cywilu całkiem dobrze (scena, w której spożywa wraz z rodziną kolację, jest wręcz powtórzeniem analogicznej sytuacji z Morderców...), nie poczuwającym się do odpowiedzialności za popełnione czyny (wyśmiewa troski Beckmanna: zrobiłeś się miękki, co?). I choć bohater Miłości 47

${ }^{153} \mathrm{Na}$ tę zmianę zwracają uwagę autorzy opracowań dotyczących Miłości 47 - zob.: Bernhard Gross, "Stunde Null" und "Liebe 47". Zur ästhetischen Disposition des deutschen Nachkriegsfilm, [w:] Im Bann der Katastrophe...; Robert G. Moeller, When Liebe Was Just a Five-Letter-Word: Liebeneiner's "Love 47", [w:] German Postwar Films. Life and Love in the Ruins, red. Wilfried Wilms, William Rasch, New York 2008. 
- inaczej niż Mertens w filmie Staudtego - nie planuje zabójstwa swego byłego dowódcy, podobieństwa fabuły Liebeneinera do Morderców... są ewidentne, przede wszystkim z uwagi na powtórzenie dwóch motywów z wcześniejszego filmu. Po pierwsze, o traumatycznym przeżyciu z czasu wojny słyszymy, że było prawie jak w Boże Narodzenie (u Staudtego, przypomnijmy, chodzi o wydarzenia z wigilii 1942 r.). Po drugie, w surrealistycznym koszmarze Beckmanna (w sekwencji tej zwraca uwagę postać generała, który gra na instrumencie z ludzkich kości) pojawia się obraz cmentarza pełnego białych krzyży - bliźniaczo podobny do tego z ostatnich ujęć filmu Mordercy sa wśród nas.

\subsection{Między pokoleniami}

Problem „apolitycznych”, czyli Mitlüuferów, został w odmienny sposób potraktowany w Rotacji/Brunatnej pajęczynie Wolfganga Staudtego (premiera we wrześniu 1949 r.). Film ten wyróżnia się na tle innych nie tylko wielowymiarową fabuła, lecz także walorami wizualnymi ${ }^{154}$ (wplecione zdjęcia dokumentalne z filmu Julija Rejzmana Berlin, ZSRR 1945) i montażowymi. Kilkakrotnie mamy w nim do czynienia z przestrzenią zautonomizowaną - bohaterowie umieszczeni zostają blisko krawędzi kadru, jakby „na marginesie zdarzeń” ${ }^{155}$. Dobrym przykładem jest scena z początku filmu, w której widok zrujnowanego Berlina zostaje ironiczne zestawiony z plakatem Wir kapitulieren nie! (Nigdy się nie poddajemy!). $\mathrm{Z}$ kolei pod koniec, w ujęciu prezentującym oddział Hitlerjugend, przywódca oddziału jest ledwie widoczny przy lewej krawędzi kadru, zaś jego prawą połowę wypełnia plakat przedstawiający Hitlera. Taka kompozycja obrazu z jednej strony zbliża Rotację/Brunatna pajęczynę do konwencji Trümmerfilm, z drugiej zaś - wyraźnie ją przekracza, grawitując w stronę rozwiązań właściwych późniejszym, „modernistycznym” twórcom lat 60.

Film otwiera zbliżenie na maszynę drukarska, w drukarni wstrząsanej pobliskimi wybuchami; długa panorama ukazuje najpierw dwie kobiety

${ }^{154}$ Za zdjęcia odpowiedzialny był Bruno Mondi, który wcześniej wykonywał zdjęcia do filmów Wolfganga Liebeneinera (do Bismarcka) i Veita Harlana (do Żyda Süssa). Po sukcesie Złotego miasta tego ostatniego (przy którym pracował), zaczął uchodzić za specjalistę od fotografii w systemie Agfa - toteż kontynuował współpracę z Harlanem przy Immensee (1944) i Kolbergu (1945); jego renoma utrzymała się po wojnie, zatem realizował zdjęcia do wielu barwnych filmów kostiumowych, na przykład do serii Sissi (dziękuję Tomaszowi Kłysowi za tę uwagę).

${ }^{155}$ Marc Silberman, The Discourse of Powerlessness: Wolfgang Staudte's „Rotation", [w:] German Cinema: Texts in Contexts, red. Marc Silberman, Detroit 1995, s. 103. 
podchodzące do maszyny, a następnie żołnierza odpoczywającego na podłodze, by wreszcie zamknąć ujęcie najazdem na gazetę, której nagłówek - Bitwa o Berlin - precyzuje czas akcji, czyli koniec wojny. W kolejnej scenie poznajemy bohatera - kamera najpierw śledzi nazwiska i daty egzekucji pozostawione na ścianach celi przez wcześniej przetrzymywanych tam więźniów (motyw ten powróci w zakończeniu filmu); dopiero po chwili pole widzenia kamery uwzględnia mężczyznę. Taki prolog ma swoje uzasadnienie zarówno dramaturgiczne (widz ma prawo przypuszczać, że protagonista oczekuje na wykonanie kary śmierci), jak i dyskursywne (wprowadza bowiem bohatera w szereg ofiar reżimu i wpisuje jego jednostkowy los w opowieść o ruchu antyfaszystowskim). Kolejna scena zawiera zrealizowane w konwencji dokumentalnej ujęcia, przedstawiające ruiny stolicy III Rzeszy (cywilów poszukujących żywności, żołnierzy walczących na ulicach, pielęgniarki ukrywające się $w$ tunelach kolejki podziemnej) i kończy się wprowadzeniem bohaterki - jak się później okaże, żony Behnkego, z którym zostaje fabularnie "połączona” następną sceną, rozgrywającą się w więziennej celi. W tym miejscu napis: Zaczęło się dwadzieścia lat wcześniej (nałożony na napisy na ścianie) inicjuje długą - niemal godzinną - retrospekcję wyjaśniająca, z jakich powodów protagonista, Hans Behnke, trafił do więzienia. Staudte kilkakrotnie wspominał, że chodziło mu o pokazanie, , ,jak do tego mogło dojść"156; losy bohatera miały zatem stanowić uogólniającą ilustrację sytuacji politycznej i ekonomicznej, która przyczyniła się do powstania i rozwoju nazizmu.

Retrospekcję można podzielić na trzy części; ich poszczególne sekwencje są wyróżniane przez ujęcia pokazujące nagłówki gazet, dzięki którym precyzowany jest czas akcji. Pierwsza część rozgrywa się między rokiem 1925 a 1933 - początek małżeństwa Hansa i Lotte oraz narodziny ich syna Helmuta zostają pokazane na tle biedy i bezrobocia Republiki Weimarskiej ${ }^{157}$. Druga część obejmuje okres od dojścia Hitlera do władzy do początku wojny. Sytuacja finansowa rodziny wyraźnie się wtedy poprawia (Hans dostaje posadę w drukarni nazistowskiej gazety „Völkischer Beobachter", dzięki czemu mogą sobie pozwolić na nowe mieszkanie), ale zarazem na horyzoncie rodzinnej idylli pojawiają się problemy:

${ }^{156}$ Cyt. za: Wolfgang Staudte, red. Eva Orbanz [1977], s. 85.

157 W sekwencji ślubu Hansa i Lotte element krytyki społecznej zostaje wprowadzony przez ciekawe odniesienie intertekstualne - wykorzystanie dwóch songów z Opery za trzy grosze Brechta/Weilla. Po premierze Rotacji/Brunatnej pajęczyny Staudte rozpocznie zresztą prace nad ekranizacją Opery..., zostaną one jednak przerwane z uwagi na konflikt z Brechtem, który w międzyczasie stał się luminarzem enerdowskiego życia kulturalnego. 
Kurt, brat Lotte, zaangażowany w ruch antynazistowski, ucieka do Czechosłowacji. Część trzecia (poprzedzona krótką migawką z materiałem dokumentalnym pokazującym maszerujących żołnierzy) rozgrywa się w czasach wojny: Kurt powraca do Berlina, zostaje aresztowany i ginie w 1944 r.; Hans, który pomagał mu drukować ulotki antynazistowskie, odwraca się od nazizmu; Helmut, członek Hitlerjugend (fot. 8), znajduje pomiędzy książkami ulotki antynazistowskie i denuncjuje ojca. Te wydarzenia prowadzą narrację do punktu wyjścia - jeszcze w więzieniu Hans dowiaduje się, że Lotte nie żyje, a Helmut bierze udział w walkach w stolicy Rzeszy.

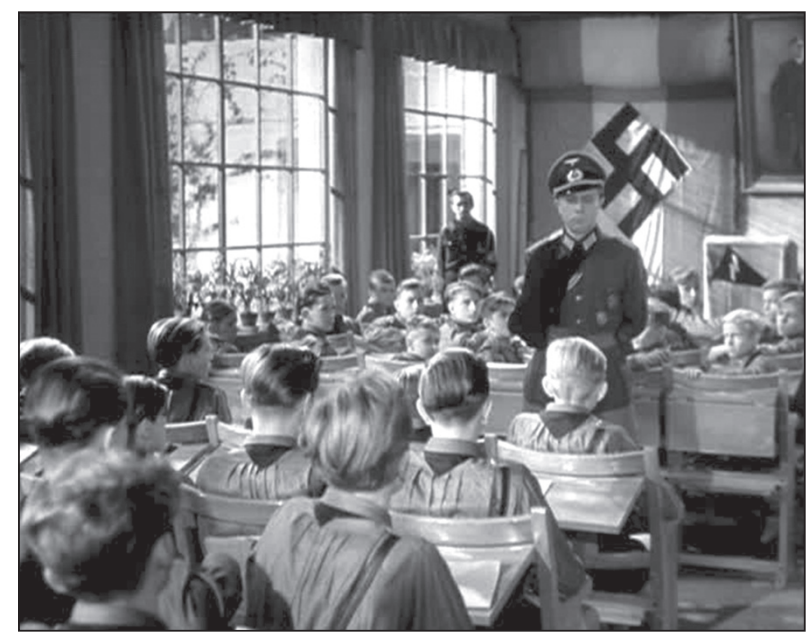

Fot. 8. Rotacja/Brunatna pajęczyna (reż. Wolfgang Staudte, 1949) Pierwsza w powojennym kinie niemieckim scena przedstawiająca indoktrynację chłopców w Hitlerjugend

Taka konstrukcja Rotacji/Brunatnej pajęczyny sprawia, że z około osiemdziesięciu minut filmu niewiele ponad pięćdziesiąt rozgrywa się w czasach III Rzeszy. Bohater skonstruowany został w ten sposób, by unaocznić w pierwszej kolejności jego „apolityczność” czy „neutralność": gdy po latach bezrobocia Hans dostaje pracę w drukarni, swe wysiłki koncentruje na tym, by nie stracić posady - dlatego staje się członkiem NSDAP (wpina odznakę partyjną w klapę marynarki). Przystąpienie do partii wynika zatem nie tyle z przekonań ideologicznych, ile z oportunizmu. Przyczyną nieszczęść, jakie później spadają na Hansa, nie jest jego faktyczna działalność wywrotowa, a jedynie niechęć do pełnego podporządkowania się systemowi; być może z tego powodu ówczesna krytyka traktowała protagonistę nie jako „typowego przeciętniaka”, 
lecz prawdziwego bohatera ${ }^{158}$, w duchu narracji heroicznej, w której godność ocalają gotowi na poświęcenie.

Stopniowe „dojrzewanie" bohatera, zmierzające do odrzucenia przezeń związków z nazizmem w części trzeciej, pokazane zostaje na tle historii rodzinnej - przede wszystkim, podobnie jak w kilku innych filmach omawianego okresu, konfliktu ojca z synem. Ten ostatni pojawia się wyłącznie w kilku scenach - w pierwszej części filmu jest jedynie przywoływany w dialogach (głównie jako wyjaśnienie politycznego oportunizmu Hansa - Mam rodzine, muszę być odpowiedzialny). W scenach rodzinnych pozostaje bądź nieobecny, bądź otrzymujemy informację, że śpi albo znajduje się w innym pokoju (przykładowo, gdy Helmut jest chory i przy jego łóżku czuwają rodzice, nigdy nie są wraz z synem wspólnie widoczni w kadrze). W części drugiej Helmut pojawia się w scenerii „oficjalnej” - jako młody adept Hitlerjugend, indoktrynowany przez swego nauczyciela (ten ostatni jest jedną z nielicznych postaci filmu, której są przypisane negatywne konotacje $)^{159}$. Ostatecznie również młody Behnke zostanie „zresocjalizowany" - w przedostatniej scenie filmu Hans, uwolniony przez sowieckich żołnierzy, unika rozstrzelania i powraca do domu, gdzie dochodzi do pojednania z Helmutem.

Scena ta zasługuje na osobny komentarz - w opracowaniach historycznofilmowych funkcjonuje bowiem w wersjach apokryficznych wobec wersji dostępnej dziś na DVD. Różnice dotyczą rekwizytu istotnego dla antynazistowskiej wymowy Rotacji/Brunatnej pajęczyny: munduru Helmuta $^{160}$. O jego kluczowym znaczeniu zaświadcza relacja Staudtego, który wspominał, że kontrowersje dotyczące tej właśnie sceny poskutkowały rocznym opóźnieniem w ukończeniu filmu ${ }^{161}$. Otóż w pierwotnym zakończeniu Hans, wręczywszy wcześniej synowi cywilny garnitur, miał spa-

${ }^{158}$ Do takiego wniosku doszła Ulrike Weckel na podstawie lektury opublikowanych po premierze recenzji, zob. Ulrike Weckel, The Mitläufer in Two German Postwar Films..., s. 83-86.

159 Scena, w której Helmut po swej zdradzie skonfrontowany jest z ojcem, stanowi punkt kulminacyjny filmu. Jest ona również ciekawie rozegrana, dialogi są bowiem zastąpione przez dobiegającą z radia V Symfonię Beethovena (to chyba pierwszy film, w którym muzyka Beethovena zostaje wykorzystana w scenie tortur; później podobny zabieg wykorzysta Stanley Kubrick w Mechanicznej pomarańczy).

160 O scenie tej piszą m.in.: Ulrike Weckel, The Mitläufer in Two German Postwar Films..., s. 74-75; Thomas Brandlmeier, Kampf ums Nachkriegsprogramm, [w:] Träume in Trümmern. Film - Produktion und Propaganda in Europa 1940-1950, red. Hans-Michael Bock, Jan Distelmeyer, Jörg Schöning, München 2009, s. 160; Maike van Hoorn, „Das sind keine Menschen...". Zur Darstellung der Nationalsozialisten in Filmen Wolfgang Staudtes, [w:] Courage und Eigensinn. Zum 100. Geburtstag von Wolfgang Staudte, red. Uschi und Andreas Schmidt-Lenhard, St. Ingbert 2006.

161 Wolfgang Staudte über die Produktionsbedingungen seiner Filme..., s. 37. 
lić nazistowski uniform syna - opatrując ten symboliczny akt stosownym dopowiedzeniem ${ }^{162}$. W kopiach dystrybuowanych w 1949 r. - jak wynika z ówczesnych recenzji - w scenie tej zachowano ujęcie pokazujące mundur w piecu. Natomiast w wersji dostępnej na DVD widać jedynie mundur rzucony na łóżku. Najpewniej scena palenia munduru została post factum usunięta z filmu (być może $\mathrm{z}$ uwagi na plany władz strefy sowieckiej dotyczące restytucji enerdowskiej armii oraz konieczność jej legitymizacji) i właśnie ta wersja została poddana digitalizacji, a dziś uchodzi za kanoniczną.

Dramaturgicznie słabo zarysowaną postacią jest Lotte - żona Hansa i matka Helmuta. W interesującej interpretacji tego wątku Anke Pinkert zwraca uwagę na napis „matka” na ścianie celi Hansa i przywołuje scenę, w której Kurt, brat Lotte, próbuje przekonać Behnkego, by ten pomógł mu w drukowaniu ulotek. Kurt stoi na tle okna, za którym widać płonące w wyniku nalotów domy; w tym samym czasie Lotte wychodzi z pokoju, reagując na wezwanie stróża, proszącego o pomoc na ulicy - w ten sposób bohaterka „zostaje wyrzucona z przestrzeni negocjacji i całkiem dosłownie wciśnięta w sferę zniszczeń spowodowanych przez naloty, które w pewien sposób sytuują się poza kontinuum antyfaszystowskiej walki"163. Później, gdy aresztowany Behnke dowiaduje się, że został zadenuncjowany przez syna (swoją drogą nie poznajemy reakcji matki na zdradę, jakiej dopuścił się Helmut), na ścianie celi widoczny stanie się inny napis: Ojcze, nie opuszczaj mnie; wymiar religijny sprowadzony jest zatem do fabularnej relacji syn-nazista/ojciec-antynazista. Pod koniec filmu Lotte zostanie - dosłownie - „wymazana” $\mathrm{z}$ narracji filmu: w rozmowie z synem Behnke przypomni imiona osób, wyryte na ścianie celi - tych, którzy poświęcili życie dla budowania lepszego społeczeństwa dla przyszłych pokoleń. Wątek matki skwitowany zaś zostanie zdaniem: teraz ja będę myz naczynia, teraz wszystko będę musiat robić sam...

Jedyna scena, w której obecna jest cała rodzina, zawiera epizod tyleż ważny, ile w narracji pokazany zdawkowo - deportację Salomonów, sąsiadów Behnków. Scena ta rozpoczyna się od ujęcia Helmuta wyglądającego z zaciekawieniem przez okno, a następnie strofowanego przez ojca. Ujęcie pokazujące, co rzeczywiście dzieje się na ulicy, trwa ledwie cztery sekundy, a zamieszanie (Hans odsuwa syna od okna) - niewiele ponad dwadzieścia; następnie widzimy, jak przez okno patrzy Hans (zanim zaciagnie zasłony), ale nie wiemy, co dokładnie obserwuje. Horyzont

${ }^{162}$ Magdalena Saryusz-Wolska porównała zachowane w Bundesarchiv dwie wersje scenariusza: w pierwszej Hans mówi: To był twój ostatni mundur, w drugiej: Chodź, teraz spalimy tę szmate - wrzucimy ją do pieca (brak wzmianki o „ostatnim mundurze”). Zob. Magdalena Saryusz-Wolska, Ikony normalizacji... (rozdział: Wina i wyparcie).

163 Anke Pinkert, Film and Memory..., s. 98-99. 
wiedzy widza jest zatem mniejszy niż bohatera - narracja odmawia pokazania tego, czego świadkiem jest protagonista ${ }^{164}$ (swoją droga, w kilku innych późniejszych filmach zrealizowanych w Niemczech znajdą się podobne sceny - w których aryjscy obywatele III Rzeszy dostrzegają przez okno aresztowanie żydowskich sąsiadów, lecz nie chcą być świadkami tego zdarzenia i zasuwają zasłony).

Impulsem, który powoduje przemianę bohatera, nie jest jednak deportacja Żydów, lecz postać szwagra - działacza ruchu robotniczego (najpewniej komunistycznego, choć to słowo w filmie nie pada). Początkowo Hans jest niechętny Kurtowi, który zarzuca mu, że ten ogranicza swe poczucie odpowiedzialności wyłącznie do rodziny (To wszystko tutaj to wasza wina). Później jednak pomaga szwagrowi - na jego prośbę naprawia maszynę drukarska, a następnie, wiedziony ciekawościa, bierze do domu jedną z ulotek ${ }^{165}$. Gdy zaś dowiaduje się o aresztowaniu i śmierci Kurta w obozie, niszczy portret Hitlera (który wisi w mieszkaniu tylko dlatego, że wcześniej jego brak został dostrzeżony przez wizytującego Behnków oficera SD). W ostatniej części retrospekcji zwraca uwagę rozbudowana, nakręcona $\mathrm{z}$ rozmachem (co podkreślały ówczesne doniesienia prasowe ${ }^{166}$ ) sekwencja ",ostatnich dni Berlina”, w tym reinscenizacja wspomnianego już wydarzenia: zalania przez oddziały SS stacji metra, w której schronili się cywile (w wyniku tej zbrodni śmierć poniosło ponad sto osób). Kolejne ujęcia pokazują ludzi uwięzionych w kanale i niemogących wydostać się na zewnątrz przez zakratowane odpływy, unoszące się na powierzchni wody walizki i znaki drogowe. Pojawia się także obraz matki tulącej dziecko, a sekwencję zamyka metonimiczny obraz ptaszka tonącego w klatce. Rotacja/Brunatna pajęczyna to jeden z pierwszych filmów pokazujących hekatombę ludności cywilnej pod koniec wojny, niewątpli-

164 Jens Thiele podaje, że Staudte chciał zaraz po tej scenie wmontować fragment Olimpiady Riefenstahl, ale pomysł ten został storpedowany przez władze Defy (Jens Thiele, Die Lehren aus der Vergangenheit: "Rotation” (1949), [w:] Fischer Filmgeschichte, t. 3, red. Werner Faulstich, Helmut Korte, Frankfurt am Main 1990, s. 135). Tytułem anegdoty można przytoczyć - za Staudtem - wspomnienie jego rozmowy z sowieckimi oficjelami na ten temat. Na pytanie Staudtego „Co przeszkadza wam w tej scenie? Przecież nawet nie było was na tych igrzyskach”, miała paść odpowiedź: „Nie mieliśmy wtedy dobrej drużyny, gdybyśmy mieli, prawdopodobnie byśmy przyjechali" (za: Wolfgang Staudte über die Produktionsbedingungen seiner Filme..., s. 69).

165 Por. następującą uwagę Gwoździa: „Nieomal identyczny schemat fabularny, oczywiście z przeciwnym znakiem wartości, eksploatował hitlerowski film Braterstwo krwi (Blutsbrüderschaft, 1940): druk prohitlerowskiej bibuły stanowił w nim oręż walki z komunistycznym zagrożeniem dla sprawy Niemiec" (Andrzej Gwóźdź, Obok kanonu..., s. 159).

166 Die Tunneldecke bricht. Bei den Aufnahmen zu Staudtes Film "Rotation", "Vorwärts", 3.02.1949; Der Tod im S-Bahnschacht. Wolfgang Staudte dreht in Babelsberg den kriegsfeindlichen Film "Rotation", „Berliner Zeitung”, 2.02.1949. 
wie istotny w genealogii tego motywu, później kilkakrotnie wykorzystywanego w niemieckim kinie.

W finale filmu, rozgrywającym się latem po zakończeniu wojny (nie wiadomo, czy to 1945 r., czy później), Helmut Behnke spotyka się z przyjaciółką nad jeziorem, by wspólnie - ironizuje Gwóźdź -

kroczyć ochoczo ku świetlanej przyszłości, w stronę „świata bezpiecznego i bez biedy" (jak uczy ojciec marnotrawnego syna), dokładnie w tym samym miejscu, w którym przed dwudziestoma laty ojciec spacerował ze swoją przyszłą żona, ufny, że nadszedł czas kończący bieg maszyny rotacyjnej historii ${ }^{167}$.

Obie sceny nie są jednak tożsame - jak podkreślał reżyser, „gdy para idzie na rozwidleniu drogą w lewo, wybiera inną drogę niż ta, na którą zdecydowali się rodzice. Uważałem wtedy, że to jest bardzo wyraźne"168. Jak widać, dla politycznego odczytania filmu ważny okazać się może nawet kierunek ruchu ekranowego postaci...

W sowieckiej strefie okupacyjnej Rotacja/Brunatna pajęczyna zyskała, rzecz jasna, dobre recenzje; kilka pozytywnych opinii pojawiło się też w prasie zachodnioniemieckiej (w 1950 r.), choć w Trizonii film nie był dystrybuowany (odbyło się tylko kilka pokazów) ${ }^{169}$. W roku 1958, gdy trafił wreszcie na ekrany zachodnioniemieckich kin (a reżyser kręcił już filmy w RFN), recenzent „,Filmforum” pytał: „Z czego wynika fakt, że Wolfgang Staudte w Niemczech cudu gospodarczego nie może zaoferować dzieła o podobnym potencjale duchowym i artystycznym? A może przyczyna tkwi właśnie w tym wszechobecnym cudzie?" ${ }^{170}$.

Propagandowe profilowanie historii Niemiec stanie się jeszcze wyraźniejsze w innej produkcji Defy - Cztery pokolenia. Filmowa adaptacja słuchowiska Berty Waterstradt to saga rodzinna: kronika dziejów niemieckiej familii od schyłku XIX w. do końca II wojny światowej, rozgrywająca się $\mathrm{w}$ takt marszu oddziałów podążających na front - i powracających z kolejnych wojen. Guste-nieślubna córka służącej, dziedzicząca po matce ten sam status - poślubia robotnika Paula, weterana I wojny, który w okresie międzywojennym podejmuje współpracę z ruchem komunistycznym. Podczas II wojny światowej Guste traci dzieci; pozostaje jej siostrzenica Christel, która po wojnie zostaje studentką (wschodnio)berlińskiego

167 Andrzej Gwóźdź, Obok kanonu..., s. 159.

168 Za: Wolfgang Staudte. Zur Retrospektive, red. Eva Orbanz, Berlin 1974, s. 47.

169 Karl Eppenhagen, Mitläuferproblematik im Film. Bemerkungen zu dem DEFA-Streifen "Rotation”, „Die Welt”, 25.05.1950; anon., Wolfgang Staudtes „Rotation”, „Süddeutsche Zeitung", 11.09.1950.

170 Paul Schallück, "Rotation”. Zehn Jahre verspätet, aber immer noch aktuell, „Filmforum" 1958, nr 3. 
Uniwersytetu Humboldta. To właśnie dla niej Guste szyje sukienkę z prześcieradła w kolorowa kratkę (tytuł oryginalny filmu).

Film zbudowany jest z kilkunastu scenek rodzajowych, które nie tworzą narracji w rozumieniu łańcucha przyczynowo-skutkowego, lecz stanowią „punktowe” ilustracje propagandowego przesłania: możni tego świata rozpętują konflikty zbrojne, maluczkim zaś dzieje się krzywda; jedynie w nowych okolicznościach politycznych, w państwie socjalistycznym, będą oni mogli poprawić swój los. Cztery pokolenia zawierają tym samym klarowną wykładnię "marksistowsko-leninowskiej” wizji dwudziestowiecznej historii: nazizm przedstawiony zostaje jako kolejne „wcielenie" militaryzmu napędzanego przez kapitalizm. Ten wymiar filmu najłatwiej dostrzec w dwóch scenach. Przede wszystkim - w wizji wojennych cierpień, jakiej doświadcza Guste pod wpływem rozmowy z kalekim weteranem I wojny, który wyjaśnia bohaterce, że koncern Kruppa zarabia miliony na zbrojeniach („uświadomiona” w ten sposób Guste z dnia na dzień porzuca pracę $\mathrm{w}$ fabryce amunicji). Z kolei dojście do władzy nazistów przedstawiono w scenie, w której rodzina czyta artykuł o spotkaniu Hitlera i przemysłowców.

Cztery pokolenia bliskie są już poetyce socrealizmu, ale w pełni jej nie realizują. Zreszta, gdy w czerwcu 1949 r. na nowego dyrektora Defy wskazano sowieckiego reżysera Aleksandra Andrijewskiego (piastował to stanowisko do 1952 r.), miał on wiele obiekcji wobec scenariusza, któremu - w odniesieniu do konstrukcji głównej bohaterki - zarzucił „polityczny indywidualizm" (zdaniem Andrijewskiego, Guste powinna zostać ukazana na tle robotniczego kolektywu) oraz tendencję „mieszczańsko-pacyfistyczną" (gdyż protagonistka nie przystępuje do „ruchu antyfaszystowskiego"). Produkcji filmu - będącego wówczas już w fazie zdjęciowej - jednak nie przerwano ${ }^{171}$. Ostatecznie kształt stylistyczny Czterech pokoleń wykazuje więcej afiliacji z kinem Ufy niż filmami socrealistycznymi - przede wszystkim z uwagi na inscenizacyjny rozmach, scenograficzny przepych oraz subiektywizujące rozwiązania wizualne. Szczególnie znamienne pod tym względem są dwie sceny rozgrywające się na sali balowej oraz wykorzystanie popularnych szlagierów. Dzięki nim dzieło Maetziga nabrało sznytu Revuefilm z lat 30. - choć sam reżyser uzasadniał takie ukształtowanie ścieżki dźwiękowej w następujący sposób:

Z lat gdy nadchodził faszyzm, pod koniec lat 20., pamiętam piosenkę Leutnant warst du einst bei dem Husaren [...]. Wykorzystałem takie trzy lub cztery szlagiery, nie tylko

171 Thomas Heimann, DEFA, Künstler und SED-Kulturpolitik. Zum Verhältnis von Kulturpolitik und Filmproduktion in der SBZ/DDR 1945 bis 1959, Berlin 1994, s. 116. 
dla charakterystyki łła historycznego, ale po to, by uprzytomnić, że służyły one zepsuciu świadomości szerokich mas ${ }^{172}$.

Temat rodziny był podejmowany w kilku innych fabułach nakręconych $\mathrm{w}$ Niemczech $\mathrm{w}$ pierwszych latach wojny. Filmy te, w odróżnieniu od omówionych dotąd tytułów, mają zawężony horyzont fabularny - rezygnują z szerszej (lub choćby tylko obejmującej lata 30.) panoramy dziejów familii, przybierając formułę filmu współczesnego, który jedynie w motywach drugoplanowych odnosi się do lat nazizmu.

Gdzieś w Berlinie - trzeci film Defy - to rozgrywająca się w ruinach Berlina historia grupy dzieciaków. Głównymi bohaterami są Willy, który w czasie wojny traci swój dom i rodziców, a także jego przyjaciel Gustaw, syn żołnierza Illera. Gdy powraca on do rodziny, dzięki wsparciu żony i miłości syna energicznie włącza się w proces odbudowy zniszczonego Berlina (fot. 9).

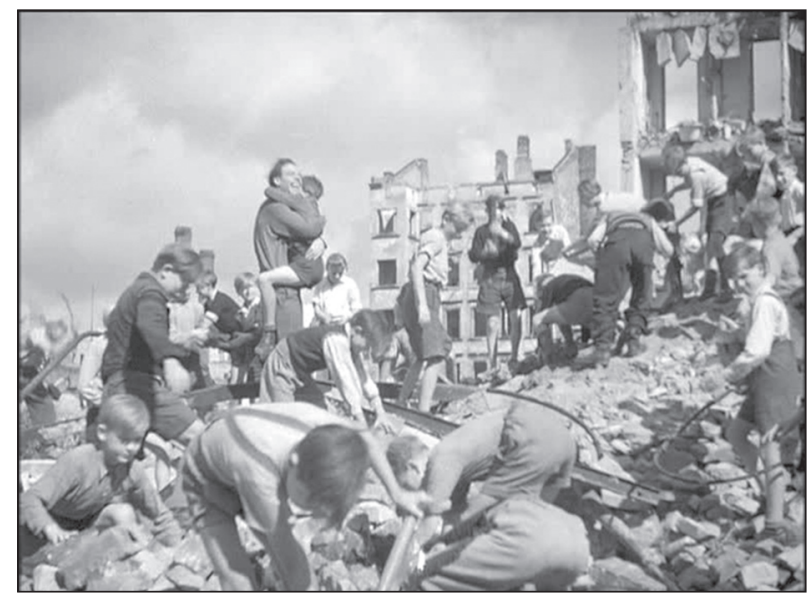

Fot. 9. Gdzieś w Berlinie (reż. Gerhard Lamprecht, 1946)

Optymistyczny finał: przyszłość należy do Was!

Film zyskał pozytywne recenzje ${ }^{173}$, w których chwalono realistyczne pokazanie powojennej rzeczywistości i skierowanie uwagi na postaci dziecięce $^{174}$. Niewiele miejsca poświęcono natomiast bohaterom dorosłym;

172 Kurt Maetzig: Filmarbeit..., s. 68.

${ }^{173}$ Walter Lennig, Irgendwo in Berlin, „Berliner Zeitung”, 20.12.1946; Werner Fiedler, Irgendwo in Berlin, „Neue Zeit”, 20.12.1946.

174 Reżyser powraca tu do dziecięcego bohatera, którym posłużył się w swoim filmie zrealizowanym jeszcze w Republice Weimarskiej, Emil i detektywi (reż. Gerhard Lamprecht, Niemcy 1931) na podstawie powieści Ericha Kästnera - drugoplanowa postać złodziejaszka 
jedynie krytyk „Tagesspiegla” przyznał, że „przykro było patrzeć”175 na postać Steidela - sąsiada Illera. Ten ostatni przedstawiony został jako człowiek, który przeszłość „zostawił za sobą” (nie wspomina nic o swych frontowych przeżyciach; jedynie scena, w której rozbija plastikowy czołg syna pozwala określić jego stosunek do wojny). Steidel jest postacią wobec niego kontrapunktową - on również powrócił z frontu, ale w odróżnieniu od Illera cierpi na poważną depresję: niewiele mówi, gapi się bezmyślnie w przestrzeń, wstaje z łóżka wyłącznie po to, by na balkonie naśladować ruchy żołnierskiej musztry (jest wyraźnie kojarzony z wojskiem: w scenie, w której pojawia się po raz pierwszy, kamera daje zbliżenie na hełm). W przeciwieństwie do Illera jawi się on jako szaleniec, który ewidentnie "nie pasuje” do społeczności (sąsiedzi skarżą się na jego „występy" i proszą matkę bohatera, aby go "usunąć $\mathrm{z}$ widoku”). Obie postaci zostają zresztą $w$ interesujący sposób zestawione w scenie, gdy Steidel dostrzega Illera ze swego balkonu i wskazuje go placem, mówiąc: Tam! (czy rozpoznaje swego dawnego kompana z wojska? A może to gest oskarżycielski? Tego fabuła nie wyjaśnia).

Steidel interpretuje wszystko, co widzi, przez pryzmat swych wojennych doświadczeń. Gdy pod koniec filmu Willy wspina się na zrujnowany budynek (aby udowodnić innym chłopcom, że nie jest tchórzem), Steidel wykrzykuje: Hura! Bohater, bohater! Chłopiec potyka się i wpada w „krater”; jego ciało zostanie złożone w łóżku, w którym wcześniej leżał Steidel. Usłyszymy jeszcze, że mężczyzna przez cała noc czuwał nad zwłokami (a w zasadzie: sprawował wartę, wache stehen). Tuż przed śmiercią dziecka, Steidel wykrzykuje: Żotnierze umieraja! Żotnierze umieraja! Scena ta - z uwagi na "anielskie” oświetlenie oraz patetyczną muzykę - zrealizowana jest w innej stylistyce niż wcześniejsze sekwencje; wedle Christiane Mückenberger stanowi „ciało obce w realistycznej tonacji filmu", u Shandleya zaś wywołała skojarzenie z „kiczem śmierci w filmach Ufy"176. Autorzy nie wyciągają jednak wniosków z tej obserwacji - tymczasem scena ta jest ważna dla dyskursywnej wymowy filmu, ustanawia bowiem relację między śmiercią dziecka i żołnierzem Wehrmachtu; ich los stapia w amalgamat znaczenia „niezawinione cierpienie Niemców”.

Bliska podobnego wniosku jest Anke Pinkert, gdy porównuje zakończenie filmu Lamprechta z finałem filmu Roberto Rosselliniego Niemcy,

\footnotetext{
Waldemara Hunke z Gdzieś w Berlinie jest niemal kopią Maxa Grundeisa z wcześniejszego filmu (w obu rolach wystąpił ten sam aktor, Fritz Rasp).

${ }^{175}$ Friedrich Luft, Irgendwo in Berlin, „Der Tagesspiegel”, 20.12.1946.

${ }^{176}$ Christiane Mückenberger, Günter Jordan, "Sie sehen selbst, Sie hören selbst...", s. 68; Robert R. Shandley, Trümmerfilme..., s. 125. Zob. także: Jaimey Fisher, Who's Watching the Rubble-Kids?..., s. 91-125.
} 
rok zerowy, gdzie również mamy do czynienia z przypadkową śmiercią dziecka. Autorka sugeruje, iż porażka fabuły Rosselliniego wśród niemieckiej widowni wynikała po części z braku analogicznego domknięcia poprzez rytuał żałoby po stracie bliskich, która pod koniec wojny nie mogła być publicznie demonstrowana:

choć ideologiczny zamysł filmu Lamprechta ma na celu demontaż wojennego bohaterstwa i ustanowienie fabuły reintegrującej byłych żołnierzy Wehrmachtu, sekwencja z metonimicznym łożem śmierci ujawnia społeczną potrzebę, aby uczcić cierpienie i śmierć ${ }^{177}$.

Ów „reintegracyjny” wymiar fabuły jest nader wyraźny w ostatniej scenie filmu: gdy budynek, w którym zginął Willy, wylatuje w powietrze, a na jego gruzach staje Iller otoczony przez dzieci - przeszłość zostaje dosłownie „zakopana”, a teraźniejszość wymaga przezwyciężenia traumatycznych doświadczeń minionych lat.

Wyłącznie w okresie powojennym rozgrywa się akcja defowskiego filmu Nasz chleb powszedni (Unser täglich Brot, reż. Slátan Dudow, Niemcy 1949), oparta na prostym schemacie dramaturgicznym, będącym wariacją opowieści o Kainie i Ablu. Karl Weber pracuje jako księgowy w fabryce, w której zatrudniony jest także jego syn Ernst (Harry Hindemith - wcześniej zagrał Illera w Gdzieś w Berlinie) ${ }^{178}$. Drugi z synów, Harry, zarabia znacznie więcej od brata, co początkowo imponuje ojcu - do momentu, gdy okazuje się, że Harry to pospolity rzezimieszek, utrzymujący się z kradzieży i rozbojów.

Film Dudowa, choć powstał przed oficjalnym zadekretowaniem socrealizmu jako poetyki obowiązującej twórców Defy (wszedł na ekrany kilka dni po powstaniu NRD, w listopadzie 1949 r.), zawiera już wyraźnie wiele jej cech. Przede wszystkim mamy do czynienia z klarownym znakowaniem postaci jako jednoznacznie dobrych (Ernst - zaangażowany w odbudowę fabryki; jego siostra Inge - nie mogąc znaleźć stałego zatrudnienia, podąża wiernie za bratem; robotnik Peter Struwe, przypominający "przodowników pracy” z socrealistycznych fabuł) i złych (Harry oraz prostytuująca się kuzynka Mary). Karl Weber natomiast to typowa postać „konwertyty”: początkowo sceptyczny wobec działań Ernsta, ostatecznie korzysta z szansy, by zmienić swe przekonania i zgadza się podjąć pracę w kierowanej przez syna fabryce (choć nie może objąć swego dawnego stanowiska - zostaje zatrudniony jako odźwierny).

177 Anke Pinkert, Film and Memory..., s. 54-55.

178 Karla gra Paul Bildt, popularny aktor Ufy, który pojawił się też w obsadzie propagandowych filmów nakręconych w III Rzeszy - Wuju Krügerze i Kolbergu. 
Opozycja my/wy wiąże się w filmie Dudowa zarówno z konfliktem pokoleniowym, jak i politycznym - na co wskazują kierowane do ojca słowa Ernsta: Gdyby Harry zrobit to samo, co robie teraz i co zawsze robiłem, oszczędzono by nam tych ruin... Sami sprowadziliście nieszczęście na wasz świat. My musimy najpierw wszystko wyczyścić, żebyśmy mogli zaczać od nowa. Konfiguracja ta stanowi odwrócenie relacji pomiędzy starszymi i młodymi bohaterami z innych filmów niemieckich tego okresu, na co zwrócił uwagę jeden z recenzentów: „dyskusje, podczas których syn popada w rozwlekłe gadulstwo, przypominają podobne konflikty między ojcami i synami z minionego czasu, kiedy to synowie pozostawali w błędzie (im Unrecht waren)"179. W filmie Dudowa rozwiązanie konfliktu ma już wymiar jawnie propagandowy - w jednej z ostatnich scen jesteśmy świadkami pojednania między ojcem a Ernestem (w tle widać zaś portret Karola Marksa).

Z kolei postać Harry'ego skonstruowana zostaje tak, by widz nie miał wątpliwości, że ma do czynienia z człowiekiem jeśli nie do szpiku kości zepsutym, to z pewnością niesympatycznym i podejrzanym: bohater domaga się większych porcji jedzenia niż inni członkowie rodziny (choć to właśnie oni mają pracę), a typy spod ciemnej gwiazdy, z którymi się spotyka, reprezentują rynek w zachodnich strefach ${ }^{180}$. O tym, że Harry walczył na froncie, dowiadujemy się jedynie z jego krótkiej wypowiedzi: Kiedy wrócitem z wojny do domu, nic nie było dla nich ważniejsze, liczyło się tylko to, że żyje. Ale teraz czuję, jakbym był gościem, z którym ledwie wytrzymuja. Przeszłość ewokowana jest wyłącznie przez fotografię Harry'ego, na którą patrzy on podczas kłótni z ojcem. Jak słusznie zauważa Anke Pinkert, rekwizyt ten „pozwala widzowi wytworzyć znaczenie pomiędzy różnymi płaszczyznami czasowymi"181, co narracja akcentuje poprzez konstrukcję montażową. Gdy Harry spogląda na fotografię, początkowo nie widzimy, co się na niej znajduje; dopiero później kontury twarzy bohatera spoglądającego na zdjęcie nałożą się na podobiznę umieszczoną za szybką ramki.

Zakończenie wątku Harry'ego nakłada na tę postać jeszcze inne skojarzenie. Pod względem fabularnym sekwencja ta zbudowana jest następująco: kiedy macocha Harry'ego prosi go o kupienie większej ilości pieczywa

179 Anon., Unser täglich Brot, „Neue Zeit Berlin”, 11.11.1949.

180 Pinkert zauważa, że w odróżnieniu od wcześniejszych filmów, w których bohaterowie wracający z wojny uzyskują szansę powrotu do społeczności, w Naszym chlebie powszednim „dyskursy naprawcze (praca, rodzina, matczyna miłość, kobiece oddanie), które mogłyby odkupić tę postać, są niedostępne” (Anke Pinkert, Film and Memory..., s. 78).

181 Ibidem, s. 79. Dalsza część interpretacji tej sceny - gdy autorka pisze o „wciągnięciu w narcystyczną pętlę" i sugeruje, że scena ta „oznacza wewnętrzną świadomość śmierci" - budzi już uzasadnione wątpliwości. 
dla rodziny (sądząc, że dysponuje on gotówką), Harry, który stracił swoje kontakty na czarnym rynku, zaczaja się nocą pod sklepem przy piekarni, a następnie podąża za małą dziewczynką która z niego wyszła. Kolejne ujęcia zrealizowane są w estetyce noir i przywołują skojarzenia z M Langa (w pewnej chwili widzimy już nie mężczyznę, który śledzi ofiarę, lecz jego cień). Dziewczynka zdaje sobie sprawę z grożącego jej niebezpieczeństwa i ucieka; Harry atakuje zaś starszego mężczyznę, nie rozpoznając, że to jego ojciec. Gdy prawda wyjdzie na jaw, bohater wybierze dobrowolną śmierć (nie zostaje ona pokazana: Harry zmierza w stronę torów kolejowych, słychać jedynie gwizd lokomotywy). Jak twierdzi Pinkert, dyskurs filmu „ucieka się do samobójstwa, aby oczyścić postfaszystowskie imaginarium Niemiec Wschodnich od tych wspomnień przeszłości, których nie można przestroić na zwycięską stronę historii"182.

Zdaniem Tima Gallwitza, wyjątkowość filmu Dudowa tkwi w pobocznym wątku inżyniera Bergstettera, dipisa (displaced person) przydzielonego do mieszkania Weberów. Gdy wprowadza się on do nich, mówi młodej Weberównie, że stracit swoja dziewczynkę; pani Weber nie wie, jak zareagować na to wyznanie - i w tym miejscu scena się urywa. Później, podczas urodzinowego przyjęcia inżynier oświadcza, że przez trzy lata szukał (bezskutecznie) swej córki Ruth, na co Weber odpowiada: Nic o tym nie wiedziałem (dwuznaczna wymowa: nie jest jasne, czy nie wiedział o poszukiwaniach kolegi, czy o mechanizmach, które doprowadziły do śmierci dziewczyny). Gdy zaś w fabryce zwalnia się inżynierskie stanowisko (po ucieczce na zachód dotychczasowego pracownika) i Bergstetterowi zostaje zaproponowana praca, odpowiada on: Widze, że potrzebujecie pomocy. A ja wiem, co to znaczy, gdy ludzie potrzebuja pomocy. Jestem gotów z wami pracować. W opinii Gallwitza, w żadnej innej niemieckiej fabule nakręconej tuż po wojnie nie pokazano tak „płynnej” i bezkonfliktowej integracji bohatera żydowskiego pochodzenia $\mathrm{z}$ niemieckim społeczeństwem ${ }^{183}$. Z drugiej jednak strony, kwestie Bergstettera są nieco sztuczne (nie ma w nich gniewu ani pretensji, wydaje się nadmiernie grzeczny, nawet służalczy wobec Weberów) i ostentacyjnie lakoniczne. Bohater „jest”, a zarazem „,jakby go nie było", jak gdyby główne zadanie tej postaci w dyskursie filmu polegało na "odnotowaniu się" na symbolicznej „liście obecności”, a zarazem "nieprzeszkadzaniu” innym bohaterom w ich projekcie budowy socjalistycznego ładu.

182 Ibidem, s. 81.

183 Tim Gallwitz, „Was vergangen ist, muss vorbei sein!”. Zur Gegenwärtigkeit des Holocaust im frühen deutschen Nachkriegsfilm 1945-1950, [w:] Die Vergangenheit in der Gegenwart. Konfrontationen mit den Folgen des Holocaust im deutschen Nachkriegsfilm, red. Thomas Möller, München 2001, s. 17. 


\subsection{Problem antysemityzmu}

Zagadnieniem praktycznie nieobecnym w ówczesnej niemieckiej debacie był antysemityzm - jako fundament nazistowskiej ideologii (pod koniec lat 40. temat ten podjęła Hannah Arendt, która pracowała wówczas nad Korzeniami totalitaryzmu, wydanymi w USA w 1951 r.; po niemiecku publikacja ukazała się cztery lata później), ale też jako niewypleniona tendencja właściwa sporej części niemieckiego społeczeństwa, wychowanego na Goebbelsowskiej propagandzie. Choćby z tego powodu warto odnotować dwa filmy fabularne, które podejmują ten problem, rzutując na tło III Rzeszy wątki rozgrywające się po wojnie.

Głównym bohaterem filmu Między dniem wczorajszym a jutrzejszym Haralda Brauna ${ }^{184}$ jest grafik Michael Rott. Powróciwszy do powojennych Niemiec z emigracji w Szwajcarii, dokąd musiał uciekać podejrzany o wywrotową działalność, szuka on w zrujnowanym Monachium wieści o swej dawnej ukochanej Anette Rodenwald, z którą ostatni raz widział się w 1938 r. Jak się okazuje, dwa lata wcześniej została ona żoną niejakiego Ebelinga, właściciela hotelu, w którym w 1938 r. rozegrały się wydarzenia będące treścią czterech retrospekcji, budujących kryminalną intrygę osnutą wokół zaginionej biżuterii Nelly Dreyfuss. W marcu 1938 r. spotyka się ona ze swoim byłym mężem Alexandrem Cortym, z którym musiała wziąć rozwód ze względu na prawo rasowe. Ponieważ Corty potrzebuje pieniędzy, Nelly prosi Rotta o przekazanie mu biżuterii; niedługo później Nelly, wiedząc o wydanym nakazie jej aresztowania, popełnia samobójstwo. Kosztowności nie docierają jednak do Corty'ego - okazuje się, że „zaopiekowała się" nimi kelnerka Kat, która już po wojnie zamierza je sprzedać na czarnym rynku. Dowiedziawszy się jednak o oskarżeniach wobec Rotta, postanawia zwrócić biżuterię. W melodramatycznym finale Kat i Rott wyznają sobie miłość; nieporozumienia z przeszłości zostaną w ten sposób ostatecznie zażegnane.

Niedorzeczność tej intrygi, dostrzeżona zresztą przez ówczesną krytykę $^{185}$, nie wymagałaby może obszerniejszego komentarza, gdyby

${ }^{184}$ W rolach głównych wystąpiła plejada gwiazd dawnej Ufy: Victor de Kowa, Winnie Markus, Sybille Schmitz, Victor Staal i Willy Birgel. Ten ostatni w czasie wojny grał w propagandowych filmach Wrogowie (Feinde, reż. Viktor Tourjansky, 1940), Towarzysze (Kameraden, reż. Hans Schweikart, 1941) i Konnica dla Niemiec (...reitet für Deutschland, reż. Arthur Maria Rabenalt, 1941).

185 Anon., In die Schablone gepreßt. "Zwischen Gestern und Morgen” im Astor-Filmtheater, „Berliner Zeitung”, 21.03.1948; Walter Panofsky, München: Festlicher Start der "Neuen Deutschen Filmgesellschaft". Zwischen gestern und morgen, „Der neue Film”, 21.12.1947. Ten ostatni pisał: „[...] tak wspaniała plejada znanych twarzy wywołuje bezwiednie (ungerufen) wiele 
nie fakt, że mamy do czynienia z jedynym nakręconym tuż po wojnie niemieckim filmem, w którym pojawia się wątek rabunku żydowskiego mienia - prywatne "śledztwo" dotyczy bowiem losów biżuterii „zaginionej” w tajemniczych okolicznościach. Gdy zaś ta w zakończeniu szczęśliwie się odnajduje (Tim Gallwitz zauważa, że nie ma mowy o tym, by odzyskali ją, na przykład, spadkobiercy Dreyfussów $\left.{ }^{186}\right)$, to główną funkcją tego rozwiązania jest oczyszczenie Niemców z zarzutów o kradzież. Nieprzypadkowo o przywłaszczenie biżuterii oskarżony zostaje przede wszystkim Rott, który w powojennej rzeczywistości nie jest witany jako reemigrant, lecz traktowany jako potencjalny przestępca i „wykluczany” z niemieckiej społeczności. Dawni znajomi bohatera zarzucają mu także konformizm i przeczekanie najgorszego w cieplarnianych warunkach:

- Rott? A tak, przypominam sobie. Świetnie pan wyglada, panie Rott. Wyglada na to, że dobrze stużyty panu te lata. Gratulacje!

- Wiem, tu musiało być ciężko.

- Co? Co pan o tym wie? Kogo tutaj nie było, drogi panie, nic na ten temat nie wie.

Jak w większości niemieckich filmów tego okresu, wspólnota cierpienia ograniczana jest przede wszystkim do Niemców - w dodatku tych, którzy pozostali w kraju. Owszem, Nelly Dreyfuss popełniła samobójstwo, ale postać ta przywoływana jest wyłącznie w dialogach, jako „echo z przeszłości” (w dodatku jednoznacznie „oznaczona” stereotypowym skojarzeniem wiążącym Żydów z majątkiem). O wiele więcej czasu ekranowego poświęcono natomiast Kat (a zatem - przypomnijmy - bohaterce, która faktycznie przejęła biżuterię). Gdy dziewczyna przypomina sobie czasy wojny, dowiadujemy się, że straciła w niej rodzinę (ich ciała spoczywaja gdzieś pod gruzami) i od tamtej pory: radzimy sobie sami. Co robić? Trzeba żyć dalej, prawda? Nie ma innego wyjścia. Dopiero wtedy, gdy Rott zaakceptuje tę narrację, wiążąc swą przyszłość z Kat, zostanie włączony do społeczności, która wcześniej traktowała go z nieufnością i niechęcią.

wspomnień z dnia minionego. Ale przez to znaczenie wielu szczerych słów zostaje złagodzone [...]. Upowszechnianie - aby nie powiedzieć: propagowanie - nowych tendencji nie może obejść się bez pewnych sprzeczności między dniem wczorajszym i jutrzejszym". 186 Tim Gallwitz, "Was vergangen ist, muss vorbei sein!"..., s. 10. Zob. także: Bernhard Gross, Wahrnehmen - Observieren - "Checken". Geschichtlichkeit als Ästhetische Erfahrung in "Zwischen gestern und Morgen”, [w:] Demokratisierung der Wahrnehmung? Das westeuropäische Nachkriegskino, red. Hermann Kappelhoff, Bernhard Gross, Daniel Illger, Berlin 2010. 
Problem niemieckiego antysemityzmu podjęty został także w filmie Powołanie ${ }^{187}$. Była to produkcja "prestiżowa" - nad premierami we Frankfurcie, Hamburgu, Düsseldorfie i Monachium honorowe patronaty objęli tamtejsi burmistrzowie; film brał udział w konkursie canneńskim, ale wyniki frekwencyjne $\mathrm{z}$ dystrybucji kinowej w Niemczech wskazuja, iż nie stał się popularny ${ }^{188}$. Odtwórcą głównej roli i autorem scenariusza inspirowanego własnymi przeżyciami był Fritz Kortner - współtwórca weimarskiej sceny teatralnej lat 20., który po powrocie z emigracji w USA otrzymał ofertę pracy $\mathrm{w}$ jednym $\mathrm{z}$ niemieckich teatrów i został oczerniony przez konkurentów donosami o antysemickim charakterze ${ }^{189}$. $\mathrm{W}$ scenariuszu wydarzenia te zostały przeniesione $\mathrm{w}$ realia uniwersytetu, w którym katedrę obejmuje profesor Mauthner, nieakceptowany przez niektórych studentów, podburzanych przez część pedagogów, m.in. doktora Fechnera (domagającego się drugiego exodusu i ubolewającego, że Hitler nie dokończył tego, co zaczą) ${ }^{190}$. Drugi ważny wątek filmu dotyczy syna profesora - żona Mauthnera pozostała w Niemczech i związała się z Aryjczykiem, którego nazwisko miało chronić chłopca przed represjami.

Dyskurs filmu porusza problemy związane z tezą o „winie zbiorowej". W pierwszej sekwencji, rozgrywającej się jeszcze w USA, Mauthner rozmawia o swoich planach powrotu $\mathrm{z}$ innym żydowskim emigrantem, który ostrzega go:

Mówię ci, choć zabrzmi to brutalnie, tam pożra cię żywcem, to kanibale, tacy oni są. Nie czujesz wobec nich żadnej nienawiści, żadnej odrazy? Nie rozumiem cię. Przecież wspótpracowali albo przygladali się temu wszyscy. Mauthner odpowiada: Pytam cię, skoro tak się przechwalasz: deklarujesz, że byłbyś w stanie ryzykować życiem, by ochronić niewinnie prześladowanych? Sa do tego okazje na świecie! Jeśli nie, zamilcz i nie żadaj tego od innych. Nie ma narodu zbrodniarzy ani narodu bohaterów!

${ }^{187} \mathrm{~W}$ niektórych polskich opracowaniach tytuł filmu tłumaczony jest, niezbyt trafnie, jako Wezwanie, gdy tymczasem chodzi o objęcie katedry na uczelni (tytuł oryginalny jest przy tym bardziej dwuznaczny, gdyż der Ruf oznacza też „reputacja”).

188 Tim Gallwitz, Remigranten und akademische Jugend. Gustav von Wangenheims „Und wieder 48" und Fritz Kortners "Der Ruf", [w:] Träume in Trümmern..., s. 15. Zob. także: Ulrike Weckel, Brutstätte des Antisemitismus und Männerdomäne: Die deutsche Nachkriegsuniversität in der Diagnose des Spielfilms „Der Ruf” von 1949, [w:] Politische Gesellschaftsgeschichte im 19. und 20. Jahrhundert. Festgabe für Barbara Vogel, red. Henning Albrecht, Hamburg 2006.

189 Zob. Helmut G. Asper, Fritz Kortners Rückkehr und sein Film "Der Ruf", [w:] Wenn wir von gestern reden, sprechen wir über heute und morgen. Festschrift für Marta Mierendorff, red. Helmut G. Asper, Berlin 1991.

${ }^{190}$ Historyk Frank Stern pisze, iż film Powołanie daje właściwy wyraz panującym wówczas nastrojom - antysemityzm był wtedy obecny na niemieckich uczelniach, które nie wykazywały zainteresowania powrotem żydowskich naukowców. Zob. Frank Stern, Im Anfang war Auschwitz. Antisemitismus und Philosemitismus im deutschen Nachkrieg, Gerlingen 1991, s. 197. 
Irmgard Wilharm wykonała kwerendę $\mathrm{w}$ archiwach firmy dystrybucyjnej Schorcht, w których zachowały się dwa interesujące doniesienia ${ }^{191}$. Narzekający na niewielkie wpływy kierownik kina w Kassel napisał: „Musimy uczyć się z wyników tego filmu. Mamy nadzieję, że głosy właścicieli kin nie pozostaną niewysłuchane i że lekcję z tego wyniesie także produkcja filmowa. Szerokie masy widzów po prostu nie chcą oglądać takich filmów"192. Natomiast z Nürtlingen koło Stuttgartu nadeszło doniesienie, że widzowie wygłaszali podczas seansu antysemickie komentarze do fabuły, a wychodząc z kina pytali przy kasie, czy jego właścicielem jest Żyd.

Konfrontacja z realiami powojennych Niemiec - w szczególności ze studentami zindoktrynowanymi nazistowską ideologią - okazuje się jednak dla Mauthnera bolesna. Wir haben Sie nicht gerufen (co znaczy: Nie my powołaliśmy pana na stanowisko, ale zarazem: Nie wzywaliśmy was - w odniesieniu do władz alianckich) - mówi jeden z nich. I właśnie on, Walter, okaże się biologicznym synem Mauthnera (wychowywanym w rodzinie nazistowskiego generała). Gdy w zakończeniu Walter akceptuje swoją żydowską tożsamość, jego ojciec umiera. Komentując tę scenę, Gallwitz pisze o „negatywnej symbiozie niemiecko-żydowskiej” - owa symbioza (można być Niemcem żydowskiego pochodzenia) ma charakter negatywny, gdyż jej warunkiem jest śmierć Żyda starszego pokolenia ${ }^{193}$.

\subsection{Obrazy obozów}

Choć obrazy nieludzkiego traktowania więźniów w kacetach (a także świadectwa masowych mordów dokonywanych w obozach zagłady) były $\mathrm{w}$ powojennych Niemczech szeroko rozpowszechniane, a zarazem dyskutowane na łamach prasy, nie były one przyporządkowywane wyłącznie Zagładzie. Również z tego powodu spośród nakręconych wówczas w Niemczech filmów o latach niedawnej wojny wyróżniają się dwa, które traktują o tragicznym losie Żydów. Oba filmy łączy perspektywa autobiograficzna (a precyzyjniej: wprowadzenie do fabuł wątków, które były udziałem producentów), a także swoista „uniwersalizująca” perspektywa wojennych cierpień (dialogi wzywające do porozumienia narodów).

Pierwszym z tych filmów jest Morituri, zrealizowany przez firmę CCC Artura Braunera, w przyszłości jednego z najważniejszych producentów zachodnioniemieckiej kinematografii. Wprawdzie może nieco ryzykowna

${ }^{191}$ Irmgard Wilharm, Filmwirtschaft, Filmpolitik und der "Publikumsgeschmack" im Westdeutschland der Nachkriegszeit, "Geschichte und Gesellschaft” 2002, nr 28, s. 281.

${ }^{192}$ Cyt. za: ibidem.

193 Tim Gallwitz, Remigranten und akademische Jugend..., s. 14. 
byłaby opinia, iż fabuła tego filmu jest „oparta na biografii Braunera"194, ale z pewnością zawiera pewne jej epizody. To zresztą Brauner był pomysłodawcą scenariusza, który napisał Gustav Kampendonk, mający doświadczenie z Ufy. Pracowali dla niej też występujący w Morituri aktorzy: Walter Richter, Winnie Markus, Karl-Heinz Schroth, Hilde Körber i Josef Sieber (ten ostatni grał $\mathrm{w}$ wielu propagandowych produkcjach III Rzeszy $)^{195}$. Reżyserię zlecono Eugenowi Yorkowi, który wcześniej asystował Walterowi Ruttmannowi, a w latach 1937-1943 realizował filmy oświatowe (Kulturfilme) dla Ufy. Autorem zdjęć został Werner Krein (wcześniej pracujący przy superprodukcji o Münchausenie z 1943 r.), zaś muzykę skomponował Wolfgang Zeller (odpowiedzialny za ścieżkę dźwiękową do Żyda Süssa).

CCC, choć miała siedzibę w amerykańskim sektorze Berlina, dysponowała licencją wydaną przez władze francuskie, jednak ani Amerykanie, ani Francuzi nie wyrazili zgody na zdjęcia do filmu o zaproponowanej przez Braunera tematyce (wcześniej wyprodukował on - za zgodą władz francuskich - tylko jeden film, Król kier [Herzkönig, reż. Helmut Weiß, Niemcy 1947). Przeniósł on więc firmę do sektora brytyjskiego, ale i tu nie uzyskał pozwolenia na rozpoczęcie zdjęć - w czerwcu $1947 \mathrm{r}$. zgłosił się zatem do administracji sowieckiej, która przychylnie ustosunkowała się do inicjatywy. Brauner zwrócił się także z prośbą do władz prowincji Sachsen i Halle o przekazanie materiału fotograficznego, dokumentującego „bramy, ogrodzenia, wieże strażnicze i inne przestrzenie"196; posłużył on do budowania dekoracji obozowej w Glienicke obok Berlina (odpowiedzialny za nie był Hermann Warm - współtwórca Gabinetu doktora Caligari!).

Akcja filmu rozpoczyna się w obozie koncentracyjnym, gdzie Leon Bronek, polski lekarz obozowy, pomaga uciec pięciu więźniom: Piotrowi (Rosjanin), Armandowi (Francuz), Royowi (Kanadyjczyk), Eddy'emu (bezpaństwowiec) i Gerhardowi (Niemiec). Bronek wraca do domu (czeka tam Maria - jego żona, Niemka), a następnie idzie do lasu, gdzie odnajduje zbiegów. Wspólnie ukrywają się w szopie (pożywienie przynosi im stary Polak, rolnik Sokół), później zaś trafiają do leśnej ziemianki, gdzie ukrywa się kilkudziesięciu uciekinierów (wśród nich: żydowski prawnik). Opiekuje się nimi Lidia, nauczycielka ze wsi - nowo przybyłym pozwala zostać kilka dni, aby nie narażali na niebezpieczeństwo pozostałych.

194 Andrzej Gwóźdź, Obok kanonu..., s. 160.

195 Ciekawostką obsadową jest udział Klausa Kinskiego w drugoplanowej roli holenderskiego więźnia.

196 Claudia Dillmann-Kühn, Artur Brauner und die CCC. Filmgeschäft, Produktionsalltag, Studiogeschichte 1946-1990, Frankfurt am Main 1990, s. 31. 
Gdy Bronek wraca do domu po Marię, z oddali obserwuje przesłuchanie żony (a może tylko: wyobraża sobie - montaż w tej sekwencji jest dość osobliwy) i poprzysięga zemstę. Wkrótce potem zdobywa informację o nadchodzącej Armii Czerwonej, próbuje więc namówić ukrywających się do akcji sabotażu (później - w pojedynkę! - rzuca granaty w pojazdy Wehrmachtu). Dochodzi do sprzeczki z Lidia, która obawia się, że wówczas Niemcy zdecydują się na przeszukanie lasu. W międzyczasie Sokół jest śledzony przez Niemca, który zostaje ujęty przez Roya. Dochodzi do procesu - jeden z ukrywających się Żydów (jego żona i dziecko zostali zamordowani przez nazistów) przyjmuje rolę obrońcy; w głosowaniu zostaje podjęta decyzja, by pozostawić Niemca przy życiu. Pilnujący jeńca Eddy wypuszcza go, gdy ten obiecuje, iż dostarczy im pożywienie. Nagle rozlegają się strzały - Niemcy przeczesują las. Lekarz zostaje zastrzelony, zaś ciężko ranny Eddy umiera w obozie, gdy grupa postanawia opróżnić zdobyczne butelki z alkoholem i ucztować (jedzenie pojawia się deus ex machina - wraz z grupą uchodźców ratujących dobytek) ${ }^{197}$. Pozostali odmawiają modlitwę i chowają rannych; w ostatniej chwili powraca żołnierz uwolniony przez Eddy'ego, wskazując drogę ucieczki.

Już z powyższego streszczenia wyłania się najbardziej charakterystyczna cecha Morituri - film koncentruje się na ofiarach i w gruncie rzeczy nie włącza $w$ ich obręb cierpień doznawanych przez Niemców. Zarazem nie wyodrębnia żadnej z prześladowanych grup jako nadrzędnej czy najważniejszej, wytwarzając swego rodzaju „uniwersalizację ofiar" 198 . Zagłada jest wprawdzie w Morituri wzmiankowana, ale los Żydów nie zostaje zaprezentowany jako zasadniczo odmienny. $\mathrm{O}$ antysemityzmie traktuje wyłącznie scena rozmowy między niemieckim pastorem a żydowskim adwokatem, w której pierwszy przyznaje: Gdy wasze świątynie płonęły, zamykałem bramy mojego kościoła od środka i czułem się narzędziem Boga. A byłem samym tylko narzędziem przemocy.

Owa „uniwersalizacja” - czy może: „internacjonalizm” - ofiar wytwarzana jest $\mathrm{w}$ wielu scenach Morituri. Pod koniec filmu ranny Eddy prosi pastora o przypomnienie łacińskiego pozdrowienia, które wypowiadali niewolnicy: Ave Caesar, morituri te salutant (Pozdrawiają cię idacy na śmierć - stąd tytuł). Scena ta tworzy klamrę z początkiem filmu - w pierwszej scenie

197 Zawarta w opracowaniu Wolfganga Beckera i Norberta Schölla opinia - iżby scena uczty była odwzorowaniem „tańca wokół złotego cielca” z Księgi Mojżeszowej - lokuje się wysoko w mym prywatnym rankingu najbardziej osobliwych nadinterpretacji (Wolfgang Becker, Norbert Schöll, In jenen Tagen... Wie der deutsche Nachkriegsfilm die Vergangenheit bewältigte, Opladen 1995, s. 60).

198 Sven Kramer, Widerkehr und Verwandlung der Vergangenheit im deutschen Film, [w:] Der Nationalsozialismus - Die zweite Geschichte. Überwindung - Deutung - Erinnerung, red. Peter Reichel, Harald Schmid, Peter Steinbach, München 2009, s. 287. 
(w obozie) Eddy zapytany o to, skąd pochodzi, mówi: Wkrótce wszyscy będziemy tej samej narodowości. Kiedy jest się martwym, można się zrozumieć bez słów. Stwierdzenie to otwiera perspektywę eschatologiczną - ale zarazem wprowadza, całkiem dosłownie, wątek komunikowania bohaterów władających różnymi językami. Dialogi kilkakrotnie podkreślają że protagoniści doskonale się rozumieja, choć mówią odmiennymi językami (na ścieżce dźwiękowej słychać, poza niemieckim, także polski, angielski, francuski i rosyjski; w ziemiance odliczają się również, poza postaciami już wzmiankowanymi, Serbowie, Duńczycy, Włoch i Holender).

Film stawia pytanie o odpowiedzialność za zbrodnie. Szczególnie charakterystyczna pod tym względem jest pierwsza sekwencja - gdy doktor Bronek prowadzi selekcję na zdolnych i niezdolnych do pracy (fot. 10). Jest ona stosunkowo długa i zbudowana z repetytywnych segmentów: gdy kolejni więźniowie wychodzą z szeregu, na zbliżeniu pojawia się twarz Bronka mówiącego „zdolny do pracy", a co pewien czas pojawiają się zbliżenia na nogi niemieckiego nadzorcy (obok wypolerowanych butów siedzi owczarek niemiecki). Monotonia sekwencji zmienia się, gdy Bronek nagle zaczyna mówić niezdolny do pracy - po każdej takiej wypowiedzi pokazane jest zbliżenie na urzędnika (widzimy tylko jego dłoń) wykreślającego nazwisko danego więźnia z książki rejestrowej. W tym momencie staje się jasne, że Bronek wydaje de facto wyroki śmierci - pokazany jest jako współsprawca. Po chwili następuje jednak wolta - gdy okazuje się, że Bronek wskazał nie tyle najsłabszych, ile zdolnych do ucieczki. Zostaje to zresztą zwerbalizowane wprost w dialogach: gdy Bronek odwiedza "wyselekcjonowanych” w baraku (Ja z Armii Ludowej - zwraca się do Rosjanina), jeden z nich mówi: może dlatego wpisat, że jesteśmy niezdolni do pracy.

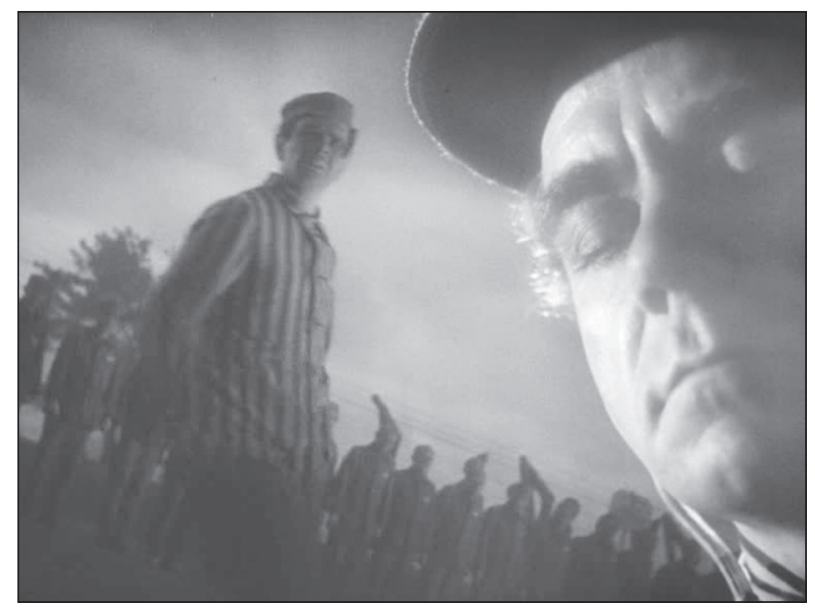

Fot. 10. Morituri (reż. Eugen York, 1948) Polski bohater - świadek czy współodpowiedzialny? 
W sekwencji przed ucieczką z obozu zwraca uwagę metonimiczne pokazanie niemieckich nadzorców (ich buty) i urzędników (dłonie). Niemcy (poza Maria, żoną Bronka i żołnierzem pochwyconym w lesie) są typowymi „postaciami bez twarzy”: jeśli słychać ich głosy - to najczęściej z offu, jeśli zaś są pokazani inaczej niż przez metonimię - to w planie dalszym (jako anonimowe sylwetki na wieżyczce strażniczej). Dyskurs filmu utrzymany jest zarazem $\mathrm{w}$ kontrze wobec tezy o winie kolektywnej, na co wskazują dwa, drugorzędne wprawdzie, wątki: Marii (podczas tortur odgraża się prześladowcom: Myślicie, że nikt nie styszy mojego krzyku, że jutro o tym zapomnicie, tak? Każdy ból, każda łza zostanie wam policzona) oraz niemieckiego żołnierza. Podczas polowego sądu jest on oskarżony przez inwalidę, któremu zamordowano żonę i dziecko, o to, iż miałby być współwinny ich śmierci (On tylko wygląda jak człowiek, śpiewa i śmieje się jak człowiek, ale ma krew na rękach). Obrońcą Niemca jest żydowski prawnik i to do jego argumentacji przychylają się pozostali uczestnicy tego zaimprowizowanego procesu (scena ta przypomina nieco sąd z $M$ Langa). W zakończeniu ów niemiecki żołnierz powraca, by pomóc zbiegom - domniemany sprawca okazuje się więc ratunkiem; został obdarzony zaufaniem, którego nie zaprzepaścił.

Spośród bohaterów najbardziej nieprzejednany wobec Niemców jest Bronek - choć postać ta pełni ważną rolę katalizatora wydarzeń, zarazem sprawia wrażenie "odklejonej” od pozostałych uciekinierów. Wprawdzie dramaturgia filmu dostarcza psychologicznego uzasadnienia działań podejmowanych przez Bronka (motywację lekarza stanowi zemsta za śmierć żony), niekiedy przecież heroicznych (w końcu to on umożliwia piątce bohaterów ucieczkę z obozu), prezentowane są one jednak jako nadmiernie brawurowe (strzelanina w lesie), nieskuteczne (zdobyczny koniak) czy wręcz szkodliwe dla grupy. Ocena taka formułowana jest w scenie kłótni z Lidia, która oponuje przeciw proponowanym przez Bronka planom sabotażu:

\footnotetext{
Lidia: Zabraniam ci!

Bronek: To nie twoja sprawa.

Lidia: Dlaczego nie moja? Przez caty rok ochraniam tych ludzi. Czy teraz znów będa musieli uciekać? Tylko dlatego, że chcesz wysadzić w powietrze kilka posterunków? A może wierzysz, że dzięki temu wojna się skończy?

Bronek: Co ty wiesz o wojnie...

Lidia: Nic, i nic nie chce wiedzieć.

Bronek: Walczę za swoja ojczyznę!

Lidia: Walcz sobie za albo przeciwko czemu tylko chcesz. Ja walcze z każdym, kto narazi tych bezbronnych ludzi na niebezpieczeństwo!
}

Prapremiera Morituri miała miejsce na festiwalu w Wenecji w sierpniu 1948 r., we wrześniu film wszedł do dystrybucji w strefach zachodnich. 
W części sowieckiej zezwolono na ledwie kilka pokazów filmu - choć powstał on przy pomocy i za zgodą władz sowieckich, na terytorium zajętym przez Sowietów. Ukazało się jednak kilka recenzji. Według autora wschodnioberlińskiej gazety "Neues Deutschland” twórcy stali się

ofiarą scenariusza, który deklaruje jedynie, iż jest dokumentem prześladowanych przez nazistowski terror. Istnieli przecież jednak nie tylko prześladowani, ale także bojownicy przeciw terrorowi, zwłaszcza $\mathrm{w}$ szeregach bohaterskiego narodu polskiego, co zostaje w filmie przemilczane. To nie przypadek, że kiedy Morituri jest w zachodniej prasie oklaskiwane, są tacy twórcy filmowi, w których umysłach krąży jeszcze marzenie o wielkoniemieckim Reichu i jego panowaniu nad rzekomo gorszymi pod względem rasowym narodami ${ }^{199}$.

W podobnym tonie wypowiadał się krytyk z komunistycznej (reaktywowanej) „Die Weltbühne":

Zamiast ukazać prawdę, która brzmi: „pozbawieni nadziei, okrążeni przez faszystowskie oddziały uciekinierzy zostali uwolnieni dzięki przemarszowi zwycięskiej Armii Czerwonej", pokazuje się jeszcze raz w pełni uzbrojonego niemieckiego żołnierza ${ }^{200}$.

W landach zachodnich przeważały pochlebne opinie krytyki; reakcje widzów były jednak złe. Przyczyn odrzucenia filmu przez publiczność trudno dociec - być może nie była ona jeszcze przygotowana na fabuły o takiej tematyce, identyfikując ją z dokumentami reedukacyjnymi. W Hanowerze odnotowano, iż widzowie opuszczali salę i domagali się zwrotu pieniędzy. Recenzentka z Hamburga pisała zaś: „Lepiej by się stało, gdyby nie pojawiały się takie głosy, jak przy wyjściu po projekcji: »Powinni to pokazywać w obozach dla nazistów «, »całkiem dobry, ale tendencyjny «" 201 . Z drugiej strony, trudno przypuszczać, by widzowie nie dostrzeli słabości warsztatowych filmu (który po dynamicznym początku, zbudowanym z krótkich, świetnie skomponowanych ujęć, z atrakcyjną ścieżką dźwiękową w drugiej części staje się bardzo teatralny) i dramaturgicznych mielizn scenariusza.

Ostatecznie dystrybutor postanowił wyświetlać film wyłącznie w dużych miastach, a później - tylko na specjalnych pokazach ${ }^{202}$. W zachodnich Niemczech Morituri zaprezentowano zaledwie w 363 kinach (spośród prawie 6 tys.), obejrzało zaś go niewiele ponad 420 tys. widzów (przy średniej

${ }^{199}$ Morituri in der Neuen Scala, "Neues Deutschland”, 21.11.1948.

${ }^{200}$ Hans Schlesinger, Morituri, „Die Weltbühne. Wochenschrift für Politik, Kunst, Wirtschaft", 30.11.1948.

${ }^{201}$ Erika Müller, Morituri Filmerstaufführung in Hamburg, „Die Zeit”, 30.09.1948.

202 Za: Claudia Dillmann-Kühn, Artur Brauner und die CCC..., s. 29-47. 
3 tys. sal i 4 mln na tytuł) ${ }^{203}$. Tę porażkę finansową Brauner komentował w swych wspomnieniach w następujący sposób: „Długi spłacałem przez pięć długich, trudnych lat. Ale nigdy nie żałowałem, że zrobiłem ten film. Nauczyłem się jednak - niestety - że kino powinno być przede wszystkim miejscem zabawy, a nie miejscem rozliczeń z przeszłością"204. W innym zaś miejscu, w nieco patetyczny sposób dopowiadał, iż intencją Morituri było „postawić pomnik uciemiężonym bez względu na narodowość, tym, którzy zawsze ponoszą wysoką cenę za działania wojenne, którzy muszą nieustannie uciekać, zawsze odczuwać strach, którym nie przysługują żadne prawa" ${ }^{205}$. Być może właśnie owa wytwarzana przez dyskurs filmu „wspólnota ofiar" była tym czynnikiem, który sprawił, że w okresie zimnej wojny i później Morituri mogło być postrzegane jako „film zrealizowany w niewłaściwym czasie" 206 .

Wątki polskie i część dialogów w języku polskim zawiera również Długa jest droga. Film - rozpoczynający się planszą Zaczęło się w Warszawie - opowiada o odysei Davida Jelina, chłopaka, którego rodzina zostaje deportowana z warszawskiego getta. Po ucieczce z transportu David dołącza do oddziału partyzantów, w którym udaje mu się doczekać końca wojny. Ojciec nastolatka ginie w Auschwitz, matka zostaje deportowana do Dachau. Po wyzwoleniu bohater poznaje w Warszawie Dorę, osieroconą Żydówkę z Niemiec, dokąd wspólnie udają się w poszukiwaniu matki chłopaka, którą odnajdują w polowym szpitalu. W amerykańskim obozie dla dipisów David i Dora biorą ślub; rodzina postanawia opuścić Europę i udać się do Izraela.

Film nakręcono latem 1947 r. w amerykańskiej strefie okupacyjnej. Na potrzeby realizacji powołano spółkę Jiddische Film Organisazie (IFO), która zebrała fundusze wśród znajdujących się w amerykańskie strefie okupacyjnej Żydów z Europy Wschodniej (był to jedyny film wyprodukowany przez IFO) ${ }^{207}$. Autorem treatmentu (a także odtwórcą głównej roli) był pochodzący z Białegostoku Israel Becker, w międzywojennej Polsce występujący w teatrach żydowskich; scenariusz napisał wraz z Georgiem Külbem, jednym z dramaturgów Ufy. Dla kinematografii III Rzeszy pracował także reżyser, Herbert Fredersdorf (współreżyserem był Marek Goldstein, o którym nie udało mi się znaleźć żadnych informacji). Pod

${ }^{203}$ Martina Thiele, Publizistische Kontroversen über den Holocaust im Film, Münster 2002, s. 152; Claudia Dillmann-Kühn, Artur Brauner und die CCC..., s. 47.

204 Atze Brauner, Mich gibt's nur einmal. Rückblende eines Lebens, München 1976, s. 76.

205 Artur Brauner, wypowiedź przytaczana w: Curt Riess, Das gab's nur einmal, t. 4: Der Deutsche Film nach 1945, Wien-München 1977, s. 199.

206 Martina Thiele, Publizistische Kontroversen..., s. 142.

207 Zob. Cilly Kugelmann, Lang ist der Weg. Eine jüdisch-deutsche Film-Kooperation, „Jahrbuch zur Geschichte und Wirkung des Holocaust” 1996. 
względem montażowym Długa jest droga łączy ujęcia inscenizowane - autorem zdjęć był Franz Koch, który wcześniej pracował jako operator przy Triumfie woli Leni Riefenstahl i SA-Mann Brand (reż. Franz Seitz, 1933) - oraz pochodzące z kronik i dokumentów filmowych będących w posiadaniu armii amerykańskiej. Wykorzystano je głównie w pierwszej części filmu, $\mathrm{w}$ scenach przedstawiających bombardowania Warszawy we wrześniu 1939 r., okupację i getto. W drugiej części pojawiają się dokumentalne zdjęcia prezentujące wojska aliantów oswobadzających więźniów obozów koncentracyjnych oraz footage z Światowego Kongresu Żydów. Do narracji włączone są też fragmenty nagrań z transmisji jego obrad: w obozie dla przesiedleńców bohaterowie przysłuchują się apelom, by żydowskim dipisom znajdującym się w tymczasowych obozach zapewnić transport do Palestyny. W ostatniej scenie filmu, gdy rodzina Jelinów oczekuje na wyjazd, Dora opowiada mężowi o swoim śnie, w którym widziała ich własny dom z ogródkiem - wówczas na ekranie pojawia się napis Ale droga jest długa.

W filmie przedstawiono panoramę różnorodnych postaw Polaków wobec Żydów. Narracja rozpoczyna się krótką sceną pokazującą „normalne życie" w przedwojennej Warszawie, zakończone bombardowaniami (co jest istotne o tyle, że wrzesień 1939 r. rzadko pokazywano w niemieckich filmach fabularnych) i okupacją. Gdy David ucieka z transportu do obozu przez leśne ostępy, umyka przed jadącym na furmance chłopem (ten bowiem kalkuluje: taki wart pare koni) i trafia do biednego gospodarstwa niejakiego Milewskiego. Ten najpierw próbuje przegonić niechcianego gościa (Żyd, z transportu? Uciekaj stąd, żebym cię tu nie widziat), ale potem przynosi jedzenie. Scena ta charakterystyczna jest również z uwagi na rekwizyt: chłop trzyma w dłoni siekierę, która wywołuje strach Davida. Wieczorem Milewski prowadzi go do lasu. W tę scenę wmontowane jest ujęcie pokazujące, jak pierwszy z chłopów, który widział Davida, wchodzi na posterunek policji. Patrol trafia na Milewskiego chwile po tym, jak nakazał on Davidowi ukryć się w lesie; gdy szmalcownik i esesman (w każdym razie: Niemiec w mundurze) odjeżdżaja, Milewski żegna się z Davidem (Ja już dalej nie mogę. Ta droga idź do lasu, tam znajdziesz dużo swoich u partyzantów. Las duży, schowa dużo takich jak ty. Masz tu jeszcze co do jedzenia. Idź z Bogiem), a następnie pada przed polnym krzyżem i modli się (Jezu Chryste, Maryjo i Józefie święci, uchron tego chłopaka od śmierci i zbaw nas od wszystkiego nieszczęścia ${ }^{208}$. Postać polskiego chłopa jest ewidentnie skojarzona z chrześcijańską ikonografią - symbolika jest tu jednak bardziej wieloznaczna: korona cier-

${ }^{208}$ Wątek polski zostaje przywołany również w dalszej części filmu, gdy - już po wojnie - bohater wraca na krótko do Warszawy, gdzie bezskutecznie próbuje odnaleźć swych bliskich. Mieszkanie Jelinów zajmuje ich dawny sąsiad - gdy otwiera Davidowi drzwi, jest kompletnie pijany: zaprasza na wódeczkę (wasi wyjeżdżaja, ale jednego może się pan z nami napić) i oferuje nocleg (ale wie pan przecież, że nam to mieszkanie przyznali). 
niowa na przenikaniu „przemienia się” bowiem w drut kolczasty, a kolejne ujęcie pokazuje selekcję więźniów w Auschwitz 209 .

Gdy chwilę później narracja powraca do głównego bohatera, partyzanci namawiają go do zabicia niemieckiego żołnierza, aby w ten sposób zdobyć karabin. W tym kontekście Ira Konigsberg zwraca uwagę, że Dtuga jest droga przedstawia dwie postawy Żydów wobec czekającej ich Zagłady ${ }^{210}$ : bierność w obawie przed zaostrzeniem represji (gdy w pociągu do Auschwitz David odrywa deski, chcąc uciec, jeden z więźniów lamentuje: Pograżysz nas wszystkich) i aktywne działanie (wśród partyzantów chłopak początkowo wyraża obawę: Nie wiem, czy umiem się bić, ale ostatecznie pozwala się przekonać i deklaruje: Tak, musimy walczyć). Natomiast w scenie rozgrywającej się w Auschwitz, Długa jest droga wykorzystuje metonimiczną metaforę śmierci w obozie zagłady za pośrednictwem obrazu dymiącego komina, który pojawia się tuż przed pokazaną na półzbliżeniu twarzą ojca Davida, stopniowo znikającą w dymie.

Zaskakujące są wypowiadane przez Davida kwestie dotyczące Niemców, zwłaszcza w tej partii filmu, której akcja rozgrywa się po zakończeniu wojny. Gdy w pociągu bohater słyszy Niemców, którzy narzekają, że muszą opuścić Polskę, reaguje komentarzem: Wszystkich nas spotyka ten sam los. Cóż, to eschatologiczny pewnik - lecz z uwagi na kontekst wydaje się, iż wypowiedź ta jest zarazem próbą wytworzenia szczególnej, niemiecko-żydowskiej wspólnoty ofiar. Z kolei gdy jeden z Żydów próbuje dociec, dlaczego David przechodzi do porządku dziennego nad odpowiedzialnością Niemców za zbrodnie wojenne, ten odpowiada: Nienawiść nie przywróci nikogo do życia. Nikomu nie życzę tego, co przeszedłem. Teraz chcę żyć w pokoju. A w jaki sposób pokój może zwyciężyć, jeśli nie przestaniemy nienawidzić? Te słowa można potraktować jako przykład rozpowszechnionego tuż po wojnie "kiczu pacyfistycznego" i przekonania o rzekomo nadchodzącej pokojowej utopii.

Długa jest droga nie trafiła do szerszej dystrybucji - po pokazach testowych Amerykanie uznali bowiem, że film nie powinien być pokazywany widzom niemieckim, lecz wyłącznie dipisom oraz publiczności międzynarodowej (,Sugerowanie, że w Europie nie ma miejsca dla Żydów,

${ }^{209}$ Gdyby połączeniu sceny w Auschwitz z wcześniejszym ujęciem pokazującym polskiego chłopa modlącego się pod krzyżem nadać znaczenia wykraczające poza proste następstwo wydarzeń, można by sformułować sądy dwojakiego rodzaju. Z jednej strony połączenie takie wytwarza korelację pomiędzy pojęciem „polskość” i „Zagłada”, z drugiej zaś - może być uznane za jej „chrystianizację”, zestawienie z męką Chrystusa. Wiele lat później tego rodzaju dyskursywizację Zagłady część krytyków zarzucała na przykład Korczakowi Wajdy.

${ }^{210}$ Ira Konigsberg, Our Children and the Limits of Cinema: Early Jewish Responses to the Holocaust, „Film Quarterly” 1998, nr 1, s. 9. 
to ostatnia rzecz na świecie, jaką należałoby sprzedać Niemcom. To jest dokładnie to, co chcieliby usłyszeć' $\left.{ }^{\prime 211}\right)$. Ostatecznie odbyło się jedynie kilka pokazów w Berlinie i Monachium. W strefach zachodnich ukazało się kilka pozytywnych recenzji ${ }^{212}$, natomiast wschodnioberlińska prasa zaatakowała "syjonistyczną" wymowę filmu ${ }^{213}$. W połowie lat 90 . został on ponownie odkryty, a odnowiona kopia spoczęła w National Center for Jewish Film w Brandeis University i posłużyła do wydania na DVD.

Thomas Brandlmeier zauważa, że już same tytuły niemieckich filmów z lat 1946-1949 (Gdzieś w Berlinie, W tamtych dniach, Film bez tytułu, Między wczoraj a dzisiaj, Zapomniana twarz, Długa jest droga) są świadectwem swoistego "zagubienia orientacji w czasie i przestrzeni" 214. Owo „zagubienie” bez trudu można odczytać również z samych filmów - zarówno gdy idzie o wykorzystane struktury dramaturgiczne (poszukiwanie domu i rodziny), jak i w szerszej perspektywie, dotyczącej postrzegania przyczyn i skutków wojny. Zdaniem Andrzeja Gwoździa

pozostaje ona wydarzeniem z daleka, stamtąd, "skąd się przychodzi”, zmarginalizowanym, nadto estetycznie wyobcowanym. I co znamienne - odpolitycznionym, pozbawionym jakichkolwiek przesłanek historyczno-społecznych; jak gdyby wojna nie wiadomo kiedy i skąd się wzięła, jakby nie miała swoich sprawców i oprawców, katów i ofiar ${ }^{215}$.

Czy można dostrzec znaczące różnice w filmach wschodniej i zachodnich stref okupacyjnych? Historycy kina odpowiadają na to pytanie w sposób ambiwalentny, skłaniając się ku odpowiedzi przeczącej, zarazem jednak sygnalizując pewne wątpliwości. Zasadniczych różnic nie widzi na przykład Kirsten Burghardt, wedle której filmy z obu stref ",tematyzują nazistowską przeszłość przede wszystkim w aspekcie oddziaływań i skutków na jednostkę", choć dosłownie w kolejnym zdaniu dodaje, iż „filmy ze strefy wschodniej silniej akcentują problemy winy i oskarżenia" ${ }^{\prime 216}$. Podobnie twierdzi Gwóźdź:

${ }^{211}$ Informacja za: Bettina Greffrath, Gesellschaftsbilder der Nachkriegszeit..., s. 81.

212 Na przykład w „Der Kurier”, 11.10.1948 oraz w „Süddeutsche Zeitung”, 16.11.1948.

${ }^{213}$ FT, Ein Film - politisch gesehen, „Berliner Zeitung”, 8.09.1948; Hugo Hermann, Ein Film klagt an, „Tägliche Rundschau”, 5.09.1958.

${ }^{214}$ Thomas Brandlmeier, Und wieder Caligari..., s. 139.

215 Andrzej Gwóźdź, Obok kanonu..., s. 164.

${ }^{216}$ Kirsten Burghardt, Moralische Wiederaufrüstung..., s. 274. 
Nawet jeśli filmy Defy wykazywały naddatek funkcji perswazyjnej w duchu ideologii komunistycznej, to zarówno pod względem tematyki, jak i środków filmowych produkcje w różnych strefach okupacyjnych niewiele od siebie różniło. A - przynajmniej w tamtym okresie - na pewno zbliżała je tematyka, którą z grubsza można określić jako antywojenna, co wcale wtedy nie musiało oznaczać: rozliczeniową ${ }^{217}$.

Przypuszczam, że te „dyskretne” różnice wynikają w pewnej mierze z odmienności polityki filmowej aliantów w części wschodniej i zachodniej. O ile bowiem w strefie sowieckiej była ona początkowo dość liberalna, o tyle w strefach zachodnich przybrała zrazu dość restrykcyjny charakter (zmiana nastąpiła około 1947 r., gdy "czynnik ideologiczny" zaczął odgrywać w Defie większą rolę, a zarazem alianci zachodni zaczęli bardziej ochoczo przyznawać licencje). W konsekwencji problem nazizmu został podjęty najpierw w filmach w strefie sowieckiej; są to także dzieła bardziej różnorodne pod względem sposobu opowiadania o rozmaitych aspektach dyktatury NSDAP (choć zarazem $\mathrm{w}$ większości z nich podkreślana jest rola komunistycznego ruchu oporu). $Z$ kolei realizacje ze stref zachodnich w większym stopniu eksponują domniemaną niewinność Niemców - Mitläuferów i Heimkehrerów. Wśród omówionych w niniejszym rozdziale filmów z pewnością można wskazać takie, które inicjują wątki dominujące w późniejszych produkcjach NRD (Rotacja/Brunatna pajęczyna, Nasz chleb powszedni) i RFN (W tamtych dniach, Miłość 47).

Wiele z tematów, które w filmach z lat 1946-1949 są jeszcze obecne, szybko zniknie z niemieckiego dyskursu publicznego. Uwaga ta dotyczy głównie fabuł traktujących o antysemityzmie i/lub Zagładzie ${ }^{218}$. Nawet $\mathrm{w}$ nich nie akcentowano jednak w żaden sposób Holocaustu (słowo to nie było zresztą wówczas używane). Ów brak można uznać za skutek globalnych polityk pamięci, które kształtowały się pod wpływem decyzji podejmowanych podczas wojny: zarówno przez Stalina, wykorzystującego efekt strat poniesionych przez ludność ZSRR i Armię Czerwona, jak i aliantów zachodnich, którzy „konsekwentnie bagatelizowali »sprawę żydowską", obawiając się, że wpadną w pułapkę propagandy nazistowskiej głoszącej, iż wojna toczy się »w obronie Żydów«"219.

Trudno mówić o istotnym wpływie kina lat 1946-1949 na niemiecki dyskurs pamięci; w okresie tuż po wojnie na jego kształtowanie silniej

217 Andrzej Gwóźdź, Obok kanonu..., s. 153.

218 Tim Gallwitz, monografista tego tematu, dzieli je na Anklagefilme (filmy oskarżycielskie) i Justizfilme (filmy o wymiarze sprawiedliwości). Do pierwszej grupy zalicza filmy: Długa jest droga, Morituri i Powołanie (uzupełniłbym tę listę o Małżeństwo w mroku), do drugiej zaś - Między dniem wczorajszym a jutrzejszym, austriacki Proces (Der Prozess, reż. Georg Wilhelm Pabst) oraz Sprawe Bluma. Zob. Tim Gallwitz, "Wir konnten nach all den Jahren nicht darauf losfilmen, als sei nichts geschehen"...; idem, "Was vergangen ist, muss vorbei sein!"...

${ }_{219}$ Stewart Liebmann, Obraz obozu w pierwszych filmach..., s. 258. 
oddziaływało ustawodawstwo denazyfikacyjne i procesy norymberskie. Jeśli jednak mielibyśmy potraktować niemieckie fabuły tamtych lat jako wyraz świadomości społecznej, wówczas powiedzieć by trzeba, że $\mathrm{w}$ wielu $\mathrm{z}$ nich eksponowana jest wspólnota ofiar wojny - przy czym do wspólnoty tej włączani są sami Niemcy. Robert Shandley formułuje tę myśl w sposób dosadny: „Niemieckim uciekinierom ze Śląska i byłym niemieckim żołnierzom powracającym z wojny przypisywane jest często takie samo znaczenie symboliczne, co ocalałym z obozów Zagłady"220. O tym, że jego opinia nie jest bynajmniej ahistoryczna, lecz dobrze osadzona $\mathrm{w}$ realiach pierwszych lat powojennych Niemiec, zaświadcza następująca obserwacja poczyniona przez Hannah Arendt jeszcze w 1946 r.:

[...] zalewa nas potok opowieści, mających zobrazować cierpienia Niemców [...]; a jeśli osoba poddawana temu małemu eksperymentowi jest przypadkiem człowiekiem wykształconym i inteligentnym, można być niemal pewnym, że po chwili przystąpi do zestawienia cierpień Niemców z cierpieniami innych, dając w ten sposób do zrozumienia, że bilans po obu stronach wypada tak samo i że wobec tego można zmienić temat rozmowy na ciekawszy ${ }^{221}$.

${ }^{220}$ Robert R. Shandley, Trümmerfilme..., s. 12-13.

${ }^{221}$ Hannah Arendt, Wizyta w Niemczech..., s. 112. 


\section{Rozdział II}

\section{Kino Niemieckiej Republiki Demokratycznej do 1965 roku: antyfaszyzm jako doktryna}

Przywódcy i ideolodzy Niemieckiej Republiki Demokratycznej, powołanej do życia w 1949 r., jej byt instytucjonalny uzasadniali kilkoma wzajemnie powiązanymi "mitami założycielskimi”, odnoszącymi się $\mathrm{w}$ większym lub mniejszym stopniu do okresu nazistowskiego. $\mathrm{O}$ ile RFN uznawała się - zgodnie z zapisami swej konstytucji - za kontynuację państwa niemieckiego, a co za tym idzie akceptowała prawną odpowiedzialność za zbrodnie III Rzeszy, o tyle NRD budowana była na koncepcji zerwania z ciągłością instytucjonalną wcześniej istniejących organizacji państwowych ${ }^{1}$. Jeśli zaś w oficjalnych dokumentach lub historiografii NRD doszukiwano się jej związków z historycznymi wydarzeniami lub instytucjami działającymi na obszarze niemieckiego kręgu kulturowego w XX w., wskazywano na przykład na tradycję Wiosny Ludów z 1848 r. ${ }^{2}$ czy Bawarską Republikę Rad (powołaną przez działaczy komunistycznych w kwietniu 1919 r. i istniejącą ledwie kilkanaście dni). Wydarzeniem mitologizowanym w enerdowskiej historii było także Powstanie Spartakusa

${ }^{1}$ Zob. studia porównawcze: Moshe Zimmermann, Die Erinnerung an Nationalsozialismus und Widerstand im Spannungsfeld deutscher Zweitstaatlichkeit, [w:] Die geteilte Vergangenheit: Zum Umgang mit Nationalsozialismus und Widerstand in beiden deutschen Staaten, red. Jürgen Danyel, Berlin 1995; Sigrid Meuschel, Legitimationsstrategien in der DDR und in der Bundesrepublik, [w:] Deutsche Vergangenheiten - eine gemeinsame Herausforderung: Der schwierige Umgang mit der doppelten Nachkriegsgeschichte, red. Christoph Kleßmann, Hans Misselwitz, Günther Wichert, Berlin 1999; Edgar Wolfrum, Die beiden Deutschland, [w:] Verbrecher erinnern: Die Auseinandersetzung mit Holocaust und Völkermord, red. Volkhard Knigge, Norbert Frei, München 2002; Antonia Grunenberg, Antitotalitarianism versus Antifascism - Two Legacies of the Past in Germany, "German Politics and Society” 1997, nr 20, s. 77.

${ }^{2}$ Jeszcze przed proklamacją NRD, w 1948 r., Defa wyprodukowała film ... i znowu 48 (...und wieder 48, reż. Gustav von Wangenheim) - z wątkiem autotematycznym (bohaterowie biorą udział w zdjęciach do rocznicowego filmu, kręconego po II wojnie światowej). 
(styczeń 1919 r.), podkreślano też rolę Komunistycznej Partii Niemiec (KPD). Jej kontynuatorką obwołała się - sprawująca w NRD partyjny monopol - Niemiecka Socjalistyczna Partia Jedności (SED - Sozialistische Einheitspartei Deutschlands), powstała w 1946 r. z przymusowego, dokonanego zgodnie z wytycznymi z Moskwy, połączenia KPD i działającej w sowieckiej strefie okupacyjnej SPD (de facto wchłoniętej przez KPD). Sekretarzem generalnym Komitetu Centralnego SED - później stanowisko to przybrało nazwę „I sekretarz” - został Walter Ulbricht (jeden z założycieli KPD, w Republice Weimarskiej - deputowany do Reichstagu z ramienia komunistów, później emigracyjny działacz Kominternu, w czasie II wojny światowej - pułkownik Armii Czerwonej), który sprawował tę funkcję aż do $1971 \mathrm{r}$.

W NRD polityka pamięci, mająca za zadanie legitymizację własnej wspólnoty, ma znamiona typowej "tradycji wynalezionej”3, szukającej w (niedawnej) przeszłości uzasadnień odrębnego państwa. Drugorzędne były dla niej specyficzne uwarunkowania niemieckiego życia społecznego (wychowania, ekonomii, sztuki itd.) w okresie Republiki Weimarskiej i wcześniej, które przyczyniły się do powstania narodowego socjalizmu właśnie na tym terytorium. W oficjalnej polityce NRD był on mianowicie traktowany nie tyle jako „,wyrwa” w dziejach Niemiec (jak czytano go w RFN), lecz - w duchu marksistowskiej historiozofii - jako logiczna konsekwencja działalności sił imperializmu i kapitalizmu, których wypadkową miał być faszyzm ${ }^{4}$. Postrzegano go zatem jako zjawisko uniwersalne, wykraczające poza chronotop Niemiec lat 1933-19455, lecz oczywiście skutecznie przezwyciężone w NRD poprzez zmianę stosunków własnościowych (a zatem usunięcie domniemanego „praźródła” faszyzmu) oraz współpracę z ZSRR. Jak pisze Anna Wolff-Powęska, „obowiązywała argumentacja, w myśl której socjalistyczny porządek społeczny sam w sobie stanowił przesłankę dla uwolnienia się od nazizmu i jego konsekwencji" ${ }^{\prime 6}$.

${ }^{3}$ Eric Hobsbawm, Terence Ranger, Tradycja wynaleziona, tłum. M. Godyń, F. Godyń, Kraków 2008.

${ }^{4}$ Wedle słynnej definicji autorstwa Georgija Dimitrowa, sformułowanej na VII Kongresie Kominternu w 1935 r., faszyzm był „terrorystyczną dyktaturą najbardziej reakcyjnych, najbardziej szowinistycznych i najbardziej imperialistycznych elementów kapitału".

${ }^{5}$ Zob. świetną monografię: Joachim Käppner, Erstarrte Geschichte. Faschismus und Holocaust im Spiegel der Geschichtswissenschaft und Geschichtspropaganda der DDR, Hamburg 1999, a także: Wolfgang Bialas, Antifaschismus als Sinnstiftung. Konturen eines ostdeutsches Konzepts, [w:] Die NS-Diktatur im deutschen Erinnerungsdiskurs, red. Wolfgang Bergem, Opladen 2003; Vielstimmiges Schweigen. Neue Studien zum DDR-Antifaschismus, red. Annette Leo, Peter Reif-Spirek, Berlin 2001.

${ }^{6}$ Anna Wolff-Powęska, Pamięć - brzemię i uwolnienie. Niemcy wobec nazistowskiej przeszłości (1945-2010), Poznań 2011, s. 231. 
Podstawą tego porządku ideologicznego był więc następujący sylogizm: skoro faszyzm był wytworem kapitalizmu, a w NRD kapitalizm został zastąpiony przez socjalizm, to NRD nie może mieć nic wspólnego z faszyzmem (i analogicznie: wróg klasowy w RFN był żywym dowodem na to, że faszyzm się nie skończył).

W enerdowskiej propagandzie nowym wcieleniem faszyzmu miała być nie tylko Republika Federalna Niemiec, lecz także USA i Izrael. Syjonizm utożsamiany był z faszyzmem przez enerdowską propagandę aż do lat 80., najsilniej jednak na początku lat $50 .{ }^{8}$ Wtedy ukształtowała się też oficjalna enerdowska pamięć o Zagładzie - żydowskie ofiary traktowane były jako jedna z grup prześladowanych przez faszyzm, w hierarchii tych ostatnich niekoniecznie najistotniejsza'; tę pozycję zajmowali bowiem ci, którzy stawiali aktywny opór, wśród nich zaś - członkowie komunistycznego ruchu oporu. Przejawem tej polityki było rozwiązanie w 1953 r. Stowarzyszenia Prześladowanych przez Reżim Nazistowski (Vereinigung der Verfolgten des Naziregimes), w którym ważną rolę odgrywały osoby żydowskiego pochodzenia, i zastąpienie go przez Komitet Antyfaszystowskiego Ruchu Oporu (Komitee der Antifaschistischen Widerstandkämpfer). Ta „hierarchia ofiar” była podtrzymywana niemal do samego końca enerdowskiego państwa - i znalazła swój wyraz również w decyzjach ekonomicznych: wysokich dodatkach do emerytur i rent dla „weteranów sprawy” oraz odmowie wypłacania odszkodowań przez NRD obywatelom innych państw ${ }^{10}$.

7 Konrad Jarausch, The failure of East German antifascism: some ironies of history as politics, „German Studies Review” 1991, nr 1, s. 87-91.

${ }^{8}$ W 1952 r. znany wschodnioniemiecki działacz komunistyczny, Paul Merker, został oskarżony jako agent obcego wywiadu. Wydarzenie to czytane jest przez pryzmat analogicznych wydarzeń w ZSRR (tzw. „spisek lekarzy”) i Czechosłowacji („proces Slansky'ego"). Merker w czasie swej emigracji w Meksyku na początku lat 40. współpracował z komunistami pochodzenia żydowskiego, wespół z którymi po powrocie do Niemiec domagał się nawiązania stosunków z Izraelem i uwzględnienia ofiar żydowskich w dyskursie antyfaszystowskim. W 1950 r. Merker został wykluczony z SED, w 1952 r. aresztowany, w 1955 r. skazany na osiem lat więzienia, zaś po słynnym referacie Chruszczowa w $1956 \mathrm{r}$. - oczyszczony z zarzutów (zob. Jeffrey Herf, Germany and the Holocaust since 1945, [w:] Memory and Power in Post-war Europe, red. Jan-Werner Müller, Cambridge 2002, s. 195-201; Mario Kessler, Zwischen Repression und Toleranz: Die SED Politik und die Juden, [w:] Historische DDR-Forschung, red. Jürgen Kocka, Berlin 1993).

9 Thomas Jung, Jenseits der Erinnerungspolitik: Oder der schwierige Umgang mit dem Holocaust in der DDR, [w:] Kulturelle Repräsentationen des Holocaust in Deutschland und den Vereinigten Staaten, red. Klaus Berghahn, Jürgen Fohrmann, Helmut Schneider, New York 2002. Zob. także: Angelika Timm, Hammer, Zirkel, Davidstern. Das gestörte Verhältnis der DDR zu Zionismus und Staat Israel, Bonn 1997.

${ }^{10} \mathrm{O}$ ile RFN ostatecznie przystało na wypłacenie odszkodowań także obywatelom innych państw (w 1965 r. - w odniesieniu do granic Rzeszy z 1937 r.), o tyle NRD 
W odróżnieniu od erefenowskiej kultury pamięci, jej enerdowski wariant słabiej akcentował zagadnienia związane $\mathrm{z}$ niemieckimi ofiarami wojny. W NRD nie działały organizacje tzw. wypędzonych (w języku urzędowym nie używano zresztą słowa Vertriebene, zadowalając się bardziej neutralnym, choć zarazem wykorzystywanym w administracyjnej procedurze kontrowersyjnej reformy rolnej, terminem Umsiedlern - „przesiedleńcy"11). W dyskursie publicznym nie było też miejsca dla bolesnego miejsca pamięci, który dotyczył przestępstw popełnianych przez żołnierzy Armii Czerwonej (przede wszystkim gwałtów na Niemkach ${ }^{12}$ ).

Ważną rolę w kształtowaniu polityki historycznej NRD miały natomiast upamiętnienia bombardowań Drezna. Wydarzenia z lutego $1945 \mathrm{r}$. przywoływane były dla doraźnych celów politycznych i przemieniały się w kampanie przeciw "faszystowskim podżegaczom wojennym" - w czasie obchodów piątej rocznicy tragedię Drezna przyrównywano do Hiroszimy, a kilka lat później do filmu oświatowego Drezno upomina Niemcy (Dresden mahnt Deutschland, NRD 1954) wprowadzono komentarz: Tak było w Dreźnie w lutym 1945 roku, tak jest dziś w Korei13. Podkreślano barbarzyństwo nalotów (wykazując, że miasto nie mogło być celem militarnym) oraz zniszczenie zabytków architektury (Zwinger i Frauenkirche). W tej wizji ludność Drezna była przedstawiana jako ofiary alianckiej agresji, wojska sowieckie zaś - jako wyzwoliciele. Bombardowanie miasta było przedmiotem olbrzymiej liczby prac naukowych, albumów i wspomnień, wydawanych w NRD w dużych nakładach ${ }^{14}$; pomimo to, nie doczekało się upamiętnienia $\mathrm{w}$ formie filmu fabularnego. Wyjątkiem był zrealizowany

dopiero kilka tygodni przed swym zniknięciem z mapy Europy zdecydowała się na deklarację otwierającą drogę do odszkodowań (były one wypłacane już w zjednoczonych Niemczech). Zob. Hans Günter Hockerts, Wiedergutmachung in Deutschland 1945-1990. Ein Überblick, „Aus Politik und Zeitgeschichte” 2013, nr 25-26.

11 Zob. Elke Mehnert, Vertriebene versus Umsiedler - der ostdeutsche Blick auf ein Kapitel Nachkriegsgeschichte, [w:] Landschaften der Erinnerung: Flucht und Vertreibung aus deutscher, polnischer und tschechischer Sicht, red. Elke Mehnert, Frankfurt 2001.

12 Birgit Dahlke, „Frau komm!" Vergewaltigungen 1945: Zur Geschichte eines Diskurses, [w:] LiteraturGesellschaft DDR, red. Birgit Dahlke, Martina Langermann, Thomas Taterka, Stuttgart 2000.

${ }^{13}$ Gilad Margalit, Der Luftangriff auf Dresden, Seine Bedeutung für die Erinnerungspolitik der DDR und für die Herausklistallisierung einer historischen Kriegserinnerung im Westen, [w:] Narrative der Shoah. Repräsentationen der Vergangenheit in Historiographie, Kunst und Politik, red. Susanne Düwell, Matthias Schmidt, Padeborn 2002.

${ }^{14} \mathrm{O}$ bombardowaniach miasta pisali m.in. dyrektor drezdeńskiej kolekcji sztuki (Max Saydewitz, Zerstörung und Wideraufbau von Dresden, Berlin [Ost] 1955) oraz burmistrz Drezna w latach 1945-1958 (Walter Weidauer, Inferno Dresden: über Lügen und Legenden um die Aktion "Donnerschlag", Berlin [Ost] 1965). Zob. też: Paul Cooke, The GDR and the Memory of the Bombing of Dresden, [w:] Germans as Victims. Remembering the Past in Contemporary Germany, red. Bill Niven, New York 2006. 
przy udziale Defy film Jana Rybkowskiego Dziś w nocy umrze miasto (1961) - o romansie Polaka, uciekiniera z transportu więźniów, oraz infantylnej i aroganckiej Niemki, rozgrywającym się podczas nocnego bombardowania Drezna przez alianckie bombowce. Co ciekawe, realizacja ta znalazła dystrybutora w Niemczech Zachodnich, ale nie była pokazywana w NRD (choć o pracach produkcyjnych pisano w dwutygodniku „Filmspiegel”, prognozując nawet zainteresowanie tytułem "po jednej i drugiej stronie Odry") ${ }^{15}$.

Kinematografia NRD funkcjonowała w zupełnie odmiennych ramach ekonomicznych i politycznych niż kinematografia Republiki Federalnej Niemiec - przede wszystkim z uwagi na państwowy mecenat (w $1953 \mathrm{r}$. Defa, wcześniej będąca sowiecko-niemiecką spółką stała się „własnością narodu"16), monopolistyczny charakter w zakresie wytwarzania komunikatów audiowizualnych (przynajmniej do powołania wschodnioniemieckiej telewizji w 1960 r., blisko zresztą współpracującej z Defą) oraz partyjny nadzór nad produkcją filmową na wszystkich jej etapach (od kontroli scenariusza po dopuszczenie do dystrybucji). W okresie 1950-1952 w strukturze SED działała Komisja ds. Defy (DEFA-Komission), w kolejnych dwóch latach Państwowa Komisja do spraw Filmu (Staatskomission für Filmfragen), po 1954 r. nadzór nad wytwórnią objął Centralny Zarząd Filmu (Hauptverwaltungfilm) w Ministerstwie Kultury ${ }^{17}$.

O znaczeniu kina dla budowy nowego państwa - „dla walki o pokój, jedność, demokrację i socjalizm" - mówiono w czasie I Konwencji Partyjnej SED na początku 1949 r., a zatem jeszcze przed powołaniem NRD. Socrealistyczna poetyka - wdrażana już wcześniej w sowieckiej strefie okupacyjnej - została oficjalnie zadekretowana w odniesieniu do literatury, muzyki i sztuk plastycznych w marcu 1951 r. (na V Zjeździe Komitetu Centralnego SED). Rezolucję $\mathrm{w}$ sprawie filmu przyjęto w lipcu 1952 r., na II Konwencji Partyjnej SED ${ }^{18}$, a dwa miesiące później podczas zjazdu twórców filmowych reprezentant komitetu centralnego domagał się od nich "dzieł sztuki postępowej”19. Zapowiedzi obrania „nowego

15 Zbigniew Pitera, Heute Nacht stirbt eine Stadt, „Filmspiegel” 1961, nr 8, s. 14-15.

${ }^{16}$ Wyodrębniono wówczas osobne przedsiębiorstwa, działające pod wspólnym szyldem Defy: w Poczdamie-Babelsbergu wytwórnię filmów fabularnych i studio filmów popularnonaukowych, w Berlinie wytwórnię filmów dokumentalnych i jednostki pomocnicze (zajmujące się udźwiękowianiem czy wytwarzaniem kopii) - zob. Ralf Schenk, Eine kleine Geschichte der DEFA, Berlin 2006, s. 74.

17 Politykę SED wobec Defy szczegółowo omawia Dagmar Schittly, Zwischen Regie und Regime. Die Filmpolitik der SED im Spiegel der DEFA-Produktionen, Berlin 2002.

${ }^{18}$ Für den Aufschwung der fortschrittlichen deutschen Filmkunst. Resolution des Politbüros des ZK der SED, Juli 1952, [w:] Dokumente zur Kunst-, Literatur-, und Kulturpolitik der SED, red. Elimar Schubbe, Stuttgart 1972.

${ }^{19}$ Hermann Axen, Über die Fragen der fortschrittlichen deutschen Filmkunst, "Neues Deutschland", 18.09.1952. 
kursu", które pojawiły się po krwawym stłumieniu robotniczych demonstracji z 17 czerwca 1953 r. przez wojska sowieckie oraz po fali represji politycznych wywołanych przez te wydarzenia (wedle oficjalnej wykładni, czerwcowy bunt był „próbą faszystowskiego puczu” i „imperialistyczną prowokacją"), stanowiły li tylko retoryczny wybieg, uzasadniający przekształcenia biurokratycznej machiny: wcielenie w życie sloganów o „walce z dogmatyzmem" było niemożliwe, gdyż on właśnie stanowił rację bytu samej doktryny.

„Intronizując" socrealizm, władza wywierała presję zarówno na twórców (środki finansowe na realizację postulatów doktryny uruchamiały mechanizmy autocenzury i samokontroli), jak i na odbiorców (ideologiczny „intertekst" regulował style odbioru) ${ }^{20}$ - tak, aby obie strony procesu komunikacyjnego zaakceptowały repertuar preferowanych, dozwolonych lub niewłaściwych zabiegów twórczych oraz sposobów odczytań. Tworzyły one konstrukcję wewnętrznie sprzeczna, zawierającą wykluczające się - a przynajmniej z trudem łączone - postulaty: teleologiczne spekulacje o procesach dziejowych (prowadzone zgodnie z marksistowską wykładnią) oraz wymóg analizy psychologicznej w ukazywaniu bohaterów "tu i teraz" (powiązany z jednoznacznością moralnych ocen).

Wedle socrealistycznej wizji procesu historycznokulturowego, rozpadał się on - najogólniej mówiąc - na dwie tendencje: realistyczna, kontynuującą doświadczenia powieści XIX-wiecznej, poszukującej wyrazu dla zjawisk typowych dla danego momentu historycznego, z drugiej zaś: awangardowa, burzącą zastane wzorce przedstawiania. Nic więc dziwnego, że negatywnym bohaterem socrealistycznego dyskursu stał się „formalizm”, profilowany jako świadectwo „mieszczańskiego dekadentyzmu” czy ",antyhumanistycznych tendencji" ${ }^{21}$. Zarzuty te ustanawiały bezpośredni związek między estetyka, ekonomią i moralnością (retoryka ta przypominała oczywiście nazistowskie ataki na sztukę zdegradowaną - także w tym wymiarze, że sztuka „zdrowa” miała być instrumentem pedagogiki społecznej, dążącej do wychowania „nowego człowieka”, budowniczego nowego społeczeństwa) ${ }^{22}$.

${ }^{20}$ Ponieważ realizm socjalistyczny należy do zjawisk dobrze rozpoznanych i wnikliwie omówionych w licznych polskich opracowaniach, a ponadto nie jest głównym tematem niniejszej książki, ograniczam się w tym miejscu do uwag natury ogólnej.

${ }^{21}$ Sformułowania te pojawiły się m.in. w programowych wystąpieniach sowieckiego komisarza ds. kultury w sowieckiej strefie okupacyjnej, Aleksandra Dymszyca (Warum wir gegen Dekadenz sind, „Tägliche Rundschau”, 21.03.1948; również: idem, Über die formalistische Richtung in die Malerei, „Tägliche Rundschau”, 19 i 24.11.1948).

22 "Antyformalistyczny" charakter socrealizmu w wydaniu enerdowskim początkowo wydawał się odwoływać do teorii „,wielkiego realizmu” György Lukácsa, który odrzucał nie tylko tradycję awangardy (zob. Stefan Morawski, Lukácsa krucjata przeciw awangar- 
Batalia przeciw "formalizmowi" miała w NRD nieco inny charakter niż $\mathrm{w}$ Polsce - o ile w przypadku polskim socrealizm miał znikome oparcie $\mathrm{w}$ rodzimej tradycji, o tyle we wschodnich Niemczech konstruktorzy „robotniczych" czy "socjalistycznych" poetyk normatywnych mogli odwoływać się nie tylko do programów ideowych z komunistycznych pism publikowanych w Republice Weimarskiej, lecz także do powstających wówczas dzieł ${ }^{23}$. Zarazem jednak owe „próby nawiązania do koncepcji i instytucji literatury proletariackiej [a także "kina proletariackiego" - przyp. K. K.] lat 20. i 30., które przywoływano czasem jako własna, odrębną tradycję realizmu socjalistycznego, skazane były na niepowodzenie $^{\prime 24}$ - gdyż w sowieckiej strefie okupacyjnej oraz we wczesnym okresie istnienia NRD sowieccy „patroni” nalegali na stosunkowo prosty transfer modelu skodyfikowanego w ZSRR.

Różnic pomiędzy polskim i enerdowskim wariantem socrealizmu było zresztą więcej. Najważniejsza z nich dotyczy okresu oddziaływania doktryny; przyjęło się bowiem sądzić, że w Polsce był on stosunkowo krótki, zamknięty umownymi datami 1949-1956 ${ }^{25}$. Odwilż, która w Polsce doprowadziła do zmian personalnych $\mathrm{w}$ aparacie partyjnym oraz do (chwilowej wprawdzie) liberalizacji i złagodzenia cenzury, w NRD ograniczyła się do wyeliminowania nielicznych, najbardziej ekstremalnych elementów stalinizmu, lecz nie pociągnęła za sobą ani istotnych zmian $\mathrm{w}$ partyjnym kierownictwie ${ }^{26}$, ani faktycznej zmiany $\mathrm{w}$ polityce kulturalnej.

dzie, „Pamiętnik Literacki” 1979, nr 3), w tym epicki teatr Brechta, lecz także romantyzm (z największymi dziełami niemieckiej literatury) - z uwagi na jego irracjonalne podglebie. Ostatecznie Lukács stał się jednak negatywnym bohaterem kampanii „,antyrewizjonistycznej”, ze względu na swój udział w „kontrrewolucyjnym” rządzie Imre Nágya (objął funkcję ministra kultury; po interwencji sowieckiej deportowano go do Rumunii). O początkowym przyjęciu, późniejszej modyfikacji, a wreszcie zakwestionowaniu Lukácsa w NRD zob. Katarzyna Śliwińska, Socrealizm w PRL i NRD, Poznań 2006, s. 62-68 i 114-117, 180-183.

${ }^{23}$ Nie bez znaczenia był fakt, iż w Republice Weimarskiej KPD cieszyła się sporym poparciem społecznym (w 1932 r. głosowało na nią ok. 6 mln wyborców), o wiele większym niż KPP w II Rzeczpospolitej. To oczywiście tylko jeden z powodów, dla których uruchomienie w PRL podobnego mitu genealogicznego było o wiele trudniejsze.

${ }^{24}$ Katarzyna Śliwińska, Socrealizm..., s. 118.

25 Znaczenie tej ostatniej cezury często podważa się w rodzimych badaniach historycznoliterackich, wskazujących na późniejsze kontynuacje socrealistycznej poetyki (Michał Głowiński, Rytuat i demagogia. Trzynaście szkiców o sztuce zdegradowanej, Warszawa 1992 - zob. zwłaszcza rozdział: Kierunek: wielka nomenklaturowa chała; Krzysztof Krasuski, Realizmu socjalistycznego śmierć i życie pośmiertne, [w:] Słownik realizmu socjalistycznego, red. Zdzisław Łapiński, Wojciech Tomasik, Kraków 2002). Podobna teza w odniesieniu do polskiego kina byłaby pewnie trudniejsza do udowodnienia, choć może nie bezzasadna (także z uwagi na złożony charakter polskiego socrealizmu - w odniesieniu do kina zob.: Piotr Zwierzchowski, Pęknięty monolit. Konteksty polskiego kina socrealistycznego, Bydgoszcz 2005).

${ }^{26}$ Walter Ulbricht nie tylko zachował stanowisko I sekretarza, które piastował od 1950 r. (przez kolejne dwie dekady), ale wkrótce nawet wzmocnił swą pozycję, znosząc 
W konsekwencji, realizm socjalistyczny - mimo pewnych symptomów erozji - zachował swą dominującą pozycję znacznie dłużej niż w Polsce i jeszcze co najmniej przez kolejną dekadę nie przestawał być sprawnie działającym mechanizmem dyscyplinującym ${ }^{27}$ (a i później pozostał istotnym współczynnikiem życia kulturalnego ${ }^{28}$ ). Niezależnie więc od tego, jakie ramy czasowe przypisalibyśmy polskiej wersji socrealizmu, z pewnością można powiedzieć, że po 1956 r. ideologizacja polityki kulturalnej była w NRD silniejsza niż w PRL, gdzie w janusowym obliczu partii spotykała się, z jednej strony, doktrynalna retoryka ${ }^{29}$, z drugiej zaś - swoisty liberalizm w kulturze, widoczny na tle innych państw bloku i będący zarazem jedną z formuł legitymizacyjnych „poodwilżowej” władzy (a może nawet - narzędziem jej sprawowania).

Z większą niż w PRL dynamiką przebiegała natomiast w NRD walka z poodwilżowym rewizjonizmem - który przecież nie odgrywał tak istotnej roli, jak w Polsce. Uruchomiona przez ekipę Ulbrichta fala represji i politycznych procesów przeciw reprezentantom środowiska akademickiego (takim jak Ernst Bloch, Wolfgang Harich czy Walter Janka) pomyślana była jako przestroga wobec tych, którzy byliby skorzy wyrazić sympatię wobec przemian, jakich domagano się w Polsce czy na Węgrzech ${ }^{30}$. Zmiana klimatu politycznego wpłynęła oczywiście także na politykę względem kinematografii - w 1958 r. w referacie wpływowego organizatora życia kulturalnego NRD sformułowana została opinia, iż „niektórzy twórcy filmowi opacznie zrozumieli i zwulgaryzowali krytykę przedsięwziętą podczas XX Zjazdu KPZR"31.

(w 1960 r., po śmierci Wilhelma Piecka) urząd prezydenta i wprowadzając na jego miejsce Radę Państwa (na czele której sam stał).

27 Zob. przemówienie Waltera Ulbrichta z 1964 r.: „Metodą naszej sztuki może być tylko realizm socjalistyczny" jako sztuka "wierna prawdzie życia, partyjna i bliska narodowi”. Tym, co miało odróżniać realizm socjalistyczny od innych („,burżuazyjnych”) formuł realizmu, miało być „,żarliwe partyjne zaangażowanie w sprawę udoskonalenia naszej socjalistycznej wspólnoty" (Walter Ulbricht, O rozwoju socjalistycznej kultury narodowej, [w:] Polityka kulturalna Niemieckiej Republiki Demokratycznej. Wybór dokumentów, red. Teresa Krzemień, Warszawa 1971, s. 95-102).

${ }^{28}$ Przykładowo, w statucie Związku Pisarzy Niemieckich (DSV) aż do rozwiązania NRD (a tym samym - związku) istniał zapis głoszący, iż metodą pisarzy NRD jest realizm socjalistyczny, zaś członkowie organizacji są zobowiązani do walki z rewizjonizmem (w statucie Związku Literatów Polskich podobne passusy usunięto w 1956 r.) - Katarzyna Śliwińska, Socrealizm..., s. 212.

${ }^{29}$ Licznych przykładów dostarczają już choćby przemówienia towarzysza Gomułki, zawierające stwierdzenia bliźniaczo podobne do przywołanych tez Ulbrichta (por. Walter Ulbricht, O rozwoju socjalistycznej kultury... i Władysław Gomułka, O aktualnych problemach ideologicznej pracy partii, „Trybuna Ludu”, 6.07.1963).

${ }^{30} \mathrm{Na}$ temat roku 1956 w NRD zob. Katarzyna Śliwińska, Socrealizm..., s. 162-171.

31 Alexander Abusch, Aktuelle Probleme und Aufgaben unserer sozialistischen Filmkunst, cyt. za: Ralf Schenk, Eine kleine Geschichte..., s. 120. 
„Polowanie na rewizjonistów” w pierwszych latach po odwilży zakończyło się w NRD kolejną (i paradoksalną gdyż pomyślaną jako propagandowe łagodzenie efektów budowy muru berlińskiego w 1961 r.) zapowiedzią liberalizacji, oficjalnie ogłoszoną na VI Zjeździe SED w 1963 r., ale faktycznie realizowaną już nieco wcześniej. W przypadku Defy zaowocowała ona m.in. powstaniem pierwszych ",artystycznych grup roboczych" (KAG - Künstlerische Arbeitsgruppen), kształtowanych na wzór zespołów filmowych funkcjonujących w Polsce i na Węgrzech ${ }^{32}$. Także za sprawą tych zmian I połowa lat 60 . uznawana bywa za jeden z najciekawszych okresów w historii kina NRD (w tym kontekście wymienia się m.in. realizacje Franka Beyera, Jürgena Böttchera, Egona Günthera, Ralfa Kirstena i Joachima Kunerta, którzy i później będą kręcić filmy wyróżniające się na tle pozostałej produkcji Defy ${ }^{33}$. W 1965 r. ponownie „przykręcono śrubę" - na XI Plenum Komitetu Centralnego SED postanowiono wstrzymać dystrybucję (lub produkcję) niemal wszystkich filmów Defy z tego roku (o czym będzie jeszcze mowa).

Oczywiście, podobne decyzje podejmowane były (choć, by tak rzec, w mniej spektakularny sposób) również wcześniej, od samego początku istnienia Defy. Zdarzało się, że nie zezwalano na rozpowszechnianie filmów autorstwa najbardziej wpływowych twórców - na przykład Konrada Wolfa, dziś uznawanego za klasyka enerdowskiej kinematografii. Ranga, jaką we wschodnich Niemczech nadano jego twórczości, wynikała nie tylko z faktycznej oryginalności nakręconych przezeń filmów, lecz także $\mathrm{z}$ roli, jaką posiadał $\mathrm{w}$ enerdowskim życiu publicznym - jako syn pisarza Friedricha Wolfa (członka KPD) i brat Markusa Wolfa, wieloletniego (1958-1987) szefa Głównego Zarządu Wywiadu (Hauptverwaltung Aufklärung - HVA) przy Ministerstwie Bezpieczeństwa Państwowego (Ministerium für Staatssicherheit - MfS), znanym jako Stasi. W 1933 r. rodzina Wolfów wyemigrowała najpierw do Szwajcarii, później do Związku

${ }^{32}$ W 1956 r. z propozycją powołania zespołów wystąpił Kurt Maetzig. Trzy lata później powstał pierwszy KAG - „Roter Kreis” (właśnie pod kierownictwem Maetziga), a wkrótce potem powołano kolejne, m.in. „Berlin” (prowadzony przez Slátana Dudowa) $i$ „Heinrich Greif” (z Konradem Wolfem jako kierownikiem artystycznym). Podobnie jak w Polsce, kształt instytucjonalny KAG-ów - ich ilość, a także zakres (względnej) niezależności wobec dyrekcji Defy - podlegał wielokrotnym przekształceniom, których opis wykracza poza cel i zakres niniejszej książki.

${ }^{33}$ Zob. Erika Richter, Zwischen Mauerbau und Kahlschlag, [w:] Das zweite Leben der Filmstadt Babelsberg. DEFA-Spielfilme 1946-1992, red. Ralf Schenk, Berlin 1994. Niektórzy autorzy twierdzą wręcz, że był to czas „nowej fali” w kinie wschodnich Niemiec (na przykład: Wilhelm Roth, 25 Jahre zu spät. Rückblick auf eine "Neue Welle” in der DDR, „epd Film” 1990, nr 7), co jednak - zdaniem innych - byłoby opinią przesadzoną (Daniela Berghahn, Hollywood behind the Wall..., s. 8; Dagmar Schittly, Zwischen Regie und Regime..., s. 13). 
Sowieckiego, który obaj bracia uznawali za swą drugą ojczyznę. Konrad Wolf powrócił do Niemiec w wieku 17 lat jako żołnierz Armii Czerwonej ${ }^{34}$; do 1947 r. pracował w administracji sowieckiej strefy okupacyjnej ${ }^{35}$, następnie studiował w moskiewskiej szkole filmowej, a obywatelstwo NRD przyjął w 1952 r. ${ }^{36} \mathrm{~W}$ kolejnych dekadach piastował wysokie stanowiska w strukturach państwowych instytucji kulturalnych (w latach 1965-1982 był przewodniczącym enerdowskiej Akademii Sztuk), a u schyłku życia został członkiem Komitetu Centralnego SED. Dla tematu niniejszej książki twórczość Wolfa - zdaniem Ulricha Gregora, jednego z nielicznych ówczesnych reżyserów podejmujących ",ciągły dialog z niemiecką historią" ${ }^{37}$ - ma znaczenie szczególne, w interesującym mnie okresie był on bowiem reżyserem pięciu tzw. filmów „antyfaszystowskich”: Ich troje (Genesung, 1956), Lissy (1957), Gwiazdy (Sterne, 1959), Uskrzydleni (Leute mit Flügeln, 1960) i Profesor Mamlock (Professor Mamlock, 1961).

Określenie to (Antifaschistischerfilm) w kulturze filmowej NRD funkcjonowało jako nazwa gatunkowa, pozwalająca odróżnić filmy nazywane w ten sposób od tzw. Gegenwartsfilme (filmów współczesnych) ${ }^{38}$. Daniela Berghahn twierdzi, że jako „antyfaszystowskie” skategoryzować można

${ }^{34}$ Autobiograficzne tropy związane ze służbą w Armii Czerwonej czytelne są w wybitnym filmie Wolfa Miałem 19 lat (Ich war neunzehn, NRD 1968).

${ }^{35}$ Wolf wspominał, że po demobilizacji w Niemczech zwracał się z prośbą o powrót do ZSRR (Konrad Wolf. Selbstzeugnisse, Fotos, Dokumente, red. Barbara Köppe, Aune Renk, Klaus Wischnewski, Berlin [Ost] 1985, s. 69). Jego brat pod koniec lat 80. napisał i wydał powieść („na podstawie pomysłu Konrada Wolfa”) o trójce przyjaciół, którzy poznali się w ZSRR w latach 30. (Markus Wolf, Die Troika. Geschichte eines nichtgedrehten Films, Berlin [Ost] 1989).

${ }^{36}$ Więcej na temat biografii Wolfa zob. na przykład: Wolfgang Jacobsen, Rolf Aurich, Der Sonnensucher. Konrad Wolf, Berlin 2005. W NRD wydano wiele publikacji poświęconych Wolfowi, m.in.: Konrad Wolf. Selbstzeugnisse, Fotos...; Konrad Wolf im Dialog. Künste und Politik, red. Dieter Heinze, Berlin (Ost) 1985; Konrad Wolf. Direkt im Kopf und Herz. Aufzeichnungen - Reden - Interviews, red. Aune Renk, Berlin (Ost) 1989. W ostatnich latach podjęto próbę włączenia twórczości Wolfa do "ogólnoniemieckiej” i „paneuropejskiej” historii kina (na przykład poprzez wskazywanie stylistycznych pokrewieństw z neorealizmem, francuską nową falą czy twórczością Fassbindera) - zob. Michael Wedel, Filmgeschichte als Krisengeschichte...; w języku angielskim: Michael Wedel, Thomas Elsaesser, Defining DEFAs Historical Imaginary: the Films of Konrad Wolf, "New German Critique" 2001, nr 82. Świadectwem akceptacji wkładu Wolfa w niemiecką kulturę filmową jest fakt, iż jego imieniem nazwano Wyższą Szkołę Filmową i Telewizyjną w Poczdamie-Babelsbergu (obecnie pod nazwą Filmuniversität Babelsberg Konrad Wolf).

${ }^{37}$ Ulrich Gregor, Konrad Wolf. Auf der Suche nach der Heimat, [w:] Film in der DDR, red. Heiko Blum, Hans Blumenberg, München-Wien 1977, s. 77. Zob. także: Marc Silberman, Remembering History: The Filmmaker Konrad Wolf, „New German Critique” 1990, nr 49.

${ }^{38}$ Określeniami tymi posługiwali się twórcy Defy jeszcze po upadku NRD - zob. na przykład: Damit lebe ich bis heute. Ein Gespräch mit Frank Beyer, [w:] Regie: Frank Beyer, red. Ralf Schenk, Berlin 1995, s. 38. 
ponad sto filmów powstałych w Defie, co stanowi około 13 procent całej jej produkcji ${ }^{39}$. Wyliczenie to zakłada, że za "filmy antyfaszystowskie” uznalibyśmy filmy o tematyce historycznej (obejmującej nie tylko okres 1933-1945) i niektóre filmy „współczesne”, związane na przykład z zimnowojenną polityką wobec RFN i państw zachodnich ${ }^{40}$.

Takie „rozciągnięcie” rozumienia antyfaszyzmu (implementowanego, rzecz jasna, nie tylko w NRD, ale przede wszystkim w ZSRR $\mathrm{i}-\mathrm{w}$ różnym stopniu - w innych krajach bloku wschodniego) jest jak najbardziej uzasadnione, ponieważ wynika z samej istoty tej doktryny. Miała ona bowiem swoje konsekwencje nie tylko dla specyficznego pojmowania okresu III Rzeszy na tle niemieckiej historii (i szerzej: historii świata zachodniego), lecz także dla legitymizacji przywódczej roli SED - rezygnacja z tego pryncypium (czy choćby jego naruszenie) zagrażałaby istnieniu samego NRD. Nic więc dziwnego, że przymiotnik „antyfaszystowski” był jednym z najbardziej pozytywnie wartościowanych określeń - inflacyjnie używanym dla uzasadnienia enerdowskiej polityki sensu stricto (zarówno wewnętrznej, jak i zagranicznej ${ }^{41}$ ), jak również polityki kulturalnej (tak $\mathrm{w}$ wymiarze teoretycznym, czyli w pracach z zakresu estetyki, jak i praktycznym, związanym z finansowaniem pola sztuki).

W tym kontekście rozpatrywać można dwie adaptacje nakręcone w 1951 r., a więc tuż po proklamowaniu NRD: Poddany (Der Untertan, reż Wolfgang Staudte, NRD), na podstawie powieści Heinricha Manna ${ }^{42}$, oraz Topór z Wandsbek (Beil von Wandsbek, reż. Falk Harnack) według Arnolda Zweiga (zob. podrozdział 2.1) ${ }^{43}$. Obaj pisarze zostali w III Rzeszy uznani

39 Daniela Berghahn, Resistance of the Heart: Female Suffering and Victimhood in DEFA's Antifascist Films, [w:] Screening War. Perspectives on German Suffering, red. Paul Cooke, Marc Silberman, Rochester 2010, s. 166.

${ }^{40}$ Formułowana $\mathrm{w}$ niektórych popularyzatorskich pracach opinia, iż kinematografia NRD została całkowicie zdominowana przez produkcję o charakterze propagandowym, nie jest prawdziwa i z pewnością nie może być odnoszona do całego dorobku Defy - na przykład do „easternów” z lat 70. i 80., czyli enerdowskich westernów, czy też wielu filmów dla dzieci (choć w niektórych filmach każdego z tych gatunków wskazać można również elementy propagandowe). Wedle wyliczeń jednego z badaczy, w całym okresie funkcjonowania Defy tzw. Kinderfilme stanowiły około jedną piątą jej produkcji (Dieter Wiedemann, Der DEFA-Kinderfilm - zwischen pädagogischem Auftrag und künstlerischem Anliegen, [w:] Zwischen Marx und Muck: DEFA-Filme für Kinder, red. Ingelore König, Dieter Wiedemann, Lothar Wolf, Berlin 1996, s. 21).

${ }^{41}$ Przykładowo, budowę muru berlińskiego w 1961 r. traktowano jako dzieło wzniesienia ",antyfaszystowskiego wału ochronnego". Zob. Anna Wolff-Powęska, Pamiećc..., s. 226.

${ }^{42}$ Henryk Mann, Poddany, tłum. M. Wołczacka, J. Marecka, Warszawa 1959. Więcej na temat relacji adaptacji do powieści zob. Michael Grisko, Der Untertan-revisited, Berlin 2007.

${ }^{43}$ Arnold Zweig, Topór z Wandsbeck, tłum. E. Sicińska, Warszawa 1951. 
za wrogów nazistowskiego ustroju, zaś u zarania NRD swymi nazwiskami legitymizowali ustrój nowego państwa ${ }^{44}$.

Powieść Manna, ukończona w 1914 r., pomyślana była jako satyra na militaryzm epoki wilhelmińskiej; filmowa adaptacja zachowuje tę ideę, lecz dopełnia ją epilogiem, w którym akcentowany jest protofaszystowski charakter czasów Kaisera ${ }^{45}$. Bohaterem jest przemysłowiec Diederich Hessling, który w młodości wstępuje do nacjonalistycznej korporacji studenckiej, a po odziedziczeniu fabryki w bezwzględny sposób wyzyskuje robotników, wiążąc się jednocześnie z elitami finansowymi, politycznymi i militarnymi ówczesnych Niemiec. Sekwencje pokazujące działalność Hesslinga są bliskie karykaturze (bohater produkuje na przykład... papier toaletowy z napisem Weltmacht - światowa potęga), również z uwagi na patetyczny sposób wygłaszania kwestii dialogowych (w tej roli wystąił Werner Peters, który po 1955 r. przeniósł się do RFN, gdzie wyspecjalizował się w postaciach bufonowatych urzędników). Groteskowość Hesslinga wynika z jeszcze innego powodu - nadużywanej żabiej perspektywy kamery (za zdjęcia odpowiedzialny był Robert Baberske, wcześniej asystent Karla Freunda, mający w swym dorobku zarówno Berlin: Symfonię wielkiego miasta [Berlin - Die Sinfonie der Grosstadt, 1927], jak i antysemickich (a także antybrytyjskich) Rotszyldów [Die Rotschilds, 1940]). Te właśnie walory, trudne do zaakceptowania w okresie „walki z formalistycznym odchyleniem", stały się przedmiotem krytyki w enerdowskiej prasie. Przykładowo, recenzent „Berliner Zeitung” komplementował wymowę filmu, ale zaznaczał jednocześnie: „aby wzmocnić postępowe oddziaływanie, prowadzenie aktorów powinno odpowiadać zawartości” ${ }^{46}$. Z kolei w "Sonntag” pisano:

nadmiar persyflażu osłabia wychowawcze oddziaływanie filmu i wytwarza zagrożenie, że postaci oraz ich działania będą przez znaczącą część widowni odbierane nie

${ }^{44}$ Heinrich Mann zmarł w Kalifornii kilka miesięcy przed planowanym wyjazdem do NRD, gdzie został wybrany przewodniczącym Niemieckiej Akademii Sztuki; w 1950 r. funkcję tę objął Arnold Zweig.

${ }^{45}$ Jedynie ów finałowy "dopisek" - explicite wskazujący na związek z okresem nazistowskim - zbliża Poddanego do kategorii, które we wprowadzeniu opisałem jako istotne dla selekcji materiału do niniejszej książki (tylko w trybie wyjątku uwzględniającej fabuły o okresie wcześniejszym niż lata 30. XX w.).

${ }^{46}$ Herbert Ihering, Neue Maßstäbe. "Der Untertan”, „Berliner Zeitung”, 4.09.1951. W recenzji tej znajduje się taki oto interesujący passus: „w literaturze niemieckiej trudno byłoby znaleźć drugą taką powieść, która z podobną ostrością demaskowałaby ów typ poddanego, zawsze dającego się wykorzystać do celów militarnych i wojennych. W filmie demaskacja ta posuwa się jeszcze dalej, aż do wrażeń wizualnych. Ta twarz, a nawet kark, oczy, usta mogą zdradzać całą określoną grupę ludzi". 
jako gorzka i przerażająca rzeczywistość, lecz jako farsa (Klamauk), jako coś niemal surrealnego ${ }^{47}$.

W końcowej scenie filmu, podczas odsłonięcia pomnika Keisera, Hessling wygłasza przemówienie: Gdy odsłaniamy dziś pomnik Wilhelma Wielkiego, jest to nasz skromny dar dla całego rodu Hohenzollernów, pod których przywództwem Niemcy staty się światowa potegg. Dziś jesteśmy elita wśród narodów i po raz pierwszy stanowimy potęę germańskiej kultury panów (Herrenkultur), która nigdy nie będzie mogła zostać prześcignięta. W tym momencie nadchodzi burza - obrazom ciemnych chmur, które zbierają się nad zgromadzonymi, towarzyszy motyw dźwiękowy z nazistowskiej kroniki filmowej Die deutsche Wochenschau (dźwięki niediegetyczne wprowadzają zatem wymiar dyskursywny, "nakładający” czas nazistowski na fabularne realia wilhelmińskie). Ale naród panów nie osiaga takiego rozkwitu w czasie sennego, leniwego pokoju. Nie! Tylko na polach bitwy wielkość narodu wykuwana jest krwia i żelazem. Gdy mgła się rozstąpi, pomnik nadal stoi na placu, ale wokół niego widać zniszczone budynki. Raz jeszcze rozbrzmiewa - tym razem jako „memento z przeszłości” - głos bohatera perorującego o "narodowej potędze" ${ }^{\prime \prime}$, po czym „kropkę nad i” stawia komentarz „wszechwiedzącego" głosu ponadkadrowego: Do tego wzywał niegdyś Diederich Hessling i wzywaja za nim nadal inni, aż do dziś. Z uwagi na tę scenę (rzecz jasna, nie ma jej u Manna), decyzją erefenowskiej komisji ds. dystrybucji filmów z bloku wschodniego film Staudtego przez kilka lat nie mógł być pokazywany w RFN ${ }^{49}$, dokąd - po przerwanych pracach nad Matka Courage i jej dziećmi oraz konflikcie z Bertoldem Brechtem w $1955 \mathrm{r}^{50}$ - przeniósł się ostatecznie reżyser. Niezależnie od tej decyzji, w NRD Staudte (który za Poddanego otrzymał Nagrodę Państwową II stopnia) zachował jednak opinię twórcy „postępowego" - ze względu na wyrażaną przez niego publiczną krytykę erefenowskiej polityki historycznej i kulturalnej (zob. podrozdział 3.5$)^{51}$.

${ }^{47}$ Wolfgang Joho, Der Untertan ist nicht ausgestorben. Zu dem neuen DEFA-Film "Der Untertan”, „Der Sonntag”, 9.09.1951.

${ }^{48}$ Na rolę ścieżki dźwiękowej w zakończeniu filmu wskazuje Detlef Kannapin, Antifaschismus im Film der DDR: DEFA-Spielfilme 1945 bis 1955, Köln 1997, s. 151.

${ }^{49}$ Decyzję zachodnioniemieckich urzędników skwapliwie wykorzystała enerdowska propaganda. Na przykład w partyjnym dzienniku „Neues Deutschland” wskazywano na paralele między recepcją powieści w momencie jej opublikowania, z jednej strony, i przyjęciem filmu w RFN, z drugiej: „w 1918 roku siły reakcji jątrzyły przeciw powieści, w 1951 roku Bonn zakazało pokazu filmu w klubie filmowym w Heidelbergu" (Hermann Müller, "Der Untertan”. Wolfgang Staudtes Film warnt vor Militarismus und Nationalismus, „Neues Deutschland”, 2.09.1951).

${ }^{50}$ Na ten temat zob.: Ralf Schenk, Mitten im Kalten Krieg: 1950 bis 1960, [w:] Das zweite Leben der Filmstadt Babelsberg..., s. 101-104.

${ }^{51} \mathrm{~W}$ pierwszej książce poświęconej twórczości Staudtego (wydanej zresztą w NRD), czołowy enerdowski krytyk pisał: „Z wyjątkiem Rotacji/Brunatnej pajęczyny, Wolfgang 


\subsection{Bohaterscy oponenci Hitlera}

W kontekście specyficznego sposobu rozumienia "antyfaszyzmu” w dyskursie publicznym (i polityce historycznej) NRD czytać można drugą - obok Poddanego - prestiżową adaptację Defy z początku lat 50.: Topór $z$ Wandsbek (Beil von Wandsbek, reż. Falk Harnack, 1951) na podstawie powieści Arnolda Zweiga (napisanej po hebrajsku i wydanej po raz pierwszy w 1943 r.; niemiecki przekład ukazał się w cztery lata później roku, kilka miesięcy po zakończeniu procesów norymberskich). Wydarzenia w niej przedstawione odnoszą się do autentycznej historii - egzekucji czterech mężczyzn skazanych za rzekome wywołanie zamieszek z 17 lipca 1932 r. w miasteczku Altona (tzw. Altonaer Blutsonntag; w rzeczywistości sprawcami morderstw wówczas popełnionych były bojówki SA).

Bohater powieści, rzeźnik Albert Teetjen z Hamburga, boryka się z problemami finansowymi. Jego żona Stine zachęca go do napisania listu z prośbą o pomoc do pułkownika SS (Standartenführer) Footha, któremu w czasie I wojny światowej Albert uratował życie. Foothowi zależy natomiast na tym, by do Hamburga zawitał Adolf Hitler, co nie będzie możliwe, póki nie zostanie wykonany wyrok śmierci na czterech komunistach siedzących $\mathrm{w}$ więzieniu. Temu z kolei przeciwstawia się lekarka, dr Neumeier, na próżno domagająca się rewizji procesu, a następnie prawa łaski (postać ta "orbituje” wokół bohaterów związanych z komunistami, ale - jako "nieskuteczna” - znika z narracji w połowie filmu). Footh przekonuje rzeźnika, by ten wykonał (w przebraniu) wyroki śmierci - za pokaźne honorarium, które Teetjenowie przeznaczają na modernizację sklepu. Gdy w miasteczku rozchodzi się wiadomość, że to Albert był katem, za przyczynę plotek Teetjenowie uznają tytułowy topór - ale ilekroć próbują się go pozbyć, tylekroć "powraca” on do nich. Stine z trudem znosi upokorzenia ze strony sąsiadów (na tej odzieży sq ślady krwi, ich nie da się wywabić - mówi pracownik pralni) i ostatecznie

\footnotetext{
Staudte nie stawiał w centrum zainteresowania swoich filmów walczącej niemieckiej klasy robotniczej. Tu spotkały się ograniczony światopogląd historyczny z bezradnością artysty w Republice Federalnej, gdzie poprzez filmy nie wolno dążyć do zmiany niesprawiedliwych stosunków społecznych [...]. Ale zarazem [...] żaden zachodnioberliński ani zachodnioniemiecki reżyser filmowy nie wykonał takiego wysiłku, jak Staudte, aby przezwyciężyć komercyjną i ideologiczną presję kapitalistycznego przemysłu filmowego. Inni, dostrzegając trudności w mówieniu prawdy w Niemczech Zachodnich, zrezygnowali lub wyjechali za granicę. Staudte wybrał niewygodną pozycję - pod względem politycznym i artystycznym. Nie dał się wcisnąć w bońskie szablony [...]. Życie i twórczość Wolfganga Staudtego nie są wolne od tragedii artysty w społeczeństwie kapitalistycznym. Ale jego najlepsze filmy stały się kamieniami milowymi niemieckiej humanistycznej sztuki filmowej XX wieku" (Horst Knietzsch, Wolfgang Staudte, Berlin [Ost] 1966, s. 50-51).
} 
popełnia samobójstwo. Podobnie postępuje Albert, który zdąży jeszcze przekazać topór bojówkarzom z SA.

Wymowa tej historii sprawiła, że powieść Zweiga wydawała się wręcz wymarzonym materiałem dla Defy. Nie bez znaczenia był również fakt, że autor powieści, wcześniej przebywający na emigracji w Palestynie, wówczas pod zarządem brytyjskim, nie zdecydował się na pozostanie w Izraelu (który proklamował niepodległość w 1948 r.), lecz osiedlił się w NRD. Aby nadać filmowi prestiżowy charakter, Biuro Polityczne SED planowało powierzyć reżyserię Staudtemu, który jednak wolał ukończyć Poddanego ${ }^{52}$. Ostatecznie film zrealizował Falk Harnack - ówczesny dyrektor artystyczny Defy (w latach 1949-1952), reżyser z "postępową" biografią. Był bratem Arvida Harnacka z Czerwonej Orkiestry (Rote Kapelle - komunistycznej organizacji antynazistowskiej działającej w podziemiu $^{53}$ ), jako kuzyn pastora Dietricha Boenhoffera miał kontakt z opozycją antyhitlerowską skupioną wokół Ludwika Becka, a w 1942 r. spotykał się wielokrotnie ze środowiskiem Sophie Scholl (o co został oskarżony - i oczyszczony z zarzutów ze względu na zniszczone dowody). Później zaś (po dezercji w 1943 r.) zaciągnął się do ELAS (greckiej Wyzwoleńczej Armii Ludowej).

Autorzy scenariusza wprowadzili doń kilka istotnych modyfikacji w stosunku do książkowego pierwowzoru ${ }^{54}$. Po pierwsze, przesunięto czas akcji - z 1937 r. u Zweiga na 1933 (zmiana ta uwypuklała aspekt źródeł niemieckiego faszyzmu). Po drugie, u Zweiga naziści traktują Teetjena instrumentalnie: wykorzystują go jako narzędzie zbrodni i nie interesują

52 Wolfgang Staudte über die Produktionsbedingungen seiner Filme, [w:] Wolfgang Staudte, red. Eva Orbanz, Berlin 1977, s. 70. Zob. też: Günter Jordan, Der Verrat oder Der Fall Falk Harnack, [w:] apropos Film 2004. Das 5. Jahrbuch der DEFA-Stiftung, red. Ralf Schenk, Erika Richter, Claus Löser, Berlin 2004.

${ }^{53}$ Jednym z jej członków był Leopold Trepper - agent GRU, który po burzliwych przeżyciach wojennych, mogących stanowić kanwę niejednego filmu, w styczniu $1945 \mathrm{r}$. został aresztowany w Moskwie i skazany na wiele lat niewoli. Po wyjściu z więzienia w 1955 r. zamieszkał w Polsce, gdzie został przewodniczącym Towarzystwa Społeczno-Kulturalnego Żydów. Zgodę na wyjazd do Izraela otrzymał dopiero w 1973 r.

54 W czołówce podane zostały następujące osoby: „Scenariusz: Hans-Robert Bortfeld i Falk Harnack, na podstawie manuskryptu Wolfganga Staudtego i Wernera Jörga Lüddecke". Kannapin zwraca uwagę, że Defa-Kommision otrzymała kolejno pięć wersji literackiego opracowania (Detlef Kannapin, Antifaschismus im Film der DDR..., s. 136), choć w swoim tekście przywołuje protokoły z trzech posiedzeń DEFA-Komission: jedno dotyczące treatmentu i dwóch oceniających scenariusze. Z kolei Heimann pisze, że część zmian następowała „pod naciskiem sowieckiego urzędnika”, nie precyzując jednak, o kogo chodzi i jaki charakter miały zmiany (Thomas Heimann, DEFA, Künstler und SED-Kulturopolitik. Zum Verhältnis von Kulturpolitik und Filmproduktion in der SBZ/DDR 1945 bis 1959, Berlin 1994, s. 125). 
się dalszym losem bohatera ( $\mathrm{w}$ filmie - nie porzucają go w potrzebie, lecz oficjalnie przyjmują w swoje szeregi i obiecują bronić). Po trzecie wreszcie, do scenariusza wprowadzono proletariacką grupę oporu, której w literackim oryginale brak. Na realizację Defa przeznaczyła dużą liczbę dni zdjęciowych, zabezpieczyła też pokaźne środki na kampanię promocyjną (miarą rangi, jaką zamierzano nadać filmowi, było otwarcie jego projekcją I Kongresu Kultury Niemieckiej w Lipsku) ${ }^{55}$.

Topór z Wandsbeck nie spełnił jednak oczekiwań politycznych mocodawców - po sześciu tygodniach od premiery został wycofany z dystrybucji ${ }^{56}$, stając się zarazem pierwszym enerdowskim "Verbotsfilmem”. Jak sugeruje Ralf Schenk, była to decyzja wymierzona w samego reżysera, mieszkającego w zachodniej części Berlina, a w przeszłości mającego kontakty z jugosłowiańską partyzantką (co w okresie stalinizmu było okolicznością obciążającą) ${ }^{57}$. O konkretnych przyczynach zatrzymania filmu można jedynie spekulować (biuro polityczne wydało tylko komunikat o zakazie publikowania recenzji oraz wycofaniu z repertuaru kin). Być może powodem był fakt, że nazizm przedstawiono $\mathrm{w}$ filmie jako fenomen masowy (ulice pokryte flagami ze swastyką - fot. 11); mowa jest także o fascynacji Niemców postacią Hitlera (To po prostu geniusz. Tylko tak przenikliwe oczy moga prowadzić tak dalekowzroczna politykę) - ale zarazem właśnie te elementy mogły zostać uznane za niewłaściwe. Według twórców zarzucono filmowi zbyt słabą reprezentację klasy robotniczej (która w zasadzie nie jest pokazana - mamy jedynie informację o bojkocie sklepu Teetjena), w tym - zbyt mało wyraziste „polityczne sprofilowanie" bohaterów (dla potrzeb propagandy ekonomiczne motywacje Teetjena były najpewniej zbyt przyziemne). Za główny zarzut uznano jednak najwyraźniej to (wątpliwości tego rodzaju pojawiły się już na zebraniach oceniających scenariusz), że konstrukcja fabuły i sposób prowadzenia narracji może wywołać sympatię bądź litość wobec bohatera ${ }^{58}$. Po wykonaniu egzekucji Teetjen jest bowiem prześladowany przez mieszkańców miasteczka, a w zakończeniu zabija się raczej w reakcji na rodzinną tragedię (samobójstwo żony), niż ze względu na rozpoznanie dokonanego przez siebie błędnego politycznego wyboru. Wprowadzenie ideologicznie motywowanego dopowiedzenia (zanim Teetjen popełni samobójstwo, ob-

55 Thomas Heimann, DEFA, Künstler..., s. 123.

${ }^{56}$ Ibidem, s. 124. Zob. też: Günther Adge, "Mitleid mit den Mördern"? Das „Beil von Wandsbeck" als Film- und Bühnenstoff, [w:] Verwaltete Vergangenheit. Geschichtskultur und Herrschaftslegitimation in der DDR, red. Martin Sabrow, Leipzig 1997.

57 Ralf Schenk, Mitten im Kalten Krieg..., s. 70.

${ }_{58}$ Zob. Spur der Filme. Zeitzeugen über die DEFA, red. Ingrid Poss, Peter Warnecke, Bonn 2006, s. 67. Podobną opinię wyraził także Staudte, który właśnie ten aspekt filmu wymienił wśród powodów, dla których zrezygnował z jego reżyserii (Wolfgang Staudte über die Produktionsbedingungen seiner Filme..., s. 70). 
jawiają mu się twarze czterech zamordowanych komunistów oraz profetyczna przestroga: Wy spłyniecie krwia, do nas należy przyszłość) najwyraźniej nie było $\mathrm{w}$ stanie rozwiać wątpliwości politycznych decydentów - a może wręcz pogorszyło sprawę, sugerując "metafizyczny" podtekst historii, mającej przecież przedstawiać „materialistyczną” walkę klas.

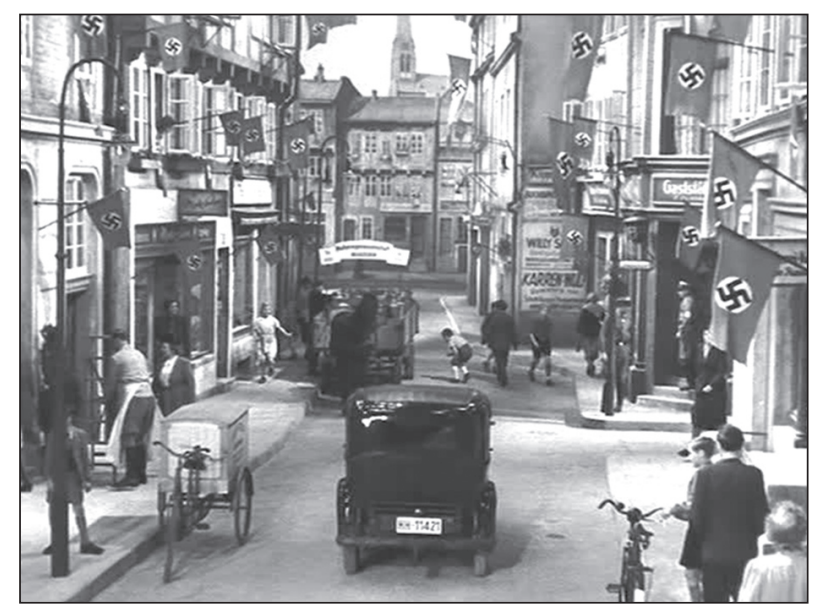

Fot. 11. Topór z Wandsbek (reż. Falk Harnack, 1951) Ulice spowite nazistowskimi flagami - rzadki obraz $\mathrm{w}$ kinie niemieckim tamtego czasu

Harnack - wraz z występującą w Toporze... Käthe Braun, prywatnie żoną reżysera - w 1953 r. przeniósł się do RFN (gdzie pracował m.in. dla Artura Braunera, a następnie dla zachodnioniemieckiej telewizji ZDF); z pewnością również ten fakt przyczynił się do podtrzymania decyzji o zatrzymaniu filmu. Do enerdowskich kin Topór z Wandsbek trafił ponownie w 1962 r. (z okazji 75. rocznicy urodzin Arnolda Zweiga), w wersji skróconej o 20 minut $^{59}$. Wersja oryginalna została pokazana w enerdowskiej telewizji dopiero w $1981 \mathrm{r} .{ }^{60}$, tym razem ponoć z okazji 75 . urodzin jednego z najbardziej uznanych aktorów Defy, Erwina Geschonnecka (i na jego prośbę), który w Toporze... zagrał Teetjena.

${ }^{59}$ Wersja ta została okrojona głównie o zakończenie - nie zawierała sceny, w której Stine zostaje odebrana pościel oraz obu samobójstw (Regina Breitkopf, Das Beil von Wandsbeck, „Beiträge zur Film- und Fernsehwissenschaft” 1984, nr 5, s. 223). Być może istniała jeszcze inna wersja filmu - jego montażystka, Käthe Rülicke-Weiler, twierdziła, że w 1954 lub 1956 r. otrzymała zlecenie usunięcia scen mogących budzić współczucie wobec Teetjenów, ale również dodania sceny z Triumfu woli Riefenstahl (Käthe Rülicke-Weiler, Weitere Bemerkungen zum Film "Beil von Wandsbeck”, „Beiträge zur Film- und Fernsehwissenschaft” 1984, nr 5, s. 176). Zob. Detlef Kannapin, Antifaschismus im Film der DDR..., s. 138.

${ }^{60}$ Spur der Filme..., s. 67. Thomas Heimann, DEFA, Künstler..., s. 124. 
Druga, oprócz dyskursywnego wiązania nazizmu z kapitalizmem, strategią typową dla enerdowskiej ideologii państwowej było przypisanie „antyfaszyzmu” ojców założycieli NRD - wszystkim obywatelom wschodnich Niemiec. Jak pisze Anna Wolff-Powęska, dokonane w propagandzie NRD „rozciągnięcie doświadczenia grupy przedwojennych komunistów na całe społeczeństwo wschodnich Niemiec było największym fałszerstwem i jednocześnie najstabilniejszym mitem założycielskim nowego państwa" ${ }^{61}$. Stabilność ta gwarantowana była oczywiście przez mechanizmy przemocy instytucjonalnej i wspierana przez działania propagandowe, ale najpewniej wynikała również z autentycznych potrzeb mieszkańców NRD. Antyfaszyzm stanowił bowiem użyteczny wzór indywidualnego „przezwyciężania przeszłości”. Mógł stać się rodzajem ekspiacji, szansą na uwolnienie od moralnej odpowiedzialności, a zarazem na dołączenie do grona zwycięzców historii. Zarazem dla Niemców w NRD poczucie winy - także wobec prześladowanych w III Rzeszy antyfaszystów i komunistów - mogło być psychologiczną bariera, która nie pozwalała na zakwestionowanie ich moralnego prawa do rządzenia ${ }^{62}$. Podobnie więc jak w innych krajach "demokracji ludowych", również w NRD szybko przystąpiono do tworzenia „panteonu bojowników z faszyzmem", wśród których najważniejsze miejsce mieli zająć byli członkowie Komunistycznej Partii Niemiec (KPD) ${ }^{63}$. Oczywiście wygaszano pamięć o tych spośród nich, którzy nie przetrwali stalinowskich "czystek" w II połowie lat 30., akcentowano natomiast rolę działaczy, którzy bądź ponieśli śmierć z rąk nazistów, bądź współtworzyli SED.

Zgodnie z wymogami socrealizmu, a dokładniej: $w$ tradycji sowieckiego filmu biograficznego ${ }^{64}$, nakręcony został panegiryczny dyptyk Kurta Maetziga poświęcony Ernstowi Thälmannowi, przywódcy KPD w latach

${ }^{61}$ Anna Wolff-Powęska, Pamięć..., s. 226.

${ }^{62}$ Adam Krzemiński, Obrachunek z politycznym zaangażowaniem pisarzy w NRD i RFN, [w:] Literatura i władza, red. Bożena Wojnowska, Warszawa 1996, s. 67.

${ }^{63} \mathrm{Z}$ tego powodu trudno się dziwić, iż władze Defy nie przyjęły propozycji Artura Braunera (jednego z najważniejszych prywatnych producentów w RFN - zob. podrozdziały 1.6 i 3.1) dotyczącej możliwej koprodukcji filmu o rodzeństwie Scholl (Ralf Schenk, Mitten im kalten Krieg..., s. 87). O ile Brauner owocnie współpracował z Defą przy swoich dwóch projektach filmowych w okresie podziału Niemiec na strefy okupacyjne, o tyle w czasie, gdy pojawił się pomysł nakręcenia fabuły o bohaterskim rodzeństwie z Monachium (w 1953 r.), o współpracy z firmami ulokowanymi w RFN czy w Berlinie Zachodnim nie mogło być już w NRD mowy.

${ }^{64}$ Sabine Hake zwraca uwagę na podobieństwa dyptyku do Geniefilm - filmu biograficznego o „wielkich ludziach”, gatunku popularnego w kinematografii III Rzeszy (Sabine Hake, Film in Deutschland. Geschichte und Geschichten seit 1985, Reinbek 2002, s. 172). Oczywiście, oba tropy są poprawne - choć palma pierwszeństwa należy się tu jednak filmom sowieckim. 
1925-1933: Na barykadach Hamburga (Ernst Thälmann - Sohn seiner Klasse, NRD 1954) i W walce $z$ Hitlerem (Ernst Thälmann - Führer seiner Klasse, NRD 1955) ${ }^{65}$. Część pierwsza rozpoczyna się w 1918 r., kończy natomiast komunistyczną rewoltą w Hamburgu pięć lat później. Kontynuacja dotyczy zaś działalności Thälmanna od 1930 r. (wydarzenie inicjujące stanowi strajk w Zagłębiu Ruhry) do egzekucji bohatera w sierpniu 1944 r. W sequelu, jak powiedzielibyśmy dzisiaj, opowieść podzielona została na trzy linie narracyjne. Akt I, dotyczący kampanii wyborczej, zostaje zwieńczony aresztowaniem Thälmanna; następnie akcja prowadzona jest dwutorowo: część sekwencji rozgrywa się w więzieniu, a pozostałe koncentrują się na działalności Fiete Jansena (postać fikcyjna; w fabule filmu to przyjaciel Thälmanna), który walczy przeciw frankistom w Hiszpanii, przyjmuje kapitulację Niemców pod Stalingradem, by później, wraz z towarzyszami z Armii Czerwonej, wyzwalać nazistowskie obozy koncentracyjne w Europie Wschodniej (w ten sposób następuje dyskursywne powiązanie roli Komunistycznej Partii Niemiec i sił sowieckich w obaleniu faszyzmu).

Na bazie kwerendy archiwalnej Detlef Kannapin wykazał, że biuro polityczne SED planowało produkcję filmu o Thälmannie jeszcze w 1949 r.; w Defie ukonstytuował się wówczas specjalny zespół („Thälmann-kollektiv"), którego zadaniem było zbieranie dokumentacji (pierwsze posiedzenie odbyło się 8 października 1949 r., a więc dzień po proklamowaniu NRD!) ${ }^{66}$. W 1951 r. do wsparcia projektu oddelegowany został przedstawiciel ZSRR, Wassilij Pronin; prace prowadzone były pod ścisłym nadzorem „komisji ds. Defy" w SED ${ }^{67}$. We wstępnej wersji scenariusza - autorstwa sprawdzonych działaczy: Willy'ego Bredela i Michaela Tschesno-Hella ${ }^{68}$ - fabuła,

${ }^{65}$ Dyptyk Maetziga należy do tych (nielicznych) filmów enerdowskich, które doczekały się wielu komentarzy i omówień w piśmiennictwie po zjednoczeniu Niemiec. Zob. na przykład: Frank Tunnat, Filmsprache als Instrument der Politik. Anmerkungen zu Kurts Maetzigs Thälmann-Film, [w:] Politik und Mythos. Kader, Arbeiter und Aktivisten im DEFAFilm, red. Klaus Finke, Oldenburg 2002; Sabine Falke, Soldat der Revolution. Zur Konstruktion des Kaders in Kurt Maetzigs Thälmann-Film, [w:] Politik und Mythos...; Detlef Kannapin, Ernst Thälmann und der DDR-Antifaschismus im Film der fünfziger Jahre, [w:] Ernst Thälmann - Mensch und Mythos, red. Peter Monteath, Amsterdam 2000; Sandra Langenhahn, Zur politische Ikonographie des DEFA-Films am Beispiel der Produktionen zu Ernst Thälmann, [w:] Visuelle Politik. Filmpolitik und die visuelle Konstruktion des Politischen, Baden-Baden 1998.

${ }^{66}$ Do końca 1949 r. miały miejsce jeszcze cztery spotkania. Działalność „,zespołu” wygasła około 1951 r. Detlef Kannapin, Antifaschismus im Film der DDR..., s. 158.

${ }^{67}$ Ibidem, s. 159; Thomas Heimann, DEFA, Künstler..., s. 180.

${ }^{68}$ O okolicznościach powstania filmu zob. wspomnienia (s. 76-89) i listy (s. 251-256) w zbiorze Kurt Maetzig. Filmarbeit. Gespräche, Reden, Schriften, red. Günter Agde, Berlin (Ost) 1987. O wczesnych wersjach scenariusza zob. też: Russel Lemmons, „Great Truths and Minor Truths": Kurt Maetzig's "Ernst Thälmann" Films, the Antifascist Myth and the Politics of Biography in the German Democratic Republic, [w:] Take Two. Fifties Cinema in Divided Germany, red. John Davidson, Sabine Hake, Berghahn 2007, s. 96-97. 
podzielona na trzy części, miała zawierać rozbudowane wątki związane z życiem prywatnym bohatera ${ }^{69}$, z czego ostatecznie, wraz z „wdrożeniem” socrealistycznej doktryny, zrezygnowano. Jako filmy modelowe dla finalnej wersji dzieła, jego twórcy wymieniali sowieckie superprodukcje Michaiła Cziaurellego (zwłaszcza głośną apologię Stalina, Przysięgę [Kлsmвва, 1946]) ${ }^{70}$.

Z faktami historycznymi scenariusz obchodził się dość beztrosko, zarówno gdy idzie o przeinaczanie wydarzeń, które w rzeczywistości przebiegały w sposób znacząco odmienny, jak i usuwanie z horyzontu fabularnego informacji niewygodnych z propagandowego punktu widzenia ${ }^{71}$. Sprytną decyzją okazało się na przykład pominięcie okresu 1924-1930, dzięki czemu film nie daje informacji o czasowym wykluczeniu Thälmanna z KPD w 1928 r. (z uwagi na przywłaszczenie przez jednego z jego współpracowników części pieniędzy komitetu wyborczego). Gdy zaś idzie o wydarzenia z lat 30., w drugiej części dyptyku pominięto poparcie Thälmanna dla inicjatywy NSDAP żądającej referendum w sprawie odwołania socjaldemokratycznego rządu Prus w 1931 r. Uwagi do scenariusza nanosili zarówno sam sekretarz generalny Walter Ulbricht ${ }^{72}$, jak i przedstawiciel władz sowieckich Władimir Siemionow ${ }^{73}$. Reżyser relacjonował natomiast, że także na etapie zdjęciowym był pod stałą kontrolą towarzyszy partyjnych ${ }^{74}$.

Jeśli warstwa estetyczna filmu nie wydaje się szczególnie imponująca, to m.in. z powodu narzuconej aktorom teatralizacji (wiele sekwencji składa się z płomiennych przemówień bohatera). W roli Thälmanna wystąpił Günther Simon, w późniejszych latach chętnie angażowany przez Maetziga do historycznych filmów propagandowych (np. Pieśn marynarzy [Lied der Matrosen, reż. Kurt Maetzig, Günter Reisch, NRD 1958]), jak i produkcji gatunkowych (pojawił się w obsadzie Milczącej gwiazdy

${ }^{69}$ Martin Brady, Discussion with Kurt Maetzig, [w:] Defa: East German Cinema, 19461992, red. Seán Allan, John Sandford, New York, s. 84.

${ }^{70}$ Ralf Schenk, Mitten im kalten Krieg..., s. 104. Swoją drogą, również w dyptyku Maetziga znalazły się sceny ze Stalinem (zostały one wycięte stosunkowo późno, bo w 1961 r. - ibidem, s. 107).

${ }^{71}$ Zob. Erich Wollenberg, Thälmann - Film und Wirklichkeit, [w:] Ernst Thälmann; Mensch und Mythos, red. Peter Monheath, Amsterdam 2000.

${ }^{72}$ Wedle wspomnień Maetziga, w następujący sposób zdystansował się on do uwag Ulbrichta: „Towarzyszu Ulbricht, gdy ktoś musi poddać się operacji, ma oczywiście prawo do wyboru chirurga. Ale gdyby leżał pan na stole operacyjnym, nie radziłbym panu kierować ręką chirurga, aby wykonał cięcie odrobinę wyżej lub niżej". Zdaniem reżysera reakcja Ulbrichta była pozytywna i całość obrócono w żart (Kurt Maetzig. Filmarbeit. Gespräche, Reden, Schriften..., s. 83).

${ }_{73}$ Dagmar Schittly, Zwischen Regie und Regime..., s. 67.

${ }^{74}$ Kurt Maetzig, Filmarbeit. Gespräche, Reden, Schriften..., s. 76. 
[Der schweigende Stern], NRD 1960). W czasie przygotowywania filmu o Thälmannie był jednak aktorem mało znanym, w dodatku - wspominał Maetzig - „pod względem politycznym nie był przygotowany do tej roli. Reprezentował idee pacyfistyczne i był obcy naukowemu rozumieniu socjalizmu. Trzeba było długiego i wyczerpującego przygotowania, by wprowadzić go w ten świat pojęć"75 (najwyraźniej, pedagogiczną intencję filmu akcentowano nie tylko na ekranie, ale i poza nim, projektując bezpośredni związek między aktorem - „niepokornym uczniem” a postacią ekranową pełniącą funkcję ideologicznego „mentora”). W zbiorze wywiadów i dokumentów Maetziga znaleźć można list reżysera do Simona, zawierający podobny osąd - sformułowany w specyficzny dla kultury stalinowskiej sposób:

\begin{abstract}
Na początku naszej drogi odbyliśmy wiele rozmów, my wszyscy, i Ty, który tkwiłeś jeszcze w pacyfistycznym światopoglądzie. My, którzy wzięliśmy na swe barki odpowiedzialność za tak wielkie przedsięwzięcie, wiele razy borykaliśmy się z pytaniem, czy Ty jesteś właściwym odtwórcą głównej roli. Bez wątpienia, na początku nim nie byłeś, tak jak ja nie byłem właściwym reżyserem, a Karl Plintzner i Horst Brandt nie byli właściwymi autorami zdjęć. Ale dziś jest jasne, i mówimy to bez popadania w przesadę, że wychowani dzięki wniknięciu w życie i walkę Ernsta Thälmanna oraz dzięki naszej wzajemnej krytyce i własnym staraniom, udało się nam znaleźć właściwe rozwiązania, które będą prowadzić nas do tego wielkiego celu ${ }^{76}$.
\end{abstract}

W postać Fiete Jansena wcielił się z kolei Hans-Peter Minetti; na jego pozycję $\mathrm{w}$ świecie aktorskim NRD mogły mieć wpływ decyzje osobiste - ojciec, Bernhard Minetti, grywał w filmach nakręconych w III Rzeszy, m.in. w antysemickich Rotszyldach (reż. Erich Waschneck, 1940), a po wojnie zdecydował się pozostać w RFN, gdzie kontynuował karierę aktorską. Oficera Quadego (nadzorującego Thälmanna w więzieniu) zagrał zaś Werner Peters, który wcześniej w Poddanym ucieleśniał „biograficzne kontynuacje reakcyjnych tendencji niemieckiej historii" ${ }^{\prime 7}$.

Poza Thälmannem w filmie pojawiają się postaci innych członków KPD (a później SED): Wilhelm Pieck i Walter Ulbricht (co ciekawe, brakuje Otto Grotewohla, innego „ojca założyciela” SED). Ważną rolę odgrywa

${ }^{75}$ Ibidem, s. 80. W innym miejscu odnalazłem informację, że w czasie przygotowań do realizacji filmu teść Simona został aresztowany za wykroczenia gospodarcze. Simon miał wówczas zażądać, by go uwolniono, co - wedle zapisu w przywoływanym przez Ralfa Schenka dokumencie wewnętrznym Defy - wydarzyło się „w międzyczasie” (Ralf Schenk, Eine kleine Geschichte..., s. 77).

${ }^{76}$ List Maetziga do Simona z 7.07.1955, [w:] Kurt Maetzig. Filmarbeit. Gespräche, Reden, Schriften..., s. 256.

${ }_{77}$ Detlef Kannapin, Antifaschismus im Film der DDR..., s. 162. 
też Georgi Dimitrow (przywódca bułgarskiej partii komunistycznej przebywający na wygnaniu, członek Komunistycznej Partii Austrii, jeden z oskarżonych o podpalenie Reichstagu). Jako sojusznicy Hitlera przedstawieni zostają natomiast... socjaldemokraci z SPD, którzy co rusz odrzucają składane przez KPD propozycje stworzenia wspólnego frontu przeciw NSDAP (Ci komuniści... Nie stworze wspólnego frontu z podpalaczami) ${ }^{78}$. Zwycięstwo Hindenburga w wyborach prezydenckich 1932 r. jest zatem ukazane jako „zdrada” ze strony członków SPD, którzy w ten sposób zostają obciążeni winą za powierzenie Hitlerowi stanowiska kanclerskiego (Ulbricht: Kierownictwo SPD odrzuciło akcje przeciw Hitlerowi, ale prawdziwi socjaldemokraci sa innego zdania). Spośród socjaldemokratów przedstawionych w filmie jedynym wyjątkiem jest Robert Dirhagen (wystąpił z SPD w 1933 r.). Postać tę wprowadzono najpewniej po to, aby unaocznić istnienie „postępowej” socjaldemokracji, która wraz z KPD stworzy Socjalistyczną Partię Jedności Niemiec.

Podobnie jak nakręcony trzy lata wcześniej Poddany, również fabuła o Thälmannie posługuje się formułą nakazującą obsadzić w rolach negatywnych bohaterów postaci kojarzone $\mathrm{z}$ militaryzmem doby fryderycjańskiej (Quade, podoficer w armii Keisera, zostaje członkiem SS) i kapitałem (za sznurki pociąga Amerykanin McFuller: Powiem otwarcie: niechętnie widzimy nasze dolary w trzęsacych się dłoniach. Dopiero gdy Niemcy będa rzadzone silna rękq...). Co ciekawe, w tej wizji kapitaliści nie tylko wspierają Hitlera (Najpierw musi dostać się na salony. Potem pójdzie jak po maśle. Najpierw zlikwiduje się KPD, później SPD, następnie zwiazki zawodowe), lecz także - gdy sytuacja na froncie przybiera dlań niekorzystny kształt - popierają ",spisek 20 lipca" (Nie można dopuścić do sytuacji, aby zamach na Hitlera się nie powiódt [...]. Trudno przewidzieć konsekwencje, jeśli się wkrótce nie porozumiemy z sitami zachodnimi). Przy czym - inaczej niż w filmach powstałych w RFN - zamach na Hitlera nie zostaje potraktowany jako akt heroizmu, lecz „pucz pałacowy” (nazwisko Stauffenberga nie pada). W filmie Maetziga dwukrotnie pojawia się też wątek robotników przymusowych (W Polsce mamy najlepsze warunki do prowadzenia biznesu), o których wie oczywiście Amerykanin. O kampanii militarnej prowadzonej przez zachodnich aliantów w filmie nie ma mowy - z jednym wyjątkiem: nalotów na Berlin (bomby spadają na więzienie dla kobiet, znajdujące się - trzeba trafu - dokładnie naprzeciwko okna z celi Thälmanna, który dzięki temu staje się mimowolnym świadkiem śmierci swej towarzyszki, Anny Jansen).

Narracja wyraźnie prowadzona jest w ten sposób, aby zaprezentować tytułowego bohatera jako antytezę Führera (słowo to pojawia się zresztą

${ }^{78} \mathrm{~W}$ rzeczywistości było odwrotnie - to SPD dążyło do stworzenia wspólnej listy wyborczej, na co nie chciało się zgodzić KPD. 
w oryginalnym tytule), wokół którego nie ma ani jednego zwolennika w cywilnym ubraniu (nie licząc Goebbelsa). Strategia ta rozwijana jest konsekwentnie już od pierwszej sceny, w której pojawia się Hitler (mniej więcej $\mathrm{w}$ połowie filmu): kiedy $\mathrm{z}$ trybuny zapowiada on czyn zbrojny, a scenę wcześniej Thälmann przemawia na cmentarzu poległych podczas I wojny światowej, deklarując pragnienie zapobiegnięcia nowej. Analogicznie w kolejnych sekwencjach: gdy w jednej scenie tytułowy bohater upomina się o niemiecko-francuskie pojednanie, w kolejnej Hitler wspomina o „czarnuchowatych (vernegerte) Francuzikach". Gdy Thälmann dziękuje wyborcom za oddane na niego głosy, Führer mówi o „osłach”; jeśli Hitler żąda od żołnierzy walki do ostatniej kropli krwi, lider KPD wykazuje troskę o losy syna jednego z więziennych strażników ${ }^{79}$.

Konstrukcji filmowego Führera warto przyjrzeć się bliżej - to bowiem jedna z nielicznych niemieckich produkcji fabularnych tamtych lat, w których wprowadzono tę postać ${ }^{80}$. Przede wszystkim zwraca uwage fakt, że Hitler nie jest demonizowany (ani przez grę aktorska, ani kompozycję obrazu, ani efekty dźwiękowe) - jako marionetka wielkiego przemysłu sprawia raczej wrażenie wykonawcy cudzych poleceń, "podwładnego" przemysłowców. Dobrym przykładem jest tu scena rozmowy Hitlera z von Papenem - aktor grający tego ostatniego umieszczony został w centralnej przestrzeni kadru, jego interlokutor znajduje się bliżej krawędzi obrazu i wydaje się mniejszy. Podobnie skomponowana została scena w bunkrze, gdzie Hitler rozmawia z generałami (krzesło, na którym siedzi, jest większe od Führera, a wisząca obok lampa - większa niż jego głowa $)^{81}$.

Finałowe sekwencje domykają oba główne wątki filmu: Jensena i Thälmanna. Pierwszy dołącza do partyzantów, którzy wyzwalają obóz przy pomocy jego więźniów (w zakończeniu ich delegacja wita sowieckich żołnierzy w dość długiej sekwencji wspólnej uczty). Można odnieść wrażenie, że ich radość została okupiona ofiarą złożoną przez Thälmanna: gdy w ostatniej scenie bohater eskortowany jest przez esesmanów do miejsca egzekucji, jeden ze strażników pyta go: Wiesz, co teraz nastapi? Thälmann odpowiada: Tak, lepsze Niemcy, Niemcy bez was. Korytarz więzienny zostaje zastąpiony powiewającą czerwoną flagą na tle której Thälmann maszeruje z wzrokiem skierowanym ku przyszłości, zaś na ścieżce dźwiękowej

79 Zob. także: Alexandra Hissen, Hitler im deutschsprachigen Spielfilm nach 1945, Trier 2010, s. 46.

${ }^{80}$ U Maetziga w roli Führera wystąpił Fritz Diez, który zagrał Hitlera również w późniejszych Zamrożonych błyskawicach (Gefrorenen Blitze, NRD 1967) oraz trzech sowieckich filmach kinowych.

81 Yael Ben Moshe, Hitler konstruieren. Die Darstellung Adolf Hitlers in deutschen und amerikanischen historischen Spielfilmen 1945-2009, Leipzig 2012, s. 187. 
pojawiają się słowa z Jak hartowała się stal Nikołaja Ostrowskiego. Konstrukcja zakończenia powiela typowy model zakończenia socrealistycznych filmów biograficznych:

Umiera jednostka, aby - dzięki złożonej w ten sposób ofierze - kolektyw mógł się stać jeszcze bardziej potężny. Śmierć jednostki jest zdarzeniem indywidualnym, które nie może mieć fundamentalnego znaczenia społecznego. Indywidualna tragedia nie liczy się dla Historii ${ }^{82}$.

Premiera I części dyptyku odbyła się w marcu 1954 r., zaś części drugiej-półtora roku później, 7 października 1955 r. (w tzw. Dzień Republiki, święto państwowe wolne od pracy). Dziennikarz partyjnego dziennika „Neues Deutschland” odnotował, że na uroczystym pokazie obecni byli I sekretarz partii Walter Ulbricht, wdowa po Thälmannie, a także „przedstawiciel delegacji sowieckiej" ${ }^{\prime 3}$. W recenzji tej, utrzymanej na wysokim diapazonie propagandowego sloganu, autor przedstawia „oficjalną" wykładnię filmu, który komplementuje za sposób przedstawienia genezy niemieckiego faszyzmu (,Kapitalistyczny monopol kupił sobie Hitlera, który za pomocą demagogicznych haseł próbował wymusić poparcie mas") oraz roli Thälmanna („Jedność klasy robotniczej, o którą walczył, ziściła się w jednej części Niemiec, w naszej republice [...] wolnej od militaryzmu, nadal żywego w zachodnich Niemczech") ${ }^{84}$. "Pedagogiczny” aspekt filmu podkreślono $\mathrm{z}$ kolei $\mathrm{w}$ innej recenzji, zawierającej bezpośredni zwrot - apel do widza:

Byłeś jednym z tysięcy tych, którzy nie przejrzeli tych zależności [...]? Zobaczysz siebie i przypomnisz sobie. A przy tym odpowiesz sobie na pytanie, jak się dawniej zachowałeś i jak dziś oceniasz ówczesne wydarzenia. O wielu sprawach nie miałeś wtedy pojęcia, wielu z nich nie mogłeś rozpoznać, ale ten film pomoże ci znaleźć właściwą odpowiedź: powie ci, jak to się stało, że nad Niemcami na dwanaście lat zapadła noc ${ }^{85}$.

82 Piotr Zwierzchowski, Spektakl i ideologia. Szkice o filmowych wyobrażeniach śmierci heroicznej, Kraków 2006, s. 103. Zob. też: Monika Brzóstowicz-Klajn, Smierci nie ma! (motyw), [w:] Słownik realizmu socjalistycznego, red. Zdzisław Łapiński, Wojciech Tomasik, Kraków 2004. Wzorcem „śmierci ofiarniczej” w kulturze stalinowskiej była oczywiście postać Czapajewa, w której - jak pisał Pudowkin - „przejawia się jaskrawo dążność ku przyszłemu socjalizmowi. On świadomie oddaje życie za tę przyszłość" (Wsiewołod Pudowkin, E. Smirnowa, Zwycięstwo prawdy bolszewickiej, tłum. A. Domalewski, „Przegląd Filmowy” 1950, nr 3-4, s. 3).

${ }^{83}$ Hermann Müller, Ernst Thälmann ist niemals gefallen, "Neues Deutschland", 8.10.1955.

${ }^{84}$ Ibidem.

${ }^{85}$ Joachim Bagemühl, Thälmann und unsere Nation, „Berliner Zeitung”, 9.10.1955. 
Sformułowania te wydają mi się szczególnie interesujące, bowiem, po pierwsze, mowa jest o "przypomnieniu” (czegoś najwyraźniej zapomnianego), po drugie zaś przyjęte zostało założenie o niewiedzy (,o wielu sprawach"), z którym zresztą fabuła filmu z lekka polemizuje.

Epos o Thälmannie (twórcy dyptyku otrzymali Nagrodę Państwową I stopnia) należał do „żelaznego" kanonu enerdowskiej propagandy jeszcze w latach 60. W RFN żadna z części nie mogła być dystrybuowana $\mathrm{w}$ kinach, najpewniej nie była również emitowana $\mathrm{w}$ telewizji (zarazem Thälmann pozostał jednym z oficjalnych bohaterów NRD - jego podobizny pojawiały się na znaczkach pocztowych w latach 80.). Kurt Maetzig w opublikowanych po latach wywiadach przyznawał, że o ile w I części dostrzega wartości artystyczne, część II dyptyku „wyraźnie odstaje, $\mathrm{z}$ uwagi na nadmiar materiału i idealizację postaci" ${ }^{86}$.

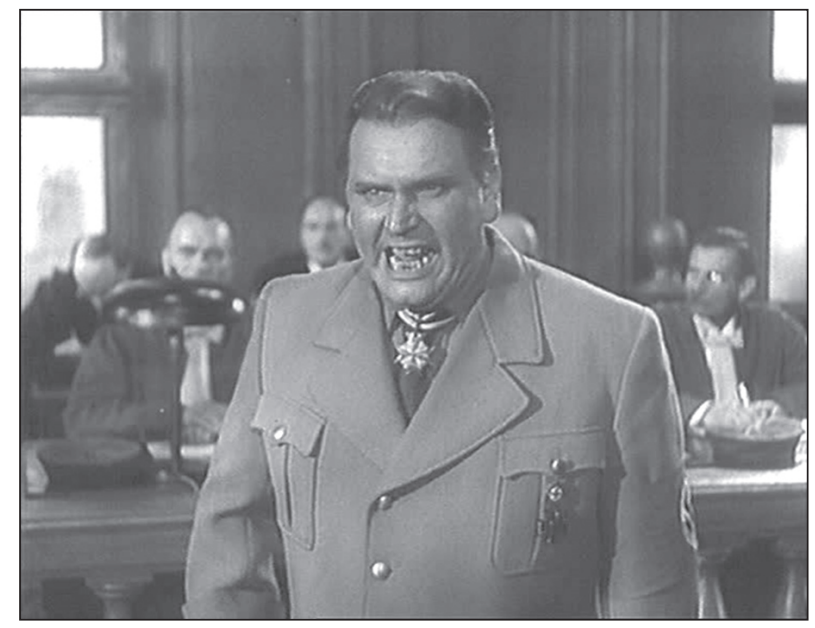

Fot. 12. W diabelskim kręgu (reż. Carl Balhaus, 1955) Horst Koch jako demoniczny Göring

Poza drugą częścią eposu o Thälmannie, akcja tylko jednego filmu zrealizowanego w omawianym okresie rozgrywała się w latach 30 . - W diabelskim kręgu (Der Teufelskreis, reż. Carl Balhaus, NRD 1955). Jest to - właśnie obok $W$ walce $z$ Hitlerem - jedna z niewielu enerdowskich realizacji, w których wśród postaci, wprawdzie w funkcji drugoplanowej, pojawiają się liderzy NSDAP (w tym wypadku Röhm i Göring - fot. 12). Fabuła rekonstruuje okoliczności podpalenia Reichstagu przez nazistów oraz oskarżenia o ten czyn komunistycznych działaczy: Bułgara Georgija

86 Wypowiedź w: Spur der Filme..., s. 96. 
Dimitrowa i Holendra Marinusa van der Lübbe (ten ostatni portretowany jest jako prowokator współpracujący z SA).

W kilku filmach Defy ewidentne jest adresowanie dyskursu do młodego pokolenia, poprzez wbudowanie w dramaturgię wątku "przekazania schedy" - zagwarantowania międzypokoleniowej ciągłości ideologicznej. Przykład stanowią choćby Silniejsi od nocy (Stärker als die Nacht, reż. Slátan Dudow, NRD 1954; twórcy filmu otrzymali Nagrodę Państwową II stopnia), opowiadający losy rodziny Löningów - robotników zaangażowanych w ruch oporu. Podobnie jak we wcześniejszych Czterech pokoleniach (zob. podrozdział 1.4), punktem ogniskującym wydarzenia jest postać kobieca - Gerda oczekuje dziecka, jej mąż Hans, działacz KPD, zostaje aresztowany i skazany na siedem lat więzienia. Gerda wychowuje dziecko sama, pozostając wierna mężowi oraz jego politycznym ideałom. Gdy Hans zostanie zwolniony z więzienia (Gestapo ma nadzieję aresztować jego współpracowników), Gerda pomaga mu organizować komórkę ruchu oporu w fabryce zbrojeniowej. W wyniku zdrady, w 1944 r. Hans wpada w ręce Gestapo; Gerda i jej syn unikają aresztowania.

Silniejsi od nocy są jednym z nielicznych enerdowskich filmów tego okresu, w którego narracji uwzględniono sekwencję obozową (nakręconą zresztą z inscenizacyjnym rozmachem, z dużą liczbą statystów). Oczywiście, jest ona podporządkowana głównemu tematowi, tj. komunistycznemu ruchowi oporu (w jednej ze scen więźniowie wspólnie śpiewają pieśni robotnicze). Zarazem w sekwencji tej pojawia się motyw rzadko występujący $\mathrm{w}$ filmach o obozach, mianowicie - zwolnienie z kacetu (mężczyźni w pasiakach życzą wychodzącemu na wolność wszystkiego dobrego, obiecując zarazem, że nie spoczną w swych działaniach na rzecz obalenia faszyzmu).

Interesujący w Silniejszych od nocy jest także sposób wprowadzenia pobocznych wątków pokazujących postawy Mitläuferów. W scenie balu nazistowskich przedsiębiorców jedna z dam inicjuje okrzyk: Sieg heil! Obraz ten zostaje "przytrzymany” i przenikaniem nałożony na kolejne ujęcia budujące sekwencję montażowa, którą można by nazwać „skutki nazistowskiego fanatyzmu" (składają się na nią następujące obrazy: niemieccy żołnierze na froncie wschodnim - cmentarz z prowizorycznymi krzyżami - małżeństwo otrzymuje wiadomość o śmierci syna - zrozpaczona twarz matki). Wprowadzony jest również wątek sąsiadów Löningów, którzy najpierw z zadowoleniem słuchają radiowych doniesień o zwycięstwach nad Armią Czerwoną, zaś pod koniec filmu - stoją bezradnie przed gruzami swego domu.

W recenzji Silniejszych od nocy, opublikowanej w 1954 r. w enerdowskim czasopiśmie „Weltbühne”, napisano: 
Bohater filmu Hans Löning nie nosi historycznego nazwiska ludzi takich, jak Edgar André, Ernst Schneller, Matthias Thesen, Ernst Thälmann i wielu innych - ludzi, którzy z podniesionym czołem szli na szafot, wiedząc, że Niemcy będą kiedyś z nich dumne. [...] List, który Löning pisze w celi śmierci do swojej żony, był pisany przez setki jemu podobnych ${ }^{87}$.

Ów pożegnalny list czytany jest przez żonę Hansa. Gdy jej głos słabnie, list przejmuje od niej syn, który kontynuuje lekturę „testamentu” ojca. Dziedzictwo ruchu komunistycznego z okresu III Rzeszy zostaje w ten sposób wręcz dosłownie (sic!) przekazane w ręce kolejnego pokolenia (w finale filmu jeszcze inni więźniowie będą cytować fragmenty listu Löninga). Słyszymy m.in.:

Moja kochana Gerdo, a więc to już, za godzinę po mnie przyjda [...]. Nie myśl o mojej śmierci, myśl o naszym życiu. O naszym bogatym, mądrym życiu. Narażaliśmy je zawsze, kiedy było trzeba. Ale nigdy nim nie gardziliśmy. Nikt nie kochał słońca bardziej niż my! Tylko jedno było dla nas ważniejsze - walka o nasz wielki cel. I kiedy teraz, w mojej ostatniej godzinie, kieruję wzrok ku przyszłości, to radość rozpiera mi pierś, bo tuż przed soba, blisko, w zasięgu ręki, widzę ten nasz cel: ze zmartwień, biedy i potu zrodzi się on - promienny nowy świat, wolny od nienawiści i wojen.

Film kończy się typową socrealistyczną apoteozą: widokiem powojennych fabryk i uniwersytetu Humboldta w Berlinie Wschodnim, pól dorodnej kukurydzy oraz fal uderzających o brzeg ${ }^{88}$, na którym młody Hans $\mathrm{z}$ narzeczoną podziwiają morze ${ }^{89}$.

Podobny happy end czeka tytułowego bohatera filmu Amigo (Sie nannten ihn Amigo, reż. Heiner Carow, NRD 1959), Rainera Meistra nazywanego "Amigo". Latem 1939 r. wraz z dwójką kolegów trafia on na uciekiniera z obozu dla więźniów politycznych, przedstawiającego się jako Pepp. Amigo, zdając sobie sprawę z możliwych konsekwencji (jego ojciec Walter, działacz komunistyczny, był wcześniej aresztowany), pomaga mężczyźnie ukryć się, a następnie dostarcza mu pożywienie. Jeden z kolegów, Sine, dowiaduje się o tym i mimowolnie staje się zdrajcą: kradnie swemu ojcu, zdeklarowanemu naziście, służbową kurtkę, którą przekazuje Peppowi. Ojciec Sine zgłasza kradzież policji, wskazując na rodzinę Meisterów jako potencjalnych winowajców. Amigo, chcąc odwrócić podejrzenia od swojego ojca (który i tak zostanie aresztowany przez Gestapo i skazany

87 Cyt. za: Obrazy Niemiec 1949-1999. Katalog przegladu, red. Grażyna M. Grabowska, Renata Prokurat, Warszawa 1999, s. 26.

${ }^{88}$ Jak zauważa Ralf Schenk, w finale tym następuje „zrównanie porządku socjalistycznego z naturalnym” (Mitten im Kalten Krieg 1950 bis 1960..., s. 118).

89 Opozycja śmierć - życie oraz motyw uosabianego przez przyrodę nowego świata budowanego dzięki ofierze krwi bohaterów była chętnie wykorzystywana w filmach sowieckich (przykładem Ziemia Aleksandra Dowżenki, 1930). 
na śmierć), a zarazem umożliwić ucieczkę Peppa, przyznaje się do kradzieży. Trafia do obozu koncentracyjnego (fot. 13), gdzie udaje mu się przetrwać najpierw dzięki pomocy "starych towarzyszy”, a następnie dzięki Armii Czerwonej, która wyzwala obóz.

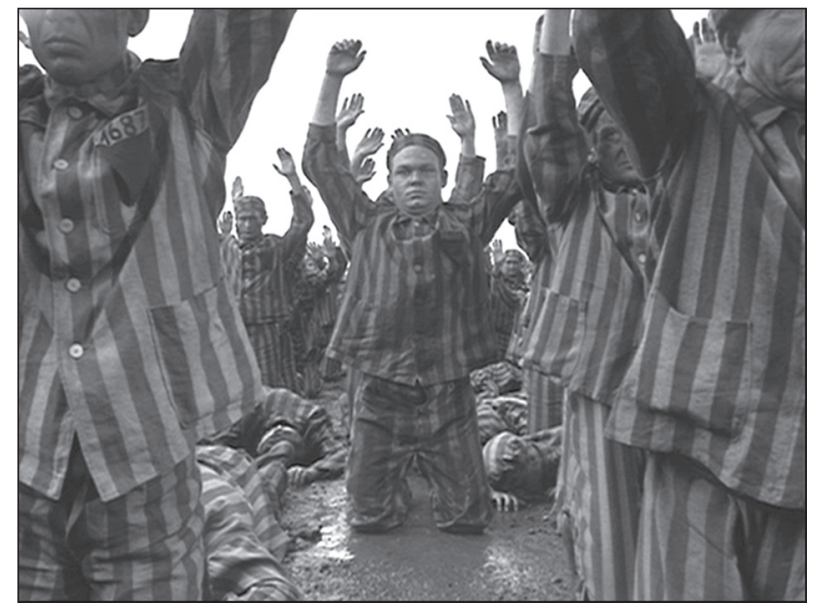

Fot. 13. Amigo (reż. Heiner Carow, 1959)

Ernst-Georg Schwill w roli tytułowego bohatera

Polityczne przesłanie tej zręcznie opowiedzianej historii akcentuje przede wszystkim znaczenie ruchu komunistycznego (prosząc Amigo o pomoc, uciekinier z kacetu deklaruje: Moje życie jest ważne dla partii) - jego wszechobecność, a także "braterską solidarność" pomiędzy towarzyszami $^{90}$. W plakatowym finale, rozgrywającym się już $\mathrm{w}$ NRD, a przedstawiającym manifestację wiwatujących obywateli, Amigo powraca - już w mundurze ludowej armii, jako dowódca czołgu (później Carow usunął tę scenę i w tej okrojonej wersji film miał być pokazywany $\mathrm{w}$ enerdowskiej telewizji w latach $\left.70 .{ }^{91}\right)$.

O ruchu antyfaszystowskim (choć w tym wypadku akcja obejmuje ostatnie lata Republiki Weimarskiej) traktuje też film Lissy (reż. Konrad Wolf, NRD 1957) na podstawie powieści Franza Weiskopfa z 1931 r. ${ }^{92}$ Ty-

${ }^{90}$ Pochodząca z filmu piosenka Wer möchte nicht im Leben bleiben („,Któż nie chce pozostać przy życiu” - słowa: Wera Küchenmeister, muzyka: Kurt Schwaen) należała do „żelaznego kanonu" enerdowskiej młodzieżówki komunistycznej.

${ }_{91}$ Informacja za: Lexikon des internationalen Films (http://www.zweitausendeins.de/ filmlexikon, dostęp: 30.04.2014). W wersji dostępnej na DVD uwzględniono „epilog z czołgiem".

${ }^{92}$ Franz Carl Weiskopf, Lissy: powieść, tłum. S. Kaltman, Warszawa 1963. Współautorką scenariusza filmu była Alex Wedding (Grete Bernheim), w okresie Republiki Weimarskiej 
tułowa bohaterka, córka socjaldemokratycznego rzemieślnika, wiąże się z przystojnym urzędnikiem Freddym. $Z$ powodu ciąży zostaje zwolniona z pracy; również jej wybranek traci posadę (żydowskie pochodzenie jego przełożonego jest $\mathrm{w}$ filmie kilkakrotnie wzmiankowane), w konsekwencji czego zostaje nazistowskim bojówkarzem. Do SA wstępuje również Paul, brat protagonistki, wcześniej związany z komunistami; zostaje jednak zamordowany przez towarzyszy Freddy'ego, którzy obarczają odpowiedzialnością za ten czyn właśnie komunistów i zamieniają pogrzeb Paula $\mathrm{w}$ inscenizację ku czci męczennika ruchu nazistowskiego. Kiedy dowódca SA mówi: Każdy z nas musi podjać decyzję - Freddy przybliża się do flagi ze swastyka, Lissy z kolei odwraca się od niej (fot. 14). Gdy w ostatnim ujęciu kobieta idzie zadrzewioną aleją w stronę kamery, głos ponadkadrowy dopowiada: Tak, każdy z nas musi dokonać wyboru. Lissy zrozumiała, że można być samotnym, nie będac osamotnionym. Wiedziała, że istnieje droga, trudna i wymagajaca wysitku, ale zarazem godna i szczera.

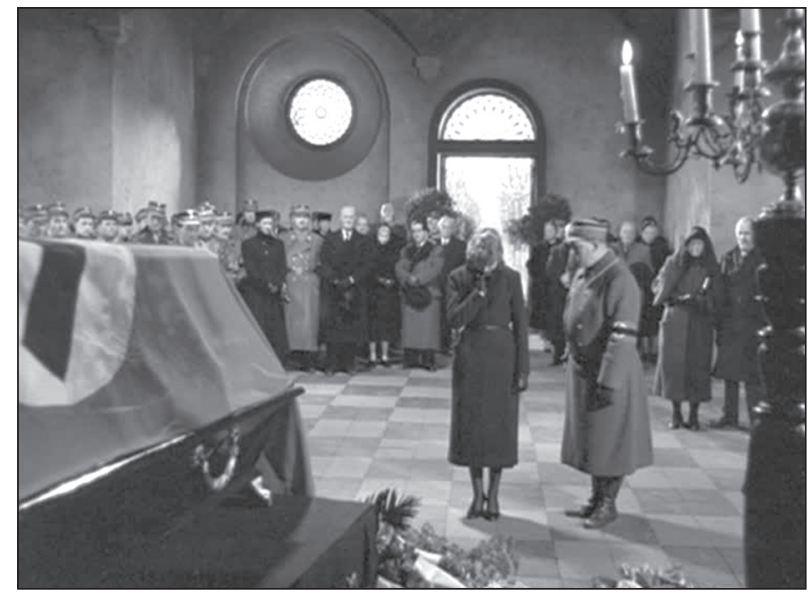

Fot. 14. Lissy (reż. Konrad Wolf, 1957)

„Ci, którzy nie są z nami, są przeciw nam" - bohaterowie postawieni przed wyborem politycznej afiliacji

Pod względem dramaturgicznym film wykazuje wiele podobieństw do wcześniejszej Rotacji/Brunatnej pajęczyny; innowacją jest zbudowanie akcji wokół kobiety, postaci ciekawie zresztą pomyślanej - w odróżnieniu od pozostałych, jednowymiarowych bohaterów, ukształtowanych jeszcze według socrealistycznej sztancy. Podobnie jak w Toporze z Wandsbeck, pojawia się motyw fałszywego oskarżenia - naziści zarzucają komunistom

związana z Carlem Weisskopfem, działaczem KPD. Debiutowała w 1931 r. jako autorka literatury dla dzieci, którą zajmowała się także - po powrocie z emigracji w USA - w NRD. 
mord, którego sami dokonali. Pod względem wizualnym natomiast Lissy nasuwa skojarzenia $\mathrm{z}$ filmami weimarskimi - odbicia postaci w szybach wystawowych przypominają analogiczne ujęcia z M Langa czy Opery za trzy grosze Pabsta, zaś scena, w której bohater wędruje od drzwi do drzwi w poszukiwaniu pracy, nawiązuje wyraźnie do podobnej sceny z Kuhle Wampe Dudowa ${ }^{93}$. Tropy te nie zostały dostrzeżone przez enerdowską krytykę po premierze filmu. Zebrał on chłodne opinie: w „Die Weltbühne” uznano zakończenie za nazbyt otwarte, a przesłanie antyfaszystowskie - za zbyt słabe ${ }^{94}$. Inny recenzent utyskiwał, że komunista, który odgrywał ważną rolę w powieści, w filmie został zmarginalizowany ${ }^{95}$.

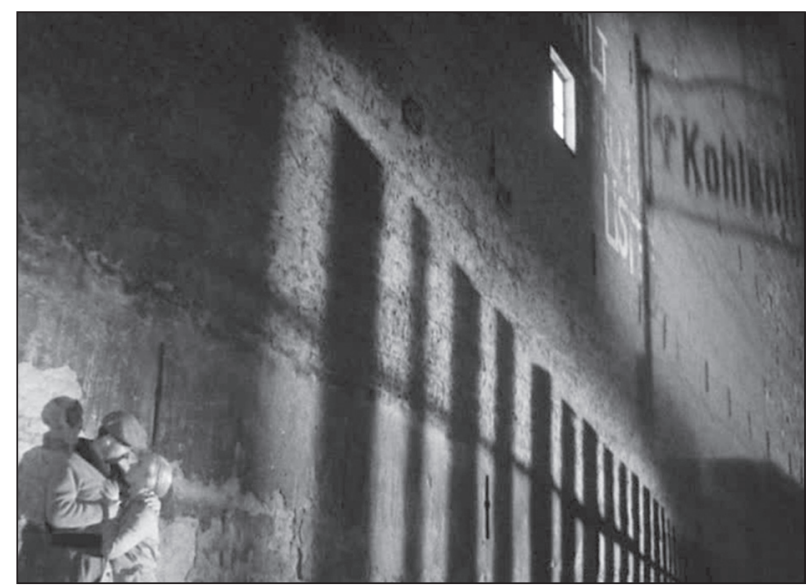

Fot. 15. Królewskie dzieci (reż. Frank Beyer, 1962)

Przykład kunsztu operatorskiego

Güntera Marczinkowskiego

W melodramatyczną opowieść splecione zostają natomiast losy bohaterów Królewskich dzieci (Königskinder, reż. Frank Beyer, NRD 1962), wbrew tytułowi (o którym będzie jeszcze mowa) pochodzących z berlińskich rodzin robotniczych. Miłosny trójkąt tworzą: Magdalena i kochający ją dwaj mężczyźni: Michael (członek partii komunistycznej) oraz Jürgen (który angażuje się w ruch nazistowski). Gdy Michael zostaje schwytany i trafia do więzienia na piętnaście lat, Magdalena kontynuuje jego polityczną misję. Początkowo w trudnych chwilach pomaga jej Jürgen (choć

${ }_{93}$ Michael Wedel, Filmgeschichte als Krisengeschichte. Schnitte und Spuren durch den deutschen Film, Bielefeld 2011, s. 345. Zob. także: Madina Spoden, „Lissy” (1957). Gedanken beim neuerlichen Sehen, "Beiträge zur Film- und Fernsehwissenschaft” 1990, nr 39.

${ }_{94}$ Udo Klaus, „.... doch alle Fragen bleiben offen”, „Die Weltbühne”, 10.09.1957.

95 Wolfgang Joho, Ein mahnendes Schicksal, „Sonntag”, 9.06.1957. 
jest już członkiem SA), później kobieta zmuszona jest uciekać do Moskwy. Podczas wojny Michael zostaje wybrany do batalionu karnego (słynnego Strafbatallion 999, o którym film nakręcono także w RFN!). Kiedy na froncie spotyka Jürgena, obaj przechodzą na stronę Armii Czerwonej (godny wspomnienia jest dialog, w którym żołnierze debatują z jakiej gazety lepiej skręcić papierosy: $\mathrm{z}$ „Prawdy” czy z „Izwiestii”). W ostatniej scenie, gdy Magdalena zostaje wysłana $\mathrm{z}$ tajną misją z powrotem do ojczyzny (a konkretnie: do Królewca), na lotnisku zauważa ją Michael. Ona jednak, nieświadoma obecności ukochanego, wsiada na pokład samolotu, który Michael będzie jeszcze starał się dogonić...

Po premierze film zebrał dobre recenzje ${ }^{96}$ - zasłużenie, gdyby za główne kryterium oceny obrać kunszt pracy operatorskiej (na uwagę zasługuje zwłaszcza doskonale zmontowana sekwencja, w której poddawany musztrze bohater przypomina sobie idylliczne chwile z Magdaleną). Epizodyczna i achronologiczna konstrukcja oparta jest na retrospekcjach - eksponujących motyw zdrady (Michael jako ofiara zdrady dziecka; Magdalena zadenuncjowana przez koleżankę; Jürgenowi zarzuca się zdradę ideałów; sowieci nie dowierzają zbiegom itp.) oraz wykorzystujących wizualne leitmotywy (schody, studnia, woda, karuzela) w pieczołowicie skomponowanych kadrach (fot. 15) ${ }^{97}$. Zakończenie jest pozornie otwarte - zarazem jednak można domniemywać, że bohaterowie, choć „zjednoczeni sprawą”, już nigdy się nie zobaczą. Konstrukcja dramaturgiczna nawiązuje bowiem do, zwieńczonej tragicznym finałem, ludowej pieśni Es waren zwei Königskinder (na trop ten wskazuje zresztą sam tytuł). Opowiada ona o królewiczu i królewnie, których miłość nie może się ziścić, gdyż oddzieleni są od siebie „wielką wodą” (choć oczywiście faktycznymi „przeszkodami” są tu faszyzm i wojna).

\subsection{Honor munduru}

W odróżnieniu od Republiki Federalnej Niemiec, w sferze publicznej NRD neutralne czy wręcz pozytywne oceny niektórych aspektów polityki narodowosocjalistycznej nie mogły być obecne. Zakazano działalności stowarzyszenia byłych żołnierzy, nie wydawano - tak popularnych

${ }^{96}$ Hartmut Albrecht, Das Licht der Königskinder, "Nationalzeitung”, 1.06.1962; Christoph Funke, Ballade einer Liebe, "Morgen”, 4.09.1962; Fred Gehler, Ein Film der künstlerischen Konsequenz, „Deutsche Filmkunst” 1962, nr 2; Horst Knietzsch, Sie konnten zusammen nicht kommen, "Neues Deutschland”, 11.09.1962.

${ }_{97}$ Regie: Frank Beyer..., s. 173. 
w RFN - czasopism i książek sławiących boje II wojny światowej, noszenie orderów przyznanych w okresie III Rzeczy było niedozwolone ${ }^{98}$. Godności i honoru niemieckiego (powojennego) munduru nie można było zatem sławić w sposób podobny do tego, który rozpowszechniony był w RFN ${ }^{99}$. Nic więc dziwnego, że cechą szczególną kina NRD stała się niewielka - w porównaniu z kinematografiami tak zachodniego, jak i wschodniego jej sąsiada - liczba filmów wojennych ${ }^{100}$. Co prawda, podobnie jak w RFN, również w państwie wschodnioniemieckim finansowanie uzyskiwały fabuły, które uzasadniały konieczność restytucji niemieckiej armii (w 1956 r., ledwie kilka miesięcy po powołaniu Bundeswehry w RFN, w NRD ustanowiono Narodową Armię Ludową [Nationale Volksarmee - NVA], a w 1962 r. wprowadzono obowiązek służby wojskowej) ${ }^{101}$. Ale $\mathrm{w}$ wypadku NRD film wojenny był gatunkiem kłopotliwym z uwagi na fakt, iż w oficjalnej polityce historycznej za „największą zbrodnię niemieckiego faszyzmu” ${ }^{102}$ uznawano napaść na ZSRR.

Od takich ograniczeń wolne były realizacje, których akcja rozgrywała się przed II wojną światową przy czym szczególnie chętnie przywoływano epizody z wojny domowej w Hiszpanii. Poza wspomnianą fabułą o Thälmannie, gdzie tym wydarzeniom poświęcono kilka sekwencji, w NRD zrealizowano kilka filmów o Spanienkrieg, m.in.: Dokądkolwiek pójdziesz... (Wo du hin gehst..., reż. Martin Hellberg, 1957), według powieści Eduarda Claudiusa, a rok wcześniej - Pić mi się chce

98 Thomas Ahbe, Der DDR-Antifaschismus. Diskurse und Generationen, Kontexte und Identitäten, Sachsen 2007, s. 29.

${ }_{99} \mathrm{~W}$ tym kontekście interesujące wydają się wnioski historyków sugerujących, że komunikacyjna (przekazywana bezpośrednio) pamięć Wehrmachtu w NRD nie różniła się zbytnio od tej, która dominowała w RFN (zob. Karin Hartewig, Militarismus und Antifaschismus: Die Wehrmacht im kollektiven Gedächtnis der DDR, [w:] Der Krieg in der Nachkriegszeit: Der Zweite Weltkrieg in Politik und Gesellschaft, red. Michael T. Greven, Oliver von Wrochem, Opladen 2000).

100 Zwraca na to uwage Thomas Heimann, Erinnerung als Wandlung. Kriegsbilder im frühen DEFA-Film, [w:] Geschichte als Herrschaftsdiskurs. Der Umgang mit der Vergangenheit in der DDR, red. Martin Sabrow, Weimar 2000. W odniesieniu do polskiego kina lat 60. zob.: Piotr Zwierzchowski, Kino nowej pamięci. Obraz II wojny światowej w kinie polskim lat 60., Bydgoszcz 2014.

${ }^{101}$ Dobry przykład strategii, jaką posługiwali się enerdowscy twórcy w filmach uzasadniających restytucję armii, stanowi Krok za krokiem (Schritt für Schritt, reż. János Veiczi, NRD 1960). Pacyfistycznie nastawiony bohater jest tu zatroskany decyzją syna o wstąpieniu do Narodowej Armii Ludowej, dopiero rozmowa z weteranem ruchu oporu oraz odwiedziny Buchenwaldu pozwalają mu zaakceptować ten wybór.

102 Thomas Ahbe, Der DDR-Antifaschismus..., s. 15. Autor przywołuje zatytułowane w ten sposób rozdziały z enerdowskich podręczników do historii z 1961 r. 
(Mich dürstet, reż. Karl Paryla) - na podstawie prozy Waltera Gorrisha, weterana Brygad Międzynarodowych ${ }^{103}$. Jego powieść posłużyła także jako pierwowzór scenariusza najważniejszego filmu - Pięciu łusek (Fünf Patronenhülsen, reż. Frank Beyer, NRD 1959), opowiadającego o internacjonalistycznym oddziale, którego członków wskazuje komisarz Witting (Niemiec). W skład grupy wchodzą: Francuz Pierre, Niemiec Willi, Polak Olek (czy raczej "Oleg” - jak przedstawiają bohatera napisy), Hiszpan José i Bułgar Dimitri, a także telegrafista Wasia, Rosjanin ${ }^{104}$ (w obsadzie odliczyli się gwiazdorzy enerdowskiego kina, m.in. Manfred Krug, Erwin Geschonneck i Armin Mueller-Stahl). Narodowości bohaterów są jednak $\mathrm{w}$ zasadzie nieodróżnialne - scenariusz rezygnuje $\mathrm{z}$ charakterystyk odwołujących się do stereotypów, preferując „internacjonalistyczne" nacechowanie postaci.

Pomysł dramaturgiczny Pięciu tusek jest następujący: ochraniając wycofujący się batalion republikanów, oddział zamierza przebić się przez teren zajęty przez wojska frankistów. Śmiertelnie ranny Witting drze kartkę papieru na pięć części, które wkłada do zużytych naboi; każdy z żołnierzy otrzymuje po jednym - z rozkazem dostarczenia tej ważnej przesyłki do dowództwa. Ważna informacja będzie mogła zostać odczytana jedynie wówczas, gdy zostanie złożona w całość. I choć nie wszystkim udaje się przeżyć, wiadomość dociera do adresata - brzmi ona: Trzymajcie się razem, tylko wtedy przetrwacie. Naturalnie, komunikat ten wykraczał poza fikcjonalne ramy, stając się wykładnią "braterstwa narodów" bloku wschodniego.

Film Beyera przypomina sowiecką fabułę Bohaterowie pustyni (Тринади̧ать, reż. Michaił Romm, ZSRR 1937), w której grupa rewolucjonistów znajduje się w potrzasku na malowniczym pustkowiu. Wizualne walory plenerów (Pięć łusek kręcono w Bułgarii) sprawiły, że film Beyera bywał określany jako „pierwszy western Defy”105 (fot. 16). Oczywiście, takie porównanie nie mogło pojawić się $\mathrm{w}$ - niezmiernie pochlebnych - recenzjach opublikowanych po premierze ${ }^{106}$. Podkreślano w nich,

${ }^{103}$ Obie powieści przełożono na język polski: Eduard Claudius, Zielone oliwki i nagie skały, tłum. J. Rawicz, Warszawa 1958; Walter Gorrish, Za wolność Hiszpanii, tłum. O. i J. Ziemilscy, Warszawa 1951.

${ }^{104}$ W czołówce bohaterowie - za wyjątkiem Wasi - przedstawieni zostali narodowościami („Bułgar”, „Niemiec”, „Hiszpan”). Wskutek interwencji komisji kolaudacyjnej postać telegrafisty podpisano "Związek Radziecki” (Regie: Frank Beyer..., s. 35).

105 Ibidem, s. 34.

106 Hartmut Albrecht, Fünf Patronenhülsen, „Nationalzeitung”, 30.10.1960; Christoph Funke, Fünf Patronenhülsen, „Sonntag” 1960, nr 46; Hans Ulrich Eylau, Fünf Patronenhülsen, „Berliner Zeitung”, 10.11.1960; Rudi Strahl, Fünf Patronenhülsen, „Filmspiegel” 1960, nr 24; Horst Knietzsch, Helden unter spanischem Himmel, „Neues Deutschland”, 4.11.1960. 
że heroizm bohaterów prezentowany jest nie poprzez batalistykę (film nie pokazuje zwycięskiej bitwy, a na dodatek rozpoczyna się od rozkazu wycofania batalionu), lecz solidarną postawę towarzyszy broni.

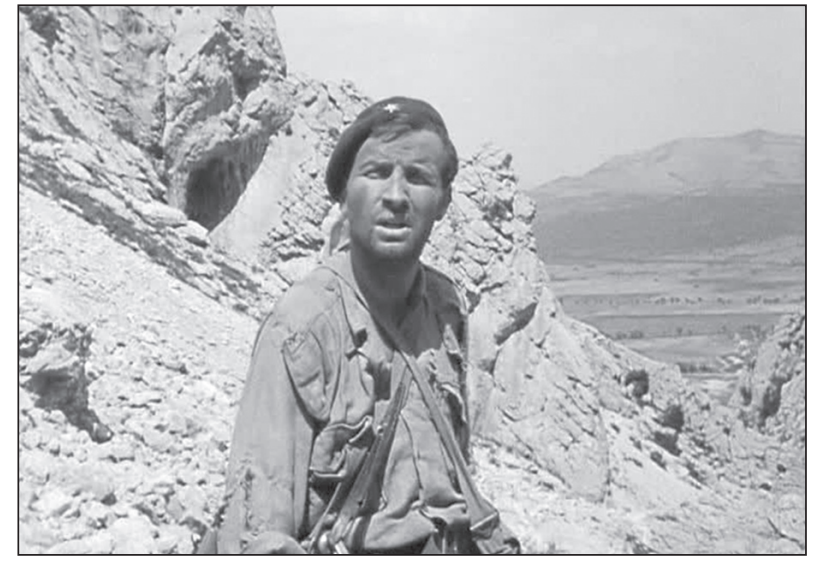

Fot. 16. Pięć łusek (reż. Frank Beyer, 1959

Westernowa sceneria $\mathrm{w}$ filmie antyfaszystowskim

W omawianym okresie zrealizowano w NRD zaledwie kilka filmów, których akcja koncentrowała się na latach II wojny światowej. Za pierwszy wojenny film Defy uważa się Oszukanych (Betrogen bis zum jüngsten Tag, reż. Kurt Jung-Alsen, NRD 1957). Fabularnym punktem wyjścia jest wypadek przy polowaniu, jaki podczas przepustki powoduje trójka żołnierzy Wehrmachtu: Paulun, Wagner i Lick (ten ostatni jest synem generała SS). Przypadkowo popełniwszy morderstwo na przechadzającej się nieopodal dziewczynie - córce jednego z oficerów, próbują oni zatuszować swój czyn, kierując podejrzenia na sowiecką partyzantkę (co ciekawe, scena ukrycia ciała dziewczyny jest zmontowana w taki sposób, że ani razu go nie widzimy - jakby pokazanie żołnierzy topiących zwłoki w polnym bagnie mogło zostać uznane za obraz zbyt drastyczny $)^{107}$. Gdy w dniu inwazji Niemiec na ZSRR (!) ciało zostaje odnalezione (a obok niego - sowiecki karabin), znający prawdę generał SS wykorzystuje ten fakt dla celów propagandowych ${ }^{108}$. Roztrzęsiony po śmierci córki kapitan

107 Horst Knietzsch, Film gestern und heute. Gedanken und Daten zu sieben Jahrzehnten Geschichte der Filmkunst, Lepizig 1967, s. 250; Klaus Wischniewski, Einzelfall oder Verallgemeinerung? "Betrogen bis zum jüngsten Tag”, "Deutsche Filmkunst. Zeitschrift für Theorie und Praxis des Filmschaffens" 1957, nr 4, s. 98.

108 Skierowanie winy przez Niemców na Rosjan może budzić, szczególnie u polskiego widza (i na zasadzie logiki à rebours), skojarzenia z kłamstwem katyńskim - o którym, naturalnie, w NRD nie można było mówić (o czym wspominam z uwagi na fakt, iż film Alsena był dystrybuowany w PRL - zob. na przykład: Władysław Leszczyński, Niemcy o sobie, „Film” 1957, nr 49). 
w odwecie zabija jeńców (zbrodnia ma więc też motywację osobistą i nie jest spowodowana jedynie narodowosocjalistyczną ideologią $\left.{ }^{109}\right)$, czym wywołuje wyrzuty sumienia u Pauluna, który postanawia przyznać się do winy. Ale Lick ogłasza go psychicznie chorym, a następnie, podczas eskortowania chłopaka do szpitala, zabija. Jedyną osobą która może wyjawić prawdę, jest Wagner... Film ten - po swej premierze porównywany w publikacjach krytycznych z Kanałem Wajdy (1957) - pokazywany był na festiwalu w Cannes (ale z uwagi na protest delegacji z Bonn nie uwzględniono go w programie konkursu ${ }^{110}$ ).

Istotną częścią historii kina są filmy, które - z przyczyn politycznych (szczególnie istotnych $\mathrm{w}$ przypadku kinematografii państw niedemokratycznych) lub innych - ostatecznie nie powstały. Z uwagi na skąpą ilość fabuł wojennych Defy warto wspomnieć o nieukończonym projekcie filmu Dom w ogniu (Haus im Feuer), przygotowanym przez Herberta Ballmanna na podstawie powieści poczytnego autora, Harry'ego Thürka ${ }^{111}$. Film miał opowiadać o niemieckich żołnierzach, którzy w 1944 r. zostają przerzuceni - w sowieckich mundurach - do Prus Wschodnich z misją sabotażu. W domu, w którym się zatrzymuja, oprócz gospodyni, Niemki Ingi, przebywa jeszcze głuchoniemy mężczyzna. Okazuje się on oficerem Armii Czerwonej, który wskutek poniesionych ran nie zdążył dołączyć do swego oddziału w momencie zmiany linii frontu. Główny bohater, podchorąży Bindig, ulega prośbie gospodyni, by nie ujawniać zbiega. Gdy sowieci ponownie zajmują wioskę, zaś znienawidzony przez Bindiga podoficer chce zniszczyć dom Ingi, bohater strzela do niego, a podczas ucieczki (w czasie której mężczyzna nadal ma na sobie mundur Armii Czerwonej) sam zostaje zastrzelony przez niemiecki oddział. Materiał ten nie został zaakceptowany przez władze Defy, które skierowały projekt do przeróbki (odpowiedzialny za nią miał być już inny reżyser, Carl Balhaus). W poprawionym scenariuszu rozwinięto postać rosyjskiego oficera, wprowadzono nowego bohatera (antyfaszystę, który miał uniemożliwić śmierć sowieckich żołnierzy) oraz zmieniono zakończenie (Bindig miał dobrowolnie oddać się do niewoli). Ale i ta wersja nie spotkała się z aprobatą (można tylko spekulować, z jakich powodów) - projekt popadł w zapomnienie, a jego pomysłodawca, Herbert Ballmann, opuścił NRD w 1959 r.

109 Między innymi z tego powodu pięć lat po premierze ministerialni nadzorcy Defy podjęli próbę wycofania filmu z dystrybucji (argumentując, że film podkreśla dystans między Wehrmachtem a SS, a tym samym zbliża swą wymowę do erefenowskiej propagandy). Ostatecznie, w 1963 r. podjęto decyzję o podtrzymaniu zgody na dalsze pokazy filmu (Ralf Schenk, Mitten im kalten Krieg..., s. 122).

110 Ibidem.

111 Informacje o Domu w ogniu podaję za: Ralf Schenk, Mitten im kalten Krieg..., s. $123-124$. 
„Pustym miejscem” pamięci historycznej był - i do pewnego stopnia nadal jest $\mathrm{w}$ już zjednoczonych Niemczech - wrzesień 1939 r., czego świadectwem pozostaje nikła obecność tego tematu $\mathrm{w}$ kinie niemieckim. Uwaga ta dotyczy zarówno kinematografii RFN - bowiem zrealizowano tam tylko jeden film, którego akcja rozgrywa się w Polsce w pierwszych dniach wojny (Pierwsza polka [Die erste Polka], reż. Klaus Emmerich, RFN 1979) - jak i NRD. W odniesieniu do produkcji Defy z omawianego okresu wskazać można również jeden tytuł - Tu Radio Gliwice! (Der Fall Gleiwitz, reż. Gerhard Klein, NRD 1961) ${ }^{112}$ - i to z zastrzeżeniem, że dotyczy on niemieckiej prowokacji z końca sierpnia $1939 \mathrm{r}$.

Scenariusz tego filmu, autorstwa Wolfganga Kohlhaasa i Güntera Rückera ${ }^{113}$, został oparty na zeznaniach oficera SS Alfreda Naujocksa, dowódcy grupy dywersyjnej, która brała udział w prowokacji gliwickiej ${ }^{114}$. Pod względem dramaturgicznym, realizacja Kleina wyłamuje się z wykorzystywanych przez twórców Defy fabularnych schematów związanych $\mathrm{z}$, mitami założycielskimi” NRD - przede wszystkim dlatego, że głównym bohaterem czyni esesmana (właśnie Naujocksa). Wprawdzie migawkowe retrospekcje dotyczące jego kariery prowadzone są zgodnie z obowiązującym kluczem politycznym (akcentującym "pruski dryl” i militaryzm jako ważne źródła faszyzmu), ale zarazem w sekwencje te włączone zostają liczne ujęcia subiektywizujące (także ujęcia POV), a zatem chwyty, których używa się często w celu „intymnego" przedstawienia postaci. Drugim ważnym bohaterem - choć nie wypowiada on ani słowa, pozostając jedynie niemym świadkiem, czy raczej mimowolnym uczestnikiem działań Naujocksa - jest Polak „wypożyczony” z obozu dla więźniów politycznych i w charakterze "konserwy” (tego kryptonimu używano podczas prowokacji, słowo to pojawia się także $\mathrm{w}$ filmie ${ }^{115}$ ) przewieziony na teren przygraniczny. Chłopak zostaje przebrany w polski mundur, uśpiony, a następnie zastrzelony na terenie niemieckiej radiostacji (w celu

112 Ulrich Tempel, Wrzesień 1939: „Tu Radio Gliwice!" Gerharda Kleina i „Lotna” Andrzeja Wajdy, tłum. D. Codogni-Łańcucka, [w:] W drodze do sasiada. Polsko-niemieckie spotkania filmowe, red. Andrzej Dębski, Andrzej Gwóźdź, Wrocław 2013, s. 318. Autor słusznie zaznacza, że wątki wrześniowe pojawiają się również w Blaszanym bębenku (Die Blechtrommel, reż. Volker Schlöndorff, RFN-Francja 1979).

113 Zob. Hannes Schmidt, Werkstatterfahrungen mit Gerhard Klein, „Aus Theorie und Praxis des Films" 1984, nr 2 oraz Wolfgang Kohlhaase, Der Fall Gleiwitz, [w:] Spur der Filme...

114 Biografia Naujocksa doczekała się wielu naukowych i popularnonaukowych opracowań. W języku polskim zob. Roman Cilek, Kulisy tajnych stużb Trzeciej Rzeszy: Alfred Naujocks, tłum. R. Majewski, Warszawa 1998; Andrzej Konieczny, Tajna broń Reinharda Heydricha, Katowice 1984.

115 A także w Operacji Himmler (reż. Zbigniew Chmielewski, Polska 1979) - nieudanym polskim filmie fabularnym o tych zdarzeniach. 
sfingowania polskiego ataku). Sceny z tą postacią również odznaczają się sporą liczbą ujęć subiektywizujących, dzięki którym film wykracza poza klasyczną narrację, zazwyczaj używaną przez twórców Defy.

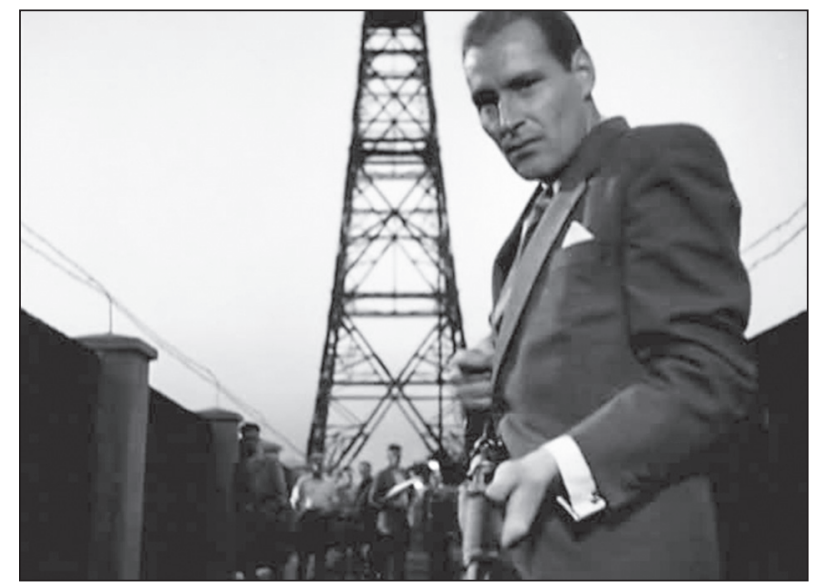

Fot. 17. Tu Radio Gliwice! (reż. Gerhard Klein, 1961) Hannjo Hasse jako Helmut Naujocks

Oryginalność dzieła Kleina wiąże się jednak przede wszystkim z wykorzystaniem chwytów wizualnych właściwych rozmaitym modelom sztuki filmowej (autorem zdjęć - częściowo wykonanych w Gliwicach - był czeski operator Jan Čuřik). Niektóre sceny zbudowane są zgodnie z estetyką filmu ekspresjonistycznego - wykorzystują niski klucz świetlny z wyraźnymi światłocieniami oraz nietypowe ustawienia kamery, zaburzające standardową perspektywę widzenia (fot. 17). Duże zbliżenia na przedmioty i elementy architektury, filmowane niczym „obiekty samoistne” w kolażach Lászla Moholy-Nagy'ego, budzą skojarzenia z estetyką „,nowego widzenia" niemieckiej awangardy lat 20. ${ }^{116} \mathrm{Z}$ kolei symetryczna kompozycja kadru oraz ujęcia przypominające Kracauerowski „,ornament z masy" (ujęcia fechtujących żołnierzy filmowane z góry) stanowią kwintesencję estetyki faszyzmu. Nieprzypadkowo zresztą ważną rolę w fabule odgrywają rozmaite media i przekazy medialne - fragmenty kronik i filmów rozrywkowych nakręconych w III Rzeszy, a także nadawane przez radio komunikaty, szlagiery oraz muzyka klasyczna (za ścieżkę dźwiękową odpowiedzialny był współpracownik Brechta, Kurt Schwaen). Ich funkcja staje się szczególnie istotna z uwagi na zredukowane dialogi.

116 Zob. Birgit Schapow, Abseits ausgetretener Pfade - „Der Fall Gleiwitz”, [w:] DEFA International... 
Kontrapunktowe wobec warstwy wizualnej użycie ścieżki dźwiękowej, chwyt stosunkowo rzadko stosowany w kinie klasycznym, w Tu Radio Gliwice! wykorzystywane jest niezwykle kunsztownie (zwłaszcza w ostatniej sekwencji: ujęciom pokazującym przygotowania do ataku na radiostację towarzyszą propagandowe wiadomości, a w scenie napadu hałas zlewa się z operetkową arią).

Prace nad filmem zostały podjęte z myślą o obchodach 20. rocznicy wybuchu wojny (mówił o tym współscenarzysta filmu, Günter Rücker ${ }^{117}$ ), ale premiera w $1961 \mathrm{r}$. odbyła się już w ramach innych uroczystości:

\begin{abstract}
„Defa zrealizowała ten film jako ostrzeżenie i napomnienie dla uczczenia piętnastolecia zjednoczenia Komunistycznej Partii Niemiec (KPD) i Socjaldemokratycznej Partii Niemiec (SPD)" - powiedział reżyser Gerhard Klein po premierze w berlińskim kinie Babylon przed zgromadzonymi gośćmi z kraju i zagranicy, którzy wzięli udział w seansie z okazji uroczystości otwarcia muzeum na terenie obozu koncentracyjnego Sachsenhausen ${ }^{118}$.
\end{abstract}

W prasie enerdowskiej ukazało się kilka pozytywnych recenzji, ale recepcja filmu nie była zbyt intensywna (być może wpłynął na to fakt wybudowania muru berlińskiego kilka miesięcy po premierze - niekoniecznie dobry czas na roztrząsanie estetycznych walorów dzieła, które w żaden sposób nie dotyczyło zachodniej części Niemiec). Co ciekawe, dwa lata po wejściu do dystrybucji w NRD film został dopuszczony do pokazywania w RFN, w niszowym obiegu niekomercyjnych klubów filmowych ${ }^{119}$ i zebrał kilka pochlebnych recenzji ${ }^{120}$. Przede wszystkim jednak przyczynił się do przypomnienia okoliczności wybuchu wojny - w „Der Spiegel” ukazał się nawet wywiad z Naujocksem, który opowiadał o szczegółach prowokacji121.

W I połowie lat 60. nakręcono w NRD jeszcze dwa filmy wojenne. Tajne archiwum nad Łaba (Geheimarchiv an der Elbe, reż. Kurt Jung-Alsen, NRD 1963), opowiadające o rywalizacji amerykańskiego i sowieckiego wywiadu o akta Gestapo (Sowietom pomagają niemieccy komuniści), oraz - wyróżniające się na tle wcześniejszych produkcji - Przygody Wernera

117 Günter Rücker, Zu einigen Filmen, [w:] idem, Die Verlobte. Der Fall Gleiwitz. Der Dritte. Wolz - Leben und Verklärung eines deutschen Anarchisten. Bis dass der Tod scheidet. Hilde, das Dienstmädchen, Berlin (Ost) 1988, s. 600.

118 G. G., Der erste Mord des zweiten Weltkriegs. Sondervorführung des neuen DEFA-Films „Der Fall Gleiwitz”, „Neue Zeit", 27.04.1961. Za: Ulrich Tempel, Wrzesień 1939..., s. 322.

119 Birgit Schapow, Abseits ausgetretener Pfade..., s. 285.

${ }^{120}$ Günter Zehm, War alles ganz anders?, „Die Welt”, 14.09.1963; Walter Osten, Der Fall Gleiwitz, „Stuttgarter Zeitung”, 28.11.1963.

${ }^{121}$ Grossmutter gestorben, „Der Spiegel” 1963, nr 46, http://www.spiegel.de/spiegel/ print/d-46172747.html (dostęp: 20.01.2014). 
Holta (Die Abenteuer des Werner Holt, reż. Joachim Kunert, NRD 1965), zrealizowane na podstawie powieści pod tym samym tytułem (a dokładniej: pierwszego jej tomu) $)^{122}$. Jej autor, Dieter Noll, był wieloletnim przewodniczącym enerdowskiego Związku Pisarzy Niemieckich (Schriftstellerverband). Do 1965 r. powieść miała w NRD dwanaście wydań, sprzedała się w wysokim nakładzie $\left(1,7 \mathrm{mln}\right.$ egzemplarzy $\left.{ }^{123}\right)$, a w wyższych klasach szkoły powszechnej była lekturą obowiązkową ${ }^{124}$.

W powieści Nolla wydarzenia fabularne podane są linearnie, w porządku chronologicznym. Scenariusz posługuje się bardziej złożoną strukturą: duża część narracji przedstawia wydarzenia retrospektywnie - gdy uwięziony w schronie bohater bezskutecznie próbuje nawiązać kontakt z innymi jednostkami, w chwilach samotności wspomina epizody z ostatnich lat. $\mathrm{W}$ odniesieniu do literackiego pierwowzoru wprowadzono istotną modyfikację zdarzeń z ostatnich miesięcy wojny: w powieści Holt walczy w oddziale wysłanym do walki z wojskami amerykańskimi, natomiast $\mathrm{w}$ fabule Kunerta historia zostaje przeniesiona do wschodniej części Niemiec. Twórcy filmu zrezygnowali też z wydarzeń przedstawionych w drugim tomie powieści, które rozgrywają się po wojnie (Holt przebywa najpierw u matki w RFN, ale ostatecznie ucieka do NRD, gdzie czekają na niego ojciec i dziewczyna). Obie modyfikacje można ocenić jako znaczące - a może nawet ryzykowne. Przeniesienie osi ciężkości na front wschodni pociagało bowiem za sobą konieczność przedstawienia konfliktu z wojskami sowieckimi (swoją droga, sowieci ukazani są jako anonimowa siła skryta w czołgach, bezlitośnie niszczących wszystko na swej drodze - w fabule Kunerta brak zindywidualizowanej postaci sowieckiego żołnierza!). Usunięcie wątków powojennych stało natomiast w sprzeczności z dotychczasową praktyką Defy, która chętnie produkowała fabuły akcentujące dokonywany przez protagonistów wybór NRD na miejsce zamieszkania.

Przygody Wernera Holta opowiadają historię grupy przyjaciół - od czasów szkolnych do ostatnich tygodni wojny. Tytułowy bohater jest typowym „przeciętniakiem” - nieco naiwnym (czemu wszyscy sa przeciw nam?),

${ }_{122}$ Dieter Noll, Przygody Wernera Holta, tłum. Z. Rybicka, Warszawa 1962.

123 Thomas Heimann, Erinnerung als Wandlung. Kriegsbilder im frühen DDR-Film, [w:] Geschichte als Herrschaftdiskurs. Der Umgang mit der Vergangenheit in der DDR, red. Martin Sabrow, Köln 2000, s. 75.

${ }^{124}$ Chodzi o tzw. POS - Polytechnische Oberschule, enerdowski odpowiednik polskich średnich szkół zawodowych. Zob. Bernhard Meier, "Schultag und Schultag nach vorgegebenen Regeln". Zum Implikazionszusammenhang von didaktischer Theorie, Lektürekanon des Lehrplans und Literaturunterricht in der DDR, [w:] Literaturdidaktik, Lektürekanon, Literaturunterricht, red. Detlef C. Kochan, Amsterdam 1990, s. 189 (niestety, nie podano tu, w jakich latach Przygody... były lekturą obowiązkową). 
niekiedy zdradzającym wątpliwości wobec decyzji dowódców, najczęściej jednak przekonanym o konieczności wypełniania rozkazów (w przeciwnym bowiem razie wszystko, co robiliśmy, będzie na próżno). Jego przyjacielem jest syn oficera, Gilbert Wolzow - ślepo posłuszny, przekonany o wielkości Niemiec, gotowy do walki do ostatniej kropli krwi. Uosabia on "tradycję niemieckiego munduru” - ten zaś, jak w wielu filmach erefenowskich, zostaje utożsamiony z Wehrmachtem. Gdy dochodzi do sporu z oddziałem SS, Wolzow trafia nawet na Gestapo (i tylko dzięki interwencji wuja w stopniu generała udaje mu się uniknąć sądu wojskowego). Ostatecznie chłopak ginie z rąk esesmanów - choć nie $\mathrm{z}$ uwagi na konflikt o charakterze politycznym, a ze względów osobistych (dowódca oddziału SS został, jeszcze w szkole, pobity przez Gilberta z powodu zhańbienia honoru jednej z koleżanek). Trzecim bohaterem, nieco słabiej zarysowanym, jest Peter Wiese - wrażliwy i utalentowany muzycznie chłopak, powołany do wojska później niż jego koledzy i zastrzelony, gdy protestował przeciw zamordowaniu jednego $\mathrm{z}$ więźniów podczas marszu śmierci.

Pierwsza, "szkolna" część filmu (fot. 18) przedstawia nie tyle propagandowe "urabianie" chłopców, ile ich dokonane już zindoktrynowanie (w duchu bardziej nacjonalistycznym niż narodowosocjalistycznym). Bohaterowie są dumni z możliwości służby, nie mogą się doczekać pierwszych misji, z chłopięcą ciekawością bawią się bronią - ale też wdają w pierwsze miłostki (Holt ma ich kilka). Drogi przyjaciół stopniowo się rozchodzą - o ile Wolzow aż do końca jest przekonany o słuszności walki i konieczności wykonywania rozkazów, o tyle Holt, w wyniku wojennych przeżyć i obserwacji zbrodni dokonywanych przez SS, zaczyna kwestionować sens wojny (by w zakończeniu zdecydować się na dezercję). Mielibyśmy więc do czynienia z typową fabułą „konwersyjną" bądź filmem "antyfaszystowskim bez antyfaszystowskiego bohatera" 125 - ten bowiem musi się dopiero "narodzić" pod wpływem tragicznych doświadczeń. Zarazem konflikt między Wolzowem i Holtem ma charakter przyjacielskiej różnicy zdań - najważniejsza okazuje się lojalność wobec towarzysza broni. Między innymi z tych powodów Przygody Wernera Holta przypominają wiele erefenowskich produkcji wojennych z II połowy lat 50. i I połowy kolejnej dekady ${ }^{126}$. Kunert unaocznił również cierpienia doświadczane przez Niemców - na przykład w scenie przedstawiającej pożogę bombardowanego miasta, kiedy Holt przedziera się przez ogień (z żoną gestapowca i dzieckiem, które owa kobieta chce zostawić w płomieniach!) i chwilę później, gdy pokazane zostają ciała zmarłych i rannych.

125 Anke Pinkert, Film and Memory..., s. 147-148.

${ }^{126}$ Nieprzypadkowo Detlef Kannapin w strukturze swej książki (Dialektik der Bilder: der Nationalsozialismus im deutschen Film; ein Ost-West-Vergleich, Berlin 2005) zestawia ten film z Mostem Wickiego (zob. też podrozdział 3.2). 


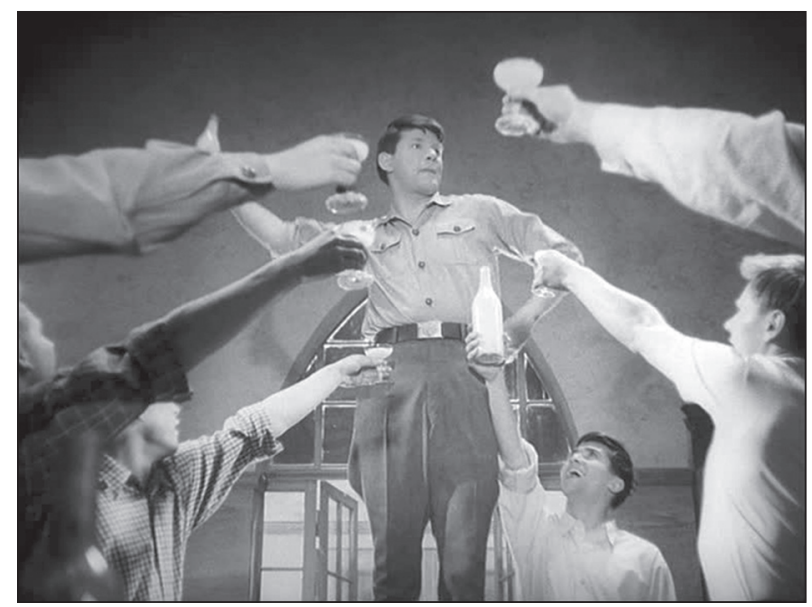

Fot. 18. Przygody Wernera Holta (reż. Joachim Kunert, 1965) Młodzi mężczyźni garną się do wojny (w centrum kadru - Manfred Karge jako Gilbert Wolzow)

Zarazem jednak Przygody Wernera Holta wyraźniej niż erefenowskie filmy wojenne akcentują zbrodnie popełniane przez Niemców: początkowo na terenie ZSRR (stosy ciał zasypywane przez żołnierzy), następnie na Słowacji. To właśnie podczas tam rozgrywających się wydarzeń dokonuje się przemiana bohatera - najpierw Holt zakochuje się w dziewczynie imieniem Gundel (niezbyt rozumiejąc, dlaczego ta nie odpowiada na jego awanse), a później, gdy otrzymuje rozkaz rozstrzelania kobiety i jej ojca, pozwala im uciec ${ }^{127}$. Co ciekawe, zbrodnie popełniane przez niemieckie oddziały zostały w filmie, dwukrotnie, zestawione z marszem żałobnym Chopina, granym w obu przypadkach przez Petera Wiese: po raz pierwszy tuż po scenie rozstrzeliwania Rosjan, zaś po raz drugi - chwilę przed scena, w której pokazano marsz więźniów z obozu koncentracyjnego. Jest wreszcie w filmie Kunerta wątek znany z wcześniejszej Rady bogów (o której będzie jeszcze mowa): ojciec tytułowego bohatera zrezygnował z pracy w IG Farben, i to od niego Holt dowiaduje się, że w wielu obozach masowo uśmiercano więźniów. Podobnie jak protagonista z filmu Maetziga, Werner nie dowierza jednak tej informacji.

${ }^{127}$ W sekwencji „słowackiej” pojawia się rozbudowana scena, w której oddział Holta odkrywa szopę, gdzie - jak możemy się domyślać - esesmani torturowali, a następnie zmasakrowali cywilów za pomocą piły mechanicznej (scena ta jest świetnie rozegrana: długie ujęcia śledzą reakcję trzech osób, kolejno wychodzących z szopy; jej wnętrze nie zostaje jednak pokazane - zgodnie z zasadą poetyki horroru, która głosi, iż to, co najbardziej potworne, rozgrywa się w wyobraźni widza). 
Przygody... stały się przebojem kasowym w enerdowskich kinach ${ }^{128}$, zaś recenzje prasowe były entuzjastyczne ${ }^{129}$ (twórcy filmu otrzymali Nagrodę Państwową II stopnia). Co więcej, od marca do sierpnia 1965 r. w kilku gazetach i czasopismach trwała debata o filmie - publikowano zapisy publicznych dyskusji oraz listy od czytelników ${ }^{130}$. W NRD Przygody... były w stałej dystrybucji do 1986 r.; wyświetlania filmu zakazano wkrótce po opuszczeniu NRD przez trójkę aktorów - w RFN postanowili zamieszkać: Manfred Karge (Wolzow), Angelika Domröse (ciotka von Barnim) i Monika Woytowicz (Gundel). W RFN dzieło Kunerta miało premierę w $1966 \mathrm{r}$. - ukazało się niewiele recenzji, ale w większości pozytywnych ${ }^{131}$ (relację z wizyty Dietera Nolla w RFN z okazji premiery zatytułowano Czy Gilbert Wolzow nadal żyje? ${ }^{132}$ ). Dziś film jest rzadko pokazywany w niemieckiej telewizji - zapewne z uwagi na fakt, iż rozpoznano jego dużą popularność wśród młodzieży związanej z neonazistowskimi organizacjami, szczególnie $w$ landach wschodnich ${ }^{133}$.

W I połowie lat 60. tematem II wojny światowej zaczyna interesować się enerdowska telewizja. Pięcioodcinkowe Niespokojne sumienie (Gewissen in Aufruhr, reż. Hans Oliva-Hagen, NRD 1961; twórcy serialu otrzymali Nagrodę Państwową I stopnia) miało być enerdowską odpowiedzią na

${ }^{128}$ Hake podaje liczbę $2 \mathrm{mln}$ widzów - choć, niestety, nie wskazuje źródła tej informacji, ani okresu, w którym film osiągnął tę liczbę widzów (Sabine Hake, Film in Deutschland..., s. 224).

129 Horst Knietzsch, Leidensweg und Erkenntnis einer Generation. Der DEFA-Film "Die Abenteuer des Werner Holt”, "Neues Deutschland”, 6.02.1965; Hartmut Albrecht, Die falschen Ideale des Werner Holt. DEFA-Film nach Dieter Nolls Roman, "Nationalzeitung", 6.02.1965; Günter Sobe, Bis fünf nach zwölf. „Die Abenteuer des Werner Holt”, ein DEFA-Film, „Berliner Zeitung", 10.02.1965.

130 Detlef Kannapin, Dialektikder Bilder..., s. 164. Autor uważa, że debata ta miała „otwarty charakter" - zdarzały się bowiem, odnotowane przez prasę, pozytywne opinie o postaci Wolzowa i jego przymiotach charakteru (braterskość, konsekwencja w dążeniu do celu itp.).

${ }^{131}$ Hans Helmut Prinzler, Die Abenteuer des Werner Holt. Heldenfiguren in der neusten DEFA-Produktion, „Stuttgarter Zeitung”, 2.03.1965; anon., Krieg als Schule der Nation. Einwände gegen den Roman "Die Abenteuer des Werner Holt" und seine Verfilmung, "Die Zeit", 29.04.1966. Pojawiła się też recenzja, w której mylnie podano, iż w zakończeniu Holt dezerteruje na stronę Armii Czerwonej - co w filmie nie zostało pokazane (anon., Richtung Rote Armee... „Frankfurter Rundschau”, 9.09.1966). Urząd ds. Oceny Filmów w Wiesbaden nadał zaś Przygodom ... predykat „szczególnie wartościowy".

${ }^{132}$ Hannes Würtz, Lebt der Gilbert Wolzow noch? "Junge Welt" sprach mit Dieter Noll über bundesdeutsche Reaktionen auf Buch und DEFA-Film "Die Abenteuer des Werner Holt”, "Junge Welt", 27.09.1966.

${ }^{133}$ Burkhard Schröder, Rechte Kerle. Skinheads, Faschos, Hooligans, Reinbek 1992, s. 62-66. Cytaty z książki (i filmu) przywoływane są również w publikacjach prasowych dotyczących neonazizmu, na przykład: http://www.pnn.de/brandenburg-berlin/763427 (dostęp: 12.01.2014). 
sukces zachodnioniemieckich produkcji telewizyjnych: Jak daleko nogi poniosa i Na zielonej plaży nad Szprewa ${ }^{134}$. Trajektoria fabularnych losów protagonisty jest następująca: Niemcy - ZSRR - Niemcy - ZSRR - NRD - RFN - NRD. W czasie tej Odysei bohater przechodzi typową dla enerdowskiego kina ",antyfaszystowskiego" przemianę: z nazisty w obywatela NRD. Ma ona początek na froncie wschodnim - traumatyczne doświadczenia sprawiaja, iż porucznik Ebershagen zaczyna wątpić w sens wojny. Po powrocie do Niemiec zostaje dowódcą obrony miasta Greifswald, które poddaje bez walki Armii Czerwonej. Gdy trafia do obozu na terenie ZSRR, jest przez swych rodaków traktowany jak zdrajca. Po zwolnieniu z obozu pomaga w odbudowie Niemiec (wschodnich); kiedy udaje się w podróż do RFN, staje się obiektem zainteresowania amerykańskich służb. Nie mogąc zwerbować Ebershagena, doprowadzają one do jego aresztowania. $\mathrm{W}$ więzieniu dla przestępców wojennych bohater zaczyna rozumieć fikcję zachodnioniemieckich rozliczeń z przeszłością - cieplarniane warunki odsiadki oraz łagodne wymogi amnestii. Gdy po trzech latach zostaje zwolniony z więzienia, powraca do swojej prawdziwej ojczyzny, NRD.

Charakterystycznym rysem enerdowskiej kultury audiowizualnej lat 60. było wprowadzanie do repertuarów kin filmów telewizyjnych (produkowanych lub współfinansowanych przez Defę, także takich, które zostały już wyemitowane na antenie). Na ekrany kin trafiła choćby Ostatnia noc (Die letzte Nacht, reż. Joachim Kunert, NRD 1961), remake teatru telewizji (Fernsehspiel) z 1957 r. o niemieckich szeregowcach skazanych na śmierć przez sąd wojskowy ${ }^{135}$. Innym przykładem $z$ tego samego roku jest - zrealizowany w Defie dla wschodnioniemieckiej stacji DFF - film Zawsze na drodze twej twarzy (Immer am Weg dein Gesicht, reż. Achim Hübner, NRD 1961) o afekcie niemieckiego żołnierza Herberta do Rosjanki Sonii (w tej roli Zofia Słaboszowska ${ }^{136}$ ), którą ratuje z opresji podczas wojny (po jej zakończeniu, jako przedstawiciel enerdowskiej firmy na delegacji w Mińsku, Herbert spotka się z przyjacielem z sowieckiej partyzantki, by powspominać dawne czasy - i wznieść toast za poległą dziewczynę). Wyjątkiem na mapie enerdowskich koprodukcji pozostaje telewizyjna realizacja

134 Thomas Beutelschmidt zwraca uwagę, że oba tytuły pojawiają się w dotyczącej Niespokojnego sumienia wewnętrznej korespondencji między Defą a enerdowską telewizją (Kooperation oder Konkurenz? Das Verhältnis zwischen Film und Fernsehen in der DDR, Berlin 2009, s. 293). Na prestiżowy charakter Niespokojnego sumienia wskazuje m.in. obsadzenie w roli głównej gwiazdora enerdowskiego kina, Erwina Geschonnecka.

${ }^{135}$ Ibidem, s. 304. O innych filmach telewizyjnych, które weszły do dystrybucji filmowej, zob. ibidem, s. 301-305.

136 Słaboszowska pojawiła się w obsadzie kilku enerdowskich filmów. Spośród polskich produkcji, w których występowała, najbardziej znany jest Ogniomistrz Kaleń (reż. Ewa i Czesław Petelscy, 1961). 
powstała we współpracy z Wielką Brytanią Przysięga szeregowca Pooleya (Der Schwur des Soldaten Pooley, reż. Kurt Jung-Alsen, NRD/Wielka Brytania 1962) - o kalekim brytyjskim żołnierzu poszukującym oficera SS, który w czasie wojny, na terenie Francji, wydał rozkaz rozstrzelania jego regimentu ${ }^{137}$. Z kolei Inny front (Die andere Front, reż. Hugo Hermann, NRD 1965), również nakręcony przez Defę dla telewizji, rozgrywa się w Rosji po ofensywie stalingradzkiej (porucznik Wehrmachtu, wątpiący w sens dalszej wojny, przyłącza się do grupy niemieckich antyfaszystów i udaje się z misją do swych przełożonych, których ma nadzieję przekonać do złożenia broni). Prawdziwy wysyp telewizyjnych filmów i seriali o tematyce wojennej nastąpi dopiero w II połowie lat 60. oraz w kolejnej dekadzie.

\subsection{Nowi sojusznicy: ZSRR}

Ponieważ Niemiecka Republika Demokratyczna była państwem suwerennym jedynie teoretycznie, w rzeczywistości zaś - całkowicie zależnym od ZSRR, mit antyfaszystowski miał szczególne znaczenie nie tylko w polityce wewnętrznej, lecz także dla kształtowania relacji z potężnym protektorem (oraz innymi państwami „bloku wschodniego”). Jak pisze Anna Wolff-Powęska,

nawet niemiecka klęska pod Stalingradem została wykorzystana do tworzenia legendy. Stalingrad stał się bowiem dla NRD punktem wyjścia do lepszej, nowej przyszłości Niemiec. W tej katastrofie postrzegano w oficjalnej retoryce źródło wschodnioniemiecko-sowieckiej przyjaźni. Stalingrad funkcjonował jako „triumf sprawiedliwej wojny" przeciw faszystowskim najeźdźcom, „wielka nauka” dla narodu ${ }^{138}$.

Pisząc o relacjach pomiędzy ZSRR a NRD w kontekście kultury filmowej, należy napomknąć o Poszukiwaczach słońca (Sonnensucher, NRD 1958, premiera kinowa w 1972 r.) wspomnianego już Konrada Wolfa. Film opowiada o konfliktach pomiędzy radzieckimi i niemieckimi pracownikami kopalni uranu na początku lat 50. Główną bohaterką jest młoda kobieta imieniem Lutz, o której względy rywalizują: szanowany przez robotników sztygar Franz Beier (gotów jest wychowywać nieślubne dziecko Lutz jak swoje własne) i rosyjski inżynier Siergiej. Ich przeżycia wojenne są tłem tej historii: Siergiej sam stracił narzeczoną z rąk SS, Beier zaś przed śmiercią zdążył wyznać, że był świadkiem zabójstwa żony Siergieja, lecz nie miał odwagi, by przeciwstawić się zbrodni.

${ }^{137}$ Kinofilską ciekawostką jest fakt, że głosu narratora w tym filmie użyczył Lindsay Anderson.

138 Anna Wolff-Powęska, Pamięć..., s. 234; Michael Kumpfmüller, Die Schlacht von Stalingrad. Metamorphosen eines deutschen Mythos, München 1996. 
Przyczyny zatrzymania filmu przez cenzurę w 1958 r. nie zostały w jednoznaczny sposób zrekonstruowane. Niektórzy autorzy wskazują że zastrzeżenia mogły być związane z konstrukcją głównych bohaterów ${ }^{139}$. Beier mógłby ucieleśniać socrealistycznego "przodownika pracy” lub wzorowego członka kadry kierowniczej - ale zarazem jest przecież byłym esesmanem. Z kolei na przykładzie Lutz nie można zilustrować dobrodziejstw, jakie władza ludowa rzekomo przynosiła młodym kobietom - to raczej przykład bezradnej, bezwolnej i wykorzystywanej fizycznie dziewczyny. Motyw seksualnego napastowania bohaterki pojawia się już na początku filmu, co znamienne, tuż po krótkiej sekwencji, w której głos ponadkadrowy (nałożony na muzykę zwykle towarzyszącą komunikatom propagandowym) informuje o pierwszej rocznicy powstania $\mathrm{NRD}^{140}$. Wydaje się jednak, że przyczyny odłożenia Poszukiwaczy słońca na półkę były związane raczej z kwestiami geopolityki i względami dyplomatycznymi: władze NRD miały zdecydować o nierozpowszechnianiu filmu (traktującego przecież o enerdowsko-sowieckiej współpracy w kopalni uranu) z uwagi na negocjacje dotyczące broni nuklearnej pomiędzy paktem warszawskim a USA ${ }^{141}$.

Jak wiadomo, propagandowa intencja fabuły często osłabia związki przyczynowo-skutkowe pomiędzy poszczególnymi jej wątkami. Modelowym wręcz przykładem takiego "pulp fiction w wydaniu enerdowskim” jest kolejny film Wolfa, Uskrzydleni (1960). Jego akcja - obejmująca wydarzenia od 1933 r., geograficznie „rozciągnięta” (od Hiszpanii po Taszkient), a prezentowana $\mathrm{w}$ szeregu retrospekcji nanizanych na rozgrywającą się w NRD w 1958 r. współczesną ramę narracyjną - obfituje w niesłychaną liczbę zbiegów okoliczności, w szczególności: „przypadkowych” spotkań bohaterów, którzy dziwnym trafem odnajdują się nawzajem w najróżniejszych punktach fabularnej czasoprzestrzeni.

Główny bohater filmu to Ludwig Bartuschek ${ }^{142}$, inżynier awiacji i działacz KPD, który u schyłku Republiki Weimarskiej zostaje

139 Wolfgang Jacobson, Rolf Aurich, Der Sonnensucher..., s. 289.

140 Podobny typ znakowania postaci kobiecych (tj. montażowego zestawienia scen stricte politycznych i intymnych) był właściwy wielu filmom zachodnioniemieckiego Nowego Kina w latach 70. Anke Pinkert dostrzega podobieństwo Lutz do straumatyzowanej i emocjonalnie niestabilnej protagonistki filmu Matka (inny polski tytuł: Niemcy - blada ojczyzna [Deutschland, bleiche Mutter, reż. Helma Sanders-Brahms, RFN 1980]). Autorka zwraca uwagę, że bohaterka filmu Sanders-Brahms ma paraliż mięśnia twarzowego, Lutz natomiast prawie w ogóle się nie uśmiecha (aż do momentu, gdy zatroszczy się o nią Beier). Zob. Anke Pinkert, Film and Memory in East Germany, Bloomington 2008, s. 133.

${ }^{141} \mathrm{O}$ kulisach powstania i zatrzymania filmu zob. Reinhard Wagner, "Sonnensucher" (1958/1972), „Beiträge zur Film- und Fernsehwissenschaft” 1990, nr 31; zob. też: Ralf Schenk, Mitten im kalten Krieg..., s. 145-146.

${ }^{142}$ Bartuschek to bohater fikcyjny, "modelowy” przedstawiciel ruchu robotniczego; wcześniej pojawił się w Pieśni marynarzy (Lied der Matrosen, reż. Kurt Maetzig, Günther 
zatrudniony w zakładach lotniczych. Po dojściu nazistów do władzy, jego szef, dr Dehlinger, jest gotów zatrzymać go w pracy, pod warunkiem zakończenia przez inżyniera działalności w partii. Bartuschek pozostaje jednak wierny swym przekonaniom: przedostaje się do Hiszpanii, gdzie obejmuje funkcję komisarza w Brygadach Międzynarodowych walczących z siłami generała Franco i wspierającym je Legionem Kondor. W jego szeregach znajduje się Dehlinger, który zostaje pojmany przez Bartuschka, ale udaje mu się uciec; ranny Ludwig otrzymuje pomoc od sowieckiego oficera, Aloszy. W czasie II wojny światowej Bartuschek dołącza do Armii Czerwonej, by w 1944 r. otrzymać zadanie zorganizowania ruchu oporu w fabryce, w której wcześniej pracował. Z pomocą Aloszy przedostaje się do Niemiec i - posługując się fałszywymi dokumentami na francuskie nazwisko - udaje mu się nawiązać kontakt z dawnymi towarzyszami z ruchu robotniczego. SS wpada jednak na trop przygotowywanego sabotażu, wskutek czego Bartuschek zostaje aresztowany i osadzony w obozie koncentracyjnym; w tym samym baraku umieszczony jest amerykański lotnik Dave, któremu udaje się przeżyć dzięki pomocy Ludwiga. Po wyzwoleniu obozu (gdy Dave żegna się z towarzyszami i dopytuje, na jaki adres ma przesyłać listy, słyszy odpowiedź: Ludwig Bartuschek. Komunistyczna Partia Niemiec, Komitet Centralny) więźniowie napotykają czołgi Armii Czerwonej; wśród sowieckich żołnierzy jest, oczywiście, Alosza. W obozie Ludwik rozpoznaje także swojego syna Hennego, wcześniej członka Hitlerjugend powołanego do Volkssturmu. Bartuschek powraca do fabryki, której robotnicy palą się do wznowienia produkcji ${ }^{143}$. Zapada decyzja o podjęciu prac nad nowym modelem samolotu pasażerskiego. Podczas prezentacji projektu na targach w Lipsku delegacja z NRD trafia na Dehringera, który pracuje w Republice Federalnej Niemiec; bezskutecznie próbuje on skaptować jednego ze wschodnioniemieckich inżynierów. W międzyczasie Henne zostaje pilotem wojskowym; w trakcie jednej z misji asekuruje w lądowaniu amerykański helikopter (w którym jednym z pilotów jest Dave). Ostatecznie, prace nad prototypem nowego samolotu zostają zakończone sukcesem.

Zakończenie filmu nie odbiega od finałowych scen innych enerdowskich realizacji o zbliżonej tematyce: podobnie jak w ostatniej scenie Amigo,

Reisch, NRD 1958), filmie o powstaniu w Kilonii w 1919 r., nakręconym dla upamiętnienia 40. rocznicy Rewolucji Październikowej. W Pieśni marynarzy Ludwiga Bartuschka gra Hilmar Thate, który w Uskrzydlonych wcielił się w Hansa, syna Ludwiga. Scenarzystami obu filmów byli Karl Egel i Paul Wiens.

${ }^{143}$ Bohater tłumaczy robotnikom, że zanim dojdzie do ponownej produkcji samolotów, należy najpierw zaspokoić najpilniejsze potrzeby społeczeństwa, dostarczając na rynek... garnki. Nie od rzeczy będzie może w tym miejscu przypomnieć, że podobne "przeprofilowanie" proponował w filmie Staudtego Mordercy sq wśród nas „czarny charakter", były oficer Brückner (zob. podrozdział 1.1). 
również tu pojawia się radosna parada (przed szpalerem nowych samolotów czekających na lotnisku) i tak samo, jak w Silniejszych od nocy, sukces polityczny podkreślony zostaje przez idyllę komunistycznej rodziny (w finale Uskrzydlonych Ludwigowi towarzyszy wnuk). Innym ważnym intertekstem Uskrzydlonych może być - nie na poziomie produkcji, lecz interpretacji, gdyż chodzi o fabułę nakręconą trzy lata później- film Nadzy wśród wilków (Nackt unter Wölfen, reż. Frank Beyer, NRD 1963), o którym będzie jeszcze mowa (zob. podrozdział 2.7). Przedstawiony przez Wolfa (fikcyjny) obóz koncentracyjny Gördeberg jest scenograficznie stylizowany na Buchenwald. Po wyzwoleniu obozu, które - podobnie jak w historii opowiedzianej przez Beyera - dokonuje się siłami komunistycznego ruchu oporu, więźniowie napotykają czołgi Armii Czerwonej. Inaczej jednak niż w filmie Nadzy wśród wilków, w Uskrzydlonych Bartuschek oraz sowieccy żołnierze aresztują i przesłuchują załogę obozu. I choć wprowadzenie tego wątku mogło być faktycznie ryzykowne z punktu widzenia ówczesnej polityki historycznej NRD ${ }^{144}$, najpewniej też inne powody przyczyniły się do rychłego wycofania Uskrzydlonych z repertuarów kinowych $^{145}$ - i to pomimo entuzjastycznych recenzji, które ukazały się początkowo zarówno w prasie branżowej, jak i partyjnej ${ }^{146}$ (film nie był również pokazywany w telewizji, nadal nie doczekał się edycji na DVD).

Pierwsza koprodukcja pomiędzy kinematografią enerdowską i sowiecką - Pięć dni, pięć nocy (Fünf Tage - Fünf Nächte, reż. Lew Arnstam, Heinz Thiel, Anatolij Golowanow, NRD/ZSRR 1961) - współtowarzyszyła nagłośnionym propagandowo obchodom ponownego otwarcia Łzw. galerii malarstwa dawnych mistrzów w Dreźnie w 1960 r., kiedy to do zniszczonego podczas nalotów (fot. 19) miasta powróciły malowidła odrestaurowane $\mathrm{w}$ ZSRR. Akcja filmu rozgrywa się tuż po zakończeniu wojny - krasnoarmiejcy, wspierani przez niemieckiego komunistę

${ }^{144}$ Buchenwald został bowiem, po przekazaniu nadzoru nad obozem sowieckiej administracji wojskowej, przekształcony w „obóz specjalny” dla nazistów. Z oczywistych powodów jego istnienie nie było opisywane w niemieckiej prasie (na ten wątek zwraca uwagę: Thomas Heimann, Bilder von Buchenwald. Die Visualisierung des Antifaschismus in der DDR (1945-1990), Köln 2005, s. 68). Debata na ten temat rozgorzała dopiero po zjednoczeniu Niemiec, gdy w 1990 r. w Buchenwaldzie i Sachsenhausen, w pobliżu dawnych kacetów, odnaleziono szczątki niemieckich jeńców wojennych, internowanych przez sowieckie władze okupacyjne między 1945 a 1949 rokiem.

145 Thomas Heimann uważa, że stało się tak z powodów związanych z ekonomicznymi relacjami pomiędzy ZSRR i NRD - Uskrzydleni mieli stanowić jakoby promocję przemysłu lotniczego NRD, który w czasie powstawania filmu liczył na sprzedaż samolotów pasażerskich do ZSRR. Tymczasem sowieci postanowili zbudować własne fabryki. Thomas Heimann, Bilder von Buchenwald..., s. 68; zob. też: Ralf Schenk, Mitten im kalten Krieg..., s. 146.

${ }^{146}$ Heinz Hofmann, Ein Held unserer Zeit, "Neues Deutschland”, 30.08.1960; Karl-Eduard von Schnitzler, Leute mit Flügeln, „Filmspiegel” 1960, nr 18. 
Ericha Brauna i zrazu nieufnego wobec nich kalekiego malarza Paula Neumanna, odnajdują ukryte malowidła w tunelach pod miastem; te, które uległy zniszczeniu, zostają przewiezione do Rosji, by mogli się nimi zająć tamtejsi konserwatorzy.

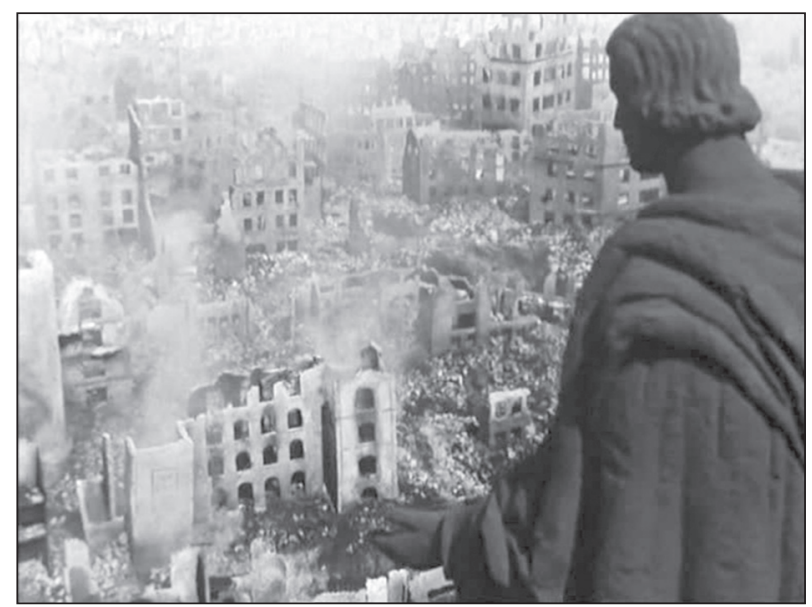

Fot. 19. Pięć dni, pięć nocy (reż. Lew Arnstam,

Heinz Thiel, Anatolij Golowanow, 1961)

Panorama zniszczonego Drezna w sekwencji otwierającej film

Thomas Heimann zwraca uwagę na scenę, w której pokazany zostaje marsz byłych więźniarek $\mathrm{z}$ obozu koncentracyjnego oraz na postać jednej z nich, Katrin: podobnie jak w przypadku bohaterek wcześniejszych wschodnioniemieckich filmów (Mordercy sa wśród nas, Kobiece losy), o szczegółach jej pobytu w obozie nie dowiadujemy się niczego ${ }^{147}$. Sam Paul wydaje się zaś nowym wcieleniem protagonistów z niemieckich Trümmerfilmów - zrazu zagubiony i pozbawiony nadziei, odzyskuje ją właśnie dzięki Katrin. Gdy na początku filmu Erich prosi Paula, aby namalował obraz zagrzewający do walki, ten odmawia, gdyż nie chce już więcej walczyć. W toku rozwoju fabuły jego pacyfizm zostaje jednak przezwyciężony - w zakończeniu Paul osiąga polityczną dojrzałość: jest gotów wykorzystać swój talent dla celów propagandy.

Pięć dni, pięć nocy zawiera wiele scen przedstawiających „sowiecko - enerdowski" sojusz. O tym, że wizerunek żołnierzy Armii Czerwonej podlegał w NRD szczególnej ochronie przekonuje przykład komedii Karbid i szczaw (Karbid und Sauerampfer, reż. Frank Beyer, NRD 1963). Jej bohater - tuż po zakończeniu wojny wysłany na drugi koniec Niemiec z misją

147 Thomas Heimann, Bilder von Buchenwald..., s. 107. 
zdobycia materiału niezbędnego do uruchomienia fabryki papierosów i dostarczenia go z powrotem do Drezna - w swej podróży przez okupowany kraj jest konfrontowany zarówno z amerykańskimi, jak i sowieckimi żołnierzami. Ponieważ ci ostatni zostają uwikłani w komiczne sytuacje, „enerdowski wiceminister kultury [...], człowiek obdarzony cywilną odwaga, wziął szpule pod pachę i pojechał do Moskwy, gdzie pokazał film w enerdowskiej ambasadzie [...]. Bawili się dobrze, więc sprawa była załatwiona" - wspominał reżyser ${ }^{148}$.

\subsection{Wróg zewnętrzny: mordercy są wśród nich}

Samookreślenie Niemieckiej Republiki Demokratycznej wobec zachodniego sąsiada ewoluowało $\mathrm{w}$ czasie jej istnienia. Z grubsza rzecz ujmując, mnie więcej do uchwalenia konstytucji z $1974 \mathrm{r}$. obowiązywała następująca wykładnia: istnieje jeden naród niemiecki (którego część znalazła się w Republice Federalnej Niemiec i jest poddana imperialistycznej propagandzie) i jedno prawowite państwo niemieckie ${ }^{149}$ (czyli $\mathrm{NRD}^{150}$ ). Koncepcja ta wynikała poniekąd z marksistowskiej interpretacji faszyzmu, która - wiążąc go strukturalnie z kapitalizmem - pozwalała na redystrybucję winy i odpowiedzialności, jej „eksternalizację" na obszar świata zachodniego, przede wszystkim zaś na Republikę Federalna, postrzeganą jako kolonia amerykańskiego imperializmu. Jego oddziaływanie było, wedle enerdowskiej ideologii, przyczyną dojścia NSDAP do władzy („,uwiódł” on mianowicie niemiecką burżuazję, która w konsekwencji wyraziła zgodę na zniewolenie Niemiec ${ }^{151}$ ) i nie zakończyło się bynajmniej wraz z ustaniem działań wojennych.

148 Regie: Frank Beyer..., s. 50. Także: Frank Beyer, Wenn der Wind sich dreht. Meine Filme, mein Leben, München 2001, s. 122-123.

${ }^{149}$ Od połowy lat 70. enerdowska propaganda lansowała już inną wizję - zakładająca, że dwóm państwom niemieckim odpowiadają dwa narody (m.in. z tego powodu enerdowski hymn zawierający słowa „Niemcy - jedna ojczyzna” mógł być tylko grany, nie śpiewany).

150 Analogicznie w RFN przez długi czas określenie „DDR” brano w cudzysłów - jako „tak zwana Niemiecka Republika Demokratyczna”, bądź określano NRD jako "sowiecką strefę okupacyjną" (czyli zachowując nazwę z okresu 1945-1949), a enerdowskie filmy opatrywano przymiotnikiem sowjetzonale. Zob. Christian Graf von Krockow, Niemcy: ostatnie sto lat, tłum. A. Kopacki, Warszawa 1997, s. 277. Jako przykład autor ten podaje wydane w 1962 r. przez Ministerstwo Spraw Ogólnoniemieckich kompendium: SBZ von A bis Z. Ein Taschen- und Nachschlagebuch über die Sowjetische Besatzungszone Deutschlands, Bonn 1962.

151 Sigrid Meuschel, Legitimation und Parteiherrschaft. Zum Paradox von Stabilität und Revolution in der DDR 1945-1989, Frankfurt am Main 1992, s. 101-122. 
Nic więc dziwnego, że ważnym kontekstem „filmów antyfaszystowskich" zrealizowanych w NRD podczas pierwszych piętnastu lat jej istnienia były napięte (zwłaszcza od zbudowania muru berlińskiego w $1961 \mathrm{r}$.) relacje między państwami niemieckimi. Duża część produkcji Defy dotyczyła sytuacji w Niemczech Zachodnich, ukazując niezborność pomiędzy cudem gospodarczym a (niedokonanym) rozliczeniem z przeszłością i niedostatkami funkcjonowania instytucji prawa. Podobnie jak w mediach peerelowskich, choć w stopniu nieporównanie silniejszym, głównym celem ataku był gabinet Adenauera (przykładowo, w oficjalnych dokumentach SED oraz wypowiedziach jej liderów polityka rządu RFN określana jest jako "nowe wydanie faszyzmu na bazie atomu”, a kanclerz nazywany wprost „Hitlerem naszych czasów” $)^{152}$.

Dyskredytowanie przeciwników politycznych przez dramaturgiczne powiązanie "zachodniego imperializmu” z niemieckim nazizmem pojawia się w Radzie bogów (Der Rat der Götter, reż. Kurt Maetzig, NRD 1950; twórcy filmu otrzymali Nagrodę Państwową I stopnia) ${ }^{153}$. Doprawdy, niewiele powie nam o filmie opinia, jakoby „naświetlał on sprawę IG Farben z różnorakich perspektyw: robotników, naukowców, menedżerów i przemysłowców"154. Owszem, rzecz jest faktycznie o IG Farben - ale przytoczone sformułowanie jest o tyle niefortunne, że może sugerować konstrukcję à la Obywatel Kane czy Rashomon; tymczasem "perspektywy”, o jakich mowa, tworzą najzupełniej spójny komunikat propagandowy.

Scenariusz Friedricha Wolfa i Filipa Gechta ${ }^{155}$ bazował na aktach procesowych z Norymbergi przeciw koncernowi IG Farben, przekazanych Defie przez urzędników sowieckiej administracji wojskowej w Niemczech (Gecht był pracownikiem wydziału cenzury SMAD ${ }^{156}$ ). Dokumenty te już wcześniej zostały wykorzystane przez wschodnioniemieckich propagandystów - zwłaszcza w wydanym w 1947 r. pamflecie Alberta Nordena ${ }^{157}$,

${ }^{152}$ Michael Lemke, Instrumentalisierter Antifaschismus und SED-Kampagnenpolitik im deutschen Sonderkonflikt 1960-1968, [w:] Die geteilte Vergangenheit..., s. 65. Zob. też: Monika Gibas, "Bonner Ultras", "Kriegstreiber" und "Schlotbarone”. Die Bundesrepublik als Feindbild der DDR in den fünfziger Jahren, [w:] Unsere Feinde. Konstruktion des Anderen im Sozialismus, red. Silke Satjukow, Rainer Gries, Leipzig 2005.

153 Zob. Anne Kober, Antifaschismus im DDR-Film. Ein Fallbeispiel "Der Rat der Götter", [w:] Der missbrauchte Antifaschismus. DDR-Staatsdoktrin und Lebenslüge der deutschen Linken, Freiburg-Basel-Wien 2002.

154 Sabine Hake, Film in Deutschland..., s. 172; opinia powtórzona przez Joannę Trajman, Narodowy socjalizm w kinie zjednoczonych Niemiec, Wrocław 2014, s. 43.

155 O różnych wersjach scenariusza zob: Detlef Kannapin, Antifaschismus im Film der DDR..., s. 116-117. Autor zwraca uwagę, że komisja ds. Defy, działająca przy komitecie centralnym SED, zadbała o szeroką dystrybucję filmu, w ilości stu kopii (ibidem, s. 130).

156 Thomas Heimann, DEFA, Künstler..., s. 114.

157 Albert Norden, Czego nas ucza dzieje Niemiec: o roli politycznej kapitatu finansowego i junkierstwa, tłum. L. Szybek, Warszawa 1949. 
zawierającym także rozdział o „światowych trustach" i relacjach między Standard Oil i IG Farben. Prócz pracy Nordena drugim źródłem inspiracji stała się dla scenarzystów książka Richarda Sasuly'ego ${ }^{158}$, który podczas procesów norymberskich był oficerem armii amerykańskiej (w narrację filmu wprowadzono zresztą dokumentalne sekwencje $\mathrm{z}$ samego procesu, również wykonane przez ekipę amerykańską ${ }^{159}$ ). Informacja o materiałach archiwalnych została umieszczona w napisach początkowych: Bohaterowie filmu zostali wymyśleni. Akcja opiera się na faktach, pochodzacych z akt procesu norymberskiego przeciw zbrodniarzom wojennym z koncernu IG oraz innych amerykańskich źródeł (co ciekawe, w książce powstałej na podstawie filmu - tzw. Nacherzählung - nie ma zwrotu o Amerykanach) ${ }^{160}$.

Czas fabularny filmu obejmuje wydarzenia od mianowania Hitlera na stanowisko kanclerza w 1933 r. do okresu powojennego, narracja zaś jest prowadzona poprzez dwa zazębiające się wątki. Pierwszy zogniskowany zostaje wokół przedsiębiorców zarządzających koncernem IG Farben (dyrektor Mauch, kierownik działu zagranicznego Tilgner oraz von Decken, dyrektor ds. technicznych). Owa "rada bogów”, jak ironicznie nazywa ją córka Maucha, związana jest z amerykańskim przedsiębiorstwem Standard Oil Company. Główny bohater drugiej linii narracyjnej to dr Hans Scholz, ambitny chemik, początkowo zainteresowany wyłącznie naukową stroną swej pracy. Pragnie on pozostać ",apolityczny": nie wstępuje do NSDAP, ale też nie ulega namowom wuja - komunisty (aresztowanego za kolportowanie ulotek), który chce pozyskać Hansa dla ruchu oporu. Początkowo bohatera nie interesuje etyczny aspekt prowadzonych badań, ale - zgodnie ze schematem opowieści socrealistycznej - stopniowo „nabiera świadomości”. „Nawrócenie” protagonisty dokonuje się podczas procesu norymberskiego - przy czym akcentowane są argumenty przeciw stanowisku obrony, wyrażającego się sloganem „nic o tym nie wiedzieliśmy" (wuj Karl zauważa: przecież mówiono o tym w radio). Doktor Scholz przyznaje się do winy i potwierdza, że wiedział o Cyklonie B i sposobach jego zastosowania. Pod koniec filmu - gdy dochodzi do eksplozji w fabryce BASF w Ludwigshafen, w której pracuje syn Scholza ${ }^{161}$ - okazuje się,

158 Zob. Richard Sasuly, I.G. Farben: z dziejów jednego kartelu, tłum. M. Marciniak, Warszawa 1949.

159 Wypowiedź Kurta Maetziga na dodatku do edycji DVD wydanej przez Icestorm. Zob. Richard Sasuly, I.G. Farben...

${ }^{160}$ Friedrich Wolf, Filip Gecht, Rada bogów, tłum. M. Wirpsza-Kurecka, Warszawa 1951 (wydanie oryginalne podpisane zostało przez Franza Fabiana, którego nazwisko nie pojawia się na okładce wydania polskiego. Są nań natomiast nazwiska obu scenarzystów, co mogło wynikać z faktu, że Friedrich Wolf był ambasadorem NRD w Polsce w latach 1949-1951).

161 Jest to nawiązanie do autentycznego zdarzenia: eksplozji w fabryce BASF w Ludwigshafen z lipca 1948 r. (wybuch spowodował śmierć 270 osób, a blisko 4000 zostało rannych). 
że wbrew zakazowi aliantów w RFN dalej produkuje się broń chemiczną, najpewniej na potrzeby nowej wojny. Scholzowi nie pozostaje więc nic innego, jak tylko przenieść się do NRD... (mamy więc tu - wykorzystany również w nakręconej dwa lata później Rodzinie Sonnenbrucków, o której będzie mowa w kolejnym podrozdziale - schemat przemiany ",apolitycznego" naukowca w "postępowego bojownika o pokój”).

Rada bogów to typowa "opowieść z kluczem" - fikcyjni bohaterowie odsyłają do autentycznych osób związanych z IG Farben. Radca Mauch to „wcielenie” Carla Kraucha, w koncernie odpowiedzialnego za współpracę między IG Farben a wojskiem (w procesie norymberskim otrzymał karę sześciu lat pozbawienia wolności - inaczej niż jego odpowiednik $\mathrm{w}$ filmie, który nie poniósł $\mathrm{w}$ zasadzie żadnych konsekwencji). $\mathrm{W}$ postaciach Tilgnera i von Deckena ówcześni widzowie mogli rozpoznać członków zarządu koncernu - odpowiednio: Maxa Ilgnera i Georga von Schnitzlera. Zgodnie z obowiązującą w NRD wykładnią faszyzmu to oni byli faktycznymi winowajcami wojennej hekatomby (przykładowo, gdy w jednej z pierwszych scen pojawia się Hitler opuszczający willę, w której dyrektorzy i finansiści dyskutują o maksymalizacji zysku, kamera nie podąża za aktorem grającym rolę Führera, ale koncentruje się właśnie na wydarzeniach w gabinecie Maucha).

Podobnie jak w filmie biograficznym o Thälmannie, w roli współwinnych obsadzono Amerykanów, w Radzie bogów reprezentowanych przez niejakiego Lawsona, reprezentanta Standard Oil. Dochodzi do podziału globalnych stref wpływów (Lawson: Pozostawiamy wam Europe Środkowa $i$ Rosje do granicy z Chinami. Mauch: A reszta świata to wasz obszar) oraz ustaleń związanych z przewidywaną wojną (Lawson cieszy się: Myślę, że wojna niestychanie ożywi nasze wspólne przedsięwzięcia). Obaj przedsiębiorcy uzyskują od szwajcarskiego bankiera gwarancję bezpieczeństwa ich pieniędzy podczas konfliktu zbrojnego, zaś Amerykanin obiecuje Mauchowi ochronę fabryki w wypadku nalotów. Rola Lawsona nie kończy się wraz z rozpoczęciem wojny - po jej zakończeniu powraca do Niemiec w mundurze US Army, by wpływać na postępowanie sądowe w procesie przeciw IG Farben (pod wpływem Amerykanina oskarżyciel zostaje zmieniony na łagodniejszego).

Polityczny dyskurs Rady bogów nie różni się zbytnio od późniejszych enerdowskich filmów - posługuje się bowiem wielokroć powielanym wzorem, podług którego faszyzm stanowi sumę kapitalizmu i militaryzmu. Jest jednak w filmie Maetziga segment narracyjny wykraczający poza ten plakatowy model - można wręcz powiedzieć: unikalny na tle niemieckich (także zrealizowanych w RFN) fabuł powstałych do lat 70. Chodzi 
mianowicie o stosunkowo rozbudowana, zbudowaną na długich ujęciach scenę aplikowania gazu zwierzętom (fot. 20). Gdy Scholz z niesmakiem obserwuje przebieg eksperymentu, dyrektor raczy go uwagą: Ależ doktorze Scholz, przecież zawsze chciał pan poznać końcowy rezultat swoich badań. Kannapin słusznie zwraca uwagę, że mamy tu do czynienia $\mathrm{z}$ „,symbolicznym przedstawieniem nieprzedstawialnego"162, które może być rzutowane na późniejsze debaty o możliwych sposobach pokazywania Zagłady. Ale ciekawe jest też to, że w narracji filmu scena ta bynajmniej nie jest momentem "przebudzenia" bohatera; ba, nawet gdy znajdzie on w ładowni przygotowane do transportu butelki Cyklonu B z napisem "Auschwitz", nadal nie dowierza temu, co wcześniej usłyszał od wuja. Dopiero pod wpływem audycji radiowych (z nielegalnej radiostacji) przyjmuje do wiadomości skalę przemysłowego mordu.

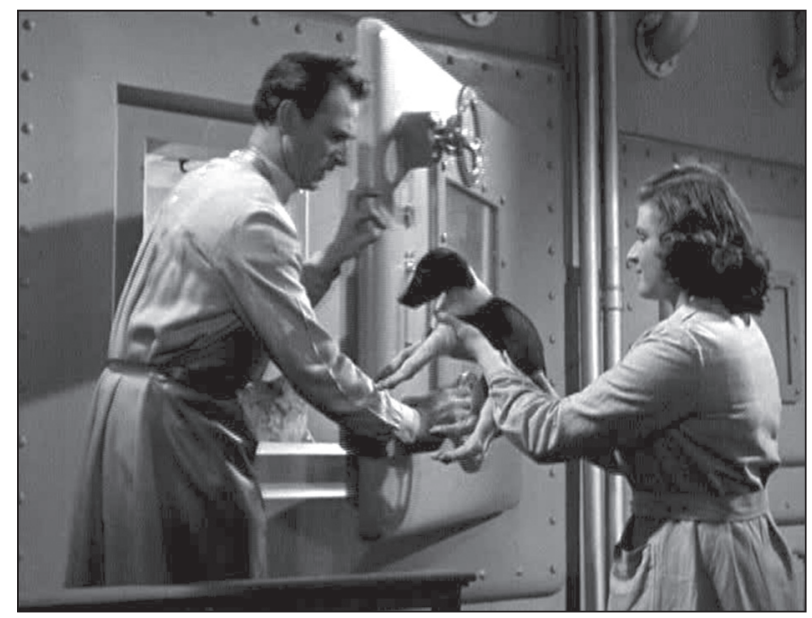

Fot. 20. Rada bogów (reż. Kurt Maetzig, 1950) Eksperyment na zwierzętach

Rola IG Farben w ludobójstwie podczas wojny nie jest jedynym - a może nawet: nie jest głównym - zarzutem, jaki stawia dyskurs filmu. W jego zakończeniu istotniejsze staje się bowiem "przeniesienie" zbrodni nazistowskich na RFN: gdy Scholz odwiedza syna, zatrudnionego po wojnie w fabryce IG Farben ${ }^{163}$, daje wyraz swej obserwacji, że nic się nie zmieniło.

162 Detlef Kannapin, Antifaschismus im Film der DDR..., s. 126.

${ }^{163}$ Koncern został oficjalnie zlikwidowany w 1952 r., kiedy wydzielono z jego struktury spółki wcześniej współtworzące koncern, m.in. Agfa, BASF i Bayer (w kierownictwie tych firm zasiedli byli szefowie IG Farben i członkowie NSDAP, m.in. Carl Wurster, prezes zarządu BASF w latach 1952-1965 oraz Fritz ter Meer, prezes rady nadzorczej Bayera w latach 1956-1964). Z pozostałości po podziale utworzono firmę I.G. Farbenindustrie 
Po wyziewach unoszących się w powietrzu po katastrofie w fabryce rozpoznaje, że produkowane są $w$ niej nadal środki służące do wytwarzania bomb. Dlatego zasadnicze oskarżenie, jakie wybrzmiewa $\mathrm{w}$ finale filmu, dotyczy erefenowskiego przemysłu: Panie Mauch, w ostatniej wojnie ludzie tacy jak pan zarobili miliardy, a pan robi wszystko, aby przygotować nowa wojne, aby zarobić kolejne miliardy. Kontrapunktem dla zachodnioniemieckiego „militaryzmu” jest tu enerdowski „pacyfizm” - ilustrowany obrazami z antywojennej demonstracji we wschodniej części Berlina. Nie bez racji jeden z zachodnioniemieckich recenzentów, którzy mogli obejrzeć Radę bogów (w RFN film nie był bowiem dystrybuowany), pisał: „To mógłby być wielki film, gdyby Defa oszczędziła nam ostatniego kwadransa"164.

O kontynuowaniu produkcji broni chemicznej w RFN mowa jest także w dwóch innych enerdowskich filmach: Tajne akta firmy Solvay (Geheimakten Solvay, reż. Martin Hellberg, NRD 1953) oraz Twarz śmierci (Der Tod hat ein Gesicht, reż. Joachim Hasler, 1961) ${ }^{165}$. Wykorzystują one typowy dla fabuł z krajów niedemokratycznych wątek sabotażu (w tym wypadku - "szkodników” na usługach RFN). Nie bez przyczyny Ralf Schenk określił Tajne akta... jako realizację „pod względem estetyki porównywalną z nazistowskim filmem Uwaga! Wróg podstuchuje (Achtung! Feind hört mit, reż. Arthur Maria Rabenalt, Niemcy 1940)"166.

Za modelowy przykład anty-erefenowskiej propagandy tego okresu można uznać krótkometrażowy dokument Pamiętnik dla Anny Frank (Ein Tagebuch für Anna Frank, reż. Joachim Hellwig, NRD 1958) ${ }^{167}$. Jednak to nie tytułowa Anna Frank jest jego bohaterką (z jej biografii zaakcentowano pracę przymusową w niemieckich fabrykach), lecz nazistowscy zbrodniarze. Po krótkiej informacji o brytyjskim trybunale wojskowym i wyrokach śmierci wykonanych na kilku z nich następuje kluczowa sekwencja: ukryta kamera pokazuje byłych nazistów jako szanowanych obywateli RFN, zaś głos ponadkadrowy czyta ich adresy zamieszkania. Film zamyka podniosłe wyznanie kierowane do Anny Frank: Byłaś ofiara - mordercy wciaż $\dot{z}$ yja. Dla ciebie zbrodnia pozostawała bezimienna - dla nas ma nazwiska. Wiemy, że mordercy nadal postapiliby tak samo, gdyby tylko mogli.

AG i.L. (I.G. Farbenindustrie AG w likwidacji), notowaną jako trust na frankfurckiej giełdzie aż do wiosny 2012 r.

164 Anon., Rat der Götter, „Tagesspiegel”, 14.05.1950. Pozostałe znane mi zachodnioniemieckie recenzje filmu były jednoznacznie negatywne. Nie trzeba chyba dodawać, że w NRD film był powszechnie chwalony.

165 W Polsce ukazała się recenzja pierwszego z filmów - zob. Stanisław Grzelecki, Tajne akta firmy Solvay, „Film” 1954, nr 3.

166 Ralf Schenk, Mitten im kalten Krieg..., s. 77.

167 Więcej o filmie zob. Sylke Kirschnick, Anne Frank und die DDR. Politische Deutungen und persönliche Lesearten, Berlin 2009, s. 83-98. 
Podobną wymowę miały liczne dokumenty telewizyjne - na przykład Mord we Lwowie (Mord in Lwow, reż. Walter Heynowski, NRD 1960) - o niechlubnym udziale erefenowskiego ministra ds. wypędzonych, Theodora Oberländera, w aresztowaniu i egzekucji lwowskich profesorów w lipcu 1941 r. (w zakończeniu pojawia się oskarżenie pod adresem RFN, będące trawestacją tytułu pierwszego filmu Defy: Mordercy sa wśród was!). Rok później Heynowski realizuje dla enerdowskiej telewizji pełnometrażowy dokument Akcja J (Aktion J, reż. Walter Heynowski, NRD 1961) ${ }^{168}$, koncentrujący się na karierze Hansa Globkego, „,szarej eminencji” gabinetów RFN w latach 50. (w filmie zastosowano montaż ujęć pokazujących przemówienia Goebbelsa i Adenauera; w pewnej chwili na obraz tego ostatniego zostaje "nałożona” sylwetka Hitlera): Tak długo, jak różni Globkowie rzadza w Bonn, Aktion J pozostaje w mocy. Komentarz ponadkadrowy prowadzony jest zgodnie z enerdowską wykładnią historii III Rzeszy - podkreśla, że komuniści ostrzegali przed nazistami, których do władzy wyniósł kapitał, zaś polityka antysemicka była „odpryskiem” walki $\mathrm{z}$ ruchem komunistycznym (Zawsze, gdy cierpi klasa robotnicza, cierpia także inne prześladowane grupy).

Filmy te trzeba rozpatrywać przez pryzmat ówczesnej polityki historycznej - w latach 1960-1963 w NRD prowadzone były bowiem zaoczne procesy pokazowe, m.in. właśnie przeciw Oberländerowi i Globkemu ${ }^{169}$. Wschodnioniemiecka prasa często publikowała materiały o byłych nazistach piastujących wysokie funkcje państwowe w RFN, w 1965 r. ukazała się zaś głośna Brunatna księga - przygotowane pod kierownictwem czołowego propagandysty NRD, Alberta Nordena, zestawienie blisko 1800 nazwisk wpływowych obywateli RFN, którzy w okresie nazistowskim byli członkami NSDAP ${ }^{170}$.

W RFN rozgrywa się też akcja filmu Hauptmann z Kolonii (Der Hauptmann von Köln, reż. Slátan Dudow, NRD 1956) ${ }^{171}$. Scenariusz - autorstwa Dudowa,

168 Więcej na ten temat - zob. Rüdiger Steinmetz, Die Film- und Fernsheh Dokumentaristen Walter Heynowski und Gerhard Scheumann, Leipzig 2002.

169 Zob. artykuły w tomie: Inszenierungen des Rechts: Schauprozesse, Medienprozesse und Prozessfilme, red. Klaus Marxen, Annette Weinke, Berlin 2006.

170 Braunbuch: Kriegs- und Naziverbrecher in der Bundesrepublik: Staat, Wirtschaft, Armee, Verwaltung, Justiz, Wissenschaft; materiał w całości na https://web.archive.org/ web/20101119233343/http://braunbuch.de/index.shtml (dostęp: 20.02.2014). W swoistym rewanżu w 1981 r. w RFN opublikowano Brunatna ksiege NRD, gdzie - dla odmiany - wymieniono blisko 900 nazwisk osób z NRD. Zob. Olaf Kappelt, Braunbuch DDR. Nazis in der DDR, Berlin (West) 1981; Henry Leide, NS-Verbrecher und Staatssicherheit. Die geheime Vergangenheitspolitik der DDR, Göttingen 2007.

${ }^{171}$ Film nie był pokazywany w RFN (ani w kinach, ani w telewizji), był natomiast dystrybuowany w Polsce - zob. Bolesław Michałek, Humor koszarowo-kaberetowy, "Film” 1958, nr 39. 
Michaela Tschesno-Hella i Henryka Keischa (wszyscy otrzymali Nagrodę Państwową II stopnia) - luźno nawiązuje (poprzez tytuł oraz, oględnie mówiąc, "krytykę militaryzmu”) do sztuki Carla Zuckmeyera Kapitan z Köpenick $^{172}$, która w tym samym roku została kongenialnie zekranizowana przez Helmuta Käutnera. Drugim źródłem fabuły były wydarzenia autentyczne: w 1952 r. Franz Richter, deputowany Bundestagu i członek działającej wówczas legalnie Deutsche Rechtspartei, został aresztowany pod zarzutem posługiwania się fałszywym nazwiskiem. W rzeczywistości nazywał się Fritz Rößler - jako były działacz NSDAP, w 1945 r. postarał się o dokumenty poświadczające jego rzekomą śmierć i pod nowym nazwiskiem wstąpił w związek małżeński ze swoją żoną (z legalnego punktu widzenia: wdową) $)^{173}$.

Pod względem dramaturgicznym, Hauptmann $z$ Kolonii wykorzystuje formułę „,komedii omyłek". Tytułowy bohater nosi charakterystyczne nazwisko (Hans Albert Hauptmann - „Albert Kapitan”), ale z zawodu jest kelnerem. W Kolonii czasów Adenauera nie może znaleźć pracy do momentu, gdy trafiwszy przypadkiem na spotkanie weteranów wojennych, zostaje wzięty za byłego oficera Wehrmachtu (kapitana - „Hauptmanna” - Hansa Alberta), ukrywającego się jakoby w Argentynie ze względu na ciążące na nim zarzuty zbrodni wojennych (tymczasem prawdziwy Hauptmann przebywa u swojej żony Adeli, którą - po przedstawieniu rzekomych dowodów, że autentyczny Hans Albert zginął podczas wojny - ponownie poślubia). „Fałszywy kapitan” robi błyskotliwą karierę - otrzymawszy list polecający od kolońskiego burmistrza, dr Seekatza, obejmuje posadę szefa działu kadr w przedsiębiorstwie Rhein-Ruhr Mon$\tan$ AG, należącym do barona Pferdeapfela, który chce zeswatać bohatera

172 Trajektorie recepcji dramatów Zuckmeyera w obu państwach niemieckich zasługiwałyby zapewne na osobne studium. Z jednej strony, Generał diabła należał do najchętniej wystawianych sztuk w zachodniej strefie (jeszcze przed proklamowaniem obu państw niemieckich), a film zrealizowany na podstawie jego sztuki święcił triumfy w RFN lat 50. Z drugiej zaś, Kapitan z Köpenick wpasowywał się we wschodnioniemiecką kampanię przeciw „militaryzmowi”, zarówno III Rzeszy, jak i zachodniej, „imperialistycznej” części Niemiec (w Małżeństwie w mroku Maetziga - zob. podrozdział 1.3 - zakaz wystawiania Kapitana z Köpenick przedstawiony jest jako dowód represyjnej polityki nazistów), choć właśnie w RFN, a nie w NRD, sztuka ta zostanie przeniesiona na ekran.

173 Sabine Hake, Politische Satire im Kalten Krieg. "Der Hauptmann von Köln" und "Rosen für Staatsanwalt", [w:] DEFA International. Grenzüberschreitende Filmbeziehungen vor und nach dem Mauerbau, red. Michael Wedel, Barton Byg et al., Wiesbaden 2013, s. 154. Richter/Rößler został skazany na półtoraroczne więzienie, odebrano mu także mandat deputowanego. Inny podobny przypadek ujawniony został w 1992 r. - przez niemal 50 lat pod fikcyjną tożsamością ukrywał się oficer SS Hans Schneider. Jako Hans Schwerte pracował na stanowisku redaktora $\mathrm{w}$ wydawnictwach naukowych, był także nauczycielem akademickim na etacie profesora; wkrótce po przejściu na emeryturę pod koniec lat 70. otrzymał Federalny Krzyż Zasługi (odebrany mu po ujawieniu prawdziwej tożsamości). 
ze swoją córką. Dzięki wpływom barona Hans Albert Hauptmann zostaje nawet członkiem Bundestagu, gdzie zmuszony jest $-\mathrm{z}$ pomocą dr. Brandstättera, bliskiego współpracownika generała Kesselmeyera - do przeforsowania ustawy amnestyjnej (przeciw której odbywają się masowe protesty - fot. 21). Wówczas może się ujawnić autentyczny Hauptmann, zaś fałszywy kapitan staje przed sądem i otrzymuje wyrok pięciu lat więzienia. Właśnie w sekwencji rozprawy sądowej najłatwiej dostrzec polityczny wymiar satyry Dudowa. Prawdziwy kapitan (już jako członek Bundeswehry) zeznaje jako świadek - podkreśla, że podczas wojny wiernie służył niemieckiej ojczyźnie, na dowód czego pokazuje swój Żelazny Krzyż. Bohater takimi „zasługami” pochwalić się nie może: zostaje skazany, ponieważ nie był zbrodniarzem wojennym - nie wskazał żadnego popełnionego przez siebie przestępstwa wojennego, które zmusiło go do przyjęcia fałszywego nazwiska.

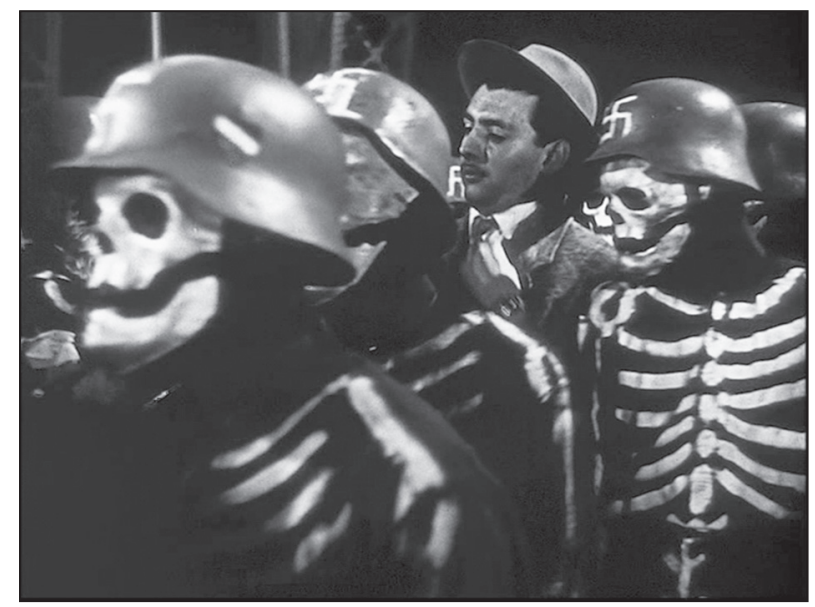

Fot. 21. Hauptmann z Kolonii (reż. Slátan Dudow, 1956) Happening à la danse macabre

Również wiele wcześniejszych scen piętnuje zachodnioniemiecką „Veteranenkultur". Punktem zwrotnym jest zlot byłych żołnierzy w jednym z kolońskich hoteli - z kalejdoskopem żelaznych krzyży na paradnych mundurach, wspomnieniami $\mathrm{z}$ frontu i piwem lejącym się $\mathrm{z}$ beczek $\mathrm{w}$ takt marszowej muzyki. Gdy jeden z podpitych weteranów siada przy pianinie i zaczyna grać melodię słynnej Horst-Wessel-Lied (uniesione flagi, zwarte szeregi...), drugi z niejakim żalem twierdzi, że "niestety” nie nadeszła jeszcze pora, żeby śpiewać takie pieśni, w czym utwierdza zebranych przemowa generała, zapewniającego, iż wkrótce jego żołnierze znów będą potrzebni. Także motywy poboczne wprowadzone zostały w filmie celem ośmieszenia 
„militaryzmu” - gdy fałszywy kapitan stara się wykazać w nowej pracy i wpada na pomysł, by obdarować dzieci czekoladkami w kształcie Grubej Berty (moździerz produkowany przez zakłady Kruppa), Pferdeapfel komplementuje jego właściwy instynkt polityczny. Gdy zaś prawdziwy Hauptmann może się ujawnić, jego żona po prostu wyciąga z szafy stary mundur męża ${ }^{174}$ (wśród pamiątkowych rupieci są również zdjęcia pokazujące Alberta jako uczestnika egzekucji, ale nie przykuwają one uwagi bohaterki). Krytyka (wyobrażonych) realiów RFN nie ogranicza się przy tym do domniemanego „militaryzmu” ${ }^{175}$ - zjadliwie potraktowana zostaje przez Dudowa także demokracja parlamentarna (deputowany zrzeka się mandatu za sowitą łapówkę, a przed głosowaniem nad kluczowymi ustawami debatuje się $\mathrm{w}$ toalecie).

Podobnie jak Rada bogów, fabuła Dudowa jest „opowieścią z kluczem”. Nazwisko filmowego generała Kesselmeyera przypomina o generale Luftwaffe, Albercie Kesserlingu, który pod koniec wojny, jako głównodowodzący frontu zachodniego, był współodpowiedzialny m.in. za masakrę ponad trzystu zakładników w Jaskiniach Ardeatyńskich. Przez brytyjski trybunał wojskowy we Włoszech został skazany na karę śmierci (później zamienioną na dożywocie), a następnie, w 1952 r., zwolniony. Po powrocie do RFN pełnił funkcję przewodniczącego reaktywowanej w $1951 \mathrm{r}$. organizacji paramilitarnej Stahlhelm (założonej jeszcze w czasach Republiki Weimarskiej, w 1933 r. wcielonej do SA) i uchodził za lidera środowisk weteranów Wehrmachtu (zwłaszcza po publikacji w 1953 r. autobiograficznej książki Żotnierz aż do końca $\left.{ }^{176}\right)$. W filmie przedstawiony jest jako omnipotentny strateg, który w więzieniu komenderuje amerykańskimi strażnikami i nad mapą Europy oddaje się planom... ataku atomowego na NRD.

174 Swoją drogą podobna scena pojawia się w filmie Nadzy wśród wilków Franka Beyera (zob. podrozdział 2.7) - z tym, że „wymiana garderoby” następuje tam, można powiedzieć, $\mathrm{w}$ odwrotną stronę: esesman $\mathrm{z}$ obozu, przewidując rychłe nadejście frontu, wyciąga z szafy cywilny garnitur. Najwyraźniej, "mundur w szafie” - chowany weń lub zeń wyciągany - mógł należeć w Niemczech do symbolicznego instrumentarium myślenia o „nierozliczonej przeszłości”.

175 Ten aspekt filmu chwalił zachodnioberliński krytyk Ulrich Gregor, zdaniem którego Hauptmann... zawiera „kilka epizodów, które w swojej groteskowej przesadzie trafiają w czuły punkt naszych ułomnych zachodnioniemieckich stosunków. Chodzi zwłaszcza o deliryczny zachwyt delegacji żołnierskich witających wypuszczonego z więzienia feldmarszałka Kesselmayera, zachwyt zakłócony jednak bezpośrednią interwencją ludzi myślących inaczej. Dudow ukazuje więc w końcu także "pozytywne siły w Republice Federalnej, tyle że czyni to w sposób marginalny i niezróżnicowany, bez żadnego przejścia pomiędzy nimi, a zwolennikami neonazizmu” („Die andere Zeitung”, 31.01.1957 - cyt. za: Obrazy Niemiec 1949-1999..., s. 37).

${ }_{176}$ Albert Kesselring, Żołnierz do końca, tłum. D. Luliński, Warszawa 1996. 
Dwie postaci z fabuły Dudowa są „,skontaminowane”, tj. każda z nich odsyła do dwóch realnie działających osób. Filmowy Seekatz to aluzja do Hansa-Christopha Seebohma (działacza Deutsche Partei, a następnie CDU, w latach 1949-1966 sprawującego stanowisko ministra transportu RFN, związanego również z organizacjami Niemców sudeckich) oraz Hansa-Joachima von Merkatz (byłego członka NSDAP, w latach 50. deputowanego do Bundestagu, piastującego w różnych okresach ważne urzędy państwowe: sekretarza stanu w Ministerstwie Spraw Wewnętrznych i ministra sprawiedliwości). Natomiast konstrukcja bohatera określanego w filmie jako Robert Alfried Pferdapfel, oficjalnie tytułowanego „Baron von Kolhen und Stahlbach", pozwala dostrzec podobieństwa do Roberta Pferdmengesa (bankiera wpływowego w środowisku kanclerza Adenauera, a w latach 50. członka Bundestagu) oraz Alfrieda Kruppa von Bohlen und Halbach (dziedzica słynnej firmy, po wojnie odpowiadającego przed sądem m.in. za niewolniczą pracę robotników przymusowych).

Cztery lata później powstał film Spotkania w mroku (Begegnung im Zwielicht, reż. Wanda Jakubowska, NRD/Polska 1960), nakręcony w koprodukcji polsko-enerdowskiej według powieści Stanisławy Fleszarowej-Muskat Pozwólcie nam krzyczeć. Jako pierwszy pokazywał on miłość między Polką i Niemcem zaistniałą w czasie wojny - wówczas to bowiem właściciel fabryki Ernst, odkrywszy talent muzyczny Magdy (w tej roli wspomniana już Zofia Słaboszowska), przymusowej robotnicy, zatrudnił ją w swym biurze i pozwolił ćwiczyć na fortepianie stojącym $w$ jego domu. Gdy po latach Magdalena, która w międzyczasie stała się wybitną pianistka, w trakcie tournée w Republice Federalnej Niemiec spotyka się z Ernstem, okazuje się, że jest on zaprzyjaźniony z byłymi hitlerowcami. Mężczyzna nie tylko zeznaje przeciw człowiekowi kiedyś pomagającemu więźniom, a teraz oskarżonemu o komunistyczne knowania, lecz także zaprzecza, by $\mathrm{w}$ przeszłości $\mathrm{w}$ jego fabryce zatrudniani byli robotnicy przymusowi. W zakończeniu Ernst ściga swym autem samochód Magdy - pojazdy zostają jednak rozdzielone przejeżdżającą kolumną samochodów wojskowych. Jak pisze autorka szkicu o polsko-niemieckich romansach filmowych, film Jakubowskiej wyraża myśl, iż wprawdzie „miłość między przedstawicielami Polski i Niemiec jest możliwa, ale [...] o losach romansu decydują nie tylko zakochani, ale także okoliczności historyczne i polityka obu krajów"177.

177 Grażyna Stachówna, „Drogi pośród nocy” Krzysztofa Zanussiego i inne filmowe romanse polsko-niemieckie, [w:] Polska i Niemcy: filmowe granice i sasiedztwa, red. Konrad Klejsa, Wrocław 2012. Nieco podobny wątek - w tym wypadku rozgrywający się między młodym Czechem sprowadzonym przymusowo w głąb Rzeszy a niemiecką pielęgniarką - pojawił się w filmie Rocznik 1921 (Jahrgang 21, reż. Václav Gajer, NRD/Czechosłowacja 1958). 
Podobnie jak w kinie erefenowskim, również w NRD nakręcono kilka filmów szpiegowskich (oczywiście, z odwróconym wektorem postaci „,dobrych" i „złych"). W dwóch spośród nich - Misji specjalnej (Sonderauftrag, reż. Heinz Thiel, NRD 1959) oraz Ataku we mgle (Nebel, reż. Joachim Hasler, NRD 1963) - fabuła odwołuje się do wydarzeń sprzed 1945 r.

Dramaturgiczny punkt wyjścia Misji specjalnej przedstawia się następująco: okręt Armii Ludowej, dowodzony przez kapitana Fischera, zostaje wysłany z misją oczyszczenia enerdowskiej części Morza Bałtyckiego z min pozostawionych po wojnie. Nieoczekiwanie natrafia na zachodnioniemiecki kuter, na którym znajduje się marynarz nazwiskiem Arendt. Fischer, dawny oficer Kriegsmarine, przypomina sobie sytuację z 1943 r., gdy szanowany przez niego major Wegner chciał się poddać duńskiemu ruchowi oporu i dołączyć do partyzantki. Sam Fischer również rozważał taką decyzję pod wpływem doniesień o obozach koncentracyjnych oraz lektury ulotek antyfaszystowskich, lecz nie był tak zdecydowany, jak jego przełożony. Ostatecznie Wegner został zadenuncjowany i skazany na śmierć, najprawdopodobniej właśnie przez Arendta. Dziś Fischer nie ma wątpliwości, że to właśnie Arendt onegdaj zdradził, a teraz pracuje jako erefenowski agent; główny bohater wybrał natomiast właściwą drogę kariery - w enerdowskiej Volksmarine.

$\mathrm{Z}$ kolei intryga kryminalna Ataku we mgle rozgrywa się na początku lat 60. w angielskim miasteczku portowym, w którym swą bazę ma stworzyć marynarka NATO. Aby doprowadzić ten zamiar do skutku, z RFN przybywa mężczyzna z zadaniem wydobycia wraku zatopionego przez U-Boota statku, którym w czasie wojny ewakuowano ze Starego Kontynentu kobiety i dzieci. Główny bohater - brytyjski nurek - odkrywa, iż Niemiec jest oficerem odpowiedzialnym za storpedowanie tego okrętu. Gdy przybysz z RFN zostaje odnaleziony martwy, podejrzenie o popełnienie morderstwa pada na Anglika; od wyroku uchroni go zeznanie dawnego niemieckiego jeńca wojennego, który był świadkiem wypadku. W porównaniu z Misja specjalnq rola wroga politycznego zostaje tu przypisana nie tylko RFN, lecz całemu NATO.

W niektórych powstałych w NRD filmach ukierunkowanych na zdyskredytowanie zachodniego sąsiada wykorzystywano omówiony wcześniej model opowieści antyfaszystowskiej. Jako przykład marginalny, acz dla polskiego widza interesujący, można wskazać film Morderstwo bez kary (Mord ohne Sühne, reż. Carl Balhaus, NRD 1962), będący fabularyzacją autentycznych wydarzeń z lat 20. - losów polskiego chłopa, Jakubowskiego, który został oskarżony o morderstwo na przybranym synu, a następnie $\mathrm{w}$ wyniku kontrowersyjnego procesu skazany na śmierć i stracony ${ }^{178}$.

178 Powieściowy pierwowzór - Theo Harych, Morderstwo bez kary: sprawa Jakubowskiego, tłum. I. Sławińska, Katowice 1965. 
W filmie w winę Jakubowskiego (Wojciech Siemion) powątpiewają policjant Lippert oraz redaktor komunistycznej gazety Hartmann. Wyrok skazujący, dobrze współgrający z antypolską propagandą, chce uzyskać prokurator Becker, który nie bierze pod uwagę dowodów niewinności oskarżonego. Istotne jest zakończenie, rozgrywające się po przejęciu władzy przez nazistów - w końcowej sekwencji filmu Lippert dołącza do antyfaszystowskiego podziemia, a prokurator Becker zostaje członkiem SS i otrzymuje awans.

Przywołane przykłady są wymowne dla tej ważnej części enerdowskiej polityki pamięci, którą - za Aleidą Assmann (zob. wprowadzenie) - określić można jako strategię „eksternalizacyjną”. Była ona silnie skorelowana z polityką zagraniczną NRD, nieodmiennie wrogą wobec zachodniego sąsiada. Być może bardziej szczegółowa analiza relacji międzynarodowych NRD, która nie zostanie tu podjęta, ujawniłaby dodatkowe konteksty interpretacyjne wspomnianych tu filmów.

\subsection{Kraj po denazyfikacji: NRD jako alternatywa}

Propaganda NRD niemal do końca istnienia tego państwa podkreślała, że denazyfikacja dokonana w jego granicach (także przed 1949 r.) zakończyła się sukcesem - w odróżnieniu od landów pozostających w Republice Federalnej. W 1950 r. nagłaśniane były "procesy waldheimskie” (od miasteczka Waldheim), w wyniku których skazano ponad 3 tys. osób i wykonano 24 wyroki śmierci (surowość kar oraz niehumanitarne warunki przetrzymywania więźniów doprowadziły do wielu protestów, głównie w zachodnich Niemczech ${ }^{179}$ ). Rzadko przypomina się jednak, że także w NRD przyjęto ustawy amnestyjne (tuż po proklamowaniu osobnego państwa: w listopadzie 1949 i październiku 1952 r.) ${ }^{180}$, dzięki czemu wielu byłych członków NSDAP oraz Mitläuferów uniknęło kary, a w niektórych wypadkach mogło wrócić do wcześniej wykonywanej pracy (choć skala "powrotów” faktycznie nie była tak duża, jak w Niemczech Zachodnich - przynajmniej w sądownictwie czy szkołach). Zreszta, już w 1949 r. Walter Ulbricht mówił:

Obecnie kryterium tego, kto jest miłującym pokój człowiekiem i chce jedności Niemiec, nie jest to, jaką członkowską legitymację ktoś wcześniej posiadał, lub czy należał

179 Zob. Wolfgang Eisert, Die Waldheimer Prozesse. Der stalinistische Terror 1950. Ein dunkles Kapitel der DDR-Justiz, München 1993.

${ }^{180}$ Zob. Norbert Frei, NS-Vergangenheit unter Ulbricht und Adenauer. Geschichtspunkte einer "vergleichenden Bewältigungsforschung”, [w:] Die geteilte Vergangenheit... 
do partii Hitlera czy też nie, lecz jedyną miarą jest, czy jesteś za traktatem pokojowym, przeciw paktowi północnoatlantyckiemu, przez który zachodnie Niemcy mają być bazą wojenną [...]. Kto dzisiaj przy obecnych warunkach stawia pytanie: czy ktoś był wcześniej członkiem partii nazistowskiej lub nie, ten pracuje przeciw tworzeniu Frontu Narodowego ${ }^{181}$.

Dla potrzeb propagandowych szczególnie istotne stały się osoby, które zdecydowały się pozostać w NRD (w tym: we wschodniej części Berlina), mając za sobą doświadczenia pracy w RFN (lub Berlinie Zachodnim). To „zapotrzebowanie” miało swoje konsekwencje również dla fabuł realizowanych w Defie, w których zaroiło się od wątków „,konwersyjnych" oraz postaci ilustrujących pożądane trajektorie politycznych wyborów.

Schemat taki zastosowano w filmie Rodzina Sonnenbrucków (Die Sonnenbrucks, reż. Georg C. Klaren, NRD 1951). Choć zrealizowano go na podstawie Niemców Leona Kruczkowskiego (współautora scenariusza), a w jednej z ról wystąpiła Aleksandra Śląska, formalnie nie była to koprodukcja między „bratnimi krajami demokracji ludowej”182 (zarazem enerdowska premiera inaugurowała „miesiąc przyjaźni niemiecko-polskiej"183). Sztuka Kruczkowskiego - w NRD znana jako Die Sonnenbrucks $^{184}$ - została już wcześniej, w 1949 r., wystawiona we wschodniej części Berlina i spotkała się ze sporym zainteresowaniem ${ }^{185}$. Jak zauważa

181 Walter Ulbricht, Warum Nationale Front des demokratischen Deutschlands? Aus dem Referat auf der Parteikonferenz der SED, 17 Mai 1949, [w:] idem, Zur Geschichte der deutschen Arbeiterbewegung. Aus Reden und Aufsätzen, t. 3: 1946-1950, Berlin (Ost) 1954, s. 291, cyt. za: Anna Wolff-Powęska, Pamięć..., s. 233.

${ }^{182}$ Na temat powstania filmu zob.: Lars Jockheck, "Rodzina Sonnenbrucków" Georga C. Klarena - pierwszy "niemiecko-polski film wspólnotowy"?, tłum. M. Orepuk, [w:] W drodze do sąsiada. Polsko-niemieckie spotkania filmowe, red. Andrzej Dębski, Andrzej Gwóźdź, Wrocław 2013; Aleksandra Jaskólska, Rodzina Sonnenbrucków, [w:] Dramat na ekranie, red. Aleksander Jackiewicz, Warszawa 1953. Film dystrybuowany był oczywiście w polskich kinach (premiera w Warszawie miała miejsce tego samego dnia, co w Berlinie) - zob. Reżyser Georg C. Klaren o filmie "Sonnenbruckowie”, „Film” 1951, nr 17; zob. także: Irena Merz, Niemcy na ekranie, „Kwartalnik Filmowy” 1951, nr 3-4.

${ }^{183}$ Lars Jockheck, „Rodzina Sonnenbrucków” Georga C. Klarena..., s. 51. Autor zwraca uwagę, że materiały zamieszczone w programie filmowym odnosiły się nie tylko do filmu, lecz także do „nowej Polski”, zaś współwydawcą broszury było Niemiecko-Polskie Towarzystwo na Rzecz Pokoju i Dobrego Sąsiedztwa (ibidem, s. 43).

184 Zmiana tytułu sztuki została dokonana z uwagi na konieczność złagodzenia (dla widowni niemieckiej) tezy o winie wszystkich Niemców, jak również ze względu na podobieństwo do nazwiska Ferdynanda Sauerbrucha, znanego chirurga, którego władze NRD starały się (bezskutecznie) przekonać do pozostania w państwie wschodnioniemieckim. Zob. Susanne Misterek, Polnische Dramatik in Bühnen- und Buchverlagen der Bundesrepublik Deutschland und der DDR, Wiesbaden 2002, s. 280.

${ }^{185}$ O recepcji sztuki zob. Ulrich Steltner, Leon Kruczkowski (1900-1962), [w:] Polnische Dramen in Deutschland. Übersetzung und Aufführungen als deutsch-deutsche Rezeptionsge- 
Lars Jockheck, Rodzina... „wyraźnie odbiegała od większości filmów zarówno wschodnio-, jak i zachodnioniemieckich poruszających problematykę narodowego socjalizmu”, ponieważ „na pierwszym miejscu stawiała europejski wymiar nie tylko zbrodni nazistowskich, lecz także oporu przeciwko nazistom w okupowanej Europie", we Francji, Norwegii i Polsce ${ }^{186}$.

W odniesieniu do literackiego pierwowzoru, w scenariuszu zmieniono niewiele. Zachowano rozgrywającą się $w$ okupowanej Polsce pierwszą scenę dramatu, która z główną linią dramaturgiczną ma niewiele wspólnego - wprowadza bowiem jedynie drugoplanową postać żandarma Hoppe. Wcześniej pracował on jako woźny w laboratorium profesora biologii Sonnenbrucka i szykuje się na urlop związany z jubileuszem pracy swojego byłego szefa. W scenie tej folksdojcz przyprowadza na komisariat żydowskie dziecko i żąda, by Hoppe je zastrzelił; na posterunku pojawia się też Polak, który stara się przekonać żandarma, by wypuścił chłopca. Ale ponieważ folksdojcz nalega, by wyrok został wykonany, Hoppe ostatecznie zabija dziecko. Główna część akcji rozgrywa się w czasie jubileuszu Sonnenbrucka w 1943 r. W willi zjawia się jego dawny asystent - komunista Peters, który uciekł z kacetu. Po pewnych wahaniach Sonnenbruck oferuje mu schronienie i obiecuje, ze nie zdradzi nieproszonego gościa; odmawia mu jednak rzeczywistej pomocy. Dochodzi do konfrontacji pomiędzy dziećmi profesora: gotową do pomocy Ruth, esesmanem Willym, a także wdową po jego bracie, nazistką Liesel. Petersowi udaje się uciec - winę bierze na siebie Ruth.

Inne niż w dramacie jest jednak zakończenie filmu. Kiedy po wojnie Sonnenbruck powraca na uniwersytet w Getyndze (w Niemczech Zachodnich), dostrzega wokół siebie postawy znane z lat III Rzeszy ${ }^{187}$. Sytuację pogarsza fakt, że podpisuje petycję przedłożoną mu przez Petersa. Gdy więc w płomiennej scenie końcowej profesor wyjaśnia studentom, dlaczego

schichte 1945-1995, Köln 2011; Heinrich Olschowsky, Zeitstück und Geschichte. Leon Kruczkowskis Drama "Die Sonnenbrucks" in der DDR, [w:] Verteidigung der Menschheit, red. Edward Kowalski, Berlin (Ost) 1975.

186 Lars Jockheck, „Rodzina Sonnenbrucków” Georga C. Klarena..., s. 45.

187 Hans Ulrich Eylau w ten oto charakterystyczny sposób pointował swą recenzję na łamach „Berliner Zeitung”: „Sonnenbruck zauważa, że może powtórzyć się sytuacja, którą z odrazą znosił przez dwanaście lat, i odnajduje wreszcie drogę do postępowych Niemiec. Ma on świadomość, że dana mu tam będzie możliwość działania, a nie tylko biernego godzenia się z istniejącymi warunkami. Taki jest sens tego ważnego filmu, takie jest przesłanie płynące do serc i umysłów widzów. Groźba faszyzmu, groźba wojny nie ustała w 1945 r. Niezależnie od tego, co miało miejsce wcześniej, już dziś trzeba podjąć decyzję, dziś trzeba toczyć bój o to, by warto było żyć i by ludzie mogli żyć w pokoju” („Berliner Zeitung", 3.3.1961 - za: Obrazy Niemiec 1949-1999..., s. 20). 
postanawia wyjechać na stałe do NRD, młodzież przyjmuje tę decyzję $\mathrm{z}$ entuzjazmem (Niech żyje profesor Sonnenbruck! Niech żyja Niemcy dnia jutrzejszego!! $)^{188}$. W Rodzinie Sonnenbrucków, podobnie jak w zrealizowanej niewiele wcześniej Radzie bogów (o której była już mowa), RFN to państwo niedemokratyczne, nie tyle zagrożone re-faszyzacja, co już „zrefaszyzowane". Ideologiczna wymowa filmu okazała się z czasem jednak zbyt ambiwalentna, a jego odczytania - podatne na polityczne fluktuacje: $\mathrm{w} 1977 \mathrm{r}$. enerdowskie Ministerstwo Kultury zakazało wyświetlania filmu, oceniając zakończenie jako rzekome orędowanie za jednością Niemiec ${ }^{189}$.

Dyskurs (auto)profilowania NRD jako alternatywy wobec zachodniego sąsiada prowadzony był $w$ dziesiątkach socrealistycznych fabuł Defy o tematyce współczesnej. Wśród tych, w których pojawiają się wątki odnoszące się do lat nazizmu, jest Matżeństwo aktorki (Roman einer jungen Ehe, reż. Kurt Maetzig, NRD 1952). W dorobku Defy to jeden z najbardziej jaskrawych przykładów kina stalinowskiego (w zakończeniu filmu na pytanie: Jak powinniśmy podziękować Stalinowi? pada odpowiedź: Nazwiemy jego imieniem tę ulicę). Po odwilży 1956 r. realizacja Maetziga trafiła na półki, choć już po premierze podniosły się głosy krytyczne, utyskujące na nazbyt patetyczne dialogi (film nie znalazł się na liście tytułów wyróżnionych podczas II Kongresu Filmowego zorganizowanego we wrześniu 1952 r.).

Początek Matżeństwa aktorki... przypomina analogiczną sekwencję z filmu Mordercy sa wśród nas: w pejzaż ruin Berlina wkracza bohaterka, która - poprzez głos ponadkadrowy (nie było go u Staudtego) - wyjaśnia, że obrazy te mają charakter retrospekcji: To było pięć lat temu. Z monologu protagonistki dowiadujemy się, że jej matka zginęła w ruinach Drezna (jak już pisałem, przypominanie o alianckich bombardowaniach należało do kanonu enerdowskiej polityki historycznej), ale obrazy wojny nie są włączane do narracji; wzmianki na jej temat nie będą już pojawiać się w dialogach.

Akcja filmu rozgrywa się $\mathrm{w}$ podzielonym na strefy okupacyjne Berlinie. Anna, młoda aktorka, dostaje angaż do sztuki Natan mędrzec Lessinga ${ }^{190}$, wystawianej przez teatr znajdujący się w części sowieckiej. Jej

${ }^{188}$ W polskiej adaptacji dramatu Kruczkowskiego, filmie Niemcy (reż. Zbigniew Kamiński, Polska-USA 1996), profesor popełnia samobójstwo.

${ }^{189}$ Lars Jockheck, "Rodzina Sonnenbrucków”" Georga C. Klarena..., s. 54.

190 Podobnie jak w Małżeństwie w mroku, również tutaj fabuła dramatu, w którego inscenizacji występują bohaterowie, metaforycznie odzwierciedla społeczne bariery stojące na przeszkodzie ich miłości. Zob. Seán Allan, "Sagt, wie soll man Stalin danken?" Kurt Maetzig's "Ehe im Schatten", "Roman einer jungen Ehe" and the Cultural Politics of Post-War Germany, "German Life and Letters" 2011, nr 2. W pierwszych latach po wojnie Natan Mędrzec był we wschodniej części Niemiec jedną z najczęściej wystawianych sztuk (Katarzyna Śliwińska, Socrealizm..., s. 42). 
scenicznym partnerem jest gwiazdor Jochen Kunert; młodzi zakochują się $\mathrm{w}$ sobie i pobierają. Wskutek rosnących napięć politycznych między wschodnią a zachodnią częścią miasta oraz jego ostatecznego podziału małżeństwo zostaje wystawione na próbę. Anna postanawia zamieszkać w Berlinie Wschodnim - wcześniej otrzymała rolę w produkowanym przez zachodnioniemiecką stację radiową słuchowisku na podstawie powieści Anny Seghers Siódmy krzyż (które jednak, zdaniem bohaterki, fałszowało wymowę powieści). Teraz Anna przygotowuje występ na okoliczność uroczystego otwarcia Alei Stalina (w nagrodę otrzymuje przydział na mieszkanie). Jochen wyraża się z pogardą na temat tej pracy (krytykuje też występ Anny we wschodnioniemieckim filmie), w konsekwencji czego małżonkowie postanawiają się rozwieść. Jochen zaczyna mieć jednak wątpliwości, czy faktycznie zachodnia część Niemiec stanowi państwo prawa: jest m.in. świadkiem występu chóru dziewcząt, jakoby uciekinierek z NRD, które (bohater czyta w enerdowskiej prasie) faktycznie zostały... porwane. Na domiar złego angaż Jochena $w$ teatrze wygasa - menedżer proponuje mu rolę nazisty w planowanym filmie rozrywkowym, którą mężczyzna odrzuca. W drodze na rozprawę rozwodową, jeszcze w zachodniej części Berlina, bohater jest świadkiem pobicia grupy pacyfistów protestujących przeciw remilitaryzacji Niemiec. Podnosi flagę z gołąbkiem pokoju i wkracza z nią na salę sądową, gdzie przyznaje się do winy i przeprasza żonę za popełnione błędy.

Film można i należy rozpatrywać przede wszystkim w kategoriach propagandowej rozgrywki, wzmożonej tuż po ostatecznym podziale Berlina, mającym swe konsekwencje także dla świata artystycznego. Małżeństwo aktorki powstało bowiem w momencie, gdy władze NRD wymuszały na artystach deklaracje, czy będą pracować we wschodnich czy zachodnich Niemczech. Istotne wątki filmu dotyczą konkretnych twórców: Jochen zostaje zaangażowany do gry w spektaklu Generat diabła Zuckmayera (jednej z najczęściej wystawianych sztuk w brytyjskiej i amerykańskiej strefie okupacyjnej, później zekranizowanej w RFN - zob. podrozdział 3.2), we wschodnich Niemczech uznawanej za dowód „rehabilitacji podżegaczy wojennych". Anna z kolei rozważa możliwość zagrania w sztuce Brudne dłonie, wówczas surowo ocenianej przez stalinistów (bohaterka odmawia, gdyż jej zdaniem dramat wymierzony jest przeciw wszystkiemu, co dobre, przyzwoite i piękne w ludziach).

Ważny wątek filmu dotyczy także Veita Harlana - nie zostaje on wprawdzie wymieniony z nazwiska (postać określona jest jako „Herr Hartmann”), lecz jest jednoznacznie identyfikowany jako „reżyser Żyda Süssa”. Twórca ten pojawia się w życiu bohaterów kilkakrotnie - bezpośrednio 
(na premierze zakazanego w III Rzeszy Natana mędrca, z której zostaje wyproszony przez teatralnego intendenta), i pośrednio: Anna śledzi informacje o toczącym się procesie "Hartmanna"191 (podczas sprawy sądowej reżyser jest pewny siebie, deklaruje "służbę sztuce”, na odchodnym zaś rzuca: Gdybym musiał nakręcić ten film jeszcze raz, nakręciłbym go w taki sam sposób). To jedna z przyczyn decyzji bohaterki o pozostaniu w NRD; Jochen natomiast z niesmakiem konstatuje, że w obronie "Hartmanna” wypowiada się wielu jego znajomych z branży (z Niemiec Zachodnich).

Zrealizowane $\mathrm{w}$ tym samym roku Kobiece losy (Frauenschicksale, reż. Slátan Dudow, NRD 1952) opowiadają historię pięciu bohaterek, które uciekły z zachodniej części Berlina do NRD. Łączy je postać męska: uwodziciel Conny, sprowadzający młode kobiety na złą drogę. Są one typowymi „bohaterkami bez przeszłości”, czy raczej: fabularna wiedza o niej ogranicza się do lat powojennych. Tylko w odniesieniu do jednej z kobiet, pani Becker, narracja wspomina o wojnie (jest mowa o jej poparzeniach podczas bombardowania Drezna i hospitalizacji). Bohaterka ta po latach powraca do Berlina, aby odzyskać córeczkę, Christel, która w międzyczasie została adoptowana przez Hertę, byłą uczestniczkę antyfaszystowskiego ruchu oporu. Ostatecznie dziecko wraca do biologicznej matki, a Herta rekompensuje swą stratę, z zapałem oddając się pracy społecznej: obejmuje kierownictwo sierocińca i wygłasza antymilitarystyczne pogadanki (radiowej transmisji jednej z nich przysłuchuje się Christel; gdy słyszymy o trudnym losie kobiet, które straciły podczas wojny swych mężów, pojawia się pani Becker, co sugeruje, że dotknęła ją podobna strata).

Najbardziej osobliwa jest historia Renate Ludwig, która... zabiła młodszego braciszka, gdy ten był świadkiem dokonanej przez siostrę kradzieży pieniędzy matki. Scena morderstwa jest dość niebywała - zarówno gdy idzie o drastyczność samego wydarzenia, zupełnie niedostosowanego do reszty filmu, jak i sposób jego prezentacji. Oto brat droczy się z siostra, żartem zapowiadając, że opowie mamie o tym, co widział. Nagle - nie mieliśmy wcześniej sygnałów świadczących ani o niezrównoważeniu Renate, ani o jej niechęci wobec brata - Renate dusi brata poduszką (Ani słowa, gamoniu; czekaj, już ja cię uciszę). W kolejnym ujęciu do domu wraca matka - dostrzegłszy ciało synka leżące na podłodze, upuszcza zakupy. Następuje scena przesłuchania matki przez policję; do tego momentu nie wiadomo z całą pewnościa, że chłopiec nie żyje. Okazuje się to dopiero na

191 O „procesie Harlana” zob: Frank Noack, Veit Harlan. „Des Teufels Regisseur”, München 2000, s. 300-315; Wolfgang Kraushaar, Der Kampf gegen den "Jud Süss" - Regisseur Veit Harlan. Ein Meilenstein in der Grundrechtssprechung des Bundesverfassungsgerichts, "Mittelweg 36. Zeitschrift des Hamburger Instituts für Sozialforschung" 1995, nr 6. 
sali sądowej - przy czym proces (transmitowany przez radio, co też wydaje się nie bez znaczenia) zostaje pokazany jako spór proceduralny, sam w sobie dość niezwykły, gdyż jest mowa o okolicznościach łagodzących: traumatycznym dzieciństwie (ojciec ginie na froncie, a matka zmuszona jest pracować w fabryce amunicji, skutkiem czego nie ma czasu na zajęcie się dziećmi). Anke Pinkert komentuje to w następujący sposób: „Pytanie, dlaczego chłopiec musiał umrzeć, należy sformułować inaczej, mianowicie: dlaczego nikt zdaje się nie zauważać, że chłopiec naprawdę nie żyje?"192. Autorka zawiesza to pytanie w próżni, nie ważąc się na konkluzję, która nasuwa się jednak dość nieuchronnie: dyskursywny sens tej sceny jest związany przede wszystkim z uargumentowaniem "okoliczności łagodzących”, natomiast śmierć chłopca pełni tu rolę „zastępnika”, znaku ewokującego „to, o czym się nie mówi”. Jeśli bowiem ideologicznym celem filmu było ukazanie, że socjalistyczne Niemcy są gotowe na integrację, także tych „uwiedzionych” przez faszyzm - utożsamiany z kapitalizmem per se - wystarczyłoby przecież, aby bohaterka została oskarżona o kradzież lub zranienie dziecka.

Na tym jednak nie koniec. Renate otrzymuje wyrok - dwa i pół roku więzienia (!). Podczas odsiadki, gdy zmuszona jest pracować w hucie (sekwencja niemal musicalowa - stal hartuje się przy pieśni: Praca nie jest przekleństwem / Jeśli nie jest się niewolnikiem), poznaje swego przyszłego narzeczonego, Helmuta. W zakończeniu zabiera on Renate (swym samochodem) na zakupy (we wschodniej części Berlina) - traf chce, że w oko wpada jej ta sama sukienka, którą wcześniej pragnęła kupić w Berlinie Zachodnim (i właśnie dlatego dziewczyna chciała ukraść matce pieniądze, co ostatecznie doprowadziło do śmierci brata); okazuje się, że już robia je u nas! Renate przez chwilę się waha, ale narzeczony przekonuje ja, że liczy się jakość materiału - kupują więc sukienkę, którą dziewczyna od razu zakłada na siebie. Para wychodzi na ulicę, gdzie trwają uroczystości 3. Światowego Festiwalu Młodzieży. W ten sposób wymazana zostaje przeszłość - ból i trauma ustępują miejsca „nowej idylli”. Zaiste, trudno uwierzyć, że enerdowscy cenzorzy nie dostrzegli - zamierzonej lub mimowolnej - przewrotności tego finału (wszak „komunistyczny” bohater Helmut, zachęcający Renate do kupna sukienki, jest tu odblaskiem zachodnioniemieckiego „kombinatora”, Conny'ego, a przyczyną śmierci dziecka staje się nie tyle „burżuazyjne” pragnienie posiadania nowej sukienki, ale wręcz - sukcesy wschodnioniemieckiego przemysłu tekstylnego). O wiele ważniejsza okazała się bowiem szansa, jaką nowe enerdowskie społeczeństwo daje tym obywatelom, którzy niegdyś zbłądzili. Gdy więc w zakoń-

192 Anke Pinkert, Film and Memory..., s. 124. 
czeniu Helmut pyta Renate, czy chce przyłączyć się do marszu, ona odpowiada: Po prostu cieszę się, że mogę tu w ogóle być.

Po odwilży 1956 r. poetyka socrealistyczna jest stopniowo wygaszana. Ich troje (Genesung, reż. Konrad Wolf, NRD 1956) nosi wyraźnie jej znamiona, choć zarazem przekracza ją z uwagi na podkreślanie osobistych (a zatem: nie tylko „klasowych”) pobudek bohatera. Fabuła opowiada historię Friedela Waltera, który w latach 30. przerwał studia medyczne (i dorabiał jako śpiewak w kasynie), planując wyjazd z kraju z ukochaną Irene. Ona jednak nie zamierza opuszczać rodzinnych stron, gdyż jest zaangażowana w ruch oporu; prosi także Friedela o pomoc medyczną dla rannego komunisty Ernsta Mehlina, uciekiniera z kacetu. W czasie wojny chłopak trafia do Wehrmachtu, gdzie pracuje jako sanitariusz; pod koniec wojny zostaje aresztowany przez Brytyjczyków, którzy omyłkowo rejestrują go pod nazwiskiem doktora Müllera. Nazwiskiem tym bohater posługuje się w czasie swojej dalszej praktyki w szpitalu, gdzie troskliwie zajmuje się przykutym do łóżka marynarzem - weteranem ruchu oporu, a także, jak się okazuje, mężem Irene. $Z$ jego pomocą Friedel postanawia ujawnić swoją prawdziwą tożsamość - w liście do towarzysza Mehlina przyznaje się do kłamstwa i prosi o wstawiennictwo. Oszustwo zostaje mu wybaczone - pod warunkiem kontynuowania studiów medycznych. Opowieść ujęta jest $\mathrm{w}$ ramę fabularną - akt oskarżenia przeciw bohaterowi, którego losy poznajemy retrospektywnie za pośrednictwem wspomnianego listu-samokrytyki. Jednym słowem: kontunuowanie kariery jest możliwe, jeśli o przewinach z przeszłości zostanie poinformowana partia.

Zasygnalizowany w Ich troje temat „zakłamanej przeszłości” (a co za tym idzie: fałszywych tożsamości) pojawia się również w filmie Drugi tor (Das zweite Gleis, reż. Joachim Kunert, NRD 1962). Główna część akcji rozgrywa się w ówczesnym NRD. Dyżurny ruchu Brock jest świadkiem kradzieży, ale pozwala ujść jednemu ze sprawców; co więcej, prosi o przeniesienie do innego miasta. W złodzieju rozpoznaje bowiem Rungego, z którym wiążą go traumatyczne przeżycia z czasów wojny - Runge zastrzelił wówczas żydowskiego uciekiniera i zadenuncjował żonę Brocka, pomagającą owemu Żydowi. Brock, odczuwający współodpowiedzialność za obie śmierci, po wojnie zmienił tożsamość, a także zataił przed córką Verą prawdę o matce (która rzekomo zginęła w czasie bombardowania). Dziewczyna i jej przyjaciel Frank odkrywają faktyczny przebieg zdarzeń; zanim jednak Brock przerwie milczenie, dojdzie do jeszcze jednego dramatu - Runge doprowadzi do tragicznego wypadku, w wyniku którego zginie Frank.

Efektowny thriller Kunerta utrzymany jest w poetyce noir, zarówno pod względem wizualnym (znakomite zdjęcia Rolfa Sohre - fot. 22), jak 
i z uwagi na walory dramaturgiczne, w szczególności: ambiwalentne postaci. Osobą najbardziej konsekwentnie dążącą do poznania prawdy jest przyjaciel Very, złodziejaszek Frank. Nawet o z pozoru demonicznym Rungem słyszymy (z ust jego byłej żony), że był kiedyś dobrym człowiekiem, zanim nie wybuchta wojna. Wyjątkowość Drugiego toru wiąże się jednak przede wszystkim z faktem, iż jest to jedyny enerdowski film, w którym pojawia się postać byłego nazisty ukrywającego się w NRD (w Poszukiwaczach słońca przeszłość Beiera - choć nie wszystkie jej szczegóły - była znana innym bohaterom). O ile w innych filmach Defy mamy do czynienia bądź z „,bohaterami bez przeszłości”, bądź z protagonistami zaangażowanymi $\mathrm{w}$ antyfaszystowski ruch oporu, film Kunerta stawia enerdowskim widzom pamiętającym lata wojny pytanie: „Co Ty robiłeś/ aś przed 1945 rokiem?". W jednym z artykułów znalazłem jeszcze inną sugestię: Drugi tor miałby być mianowicie czytany przez analogię do zachodnioniemieckiego Pożegnania z dniem wczorajszym Klugego - z uwagi na, po pierwsze, akcentowanie roli kobiecej bohaterki, po drugie zaś - , ,atmosferę przemilczeń" ${ }^{193}$. Jest to jednak chybione porównanie - różnice stylistyczne, tematyczne oraz dramaturgiczne pomiędzy filmami są bowiem zbyt duże, by w przekonujący sposób dowodzić pokrewieństw między dziełem Klugego a realizacją Kunerta.

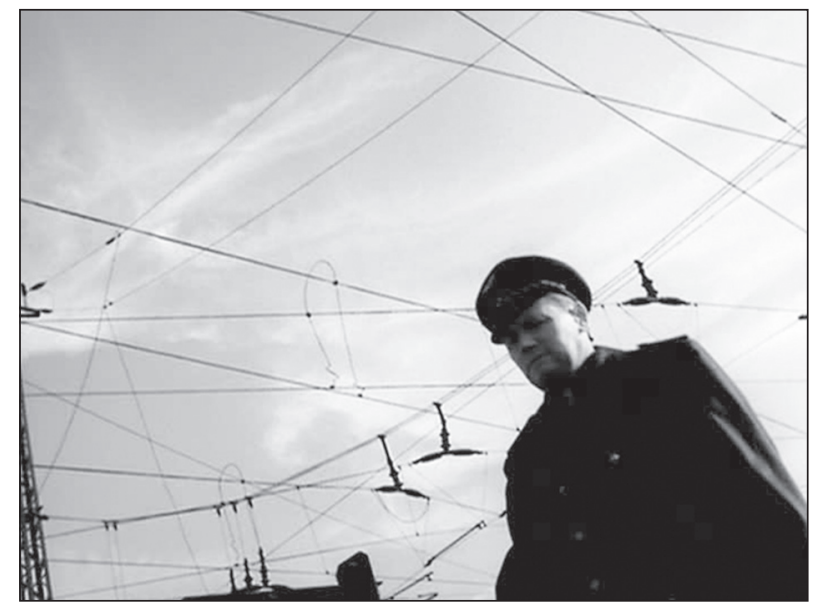

Fot. 22. Drugi tor (reż. Hans-Joachim Kunert, 1962)

Protagonista pochwycony w sieć kłamstw i przemilczeń

${ }^{193}$ Frank Stern, Real existierende Juden im DEFA-Filme. Ein Kino der subversive Widersprüche, [w:] Zwischen Politik und Kultur. Juden in der DDR, red. Moshe Zuckermann, Göttingen 2002, s. 151. 


\subsection{Problem antysemityzmu}

Na faktyczny brak debaty o antysemickim charakterze III Rzeszy w dyskursie publicznym NRD początku lat 50. wpłynęły okoliczności związane z „walką frakcyjną" w KPZR i SED (w tym: wspomniane na wstępie aresztowania osób podejrzewanych o uczestnictwo w „syjonistycznym spisku" $)^{194}$. Później sytuacja uległa pewnej zmianie - jak pisze (w niezbyt może fortunny sposób) Anna Wolff-Powęska:

Kiedy po śmierci Stalina klimat polityczny w NRD poprawił się, osoby żydowskiego pochodzenia, jak Alexander Abusch, Albert Norden, Gerhard Eisler, Hilda Benjamin, Hermann Axen, Friedrich Karl Kaul zajęli wysokie stanowiska w partii i państwie ${ }^{195}$.

Gdy w okresie „poodwilżowym” zaczęto akcentować znaczenie antysemityzmu jako zjawiska powiązanego z faszyzmem, rzutowano je geograficznie na ideologicznego wroga, czyli Republikę Federalną Niemiec. W tej perspektywie można i należy rozpatrywać cztery filmy: Skandal w Benderath (Zwischenfall in Benderath, reż. János Veiczi, NRD 1956), Proces zostat odroczony (Der Prozess wird vertagt, reż. Herbert Ballmann, NRD 1958), Teraz i w godzinę śmierci mojej (Jetzt und in der Stunde meines Todes, reż. Konrad Petzold, 1963) oraz Kronikę pewnego morderstwa (Chronik eines Mordes, reż. Joachim Hasler, NRD 1964) ${ }^{196}$.

Akcja Skandalu w Benderath rozgrywa się w zachodnioniemieckim miasteczku, w którym żydowski licealista Jakub Lewin staje się przedmiotem docinków ze strony nauczyciela historii Päkera (opisuje on ucznia jako wrogi element i tchórza o wschodnich rysach). Inni uczniowie, z grupy określającej się jako „Trojanie”, solidaryzują się z Jakubem i przywołują nauczyciela do porządku. Gdy ten odmawia wycofania swych słów, chłopcy opuszczają lekcję. Większość rodziców wstawia się za uczniami, nauczyciel musi przeprosić Lewina i zostaje przeniesiony do innej szkoły, gdzie zapewne nadal będzie głosił swe poglądy (należy bowiem do wpływowej grupy urzędników, którzy podzielają jego przekonania). Tak przedstawione streszczenie zawiera wprawdzie główną wymowę filmu (niewypleniony

194 Zob. Joachim Käppner, Erstarrte Geschichte. Faschismus und Holocaust im Spiegel der Geschichtswissenschaft und Geschichtspropaganda der DDR, Hamburg 1999, s. 71-75; Mario Kessler, Zwischen Repression und Toleranz...

195 Anna Wolff-Powęska, Pamięć..., s. 477. Zob. też: Lothar Mertens, Juden in der DDR. Eine schwindende Minderheit, „Deutschland Archiv” 1986, nr 11.

${ }^{196} \mathrm{Na}$ znaczenie tych filmów wskazuje m.in.: Elke Schieber, "Vergesst es nie - Schuld sind sie!". Zur Auseinandersetzung mit dem Völkermord an den Juden in Gegenwartsfilmen der DEFA, [w:] Die Vergangenheit in der Gegenwart. Konfrontationen mit den Folgen des Holocaust im deutschen Nachkriegsfilm, red. Claudia Dillmann, Ronny Loewy, Frankfurt am Main 2001. 
na Zachodzie faszyzm i antysemityzm), lecz powinno zostać uzupełnione o dwa wątki dodatkowe, eksponujące alternatywę wobec piętnowanych postaw. Po pierwsze, do sporu między Päkerem a "Trojanami” dochodzi w czasie lekcji, na której omawiane jest powstanie Spartakusa; po drugie, faktycznym celem Päkera pozostaje ojciec Jakuba - komunista, publicznie krytykujący militaryzację RFN i wstąpienie do NATO.

Bohaterem filmu Proces zostat odroczony, zrealizowanego na podstawie powieści Leonharda Franka Michels Rückkehr, jest Michael Vierkant, niemiecki Żyd, który - jako obywatel brytyjski - powraca do RFN. W urzędniku Kornie rozpoznaje nazistę, będącego współwinnym śmierci siostry Vierkanta. Gdy dochodzi do konfrontacji, Michael informuje o zamiarze postawienia Korna przed sądem, a ten zasłania się swoimi wpływami i znajomościami. W czasie szarpaniny Korn zostaje przypadkowo, $\mathrm{w}$ akcie samooobrony, zastrzelony przez Vierkanta, który jest zmuszony do ucieczki, a później aresztowany (media próbują przedstawić go jako komunistycznego szpiega). Bohater ma poparcie Marii Jäger ${ }^{197}$ (publicystyka jej ojca została zakazana przez nazistów), brytyjskiego dziennikarza Crosserta (gazeta, w której pracuje, odmawia napisania prawdy o Vierkancie) i zachodnioniemieckiego komunisty (z którym przez pewien czas protagonista dzieli celę). Zwołują oni międzynarodową konferencję prasową podczas której szczególnie aktywni są dziennikarze ze wschodnich Niemiec i ZSRR. Zainteresowanie mediów sprawia, że proces zostaje odroczony.

Trzeci film z tej grupy - Teraz i w godzine śmierci mojej - ma formułę thrillera (scenariusz napisał Egon Günther, później jeden ze zdolniejszych enerdowskich reżyserów). Ten gatunek zapowiadają już pierwsze sceny filmu: para turystów jest śledzona przez tajemniczych opryszków, a gdy chwilę później, na plaży, młody mężczyzna zmierza w stronę morza, pada strzał... Następnie akcja przenosi się do Jerozolimy, gdzie zachodnioniemiecka dziennikarka Ella Conradi relacjonuje proces Eichmanna; zdruzgotana skalą ujawnionych zbrodni postanawia powrócić do RFN i prosi o przydzielenie jej mniej obciążających obowiązków. Bohaterka otrzymuje zlecenie napisania o procesie w sprawie morderstwa, w którym oskarżonym jest Ralf Jordan, pragnący dowieść swej niewinności. Ella daje wiarę jego zeznaniom i przeprowadza dziennikarskie śledztwo, w wyniku którego trafia na spisek dawnych nazistów, dążących do wyeliminowania każdego, kto mógłby świadczyć w procesie Eichmanna. Wszyscy chcący odkryć prawdę (oprócz bohaterki - także młody policjant i reporter) są

${ }^{197}$ W tej roli wystąpiła Gisela Uhlen - aktorka, która z Republiki Federalnej Niemiec przeprowadziła się do NRD, o czym nie omieszkała wspomnieć wschodnioniemiecka krytyka (Hartmut Albrecht, Ein neuer DEFA-Film - frei nach Leonard Frank, "Nazionalzeitung”, 2.10.1958; Horst Knietzsch, Versuch eines poetischen Films, „Vorwärts”, 29.09.1958). 
odsuwani od sprawy przez przełożonych. Jordan ginie jako niewygodny świadek, również Conradi będzie musiała zapłacić najwyższą cenę za swą dociekliwość. Film Petzolda różni się od pozostałych brakiem wprowadzenia postaci „dobrego komunisty” - nacisk położony został na pokazanie omnipotencji byłych funkcjonariuszy reżimu (w spisek zaangażowani są też prokurator i naczelnik policji, zaś wydawca wycofuje poparcie dla dziennikarza po telefonie, w którym anonimowy rozmówca straszy go doprowadzeniem do ruiny). O zagrożeniu ze strony „faszystów” przypomina się w filmie nieustannie - amerykański kolega bohaterki pyta ją: Jakie miejsce na ziemi wychowało kogoś takiego jak Eichmann? Na jakiej ziemi wyróst taki ktoś? Ktoś taki może znowu się pojawić, dziś, jutro, w każdej chwili...

Z kolei Kronika pewnego morderstwa, na podstawie prozy Leonharda Franka Młody Jezus, opowiada historię młodej Żydówki Ruth Bodenheim, która powraca do południowych Niemiec, pragnąc wyrównać rachunki z niejakim Zwischenzahlem. W przeszłości, jako członek SA, przyczynił się on do deportacji rodziców bohaterki, w wyniku czego ona sama - jak dowiadujemy się z retrospekcji - trafiła do domu publicznego dla żołnierzy Wehrmachtu. Bodenheim ma dokumenty obciążające Zwischenzahla, który „dobił targu” z Amerykanami, a po wojnie mógł wyjechać do Ameryki Południowej, zaś po powrocie do ojczyzny został szanowanym przedsiębiorcą i zamierza kandydować na stanowisko burmistrza. Ruth odrzuca ofertę finansowej rekompensaty, domagając się sprawiedliwości - a ponieważ nikt nie chce jej pomóc, postanawia zabić Zwischenzahla w dniu jego zaprzysiężenia na nowe stanowisko. Aby nie dopuścić do wyjawienia prawdy, kobieta zostaje umieszczona w zakładzie psychiatrycznym. Dzięki jej determinacji dochodzi jednak do procesu, podczas którego Ruth upublicznia zło, jakie wyrządził Zwischenzahl (na uwage prokuratora, że niesprawiedliwość chciała zwalczyć niesprawiedliwością odsłania numer na przedramieniu...). Również ten film rezygnuje z postaci "dobrego komunisty", akcentuje natomiast polityczne uwikłania zachodnioniemieckiej elity (negatywną rolę odgrywają tu także Amerykanie) oraz zabiegi mające doprowadzić do „wyciszenia” prawdy o nazistowskich zbrodniach (rozbudowany wątek odszkodowania).

$\mathrm{O}$ ile podkreślanie antysemickich tendencji jakoby powszechnych we wrogiej RFN wpisywało się doskonale w główną linię enerdowskiej propagandy, o tyle bardziej problematyczne były kwestie związane z przedstawianiem prześladowań Żydów w okresie III Rzeszy ${ }^{198}$. Jak już wspomniałem we wstępie do niniejszego rozdziału, w zinstytucjonalizo-

198 Zob. Thomas Jung, Nicht-Darstellung und Selbst-Darstellung: Der Umgang mit der "Judenfrage" in der SBZ und der frühen DDR und dessen Niederschlag in Literatur und Film, „Monatshefte” 1998, nr 1. 
wanej enerdowskiej pamięci pod pojęciem "ofiar faszyzmu" rozumiano - podobnie zresztą jak w innych krajach "bloku wschodniego" - przede wszystkim osoby związane z partią komunistyczną ${ }^{199}$. Dopiero w kwietniu 1990 r., chwilę przed upadkiem NRD, jej Izba Ludowa ogłosiła rezolucję treści:

Nacjonalizm i rasistowski obłęd doprowadziły do ludobójstwa, w szczególności na Żydach ze wszystkich krajów europejskich, na narodach Związku Radzieckiego, narodzie polskim, Sinti i Roma [...] wyrażamy współodpowiedzialność za upokorzenie, wypędzenie i zamordowanie żydowskich kobiet, mężczyzn i dzieci [...]. Prosimy Żydów na całym świecie o wybaczenie. Prosimy naród Izraela o wybaczenie obłudy i wrogości w polityce NRD wobec państwa Izrael oraz za prześladowanie i pozbawienie godności żydowskich współobywateli także po 1945 roku w naszym kraju ${ }^{200}$.

Paradygmatyczną master narrative enerdowskiej interpretacji wydarzeń z lat 30. jest Profesor Mamlock (1961) ${ }^{201}$. Film powstał na podstawie sztuki napisanej w 1933 r. przez ojca reżysera, Friedricha Wolfa (zekranizowanej po raz pierwszy w 1938 r. w ZSRR przez Adolfa Minkina oraz współpracownika Pabsta, Herberta Rappaporta). Opowieść rozpoczyna się w 1933 r. Tytułowy bohater, Niemiec żydowskiego pochodzenia, jest szefem uniwersyteckiej kliniki, uważającym działalność NSDAP za stosunkowo nieszkodliwa, za "chwilowy wybryk" historii. W jego przekonaniu naziści nie będą $\mathrm{w}$ stanie zaprzepaścić dorobku niemieckiej nauki i kultury, z którym protagonista silnie się identyfikuje. Mamlock wyrzuca z domu swego syna, Rolfa, gdy ten deklaruje swą współpracę z komunistami, nie dowierza też córce, która pada ofiarą antysemickich docinków w szkole i bagatelizuje działania swego asystenta, doktora Hellpacha, członka NSDAP. Ostatecznie to właśnie on obejmuje klinikę, zaś profesor zostaje zwolniony z pracy (fot. 23). Dopiero wówczas tytułowy bohater pojmuje grozę sytuacji: nie widząc innego rozwiązania, popełnia samobójstwo, a przed śmiercią przyznaje rację synowi.

W fabule Wolfa Żydzi są przedstawieni jako „klasa burżuazyjna”, biernie akceptująca politykę nazistów, pozbawiona politycznego zaangażowania i gotowości do walki. Gdy w zakończeniu nad twarzą

${ }^{199} \mathrm{Na}$ ten temat zob.: Jürgen Danyel, Die Opfer- und Verfolgtenperspektive als Gründungskonsens? Zum Umgang mit der Widerstandstradition und der Schuldfrage in der DDR, [w:] Die geteilte Vergangenheit...; Olaf Groehler, Verfolgten- und Opfergruppen im Spannungsfeld der politischen Auseinandersetzungen in der Sowjetischen Besatzungszone und in der DDR, [w:] Die geteilte Vergangenheit...; Harald Schmid, Antifaschismus und Judenverfolgung. Die Reichskristallnacht als politischer Gedenktag in der DDR, Dresden 2004.

200 Anna Wolff-Powęska, Pamięć..., s. 247.

201 O Profesorze Mamlocku zob. obszerny rozdział pracy Anne Barnert, Die Antifaschismus-Thematik der DEFA. Eine kultur- und filmhistorische Analyse, Marburg 2012. 


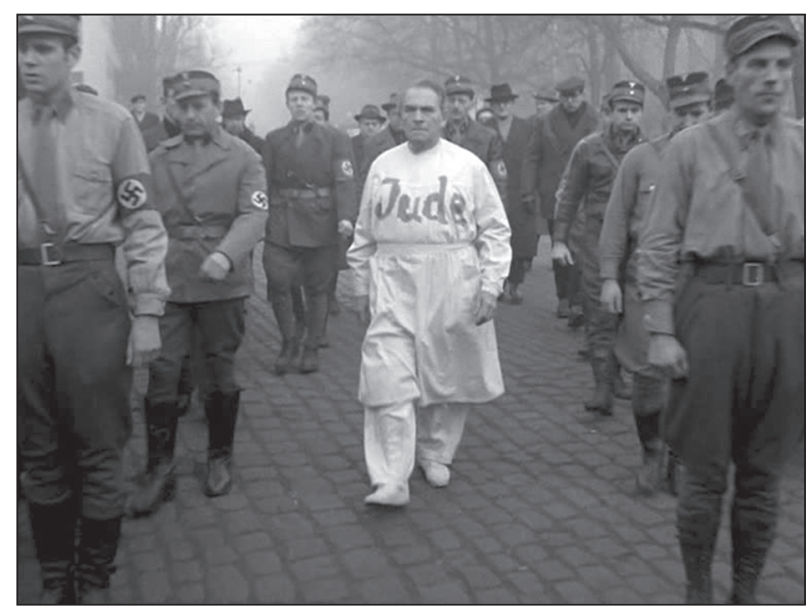

Fot. 23. Profesor Mamlock (reż. Konrad Wolf, 1961)

W kluczowej scenie filmu Mamlock wyprowadzany jest z kliniki przez nazistowskich bojówkarzy

nieżyjącego Mamlocka pojawia się napis: Nie ma większej zbrodni niż brak woli walki, kiedy trzeba ja podjać!, ujawnia on wprost to, co wcześniej było ledwie sygnalizowane: „niemieccy Żydzi, jako część burżuazji, są współwinni" ${ }^{202}$. W ten sposób film rozwija więc dyskurs, który w kinie wschodnioniemieckim zainicjowany został przez "strefowe" Małżéstwo w mroku (zob. podrozdział 1.3): ci, którzy nie dołączyli do komunistów, sami ponoszą odpowiedzialność za swój los ${ }^{203}$.

\subsection{Obrazy obozów}

Charakterystyczna dla kultury politycznej NRD „hierarchia ofiar" odzwierciedla się dobrze $w$ tematycznych preferencjach Defy - jak podaje Elke Schieber, wśród wszystkich pełnometrażowych filmów fabularnych, nakręconych w całym okresie istnienia wytwórni, było zaledwie dziesięć, które traktowały o Zagładzie ${ }^{204}$. Jeśli w enerdowskich filmach fabularnych omawianego okresu obecne były wątki lub sceny prezentujące obozy, zazwyczaj pojawiały się one w kontekście walki politycznej i/lub komuni-

${ }^{202}$ Gertrud Koch, On the Disappearance of the Dead Among the Living: The Holocaust and the Confusion of Identities in the Films of Konrad Wolf, "New German Critique" 1993, nr 60, s. 68.

${ }^{203}$ Jedna ze współczesnych interpretatorek twierdzi wręcz, że ideologiczna wymowa filmu Wolfa nie jest wolna od antysemityzmu (Martina Thiele, Publizistische Kontroversen über den Holocaust im Film, Münster 2002, s. 99).

${ }^{204}$ Elke Schieber, „Vergesst es nie - Schuld sind sie!”..., s. 42. 
stycznego ruchu oporu. Dobrych przykładów dostarcza wspomniany już film Amigo (w pierwszej i przedostatniej sekwencji) oraz scena z przywoływanego już filmu o Thälmannie, przedstawiająca uwolnienie więźniów z obozu koncentracyjnego (fot. 24): wszyscy oswobodzeni, bez wyjątku, noszą na pasiakach czerwony trójkąt. Akcentowanie znaczenia Zagłady było politycznie niewłaściwe - jak zauważył Konrad Jarausch ${ }^{205}$, stanowiła ona (czy raczej: mogłaby stanowić) dowód na to, iż konflikty na tle rasy przewyższały swą wagą walkę klasową ${ }^{206}$. Los tych, którzy zostali zamordowani z uwagi na religię lub pochodzenie był mniej zdatny, by wspierać „mit fundacyjny" NRD. Dopiero pod koniec lat 50. zaczynają pojawiać się pierwsze dzieła literackie i filmowe przepracowujące tragedię Shoah.

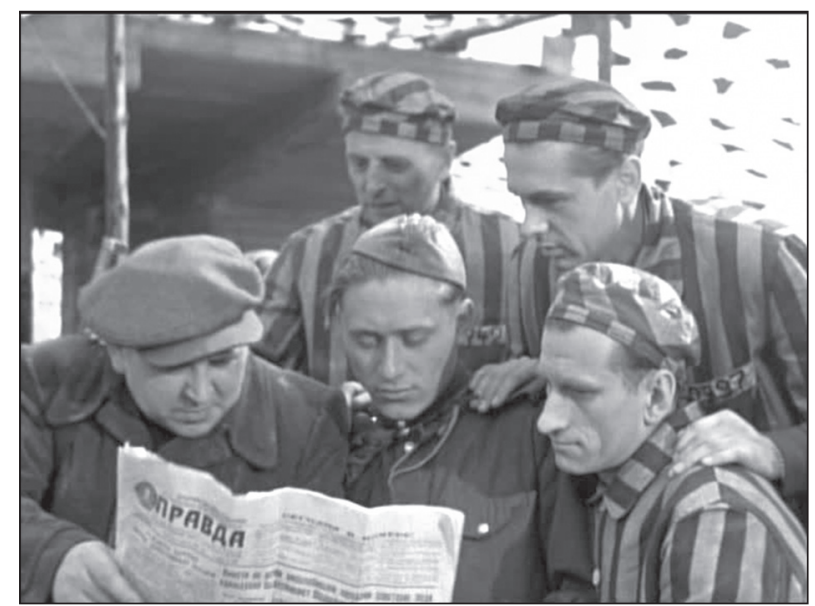

Fot. 24. W walce z Hitlerem (reż. Kurt Maetzig, 1955) Niemiecko-sowiecka idylla w wyzwolonym obozie

O stosunku władz enerdowskiej kinematografii wobec tematyki obozów zagłady świadczą również dystrybucyjne perypetie innych podejmujących ją filmów. Jedynie ograniczoną dystrybucję miała Noc i mgła Alaina Resnais - i to pomimo wykorzystanej w filmie muzyki stałego współpracownika Brechta, Hannsa Eislera (w liście Defy do paryskiego dystrybutora Argos-Film pojawia się deklaracja, iż film mógłby być rozpowszechniany na szeroką skalę, ale pod warunkiem zmiany komentarza

${ }^{205}$ Konrad Jarausch, The Failure of East German Anti-Fascism..., s. 90.

206 Do pewnego stopnia obserwację tę - w powiązaniu z opisaną już wcześniej, ideologicznie motywowaną "hierarchią ofiar" - można odnieść do innych krajów „demokracji ludowych”. W przypadku Polski dodatkowym kontekstem jest "polonizacja Zagłady” - por. Katarzyna Mąka-Malatyńska, Widok z tej strony. Przedstawienia Holocaustu w polskim filmie, Poznań 2012. 
ponadkadrowego; pomimo nałożenia nowego voice-over, z różniącym się od pierwowzoru tłumaczeniem, w NRD zorganizowano ledwie kilka seansów $)^{207}$. Na swą enerdowską premierę kilka lat musiała także poczekać Pasażerka Andrzeja Munka ${ }^{208}$.

Pierwszym wschodnioniemieckim filmem podejmującym problematykę Zagłady były Gwiazdy (Sterne, NRD 1959) Konrada Wolfa - niewątpliwie wyróżniające się na tle innych fabuł zrealizowanych w Europie $\mathrm{w}$ pierwszym dwudziestoleciu po zakończeniu wojny, takich jak Ulica Graniczna Forda czy wspomniana Noc i mgła Resnais. Z tą ostatnią realizacją łączy film Wolfa ikonografia Zagłady, w szczególności: metonimicznie zastępujące ją obrazy torów kolejowych (finałowe ujęcie to zbliżenie Ruth, która wpatruje się w niebo przez kraty bydlęcego wagonu). Element wspólny z dziełem Forda stanowi zaś piosenka w jidysz autorstwa Mordechaja Gebirtiga (w czołówce Gwiazd pojawia się napis: zginąt w 1943 roku - brak informacji, że zmarł w krakowskim getcie). U Wolfa została ona podłożona pod ujęcia toczących się wagonów na początku filmu (jak zauważa Frank Stern, jest „śpiewana w taki sposób, aby niemiecki widz mógł zrozumieć słowa piosenki" 209: kiedy miasteczko / jest Wam drogie / weźcie wiadra / ugaście ogień").

Otwierające Gwiazdy obrazy deportacji przedstawiają wydarzenia, które domykają fabułę - ta achronologiczna konstrukcja oznacza, że w czasie oglądania filmu widzowie znająjuż jego tragiczne zakończenie. Gwiazdy zaczynają się od sceny pokazującej przygotowania do deportacji: serię zbliżeń na twarze Żydów oczekujących na transport kończy ujęcie w planie amerykańskim, wyodrębniające bohaterkę, która ogląda się za siebie, najwyraźniej kogoś oczekując. Następuje scena ukazująca wprowadzanie więźniów do bydlęcych wagonów - jak zauważa Claus Loeser, nie ma tu "elementów typowych": owczarków ani oślepiających reflektorów ${ }^{210}$, jeden z żołnierzy wręcz szarmancko pomaga kobiecie i jej dziecku wejść do pociągu, zaś inny wykonuje kredą napis wskazujący „zawartość" oraz kierunek transportu: „Juden. Polen”. Po odjeździe wagonów na peronie pojawia się bohater - niemiecki żołnierz, który podnosi porzuconą w błocie gwiazdę Dawida, a następnie - bezskutecznie - stara się dogonić pociąg.

207 Zob. Ewout van der Knaap, Enlightment and Process: The Reception of "Nacht und Nebel" in Germany, [w:] Uncovering the Holocaust. The International Reception of "Night and Fog", red. Ewout van der Knaap, London 2006.

208 Thomas Heimann, Bilder von Buchenwald..., s. 132.

${ }^{209}$ Frank Stern, Real existierende Juden..., s. 150. Zob. także: Konrad Schwalbe, Sterne, „Beiträge zur Film- und Fernsehwissenschaft” 1990, nr 39.

${ }^{210}$ Claus Löser, Liebe und Schuld im Zeichen des Holocaust. Konrad Wolfs Spielfilm "Sterne", [w:] "Welchen der Steine du hebst". Filmische Erinnerung an den Holocaust, red. Claudia Bruns, Asal Dardan, Anette Dietrich, Berlin 2012, s. 312. 
Żołnierzem tym jest Walter, w cywilu student akademii sztuk pięknych, $\mathrm{w}$ armii jeden $\mathrm{z}$ podoficerów $\mathrm{w}$ oddziale Wehrmachtu stacjonującym w Bułgarii i nadzorującym obóz przejściowy dla Żydów, którzy mają być przewiezieni do Auschwitz. Pewnego dnia jedna z więźniarek - Ruth, nauczycielka z Grecji - prosi Waltera o udzielenie pomocy ciężarnej kobiecie (fot. 25). Bohater zrazu odmawia, ale nazajutrz sprowadza lekarza, w wyniku czego popada w konflikt ze swym przełożonym Kurtem, traktującym pobyt w Bułgarii jako okazję do zabawy i odnoszącym się z pogardą do "nie-Aryjczyków”. Walter zakochuje się w Ruth (podczas wieczornych spacerów para prowadzi filozoficzne dysputy o obecności zła w świecie) i chce jej pomóc. Początkowo nie godzi się jednak na współpracę z bułgarskimi komunistami, mając nadzieję, że sam znajdzie sposób na wydostanie ukochanej z obozu. Gdy przybywa na dworzec, by ocalić ją z transportu, okazuje się, że pociąg już odjechał; po dziewczynie pozostała jedynie odpruta gwiazda Dawida - ironiczne potwierdzenie wcześniejszych słów Ruth: Każdy ma na niebie opiekuńcza gwiazdę, ale gdy się ja usunie, człowiek nie może zrobić nic innego, jak tylko zniknaćc ${ }^{111}$.

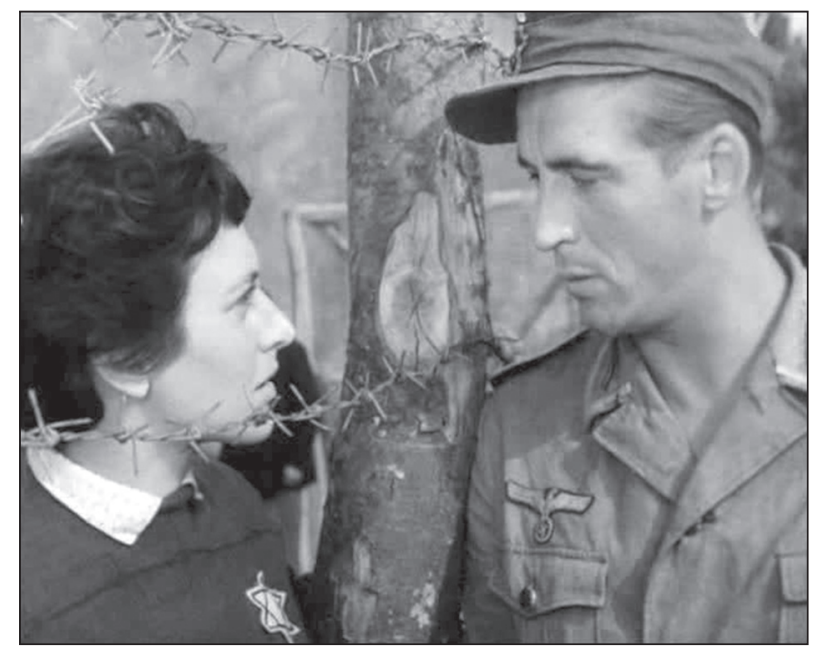

Fot. 25. Gwiazdy (reż. Konrad Wolf, 1959)

Żydówka Ruth (Sascha Kruscharska) prosi o pomoc podoficera Waltera (Jürgen Frohriep)

Los bohaterki, znany od prologu Gwiazd, jest sugerowany w kilku innych scenach. W drugiej sekwencji filmu, przedstawiającej ulice bułgarskiego miasteczka, Walter przechadza się po targowisku. Na jednym ze stoisk jego uwagę przykuwają małe laleczki z wyszytą gwiazdą Dawida

${ }^{211}$ Zob. także: ibidem. 
(jedną z nich bierze do ręki, a następnie rzuca na stos - sic! - innych podobnych pacynek). Chwilę później wdaje się w krótką rozmowę z chłopakiem majstrującym przy podwoziu ciężarówki (padają słowa: Jednemu wesele, innemu pogrzeb); na deskach naczepy protagonista kilkoma ruchami pędzla maluje kontury kobiecego ciała (ujęcie to buduje analogię ze wspomnianym pisaniem kredą na wagonie). Mniej więcej w połowie filmu pojawia się zaś osobliwa scena na jarmarcznej strzelnicy - świetnym strzelcem okazuje się Kurt: po jego strzale w nagrodę wysuwa się figurka nagiej kobiety (z budki, na której napisane jest „żeńska łaźnia”!). Oficer śmieje się, a po cięciu następuje ujęcie... szaszłyków na ruszcie.

Problem niemieckiej odpowiedzialności za Zagładę prowadzony jest w Gwiazdach nieco inaczej niż we wcześniejszych enerdowskich filmach. Wyrazicielem opinii o nieopisywalności Zagłady i jej uniwersalnym charakterze pozostaje tu Walter (zło jest wieczne), tymczasem Ruth oskarża: Jesteście wszyscy winni, winni w ten sam sposób. Odmiennie prowadzony jest też wątek ruchu komunistycznego: Walter to "dobry Niemiec” - nie dlatego, że sympatyzuje z komunistami (do tego musi „dojrzeć"), lecz pomimo to. Już „na wejściu” pokazany jest bowiem jako człowiek, który nie darzy nazistów szczególną atencją (choć z powodów, by tak rzec, raczej estetycznych niż etycznych - co narracja obrazuje, podkreślając „nieobyczajność" Kurta, nazywanego przez Waltera matpa). Taka konstrukcja postaci nie wszystkim przypadła jednak do gustu - Ulrich Gregor wyraził opinię, iż „w scenariuszu większy wysiłek włożono w charakterystykę Niemców niż Żydów" ${ }^{212}$. Claus Löser polemizuje z tym stwierdzeniem, słusznie zauważając, że z punktu widzenia "dramaturgicznej ekonomii" jest to zarzut bezzasadny (ponieważ głównym bohaterem pozostaje Niemiec, tematem zaś - jego moralne rozterki); dostrzega zarazem, że Żydzi „W żadnej scenie filmu nie są przedstawieni jako anonimowa, apatyczna masa" 213. Jeśli można mówić o jakiejś (stereo)typizacji, to dotyczy ona bułgarskiego ruchu oporu (koturnowi partyzanci przepełnieni troską o deportowanych) - dołączenie do ruchu oporu kłóci się z wcześniejszymi sekwencjami i jest nieumotywowane psychologicznie ${ }^{214}$.

Przedostatnia sekwencja Gwiazd stanowi powtórzenie sytuacji z prologu - lecz nie jest kopią sekwencji otwierającej film. Ta bowiem kończy się sceną pogoni bohatera za pociągiem: Walter biegnie po nasypie, a gdy dociera na jego szczyt, kamera pokazuje koła wagonów, a następnie pociąg wjeżdżający w tunel. Zakończenie zrazu powiela większość ujęć z prologu. Następnie mamy scenę, w której Walter - powróciwszy

\footnotetext{
${ }^{212}$ Ulrich Gregor, Sterne, „Filmkritik” 1960, nr 6.

${ }^{213}$ Claus Löser, Liebe und Schuld im Zeichen des Holocaust..., s. 319.

${ }^{214}$ Ibidem, s. 313.
} 
do miasteczka - rozmawia z członkiem bułgarskiego ruchu oporu; epizod wieńczy ujęcie niczym z Casablanki: kamera unosi się w górę, a mężczyźni odchodzą w dal pod osłoną nocy (można powiedzieć: będzie to początek pięknej przyjaźni ${ }^{215}$ ). Potem następuje wreszcie sekwencja finałowa, złożona z krótkich, dynamicznie zmontowanych ujęć: lokomotywa - kobieta za kratami wagonu - tory - kobieta za kratami - tory - pociąg wjeżdżający do tunelu. Ostatnie ujęcia zmontowane są na przenikaniu: dym - twarz kobiety - dym; na ekranie pojawiają się słowa piosenki: es brennt. Wreszcie, na długim zbliżeniu, aktorka kieruje wzrok w stronę kamery. W żadnym innym - ani enerdowskim, ani erefenowskim - filmie tego okresu nie znajdziemy ani jednej podobnej sceny.

Interesujące są okoliczności realizacji i dystrybucji Gwiazd. W obsadzie tej enerdowsko-bułgarskiej koprodukcji znaleźli się bułgarscy aktorzy, zaś autorem scenariusza był Angel Wagenstein, urodzony w żydowskiej rodzinie członek bułgarskiej partii komunistycznej i związanej z nią partyzantki, pod koniec wojny aresztowany i skazany na śmierć (wyrok nie został wykonany z uwagi na zbliżającą się Armię Czerwoną) ${ }^{216}$. Gwiazdy (wysoko ocenione zarówno przez wschodnioniemiecką krytykę 217 , jak i „czynniki oficjalne" - reżyser i autor zdjęć, Werner Bergmann, otrzymali Nagrody Państwowe II stopnia) długo nie mogły jednak doczekać się premiery w bułgarskich kinach ze względu na możliwość takiej interpretacji realiów świata przedstawionego filmu, zgodnie z którą Bułgaria (w czasie wojny włączona do Rzeszy) była współodpowiedzialna za Zagładę.

Dzieło Wolfa zostało zgłoszone do konkursu canneńskiego w 1959 r., ale na skutek interwencji ze strony Republiki Federalnej Niemiec (która nie uznawała państwowości NRD i obligowała organizatorów festiwali, by nie uwzględniali w programie filmów z tego kraju) jako produkcja wyłącznie bułgarska. Gdy okazało się, że Gwiazdy mają być pokazane w ramach konkursu, zachodnioniemieckie ministerstwo spraw wewnętrznych wystosowało protest, w którym znalazł się niefortunny zwrot „film traktuje o problemie żydowskim (Judenproblem)"218. Ostatecznie Gwiazdy wyświetlono w sekcji

215 Jak pisze Ralf Schenk, Gwiazdy „kończą się tam, gdzie wiele innych filmów Defy się rozpoczyna - scena, w której bohater (prawdopodobnie) przyłącza się do partyzantów" (Ralf Schenk, Mitten im kalten Krieg..., s. 115).

${ }^{216}$ Wagenstein był scenarzystą także kilku innych enerdowskich fabuł, m.in. Kroniki pewnego morderstwa (1964) i filmu science-fiction Eolomea (1972). Zob. Angel Wagenstein, Ich bin ein balkanischer Europäer, „Neues Deutschland”, 17.04.1999.

217 Na przykład: Hans-Dieter Tok, "Sterne": ein nachhaltiger Film über die Liebe zweier Menschen in einer trostlosen Zeit, "Leipziger Volkszeitung”, 3.04.1959; Wolfgang Joho, Poesie und Wirklichkeit. "Sterne" - ein deutsch-bulgarischer Gemeinschaftsfilm, "Der Sonntag", 12.04.1959 (autor tej ostatniej recenzji napisał jednak, iż przemiana głównego bohatera w tak krótkim czasie wydaje mu się mało wiarygodna).

218 Za: Wolfgang Jacobsen, Rolf Aurich, Der Sonnensucher..., s. 284. 
pozakonkursowej (co nie przeszkodziło w uhonorowaniu ich Nagrodą Specjalną Jury ${ }^{219}$ ). Z uwagi na zainteresowanie medialne, w 1960 r. film wprowadzono do dystrybucji w RFN - w wersji skróconej o ostatnią scenę (!), w której bohater dołącza do bułgarskiej partyzantki komunistycznej220. Urząd ds. Oceny Filmów (Filmbewertungstelle - zob. rozdział III) uznał Gwiazdy za dzieło „szczególnie wartościowe” - w ocenie napisano o „nadmiernym realizmie” (!) i „patetycznej przesadzie”. Uzasadnienie kończy się zdaniem:

Ten film jest dokumentem szczególnego rodzaju: w mniejszym stopniu jako przedstawienie prawdopodobnej sytuacji z przeszłości, w większym zaś - jako dowód wewnętrznej kondycji wielu żyjących dziś ludzi, którzy nie wierzą we wszechpotęgę nienawiści, lecz w zbawczą siłę człowieczeństwa ${ }^{221}$.

Dzieło Wolfa zyskało w RFN dobre recenzje - choć niektóre podszyte były dyskursem wewnątrzniemieckich animozji. W „Die Welt” napisano: „Komu pozwoliliśmy to sobie powiedzieć? [...] Światu, który jest równie ponury i w równym stopniu gardzący życiem jak ten, który tu potępia" ${ }^{222}$. Podobny ton, choć sformułowany w łagodniejszym stylu, pojawił się na łamach "Berliner Morgenpost”: „Niektórzy powiedzą: szkoda, że tak sprawiedliwy i czysty film powstał akurat w sowiecko-niemieckiej Defie. Ja dostrzegam szkodę o wiele większą - taką mianowicie, że naszej wolnej produkcji filmowej nadal nie udało się doprowadzić do podobnej debaty na tak bolesny temat" ${ }^{\prime 223}$. Z kolei Ulrich Gregor z lekką ironią wymierzoną pod adresem zachodnioniemieckiego kina zauważał: „To nie jest film, po którym wraca się do domu z poczuciem ukojenia, jak w wypadku niektórych "prawdziwych « filmów wojennych" 224 .

Drugim ważnym dziełem podejmującym temat Zagłady - choć, podobnie jak Gwiazdy, w gruncie rzeczy jedynie ją sygnalizującym - był film z 1963 r. Nadzy wśród wilków w reżyserii Franka Beyera, na podstawie

${ }^{219}$ Zob. Elisabeth M. Ward, Screening out the East: the Playing out of Inter-German Relations at the Cannes Film Festival, "German Life and Letters" 2015, nr 1.

${ }^{220}$ Peter Reichel pisze (nie podając szczegółów oraz nie wskazując, niestety, źródła tej informacji), że na przełomie lat 50. i 60. delegaci Defy pokazywali w RFN pełną wersję filmu na zachodnioniemieckich uniwersytetach. Zgodnie z tą relacją na Uniwersytecie w Hamburgu seans został jakoby przerwany przez grupę osób skandujących: „Zdrajcy!” (Peter Reichel, Erfundene Erinnerung..., s. 211).

${ }^{221}$ Jako kraj pochodzenia wpisano zaś: "sowiecka strefa okupacyjna”. Besonders wertvoll: die mit dem Prädikat "Besonders wertvoll” ausgezeichneten Filme, red. Filmbewertungsstelle Wiesbaden, Wiesbaden 1960, s. 130 (zbiór Folge 1.1958-9.1966).

${ }^{222}$ Martin Beheim-Schwarzbach, Sterne der Sehnsucht, Sterne der Vernichtung, „Die Welt", 30.04.1960.

223 Günther Geisler, „Berliner Morgenpost”, 19.06.1960.

${ }^{224}$ Ulrich Gregor, Sterne... 
opublikowanej pięć lat wcześniej powieści Bruna Apitza 225 (na przełomie lat 20. i 30. był on członkiem KPD, później - więźniem Buchenwaldu, po wojnie pracował jako dziennikarz w Lipsku, a następnie jako dramaturg w Defie). Pracę nad historią o dziecku przeszmuglowanym z Auschwitz do Buchenwaldu i ukrywanym tam przez więźniów należących do ruchu oporu, który doprowadza do wyzwolenia obozu, Apitz rozpoczął wiele lat wcześniej. W I połowie lat 50. związek enerdowskich literatów nie zgodził się jednak na wydanie powieści ${ }^{226}$, a na przełomie 1954 i 1955 r. projekt scenariusza odrzuciły władze kinematografii, które uznały projekt Apitza za "problematyczny” i „nieistotny dla obecnej walki z faszyzmem"227. Gdy na fali odwilży powieść została opublikowana i odniosła sukces wydawniczy 228 , jej autor w 1958 r. otrzymał Nagrodę Państwową III stopnia. W kwietniu tego samego roku w enerdowskim radiu emitowane było słuchowisko na podstawie powieści ${ }^{229}$. Na tym jej kariera się nie kończy: w 1970 r. książka trafiła do kanonu lektur szkolnych w NRD (do 1989 r. miała 58 wydań! ${ }^{230}$ ), co ostatecznie przypieczętowało jej rolę jako jednego z „mitów fundacyjnych NRD”231.

Powieść Apitza (a za nią - także film) inspirowana jest prawdziwą historią tzw. "dziecka z Buchenwaldu”. Chłopiec przeszmuglowany z Auschwitz i ukrywany w Buchenwaldzie nazywał się w Stefan Jerzy Zweig. Urodziłsięw krakowskim getcie, a po wojnieodbyłsłużbę wojskową w Izraelu, następnie studiował w Paryżu. O powieści i scenariuszu Apitza nie wiedział dopóty, dopóki na trop „dziecka z Buchenwaldu” nie trafili - po sukcesie filmu na festiwalu filmowym w Moskwie w 1963 r. - dziennikarze enerdowskiej gazety „Berliner Zeitung am Abend”232. Swe przeżycia

${ }^{225}$ Thomas Heimann pisze w swej monografii o jeszcze jednej fabule - Esther (reż. Robert Trösch), zrealizowanej na podstawie opowiadania Apitza, a podejmującej tym razem tematykę seksualności w rzeczywistości obozowej. Film nakręcono dla enerdowskiej telewizji w 1961 r., ale wyemitowano dopiero w $1980 \mathrm{r}$.

${ }^{226}$ O książce zob.: Susanne zur Nieden, ...stärker als Tod. Bruno Apitz' Roman „Nackt unter Wölfen" und die Holocaust-Rezeption in der DDR, [w:] Bilder der Holocaust: Literatur - Film - Bildende Kunst, red. Manuel Köppen, Klaus Scherpe, Köln 1997.

227 Thomas Heimann, Bilder von Buchenwald..., s. 72.

${ }^{228}$ Heimann zauważa, że na powieść Apitza zwrócono uwagę również dlatego, iż ważne dzieła poruszające tematykę obozową (zarówno eseistyczne, jak Der SS-Staat Eugena Kogona z 1946 r., jak i beletrystyczne, jak Iskra życia Ericha Marii Remarque'a z 1952 r.) były w NRD „na indeksie” (Thomas Heimann, Bilder von Buchenwald..., s. 73).

${ }^{229}$ Ibidem, s. 74.

${ }^{230}$ Ibidem, s. 71.

231 Bill Niven, The Buchenwald Child: Truth, Fiction and Propaganda, Rochester 2007, s. 122.

${ }^{232}$ W 1963 r. Zweig pojechał do RFN, gdzie zeznawał podczas procesów frankfurckich i odwiedził Willy'ego Bleichera - jednego z więźniów Buchenwaldu zaangażowanych w ruch oporu i ukrywanie dziecka, a w RFN lidera związków zawodowych w Stuttgarcie. W kolejnym roku Zweig przeniósł się do NRD, gdzie spotkał się z Apitzem, poznał przy- 
z dzieciństwa Zweig znał z relacji ojca Zachariasza. Tuż przed śmiercią poprosił on syna, by jego wspomnienia udostępnić po pewnym czasie; zapiski te ukazały się drukiem w 1987 r. ${ }^{233}$ Różnice pomiędzy autobiografią Zachariasza Zweiga i fabułą Apitza wylicza Bill Niven:

Po pierwsze, Apitz zmienił status Zachariasza - w powieści Nadzy wśród wilków nie jest on ojcem dziecka, tylko więźniem przygarniającym osieroconego chłopca, którego rodzice zginęli w Auschwitz. Po drugie, Apitz koncentruje się tylko na Buchenwaldzie, podczas gdy Zachariasz wiele mówi o krakowskim getcie. Po trzecie, w powieści Stefan i jego wybawiciel trafiają do Buchenwaldu dopiero w marcu 1945 roku, tymczasem obaj byli tam od sierpnia 1944. Po czwarte, Zachariasz ujawnia, w jaki sposób nie tylko jego syn, ale i on sam przetrwał Buchenwald. Opisuje wreszcie swoją rolę w ratowaniu chłopca w trakcie ewakuacji, podczas gdy w Nagich wśród wilków dziecko jest chronione tylko przez innych skazańców ${ }^{234}$.

Zarówno powieść Apitza, jak i jej radiowe i filmowe remediacje można czytać przez pryzmat polityki historycznej NRD, dla której Buchenwald był ważnym „miejscem pamięci” (a zarazem budulcem „wynalezionej tradycji" - w rozumieniu Erica Hobsbawma). W 1958 r. władze decydują się ufundować miejsce pamięci w Buchenwaldzie ku czci poległych bojowników ruchu antyfaszystowskiego, w szczególności członków podziemnej organizacji komunistycznej, która - wedle historiografii NRD - miała doprowadzić do wyzwolenia obozu ${ }^{235}$. Była to legenda spreparowana na potrzeby enerdowskiej propagandy - co prawda, w Buchenwaldzie istniała grupa zbrojnego oporu, która 11 kwietnia 1945 r., w dzień ewakuacji SS z obozu, chwyciła za broń, ale obóz został faktycznie wyzwolony przez Amerykanów ${ }^{236}$. Ewidentnym zafałszowaniem historycznym jest więc

szłą żonę i podjął studia operatorskie w szkole filmowej w Poczdamie-Babelsbergu. Z NRD wyjechał w 1972 r., by osiedlić się w Austrii, gdzie do emerytury pracował dla państwowej telewizji ORF. Gdy w 1982 r. enerdowski dokumentalista Peter Rocha nakręcił film W przeciwnym razie bylibyśmy zgubieni (Sonst wären wir verloren), sceny ze Zweigiem nie mogły być wykorzystane - być może z uwagi na jego służbę wojskową w Izraelu, być może z powodu osiedlenia się w Austrii. Za: Martina Thiele, Publizistische Kontroversen..., s. 238.

${ }^{233}$ Zacharias Zweig, "Mein Vater, was machst du hier...?". Zwischen Buchenwald und Auschwitz. Der Bericht des Zacharias Zweig, Frankfurt am Main 1987; także: Willy Bleicher. Ein Leben für die Gewerkschaften, red. Georg Benz, Kurt Georgi, Leonhard Mahlein, Frankfurt am Main 1983.

${ }^{234}$ Bill Niven, Das Buchenwaldkind. Wahrheit, Fiktion und Propaganda, Halle 2009, s. 140.

${ }^{235} \mathrm{O}$ roli Buchenwaldu dla enerdowskiej polityki pamięci zob.: Thomas Taterka, "Buchenwald liegt in der DDR". Grundzüge des Lagerdiskurses der DDR, [w:] Literatur Gesellschaft DDR. Kanonkämpfe und ihre Geschichte(n), red. Birgit Dahlke, Martina Langermann, Thomas Taterka, Weimar 2000; Volkhard Knigge, Jürgen Maria Pietsch, Thomas A. Seidel, Versteinerstes Gedenken. Das Buchenwald Mahnmal von 1958, Spröda 1997; Manfred Overesch, Buchenwald und die DDR oder die Suche nach Selbstlegitimation, Göttingen 1995.

236 Zob. Joachim Trenkner, Podmiana ofiar. Jak władze NRD fałszowaty historie obozu koncentracyjnego w Buchenwaldzie, tłum. W. Pięciak, [w:] idem, Naród z przeszłością. Eseje o Niem- 
zakończenie Nagich wśród wilków, pokazujące zbrojne wyzwolenie Buchenwaldu przez obozowy ruch oporu: gdy SS szykuje się do wycofania, uzbrojeni więźniowie biegną przez plac apelowy. Amerykańskich żołnierzy nie widać, militarne wsparcie ze strony US Army nie jest odnotowane - powstaje wrażenie, że obóz został wyzwolony siłami „wewnętrznymi”, przed przybyciem wojsk alianckich.

Ukazana w powieści, a następnie w filmie grupa konspiracyjna z Buchenwaldu ma "internacjonalistyczny” charakter: do organizacji należą niemieccy komuniści, Rosjanie i Polacy (w pierwowzorze literackim także Francuzi i Duńczycy, pominięci w realizacji Beyera). Początkowo rada tego zakonspirowanego komitetu (funkcje kierownicze pełnią Rosjanie - Bogorski i Bochow oraz Niemiec Krämer) postanawia odesłać przeszmuglowane z Auschwitz dziecko kolejnym transportem. Höfel, Kropiński i Pippig, pracujący w tzw. Effektenkammer, czyli „izbie rzeczy wartościowych", nie podporządkowują się temu zaleceniu - mimo świadomości, iż w przypadku odkrycia chłopca zagrożone jest nie tylko jego życie, lecz także cała organizacja przygotowująca zbrojny opór przeciw SS (do powstania zagrzewa szczególnie Polak Pribula). Höfel i Kropiński zostają aresztowani, nie wydają jednak sekretów grupy (Bogorski: Wszyscy widza w Höfelu tylko małego, słabego człowieka. Ja widze w nim komunistę). Wskutek zdrady innego więźnia (torturowanego Rose) nazistowscy strażnicy wpadają na trop chłopca (Gdy znajdziemy dziecko, znajdziemy też partie - ta ostatnia zostaje utożsamiona z przyszłością). Ich motywacje są zróżnicowane - najbardziej okrutny i zwyrodniały Kluttig torturuje więźniów z sadystyczną przyjemnościa, natomiast esesman Zweiling zastanawia się, czy uratowanego dziecka nie mógłby wykorzystać jako karty przetargowej w ewentualnych negocjacjach z nadciągającymi Amerykanami. Retorsji z ich strony obawia się też komendant Schwahl, który chce wysłać więźniów do Dachau, Reineboth natomiast najwyraźniej ma zamiar zdezerterować - w szafie ma już naszykowane cywilne ubranie. W zakończeniu, tuż przed planowaną ewakuacją obozu, Krämer ogłasza rozpoczęcie zbrojnego powstania.

Druga kłopotliwa okoliczność związana z rolą Buchenwaldu w NRD wynikała z faktu, iż wprawdzie wśród działaczy organizacji komunistycznej

czech, Poznań 2004. O roli komunistów w „wyzwoleniu” Buchenwaldu zob. też: Katrin Greiser, "Die Masse von ihnen stellt kein kampffähiges Element dar". Deutsche Kommunisten zur Evakuierung in Buchenwald, [w:] Tatort KZ. Neue Beiträge zur Geschichte der Konzentrationslager, red. Ulrich Fritz, Nicole Warmbold, Ulm 2003. W historiografii NRD nie mogło być oczywiście mowy również o tzw. Speziallager nr 2, prowadzonym przez sowieckie władze okupacyjne i działającym w latach 1945-1950, w którym (jak ustalono w toku podjętych dopiero po zjednoczeniu pracach historycznych) życie straciło kilka tysięcy więźniów. 
w obozie było wielu późniejszych prominentnych działaczy SED, ale pełnili oni często funkcję $\mathrm{kapo}^{237}$. W piśmiennictwie NRD (oraz w filmie Beyera) fakt ten nie został wprawdzie przemilczany, ale zarazem nie ukazano szczegółów tej działalności (przede wszystkim nie wspomniano o tym, iż jednym z zadań kapo była selekcja do obozów zagłady ${ }^{238}$ ). Wrażenie wytwarzane przez fabułę Nagich wśród wilków - to mianowicie, że w obozie przetrzymywano niemal wyłącznie więźniów politycznych i to oni głównie stanowili ofiary represji - było niezgodne z prawdą. Wedle ustaleń historyków, wśród 50 tys. ludzi, którzy zginęli w Buchenwaldzie, śmierć poniosło łącznie 72 niemieckich komunistów ${ }^{239}$. Ponadto, w NRD Buchenwald funkcjonował jako synonim obozu dla więźniów politycznych - dzieje tzw. małego obozu, w którym w o wiele gorszych warunkach przetrzymywani byli Żydzi i Cyganie, zaczęto badać dopiero w latach $90 .{ }^{240}$

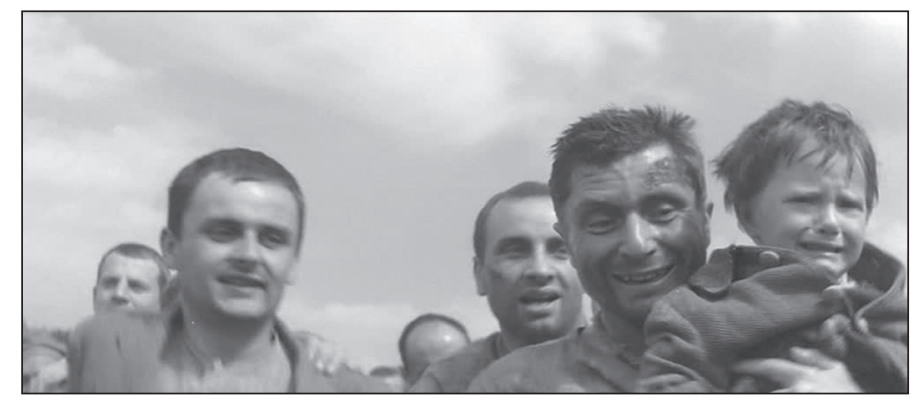

Fot. 26. Nadzy wśród wilków (reż. Frank Beyer, 1963) Żydowskie dziecko niczym hitchcockowski MacGuffin - jedna z nielicznych scen, w których pojawia się w kadrze

W filmie Beyera istnienie tzw. małego obozu zostało jedynie zasugerowane - Zachariasz Jankowski jest przetrzymywany w zupełnie innym miejscu niż główni bohaterowie. Poza pierwszą sceną pojawia się on

${ }^{237}$ Przykładem narracji eksponujących rolę komunistycznego ruchu oporu w Buchenwaldzie, a zarazem tabuizujących inne tematy, są: Günther Kühn, Wolfgang Weber, Stärker als die Wölfe. Ein Bericht über die illegal militärische Organisation im ehemaligen Konzentrationslager Buchenwald, Berlin (Ost) 1978; Klaus Drobisch, Widerstand in Buchenwald, Berlin (Ost) 1989.

${ }_{238}$ Zob. Lutz Niethammer, Der gesäuberte Antifaschismus. Die SED und die roten Kapos von Buchenwald, Berlin 1994, s. 55. W 1996 r. nakręcono film dokumentalny Czerwoni kapo z Buchenwaldu (Die roten Kapos von Buchenwald, real. Ute Bönnen i Gerald Endres, RFN 1996).

239 Ibidem, s. 45.

${ }^{240}$ Dużą rolę odegrał tu zbiór wspomnień: Fred Wander, Der siebente Brunnen, Frankfurt am Main 1997. 
jeszcze tylko dwa razy: gdy na moment może ponownie ujrzeć chłopca i gdy idzie w kolumnie więźniów (dokąd zmierzających - można się tylko domyślać). Temu marszowi przypatrują się Höfel, Bochow i Krämer; ten ostatni mówi nawet: czasami zastanawiam się, czy nie staliśmy się aby zbyt bezduszni. Scena ta sygnalizuje istnienie w obozie pewnej hierarchii więźniów (która oznaczała, iż różne ich grupy były dalej lub bliżej śmierci) oraz dwuznacznej roli "czerwonych kapo" - rzecz jasna, wszystko na poziomie sugestii i niedopowiedzeń.

Pojawienie się w fabule Nagich wśród wilków żydowskiego dziecka w obozie dla „politycznych” zaciera podział, który faktycznie w Buchenwaldzie funkcjonował. W filmie jest on ledwie sygnalizowany - w krótkich scenach pokazujących transport żydowskich więźniów (golenie głów, obrzucanie wyzwiskami). Ci ostatni prezentowani są jako masa - jedyną zindywidualizowaną postacią jest właśnie Jankowski, on jednak zostaje określony jako Polak (podobnie w książce Apitza, gdzie tylko raz nazwany jest Żydem). Również o chłopcu więźniowie mówią jak o polskim dziecku (jedynie niemieccy nadzorcy używają słowa Judenbalg $)^{241}$. Żydowskie dziecko funkcjonuje w dramaturgii filmu niczym przedmiot - jego "przerzucanie z kąta w kąt” jest wprawdzie fabularnie uzasadnione, ale zarazem pokazane zostaje niczym "szmuglowanie” kontrabandy i pretekst do podkreślenia roli komunistycznego podzie$\mathrm{mia}^{242}$ (fot. 26).

Pierwszą ekranizację powieści Apitza - w formule teatru telewizji (Fernsehspiel Deutscher Fernsehfunk), w którym część scen grano na żywo, część zaś została nagrana wcześniej - zrealizowano w 1960 r. (reż. Georg Leopold) na okoliczność 15. rocznicy wyzwolenia Buchenwaldu ${ }^{243}$. Wówczas Defa podjęła starania o pozyskanie autora pierwowzoru literackiego do projektu filmu kinowego. Apitz stawiał wyśrubowane warunki - w roli reżysera widział Wolfganga Langhoffa, twórcę teatralnego, który sam był

${ }^{241}$ Zob. na ten temat: Bill Niven, Der Umgang mit dem Jüdischen in der DDR-Rezeption der Rettung Stefan Jerzy Zweigs, [w:] Umdeuten, verschweigen, erinnern: Die späte Aufarbeitung des Holocaust in Osteuropa, red. Micha Brumlik, Karol Sauerland, Frankfurt am Main 2010.

${ }^{242}$ W nieoględny sposób opinię tę wyraziła Ruth Klüger: „Apitz jest bardziej utalentowanym pisarzem niż Hans Scholz [zob. podrozdział 3.4 - dop. KK], ale i tak powiela ten sam szablon, mianowicie: Żyd jako bezbronne dziecko, które chronione jest przez gotowych do działania, dorosłych Niemców [...]. Żyd jako ofiara Holocaustu zostaje zredukowany do małego dziecka, dosłownie zdziecinniały, jak gdyby Żydzi byli przypadkowymi, drugoplanowymi ofiarami nazizmu [...]. Katastrofa, która dotknęła Żydów, w tym masowe mordy na dzieciach, zostaje w ten sposób zniesiona i pominięta" (Ruth Klüger, Katastrophen. Über deutsche Literatur, Göttingen 2009, s. 11-12).

${ }^{243} \mathrm{Na}$ ten temat zob.: Thomas Heimann, Bilder von Buchenwald..., s. 74-81. Ciekawe, że niektórzy z aktorów udzielili wcześniej głosu postaciom ze słuchowiska radiowego z 1958 r., inni zaś zagrali w późniejszym filmie kinowym. 
więźniem w obozie koncentracyjnym ${ }^{244}$. Beyer dołączył do projektu nieco później, jako reżyser „wynajęty” przez Defę ${ }^{245}$, która nie szczędziła środków na produkcję 246 (zdjęcia plenerowe wykonano w Buchenwaldzie, gdzie na potrzeby scenografii dobudowano wieżyczki strażnicze i część baraków $\left.{ }^{247}\right)$.

Zdaniem jednego z autorów porównujących obie ekranizacje (telewizyjną i kinową), zasadnicza różnica między nimi polega na tym, iż w późniejszym filmie bardziej rozwinięta fabularnie jest postać Jankowskiego (mężczyzny, który przemycił do obozu dziecko), niemal nieobecna $\mathrm{w}$ inscenizacji Langhoffa. Z kolei w wersji telewizyjnej znalazło się więcej scen drastycznych (u Beyera tortury nie są pokazane - widzimy jedynie zmasakrowanego Rosego wprowadzanego do celi). Z kolei w filmie kinowym „relacja Krämer - Bochow została przedstawiona w sposób bardziej wyważony"248. Do podobnej opinii skłania się też Thomas Heimann, który uważa, że w stosunku do wersji telewizyjnej Beyer słabiej eksponuje rolę Bogorskiego oraz znaczenie dyscypliny partyjnej (brak sceny składania przysięgi wierności przez członków organizacji $^{249}$. Spostrzeżenia te zdają mi się rodzajem interpretacyjnej kazuistyki: film Bayera tak czy inaczej upstrzony jest długimi scenami politycznych dysput i przemówień.

Berlińska premiera filmu Beyera odbyła się 10 kwietnia 1963 r. Produkcji z udziałem enerdowskich gwiazdorów (Erwin Geschonneck jako Krämer, Armin Müller-Stahl jako Höfel) oraz aktorów polskich (Krystyn Wójcik, Bolesław Płotnicki, Zygmunt Malanowicz) i rosyjskich (Bogorskiego zagrał Wiktor Awdjuszewko, który wcześniej pojawił się w Poszukiwaczach słońca Wolfa) nadano odpowiednią rangę. Eksponowano także fakt, iż był to pierwszy film Defy w formacie Cinemascope. Enerdowska krytyka oceniła Nagich wśród wilków jako dzieło wybitne ${ }^{250}$. W 1963 r. na

${ }^{244}$ Ibidem, s. 83.

${ }^{245}$ Hans Müncheberg, Vom Bildschirm ins Kino, [w:] Regie: Frank Beyer..., s. 180. Zob. również zamieszczony w tym tomie wywiad z Beyerem (zwłaszcza s. 38).

${ }^{246}$ Heimann twierdzi, że był to jeden z najdroższych filmów Defy (Thomas Heimann, Bilder von Buchenwald..., s. 97).

247 Ibidem, s. 84.

${ }^{248}$ Hans Müncheberg, Vom Bildschirm..., s. 183.

249 Thomas Heimann, Bilder von Buchenwald..., s. 91.

250 Erika Richter, Romangestalten auf der Leinwand, „Filmspiegel” 1963, nr 9; Hartmut Albrecht, Wahrheit von Buchenwald, "Nationalzeitung”, 5.04.1963; Horst Knietzsch, Ein Lied vom wahren Menschen, "Neues Deutschland”, 11.03.1963; Peter Edel, Das Kind vom Ettersberg: Gedanken über ein kleines Bild und einen großen Film, "Die Weltbühne”, 8.05.1963; Helmut Ulrich, Vom Triumph menschlicher Würde, "Neue Zeit”, 11.04.1963; Fred Gehler, Nackt unter Wölfen, „Filmstudio” 1964, nr 44. Zob. też przedruki w: Spielfilme der Defa im Urteil der Kritik. Ausgewählte Rezensionen 1946-1969, red. Lissi Zilinski, Berlin (Ost) 1970. 
festiwalu w Moskwie nie otrzymał wprawdzie głównej nagrody ${ }^{251}$, która przypadła Osiem i pót, ale wyróżnienie za reżyserię dostał właśnie Beyer (wraz z innymi twórcami filmu, otrzymał on Nagrodę Państwową I stopnia). Film Nadzy wśród wilków okazał się też jednym z największych „hitów eksportowych" Defy ${ }^{252}$. Do erefenowskich kin trafił w 1968 r. (choć został dostrzeżony już w czasie enerdowskiej premiery; w międzyczasie powieść Apitza miała również swą zachodnioniemiecką edycję²53). Recepcja w zachodnich Niemczech była jednak dość skromna ${ }^{254}$; częściej niż o samym filmie pisano o Stefanie Zweigu oraz Willim Bleicherze - jednym z członków ruchu oporu w Buchenwaldzie, który w RFN był wpływowym działaczem jednej z central związkowych.

W NRD Nadzy wśród wilków doczekali się powtórnej premiery w 1975 r. - tym samym, w którym na ekrany kin trafiła inna ważna „fabuła obozowa" Defy w reżyserii Beyera: Jakub kłamca (Jakob der Lügner, NRD 1975). Co ciekawe, historia tego filmu sięga 1963 r. - wtedy bowiem z pomysłem na „historię o Holocauście w konwencji komediowo-baśniowej" zgłosił się do Defy Jurek Becker, przyszły autor scenariusza ${ }^{255}$. Jego pierwszą wersję przedłożono w wytwórni w grudniu 1965 r., w przeddzień XI plenum Komitetu Centralnego SED, którego postanowienia uznawane są za punkt przełomowy w historii enerdowskiej kultury ${ }^{256}$.

${ }^{251}$ Beyer utrzymywał, że nie otrzymał głównej nagrody z uwagi na sprzeciw polskiej delegacji (Frank Beyer, Wenn der Wind..., s. 117). Informacji tej nie udało mi się zweryfikować, jednak prawdą jest, iż w polskiej prasie przeważały negatywne recenzje.

252 Thomas Heimann, Bilder von Buchenwald..., s. 97.

${ }^{253}$ Brigitte Jeremias, Zwei deutsche K-Filme. "Nackt unter Wölfen" und "Mensch und Bestie”, „Frankfurter Allgemeine Zeitung”, 11.07.1963; Ulrich Gregor, Nackt unter Wölfen, „Filmkritik” 1964, nr 6.

${ }^{254}$ Friedrich Luft, Das Kind von Buchenwald: der DEFA-Film "Nackt unter Wölfen" läuft jetzt auch im Westen, "Die Welt”, 20.07.1968.

255 Sander L. Gilman, Jurek Becker, Die Biografie, Berlin 2002, s. 86. Fabuła zaproponowana przez Beckera jest transpozycją wydarzeń z łódzkiego getta (w którym był też Becker) - autentycznej historii Chaima Widawskiego, który w getcie ukrywał radio i przekazywał współziomkom krzepiące opowieści o zbliżającym się końcu wojny (Gila Flam, Singing for Survival: Song of the Lodz Ghetto 1940-45, Urbana 1992, s. 176). Na bazie treatmentu Becker napisał powieść, która - wydana w 1969 r. - szybko zyskała popularność, a wkrótce stała się lekturą obowiązkową w enerdowskich szkołach. W 1999 r. historia ta została spopularyzowana przez hollywoodzki remake z Robinem Williamsem - Jakub łgarz (Jakob the Liar, reż. Peter Kassovitz). Zob. także: Kalina Kupczyńska, Elżbieta Kapral, O medialności kłamstwa i iluzji: Jakub „Egarz" a Jurek „Pisarz”, [w:] Przestrzenie intermedialności. Adaptacje literatury niemieckojęzycznej, red. Kalina Kupczyńska, Magdalena Saryusz-Wolska, Wrocław 2012.

${ }^{256}$ Informacje o okolicznościach powstania filmu podaję za autobiografią reżysera (Frank Beyer, Wenn der Wind..., s. 180-197) oraz wywiadem rzeką (Damit lebe ich bis heute..., s. 53-72). 
Wkrótce potem Frank Beyer popadł w niełaskę decydentów, a projekt Jakub kłamca musiał poczekać na swój czas - jeszcze dwanaście lat.

$$
* * *
$$

Podczas wspomnianego XI plenum KC SED (później określanego jako „Kahlschag”, czyli „karczowanie lasu” - choć, z uwagi na konteksty okołofilmowe, może zasadniej byłoby użyć słowa „poręba"?) partyjni aparatczycy przypuścili atak na „rozkładowe wpływy zachodniej kultury”, którym przeciwstawiono „zasady etyki socjalistycznej” 257. Poddano ostrej krytyce m.in. twórczość niektórych pisarzy (Stephana Heyma, Wolfa Biermanna i Manfreda Bielera), a także politykę repertuarową Defy, jej kierownictwo ${ }^{258}$ oraz konkretnych filmowców (w głównym referacie, wygłoszonym przez Ericha Honeckera, późniejszego I sekretarza $\mathrm{SED}^{259}$ ). Wstrzymano dystrybucję dwunastu pełnometrażowych filmów nakręconych (bądź będących w fazie realizacji) w tym roku; twórcy zaklasyfikowani jako "elementy antysocjalistyczne” stracili pełnione do tej pory funkcje lub zostali objęci zakazem wykonywania zawodu. Szczególnie mocno krytykowane były filmy Ślad kamieni (Spur der Steine) Franka Beyera oraz Jestem króliczkiem (Das Kaninchen bin ich) Kurta Maetziga - określone przez Paula Vernera, członka biura politycznego Komitetu Centralnego SED, jako filmy „politycznie fałszywe i szkodliwe, stanowiące atak na nasze socjalistyczne społeczeństwo"260. Od ostatniego z wymienionych tytułów bierze swą nazwę niemiecki odpowiednik polskich „półkowników” 261 - niektóre z tzw. „filmów króliczych” (Kannin-

257 Pasjonat dziejów NRD zechce może sięgnąć do - stylizowanych na dekalog - „przykazań moralności i etyki socjalistycznej”, które w 1958 r. podczas V Zjazdu SED sformułował Walter Ulbricht (Zasady moralności i etyki socjalistycznej, [w:] Polityka kulturalna Niemieckiej Republiki Demokratycznej. Wybór dokumentów, red. Teresa Krzemień, Warszawa 1971, s. 37-38).

${ }^{258}$ Kahlschlag. Das 11. Plenum des ZK der SED 1965. Studien und Dokumente, red. Günther Agde, Berlin 1999. Zob. też o plenum: Xavier Carpentier-Tanguy, Die Maske und der Spiegel. Zum XI. Plenum der SED 1965, [w:] DEFA-Film als nationales Kulturerbe?, red. Klaus Finke, Berlin 2001.

${ }^{259}$ Erich Honecker, Bericht des Politbüros an die 11. Tagung des Zentralkomitees der Sozialistischen Einheitspartei Deutschlands, 15-18 Dezember 1965, [w:] Dokumente zur Kunst-, Literatur-, und Kulturpolitik der SED...

${ }^{260}$ Paul Verner, Der Künstler soll Mitgestalter unserer Gesellschaftsordnung sein, „Neues Deutschland", 20.12.1965, za: Martina Thiele, Publizistische Kontroversen..., s. 254.

${ }^{261}$ Scenariusze do dwóch „filmów króliczych" (w języku niemieckim używane są też terminy Regalfilme i Kellerfilme) wydano w 1990 r. - Prädikat: Besonders schädlich. Manfred Bieler/Kurt Maetzig: Das Kaninchen bin ich. Manfred Freitag/Joachim Nestler: Denk bloß nicht, ich heule, red. Christiane Mückenberger, Berlin 1990. 
chenfilme) musiały czekać na swą premierę kilkanaście lat (jedynie Zaginiony anioł [Der verlorene Engel, reż. Ralf Kirsten] trafił do ograniczonej dystrybucji, w ocenzurowanej formie, w 1971 r. $)^{262}$.

Spośród produkcji zatrzymanych przez Kahlschlag dwie nawiązywały tematycznie do nazistowskiej przeszłości Niemiec. Jednym z nich był wspomniany film Kirstena, opowiadający o Ernście Barlachu - rzeźbiarzu, którego dzieła zostały zaliczone przez nazistów do „sztuki zdegradowanej”"263. Jego najważniejsza praca (tytułowy anioł) została usunięta z kościoła, protagonista zaś - zmuszony do rezygnacji z pracy w Akademii Sztuk Pięknych i postawiony przed wyborem: albo sam zniszczy swe dzieła, albo będą one skonfiskowane. Z kolei tytułowa bohaterka drugiego filmu, Karla (reż. Herrmann Zschoche, premiera latem 1990 r.), młoda nauczycielka pracująca w szkole w małym miasteczku na północy NRD, musi skonfrontować swe ambicje z biurokratycznymi realiami. Jeden z wątków pobocznych dotyczy jej pryncypała - Karla odkrywa mianowicie fotografię dyrektora szkoły w mundurze SA (ostatecznie okazuje się, że zdjęcie zrobiono podczas spektaklu antyfaszystowskiego teatru amatorskiego już po wojnie).

Przywołane wcześniej tytuły potwierdzają iż w okresie 1946-1965 pamięć lat nazizmu w kulturze wschodnich Niemiec była wysoce selektywna i podporządkowana autoidentyfikacyjnej polityce NRD jako „państwa antyfaszystowskiego”. W tej właśnie selektywności wyrażała się właściwa filmom Defy, jak określa to Detlef Kannapin, „sprzeczność pomiędzy dążeniem do historycznego wyjaśnienia a politycznie oczekiwaną, antyzachodnią interpretacją"264. Podobnie jak filmy erefenowskie, również fabuły Defy akcentowały postaci (wielu) "dobrych" i (nielicznych) „złych" Niemców - z tym, że w kinie NRD tymi pierwszymi byli niemal wyłącznie członkowie komunistycznego ruchu oporu, zaś odium „faszystowskich” zbrodni zostało symbolicznie „przeniesione” na obszar RFN. W filmach Defy stosunkowo rzadko wykorzystywano natomiast (tak popularną w kinie zachodnioniemieckim tego czasu) narrację, którą można by opatrzyć nagłówkiem: „Niemcy jako ofiary”. Status ten

262 Osiem z zatrzymanych filmów trafiło do kin w sezonie 1989/1990, dwa zostały zrekonstruowane na podstawie zachowanych materiałów i miały premiery dopiero w pierwszej dekadzie XXI w.; jeden (film dyplomowy) nie został ukończony. O losach "filmów króliczych" zob.: Erika Richter, Zwischen Mauerbau..., s. 197-210.

${ }^{263}$ Co ciekawe, do losów dzieł Barlacha nawiązuje jeden z wątków erefenowskiego filmu telewizyjnego Zanzibar, albo ostatnia przyczyna (Sansibar oder der letzte Grund, reż. Rainer Wolffhardt), zrealizowanego w 1961 r. na podstawie powieści Alfreda Anderscha z 1957 r. Drugą telewizyjną wersję Zanzibaru... (opowiadającego o ucieczce do Szwecji „wrogów politycznych” III Rzeszy: członka KPD, Żydówki i pastora - właśnie on pragnie uratować rzeźbę Barlacha) nakręcił w koprodukcji erefenowsko-enerdowsko-szwajcarskiej Bernhard Wicki w 1987 r.

${ }^{264}$ Detlef Kannapin, Dialektik der Bilder..., s. 73. 
zarezerwowany został dla bohaterów legitymujących się związkami z ruchem komunistycznym, nie był zaś przypisany „wszystkim Niemcom” - ze względu na lokowanie NRD wśród „zwycięzców nad faszyzmem”.

"Antyfaszystowskie" kino Defy w swoich preferencjach tematycznych i schematach narracyjnych było tworem $\mathrm{w}$ wysokim stopniu skonwencjonalizowanym, podporządkowanym obowiązującym szablonom ideologicznym. Jako ostatni przykład ich implementowania do filmowych fabut produkowanych w NRD przywołajmy pięcioodcinkowy serial telewizyjny Doktor Schlüter (Dr. Schlüter, reż. Achim Hübner, NRD 1965)265. Gdy poznajemy tytułowego bohatera, jest on młodym chemikiem stojącym u progu kariery. Znajduje zatrudnienie w fabryce należącej do zamożnego Vahlberga. Bohater sprzeniewierza się przyjaciołom ze swojej klasy społecznej - komuniście Demminowi i ukochanej Ewie, którą porzuca, by poślubić córkę Vahlberga. W czasie wojny interesy mają się znakomicie - na prośbę teścia Schlüter ma kierować oddziałem koncernu w jednym z obozów. Aby tego uniknąć, bohater zaciąga się do wojska i trafia na front. Udaje mu się nawiązać kontakt z partyzantami, dezerteruje i na Syberii pomaga budować kombinat chemiczny (!). Po wojnie wraca do Niemiec - ale ponieważ w zachodniej części (w której koncernem zarządza Vahlberg) nie może znaleźć dla siebie miejsca, postanawia przenieść się do NRD, gdzie dyrektorem chemicznego przedsiębiorstwa jest Demmin.

Synopsis serialu jest, by tak rzec, esencją enerdowskiego dyskursu o faszyzmie - mamy tu bowiem chyba wszystkie elementy przewijające się przez omówione wcześniej filmy Defy: militaryzm przedstawiony jako zjawisko nieodłącznie splecione $\mathrm{z}$ kapitalizmem, ambiwalentną ocenę Wehrmachtu oraz wizję NRD jako jedynego właściwego wyboru dla „przyzwoitego Niemca”. Aporie tego bez mała schizofrenicznego splotu wyparcia rzeczywistej historii, dumy z (przecenianej) roli komunistycznego ruchu oporu i oskarżeń kierowanych pod adresem zachodniego sąsiada staną się jeszcze bardziej wyraźne w kolejnych dekadach.

${ }^{265}$ Wprawdzie realizacje telewizyjne nie są głównym obszarem mego zainteresowania, lecz wspomnieć można jeszcze o dwóch tytułach, które były pokazywane w polskich kinach. Film Ktoś obok ciebie (Der andere neben dir, reż. Ulrich Thein, NRD 1963) jako jeden z nielicznych stawia pytanie o uwikłanie enerdowskiej elity w struktury III Rzeszy (z przeszłością skonfrontowany zostaje tu wybitny neurochirurg: żona jego współpracownika została wydana w ręce Gestapo przez syna profesora, ten zaś nie podjął starań, by ją uratować). Z kolei Skrytobójcy (Der Nachfolger, reż. Ingrid Sander, NRD 1965) to kolejna produkcja "antyerefenowska” - tym razem o "seryjnym samobójcy” działającym w zachodnich Niemczech na początku 1964 r. Scenariusz fabularyzował autentyczne wydarzenia $\mathrm{z}$ tygodni poprzedzających proces przeciw lekarzom odpowiedzialnym za eutanazję $\mathrm{w}$ nazistowskich obozach - w odstępie kilku dni życie odebrali sobie oskarżeni: Werner Heyde, Friedrich Tillman i Edo Osterloh (nawiasem mówiąc, ojciec chrzestny przyszłej terrorystki, Ulrike Meinhoff). 


\section{Rozdział III}

\section{Kino Republiki Federalnej Niemiec do 1965 roku: przemilczenia i mitologizacje}

Konstytucja RFN z maja 1949 r. - w swej preambule stanowiąca, iż została przyjęta dla całego narodu niemieckiego (także dla „każdego Niemca, któremu zabroniono współdziałać" w jej uchwaleniu, a zatem również dla landów pozostających w NRD) - w sposób jednoznaczny określała nowe państwo jako demokratyczne. Istnienie konstytucji nie implikowało jednak pełnej suwerenności - instytucje okupacyjne zostały zlikwidowane dopiero w 1955 r. (choć państwa alianckie zachowały pewien instytucjonalny nadzór nad RFN aż do 1990 r.). Warunkiem dołączenia do wspólnoty państw demokratycznych było prowadzenie polityki, która zabezpieczałaby podstawowe standardy wcześniej narzucane przez zachodnich aliantów, również w kwestiach dotyczących rozliczeń ze schedą po narodowym socjalizmie. Proces prowadzący do osiągnięcia tych celów stanowił

\footnotetext{
wyzwanie podwójne: wewnętrzne - ciągła konfrontacja z grupą społeczeństwa, która mentalnie pozostawała w związku z III Rzeszą i jej ideologią, oraz zewnętrzne - stawienie czoła oczekiwaniom państw ofiar (skoro RFN występowała jako wyłączna kontynuatorka państwa niemieckiego, na niej spoczywały wszystkie obciążenia wynikające z następstw II wojny światowej) $)^{1}$.
}

W wielu opracowaniach spotkać można opinię, iż do końca lat 50. zarówno niemieckie winy, jak i własne cierpienia narodu niemieckiego były tłumione, traktowane jako tabu. Ogląd taki utrwalił się pod wpływem popularności pracy Alexandra i Margarete Mitscherlichów Die Unfähigkeit zu trauern (Niezdolność do żałoby), wydanej w 1967 r. (współcześnie do tego

1 Anna Wolff-Powęska, Pamięć - brzemię i uwolnienie. Niemcy wobec nazistowskiej przeszłości (1945-2010), Poznań 2011, s. 248. 
poglądu skłania się także Aleide Assmann²). W kolejnej dekadzie, z jednej strony pod wpływem ruchu kontestatorskiego domagającego się rozliczenia „,winy ojców”, z drugiej za sprawą nowej polityki pamięci prowadzonej przez gabinety Willy'ego Brandta, a następnie Helmuta Schmidta - także w środowisku historyków zaczęto zastanawiać się nad powodami niewystarczającego zainteresowania przeszłością nazistowską w RFN lat 50. To, co Mitscherlichowie uznali za kliniczny przypadek wyparcia, warty zbiorowej psychoanalizy, niemiecki filozof Hermann Lübbe na początku lat 80 . ocenił jako wybór pragmatyczny i pożądany z socjopsychologicznego punktu widzenia ${ }^{3}$ - jego zdaniem „,swoista cisza” (gewisse Stille) i „komunikatywne przemilczenie" (kommunikatives Beschweigen ${ }^{4}$ ) były niezbędne dla pozyskania Niemców dla projektu odbudowy demokratycznego państwa, stanowiąc „medium społecznej integracji”" Esej Lübbego stał się pod koniec lat 80. początkiem intensywnej debaty, w której pojawiło się też - ukute przez Ralpha Giordano - określenie „druga wina” (zweite Schuld); polegać ona miała na „wyparciu oraz zakwestionowaniu tej pierwszej”. Retrospektywne oceny „dekady Adenauera” silnie wpłynęły na piśmiennictwo akademickie dotyczące tego okresu. W latach 50 . w użyciu było natomiast inne określenie wprowadzone przez Mitscherlichów w odniesieniu do kondycji niemieckiego społeczeństwa - „kompleks Kaspara Hausera”7

2 Aleida Assmann, Der lange Schatten der Vergangenheit: Erinnerungskultur und Geschichtspolitik, München 2006, s. 98-101.

${ }^{3}$ Hermann Lübbe, Der Nationalsozialismus im deutschen Nachkriegsbewußtsein, "Historische Zeitschrift” 1983, nr 236. Zob. również: idem, Verdrängung? Über eine Kategorie zur Kritik des deutschen Vergangenheitsverhältnisses, [w:] Lerntag über den Holocaust in der politische Kultur seit 1945, red. Herbert Strauss, Norbert Kampe, Berlin (West) 1985.

${ }^{4}$ Takie tłumaczenie proponują: Joanna Jabłkowska, Leszek Żyliński, Rozrachunek z narodowosocjalistyczna przeszłościa a tożsamość niemiecka, [w:] O kondycji Niemiec. Tożsamość niemiecka w debatach intelektualistów po 1945 roku, red. Joanna Jabłkowska, Leszek Żyliński, Poznań 2008, s. 13; Kazimierz Wóycicki posługuje się inną formułą - „milczenie porozumiewawcze" (Niemiecki rachunek sumienia. Niemcy wobec przeszłości 1933-1945, Wrocław 2004, s. 70).

${ }^{5}$ Współcześnie w zbliżony sposób wypowiadał się Jörn Rüsen, zdaniem którego przemilczanie zbrodni można uznać za skuteczną strategię integrującą: świadomość klęski uniemożliwiała bowiem "włączenie do pamięci oraz uznanie uwikłania i winy jako części historii własnego życia" (Jörn Rüsen, Pamięć o Holocauście a tożsamość niemiecka, tłum. P. Przybyła, M. Saryusz-Wolska, [w:] Pamięć zbiorowa i kulturowa. Wspótczesna perspektywa niemiecka, red. M. Saryusz-Wolska, Kraków 2009, s. 421).

${ }^{6}$ Ralph Giordano, Die zweite Schuld oder Von der Last Deutscher zu sein, München 1987, zwłaszcza rozdział: Kollektivschuld? Kollektivunschuld? Kollektivscham?, s. 258-279.

7 Alexander Mitscherlich, Ödipus und Kaspar Hauser, „Der Monat” 1950, nr 25 (chodziło o dziecko, które było przetrzymywane w odosobnieniu przez nieznaną osobę lub osoby i dopiero po latach zetknęło się ze światem zewnętrznym oraz innymi ludźmi). O tym, że było to pojęcie wpływowe (wówczas i jeszcze w latach 80.), niech zaświadczy 
Robert Moeller podkreśla, iż opinia o „zmowie milczenia” jest cokolwiek przesadzona, znaleźć można bowiem (również na obszarze kultury filmowej) wiele argumentów na rzecz tezy jeśli nie przeciwnej, to bardziej zniuansowanej. ${ }^{8}$ W życiu publicznym RFN lat 50. silnie zaznaczyły się przecież „rytuały pamięci” odnoszące się do niemieckich ofiar wojny ${ }^{9}$ (wiele przykładów dostarcza kino tamtej dekady, o czym będzie jeszcze mowa). Wprawdzie w zniszczonym Nikolaikirche w Hamburgu odbywały się coroczne spotkania upamiętniające ofiary brytyjskich nalotów w ostatnim tygodniu lipca 1943 r., ale nie miały one oficjalnego charakteru (jak w NRD w wypadku Drezna). Nie powstawały też istotne dzieła fabularyzujące alianckie naloty bombowe na niemieckie miasta ( $\mathrm{zw}$. Bombenkrieg $)^{10}$ - ten temat pojawi się $\mathrm{w}$ niemieckiej kulturze ze zdwojoną siłą dopiero po zjednoczeniu Niemiec ${ }^{11}$. Dążąc do legitymizacji polityki antykomunistycznej, eksponowano natomiast tragiczne wydarzenia, w których swój udział miała Armia Czerwona. Wiele z tych i podobnych tendencji widać także $\mathrm{w}$ publikacjach historycznych tamtych lat - w wydanej po raz pierwszy w $1958 \mathrm{r}$. i niezwykle wówczas popularnej syntezie najnowszych dziejów Niemiec pióra Golo Manna ${ }^{12}$ Niemcy jawią się jako „pierwsze ofiary” Hitlera, który z kolei obsadzony zostaje w roli „obcego najeźdźcy".

fakt, iż Hermann Glaser, redaktor antologii Bundesrepublikanisches Lesebuch. Drei Jahrzehnte geistiger Auseinandersetzung (München 1978), określił tym podtytułem jeden z jej działów.

${ }^{8}$ Robert G. Moeller, War Stories: The Search for a Usable Past in the Federal Republic of Germany, Berkeley 2001.

9 Zob. także: Jörg Echternkamp, Von Opfern, Helden und Verbrechern: Anmerkungen zur Bedeutung des Zweiten Weltkriegs in den Erinnerungskulturen der Deutschen 1945-1955, [w:] Kriegsende 1945 in Deutschland, red. Jörg Hillmann, John Zimmermann, München 2002.

10 Thomas W. Neumann, Der Bombenkrieg: Zur ungeschriebenen Geschichte einer kollektiven Verletzung, [w:] Nachkrieg in Deutschland, red. Klaus Naumann, Hamburg 2002, s. 330-341.

${ }^{11}$ W 1999 r. Winfried Sebald opublikował w formie książkowej swoje wykłady (wygłoszone dwa lata wcześniej w Zurychu), w których zwrócił uwagę na słabą obecność tematu bombardowań niemieckich miast w rodzimej literaturze (Winfried G. Sebald, Wojna powietrzna i literatura, tłum. M. Łukasiewicz, Warszawa 2012). Krytycy pracy Sebalda ripostowali, że jego kwerenda nie była dokładna (Andreas Huyssen, Rewriting and New Beginnings: W. G. Sebald and the Literature on the Air War, [w:] idem: Present Pasts: Urban Palimpsests and the Politics of Memory, Stanford 2003). O bombardowaniach pisali bowiem m.in. Heinrich Böll, Hans Nossack, Eric Maria Remarque, Arno Schmidt i Dieter Forte. Potwierdziły to książki przygotowane wkrótce potem przez Volkera Hage (kierownika działu literackiego „Der Spiegel”): zbiór wywiadów z pisarzami i krytykami literackimi oraz antologia prac literackich o bombardowaniu Hamburga w 1943 r. (Volker Hage, Zeugen der Zerstörung: Die Literaten und der Luftkrieg, Frankfurt am Main 2003; idem, Hamburg 1943: Literarische Zeugnisse zum Feuersturm, Frankfurt am Main 2003). Hage podkreślał, iż wrażenie niewielkiej obecności tematu bombardowań w literaturze niemieckiej nie wynikało z ilościowych parametrów produkcji artystycznej, ale było efektem słabej jej recepcji.

12 Golo Mann, Niemieckie dzieje w XIX i XX wieku, tłum. A. Kopacki, Olsztyn 2007. 
Wpływowym środowiskiem w życiu publicznym RFN były - aż do lat 80. - organizacje skupiające osoby wysiedlone (niem. Vertriebene - „wypędzeni") z terenów, które w 1945 r. przypadły Polsce, Czechosłowacji lub ZSRR (obszarów określanych w wielu podręcznikach historycznych, książkach popularyzatorskich i mapach wydawanych w RFN w latach 50. i 60 . jako „ziemie pod tymczasowym zarządem” tych państw). W tzw. Karcie Wypędzonych, głośnym dokumencie przyjętym w 1950 r. przez instytucje reprezentujące te środowiska, mowa była o ich „rezygnacji z zemsty i odwetu" oraz enigmatycznych "cierpieniach, jakie przypadły w udziale ludzkości, szczególnie w ostatnim dziesięcioleciu". I choć w wyborach do Bundestagu w 1957 r. partia wypędzonych (BHE) nie przekroczyła pięcioprocentowego progu wyborczego, ich środowiska zachowały spory wpływ na politykę koalicji CDU-CSU. W latach 1949-1969 istniało nawet osobne ministerstwo ds. wypędzonych (Bundesministerium für Vertriebene, Flüchtlinge und Kriegsgeschädigte $)^{13}$. W 1952 r. uchwalono rekompensaty majątkowe dla obywateli niemieckich, którzy ponieśli straty materialne podczas wojny (Lastenausgleichgesetz); wśród nich największą grupę stanowili właśnie wysiedleni (według szacunków do RFN trafiło ich około $8 \mathrm{mln}$ ). Wtedy też ustanowiono Dzień Pamięci Narodowej (Volkstrauer$\operatorname{tag})^{14}$, będący rokrocznie okazją do wystąpień reprezentantów wypędzonych i sympatyzujących z nimi (bądź jedynie zabiegających o ich głosy) polityków. W latach 1954-1963 ukazywały się również kolejne tomy monumentalnej Dokumentacji Wypędzeń Niemców, która w kolejnych dekadach była dwukrotnie wznawiana (w 1984 i 2004 r.) $)^{15}$.

Polityka wewnętrzna RFN lat 50. kierowała się - podług sformułowania Helmuta Königa - „podwójną strategią"16: z jednej strony, „ojcowie założyciele" i organy państwowe nowej Bundesrepublik jednoznacznie potępiały narodowy socjalizm; z drugiej zaś - dążono do zintegrowania społeczeństwa (także tej jego części, która wcześniej wspierała nazistowski reżim). W odróżnieniu od NRD czy Austrii, RFN uznawała się za prawnego następcę III Rzeszy - z wszelkimi konsekwencjami tej decyzji. Adenauer przeforsował zatem - mimo oporów ze strony członków wła-

${ }^{13}$ Jednym z urzędników tego resortu był Werner Ventzki - w czasie wojny oficer SS i burmistrz Liztmannstadt (jak przemianowano włączoną do Rzeszy Łódź).

14 Święto istniejące pod taką nazwą od zakończenia I wojny zostało wcześniej przemianowane przez nazistów na Dzień Pamięci Bohaterów.

${ }_{15}$ Kierownik tego projektu, Theodore Schieder, na początku wojny opracowywał plany wysiedlania Polaków z zajętych przez III Rzeszę terytoriów II RP i „odżydzania” (Entjudung) Europy Wschodniej. Zob. wywiad z uczniem Schiedera: http://www.spiegel. de/spiegel/spiegelspecial/d-22937239.html (dostęp: 20.04.2013).

${ }_{16}$ Helmut König, Die Zukunft der Vergangenheit: Der Nationalsozialismus im politischen Bewusstsein der Bundesrepublik, Frankfurt am Main 2003, s. 24-29. 
snej partii - odszkodowania dla Żydów oraz państwa Izrael (Wiedergutmachung), a jednocześnie podjął działania na rzecz zakończenia denazyfikacji, powszechnie zresztą krytykowanej, a niekiedy wręcz wyśmiewanej (choćby w opublikowanej w 1951 r. bestsellerowej książce Ernsta von Salomona Der Fragebogen [Formularz] ${ }^{17}$ ).

Szacuje się, że amnestia z września 1949 r., dotycząca wszystkich przestępstw zagrożonych karą do pół roku więzienia, objęła około 800 tys. obywateli $^{18}$. W $1951 \mathrm{r}$. przyjęto ustawę (tzw. 131er-Gesetz) nakazującą ponowne zatrudnienie na tym samym stanowisku (lub prawo do świadczeń emerytalnych i socjalnych) urzędników, w tym nauczycieli i sędziów, którzy w wyniku działań wojennych stracili pracę, jaką wykonywali w latach 1933-1945, a nie zostali zaklasyfikowani jako Hauptschuldige lub Belastete. W konsekwencji, do pracy w administracji tak federalnej, jak i lokalnej powróciły osoby piastujące analogiczne stanowiska w okresie III Rzeszy ${ }^{19}$. Nowe procesy wytaczano rzadko, niemal wyłącznie wobec nagłośnionych medialnie przypadków bądź wskutek determinacji tych nielicznych prokuratorów, którzy mieli dość odwagi cywilnej, by - także wbrew swojej grupie zawodowej - domagać się ukarania osób współodpowiedzialnych za nazistowski terror.

Niemieckie środowiska intelektualne zaniepokojone tymi procesami - w tym literaci z tzw. Grupy 47 (m.in. Günter Grass ${ }^{20}$ ) - były w RFN w latach 50. jeszcze zbyt nieliczne i zbyt mało wpływowe, aby dobitnie wyrazić swój sprzeciw wobec praktyk "restauracji”. Impuls do podejmowania konkretnych działań - protestów, listów otwartych, żądań postawienia przed sądem lub wykluczenia byłych nazistów z życia publicznego -

przyszedł z zewnątrz: z Izraela, który jako kraj ofiar poszukiwał przestępców wojennych, następnie z państw bloku wschodniego, które wobec groźby przedawnienia najcięższych zbrodni przedstawiły teraz dokumenty i ofiary obłędnej niemieckiej idei "przestrzeni życiowej” na wschodzie, ale przede wszystkim z NRD, która

17 Ernst von Salomon, Der Fragebogen, Hamburg 1951. Zob. także: Christian Graf von Krockow, Niemcy. Ostatnie sto lat, tłum. A. Kopacki, Warszawa 1997, s. 257.

${ }^{18}$ Norbert Frei, Polityka wobec przeszłości..., s. 50-51.

19 Zob. na przykład: Verwandlungspolitik. NS-Eliten in der westdeutschen Nachkriegsgesellschaft, red. Wilfried Loth, Bernd A. Rusinek, Frankfurt am Main 1998. W języku polskim: Norbert Frei, Kariery w pótmroku. Hitlerowskie elity po 1945, tłum. B. Ostrowska, Warszawa 2011. W okresie PRL ukazało się wiele publikacji na ten temat, w tym wysokonakładowych prac popularnonaukowych, na przykład opracowanie Edmunda Męclewskiego Spadkobiercy Rzeszy (kilka wydań).

20 Z czasem legenda o antyfaszystowskich poglądach członków Grupy 47 została podana w wątpliwość. W 2002 r. ukazała się kontrowersyjna książka Pogarda i tabu, w której autor przytaczał antysemickie wypowiedzi poszczególnych pisarzy (Klaus Briegelb, Missachtung und Tabu. Eine Streitschrift über die Frage: wie antisemitisch war die Gruppe 47?, Berlin 2002), a cztery lata później sensację wywołało wyznanie Grassa o jego służbie w Waffen-SS. 
od połowy lat pięćdziesiątych nie szczędziła konspiracyjnej energii, aby fakty i problemy „nieprzezwyciężonej przeszłości” wykorzystać do destabilizacji Republiki Federalnej $^{21}$.

Nazistowską hipoteką obciążeni zostali m.in. Hans Globke (współtwórca norymberskich przepisów rasowych, od 1953 r. szef urzędu kanclerskiego), Teodor Oberländer (minister ds. wypędzonych w gabinecie Adenauera) i Kurt Kiesinger (w latach 1940-1945 szef działu propagandy w ministerstwie spraw zagranicznych, 1959-1966 - premier rządu landu Badenia-Wirtembergia, 1966-1969 - kanclerz RFN). Na amnestię zdecydowali się także alianci, którzy w dawnych strefach dysponowali własnymi więzieniami ${ }^{22}$. Trudno jednak uznać ten stan rzeczy za „renazyfikację", jak chciała propaganda bloku wschodniego: jak zauważa Kazimierz Wóycicki,

\begin{abstract}
z jednej strony prawdą jest, że np. w niemieckich ministerstwach zastraszająco wysoki był odsetek dawnych członków NSDAP, co często podawano jako koronny i oburzający przykład. Z drugiej strony, gdyby jednak ten właśnie przykład poddać analizie, należałoby stwierdzić, że byli to często urzędnicy, którzy najchętniej wymazaliby ze swojej biografii epizod z NSDAP. Pragnęli kontynuować swoje kariery w nowych warunkach, których w najmniejszym stopniu nie zamierzali kwestionować. Nie renazyfikacja więc, lecz masowa ucieczka od odpowiedzialności charakteryzuje niemieckie lata pięćdziesiąte i dwie pierwsze kadencje rządów Adenauera ${ }^{23}$.
\end{abstract}

Procesy karne w związku z przestępstwami popełnionymi w imię ideologii nazistowskiej wytaczano w pierwszych latach istnienia RFN jedynie wobec tych osób, które dopuściły się zbrodni najbardziej haniebnych. Szczególnie głośny był, prowadzony w Ulm i zakończony w 1958 r. wyrokami wieloletniego więzienia, proces dziesięciu członków tzw. Grupy Operacyjnej (Ulmer Einsatzkommando-Prozess), odpowiedzialnych za rozstrzeliwanie ludności cywilnej w okolicach Tylży (obecnie Sowieck w obwodzie kaliningradzkim). Wskutek medialnego zainteresowania tym procesem, a także w wyniku działalności kilku prokuratorów, któ-

${ }^{21}$ Norbert Frei, Polityka wobec przeszłości..., s. 434.

${ }^{22}$ W 1958 r. ostatni przestępcy nazistowscy, skazani przez aliancką Komisję Mieszana, opuścili więzienie w Landsbergu. $Z$ drugiego znanego więzienia „ponadterytorialnego", czyli pozostającego pod wspólną administracją czterech państw alianckich Spandau w Berlinie Zachodnim, w 1954 r. zwolniono Konstantina von Neuratha (do 1939 r. Ministra Spraw Zagranicznych III Rzeszy, późniejszego „protektora” Czech i Moraw), w 1955 r. Ericha Raedera (naczelnego dowódcę Kriegsmarine), w 1956 r. wypuszczono na wolność Karla Dönitza (naczelnego dowódcę Wehrmachtu), zaś dziesięć lat później - Baldura von Schiracha i Alberta Speera (ostatni więzień Spandau, Rudolf Höss, popełnił samobójstwo w 1987 r.).

${ }^{23}$ Kazimierz Wóycicki, Niemiecki rachunek sumienia..., s. 51. 
rzy wskazywali na możliwość i konieczność prowadzenia dalszych prac, w grudniu tego samego roku powołano w Ludwigsburgu (z oddziałami w innych miastach) Centralną Jednostkę Krajowych Administracji Organów Sprawiedliwości ds. Wyjaśnienia Zbrodni Narodowowosocjalistycznych $^{24}$ (Zentrale Stelle der Landesjustizverwaltungen zur Aufklärung nationalsozialistischer Verbrechen; dalej: Centrala w Ludwigsburgu). $\mathrm{Na}$ efekty jej wysiłków trzeba było poczekać jeszcze kilka lat ${ }^{25}$. W pierwszym okresie istnienia jednostka ta była wielokrotnie poddawana krytyce przez środowiska skrajnie nacjonalistyczne, a jej praca utrudniana (pracownicy mieli problem ze znalezieniem mieszkania $\left.{ }^{26}\right)$.

Faktyczna rezygnacja $\mathrm{z}$ instytucjonalnie prowadzonej denazyfikacji miała swe konsekwencje również dla branży filmowej. Hans Peter Kochenrath wyliczył w 1966 r., biorąc pod uwagę filmy z lat 1946-1960, że w okresie tym 70 procent spośród wszystkich reżyserów i scenarzystów pracowało wcześniej w kinematografii III Rzeszy ${ }^{27}$. Byli wśród nich twórcy, którzy wcześniej realizowali filmy propagujące narodowosocjalistyczną ideologię. O Wolfgangu Liebeneinerze była już mowa (podrozdział 1.3), wymieńmy więc jeszcze kilka innych nazwisk. Carl Froelich, w czasie wojny przewodniczący Izby Filmowej Rzeszy, Franz Seitz (senior), który wyreżyserował SA-Mann Brandt (Niemcy 1933), Erich Waschneck, reżyser antysemickich (i antybrytyjskich) Rotszyldów (Die Rotschilds, Niemcy 1940), Gustav Ucicky, twórca m.in. słynnej antypolskiej fabuły Powrót do ojczyzny (Heimkehr, Niemcy 1941), Karl Ritter, kierownik produkcji i reżyser wielu filmów nazistowskich - wszyscy oni na początku lat 50. powrócili (na krótko wprawdzie) do branży. Rozrywkowe filmy kręcili w pierwszym okresie istnienia RFN również inni twórcy, o których można domniemywać, że ich postawa wobec hitlerowskiego reżimu była w okresie III Rzeszy bardziej aprobatywna niż obojętna (m.in. Arthur Maria Rabenalt, Alfred Braun, Eduard von Borsody, Heinz Paul, Jürgen von Alten, Johannes Häußler, Fritz Peter Buch, Gerhard Buchholz czy Alfred

${ }^{24} \mathrm{~W}$ polskich publikacjach znaleźć można różne warianty tej nazwy.

25 Pierwszy szef, Erwin Schüle, we wrześniu 1966 r. ustąpił ze stanowiska, gdy wyszło na jaw jego byłe członkostwo w SA i NSDAP.

${ }^{26}$ Paul Kohl, Strafverfolgung mit Hindernissen. Die Gründung der "Zentralen Stelle" Ludwigsburg, dostępny przez: http://www.deutschlandfunk.de/strafverfolgung-mit-hindernissen.724.de.html (dostęp: 20.09.2013).

${ }_{27}$ Hans Peter Kochenrath, Kontinuität im deutschen Film, „Filmstudio” 1966, nr 50, s. 29-33. Także w: Film und Gesellschaft in Deutschland, red. Wilfried von Bredow, Rolf Zurek, Hamburg 1966. Opracowanie Kochenratha zawiera listę niemal 200 scenarzystów i reżyserów aktywnych zawodowo zarówno w kinie III Rzeszy, jak i po wojnie. Zob. też: Klaus Kreimeier, Der westdeutsche Film in der fünfziger Jahren, [w:] Die fünfziger Jahre. Beiträge zu Politik und Kultur, red. Dieter Bänsch, Tübingen 1985. 
Weidenmann). Prawdziwym „stachanowcem” erefenowskiego kina okazał się zaś Herbert Reinecker - w III Rzeszy dziennikarz nazistowskich pism, wzięty dramaturg (jego sztuka Wieś obok Odessy [Das Dorf bei Odessa], opowiadająca o losie folksdojczów z ZSRR, była jedną z najczęściej wystawianych sztuk w III Rzeszy), a po 1945 r. scenarzysta ponad stu fabuł kinowych (i jeszcze większej liczby produkcji telewizyjnych), wśród nich pięciu filmów wojennych, które zostaną wzmiankowane w dalszej części rozdziału.

Tylko nieliczna grupa twórców poddana była środowiskowej anatemie; znamienny jest tu casus Veita Harlana. W latach 50. - uzyskawszy w 1949 r. wyrok uniewinniający w procesie o zbrodnie przeciw ludzkości - nakręcił on w RFN dziesięć filmów fabularnych. Dla części opinii publicznej Harlan pozostawał jednak symbolem nierozliczonej nazistowskiej przeszłości, toteż jego produkcje spotykały się z protestami ${ }^{28}$. We wrześniu 1950 r. Erich Lüth, kierownik państwowej agencji prasowej w Hamburgu, wezwał do bojkotu filmu Nieśmiertelna miłość (Unsterbliche Geliebte) w reżyserii Harlana, ten zaś zaprotestował przeciw rzekomemu szarganiu jego dobrego imienia. Sprawa była rozpatrywana na kolejnych szczeblach sądownictwa, łącznie z Trybunałem Konstytucyjnym, który ostatecznie w 1958 r. stwierdził ( Lüth-Urteil ${ }^{29}$ ), że wolność wypowiedzi jest ważniejsza niż względy ekonomiczne.

Szczególnym nadzorem objęto w RFN obrazy - filmy oraz inne materiały wizualne, zarówno dokumentalne, jak i fikcjonalne - powstałe w okresie III Rzeszy. Materiały pochodzące z notacji filmowych o prywatnym charakterze (dziś określilibyśmy je jako home movies), na przykład te $\mathrm{z}$ archiwum Ewy Braun (po wojnie uległo ono konfiskacie), wykorzystano po raz pierwszy w filmie dokumentalnym Do za pięć dwunasta (Bis 5 nach 12, real. Richard von Schenk, Gerhard Grindel, RFN 1953), który dopuszczono do dystrybucji pod warunkiem dokonania skrótów. W listopadzie 1953 r. film został jednak zakazany (jako pierwszy i jedyny w dziejach RFN) przez administrację federalną. W jego sprawie zabrał głos sam kanc-

${ }^{28}$ W 1950 r. we Freiburgu i Göttingen studenci zakłócali seanse i prowadzili pikiety w kinach, które wyświetlały film Harlana - zob. Gustav Meier, Filmstadt Göttingen: Bilder für eine neue Welt? Zur Geschichte er Göttinger Spielfilmproduktion 1945 bis 1961, Hannover 1996, s. 130-140.

${ }_{29}$ Zob. Werner Bergmann, Antisemitismus in öffentlichen Konflikten. Kollektives Lernen in der politischen Kultur der Bundesrepublik, Frankfurt am Main 1997, s. 86-117; Wolfgang Kraushaar, Der Kampf gegen den "Jud Süß”" - Regisseur Veit Harlan. Ein Meilenstein in der Grundrechtssprechung des Bundesverfassungsgerichts, "Mittelweg 36. Zeitschrift des Hamburger Instituts für Sozialforschung" 1995, nr 6; Frank Noack, Veit Harlan. „Des Teufels Regisseur", München 2000, s. 300-315. Zob. także: Siegfried Zielinski, Veit Harlan: Analysen und Materialien zur Auseinandersetzung mit einem Film-Regisseur, Frankfurt am Main 1981; Jörn Bollinger, Das Lüth-Urteil: Darstellung des (Verfassungs-) Konflikts und eine Analyse seiner Folgen, München 2009. 
lerz Adenauer, który ocenił realizację jako „mieszankę obrazów o potędze i codzienności narodowego socjalizmu oraz człowieczeństwa Hitlera, ukrytą propagandę narodowosocjalistyczną wymierzoną w europejską wspólnotę obronną" ${ }^{30}$. Po miesiącu zakaz zniesiono - film mógł być dystrybuowany w wersji skróconej zgodnie z zaleceniami FSK.

W 1961 r. na ekranach kin pojawił się dokument biograficzny Życie Adolfa Hitlera (Das Leben von Adolf Hitler), zrealizowany przez mistrza brytyjskiej dokumentalistyki, Paula Rothę; część wykorzystanych przez niego materiałów użyto rok wcześniej w filmie kompilacyjnym Erwina Leisera Mein Kampf z 1960 r. ${ }^{31}$ Nominalnie jest to produkcja szwedzka (rodzina Leiserów wyemigrowała do Szwecji w 1938 r.), choć materiały wchodzące w jej skład autor zebrał w archiwach RFN i NRD. Leiser wykorzystał m.in. fragment z Triumfu woli, wskutek czego Leni Riefenstahl zażądała tantiem w wysokości 35 tys. marek ${ }^{32}$, co zapoczątkowało długi, toczony $\mathrm{w}$ trzech instancjach, proces sądowy. Dopiero po wypłaceniu przez producentów na rzecz Riefenstahl dobrowolnego zadośćuczynienia Federalny Trybunał Sprawiedliwości wydał orzeczenie, że Triumf woli jest własnością państwową ${ }^{33}$. Leiser w $1961 \mathrm{r}$. przeprowadził się do Zurychu, gdzie (we współpracy z Arturem Braunerem) zrealizował dokument Eichmann i Trzecia Rzesza (Eichmann und das Dritte Reich, Szwajcaria/ RFN 1961) wykorzystujący materiały archiwalne oraz wywiad z Fritzem Bauerem, wówczas prokuratorem generalnym Hesji i jednym z inicjatorów procesów oświęcimskich (1963-1965). Według relacji Leisera, jeszcze w czasie realizacji filmu dostawał on anonimy z pogróżkami, zaś w austriackich kinach, w których wyświetlano dokument, wybijano witryny reklamowe ${ }^{34}$.

${ }^{30}$ Walter Euchner, Unterdrückte Vergangenheitsbewältigung..., s. 353-357. Zob. też artykuł Freiwilliger Zwang, „Die Zeit” 1953, nr 49. Ponadto: Frank Bösch, Der Nationalsozialismus im Dokumentarfilm: Geschichtsschreibung im Fernsehen, 1950-1990, [w:] Public History. Darstellungen des Nationalsozialismus jenseits der Geschichtswissenschaft, red. Frank Bösch, Constantin Goschler, Frankfurt am Main 2009.

31 Zob. też: Erwin Leisers Film "Mein Kampf". Eine Bilddokumentation der Jahre 19141945, Frankfurt am Main 1960.

${ }^{32}$ Leni Riefenstahl, Pamiętniki, tłum. J. Łaszcz, Warszawa 2003, s. 390-391 (zob. także krytyczną recenzję przekładu - Andrzej Gwóźdź, Zmarnowana szansa, „Kino” 2004, nr 4). Na język polski przełożono również dwie biografie Riefenstahl, które w dużej mierze powielają informacje z Pamiętników: Jürgen Trimborn, Riefenstahl: niemiecka kariera, tłum. A. Kowaluk, K. Kuszyk, Warszawa 2008; Steven Bach, Leni. Życie i twórczość Leni Riefenstahl, tłum. T. i P. Grzegorzewscy, Wrocław 2008.

${ }_{33}$ Erwin Leiser, Gott hat kein Kleingeld. Erinnerungen, Köln 1993, s. 154. Zob. także: Riefenstahl - ihr Kampf, „Der Spiegel” 1961, nr 3.

${ }^{34}$ Martina Thiele, Publizistische Kontroversen über den Holocaust im Film, Münster 2002, s. 228. 
Wspomniany proces Riefenstahl z Leiserem był jedną z odsłon wieloletniej kampanii prowadzonej przez nią w celu obrony swego imienia i dorobku artystycznego. Na początku lat 50. reżyserka podjęła też próbę sfinalizowania swego dawnego projektu - fabuły zatytułowanej $\mathrm{Ni}$ ziny (Tiefland), której akcja rozgrywa się częściowo w cygańskim obozie. Riefenstahl zaczęła kręcić film w czasie wojny, ale nie ukończyła zdjęć. Negatywy trafiły do francuskiej strefy okupacyjnej; po rozmaitych perturbacjach, Francuzi zwrócili reżyserce jej materiały na początku lat 50 . W międzyczasie, w maju 1949 r., w jednym z ilustrowanych magazynów ukazał się materiał, w którym sugerowano, że na potrzeby swego filmu sześć lat wcześniej autorka Triumfu woli „wypożyczyła” z obozów koncentracyjnych kilkudziesięciu cygańskich więźniów. Po występie przed kamera, „aktorzy” mieli być odesłani z powrotem do obozu, gdzie najpewniej zginęli. Riefenstahl wytoczyła wydawcy proces - i wygrała ${ }^{35}$. Niziny weszły na zachodnioniemieckie ekrany w $1954 \mathrm{r}$. W tym samym roku film miał być pokazany $\mathrm{w}$ ramach konkursu na festiwalu w Cannes (o co zabiegał, wedle reżyserki, Jean Cocteau), nie wyraził jednak na to zgody minister spraw zagranicznych RFN (ostatecznie film wyświetlono w sekcji pozakonkursowej $\left.{ }^{36}\right)$.

Riefenstahl starała się też wprowadzić powtórnie na ekrany swą Olimpiade (Olympia, Niemcy 1938). W 1958 r. przedstawiła film do oceny FSK, która początkowo dopuściła do rozpowszechniania tylko drugą część filmu, a po okazaniu rekomendacji z Międzynarodowego Komitetu Olimpijskiego - także część pierwsza, pod warunkiem wprowadzenia kliku cięć oraz przeznaczenia dla widzów pełnoletnich (co uzasadniano, według Riefenstahl, względami obyczajowymi ${ }^{37}$. Przedmiotem medialnych doniesień stała się również afrykańska ekspedycja Riefenstahl w 1962 r. (notabene, sponsorowana przez wpływowego przemysłowca, Alfrieda Kruppa von Bohlen und Halbach). Zdjęcia z wyprawy opublikował w 1964 r. magazyn „Kristall”, należący do koncernu Axel Springer, a następnie pisma francuskie, włoskie i amerykańskie ${ }^{38}$.

W związku z doświadczeniami lat III Rzeszy, w RFN doby Adenauera i Erharda wspierano kapitalistyczną rywalizację między producentami i dystrybutorami oraz zrezygnowano z państwowej cenzury filmowej. Nie oznacza to jednak, że władze polityczne nie dysponowały możliwościami wpływania na produkcję i dystrybucję filmów. Producenci mieli

${ }^{35}$ Leni Riefenstahl, Pamiętniki..., s. 306-310.

${ }^{36}$ Ibidem, s. 342-343.

37 Ibidem, s. 374-379. Ostatecznie, film pokazano w kilku kinach: w Berlinie Zachodnim, w Monachium i Bremie.

${ }^{38}$ Ibidem, s. 402 i 443. 
możliwość uzyskiwania wsparcia za pośrednictwem - koordynowanego przez Ministerstwo Gospodarki - mechanizmu gwarancji państwowych (Bundesbürgschaft), umożliwiającego redukcję strat (w tym spłatę kredytu) w przypadku produkcji, które nie przyniosły istotnych wpływów kasowych $^{39}$. Na wzór amerykański, w lipcu 1949 r. stowarzyszenie twórców filmowych (SPIO - Spitzenogranisation der Filmwirtschaft) powołało do życia Urząd Dobrowolnej Samokontroli Przemysłu Filmowego (Freiwillige Selbstkontrolle der Filmwirtschaft - FSK) w Wiesbaden, który dopuszczał filmy do dystrybucji $\mathrm{w}$ zrzeszonych kinach i określał ich kategorie wiekowe ${ }^{40}$. Drugą instytucją regulacyjną (obie zresztą istnieją do dziś) stał się, ustanowiony w 1951 r., Urząd Oceny Filmów (Filmbewertungsstelle - FBW, także z siedzibą w Wiesbaden), nadający filmom, również zagranicznym, tzw. predykaty („,wartościowy” lub „szczególnie wartościowy" $)^{41}$, uprawniające do zniżek podatkowych. W obu komisjach zasiadali eksperci - reprezentujący nie tylko branżę filmową lecz także „czynniki społeczne" (przedstawiciele nauki, stowarzyszeń i Kościołów), dzięki czemu władze polityczne mogły pośrednio wpływać na producentów i dystrybutorów. Ponadto, coroczne nagrody filmowe (Deutscher Filmpreis, potocznie Bundesfilmpreis) fundowane były przez ministerstwo spraw wewnętrznych (!), a za delegowanie filmów na zagraniczne festiwale odpowiadało Ministerstwo Spraw Zagranicznych.

Opinie FSK i FBW były niekiedy bardzo kontrowersyjne (jak ironizuje Thomas Elsaesser, „oficjalny wykaz »filmów wartościowych « nie przypomina przewodnika po narodowej kulturze filmowej, lecz wygląda niczym lista najgorszych filmów świata" ${ }^{42}$ ). W latach 50 . wśród (niesformalizowanych) kryteriów oceny uwzględniano kwestie związane z wizerunkiem Niemiec, w tym też reprezentacji nazizmu, o czym zapewne doskonale wiedzieli dystrybutorzy. Być może dlatego Casablanca (reż. Michael Curtiz, USA 1942) weszła na zachodnioniemieckie ekrany w 1952 r. w wersji

${ }^{39}$ Podobne instytucje funkcjonowały też w niektórych landach związkowych i umożliwiały wspieranie produkcji filmowej pożyczkami. Temat ten, jak się wydaje, zasługuje na bardziej wnikliwe opracowanie - zob. Zwischen gestern und morgen: westdeutscher Nachkriegsfilm 1946-1962, red. Hilmar Hoffmann, Walter Schober, Frankfurt am Main 1989, s. 80-82.

${ }^{40}$ Michael Humberg, Vom Erwachsenenverbot zur Jugendfreigabe. Die Filmbewertungen der FSK als Gradmesser des kulturellen Wertewandels, Münster 2013; Jürgen Kniep, "Keine Jugendfreigabe!" Filmzensur in Westdeutschland 1949-1990, Göttingen 2010.

${ }^{41}$ System „predykatów" funkcjonował w Niemczech od lat 20. (w okresie III Rzeszy został rozbudowany - wprowadzono m.in. kategorię staatspolitisch wertvoll, czyli „wartościowy dla państwa"). Z opiniami wydanymi przez erefenowskie FBW można się zapoznać na stronie: http://www.fbw-filmbewertung.com/search/ (dostęp: 20.04.2014). Zob. także: 50 Jahre FBW - 50 Jahre Filmgeschichte: Filmbewertung 1951-2001, red. Steffen Wolf, Alf Mayer-Ebeling, Gerd Albrecht, Wiesbaden 2001.

${ }^{42}$ Thomas Elsaesser, New German Cinema: A History, New Brunswick 1989, s. 20. 
skróconej o 20 minut, a gdy rok wcześniej do kin trafiła Osławiona (Notorious, USA 1946) Alfreda Hitchcocka - pod tytułem Weißes Gift (Biała trucizna) - nazistowscy towarzysze ojca bohaterki „zamienili się" w niemieckim dubbingu na... bossów narkotykowego gangu ${ }^{43}$.

Ponadto, od 1954 r. w Republice Federalnej Niemiec działała Międzyresortowa Komisja do Spraw Oceny Filmów (Interministerielle Filmprüfungsauschuss - IMF), później przemianowana na Międzyresortową Komisję do Spraw Relacji Filmowych Wschód-Zachód (Interministereiller Ausschuß für Ost/West Filmfragen); w jej skład wchodzili urzędnicy z ministerstwa przemysłu, sprawiedliwości, spraw wewnętrznych i spraw zagranicznych. Do 1967 r. - gdy komisję uznano za sprzeczną z konstytucją i rozwiązano - kontrolowała ona import filmów z tzw. bloku wschodniego ${ }^{44}$, w tym z NRD ${ }^{45}$. W praktyce, w zachodnioniemieckich mediach od czasu do czasu pojawiały się recenzje wschodnioniemieckich filmów - pisane głównie przez dziennikarzy mających możliwość (do momentu zbudowania muru berlińskiego) obejrzenia produkcji Defy we wschodniej części Berlina.

W tym kontekście znamienny jest przypadek filmu Wolfganga Staudtego Poddany (Der Untertan, NRD 1951 - zob. rozdział 2). Tuż po enerdowskiej premierze $\mathrm{w}$ zachodnioniemieckiej prasie ukazały się dwie jego recenzje: pierwsza $\mathrm{z}$ nich, opublikowana $\mathrm{w}$ prestiżowym czasopiśmie kulturalnym, była niezwykle pozytywna (chwaląca „obrazy o gęstości wyrazu dawno nie widzianej w niemieckim filmie" ${ }^{46}$ ), druga zaś, wydru-

${ }^{43}$ Za: Dietrich Kuhlbrodt, Deutsches Filmwunder. Nazis immer besser, Hamburg 2006, s. 12-13. Według autora wersję z dubbingiem bardziej zbliżonym do oryginału pokazano (pod tytułem Berüchtigt) dopiero w 1969 r. w telewizji ZDF (renomowany leksykon Zweitausendeins podaje rok 1975 i stację ARD). Kuhlbrodt wymienia jeszcze inne przykłady filmów (De Siki, Eisensteina, Tourneura i Hustona), wobec których FSK wyraziło zastrzeżenia.

${ }^{44}$ Sabine Hake podaje, że z ponad tysiąca filmów sprawdzanych w latach 50., dziewięćdziesiąt zostało zakazanych z uwagi na "tendencje komunizujące” (Sabine Hake, Film in Deutschland. Geschichte und Geschichten seit 1985, Reinbek 2002, s. 163).

${ }^{45}$ Walter Euchner, Unterdrückte Vergangenheitsbewältigung. Motive der Filmpolitik in der Ära Adenauer, [w:] Gegen Barbarei. Essays Robert Kempner zu Ehren, red. Rainer Eisfeld, Ingo Müller, Frankfurt am Main 1989; zob. również Stephan Buchloh, „Pervers, jugendgefährdend, staatsfeindlich". Zensur in der Ära Adenauer als Spiegel des gesellschaftlichen Klimas, Frankfurt am Main 2002, s. 183-286; Roland Seim, Zwischen Medienfreiheit und Zensureingriffen: Eine medien- und rechtssoziologische Untersuchung zensorischer Einflußnahmen auf bundesdeutsche Populärkultur, Münster 1997, s. 161-173. Na temat cenzury filmów Defy w RFN zob.: Andreas Kötzing, Zensur von DEFA-Filmen in der Bundesrepublik, „Aus Politik und Geschichte” 2009, nr 1-2.

${ }^{46}$ Wilfried Berghahn, Deutschenspiegel für Ost und West. Zu dem DEFA-Film "Der Untertan”, „Frankfurter Hefte” 1952, nr 9. W publikacji poświęconej Staudtemu pojawia się informacja, iż autor tej recenzji obejrzał film na południu Niemiec, z kopii „przeszmuglowanej” z NRD (Wolfgang Staudte, red. Eva Orbanz, Hans Helmut Prinzler, Berlin 1991, s. 36). 
kowana w branżowym piśmie kiniarzy i dystrybutorów, niezmiernie krytyczna, mająca de facto charakter paszkwilu (anonimowy autor przedstawił reżysera jako „dawnego protegowanego Goebbelsa”, który wysługuje się „nowym panom ze Wschodu" ${ }^{47}$ ). FSK nie wydało wówczas zgody na dystrybucję Poddanego w RFN - i dopiero po otrzymaniu przez film nagrody na festiwalu w Karlovych Warach oraz pozytywnych recenzji w kilku krajach zachodnich, w 1956 r. dopuszczono go do dystrybucji (wszedł na ekrany erefenowskich kin w kolejnym roku) w wersji skróconej o 12 minut i z dopiskiem w czołówce, iż fabuła pokazuje przypadek jednostkowy i nie jest parabola zachowania Niemców w wieku dwudziestym ${ }^{48}$. Gdy zaś w 1958 r. inny film Staudtego - Rotację/Brunatna pajęczyne (zob. podrozdział 1.4) - pokazano $\mathrm{w}$ zachodnioniemieckiej telewizji, członek rady programowej radia i telewizji (Rundfunkrat) wystosował protest, w którym przestrzegał stację przed przeistoczeniem się w platformę bolszewickiej propagandy ${ }^{49}$.

Fakt, że kino erefenowskie lat 50 . było zdominowane przez komercyjną produkcję gatunkowa, nie był oczywiście (ani wtedy, ani w okresie III Rzeszy, ani w kolejnych dekadach zbyt często i zbyt jednoznacznie utożsamianych z Nowym Kinem Niemieckim) szczególną cechą tej akurat kinematografii. Być może specyfiki kina erefenowskiego na tle innych kinematografii zachodnioeuropejskich należałoby szukać w preferowanych gatunkach. Manfred Barthel - świadek epoki, scenarzysta wielu ówczesnych fabuł - w opublikowanych po latach wspomnieniach żartobliwie stwierdził, że dla niemieckiej produkcji filmowej lat 50. niezbędne były cztery kostiumy: „sutanna księdza, kitel lekarski, mundur niemieckiego żołnierza i płaszcz detektywa" ${ }^{50}$. Trzy ostatnie związane były z popularnymi wówczas gatunkami: filmami o lekarzach $(\text { Arztfilme })^{51}$, filmami

47 Ein Film gegen Deutschland: „Der Untertan”, „Filmpress” 1951, nr 45, s. 27 (przedruk w: Wolfgang Staudte, red. Eva Orbanz, Hans Helmut Prinzler). Mniej więcej w tym samym czasie Staudte realizował w zachodnich Niemczech film Gift im Zoo - gdy po tygodniu zdjęć Ministerstwo Spraw Wewnętrznych RFN zażądało od reżysera deklaracji, iż nie będzie kręcił więcej filmów dla Defy, Staudte odmówił, a zdjęcia dokończył inny reżyser. (Wolfgang Staudte..., s. 254-255).

${ }^{48}$ Heinz Kersten, Ankläger der Mörder und Untertanen, [w:] Wolfgang Staudte, red. Eva Orbanz [1977], s. 26. Zob. również rozdział 2 niniejszej książki.

${ }^{49}$ List otwarty Waltera Bechera, "fff Press" 1958, nr 17, s. 36 (podaję za: Bettina Greffrath, Gesellschaftsbilder der Nachkriegszeit. Deutsche Spielfilme 1945-1949, Pfaffenweiler 1995; tam także cytowana jest odpowiedź przedstawicieli zachodnioniemieckiej telewizji).

${ }_{50}$ Manfred Barthel, Als Opas Kino jung war: Der deutsche Nachkriegsfilm, Frankfurt am Main 1991, s. 247-278.

51 Udowodnienie zasadności użycia terminu "gatunek" wobec „filmów o lekarzach" wymagałoby obszerniejszego wywodu, który nie zostanie w tym miejscu podjęty. Dość powiedzieć, że kilka spośród filmów wojennych wymienionych w dalszej części niniejszego rozdziału wpisywałoby się w tę charakterystykę. Jednym z najbardziej popularnych 
wojennymi (z których zdecydowana większość dotyczyła II wojny światowej) oraz kryminałami (zwłaszcza adaptacjami Edgara Wallace'á) ${ }^{52}$. Podobnie jak $w$ innych krajach zachodnich dużą oglądalność miały również melodramaty i filmy muzyczne. Charakterystyczny jest zwłaszcza sukces filmu Rodzina Trappów (Die Trapp-Familie, reż. Wolfgang Liebeneiner, RFN 1956), zrealizowanego na podstawie wspomnień Marii Augusty von Trapp (które posłużyły jako kanwa scenariusza obsypanych Oscarami Dźwięków muzyki), opowiadających o muzykalnej rodzinie z Austrii, która po jej anszlusie decyduje się wyjechać do USA ${ }^{53}$ (sukces filmu skłonił do nakręcenia sequela, Rodzina Trappów w Ameryce [Die Trapp-Familie in Amerika], reż. Wolfgang Liebeneiner, RFN 1958). Rodzina Trappów zawiera wątki charakterystyczne dla gatunku najbardziej typowego dla zachodnioniemieckiego kina lat 50. - heimatfilmu (proponowane onegdaj tłumaczenie - „film ojczyźniany" 54 - nie oddaje specyfiki określenia Heimat, bliższego rozumieniu "małej ojczyzny" $)^{55}$. Jego szczegółowy opis jest w tym miejscu zbędny; na potrzeby niniejszego wywodu ograniczę się do wyliczenia najważniejszych cech tego nurtu, takich jak: bukoliczne przestrzenie niemieckiej prowincji (przypominające "filmy górskie" z lat 20. i 30.), wprowadzenie elementów ludowego folkloru (kostiumy, popisy muzyczne i taneczne), typizacja bohaterów (leśniczy, aptekarz, właściciel gospody itp.) oraz obecność wątków antymodernizacyjnych (zagrożenie płynące „z miasta"). Wymowa polityczna heimatfilmów podkreślała ahistoryczne „długie trwanie" narodu niemieckiego i konieczność jego integracji wokół tradycyjnych wartości. W fabułach nie przypominano (a przynajmniej: nie wprost) o wydarzeniach z czasów wojny - choć pojawiały się postaci

ówczesnych filmów o tej tematyce był Sauerbruch (Sauerbruch - Das war mein Leben, reż. Rolf Hansen, RFN 1954), inspirowany bestsellerową autobiografią znanego chirurga, lecz przemilczający jego oportunistyczną postawę w okresie III Rzeszy (zob. Udo Benzenhöfer, "Schneidet für Deutschland!". Bemerkungen zu dem Film "Sauerbruch - Das war mein Leben" (1954), [w:] Medizin im Spielfilm der fünfziger Jahre, red. Udo Benzenhöfer, Wolfgang U. Eckhardt, Pfaffenweiler 1993; Gerhard Bliersbach, So grün war die Heide. Der deutsche Nachkriegsfilm in neuer Sicht, Basel 1985, s. 51-62).

52 Popularne były też „filmy szlagierowe” (zob. Manfred Hobsch, Liebe, Tanz und 1000 Schlagerfilme, Berlin 1998) oraz, podobnie jak w innych krajach, komedie (ich gwiazdorami byli m.in. Heinz Erhardt i Heinz Rühmann).

${ }^{53}$ Przejęcie władzy przez nazistów i anszlus Austrii zasygnalizowano w krótkiej sekwencji, w której Trappowie słuchają audycji radiowej na ten temat, a następnie do ich domu przybywa lokalny kacyk NSDAP, domagając się wywieszenia flagi ze swastyka, zaś ich kamerydyner ujawnia, że przez lata był członkiem partii nazistowskiej.

${ }_{54}$ Zob. Jerzy Toeplitz, Historia sztuki filmowej, t. VI: 1946-1953, Warszawa 1990, s. 428-429.

${ }_{55} \mathrm{~W}$ języku polskim zob.: Andrzej Gwóźdź, Obok kanonu. Tropami kina niemieckiego, Wrocław 2011 (rozdział: Heimatfilm, albo realizm kapitalistyczny Niemiec Zachodnich); Beata Kosińska-Krippner, Heimatfilm - zarys dziejów gatunku, „Kwartalnik Filmowy” 2009, nr 67-68. 
Heimkehrerów (żołnierzy powracających z obozów dla jeńców wojennych) oraz Vertriebene (osób wysiedlonych z obszarów przyłączonych do Polski, Czechosłowacji i ZSRR).

Silna stereotypizacja wykorzystywana $w$ tych filmach sprawia, że są one wdzięcznym obiektem analiz czynionych z perspektywy studiów kulturowych, które w niektórych interpretacjach ujawniają miejsca „pęknięć" ideologicznej podbudowy dyskursu. Przykładowo, w filmie Studnia przed brama (Am Brunnen vor dem Tore, reż. Hans Wolff, RFN 1952) zamiary Inge, właścicielki gospody, która chce związać się z Kurtem, szarmanckim właścicielem stacji benzynowej, zostają udaremnione przez pojawienie się Roberta, angielskiego lotnika stacjonującego we wsi podczas wojny i byłego kochanka bohaterki. Jak komentują autorki przenikliwego studium o heimatfilmie,

bogaty angielski absztyfikant wymazuje [screens out] ciemniejsze aspekty czasu okupacji - gdy granica pomiędzy gwałtem a prostytucją była płynna. Żołnierze, którzy odwdzięczali się papierosami i czekoladą za seks, raczej nie powracali z ofertą małżeństwa ${ }^{56}$.

Ogólnie rzecz biorąc, kino zachodnioniemieckie lat 50. i I połowy lat 60. uchodziło - również w opiniach wyrażanych w mediach zagranicznych - za niezmiernie słabe ( $w$ RFN taki pogląd reprezentowali zwłaszcza krytycy skupieni wokół, założonego w 1957 r., czasopisma „Filmkritik”). Miarą porównań były tu inne kinematografie europejskie, także z Europy Wschodniej, ale też dziedzictwo kina Republiki Weimarskiej (niemiecki przekład Kracauerowskiego Od Caligariego do Hitlera - wydanego po angielsku w 1947 r. - ukazał się w 1958 r. i początkowo nie miał szerokiej recepcji w RFN). Festiwal filmowy w Berlinie Zachodnim, który swą pierwszą edycję miał w $1951 \mathrm{r} .{ }^{57}$, był zrazu pomyślany jako impreza o ważnym wymiarze propagandowym, pokazująca berlińczykom integrację zachodniej części Niemiec z kulturą demokratycznego i zamożnego świata, czego symbolem pozostał $\mathrm{z}$ jednej strony glamour hollywoodzkich gwiazd, z drugiej zaś - brak filmów z krajów należących do sowieckiej strefy wpływów $^{58}$. Niemieckie Nagrody Filmowe trafiały do filmów wyróżniających

56 Elisabeth Boa, Rachel Palfreyman, Heimat - a German Dream: Regional Loyalties and National Identity in German Culture, 1890-1990, Oxford 2000, s. 91.

57 Pomysłodawcą festiwalu był Oscar Martay, oficer odpowiedzialny za sprawy kinematografii w amerykańskiej strefie okupacyjnej, a dyrektorem (do 1976 r.) historyk filmu Alfred Bauer. Na pierwszym festiwalu jury złożone było wyłącznie z reprezentantów Niemiec, zaś podczas kolejnych czterech edycji nagrody przyznawała publiczność. Międzynarodowe jury powoływano od 1956 r. Zob. Peter Cowie, Die Berlinale. Das Festival, Berlin 2010.

58 Ów brak wynikał zapewne przede wszystkim z woli decydentów w krajach „demokracji ludowych". O filmach Defy na Berlinale zob. Zwischen uns die Mauer: DEFA-Filme auf der Berlinale, red. Jürgen Haase, Berlin 2010. 
się na tle rodzimej produkcji, ale słabo istniejących w obiegu międzynarodowym. „Przesilenie” nastąpiło na początku lat 60., gdy przez kolejne trzy lata (1961-1963) nie przyznano nagród ani dla najlepszej pełnometrażowej fabuły, ani dla najlepszego reżysera. A w 1962 r. młodzi filmowcy ogłosili podczas festiwalu filmów krótkometrażowych w Oberhausen głośny manifest, w którym stwierdzali: „Klęska konwencjonalnego filmu niemieckiego pozbawia wreszcie podstaw ekonomicznych tę mentalność, którą odrzucamy. Dzięki temu nowy film ma szansę stać się żywy"59. Na ich pierwsze kinowe filmy widzowie musieli jednak poczekać do $1965 \mathrm{r}$.

\subsection{Bohaterscy oponenci Hitlera}

Tuż po ukonstytuowaniu się Republiki gabinet Adenauera rozpoczął intensywne działania zmierzające do powołania zachodnioniemieckich sił zbrojnych. W 1950 r. ustanowiono „urząd Blanka”, mający na celu przygotowanie stosownych procedur ${ }^{60}$. W debatę o remilitaryzacji (Wiederbewaffnung) aktywnie włączały się także środowiska byłych oficerów Wehrmachtu ${ }^{61}$. Cel osiągnięty został w 1955 r., a kilka miesięcy później weszła w życie ustawa o obowiązkowej służbie wojskowej. Wpływowym w RFN środowiskiem były organizacje weteranów (Veteranerkultur ${ }^{2} 2$ ), organizujące cykliczne spotkania w dużych i mniejszych miastach. Ich członkowie - również dawni oficerowie i generalicja ${ }^{63}$ - publikowali wspomnienia

${ }^{59}$ Europejskie manifesty kina. Od Matuszewskiego do Dogmy. Antologia, red. Andrzej Gwóźdź, Warszawa 2002. Zob. też: Die Oberhausener. Rekonstruktion einer Gruppe 19621985, red. Rainer Lewandowski, Diekholzen 1982; ostatnio także: Michaela S. Ast, Der alte Film ist tot. Wir glauben an den neuen: die Genese des jungen deutschen Films, Marburg 2013.

${ }^{60}$ Oficjalna nazwa instytucji brzmiała: Dienststelle des Bevollmächtigten des Bundeskanzlers für die mit der Vermehrung der alliierten Truppen zusammenhängenden Fragen. Stojący na czele urzędu Theodor Blank w 1956 r. został pierwszym w historii RFN ministrem obrony.

${ }^{61} \mathrm{~W}$ sporządzonym przez nich w sierpniu 1950 r., na wiele lat utajnionym dokumencie (Himmeroder Memorandum), postulowano działania mające na celu „zrehabilitowanie niemieckiego żołnierza".

${ }^{62}$ Zob. Thomas Kühne, Zwischen Vernichtungskrieg und Freizeitgesellschaft. Die Veteranenkultur in der Bundesrepublik 1945-1995, [w:] Nachkrieg in Deutschland...; Jörg Echternkamp, Mit dem Krieg seinen Frieden schließen - Wehrmacht und Weltkrieg in der Veteranenkultur (1945-1960), [w:] Von der Kriegskultur zur Friedenskultur. Zum Wandel der politischen Mentalität in Deutschland nach 1945, red. Thomas Kühne, Münster 2000.

${ }_{63}$ Zob. Rolf Düsterberg, Soldat und Kriegserlebnis. Deutsche militärische Erinnerungsliteratur (1945-1961) zum Zweiten Weltkrieg, Osnabrück 1999; Oliver von Wrochen, Deutsche Generalsmemoiren nach 1945 als Grundlage nationaler Opfernarrative, [w:] Autobiographische Aufarbeitung. Diktatur und Lebensgeschichte im 20. Jahrhundert, red. Martin Sabrow, Helmstedt 2012. 
(autorem szczególnie poczytnych był generał Erich von Manstein), z których wyłaniał się obraz ojczyzny zwiedzionej na manowce przez demonicznych szaleńców z wierchuszki NSDAP.

Centrum zachodnioniemieckich narracji o nazistowskim ruchu oporu stanowił w RFN nieudany zamach na Adolfa Hitlera z 20 lipca 1944 r., dokonany w Wilczym Szańcu przez pułkownika Clausa von Stauffenberga, ówczesnego szefa sztabu armii rezerwowej, która po śmierci Führera miała - w ramach „planu Walkiria” - pomóc w przejęciu władzy nad Rzeszą przez tymczasowy rząd, zamierzający prowadzić negocjacje $\mathrm{z}$ aliantami ${ }^{64}$. Podjęte przez zachodnioniemieckie elity na początku lat 50 . pierwsze próby upamiętniania antyhitlerowskiego ruchu oporu były niezmiernie ważne dla kształtowania nowej (zachodnio)niemieckiej tożsamości - z trzech powodów. Po pierwsze, stanowiły swego rodzaju kontrę wobec dominującego zaraz po wojnie, a wspieranego przez aliantów, aksjomatu „winy zbiorowej”. Po drugie, w I połowie lat 50. wśród większości niemieckiego społeczeństwa panowało autentyczne przekonanie, iż niemieccy oponenci Hitlera, rekrutujący się ze sfer mundurowych, byli zdrajcami $^{65}$. Można założyć, że duża część ówczesnego społeczeństwa Niemiec dała wiarę nazistowskiej propagandzie, która w pierwszych dniach po zamachu przedstawiała Stauffenberga i spiskowców z jego grupy tak, jak uczynił to Hitler w radiowym przemówieniu z 21 lipca (jako „klikę ambitnych, pozbawionych skrupułów, a jednocześnie głupich oficerów"66), a kilka tygodni później „wyciszyła” oskarżycielski ton, próbując marginalizować znaczenie puczu, a tym samym skazać ruch oporu na zapomnienie. Po trzecie wreszcie, spisek z 20 lipca 1944 r. zyskiwał legitymizację przez porównanie $\mathrm{z}$,powstaniem berlińskim” enerdowskich robotników

${ }^{64}$ Wcześniejsze działania spiskowców, określanych retrospektywnie jako „Ruch 20 Lipca" (skupionych wokół gen. Ludwika Becka i Carla Goerdelera przewidzianego do pełnienia funkcji premiera w rządzie tymczasowym), okoliczności zamachu oraz bezpośrednie jego konsekwencje zostały drobiazgowo opisane w licznych monografiach przedmiotu. W języku polskim: Ian Kershaw, Walkiria. Historia zamachu na Hitlera, tłum. R. Bartołd, Poznań 2009. Odnosząc się do zamachu Stauffenberga, będę posługiwał się terminami „pucz" i „spisek” w ścisłym, nie zaś wartościującym ich znaczeniu.

65 Przykładowo, w 1952 r. 50 procent ankietowanych sprzeciwiło się nazywaniu szkół imieniem Stauffenberga (Erich-Peter Naumann, Elisabeth Noelle, Jahrbuch der öffentlichen Meinung 1947-1955, Allensbach 1956, s. 138). Zob. także: Peter Steinbach, Widerstand im Dritten Reich - die Keimzelle der Nachkriegsdemokratie? Die Auseinandersetzung mit dem Widerstand in der historischen politischen Bildungsarbeit, in den Medien und in der öffentlichen Meinung nach 1945, [w:] Der 20. Juli: Das "andere Deutschland” in der Vergangenheitspolitik nach 1945, red. Robert Buck, Gerd Ueberschär, Berlin 2008.

${ }^{66}$ Cyt. za: Przemówienie Adolfa Hitlera, wygłoszone 21 lipca 1944 roku, [w:] Ian Kershaw, Walkiria..., s. 127. Materiał audio z Deutsches Rundfunkarchiv Frankfurt (sygnatura nagrania: 2623118) dostępny: http://www.1000dokumente.de (dostęp: 10.11.2010). 
z 17 czerwca 1953 r. (Edgar Wolfrum podaje przykłady wypowiedzi zachodnioniemieckich polityków, którzy zestawiali oba wydarzenia jako „podwójny dowód” na zdolność niemieckiego społeczeństwa do „użycia wewnętrznych sił, by zwrócić się przeciw dyktaturze" ${ }^{67}$ ).

Instytucjonalne ramy formowania pamięci o Stauffenbergu i zamachu z 20 lipca zaczęły powstawać na przełomie lat 40. i $50 .{ }^{68} \mathrm{~W} 1949$ r. powołano - z inicjatywy ówczesnego prezydenta RFN, Theodora Heussa - fundację „Hilfswerk 20. Juli 1944" ${ }^{69}$. Jej początkowym celem było materialne wsparcie dla pozostałych przy życiu członków ruchu oporu oraz rodzin tych, którzy stracili życie podczas wojny. W 1952 r. czasopismo „Das Parlament" wydało dodatek poświęcony wydarzeniom 20 lipca ${ }^{70}$, zaś rok później na dziedzińcu Bendlerblock (główna siedziba działań spiskowców i miejsce, gdzie zostali straceni) odsłonięto pomnik, powstały z inicjatywy rodzin uczestników puczu ${ }^{71}$. Dziesiąta rocznica zamachu miała już oficjalny charakter: prezydent Heuss wygłosił w Berlinie mowę, w której podważył werdykt doraźnego sądu skazującego spiskowców, sławiąc jednocześnie ich etyczne walory ${ }^{72}$; zmieniono też nazwę ulicy Bendlerstraße na Stauffenbergstraße. Gdy w 1955 r. powołano komisję weryfikacyjną (Personalgutachterausschuss), która przez kolejne dwa lata oceniała przydatność byłych oficerów Wehrmachtu do służby w Bundeswehrze, opracowane przez nią procedury rekrutacyjne zawierały m.in. pytanie o stosunek do spisku Stauffenberga ${ }^{73}$. Stał się on zatem użytecznym symbolem - mógł bowiem stanowić swoiste centrum polityki historycznej, wokół której miała się wytworzyć tożsamość nowych instytucji młodej republiki.

${ }^{67}$ Edgar Wolfrum, Geschichtspolitik in der Bundesrepublik Deutschland. Der Weg zur bundesrepublikanischen Erinnerung 1948-1990, Darmstadt 1999, s. 78 i 195.

${ }_{68}$ Pierwsza książka o Stauffenbergu - napisana przez Fabiana von Schlabrendorffa, który sam był zaangażowany w wojskowy spisek - została opublikowana nie w Niemczech, lecz w Austrii (Fabian von Schlabrendorff, Offiziere gegen Hitler, Zürich 1946).

69 Zob. Christiane Toyka-Seidl, Gralshüter, Notgemeinschaft oder gesellschaftliche "Pressure-Group"? Die Stiftung "Hilfswerk 20. Juli. 1944" im ersten Nachkriegsjahrzehnt, [w:] Der 20. Juli. Das andere Deutschland... Kontynuatorką "Hilfswerk” jest istniejąca do dziś "Stiftung 20. Juli 1944" (zob.: www.stiftung-20-juli-1944.de [dostęp: 10.07.2011]).

70 „Das Parlament” 1953, nr 28. Czasopismo było finansowane przez Bundeszentrale für Heimatdienst - instytucję federalna, która później przekształciła się w (istniejącą do dziś i prężnie działającą) Bundeszentrale für Politische Bildung (zob. www.bpb.de [dostęp: 10.11.2010]).

${ }^{71}$ Pomnik przedstawia młodego mężczyznę ze związanymi rękami. W $1968 \mathrm{r}$. Bendlerblock został przekształcony w placówkę muzealną o nazwie Pomnik Niemieckiego Ruchu Oporu (Gedenkstätte Deutscher Widerstand); zob. www.gdw-berlin.de (dostęp: 10.10.2010).

${ }^{72}$ Pełny tekst tego wystąpienia pod adresem: http://www.20-juli-44.de/pdf/1954_ heuss.pdf (dostęp: 10.10.2010).

${ }_{73}$ Zob. Robert Buck, Die Rezeption des 20. Juli 1944 in der Bundeswehr, [w:] Der 20. Juli: Das andere Deutschland... 
Erefenowskim filmom o bohaterskich przeciwnikach Hitlera wśród kadry oficerskiej szlak przetarły hollywoodzkie produkcje. Dużą popularnością cieszył się amerykański melodramat w kostiumie filmu wojennego, Lis pustyni (Desert Fox, reż. Henry Hathaway, USA 1951) - z Jamesem Masonem w roli generała Rommla, rozdartego pomiędzy powinnościami sumienia i żołnierską przysięgą ${ }^{74}$ (wbrew tytułowi, w centrum zainteresowania nie znajdowała się kampania w Afryce Północnej, ale kontakty Rommla z ruchem oporu po jego odwołaniu do Niemiec) $)^{75}$. Film ten ustalił schemat fabularny ",szlachetny Wehrmacht kontra zbrodniarze z SS i kierownictwo NSDAP", który będzie powielany przez wiele zachodnioniemieckich filmów. Ponieważ miały one wysoką oglądalność, najpewniej dobrze odpowiadały na społeczne zapotrzebowanie niemieckiej widowni (mit „dobrego Wehrmachtu” będzie utrzymywał się w społeczeństwie RFN praktycznie do lat 90., do słynnej wystawy Wehrmachtsausstellung z 1995 r.).

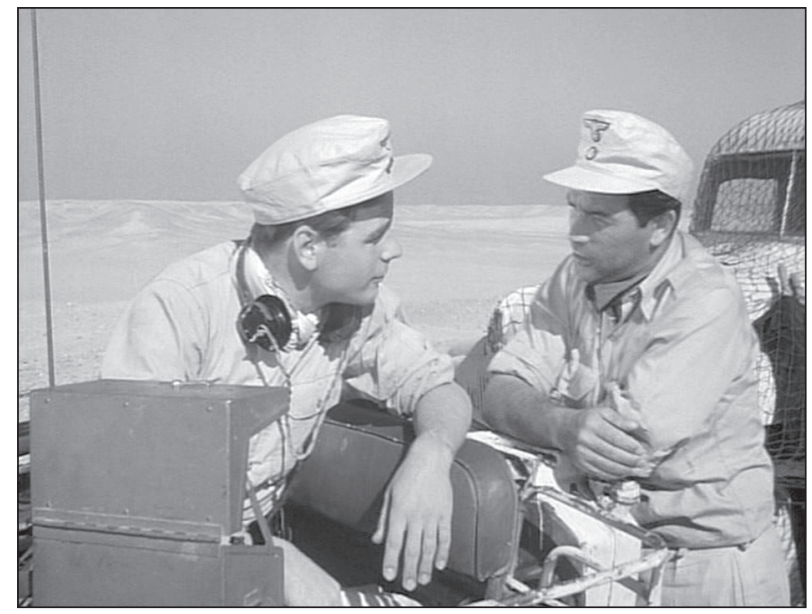

Fot. 27. Rommel wzywa Kair (reż. Wolfgang Schleif, 1959) Pustynne plenery jako tło opowieści o Rommlu

${ }^{74}$ Innym amerykańskim filmem o tematyce wojennej, który można tu przywołać ze względu na wątek niemieckich żołnierzy występujących przeciw nazistowskiej władzy, jest Decyzja przed świtem (Decision Before Dawn, reż. Anatole Litvak, 1952).

${ }^{75}$ W pamięci zbiorowej RFN - kulturowej, a w latach 50. zapewne również komunikacyjnej w ujęciu małżeństwa Assmannów - dowódca Afrika Korps był traktowany niczym bohater narodowy (jego nazwiskiem nazywano ulice, a popularność generała najpewniej pomogła synowi, Manfredowi Rommlowi, w uzyskaniu - trzykrotnie - fotela burmistrza Stuttgartu). W latach 50. nakręcono w RFN pełnometrażowy film dokumentalny Taki byt nasz Rommel (Das war unser Rommel, lub Rommel - Schlachtfeld in der Wüste, reż. Horst Wiganko, RFN 1953) oraz wojenno-szpiegowski film fabularny Rommel wzywa Kair (Rommel ruft Kairo, reż. Wolfgang Schleif, RFN 1959) - fot. 27. 


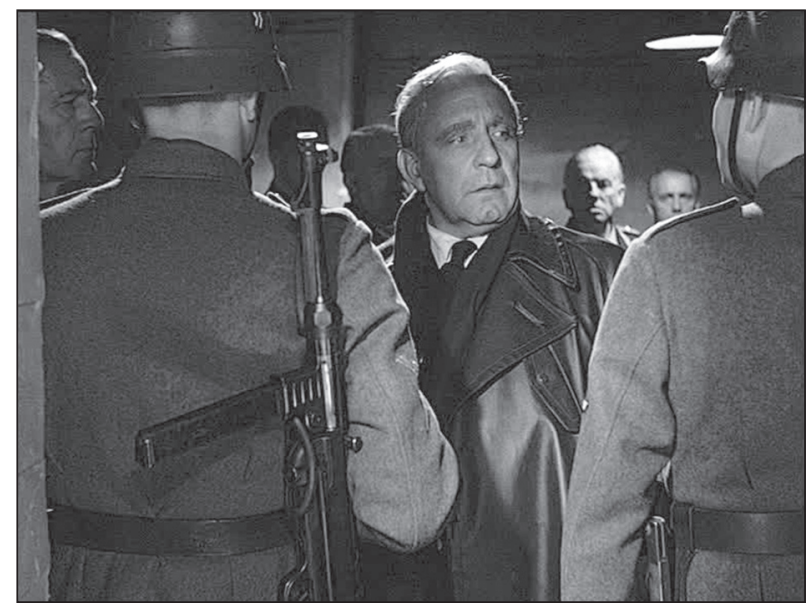

Fot. 28. Canaris (reż. Alfred Weidenmann, 1954) Canaris (Otto E. Hasse) jako oponent polityki Hitlera

Pierwsza zachodnioniemiecka produkcja filmowa podejmująca temat niemieckiego antyhitlerowskiego ruchu oporu nie dotyczyła jednak Stauffenberga. W bijącym wówczas rekordy oglądalności ${ }^{76}$ filmie Canaris (reż. Alfred Weidenmann, RFN 1954) dramaturgia zbudowana jest na konflikcie między tytułowym bohaterem, szefem Abwehry (kontrwywiadu wojskowego) w latach 1937-1944 a Heydrichem, szefem SD. Sporą część narracji zajmują - tylko niektóre, starannie wyselekcjonowane - wydarzenia sprzed wybuchu wojny ${ }^{77}$ (m.in. nawiązanie przez Canarisa kontaktu z generałem Beckiem, który w proteście przeciw inwazji na Czechosłowację rezygnuje ze stanowiska szefa sztabu generalnego). Canaris jest pokazany jako genialny strateg, który na próżno ostrzega Hitlera przed uderzeniem na ZSRR. Aby ocalić Niemcy, dołącza do spiskowców planujących zamach na Führera (jeden ze współpracowników bohatera zostaje aresztowany przy próbie przeszmuglowania zapalników ze Szwajcarii i jest przesłuchiwany przez SD; niebezpieczeństwo dla spiskowców zostaje zażegnane dzięki zamachowi na Heydricha w Pradze). Takie hagiograficzne przedstawienie Canarisa niekoniecznie jest zgodne z prawdą hi-

76 Zob. obszerny artykuł w „Der Spiegel” (anon., Erdachte Verschwörung, „Der Spiegel" 1954, nr 26).

${ }^{77}$ Jak pisze Peter Reichel: „o tym, że Canaris był powiązany z mordercami Róży Luksemburg i Karla Liebknechta, że należał do najbliższych współpracowników ministra obrony Gustava Noskego, który uczestniczył w tzw. puczu Kappa, że był powiązany z organizacją Consul, z której pochodził morderca Rathenaua - o tym na Zachodzie wiedzieli tylko ci, którzy czytali gazety z NRD" - Peter Reichel, Erfundene Erinnerung: Weltkrieg und Judenmord in Film und Theater, München 2004, s. 66. 
storyczną (wprawdzie roztaczał on parasol ochronny nad ruchem oporu, ale sam odrzucił możliwość uczestnictwa w zamachu), lecz buduje prosty wniosek: gdyby w III Rzeszy znalazło się więcej tak rozsądnych generałów, wojna nie skończyłaby się klęską Niemiec ${ }^{78}$. Konkluzja ta - uzupełniona o dyskretną aluzję do Bundeswehry - zostaje zresztą sformułowana expressis verbis $\mathrm{w}$ płomiennym przemówieniu filmowego Canarisa: Jakże inaczej mogły sie potoczyć wypadki. Nie wiem, czy tego doczekam, ale kiedyś, gdy nie będzie Hitlera, Niemcy odbuduja swe sity zbrojne i na ich czele stana nie kaprale, lecz generałowie (fot. 28).

Podobną wymowę ma drugi "film oficerski” (Offiziersfilm) z 1954 r. - Generat diabta (Des Teufels General, reż. Helmut Käutner, RFN 1955), zrealizowany na podstawie sztuki Carla Zuckmayera, powstałej jeszcze podczas pobytu pisarza na emigracji w Stanach Zjednoczonych (a zatem w czasie, gdy dramaturg przygotowywał swój Geheimraport, później wykorzystywany w postepowaniu denazyfikacyjnym pracowników kinematografii - zob. rozdział I). Pierwowzorem głównego bohatera, generała Harrasa, był Ernst Udet - lotnik, który wsławił się bohaterstwem podczas I wojny światowej, a w III Rzeszy pełnił ważne funkcje w ministerstwie lotnictwa ${ }^{79}$. W 1941 roku, po fiasku bitwy o Anglię, popełnił samobójstwo, co w propagandzie nazistowskiej przedstawiono jako nieszczęśliwy wypadek. Autor dramatu wprowadził do tej opowieści znaczącą modyfikację: ukazał bohatera jako człowieka osaczonego przez Gestapo ${ }^{80}$. Historia opowiedziana przez Zuckmayera była w zachodnich Niemczech dobrze znana - jego sztuka należała do najczęściej wystawianych w brytyjskiej i amerykańskiej strefie okupacyjnej ${ }^{81}$, zaś film Käutnera osiągnął sukces kasowy w kinach (później zaś wielokrotnie pokazywano go w erefenowskiej telewizji). Nic więc dziwnego, że w głośnym projekcie badawczym

78 Zob. także: Erica Carter, Men in Cardigans: „Canaris” (1954) and the 1950s West German Good Soldier, [w:] War-Torn Tales: Representing Gender and World War II in Literature and Film, red. Danielle Hipkins, Gill Plain, Oxford 2007.

${ }^{79}$ Udet zagrał też w kilku niemieckich ,filmach górskich”, zrealizowanych u schyłku Republiki Weimarskiej przez Arnolda Fancka: u boku Leni Riefenstahl w Białym piekle (Die weiße Hölle vom Piz Palü, 1929) i Tragedii na Mont Blanc (Stürme über dem Montblanc, 1930), a także w SOS - góra lodowa (SOS - Eisberg, 1933) tego samego reżysera. Najważniejszym i emblematycznym dla filmowej kariery Udeta jest - sponsorowany przez Göringa - film Heinza Paula Cud awiacji (Wunder des Fliegens, Niemcy 1935), gdzie gra... samego siebie - sławnego lotnika Udeta, który ułatwia karierę lotniczą chłopakowi z górskiej wioski (dziękuję za tę uwagę Tomaszowi Kłysowi).

${ }^{80}$ Udet - jeśli wierzyć Leni Riefenstahl, ciepło wspominającej go w swych Pamiętnikach - „nie był, jak twierdzi Zuckmayer, ofiarą Gestapo, a przedstawienie go jako przeciwnika Hitlera rozmija się z prawdą" (Leni Riefenstahl, Pamiętniki..., s. 240).

81 Zob. Katrin Weingran, "Des Teufels General” in der Diskussion. Zur Rezeption von Carl Zuckmayers Theaterstück nach 1945, Marburg 2004. 
prowadzonym przez zespół Haralda Welzera w końcu lat 90., zbierającym rodzinne opowieści o czasach narodowego socjalizmu, Generał diabła przywoływany jest jako przykład fabuły, która w istotny sposób wpływała na tworzenie "fikcji kanonicznej opowieści rodzinnej"82.

Akcja filmu rozpoczyna się podczas uroczystej kolacji w restauracji, gdzie na przyjęciu ku czci lotnika Eilersa bawi się elita, wśród niej generał Harras. Jego przyjaciółka namawia Harrasa, by pomógł w ucieczce małżeństwu Rosenfeldów. Sceptyczna postawa generała wobec tego pomysłu nie udaremnia uwięzienia bohatera przez oficera SS, Schmidt-Lausitza, który prowadzi śledztwo w sprawie katastrof lotniczych. Po wypuszczeniu $\mathrm{z}$ aresztu Harras odkrywa, że sabotaż faktycznie miał miejsce, a jego sprawcą jest inżynier Oderbruch. Generał bierze odpowiedzialność za wypadki, siada za sterami niesprawnego samolotu i w konsekwencji popełnia samobójstwo.

Generat diabła to jeden z nielicznych zachodnioniemieckich filmów, w którym jako bohaterowie pojawiają się najwyżsi rangą funkcjonariusze NSDAP, w tym wypadku: Göring i Himmler. Tryb ich wprowadzenia jest typowy dla tej grupy filmów - czołowi funkcjonariusze NSDAP są prezentowani poprzez "obraz w obrazie" (Harras pokazywany jest pod portretem Göringa, Schmidt-Lausitz zaś - pod portretem Himmlera; taka kompozycja dowodzi „uwiedzenia” oficerów przez kierownictwo partii narodowosocjalistycznej) bądź przez metonimię. Przykładem tego wariantu jest scena rozmowy Harrasa $z$ oficerami, przerwanej przez skrzypienie drzwi; gdy mężczyźni milkna, generał wyjaśnia: To Hermann, a postać Göringa zaprezentowana zostaje tylko jako przelotny cień za półprzezroczystymi drzwiami. Z kolei w scenie, w której Himmler wydaje Schmidtowi-Lausitzowi zgodę na aresztowanie Harrasa, kamera pokazuje na zbliżeniu ramię, na którym spoczywa ręka szefa SS.

Harras reprezentuje u Käutnera „dobre Niemcy” - to świat wokół uległ zepsuciu, zaś przyczyną fermentu są naziści. Kontrast ten unaoczniany jest w wielu sekwencjach filmu. Już w pierwszej, rozgrywającej się $\mathrm{w}$ restauracji, pokazana została skala inwigilacji przez aparat nazistowskiej bezpieki (jeden z kelnerów włącza ukryty mikrofon; w sąsiednim pomieszczeniu esesmani podsłuchują prowadzone dyskusje). W odniesieniu do dramatu w scenariuszu dokonano istotnej zmiany: $\mathrm{u}$ Zuckmayera

82 Harald Welzer et al., "Opa war kein Nazi”. Nationalsozialismus und Holocaust im Familiengedächtnis, Frankfurt am Main 2002, s. 164. Polski przekład fragmentu tej pracy (Pamięć zbiorowa i kulturowa...) nie zawiera rozdziału poświęconego filmowi Käutnera; kompetentne omówienie badań i obserwacji Welzera znaleźć można w: Bartosz Korzeniewski, Filmowe zapośredniczenia niemieckiej pamięci o II wojnie światowej, [w:] Przemiany pamięci społecznej a teoria kultury, red. Bartosz Korzeniewski, Poznań 2007. 
zatrzymanie Harrasa w więzieniu jest ledwie wzmiankowane, w filmie zaś sekwencja ta trwa niemal dziesięć minut (zamknięty w zaciemnionej celi Harras przysłuchuje się strzałom dobiegającym $z$ offu; chwilę później w celi zapala się światło, a z korytarza dochodzą kroki żołnierzy).

Najważniejsza zmiana dotyczyła jednak wątku prześladowań Żydów - w sztuce Zuckamayera zawarta jest jedynie wzmianka o żydowskim chirurgu Samuelu Bergmannie, który uciekł z obozu koncentracyjnego, lecz nie mogąc wyjechać z Rzeszy, wraz z żoną popełnił samobójstwo. W produkcji Käutnera Bergmannowie stają się Rosenfeldami, zaś ich los zostaje bezpośrednio związany z działaniami Harrasa - choć zarazem związek ten objawia się jedynie $w$ dialogach: $w$ całym filmie są zaledwie dwie sceny z małżeństwem. Wątek Żydów zostaje wprowadzony w garderobie śpiewaczki Geiss. Jenny Rosenfeld, z gwiazdą Dawida na ramieniu płaszcza, wyjaśnia, że jej mąż został przewieziony z obozu w Buchenwaldzie do policyjnego szpitala, gdzie oczekuje na transport do Polski. To ciekawy dialog o tyle, że wymieniono w nim konkretne miejsca Zagłady, a także dlatego, że to jedyna kwestia Jenny; później inni bohaterowie będą mówić niejako „za nią". Rosenfeld ma zostać przeszmuglowany ze szpitala do domu Geiss, a małżonków na lotnisko ma odwieźć szofer Harrasa. Plan ten zostaje udaremniony przez aresztowanie generała - o ile pobyt Rosenfelda $\mathrm{w}$ Buchenwaldzie jest jedynie wzmiankowany $\mathrm{w}$ dialogu, o tyle torturowanie Harrasa pokazano w osobnej, przywołanej już, sekwencji filmu.

Rozwiązanie wątku żydowskiego małżeństwa następuje - podobnie jak we wcześniejszym Małżeństwie w mroku oraz jednym z epizodów filmu $W$ tamtych dniach (zob. rozdział I) - poprzez wspólne samobójstwo, które para popełnia na dworcu autobusowym. To interesująca sekwencja. Gdy Harras wychodzi z zakochaną w nim młodą Geiss z jej domu, mijają dwóch chłopaków, którzy spieszą się na dworzec, gdyż zdarzyło się tam coś niebywatego: na ławce siedzą dwie osoby z gwiazdą Dawida na ubraniach, a niezwykłość polega na tym, że po pierwsze, im nie wolno wchodzić na dworzec, a po drugie - oboje nie żyja. Scena na dworcu zbudowana jest na zasadzie wizualnej paraleli (lustrzanego odbicia) pomiędzy parą (nieżyjących) Rosenfeldów a (niemieckim) duetem Harras i Geiss. W pierwszym ujęciu pokazane zostały ciała Rosenfeldów leżące bezwładnie na przystanku, on po lewej stronie kadru, jej głowa spoczywa na ramieniu męża (fot. 29); na dalszym planie widać, nad głową bohaterki, postać z plakatu na ścianie. W kolejnym ujęciu Harras i Geiss przepychają się przez tłum (tym razem to kobieta jest po lewej stronie kadru), w tle sylwetka policjanta miga nad ramieniem kobiety. W ten sposób para Harras-Geiss zostaje wizualnie przyrównania do małżeństwa Rosenfeldów - i właśnie niemieckim cierpieniom (i niebezpieczeństwom, jakie grożą bohaterom ze strony nazistów) poświęcono w filmie najwięcej czasu ekranowego. 


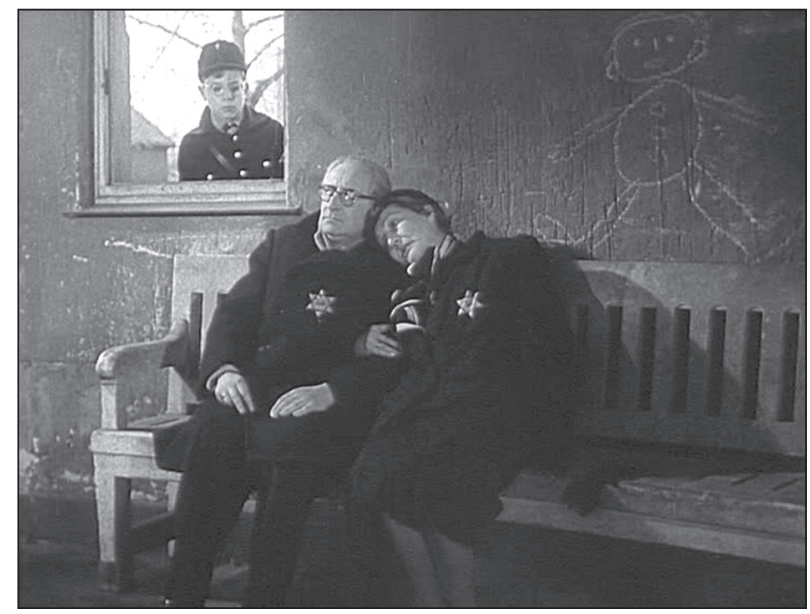

Fot. 29. Generat diabła (reż. Helmut Käutner, 1955) „Zdarzyło się coś niebywałego..."

- martwi Rosenfeldowie na dworcu autobusowym

W Generale diabła nazizm skorelowany jest z osobistymi tragediami zakochanych (wątek porucznika Hartmanna, który zrywa zaręczyny i myśli o samobójstwie) oraz małżeństw. Gdy ginie lotnik Eilers, generał składa wdowie kondolencje; kiedy Harras, wraz z towarzyszącymi mu żołnierzami, wchodzi do domu Eilersów, by przekazać smutną nowinę, pozycja kamery obniża się tak, że widać jedynie żołnierskie buty i dziecięce zabawki. W ten sposób scena zmienia swój ładunek informacyjny: przestaje prezentować wyłącznie konkretną sytuację w domu Eilersów, lecz nabiera wymiaru uniwersalnego, wytwarzając zestawienie „wojna i sieroty". Scenę kończy ekspiacja, którą wdowa po lotniku czyni przed współczującym Harrasem: To, w co wierzył Friedrich, było żałosne i brudne, ale nie miałam odwagi mu tego powiedzieć [...]. Nigdy nie mogłam mu powiedzieć, że walczy dla kilku drani.

W dramacie Zuckmayera ważniejszą niż w filmie rolę odgrywa inżynier Oderbruch, który przez sabotaż chce skrócić wojnę. U Käutnera to postać dwuznaczna o tyle, iż właśnie Oderbruch jest współwinny śmierci Eilersa - pilota wadliwego samolotu. Zarazem to właśnie inżynier - w przedostatniej sekwencji filmu - wypowiada słowa, które stanowią swoiste podsumowanie politycznego dyskursu filmu: Pewnego dnia zaczqłem się wstydzić tego, że jestem Niemcem, że w imieniu narodu, czyli także mnie, wyrządza się tyle złego innym narodom, a przede wszystkim Niemcom. Kwestia ta jest trawestacją słów Stauffenberga - w fabule filmu Oderbruch pełni rolę swoistego „zastępnika” feralnego spiskowca (podobnie jak jego autentyczny "pierwowzór", bohater ma sztuczne przedramię). 
O samym Stauffenbergu w RFN nakręcono - jedenaście lat po jego zamachu, a zarazem w okrągłą rocznicę zakończenia wojny - dwa filmy fabularne: 20 lipca (Der 20. Juli, reż. Falk Harnack, prod. CCC-Film, w roli głównej Wolfgang Preiss) oraz Zdarzyło się 20 lipca (Es geschah am 20. Juli, reż. Georg W. Pabst, prod. Ariston-Film/Arca-Filmproduktion, z Bernhardem Wickim jako Stauffenbergiem) ${ }^{83}$. Pojawienie się na ekranach kin w tym samym czasie dwóch filmów o niemal identycznej fabule jest zjawiskiem rzadkim - nic więc dziwnego, że przykuło ono uwagę ówczesnej prasy. O tej „zdublowanej” inicjatywie pisano najczęściej w tonie sensacyjnym (na przykład zwracając uwagę, że Stauffenberg w filmie Harnacka ma opaskę na niewłaściwym, prawym oku - fot. 30) i z niesmakiem, wynikającym z "brudnej” rywalizacji pomiędzy producentami (Ogladacie "40 lipca" - brzmiał nagłówek jednego z artykułów $\left.{ }^{84}\right)$.

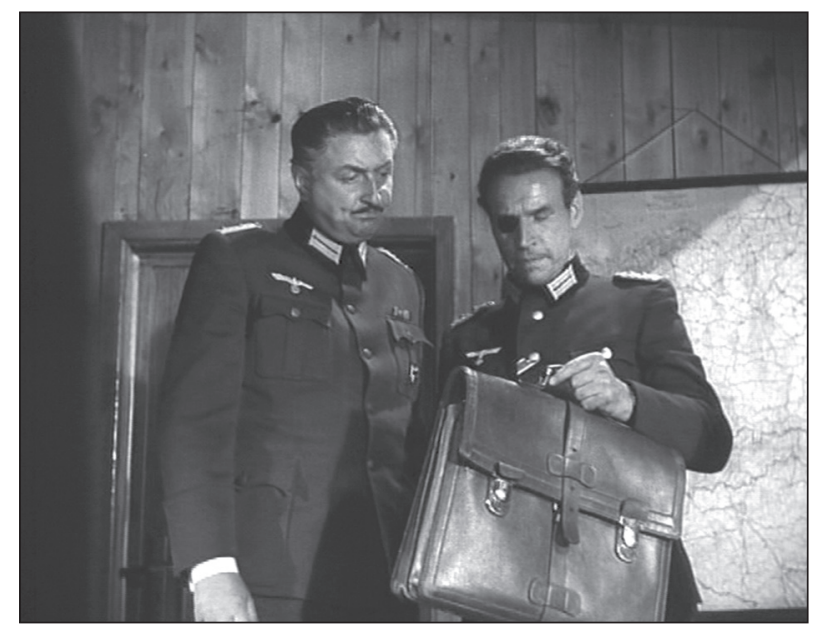

Fot. 30. 20 lipca (reż. Falk Harnack, 1955)

Wolfgang Preiss jako Stauffenberg

Burzliwe losy Zdarzyło się... i 20 lipca - przedstawione obszerniej $\mathrm{w}$ innym miejscu ${ }^{85}$ - są interesujące nie tylko z uwagi na ekonomiczną

${ }^{83} \mathrm{~W}$ niemieckojęzycznym piśmiennictwie filmy te doczekały się omówienia w dwóch opracowaniach. Peter Reichel poświęca im jeden (krótki) podrozdział swojej pracy (Erfundene Erinnerung...). Natomiast Drehli Robnik analizuje filmy o Stauffenbergu, posiłkując się poststrukturalistyczną metodą „gry skojarzeń", co prowadzi - moim zdaniem - do licznych nadinterpretacji (Drehli Robnik, Geschichtsästhetik und Affektpolitik. Stauffenberg und der 20. Juli im Film 1948-2008, Wien 2009).

84 Anon., Sie sehen den 40. Juli, „Der Abend”, 21.06.1955.

85 Więcej na temat okoliczności powstania filmu piszę w: Konrad Klejsa, Pierwsze filmowe opowieści o Clausie von Stauffenbergu i ich filmowe konteksty, [w:] Historia w kulturze 
rywalizację obu spółek, ale przede wszystkim ze względu na kontrowersje dotyczące prawnych aspektów przedstawiania na ekranie postaci historycznych (w próby rozstrzygnięcia tych sporów zaangażowani byli nie tylko prawnicy obu firm, lecz także przedstawiciele branżowych organizacji filmowych, instytucje federalne oraz rodziny uczestników spisku 20 lipca). Niebagatelną rolę odegrały również biografie twórców zaangażowanych w produkcję. Pomysłodawca projektu "berlińskiego" - Artur Brauner - napisanie scenariusza zlecił lewicującemu pisarzowi Güntherowi Weisenbornowi, który w czasie wojny był członkiem Rote Kapelle (karę śmierci zmieniono mu na dziesięć lat więzienia) ${ }^{86}$. Zważywszy na fakt, iż film miał być debiutem scenariopisarskim Weisenborna ${ }^{87}$, można powiedzieć, że został on zaproszony do współpracy przy projekcie głównie ze względu na biografię, co wywołało sprzeciw jednego z uczestników spisku, komendanta (Generalmajor) Rudolfa Freiherr von Gersdorffa (to on dostarczył Stauffenbergowi materiały wybuchowe). W kwietniu 1955 r. von Gersdorff pisał w liście do Braunera: „Podobnie jak Pan jestem zdania, że chodzi przede wszystkim o to, by przy tym filmie pracowali antynaziści, ale ponieważ musimy liczyć się ze sceptycyzmem lub nawet oporem wobec filmu, udział człowieka, który wspiera inny totalitarny reżim byłby wielkim obciążeniem" ${ }^{\prime 88}$.

W czasie, gdy von Gersdorff formułował te słowa, nie było jeszcze jasne, kto wyreżyseruje film. Wstępną ofertę - z pierwszą wersją scenariusza - przesłano na początku marca Fritzowi Langowi, który od 1934 r. przebywał na emigracji w USA. Trudno o lepszy wybór: po pierwsze,

współczesnej. Niekonwencjonalne podejścia do przeszłości, red. Mariusz Mazur, Piotr Witek, Lublin 2011 (niniejszy podrozdział zawiera część materiału tam opublikowanego). O kontekstach prawnych i ekonomicznych obu produkcji traktuje również album wydany przez Deutsches Filmmuseum, który zawiera przedruki niektórych materiałów produkcyjnych, ale wielu z nich nie komentuje (2 x 20. Juli. Die Doppelverfilmung von 1955, red. Claudia Dillmann, Ronny Loewy, Frankfurt am Main 2004).

${ }^{86}$ W okresie Republiki Weimarskiej Weisenborn pozostawał w orbicie artystów związanych z komunistami (współpracował ze Slátanem Dudowem oraz Bertoldem Brechtem nad teatralną adaptacją Matki Gorkiego). W 1948 r. napisał on na poły autobiograficzną książkę Memorial oraz dramat Die Illegalen (o dwóch organizacjach antynazistowskich próbujących nawiązać ze sobą kontakt), a pięć lat później (jako współautor) Der lautlose Widerstand - fabularyzowaną opowieść o ruchu oporu, opartą na wspomnieniach jego uczestników. Zob. Roswita Schwarz, Vom expressionistischen Aufbruch zur inneren Emigration, Günther Weisenborns weltanschauliche und künstlerische Entwicklung in der Weimarer Republik und im 3. Reich, Frankfurt am Main 1995.

${ }^{87}$ Weisenbornowi do pomocy przydzielono Jörga Lüddecke, współautora scenariusza do filmu Topór $z$ Wandsbeck - zob. podrozdział 2.1.

${ }^{88}$ List von Gersdorffa do Braunera z 23 kwietnia 1955 r. - w zbiorach DF, skoroszyt 20. Juli G-Z (von Gersdorff ukrywa nazwisko scenarzysty pod kryptonimem „W"). 
Lang był bez wątpienia najwybitniejszym spośród żyjących wówczas niemieckich reżyserów; po drugie, autora Metropolis uznawano za „ofiarę nazizmu" (co przy temacie filmu w naturalny sposób byłoby atutem). Lang odrzucił jednak ofertę; ostatecznie reżyserię 20 lipca Brauner powierzył Falckowi Harnackowi (jeszcze nie tak dawno pracującemu dla Defy), który w swej biografii również miał epizody związane z ruchem oporu (zob. podrozdział 2.1).

Spółka Ariston, która produkowała drugi film, nie mogła pochwalić się współpracownikami o równie "kombatanckich” życiorysach ${ }^{89}$. Reżyserię powierzono doświadczonemu Georgowi Wilhelmowi Pabstowi, którego dwa nakręcone po wojnie filmy (Proces [Der Prozess] z 1947 r. - o pogromach w XIX-wiecznych Węgrzech oraz powstały siedem lat później Ostatni akt [Der letzte Akt] z 1954 r. - o ostatnich dniach w bunkrze Hitlera) można odczytywać jako próbę obrony przed oskarżeniami o kolaborację (podnoszonymi ze względu na fakt wyreżyserowania przez Pabsta w 1943 r. Paracelsusa, biograficznej superprodukcji o ambiwalentnej-zdaniem niektórych utrzymanej $\mathrm{w}$ duchu nazistowskiej propagandy - wymowie) ${ }^{90}$.

Oba filmy trafiły na ekrany zachodnioniemieckich kin $\mathrm{w}$ połowie czerwca 1955 r. (w ten sam weekend), w atmosferze skandalu wynikającego z serii pozwów sądowych, wytaczanych przez rodziny osób zaangażowanych w spisek Stauffenberga. Pod koniec miesiąca pozew przeciw firmie Ariston wniósł Otto Remer, świadek - a w zasadzie mimowolny uczestnik - puczu (jako dowódca garnizonu, Remer zajął Ministerstwo Propagandy celem aresztowania Goebbelsa, który odwiódł go od wykonania tego rozkazu, łącząc się telefonicznie z Wilczym Szańcem i potwierdzając w ten sposób, że Hitler przeżył zamach). Remer - na początku lat 50. lider faszyzującej Sozialistischer Reichpartei (zdelegalizowanej

${ }^{89}$ Autorami scenariusza do Zdarzyło się... zostali: Gustav Machaty, niegdysiejszy reżyser głośnych filmów Erotikon (1929) i Ekstaza (1932) oraz Werner Zibaso, który miał na koncie kilka komedii wyprodukowanych w III Rzeszy w II połowie lat 30. (później, w latach 60., pisywał scenariusze do tzw. Aufklärungsfilme, czyli soft-porno skrywającego się pod płaszczykiem [sic!] edukacji seksualnej).

90 Ewentualne przyjęcie przez Langa propozycji Braunera mogłoby oznaczać swoisty „reżyserski pojedynek” pomiędzy wybitnymi twórcami kina Republiki Weimarskiej. Byłoby to tym bardziej interesujące, iż sam Stauffenberg (z protezą zamiast dłoni i szklanym okiem) przypomina do pewnego stopnia cyborgi i "automatony” z filmów science-fiction. Drehli Robnik, z dekonstrukcyjną przesada, nadaje kalectwu bohatera jeszcze inne znaczenie: mianowicie zwraca uwagę, iż jest on „niepełnym” organizmem, co - jej zdaniem - można potraktować jako ekwiwalent „dziurawej” pamięci historycznej, a nawet czytać przez pryzmat podziału Niemiec na dwa odrębne państwa (zob. Drehli Robnik, Geschichtsästhetik und Affektpolitik..., s. 31). 
w 1952 r..$^{91}$ ) - wielokrotnie twierdził, iż Stauffenberg i jego współpracownicy dopuścili się nie tylko złamania przysięgi wojskowej (Hochverrat), lecz także zdrady stanu (Landesverrat), uniemożliwiając Niemcom zwycięstwo w wojnie. We wzmiankowanym pozwie nie chodziło jednak Remerowi - a w każdym razie nie wyłącznie - ani o sposób prezentacji Stauffenberga, ani o własny wizerunek ${ }^{92}$, ale o fakt, że jego sugestie, przedstawione na prośbę producenta, nie zostały w wystarczającym stopniu uwzględnione. $\mathrm{O}$ ile sam pozew Remera nie był dla Aristonu szczególnym problemem, o tyle już publiczne ujawnienie, iż firma poprosiła go $\mathrm{o}$ „konsultację", stało w sprzeczności z kampanią marketingową filmu. Wszak producenci Zdarzyło się... chętnie przypominali udział "czerwonych" (Harnacka i Weisenborna) w produkcji Braunera...

Za sprawą Zdarzyło się... i 20 lipca ówcześni widzowie obejrzeli opowieść, której w znarratywizowanej formie zobaczyć wcześniej nie mogli. Choćby z tego powodu znaczenie obu filmów jest trudne do przecenienia - „wymazywały” one bowiem tę część pamięci kulturowej, którą w 1944 r. wymodelowała Goebbelsowska propaganda ${ }^{93}$, a jednocześnie wpłynęły na publiczny wizerunek ruchu oporu w okresie Wiederbewaffnung. Zarazem ustanowiły swego rodzaju wzorzec narracyjny, który będzie wykorzystywany przez późniejsze filmy fabularne o Stauffenbergu ${ }^{94}$.

O ile Zdarzyło się... koncentruje się wyłącznie na przebiegu zdarzeń tego dnia, o tyle w 20 lipca jedynie ostatnia część filmu pokazuje zamach i jego bezpośrednie konsekwencje. Oznacza to również, że u Harnacka narracja jest bardziej oszczędna w przekazywaniu informacji o detalach wydarzeń w Wilczym Szańcu, zaś u Pabsta poziom uszczegółowienia zdarzeń jest większy. Podczas gdy Zdarzyło się... rozgrywa się wyłącz-

${ }^{91}$ Oskarżycielem w tym procesie był prokurator generalny Fritz Bauer, później znany jako oskarżyciel w tzw. drugim procesie oświęcimskim (1963-1965). Więcej na temat Remera w: Norbert Frei, Polityka wobec przeszłości. Poczatki Republiki Federalnej i przeszłość nazistowska, tłum. B. Ostrowska, Warszawa 1999, s. 349-385.

${ }_{92}$ Swoją droga, w Zdarzyło się... obraz Remera nie jest wcale taki zły (abstrahując, oczywiście, od tej oto okoliczności, że historycznie rzecz ujmując był „człowiekiem, który mógł obalić totalitarny system, lecz tego zaniechał"). W filmie Pabsta bohater ten jest wręcz usprawiedliwiany jako osoba manipulowana (byłoby lepiej nie wtajemniczać go w nasz plan) i "prosty chłopak", który mimowolnie zostaje włączony w walkę potężniejszych od niego sił.

93 Walor ten został dostrzeżony przez krytykę. Przykładowo, w jednej z recenzji określono film Pabsta jako „kronikę zarejestrowaną post factum” (Karena Niehoff, Bemühte Unzulänglichkeit, „Der Tagesspiegel”, 25.06.1955).

${ }_{94}$ Są wśród nich dwa zachodnioniemieckie filmy telewizyjne - Portret zamachowca (Porträt eines Attentäters, reż. Rudolph Nussgruber, 1968), Zamach w Wilczym Szańcu (Stauffenberg, reż. Jo Baier, 2004) - oraz dwa filmy amerykańskie: Zabić Adolfa Hiltera (The Plot to Kill Adolf Hitler, reż. Lawrence Schiller, 1990) i Walkiria (Valkyrie, reż. Bryan Singer, 2008). 
nie w Niemczech, to u Harnacka akcja została umieszczona na różnych szerokościach i długościach geograficznych (kilka scen traktuje o froncie wschodnim). Ponadto, u Pabsta wyłącznie w jednej kwestii dialogowej pojawia się informacja o wcześniejszych zamachach (już kosztowaty nas zbyt wiele czasu), tymczasem film Harnacka unaocznia backstory $\mathrm{w}$ obszernej sekwencji pokazującej nieudany zamach podjęty przez Henninga von Treskowa (bomba umieszczona w pudełku imitującym opakowanie butelki koniaku), który jest zresztą jednym z głównych bohaterów filmu (wątek ten będzie wykorzystywany także w późniejszych filmach o Stauffenbergu). W porównaniu z filmem Pabsta narracja 20 lipca jest zatem topograficznie i historycznie bardziej „rozciągnięta”.

Wspólną cechą obu filmów są obrazy wojny, które zarówno w Zdarzyło się..., jak i u Harnacka (tu z wyjątkiem frontu wschodniego, o czym będzie jeszcze mowa) dotyczą sytuacji w Niemczech. Film Pabsta rozpoczyna się długim dokumentalnym footage pokazującym bomby spadające na miasta i płonące domy. Komentarz ponadkadrowy informuje: „,20 lipca rozpoczął się jak każdy inny dzień - nokturnami dudniących bomb, piekłem wojny totalnej". Punktem ogniskującym wszystkie wątki poboczne są wojenne cierpienia Niemców, zaś podstawowym celem spiskowców jest odsunięcie od władzy nieodpowiedzialnej elity, która owe męki na swój naród sprowadziła. Szczególnie mocno podkreślona została trudna sytuacja armii na froncie wschodnim - w Zdarzyło się... przywołany został rozkaz Führera o powstrzymaniu sił sowieckich za wszelką cenę; w 20 lipca mamy natomiast scenę, w której podczas zebrania sztabowego (sic!) odrzuca on prośbę o udzielenie urlopu żołnierzom.

Jeśli chodzi o sposób pokazania Hitlera, oba filmy wykazują symptomy dobrowolnego Bildverbot, który - po nieprzychylnym przyjęciu przez widownię wspomnianego już filmu Ostatni akt Pabsta - będzie charakterystyczną cechą niemieckiego kina przez kolejnych pięć dekad (nie licząc kilku marginalnych wyjątków). W 20 lipca są dwie sceny, w których pojawia się Führer; w żadnej nie widzimy jego twarzy. Podczas wizyty na froncie mamy krótkie, lecz intrygujące ujęcie z POV (widz dzieli z bohaterem perspektywę spojrzenia). Natomiast w scenie rozgrywającej się podczas zebrania w Wilczym Szańcu widzimy jedynie Hitlera... nogi (tupiące ze złości pod stołem), zaś jego wypowiedzi słyszymy w dźwięku z offu. W filmie Pabsta są trzy ujęcia pokazujące Führera w scenie zamachu: 1) w otoczeniu oficerów, z frontalnego ustawienia kamery, ale „chwyta" ona jedynie pochyloną głowę i kawałek czoła; 2) z boku, gdy Führer jest pochylony nad stołem, a tym samym słabo widoczny; 3 ) tyłem. Hitler ,jest zatem, a jakby go nie było" - jego obecność ewokują natomiast zawieszone na ścianach portrety. 
Problem ofiar $\mathrm{w}$ narracjach o II wojnie światowej jest nieodłącznie związany z pytaniem o sposób włączania w nie tematu Zagłady. Zatem trzeba powiedzieć od razu, że Zdarzyło się... nie wspomina o niej w ogóle. Gdy zaś idzie o 20 lipca, starczy odrobina wyczulenia na niuanse stylu, by dojść do wniosku, że w filmie Harnacka "jest coś nie tak": narracja sugeruje widzom kontekst Zagłady, ale nie unaocznia go (można powiedzieć: mamy tu przykład „signifié bez signifiant” - sens wytwarzany jest poprzez znamienny brak).

Wątek żydowski przedstawiony zostaje eksplicytnie w pierwszej części filmu Harnacka, w sekwencjach rozgrywających się w kamienicy, w której mieszkają postaci fikcyjne (m.in. Lindner oraz późniejsza sekretarka Stauffenberga). W scenie wprowadzającej tę lokalizację płynna jazda i panorama kamery pokazuje w planie ogólnym bohaterów ukrywających się przed nalotem w schronie. Osobne ujęcie (co ważne - montażowo „wywołane” nadzorującym spojrzeniem żandarma ze swastyką widoczną na opasce ramienia) zostaje zarezerwowane dla siedzącego w kącie milczącego staruszka z gwiazdą Dawida w klapie. Żandarm zwraca się do niego wyniośle: Sa tacy, co bezprawnie zajmują całe piętro! Doprawdy, trudno uznać taką scenę za prawdopodobną w historycznych realiach Berlina w 1944 r. - jesteśmy zatem bez wątpienia w porządku symbolicznym. Poprzez wprowadzenie bohatera - Żyda w tym właśnie epizodzie, wytworzone zostaje intrygujące znaczenie: „,wszyscy byli ofiarami”. Mamy oto żydowsko-niemiecką „wspólnotę ofiar”, która cierpi z powodu alianckich nalotów; żydowski bohater (doktor Adler) jest jedynie marginalną jej częścią - ową „wspólnotę” zasiedlają bowiem przede wszystkim ci, których dyskurs filmu określa pojęciem „front”. Adler doń jednak nie przynależy, jakoś tu "nie pasuje” - słusznie więc Ronny Loewy w swym krótkim szkicu krytycznym określa sceny z tym bohaterem jako „Alibi-Episode" ${ }^{\prime 9}$.

Postać doktora powróci kilka minut później - gdy esesmani aresztują Adlera na dziedzińcu kamienicy. Scena ta rozegrana jest w sposób, który przywodzi na myśl dziesiątki późniejszych filmów (film Harnacka powstał w momencie, gdy kody reprezentacji Holocaustu nie były jeszcze ustalone): podczas aresztowania staruszek gubi okulary; pyta, czy może je odszukać - ale esesman złowieszczo zapowiada: Tam, dokad jedziesz, nie będa Ci już potrzebne. Scenę wieńczy zbliżenie na roztrzaskane okulary - po czym następuje przejście do pokoju sekretarki Stauffenberga, obser-

95 Ronny Loewy, Voltaire und die Aufklärung, [w:] 2 × 20. Juli. Die Doppelverfilmung..., s. 61. W podobnym kontekście Reichel przypomina, iż pewien szwajcarski recenzent napisał o filmie Harnacka: „więcej niż jeden Żyd na ekranie - to najwyraźniej byłoby nie do zniesienia" (cyt. za: Peter Reichel, Erfundene Erinnerung..., s. 77). 
wującej zajście przez okno. Jej komentarz jest doprawdy osobliwy: Doktor Adler! Lekarz, który często zapominat przesyłać rachunki, bo wiedziat, jakich poświęceń wymaga ich zapłacenie!96

Irytującą cechą obu Stauffenbergów Anno Domini 1955 jest ich absolutna niezłomność. W obu filmach (inaczej niż w wersjach z 2004 i 2008 r.) protagonista nie ma rodziny - co można, rzecz jasna, tłumaczyć obawami producentów przed procesami o naruszenie dóbr osobistych osób żyjących. Psychologiczna "płaskość" Stauffenbergów w obu produkcjach nie wynika jednak wyłącznie z braku "obudowania” ich drugoplanowymi postaciami, z którymi mogłyby ich łączyć jakieś emocjonalne więzi. Chodzi raczej o to, że bohaterowie definiowani są wyłącznie przez cel, do którego zresztą od samego początku z niezwykłą determinacją zmierzają. To interesujące $\mathrm{w}$ zestawieniu z późniejszymi filmami o 20 lipca, w których protagonista przechodzi światopoglądową konwersję - „Stauffenberg XXI wieku" najpierw jest szczerym wyznawcą nazistowskiej ideologii, dopiero później (pod wpływem wojennych przeżyć) decyduje się na przystąpienie do ruchu oporu. U Harnacka proces ten został scedowany na postać fikcyjną (porucznika Lindnera), a dokonuje się pod wpływem nabycia przez bohatera wiedzy o zbrodniach wojennych.

„Przysięga" i „zdrada” powracają nieustannie jako przedmiot rozmów protagonistów obu fabuł, co - jak wspomniałem - należy czytać przez doraźny kontekst polityczny (powołanie Bundeswehry i akcesję RFN do NATO). W Zdarzyło się... Stauffenberg peroruje: Czy zdrada jest wiara w lepsze Niemcy? Czy chce pan dalej patrzeć, jak wszystko się wali, jak zhańbiony zostaje honor Niemiec? Czy sprzeciw wobec tego można nazwać $z$ drada? Z kolei w analogicznej scenie zebrania spiskowców w 20 lipca jeden z nich cytuje fragment z Kurzer Katechismus für Soldaten Ernsta Moritza Arndta z 1812 r. (scenarzyści postanowili uświadomić widzom, kim był autor - to tylko stowa poety... i historyka... i patrioty). Wspomniany passus mówi o tym, że nikt i nic nie może zmusić wolnego człowieka do czynienia zła.

Przywołany w scenariuszu Weisenborna/Lüddeckego Kurzer Katechismus podkreśla rolę Kościoła w ruchu oporu; podobną funkcję pełnią sceny kazania w świątyni oraz postać księdza przesłuchiwanego przez SS. Jednak w 20 lipca o wiele bardziej eksponowany jest wątek robotniczego ruchu oporu: oprócz sceny, w której zadenuncjowani zostają autorzy antynazistowskich haseł malowanych na murach, mamy też sekwencje w tajnej

96 Drehli Robnik nie od rzeczy pyta: „Czy deportowanie żydowskiego lekarza byłoby mniej szokujące, gdyby żądał wysokich honorariów?" (Drehli Robnik, Geschichtsästhetik und Affektpolitik..., s. 38). 
„kwaterze”, gdzie toczą się zebrania i składowane są ulotki. W 20 lipca postaci należące do "czerwonej” grupy są zindywidualizowane (mają własną historię, o której dowiadujemy się w dialogach; istnieją miedzy nimi więzi emocjonalne itd.). Wreszcie, scena „nalotu” SS na bazę komunistów (choć określenie to nie pada ani razu) należy do „najmocniejszych” punktów narracji ( $\mathrm{z}$ uwagi na dramatyzm wydarzeń - jeden z robotników zostaje zastrzelony). Wytwarzane jest zatem wrażenie, że ruch robotniczy faktycznie stara się działać, podczas gdy wojskowa "arystokracja” traci czas na abstrakcyjnych dysputach. $Z$ drugiej jednak strony można przecież powiedzieć, że sam fakt „wpadki” demaskuje lewicowy ruch oporu jako nieskuteczny.

Jakkolwiek by nie było, film Harnacka rewiduje - rozpowszechnianą przez goebbelsowską propagandę - opinię, że ruch oporu był małą, działającą w izolacji grupką oficerów. Scenariusz sprawia wrażenie, jakby pisany był podług wytycznych socjologicznej ankiety - co wynika nie tylko z mnogości postaci demonstrujących swój sprzeciw wobec polityki Hitlera, lecz także z ich różnorodności: są tu kobiety i mężczyźni, młodzież i staruszkowie, oficerowie frontowi i szeregowi żołnierze, księża oraz robotnicy, socjaldemokraci i monarchiści... W porównaniu z 20 lipca ruch oporu w filmie Pabsta sprawia istotnie wrażenie „kliki ambitnych oficerów".

Dyskretne różnice w potraktowaniu tematu 20 lipca uwidaczniają się w finałach obu filmów. Zdarzyło się... wieńczy scena egzekucji na dziedzińcu Bendlerblock (przypomina ona analogiczną scenę rozstrzelania księdza, członka ruchu oporu, w Rzymie, mieście otwartym Roberta Rosselliniego, 1946). Natomiast 20 lipca - zgodnie z wykorzystaną przez dramaturgię tego filmu zasadą "geograficznego rozciągnięcia" - kończy się samobójstwem Treskowa na froncie wschodnim (nie zostaje ono pokazane, ale jest ewokowane dość kiczowatym odejściem bohatera ku mgle). Obu finałom towarzyszy ekstradiegetyczny komentarz. Napis kończący film Harnacka brzmi: A wojna trwała dalej. Miasta pograżały się w ruinach. Po 20 lipca na frontach $i$ w ojczyźnie zginęło więcej ludzi, niż w ciagu pięciu lat wojny. Temu krwawemu i bezsensownemu dziełu zniszczenia uczestnicy ruchu oporu chcieli położyć kres. Natomiast u Pabsta słyszymy: To były pierwsze cztery ofiary 20 lipca. Kolejne tysiace kazał stracić Hitler w ślepej nienawiści. A wojna trwała nadal. Miliony mężczyzn, kobiet $i$ dzieci w rożnych częściach świata straciło życie. Teraz od nas zależy, czy ta ofiara była nadaremna. Ostatnie zdanie jest symptomatyczne - ma charakter apelu skierowanego do widowni, zdradzając zarazem swoisty brak przekonania co do poglądów widzów o wydarzeniach 20 lipca. 


\subsection{Honor munduru}

Zdaniem Anny Wolff-Powęskiej, w RFN doby Adenauera „zdecydowana większość polityczna uważała, że nadmierne zajmowanie się przeszłością spowoduje przegranie przyszłości, zaszkodzi zbiorowej tożsamości narodowej" ${ }^{\prime \prime}$. Dominował pogląd, iż „faktyczni przestępcy”, czyli ideolodzy NSDAP i przedstawiciele władz politycznych III Rzeszy, zostali już osądzeni i skazani. Zarazem, jak pisze Norbert Frei,

przeważająca większość Niemców nie akceptowała ścigania przestępstw popełnionych w związku z działaniami wojennymi [...]. Zwłaszcza byli żołnierze najwyraźniej odczuwali ściąganie tych czynów jako pośredni zarzut wobec siebie, jako podważenie ich rozumienia pojęcia wojny i deprecjonowanie ich własnej, często ofiarnej służby. [...] w walce o zwolnienie więzionych żołnierzy famę o „niesplamionej tarczy” Wehrmachtu, który prowadził jakoby "normalną wojnę” (w najlepszym razie w odróżnieniu od ściśle określonej części SS), podsycano na początku lat pięćdziesiątych $\mathrm{w}$ taki sposób, że historykom aż po lata osiemdziesiąte nader trudno było ją obalić ${ }^{98}$.

We wprowadzaniu rozwiązań, które wspierały ten mit, rządząca chadecja mogła liczyć na wsparcie polityków innych ugrupowań, nie tylko akceptujących amnestię dla członków mundurowych formacji III Rzeszy, ale nierzadko zgłaszających jeszcze radykalniejsze pomysły. Przykładowo, w 1951 r. Kurt Schumacher, przewodniczący SPD, wypowiadał się na temat Waffen-SS: „Większość z tych 900 tysięcy ludzi zepchnięto do rangi prawdziwych pariasów [...]. Wydaje się nam, że ludzką i obywatelską powinnością jest rozerwanie tego kręgu i utorowanie wielkiej rzeszy byłych członków Waffen-SS drogi prowadzącej do normalnego życia"99. A rok później Erich Mende, polityk FDP (i jej późniejszy przewodniczący) zażądał, aby z okazji rocznicy kapitulacji zwolnić wszystkich więźniów powyżej 60. i poniżej 28. roku życia - bowiem armia "to żywy organizm, którego decydujący element stanowi uskrzydlający go duch. Jednak duch ten, jeśli chodzi o solidarność europejską i gotowość obrony, nie może się zrodzić w żadnej dywizji niemieckiej, która ma świadomość, że jej byli dowódcy czy koledzy siedzą jeszcze w alianckich więzieniach" ${ }^{\prime 100}$.

\footnotetext{
97 Anna Wolff-Powęska, Pamięć - brzemię i uwolnienie..., s. 257.

98 Norbert Frei, Polityka wobec przeszłości..., s. 314.

99 Cyt za: Heinrich August Winkler, Długa droga na Zachód. Dzieje Niemiec, t. 2: 19331990, tłum. K. Huszcza, V. Grotowicz, Wrocław 2007.

100 Cyt. za: Norbert Frei, Polityka wobec przeszłości..., s. 287.
} 
Prawno-politycznej debacie o Wiederbewaffnung i - stanowiącemu jej podglebie - przekonaniu o „dobrym Wehrmachcie” współtowarzyszyły fenomeny kulturowe. Bestsellerem stała się, wydana po raz pierwszy w 1952 r., książka Petera Bamma Die unsichtbare Flagge - autobiograficzna relacja $\mathrm{z}$ frontu wschodniego, napisana przez dawnego lekarza wojskowego (tytułowa "niewidzialna flaga” to symbol humanitaryzmu, pod którym walczyć mieli żołnierze bez względu na narodowość). Na łamach wysokonakładowej prasy, w magazynach "Stern" i "Quick", ukazywały się podejmujące tematykę wojenną niby-komiksy - „powieści ilustrowane" w odcinkach, a losy bohaterów co tydzień śledziło około 20 milionów czytelników ${ }^{101}$. Jak sugeruje autor opracowania na ten temat, opisy wroga bohaterskiego Wehrmachtu odpowiadały rasistowskiej „,nauce”, zaś podboje na Wschodzie określane były jako „porządkowanie" i „oczyszczanie" 102 .

Istotnym wkładem do zachodnioniemieckiej kultury popularnej były fabularyzowane wspomnienia, publikowane jako opowiadania lub krótkie powieści, które z czasem zaczęto określać jako Landserromane - od tygodnika „Der Landser”, zamieszczającego materiały na temat II wojny światowej ${ }^{103}$. Półki księgarskie zapełniały się powieściami frontowymi, które ćwierć wieku później Jochen Pfeifer określił jako „literaturę podoficerów" (Obergefreitenliteratur) - bohaterowie byli bowiem „zwykłymi żołnierzami”, wśród których w zasadzie nie pojawiają się „prawdziwi naziści"104. Autorem najpoczytniejszych powieści był Gerd Ledig, autor m.in. Stalinorgel (1955) - o froncie wschodnim oraz Die Vergeltung (1956) - o alianckich nalotach bombowych; do grona bestsellerowych autorów dołączyli wkrótce Hans Hellmut Kirst i Heinz Konsalik. Spośród powieści podejmujących tematykę wojenna, w latach 50. tylko nieliczne - autorstwa Heinricha Bölla (Gdzie byłeś, Adamie, 1951) czy Güntera Grassa (Blaszany bębenek, 1959) - wykraczały poza schematy Obergefreitenliteratur.

${ }^{101}$ Herbert Knittel, Der Roman in der deutschen Illustrierten, Berlin 1967, s. 17.

102 Michael Schornstheimer, "Harmlose Idealisten und draufgängerische Soldaten”. Militär und Krieg in den Illustriertenromanen der fünfziger Jahre, [w:] Vernichtungskrieg. Verbrechen der Wehrmacht 1941-1944, red. Hannes Heer, Klaus Naumann, Hamburg 1995, s. 641-644. Zob. także: idem, Michael Schornstheimer, Die leuchtenden Augen der Frontsoldaten. Nationalsozialismus und Krieg in den Illustriertenromanen der fünfziger Jahre, Berlin 1995.

${ }_{103}$ Czasopismo ukazywało się od roku 1957 do 2013 (!). Słowo der Landser oznacza żołnierza rekrutującego się z niższych warstw społecznych; być może właściwym polskim odpowiednikiem Landserliteratur byłaby „literatura kamaszy"?

${ }^{104}$ Jochen Pfeifer, Der deutsche Kriegsroman 1945-1960: Ein Versuch zur Vermittlung von Literatur und Sozialgeschichte, Königstein 1981, s. 135. Zob. też: Jost Hermand, Darstellungen des Zweiten Weltkrieges, [w:] Literatur nach 1945: Politische und Regionale Aspekte, red. Jost Hermand, Wiesbaden 1979, s. 30. 
Na popularność tematyki wojennej w sferze publicznej nie pozostali obojętni producenci filmowi. Jak dowodzą autorzy zajmujący się statystyką filmowa, wprawdzie w całym okresie 1949-1965 filmy wojenne (wliczając w to opowieści o wojnie $1870 \mathrm{r}$. oraz o I wojnie światowej) stanowiły jedynie około 7,5 procent całej erefenowskiej produkcji (24 procent - Heimatfilm $)^{105}$, to szczególnie dużo fabuł tego gatunku powstało w okresie 1955-1961 ${ }^{106}$, a w sezonie 1959/1960 przyniosły one największe wpływy kasowe ${ }^{107}$. Niektóre z zachodnioniemieckich filmów wojennych z lat 50 . zdobywały także nagrody - Złotą Nagrodę Filmową w 1955 r. otrzymał Canaris (reż. Alfred Weidenmann, RFN 1954), a w 1960 r. Most (Die Brücke, reż. Bernhard Wicki, RFN 1959) ${ }^{108}$. Już wtedy Werner Jungeblodt z Katolickiej Komisji Filmowej zauważył, że między 1952 a 1958 rokiem liczba zachodnioniemieckich filmów wojennych podwoiła się - i wyraził opinię, iż to amerykańskie kino „uczyniło niemiecką publiczność złaknioną tematów poświęcenia, dumy, obowiązku, bohaterskiej śmierci, ślepego posłuszeństwa i bitewnej sławy"109.

${ }^{105}$ Martin Osterland, Gesellschaftsbilder in Filmen. Eine soziologische Untersuchung des Filmangebots der Jahre 1949-1964, Stuttgart 1970, s. 64-74.

106 Zarówno liczba, jak i wymowa tych filmów spotykały się niekiedy z negatywną oceną opinii publicznej - nie tylko krytyków filmowych (choć trudno orzec, na ile reakcje te były szczere, a na ile - jeśli w ogóle - sterowane przez enerdowską propagandę). Przykładowo, już w 1952 r., gdy w prasie ukazały się informacje o planowanym filmie o Rommlu, do senatu Berlina Zachodniego wpłynął protest ze strony Demokratycznego Zrzeszenia Kobiet (Demokratischer Frauenbund Deutschlands). W archiwach zachował się także list wystosowany w 1958 r. przez niejaką Anneliese Boese z Berlina Zachodniego do senatora odpowiedzialnego za edukację. Autorka w następujący sposób pisała o modzie na filmy wojenne (jako jedyny tytuł wymieniając Lekarza ze Stalingradu): „Kto jest odpowiedzialny za to, że takie filmy produkowane są w wolnej części Niemiec i sprzedawane za granicę? Gdzie się podziała cenzura? [...] Wiele naszych »braci i sióstr « po drugiej stronie żelaznej kurtyny przychodzi na seanse do Wolnego Berlina. Czy myśli pan, że są zadowoleni, oglądając takie filmy? Nie wiem, czy te niebywałe filmy znajdują oddźwięk w Niemczech Zachodnich - ale z własnego doświadczenia wiem, że duch Hitlera błąka się tam w wielu umysłach. My z wyspy [Insulaner] wolelibyśmy, by oszczędzono nam tych szmatławych filmów wojennych. Proszę, aby jako osoba odpowiedzialna za edukację zatroszczył się pan jak najszybciej o to, by takie filmy nie trafiały do zachodnioniemieckich kin". W odpowiedzi senator napisał, że za dopuszczenie filmu do emisji odpowiada FSK i wyraził opinię, że „na ekranach pojawiają się także liczne filmy, które próbują przedstawić prawdziwszy obraz wojny i niedawnej niemieckiej przeszłości" (wszystkie przywoływane w tym przypisie dokumenty pochodzą z: Landesarchiv Berlin, Sign: CRep 014/351 - dziękuję Magdalenie Saryusz-Wolskiej za ich wskazanie).

107 Anna Sarah Vielhaber, Der populäre deutsche Film 1930-1970, Norderstedt 2012, s. 70.

108 Podobną tematykę podejmował film Ostatni most (Die letzte Brücke, reż. Helmut Käutner, Austria/Jugosławia 1954), w którym niemiecka pielęgniarka zostaje napiętnowana jako zdrajczyni, ponieważ pomaga rannemu jugosłowiańskiemu jeńcowi. Film ten był pokazywany w RFN, ale nie odniósł większych sukcesów. Uznawany jest jednak za jeden z tytułów, które "przetarły szlak” niemieckojęzycznym fabułom o II wojnie światowej.

109 Werner Jungeblodt, Kriegsfilme - noch und noch, Stuttgart 1960, s. 9. 
Charakterystyczną cechą tych produkcji jest "odpolitycznienie” wojny (podobnie jak w filmach $\mathrm{z}$ okresu 1946-1949, nie jest ona przedstawiona jako skutek politycznych działań, ale nieuchronne działanie losu) oraz pozytywny obraz armii i „zwykłych żołnierzy”, niekiedy przeciwstawianych tępym lub okrutnym podoficerom. Bärbel Westermann w monografii zachodnioniemieckiego kina lat 50. stwierdza, że Wehrmacht i nazistowscy przywódcy pojawiają się w nim jako „dwa odmienne światy"110, Klaus Kreimeier w przeglądowym artykule o kinie tamtej dekady pisze zaś wprost o „apologiach Wehrmachtu” (Wehrmachtsapologien) ${ }^{111}$.

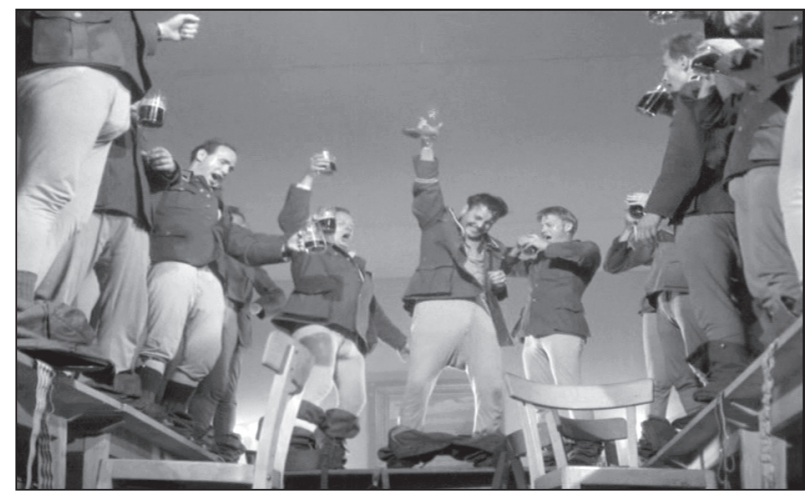

Fot. 31. 08/15 (reż. Paul May, 1955)

W koszarach bywa dość wesoło

Pierwszą zachodnioniemiecką produkcją o takiej wymowie był, cieszący się dużą popularnością wśród widzów, trzyczęściowy (kinowy) film 08/15 (reż. Paul May, RFN 1954) na podstawie powieści Hansa Hellmuta Kirsta pod tym samym tytułem ${ }^{112}$. Głównym bohaterem jest żołnierz Asch - w części pierwszej (fot. 31), rozgrywającej się w koszarach (pod ostatnie ujęcia tej części podłożona zostaje niediegetyczna audycja radiowa o strzałach na niemiecko-polskiej granicy), jest on konfrontowany z sadystycznym sierżantem Schulzem i "dobrym majorem” Luschke. W części drugiej natomiast - podług identycznego schematu, tym razem rozwijanego na tle kampanii na froncie wschodnim zimą 1942 r. - protagonista zestawiony zostaje $\mathrm{z}$ „dobrym” kapitanem von Plöniesem i nazistowskim karierowiczem Wittererem, który gotów jest wysłać żołnierzy na pewną śmierć, byle tylko uzyskać Żelazny Krzyż. W części trzeciej

${ }^{110}$ Bärbel Westermann, Nationale Identität im Spielfilm der fünfziger Jahre, Frankfurt am Main 1990, s. 36.

${ }^{111}$ Klaus Kreimeier, Der westdeutsche Film in der fünfziger Jahren..., s. 284.

112 Hans Hellmut Kirst, 08/15, tłum. J. Frühling, t. I-III, Warszawa 1956-1959. 
(zatytułowanej W ojczyźnie), Asch udaremnia plan dwóch oficerów SD, którzy - podszywając się pod żołnierzy Wehrmachtu - chcą uciec wraz z wyszabrowanymi łupami. Jeden z nich zostaje skazany na śmierć przez von Plöniesa, który w konsekwencji zostaje oskarżony przez Amerykanów o zabójstwo.

Film powstał w czasie powołania do życia Bundeswehry, co w naturalny sposób narzuca tryb jego odczytania. Trzeba jednak dopowiedzieć, że służąca jako pierwowzór scenariusza powieść Kirsta krótko po swej publikacji stała się w Niemczech Zachodnich symbolem protestu przeciw Wiederbewaffnung. Do takiej interpretacji przyczyniły się zarówno immanentne cechy samego dzieła (choćby „mówiące” nazwisko bohatera: Asch jako „popiół”, ale też przez podobieństwo do wyrazu Arsch - „dupek”), jak i wypowiedzi Franza Josefa Straußa, ówczesnego ministra obrony, który wezwał do bojkotu książki i jej autora. Filmowa adaptacja w znacznym stopniu łagodzi wymowę powieści ${ }^{113}$ - może dlatego, że do opracowania scenariusza zatrudniono Ernsta von Salomona (autora wspomnianego już Formularza) ${ }^{114}$. Ta „,korekta” została dostrzeżona przez ówczesną krytykę, która utyskiwała głównie na osuwanie się filmu ku konwencji komediowej ${ }^{115}$. W jednym $\mathrm{z}$ bawarskich dzienników wyrażono niezadowolenie z faktu, że druga część nie pokazuje zbrodni Armii Czerwonej, a trzecia - skali zniszczeń w Niemczech („,mieliśmy całkiem ładną klęskę” - ironizował recenzent $\left.{ }^{116}\right)$.

Tymczasem z filmowej wersji 08/15 wyłania się następująca wizja: wojna przyniosła zło i cierpienie - nie tyle wśród podbitych narodów, ile wśród „zwykłych" Niemców, prowadzonych przez fanatycznych,

113 Jak ujawnia Detlef Kannapin, w NRD w 1967 r. trwały przygotowania do nakręcenia filmu 08/15 - część czwarta (08/15 - viertel Teil), który miałby zaświadczać o „przestępczym charakterze Bundeswehry" (Detlef Kannapin, Dialektik der Bilder: der Nationalsozialismus im deutschen Film; ein Ost-West-Vergleich, Berlin 2005, s. 136). Na podstawie - ostatecznie niezrealizowanego - scenariusza Hansa von Oettingena powstała powieść oraz słuchowisko radiowe zatytułowane Rostiger Ruhm.

${ }_{114}$ W Republice Weimarskiej był on członkiem antysemickiej organizacji Consul, odpowiedzialnej m.in. za mord na ministrze spraw zagranicznych Waltherze Rathenau. W III Rzeszy był członkiem NSDAP, pracował jako scenarzysta, był m.in. współautorem scenariusza do antybrytyjskiego filmu Carl Peters (reż. Herbert Selpin, Niemcy 1941).

115 Karl Korn, Ordnung? Gehorchen? Ein Nachruf zu "08/15”, „Frankfurter Allgemeine Zeitung", 3.11.1954; Werner Fiedler, "08/15" mit Ladehemmung. Die Revolte des Gefreiten Asch, „Der Tag”, 10.11.1954; Gunter Groll, Barsch, aber mit Bravour - „Null-Acht Fünfzehn”, „Süddeutsche Zeitung”, 2.10.1954.

116 Herbert Hohenemser, ... Übrig bleibt brüllendes Vergnügen, „Münchner Merkur”, 28.05.1955. O recepcji filmu zob. Knut Hickethier, Militär und Krieg: „08/15”, [w:] Fischer Filmgeschichte, t. 3: Auf der Suche nach Werten. 1945-1960, red. Werner Faulstich, Helmut Korte, Frankfurt am Main 1990, s. 222-251. 
niewykształconych przywódców. Jak z perspektywy lat pisał Peter Reichel: „Koncentrując się na szkoleniu rekrutów w koszarach przed wojną, film ma swój wkład w budowanie mitu nowoczesnej armii - także dlatego, że nie zadaje pytań o przyczyny wojny ani o historyczno-polityczną rolę Wehrmachtu, który [w trzeciej części filmu - przyp. K. K.] udało się własnymi siłami oczyścić z narodowosocjalistycznych elementów"117. Innymi słowy - to nie ideologia narodowosocjalistyczna została poddana krytyce, lecz sposób zarządzania armią.

Argumentów na rzecz takiej interpretacji dostarcza już choćby sekwencja otwierająca pierwszą część filmu. Napisy początkowe nałożone są na obraz muru, zwieńczonego drutem kolczastym, co zostaje wyraźnie podkreślone przez sposób filmowania. Następnie kamera umieszczona na kranie „przeskakuje” przez mur i obniża się, filmując czarne skórzane buty (na ścieżce dźwiękowej słychać: Uwaga, spocznij). W kolejnym ujęciu pokazane zostają nogi musztrowanych żołnierzy, dopiero czwarte ujęcie ujawni twarz sierżanta w groteskowo dużym zbliżeniu. W końcowej scenie tej części filmu powtórzony zostanie wzór zastosowany w sekwencji początkowej - najpierw jazda kamery, pokazująca po kolei twarze żołnierzy (kontrast wizualno-dźwiękowy: nie ma na nich śladu radości, choć na ścieżce dźwiękowej słychać wiwatujące tłumy), następnie kamera oddala się od koszar, „przechodzi” ponad murem i unosi w stronę zachmurzonego nieba, na którym pojawiają się błyskawice (na ścieżce dźwiękowej „rata-ta-tam”, niczym wystrzały z karabinu maszynowego). Trudno o bardziej ewidentny przykład utożsamienia wojny z "katastrofą naturalną" (jak komentuje Jennifer Kapczynski, widz ma odnieść wrażenie, że „konflikt »przydarza się« bohaterom, nie jest zaś przez nich prowadzony"118).

Drugoplanowe postaci 08/15 ucieleśniają postawy „zwykłego żołnierza", "tępego sierżanta" i „dobrego oficera”. Do pierwszej kategorii należy, prócz Ascha, jego przyjaciel Vierbein - w otwierającym cykl filmie to typowy „mięczak”, który zamiast uroków życia rekruta preferuje literaturę i muzykę klasyczną. W kolejnym filmie Vierbein jest już inny - udało mu się wykonać tajną misję, został odznaczony medalem za samodzielne zniszczenie kilku (!) rosyjskich czołgów. Vierbein cierpi jednak na halucynacje - w pewnej chwili wyobraża sobie, że nowi rekruci stają się chodzącymi szkieletami i, zgodnie z "samospełniającą się przepowiednią", sam ginie $\mathrm{w}$ absurdalnym ataku zaordynowanym przez niekompetentnego oficera Witterera. Ten ostatni należy do drugiej kategorii bohaterów

117 Peter Reichel, Erfundene Erinnerung..., s. 106-107.

118 Jennifer Kapczynski, Armchair Warriors: Heroic Postures in the West German War Film, [w:] Screening War. Perspectives on German Suffering, red. Paul Cooke, Marc Silberman, Rochester 2010, s. 29. 
- podobnie jak sierżant Schulz z części „koszarowej”. Aktora grającego tę rolę w wielu ujęciach filmuje się w ten sposób, by wyeksponować swastykę na noszonym przezeń mundurze; w części drugiej mamy zaś scenę, w której leżący na łóżku Schulz jest dosłownie „owinięty” w egzemplarz nazistowskiej gazety „Völkischer Beobachter" (i niezbyt zainteresowany swą korpulentną żoną). W 08/15 występuje jednak i trzecia kategoria żołnierzy - „dobry oficer”. Gdy Asch planuje w części trzeciej uwolnić generała von Plöniesa z aresztu, ten oświadcza, że nie opuści swoich żołnierzy; nadto wyznaje, że nie zrobił wystarczająco dużo, by powstrzymać nazistowskie zbrodnie i za to zaniechanie musi ponieść karę. Tak czy inaczej, problem odpowiedzialności za przestępstwa wojenne rezerwowany jest tu dla przywódców NSDAP - ci, którzy "tylko wykonywali rozkazy", nie muszą zaprzątać sobie nią głowy ${ }^{119}$.

Nieco inny obraz „zwykłego żołnierza” buduje film Afrykańska gwiazda (Der Stern von Afrika, reż. Alfred Weidenmann, RFN 1957). Jego bohaterem jest Hans Jochen Marseille, nieustraszony młody pilot Luftwaffe, który wyróżnia się w walkach powietrznych (film zawiera kilka sekwencji batalistycznych, wykorzystujących wyimki z archiwalnych materiałów dokumentalnych). W charakterystycznej sekwencji pokazującej początek wojny komentarz ponadkadrowy brzmi: I nadeszła wojna. Zaczą się dramat niemieckiej młodzieży, która w ślepej wierze zmierzała do swej klęski. Wojna „nadeszła" (kto ją rozpętał i z jakiego powodu - głos nie informuje), jej skutkiem zaś był "dramat niemieckiej młodzieży”. Bohater zostaje skierowany do eskadry stacjonującej w Afryce, gdzie poniesie śmierć (nie wskutek działań wojennych, lecz w niefortunnym wypadku); głos ponadkadrowy komentuje: Hans-Jochen Marseille zmart w wieku 23 lat jako jeden z milionów młodych ludzi, którzy dziś mogliby żyć.

Spośród wojennych filmów nakręconych w RFN w latach 50. Afrykańska gwiazda wyróżnia się specyficzna, można by zażartować, „denazyfikacją" obrazu: nawet w scenie, w której Jochen odbiera w Berlinie przyznany mu Żelazny Krzyż, nie ma śladu swastyk (ani hitlerowskiego pozdrowienia). Z sekwencji rozgrywającej się w Paryżu wynika natomiast, że Francuzi witali niemieckich żołnierzy z radością - ci ostatni zaś pobyt nad Sekwaną traktują niczym zasłużony urlop. Romans, jaki nawiązuje Jochen, prowadzi go na skraj „nieodpowiedzialnych” marzeń o małżeńskiej stabilizacji - dopiero interwencja przyjaciela przypomina bohaterowi o jego wojskowych powinnościach.

119 Zob. także: Robert G. Moeller, Kämpfen für den Frieden: "08/15" und westdeutsche Erinnerungen an den Zweiten Weltkrieg, "Militärgeschichtliche Zeitschrift” 2005, nr 64. 
Co ciekawe, ten sam reżyser w III Rzeszy nakręcił Młode orły (Junge Adler, Niemcy 1944), propagandową fabułę o młodych mężczyznach pracujących w fabryce samolotów; scenarzystą był zaś Herbert Reinecker, który podpisał również skrypt Afrykańskiej gwiazdy. Zależność między filmami - wynikającą z pracy nad nimi tego samego reżysera i scenarzysty, ale też z fabularnych zbieżności - dostrzegli zachodnioniemieccy krytycy w recenzjach opublikowanych tuż po premierze: „oni nadal lataja znowu zwyciężają i ponownie upadają choć tym razem dyskretnie i bez rozlewu krwi” - ironizował recenzent „Süddeutsche Zeitung"120. Dopiero po latach zwrócono uwagę na rasistowską wymowę sekwencji rozgrywającej się w Paryżu ${ }^{121}$ : gdy w czasie urlopu bohater korzysta z rozrywek dostarczanych przez francuskie kabarety, w jednym z nich trafia na występ czarnoskórego Matthiasa, który wkrótce zostaje "służącym” protagonisty.

Swego rodzaju kontrapunktem wobec Afrykańskiej gwiazdy był film Rekiny i mate rybki (Haie und kleine Fische, reż. Frank Wisbar, RFN 1957) na podstawie powieści Wolfganga Otta ${ }^{122}$. Fabuła opowiada o losach czwórki przyjaciół, którzy w czasie służby na trałowcu przeobrażają się z nieokrzesanych kadetów w wykwalifikowanych marynarzy. Głównym bohaterem jest Teichmann (grany przez Hansjörga Felmy'ego, gwiazdora erefenowskich filmów wojennych tamtej dekady - fot. 32), beztroski podrywacz (rozbudowany wątek romansowy), z trudem znoszący trudy służby na łodzi podwodnej podczas wojny. Tytułowe „rekiny” odnoszą się do - niepokazanych w filmie - przywódców w Berlinie. Film Wisbara wyróżnia się - na tle innych erefenowskich fabuł wojennych z lat 50. - „brakiem nazisty jako zła wcielonego, który mógłby odciążyć politycznie marynarzy"123. Kapitan U-Boota jest postacią ambiwalentną - wprawdzie z początku wydaje się osobą odstręczająca, lecz ostatecznie poświęca życie, by ocalić swego kadeta (co Enno Patalas skwitował następującym komentarzem: „Marzenie poddanych o twardym, ale sprawiedliwym przywódcy przetrwało wszelkie załamania. Uszkodzony autorytet został poddany renowacji"124).

120 „Süddeutsche Zeitung”, 9.09.1957 (recenzja anonimowa i bez tytułu). W podobnym tonie wypowiadał się recenzent pisma kojarzonego z lewą flanką SPD - Hans-Gerd Sellenthin, Sind Heldenflieger Filmhelden? Zum einen neuen Film im UFA-Stil, "Vorwärts”, 13.09.1957.

${ }_{121}$ Zob. też: Guido Limburg, Fliegen und Abschießen - Ja, was soll ich da anderes denken? Der "Stern von Afrika" und der bundesdeutsche Nachkriegs-Kriegsfilm, [w:] Zeitmaschine Kino: Darstellungen von Geschichte im Film, red. Hans-Arthur Mariske, Marburg 1992.

${ }^{122}$ Wolfgang Ott, Rekiny i małe rybki, tłum. R. Stiller, Warszawa 2004.

${ }^{123}$ Dietrich Kuhlbrodt, Nazis immer besser, Hamburg 2006, s. 21. Uwaga ta nie zmienia jednak opinii krytyka, iż „film Wisbara wygląda tak, jakby pochodził z czasów nazistowskich, jakby został nakręcony powiedzmy w 1942 roku" (ibidem, s. 20).

124 Enno Patalas, Haie und kleine Fische, „Filmkritik” 1957, nr 11. 
Zwykli żołnierze po prostu walczą o swoją ojczyznę - a o tym, że prowadzi ona zbrodniczą politykę, mowa jest w jednej tylko scenie, pod koniec filmu. Kolega Teichmanna, otrzymawszy wiadomość o śmierci swego ojca w obozie Bergen-Belsen, popełnia samobójstwo. Zanim jednak to uczyni, wikła się w rozważania, co stałoby się, gdyby poślubił Aryjkę; wówczas, jak zauważa, jego dzieci miałyby większą szansę przeżycia, gdyż byłyby Żydami w jednej ósmej (Achteljuden).

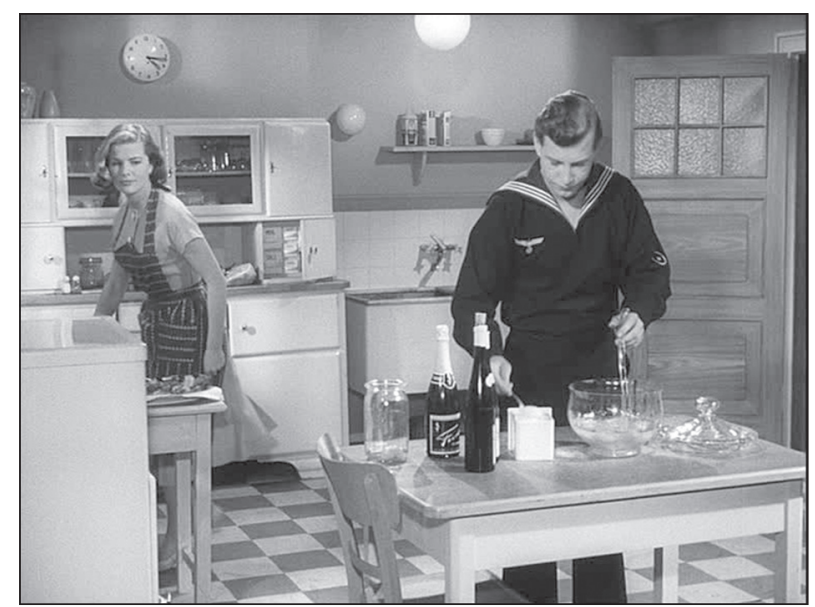

Fot. 32. Rekiny i małe rybki (reż. Frank Wisbar, 1957) Domowe milieu żołnierza Kriegsmarine

Na statku podwodnym (oraz w gabinetach berlińskich urzędników) rozgrywa się także akcja filmu Prien, kapitan U-47 (U47-Kapitänleutnant Prien, reż. Harald Reinl, RFN 1958), do którego ikonografii będzie nawiązywał (fot. 33) niemal ćwierć wieku przebój kasowy Okręt (Das Boot, reż. Wolfgang Petersen, RFN 1981). Frapujące dla polskiego widza są już pierwsze sekundy filmu Reinla: jeszcze przed napisami początkowymi głos narratora w następujący sposób wprowadza tło historyczne: 3 września 1939 roku, w samo południe. Od godziny jedenastej Niemcy znajduja sie $w$ stanie wojny $z$ Wielka Brytania.

Tytułowy bohater jest żołnierzem bez wahania wykonującym rozkazy i dobrym opiekunem swej załogi. Fabuła prowadzona jest tak, by unaocznić proces dojrzewania protagonisty, z czasem zaczynającego dostrzegać barbarzyństwo nazistowskiej polityki. O ile w „konwersyjnych” fabułach kręconych w NRD katalizatorem przemiany bywał najczęściej działacz komunistyczny, tu funkcję taką ma pastor Kille (w narracji pojawia się on jeszcze przed Prienem), który pomaga ludziom prześladowanym przez 
reżim. Gdy prosi Priena o pomoc, by wstawił się za nimi, kapitan zrazu odmawia; ,"przebudzenie” następuje, gdy okręt podwodny Priena zatapia statek z uchodźcami z Niemiec (wątpliwości ma także załoga: Marynarz Christansen prosi o zgode na zapytanie: czy doniesienia o obozach koncentracyjnych sa prawdziwe?). Gnębiony wyrzutami sumienia, Prien odwiedza w więzieniu pastora Kille i zwraca się doń następującymi słowami: Jako żotnierz wypetnitem swój obowiazek i będę wypetniać go nadal, ale nie po to, by ktoś miałby nam krzyczeć prosto w twarz: Mordercy. Scena rozpoczyna się i kończy przenikaniem: w pierwszym ujęciu na obraz morza nałożona zostaje twarz Priena, w ostatnim ujęciu zaś - twarz pastora. Dzięki tej symetrycznej konstrukcji obaj bohaterowie zostają symbolicznie zrównani ze sobą ${ }^{125}$. Obaj stają się męczennikami - Prien ginie w ostatniej misji (żona, wraz z dwójką małych dzieci, wysłuchuje radiowej informacji o zatonięciu statku).

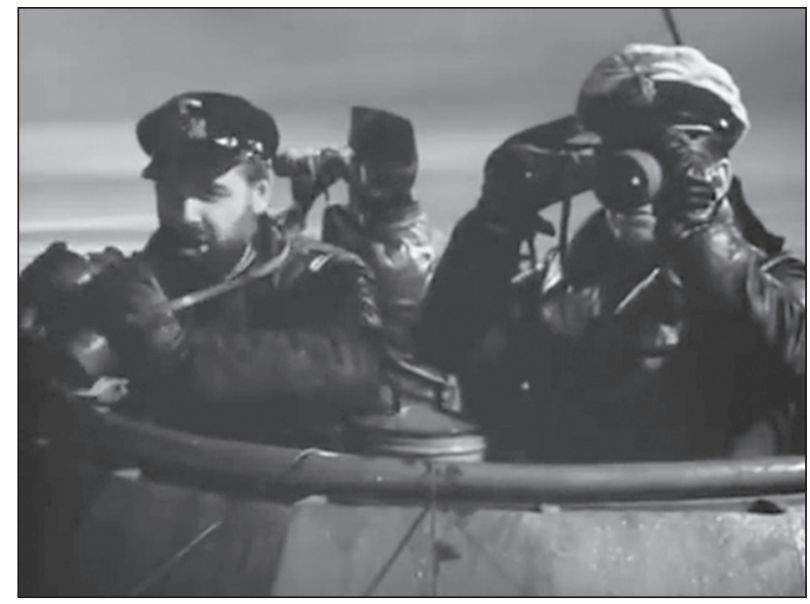

Fot. 33. Prien, kapitan U-47 (reż. Harald Reinl, 1958)

Podobnie skomponowane kadry pojawiają się w kasowym hicie Okręt (reż. Wolfgang Petersen, 1981)

Problem moralnej odpowiedzialności rozumianej w perspektywie religijnej akcentuje również film Niespokojna noc (Unruhige Nacht, reż. Falk Harnack, RFN 1958), zrealizowany na podstawie noweli Albrechta Goesa $^{126}$. Główny bohater, protestancki pastor (o nazwisku Brunner) służący $\mathrm{w}$ Wehrmachcie $\mathrm{w}$ oddziale na froncie wschodnim, otrzymuje roz-

${ }^{125}$ Manuel Köppen, The Rhetoric of Victim Narratives in West German Films of the 1950s, [w:] Screening War..., s. 64.

126 Albrecht Goes, Niespokojna noc, tłum. M. Morstin-Górska, G. Mycielska, Warszawa 1955. 
kaz udania się do szpitala wojskowego, aby wyspowiadać niejakiego Baranowskiego, żołnierza skazanego na wyrok śmierci za dezercję i przekazywanie wiadomości wrogowi - rosyjskiej chłopce imieniem Ljuba. W ostatniej scenie Brunner idzie przez cmentarny „las krzyży” (podobnie jak w filmie Mordercy sa wśród nas - zob. podrozdział 1.1 - nie jest jasne, czy w mogiłach pochowani są niemieccy żołnierze czy cywile) w poszukiwaniu kobiety, której ma przekazać list od rozstrzelanego.

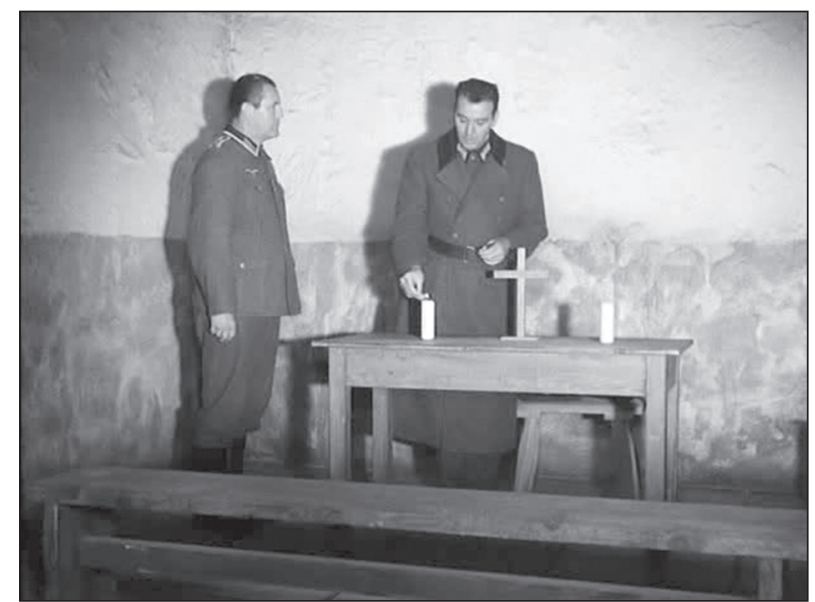

Fot. 34. Niespokojna noc (reż. Falk Harnack, 1958)

W kilku zachodnioniemieckich filmach wojennych wykorzystywano symbolikę chrześcijańską

Postępowanie nazistów zostaje przez Harnacka skontrastowane z cnotami chrześcijańskimi (fot. 34) m.in. w scenie, w której Brunner, aby umożliwić zakochanym ostatnie spotkanie, pozwala Baranowskiemu spędzić noc $\mathrm{w}$ jego kwaterze, sam zaś trafia do celi więźnia, rozmyślając o tym, co wydarzy się następnego dnia. Podobnie jak wiele innych filmów tego okresu, Niespokojna noc przepełniona jest wiarą w "dobro, które ostatecznie zwycięży": w rozmowie z dowódcą oddziału egzekucyjnego, byłym pastorem, Brunner zwraca uwagę, że Kościół zawiódł; zarazem wyraża przekonanie, że gdy dyktatura w końcu upadnie, będzie ich, duchownych, obowiązkiem zadbać o to, aby wojna nigdy się nie powtórzyła. Trop religijny został dostrzeżony w recenzjach - na łamach "Süddeutsche Zeitung" i „Frankfurter Allgemeine Zeitung” chwalono film jako „odważny” $\mathrm{i}$ „niewygodny" 127 , recenzent „Die Welt” utyskiwał zaś na niedorzeczny

127 Gunter Groll, Leise und deutlich: ,Unruhige Nacht”, ,"Süddeutsche Zeitung”, 3.11.1958; Karl Korn, Der Pfarrer und der Deserteur, „Frankfurter Allgemeine Zeitung”, 1.12.1958. 
wątek romansowy, z powodu którego „film jest mdły tam, gdzie powinien być drapieżny"128.

Wątki religijne eksponowała także pierwsza ekranizacja powieści Hansa Hellmuta Kirsta Fabryka oficerów (Fabrik der Offiziere, reż. Frank Wisbar, RFN 1960). Główna linia intrygi dotyczy - jak w książkowym pierwowzorze $^{129}$ - śledztwa prowadzonego przez podporucznika Kraffta w sprawie wypadku jednego z podoficerów. Ponieważ podejrzany jest fanatycznym wyznawcą narodowego socjalizmu, Krafft i jego świadek Böhmke (fot. 35) zostają oskarżeni o spisek; usiłując bronić Böhmkego, Krafft ginie. Porównanie filmu z powieścią Kirsta przynosi ciekawe wnioski: u Wisbara niewiele miejsca poświęcono tym scenom z książki, które ukazywały ideologiczną indoktrynację wychowanków Akademii Wojskowej. Rozbudowano natomiast wątki religijne, w zasadzie nieobecne $\mathrm{w}$ powieści, w której jedynie wspomina się o autorytarnym wychowaniu przez ojców - pastorów ${ }^{130}$ ( $w$ filmie Böhmke otrzymuje list od rodziny, z notacją: Królestwo boskie jest wieczne, a imperium Führera wkrótce rozpadnie się w pyt i popiót. Drogi synu, zawierz raczej Bogu niż jemu). Ideologia narodowego socjalizmu nie zostaje jednak w filmie potępiona, przybiera postać spisku zawiązanego przez oportunistów z towarzyskiej koterii, którzy pogardzają prawem i honorem, ucieleśnianym przez „dobrego" podporucznika oraz jego wychowanka. Wrażenie żalu ewokowane przez piosenkę w końcowej sekwencji odnosi się raczej do pojęć związanych z brakiem lojalności i ,,intrygami małych ludzi”, niż ze zbrodniami totalitarnej ideologii.

Religijne dylematy wprowadzone do charakterystyki bohatera $\mathrm{Fa}$ bryki oficerów wchodzą $\mathrm{w}$ dialog z analogicznymi wątkami wcześniejszego filmu Wisbara Psy, chcecie żyć wiecznie? (Hunde, wolt ihr ewig leben?, RFN 1959) ${ }^{131}$, zrealizowanego na podstawie powieści Fritza Wössa pod tym samym tytułem. Główna część filmu dotyczy kampanii stalingradzkiej, widzianej z perspektywy oddziałów Wehrmachtu. Była to zatem produkcja "prestiżowa”, wzbudzająca spore zainteresowanie mediów - w czasie prac produkcyjnych w prasie ukazywały się materiały, w których reżyser

${ }^{128}$ Friedrich Luft, Menetekel wurde zum Kinostück. Wichtiges Thema leider vertan: Falk Harnacks „Unruhige Nacht”, „Die Welt”, 1.11.1958.

${ }^{129}$ Hans Hellmut Kirst, Fabryka oficerów, tłum. E. Werfel, Warszawa 1963.

130 David Clark, German Martyrs: Images of Christianity and Resistance to National Socialism in German Cinema, [w:] Screening War..., s. 55.

${ }^{131}$ O podobieństwach Psów... do innych zachodnioniemieckich fabuł tamtego czasu zob.: Helen Wolfenden, The Representation of Wehrmacht Soldiers as Victims in Post-war West German Film: "Hunde, wollt ihr ewig leben" and "Der Arzt von Stalingrad", [w:] A nation of victims? Representations of German wartime suffering from 1945 to the present, red. Helmut Schmitz, Amsterdam 2007. 


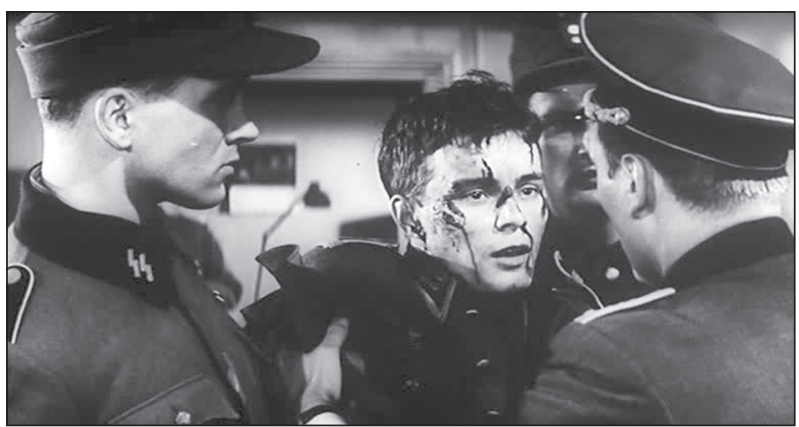

Fot. 35. Fabryka oficerów (reż. Frank Wisbar, 1960) Skatowany świadek machinacji w Akademii Wojskowej

opowiadał o przygotowaniach do realizacji: o lekturze pamiętników żołnierzy 6. Armii i wysyłanych przez nich do bliskich listów, o rozmowach z ich dowódcami (jak również z synem nieżyjącego już wówczas feldmarszałka Paulusa) ${ }^{132}$. Wisbar wyraził opinię, iż Stalingrad „odzwierciedla niemiecki los - opowiada o tym, jak naród bez własnej winy (sic! - przyp. K. K.) może zostać uwikłany w katastrofę ${ }^{\prime 133}$. Doniesienia te można interpretować jako element marketingowej gry, a może i działań, które miały skłonić instytucje państwowe do zaangażowania się w projekt. Franz Josef Strauß, ówczesny minister obrony, nie wyraził jednak zgody na użycie do celów produkcyjnych sprzętu zachodnioniemieckiej armii i żołnierzy, argumentując w liście do reżysera, iż Niemcy „nie dojrzały jeszcze do przekonującej reprezentacji tych strasznych wydarzeń [...]. Takie filmy nie są w interesie Bundeswehry"134.

Narrację otwiera sekwencja parady wojskowej w Berlinie: Hitler i inni dygnitarze zgromadzeni na trybunach pozdrawiają maszerujących żołnierzy. Głos ponadkadrowy komentuje:

Wspaniale jest podziwiać paradę. W takt marszowej muzyki, wypolerowane żotnierskie buty uderzaja w asfalt. Z błyskiem w oku, ida do przodu w jednym rytmie. I kończa dopiero, gdy śnieg i wiatr otulaja trupy [...]. Dla poległych żotnierzy nie ma żadnego znaczenia, kto przegrat wojnę.

132 Stalingrad. Frei nach Schiller, „Der Spiegel” 1959, nr 16.

133 Podaję za: Josef Schmidt, Stalingrad für die Kinoleinwand, "Süddeutsche Zeitung", 24.01.1959.

${ }^{134}$ Cyt. za: Stalingrad. Frei nach Schiller... Zob. także: Robert Möller, Victims in Uniform, 1950s Combat Movies, [w:] Germans as Victims. Remembering the Past in Contemporary Germany, red. Bill Niven, New York 2006. 
Pierwszoplanowy bohater filmu, porucznik Gerd Wisse (znaczące nazwisko: od wissen - „wiedzieć"), jest początkowo przedstawiony jako lojalny wyznawca narodowego socjalizmu. Ale nie jest postacią negatywną - przeciwnie, boleje nad okrucieństwem wojny i wykazuje zrozumienie dla cierpień rosyjskiej ludności cywilnej (ba, mówiącej po niemiecku Katji chce nawet... załatwić posadę w bibliotece!). W trakcie wojny Wisse doświadcza niekompetencji i tchórzostwa innych fanatycznych oficerów, głównie majora o znamiennym nazwisku Linkmann („Lewus”). W dialogach powtarzane są skargi na braki sprzętowe, złą aprowizację (okazuje się nawet, że sowieccy żołnierze wyposażeni są w lepszy ekwipunek) i niewłaściwą strategię. Gdy Szósta Armia poddaje się, a niektórzy z oficerów próbują obciążyć winą generałów, jeden z dowódców mówi: Nie łudźcie się, winien jest każdy, kto mógł zapobiec tej tragedii, a tego nie zrobit.

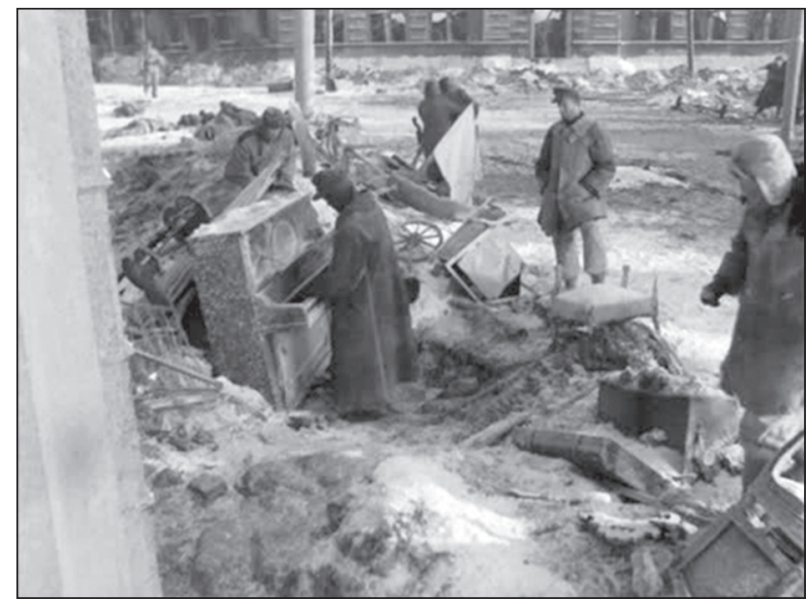

Fot. 36. Psy, chcecie żyć wiecznie? (reż. Frank Wisbar, 1959) Elegijna scena zawieszenia broni

Wisse reprezentuje człowieka zwiedzionego przez „zastępczych ojców". Bohater jest bliski nawrócenia pod wpływem kapelana Buscha. Gdy spotykają się po raz pierwszy, dzielą się posiłkiem z rosyjską rodziną i dostrzegaja, jak dziecko wykonuje znak krzyża przed ikoną Matki Boskiej. Busch stwierdza wprost, że zarówno sowiecki komunizm, jak i niemiecki nazizm chciały - bezskutecznie - wyplenić wiarę chrześcijańską: Widzi pan, panie Wisse, wszystko przemija, ale to pozostaje, na tym można polegać. Po mszy sprawowanej pod Stalingradem przez Buscha, Wisse wyznaje: Nie jestem już niczego pewien, ojcze. To wszystko jest zbyt trudne. Nieustannie zadaje sobie pytanie, jaki jest sens tego wszystkiego. 
Podobnie jak w wielu innych zachodnioniemieckich filmach wojennych, sceny batalistyczne w Psach... są sprawnie zmontowane z dokumentalnymi notacjami działań frontowych - zarazem jednak Wisbarowi udało się wykroczyć poza stylistyczną sztampę. Wyróżnia się na przykład stosunkowo długa scena chwilowego zawieszenia broni, rozgrywająca się na polu walki: gdy żołnierze przenoszą ciała rannych lub poległych towarzyszy broni, jeden z bohaterów zaczyna... grać na ocalałym z pożogi pianinie (fot. 36). Z ruin wychodzą niedobitki ludności cywilnej, by wraz z żołnierzami obu stron konfliktu choćby przez chwilę móc posłuchać muzyki. Scena kończy się gromkim okrzykiem Czas miną - biała flaga zostaje rzucona na ziemię, za moment rozlegną się strzały...

Frank Wisbar otrzymał Niemiecką Nagrodę Filmową za reżyserię, film zaś - bardzo dobre recenzje ${ }^{135}$. Podkreślano w nich, że traktuje on $\mathrm{o}$ „,największej tragedii w niemieckiej historii” $\mathrm{i}$ stanowi „,idealny przykład budzących grozę konsekwencji autorytaryzmu, bazującego na władzy absolutnej i niewolniczym posłuszeństwie"136. Psy, chcecie żyć wiecznie? odniosły także duży sukces kasowy (drugi najpopularniejszy film 1959 r.) i stały się symbolem dekady, o którym Erich Kuby - jeden z prekursorów „nowej lewicy" - pisał:

Nasze życie w Niemczech Zachodnich po 1950 roku może zostać zrozumiane tylko wówczas, jeśli pojmiemy, że wtedy każdy Niemiec chciał wygrać wojnę, którą przegraliśmy [...]. Każdy Niemiec, który opuszcza kino po obejrzeniu tego filmu, może poczuć się rozgrzeszony: tak, gdyby tylko dali nam kilka czołgów i parę dywizji więcej, bylibyśmy naprawdę świetni ${ }^{137}$.

Trylogię wojenną Franka Wisbara, której wcześniejsze części stanowiły Rekiny i małe rybki oraz Psy, chcecie żyć wiecznie?, domyka Noc zapadła nad Gotenhafen (Nacht fiel über Gotenhafen, reż. Frank Wisbar, RFN 1959). W materiałach promocyjnych zapowiadano „pierwszy film o zatonięciu Gustloffa"138 oraz informowano, że fabuła oparta jest na dokumentach i wspomnieniach pozyskanych z bońskiego Ministerstwa

135 Przykładowo: Friedrich A. Wagner, Die Wolga war ihr Schicksal, „Frankfurter Allgemeine Zeitung", 23.04.1959.

136 Gert Koegel, Kerls, wollt ihr niemals lernen?, „Vorwärts”, 8.05.1959.

137 Erich Kuby, Mein ärgerliches Vaterland, München 1989, s. 210.

138 Statek Gustloff jest ważnym niemieckim „miejscem pamięci” skorelowanym z dyskursem cywilnych ofiar wojny. Zwodowany w 1938 r., przez jakiś czas służył jako prom turystyczny nazistowskiej organizacji Kraft durch Freude, podczas wojny zaś - jako okręt treningowy dla marynarki wojennej. 30 stycznia $1945 \mathrm{r}$. wypłynął na pierwszy od lat rejs na morzu. Na pokładzie znajdowało się około 8 tys. cywilów i 1 tys. żołnierzy marynarki wojennej oraz ranni żołnierze Wehrmachtu. W wyniku storpedowania statku przez sowiecki okręt podwodny, statek zatonął w okolicach Ustki; przeżyło około 1250 osób. 
ds. Wypędzonych ${ }^{139}$. Jako doradcę i współautora scenariusza zatrudniono Heinza Schöna, autora pierwszej obszernej pracy o tych wydarzeniach ${ }^{140}$ (wydanej w 1952 r., a później wielokrotnie wznawianej).

W rzeczywistości Gustloff pojawia się jedynie w zakończeniu filmu ${ }^{141}$ oraz w prologu (w zapowiadających finał ujęciach pokazujących dryfujące ciała, następnie w scenie przypominającej chrzest statku: Nadaję ci imię męczennika naszego ruchu), wytwarzającym przyczynowo-skutkowy związek między przedwojenną propaganda, nazistowskim militaryzmem i wojenną hekatombą. Podobny charakter ma krótka sekwencja zaczynająca się w szóstej minucie: na ekranie pojawia się najpierw Żelazny Krzyż, który zostaje „zmultiplikowany” w swoistą mozaikę (fot. 37), wreszcie - jak w zakończeniu filmu Mordercy sa wśród nas - oglądamy "las krzyży” (od Narwiku po Tobruk, od Monte Cassino po Stalingrad); kolejne cztery ujęcia pokazują krzyże. Następnie pod komentarz brzmiący niemieckie kobiety okupiły bohaterstwo swych mężów samotnymi i bezsennymi nocami nałożona zostaje - przypominająca Griffithowską apoteozę - seria sześciu zbliżeń na jasno oświetlone twarze kobiet.

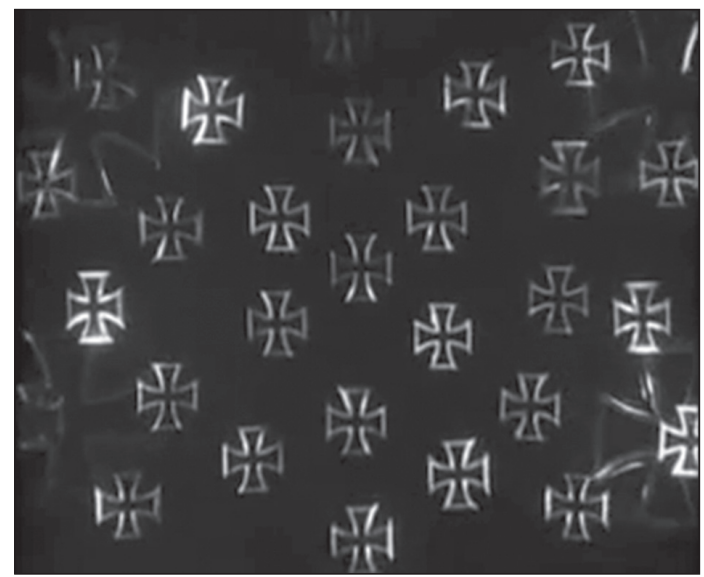

Fot. 37. Noc zapadta nad Gotenhafen

(reż. Frank Wisbar, 1959)

Mozaika Żelaznych Krzyży

139 Za: Frank Wisbar bei den Dreharbeiten zu „Nacht fiel über Gotenhafen”, „Spiegel” 1960, nr 3.

${ }^{140}$ Heinz Schön, Tragedia Gustloffa, tłum. M. i J. Zepp, Zakrzów 2006.

${ }^{141}$ Podczas kwerendy internetowej kilkakrotnie trafiałem na informację (w języ$\mathrm{ku}$ angielskim), jakoby ostatnie, dramatyczne sekwencje rozgrywające się na pokładzie Gustloffa zwieńczone zostały „zimnowojennym” epilogiem, w którym pojawiać się miały obrazy... grzyba atomowego (w filmie jest on przestrogą przed III wojną światową). Być może na rynek anglojęzyczny trafiła tak właśnie „wzbogacona” wersja, choć wydaje się to jednak mało prawdopodobne. Takiego „aneksu” nie ma również na znanej mi edycji DVD. 
Zasadniczą część filmu wypełnia klasyczny melodramat. Krótko przed wybuchem wojny spikerka radiowa Maria poślubia Kurta; później mieszka z jego rodzicami, gdy ten zostaje powołany do wojska. Podczas przyjęcia kobieta poznaje Hansa, oficera marynarki, z którym zachodzi w ciążę. Razem z dzieckiem przenosi się do majątku należącego do rodziny jej przyjaciółki Edith w Prusach Wschodnich. Edith zostaje zamordowana przez żołnierzy Armii Czerwonej, zaś Maria z dzieckiem udają się do gdyńskiego portu; dołącza do nich ranny Kurt. Z pomocą Hansa, który pełni służbę na Gustloffie, dostają się na pokład. Pierwszej nocy po wypłynięciu w rejs statek zostaje zatopiony, dziecko Marii jest wśród nielicznych ocalałych.

Podobnie jak wcześniejsza Miłość 47 Liebeneinera, również Noc zapadła na Gotenhafen w sekwencjach dotyczących Prus Wschodnich zawiera kanoniczne (w niemieckiej pamięci kulturowej) obrazy idylli w czasach pokoju oraz koszmaru ucieczki przed Armią Czerwoną ${ }^{142}$. Edith i Maria zatrzymują się u baronowej von Reuss (nazywanej „panią generałową"), która jest reprezentantką „dobrych Niemiec" - na warunki pracy u niej nie może narzekać nawet Francuz Gaston (robotnik przymusowy, Zwangsarbeiter - w filmie pada określenie Fremdarbeiter, czyli „robotnik cudzoziemski" $)^{143}$. Sama baronowa poucza zaś, jakby cytując goebbelsowską propagandę, że my Niemcy zawsze przyzwoicie traktujemy swoich więźniów. Kontrapunktem dla tej postawy są naturalnie hordy krasnoarmiejców, wyposażone w ulotki z odezwą napisaną przez Ilję Erenburga (nawołującą: „,śmierć dla wszystkich faszystów!" ${ }^{144}$ ).

Również i w tym filmie ofiarami są zatem niemal wyłącznie Niemcy - z jednym wyjątkiem. Chodzi o niezwykle osobliwą (w żaden sposób niepowiązaną ani z wcześniejszymi, ani z późniejszymi wątkami) scenę pojmania na przyjęciu młodej Żydówki i jej ojca, ukrywającego się za ścianą gabinetu. $Z$ uwagi na brak fabularnego umotywowania tej sceny jeden z niemieckich recenzentów określił ją wręcz słowem "gag"145. Scena ta - komentował Theodor Kotulla -

142 Robert G. Moeller zauważa, że wątek „,niemieckich kresów” został w filmie Wisbara szczególnie mocno zaakcentowany (Robert G. Moeller, Der "Barde des Zweiten Weltkrieges" und der Zusammenbruch des „Deutschen Ostens": Frank Wisbars "Nacht fiel über Gotenhafen", [w:] Mediale Mobilmachung 3. Das Kino der Bundesrepublik Deutschland als Kulturindustrie, 1950-1962, red. Harro Segeberg, München 2009).

${ }^{143}$ Co ciekawe, francuscy robotnicy pojawią się też w zrealizowanej cztery dekady później Ucieczce (Die Flucht, reż. Kai Wessel, RFN 2007), również opowiadającej o tzw. Flucht und Vertreibung z Prus Wschodnich.

${ }^{144} \mathrm{~W}$ materiałach prasowych, które ukazywały się tuż przed premierą filmu lub tuż po niej, przypominano treść tej ulotki (sugerując, niezgodnie z prawda, że nawoływała ona także do gwałtów) - zob. Aus jenen Tagen, „Der Spiegel” 1960, nr 3.

${ }^{145}$ F. J. R., Vor den Leinwand notiert, „Süddeutsche Zeitung”, 14.04.1960. Inne recenzje skupiały się głównie na wątkach Prus Wschodnich oraz reprezentacjach postaci kobiecych 
jest do tego stopnia niepowiązana i pozbawiona ciągu dalszego, że sprawia wrażenie ciała obcego. Odpolitycznienie II wojny światowej w kierunku jakiejś wyobrażonej »wojny samej w sobie« zostaje w tym filmie tak daleko posunięte, jak nigdy dotąd $\mathrm{w}$ żadnym z tych wszystkich kłopotliwych niemieckich filmów wojennych ${ }^{146}$.

Główna część filmu Wisbara ma jednak charakter melodramatyczny, osnuty wokół trójkąta: Maria - Kurt - Hans. Zwraca uwagę odważny na owe czasy wątek zdrady małżeńskiej, do której dochodzi podczas nalotu. Gdy Kurt nie może wybaczyć Marii jej niewierności, jest strofowany przez swojego przyjaciela: Nie możesz przykładać standardów z czasu pokoju do tej szalonej wojny. To kluczowe dla wymowy filmu zdania - w dyskursie Noc zapadła nad Gotenfahen wojna jest okresem zawieszenia moralności, swoistym karnawałem śmierci, który nie może być oceniany według „normalnych” standardów (podobnie w innej scenie - gdy Kurta prosi o pomoc Polka, której dom spalili żołnierze Wehrmachtu, odpowiada on pytaniem: Co ja moge poczać?). Swoją droga w drugim niemieckim filmie fabularnym o Gustloffie, nakręconym niemal pół wieku później, w zjednoczonych Niemczech (Gustloff - rejs ku śmierci [Die Gustloff], reż. Joseph Vilsmaier, Niemcy 2008) - problem odpowiedzialności profilowany jest inaczej: „O ile Wisbar poddaje krytyce pogląd, że kodeks moralny czasów pokoju mógł zostać utrzymany w czasie wojny, o tyle film Vilsmaiera jest tego poglądu potwierdzeniem"147.

Na tle adaptacji Kirsta i filmów Wisbara wyróżniała się superprodukcja Douglasa Sirka Czas życia i czas śmierci (A Time to Love and a Time to Die, USA $1958^{148}$ ) - film nominalnie amerykański (produkcja Universal Pictures), choć zrealizowany w Niemczech, z niemieckimi aktorami, wyreżyserowany przez autora o niemieckim pochodzeniu, na podstawie powieści Ericha Marii Remarque'a ${ }^{149}$ (który zresztą u Sirka zagrał profesora Pohlmanna, ukrywającego w swym mieszkaniu żydowskiego uciekiniera).

- zob. Manfred Delling, Der Untergang der "Wilhelm Gustloff” - ein Symbol. Frank Wisbars neuer Antikriegsfilm, „Die Welt”, 5.03.1960; Volker Baer, Blick auf die Leinwand: Zwischen Leitartikel und Reportage. "Nacht fiel über Gotenhafen", „Der Tagesspiegel”, 15.05.1960.

146 Theodor Kotulla, Nacht fiel am Gotenhafen, „Filmkritik” 1960, nr 4.

147 Bill Niven, The Good Captain and the Bad Captain: Joseph Vilsmeier's "Die Gustloff" and the Erosion of Complexity, "German Politics and Society” 2008, nr 4, s. 96. Zob. też: Konrad Klejsa, Drezno i Gustloff-miejsca pamięci niemieckich ofiar II wojny światowej i ich reprezentacje w filmach telewizyjnych stacji ARD i ZDF z lat 2006-2008, [w:] Paradygmaty kina wspótczesnego, red. Ryszard W. Kluszczyński, Tomasz Kłys, Natasza Korczarowska-Różycka, Łódź 2014.

${ }_{148}$ Tak brzmi oryginalny tytuł filmu oraz anglojęzycznego przekładu powieści. W niemieckim oryginale została ona opublikowana jako Zeit zu leben, Zeit zu sterben (a zatem: „,czas życia”, nie „czas miłości” - pod tym właśnie tytułem wprowadzono film Sirka do niemieckich kin.

149 Erich Maria Remarque, Czas życia i czas śmierci, tłum. J. Stroynowski, Poznań 2013. 
Akcja filmu rozpoczyna się na froncie wschodnim, gdzie oddział Wehrmachtu otrzymuje rozkaz likwidacji ludności cywilnej. Jeden z żołnierzy, Ernst Gräber - główny bohater opowieści - wykonuje zadanie, choć doskwierają mu wyrzuty sumienia. W tej części film Sirka zawiera motywy podobne do innych zachodnioniemieckich fabuł wojennych tamtego czasu - w oddziale, w którym walczy Gräber, żołnierze nastawieni są do wojny dość sceptycznie i konfrontowani z fanatycznym gestapowcem. Zarazem jednak autorski styl Sirka pozwala niekiedy na przekroczenie stereotypu - co widoczne jest zwłaszcza w początkowej sekwencji. Gdy żołnierze odkrywają zakopane w śniegu ciało niemieckiego oficera, następuje dialog balansujący na skraju parodii: Wygląda, jakby płakat / Jego gałki oczne zamarzły, to lód topnieje / Znak nadchodzącej wiosny.

Właściwa - melodramatyczna - część filmu rozgrywa się w Niemczech, dokąd bohater powraca podczas trzytygodniowej przepustki. Ernst zakochuje się wtedy w Elisabeth, córce lekarza, który został osadzony, a następnie - o czym dziewczyna dowiaduje się już po ślubie - zgładzony w nazistowskim obozie. Wątek drugoplanowy dotyczy dawnego kolegi Gräbera, niejakiego Bindinga, który korzystając z przywilejów partyjnego aparatczyka, oddaje się życiu sybaryty wraz z innymi nazistowskimi degeneratami.

Analizując różnice pomiędzy książką a filmem, Andrzej Pitrus zwrócił uwagę na dokonaną w ekranizacji lekką zmianę motywacji bohaterów, wprowadzającą do opowieści logikę melodramatu:

Książka opowiada nie tyle o wielkim porywie uczuć, co o relacji niejako wymuszonej przez okoliczności zewnętrzne. To wojna, niosąca ze sobą poczucie zagrożenia, sprawia, że bohaterowie filmu zbliżają się do siebie. Ich miłość nie jest wartością samoistna, lecz raczej reakcją obronną na zło otaczającego świata [...]. W powieści decyzja o małżeństwie jest przypadkowa. Bohaterowie podejmują ją licząc na przysługujący żonom żołnierzy zasiłek. Gräber jest też początkowo przekonany, że ślub z żołnierzem udekorowanym Żelaznym Krzyżem pomoże Elżbiecie, której ojciec trafił do obozu koncentracyjnego, uniknąć podobnego losu. Nie jest to małżeństwo z rozsądku, ale bliskość bohaterów jest wyraźnie ukazana jako pochodna okoliczności. Film odchodzi od tej oczywistości. Choć wspomniane wątki - nadzieja na zasiłek i strach przed osadzeniem w obozie - zostały zasygnalizowane ${ }^{150}$.

Istotniejsza wydaje się zmiana wprowadzona przez Sirka do ostatniej sceny. Po powrocie na front wewnętrznie odmieniony bohater zabija swego kolegę, zamierzającego rozstrzelać grupę cywilów. Ernst uwalnia

150 Andrzej Pitrus, Dotykajac lustra. Melodramaty Douglasa Sirka, Kraków 2006, s. 183, 185-188. 
„więźniów”, ale jeden z nich śmiertelnie go rani. Bohater umiera, czytając list od ukochanej, w którym kobieta informuje go o swej ciąży. W powieści

mamy jednak do czynienia z przypadkiem: człowiek, który strzela do Ernsta, nie wie, że zabija swego dobroczyńcę. W filmie po broń sięga on w sposób świadomy - zdając sobie sprawę, że Gräber zabił swego kolegę, by uwolnić jeńców, którym grozi śmierć. Inna jest też motywacja [...]. W książce Gräber także czyta listy od Elżbiety, lecz Remarque nie sugeruje związku przyczynowo-skutkowego między otrzymaniem korespondencji i uwolnieniem jeńców ${ }^{151}$.

Melodramatyczne sublimacje Sirka doceniono dopiero z czasem (głównie pod wpływem inspirującego się nimi Fassbindera). Czas życia $i$ czas śmierci został po swej premierze odrzucony przez niemiecką widownię, nie spotkał się również z akceptacją krytyki, która utyskiwała na "zgliszcza w kolorze lemoniady"152 i "fotogeniczne efekciarstwo"153. W niektórych recenzjach dostrzeżono, iż był to jeden $\mathrm{z}$ nielicznych filmów, w którym zobrazowano (nie w jednej, a w kilku scenach) alianckie naloty na niemieckie miasta; najwyraźniej brak tego rodzaju reprezentacji był odczuwany jako deficyt zachodnioniemieckiego kina wojennego tamtej dekady.

Pojawiły się także filmy mitologizujące konkretne formacje czy oddziały walczące w czasie wojny. Batalion karny 999 (Strafbataillon 999, reż. Harald Philipp, RFN 1959) na podstawie powieści Heinza Konsalika, nawiązywał do - faktycznie powołanej do życia po rozpoczęciu kampanii wschodniej - dywizji, złożonej z więźniów skazanych na śmierć lub wieloletnie pozbawienie wolności, a wysyłanej na froncie wschodnim do najtrudniejszych misji. W odróżnieniu od innych zachodnioniemieckich fabuł wojennych tamtego czasu, bohaterowie (m.in. zdegradowany oficer, dezerter z prowincji, naukowiec - biolog i drobny kryminalista) walczą bardziej z przymusu niż z własnej woli (osobna linia fabularna dotyczy zresztą podejmowanych w Berlinie przez żonę biologa - gra ją Sonja Ziemann - starań o cofnięcie niesprawiedliwego wyroku). Oprócz tej modyfikacji schematu erefenowskiego kina wojennego inne jego elementy pozostają bez zmian (życie utrudnia rekrutom sadystyczny podoficer, a heroiczna walka okupiona zostaje cierpieniem, zawinionym przez niekompetentne dowództwo). Z kolei w filmie Dywizja Brandenburg (Division Brandenburg, reż. Harald Philipp, RFN 1960) - na podstawie powieści fabularyzującej autentyczne wydarzenia, a napisanej przez poczytnego autora, Willa Bertholda - ukazano dwie misje (w Rumunii i w ZSRR) prze-

${ }^{151}$ Ibidem, s. 188.

152 Zeit zu Leben und Zeit zu sterben, „Der Spiegel”, 1.10.1958.

153 Ulrich Gregor, A Time to Love and a Time to Die, „Filmkritik” 1958, nr 9. 
prowadzone przez tytułowy oddział. Zostaje on przedstawiony na początku filmu w ponadkadrowej narracji, której wielce charakterystyczna treść brzmi następująco:

Dywizja Brandenburg - taka nazwe nosita najbardziej niezwykła jednostka niemieckiego Wehrmachtu, osobista drużyna admirała Canarisa. Tajemnica, która otaczała to komando, nimb idacych na pewna śmierć, ich petne przygód misje na tyłach wroga [...], ich bezkompromisowe misje odwetowe - to wszystko budowało legendę, która przybierała formułe bohaterskiego mitu. Oni nie byli bohaterami. Byli zaślepionymi idealistami i poszukiwaczami przygód, ofiarami zbrodniczego, prześladujacego ich systemu. Byli gotowi na śmierć, wiedzac, jaki koniec ich czeka. Ich groby leża między Przyladkiem Pótnocnym i Afryka, między Atlantykiem a Kaukazem. Dziś pozostało po nich tylko wspomnienie grozy, która rozprzestrzeniali. $\mathrm{Na}$ ich flagach widniał napis: „Macie być zgraja złodziei, z pomoca których będzie można wyciagnać diabła z piekła".

Interesujące (bardziej niż sam film) są kulisy powstania Urlopu na słowo honoru (Urlaub auf Ehrenwort, reż. Wolfgang Liebeneiner, RFN 1955) ${ }^{154}$. Produkcja ta była remakiem filmu Karla Rittera z 1937 r. (!), opowiadającym o członkach regimentu, którzy korzystają z tytułowej przepustki, nie ulegają pokusie dezercji i jak jeden mąż stawiają się z powrotem do służby. Gdy reżyser postanowił przenieść akcję filmu z I na II wojnę światowa, dystrybutor miał postawić trzy warunki: 1) film nie może być ani "pro-", ani "antywojenny"; 2) wojna musi być pokazana z „czysto ludzkiego punktu widzenia"; 3) całość musi być „wolna od polityki”. Po obejrzeniu wstępnej wersji odmówiono wypłacenia reżyserowi pozostałej części honorarium - dystrybutor zażądał bowiem wycięcia dwóch fragmentów dialogu (krytycznych wobec Hitlera słów wypowiadanych przez żonę jednego z żołnierzy: Hitler zawsze przyrzekat nam pokój, wolność i chleb. A co teraz mamy? Bomby i kartki żywnościowe. Pary z gęby nie można puścić, oraz kwestii oficera SS mówiącego o znanym z antyhitlerowskiego nastawienia karykaturzyście: nie moge sobie wyobrazić, że on przetrwa. My przetrwamy). Wymógł też zmianę w końcowej scenie, pokazującej meldunek składany pułkownikowi przez oficera donoszącego o powrocie wszystkich żołnierzy z urlopu. Dialog, który w oryginalnej wersji brzmiał: To jest pierwszy cud, który widziałem na tej wojnie. Jest pan chyba zadowolony? / Nie, panie pułkowniku - miał zostać zmieniony na następujący: Jest Pan chyba dumny? / Jawohl, panie pułkowniku. Jestem dumny z tych ludzi. Reżyser przystał na te zmiany - ale już bez jego wiedzy wprowadzono dalsze: wycięto parodię ulubionego marsza Hitlera i usunięto antywojenny dialog żony żołnierza z oficerem (I pan jeszcze wierzy, że wojna się dobrze skończy? Nie,

154 Omawiam je, bazując na: Mit kleinen Schnitten, „Der Spiegel” 1956, nr 12. Perypetie Leibeneinera relacjonowano też w ówczesnej polskiej prasie filmowej („Film” 1956, nr 21). 
pan w to nie wierzy. A mimo to bijecie się dalej). W odpowiedzi Liebeneiner skierował do sądu sprawę przeciw samowoli dystrybutora, ten zaś wystosował kontrpozew, domagając się rekompensaty za dokonane „niezbędne skróty” oraz poniesione straty. Niezależnie od finału sprawy („Der Spiegel" donosił, że zakończyła się ona ugodą, a reżyser otrzymał obiecane mu wynagrodzenie ${ }^{155}$ ) znakomicie ilustruje ona nie tylko napięcia związane $\mathrm{z}$ fabularnymi reprezentacjami lat nazizmu, lecz także wpływ, jaki na kształtowanie ówczesnego kina mieli dystrybutorzy.

Katalog zachodnioniemieckich filmów o Wehrmachcie nie ogranicza się do wzmiankowanych tytułów - można go uzupełnić o wiele innych. W czterech nowelach filmu Bohaterstwo po zamknięciu kramu (Heldentum nach Ladenschuß, reż. Erik Ode, RFN 1955) przedstawiono historyjki o komediowym zabarwieniu, traktujące o zdemobilizowanych żołnierzach, którzy w pierwszych dniach po kapitulacji usiłują wydostać się z obozów dla internowanych, uniknąć aresztowania lub po prostu wrócić bezpiecznie do rodziny. W Operacji Śpiwór (Unternehmen Schlafsack, reż. Arthur Maria Rabenalt, RFN 1955) kapitan Werhmachtu ratuje swoich żołnierzy przed pewną śmiercią na froncie wschodnim. Niesprawiedliwie potraktowani zostają bohaterowie Sądu wojskowego (Kriegsgericht, reż. Kurt Meisel, RFN 1959156) - trzej marynarze ocaleni z zatopionego przez Anglików krążownika najpierw są honorowani jako bohaterowie wojenni, by później otrzymać wyroki śmierci za rzekome tchórzostwo. W Zielonych diabłach spod Monte Cassino (Die grünen Teufel von Monte Cassino, reż. Harald Reinl, RFN 1958) niemieccy żołnierze bronią włoskiego klasztoru, a główny bohater, szlachetny porucznik Reiter, wspierany przez dzielną pielęgniarkę, stara się ochronić dzieła sztuki, które mają zostać przewiezione do Rzymu... Sama lektura streszczeń tych filmów może przyprawić o zawrót głowy - a samopoczucia nie poprawia ich ogląd: są to bowiem w zdecydowanej większości produkcje słabe pod względem warsztatowym, rażące koturnowym aktorstwem i niechlujnym montażem.

Na ich tle wyróżniają się dwa filmy opowiadające o niemieckich nastolatkach wcielonych do Wehrmachtu pod koniec wojny. Producentem pierwszego z nich był Erich Pommer - legendarny współtwórca potęgi Ufy, który w 1933 r. musiał opuścić III Rzeszę, a w 1945 r. powrócił do Nie-

155 Trzy lata wcześniej Liebeneiner nakręcił w Austrii film 1 kwietnia 2000 (1. April 2000, 1952) - satyryczne science fiction w formule historii alternatywnych (pod koniec XX w., po ponad pięciu dekadach, Austria - znajdująca się nadal pod okupacją amerykańską - decyduje się ogłosić niepodległość. Ponieważ międzynarodowa komisja oskarża Austrię o ponowne - po I i II wojnie światowej - złamanie światowego pokoju, ta próbuje udowodnić, że zasługuje na niezależny byt państwowy).

156 W latach III Rzeszy Meisel był aktorem specjalizującym się w rolach negatywnych - grał niegodziwego czeskiego kuzyna w Złotym mieście Harlana i kosmopolitę-zdrajcę w Kolbergu (dziękuję Tomaszowi Kłysowi za tę informację). 
miec jako amerykański oficer odpowiedzialny za denazyfikację kinematografii (zob. rozdział I). W powojennych Niemczech Pommer wyprodukował cztery filmy. Ostatni z nich, adaptacja powieści Herberta Reineckera (powstałej na podstawie ilustrowanych historii publikowanych $\mathrm{w}$ czasopiśmie "Quick"), nosił tytuł Dzieci, matki i generał (Kinder, Mütter und ein General, reż. Lásló Benedek, RFN 1955)157. Film ukazuje wahania oraz wybory Niemców w ostatnich miesiącach wojny: z jednej strony mamy odczuwaną przez zindoktrynowanych nastolatków chęć walki, z drugiej zaś - rodzicielskie uczucia i zdrowy rozsądek.

Akcja filmu rozgrywa się pod koniec wojny w okolicach Szczecina. Pięciu chłopców dołącza do oddziału Volkssturmu; ich matki nie akceptują tego wyboru i udają się na poszukiwanie synów, w staraniach tych nie uzyskując wsparcia od tytułowego generała. Na swej drodze kobiety spotykają zniechęconych walką żołnierzy - jedynymi, którzy nadal chcą walczyć, są właśnie nastolatkowie. Ich życie ratuje oficer, który sprzeciwia się rozkazowi, za co ma stanąć przed sądem wojennym, ale ostatecznie zostaje wysłany ponownie na front. Aby podobnego losu mogli uniknąć chłopcy, matki - korzystając z ogólnego tumultu (i za radą innych żołnierzy!) - ukrywają ich w stodole. Dalsze losy bohaterów w obliczu nadciągających wojsk sowieckich nie zostają pokazane. W początkowej wersji planowano jednak inne zakończenie ${ }^{158}$ - chłopcy mieli dołączyć do oddziału, a matki pozostać same. Według ustaleń Irmgard Wilharm, wersję z takim zakończeniem pokazano w Szwecji i w Belgii, jednak dystrybutor uznał, że tego rodzaju finał nie zostanie zaakceptowany przez niemiecką widownię ${ }^{159}$. Twórcy filmu zagrozili, że wycofają swoje nazwiska - a Pommer (który bronił pierwotnej wersji w taki oto sposób: „Film powstał przy pomocy Bundesgrenzschutzu. Skoro Bonn przysłało sprzęt i żołnierzy, to wie, co robi. Nie słyszeliśmy żadnych skarg" ${ }^{\prime 160}$ ) nalegał na pokazy próbne.

${ }^{157}$ Zob. więcej: Felicitas Milke, „Die Zeit ist für einen solchen Film noch nicht reif”. "Kinder, Mütter und ein General” (1955) als Vermächtnis von Erich Pommer. „Filmblatt” 2011, nr 45; Robert G. Moeller, What Did You Do in the War, Mutti? Courageous Women, Compassionate Commanders, and Stories of the Second World War, "German History” 2004, nr 22.

${ }^{158}$ Irmgard Wilharm, Filmwirtschaft, Filmpolitik und der "Publikumsgeschmack" im Westdeutschland der Nachkriegszeit, "Geschichte und Gesellschaft” 2002, nr 28, s. 285.

159 Ostatecznie film i tak nie odniósł sukcesu kasowego. Scenarzysta po latach skomentował to w następujący sposób: „Benedek pokazał niemieckich żołnierzy tak, jak ich sobie wyobrażał. W ruchach, zachowaniach i wypowiedziach wyobrażenie to nie odpowiadało temu, co wielu wówczas poznało, więc pojawił się przedziwny efekt obcości, który zniknął dopiero po trzydziestu latach [...]. Film dostał fantastyczne recenzje, ale ludzie nie chcieli na to patrzeć" (Herbert Reinecker, Ein Zeitbericht unter Zuhilfenahme des eigenen Lebenslauf, Wien 1990, s. 231).

160 Cyt. za: Irmgard Wilharm, Filmwirtschaft, Filmpolitik..., s. 258. To alternatywne zakończenie uwzględniono w dodatkach do edycji DVD filmu. 
Odbyły się one dwukrotnie: widzowie pierwszego seansu, na który zaproszono dziennikarzy, przedsiębiorców i naukowców, optowali za pierwotnym, „ostrym” zakończeniem, natomiast na drugim pokazie próbnym, z udziałem właścicieli kin, wyżej oceniono wersję, w której matkom udaje się ukryć chłopców (fot. 38) ${ }^{161}$.

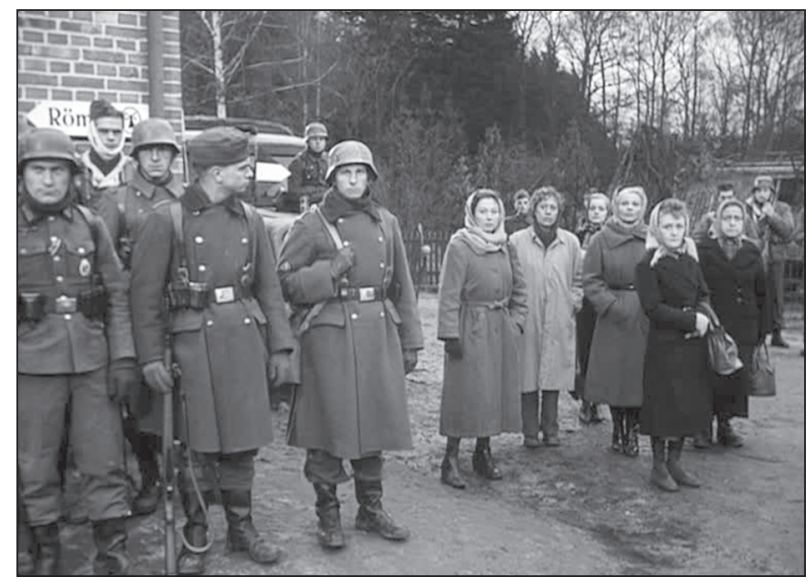

Fot. 38. Dzieci, matki i generat (reż. Lásló Benedek, 1955) Matki młodych rekrutów przeciwstawiają się oficerskiej wierchuszce

W filmie Dzieci, matki i generat w roli porucznika Dornberga - dowódcy oddziału, do którego wcieleni zostają chłopcy - wystąpił Bernhard Wicki. Pięć lat później wyreżyserował on inny film o podobnej tematyce: Most (Die Brücke, RFN 1959) na podstawie powieści Manfreda Gregora ${ }^{162}$ - obsypany nagrodami, powszechnie zaliczany do kanonu niemieckiego kina i po wielokroć emitowany w niemieckiej telewizji publicznej ${ }^{163}$. Miarą jego znaczenia jest choćby fakt, iż - jak ustalił Harald Welzer analizujący narracje biograficzne Niemców - wiele niemieckich wspomnień modelowanych jest według filmu Wickiego:

topos straconej młodości sprawia, że [...] bohaterowie stają się idealną podstawą dla budowania modelu identyfikacji dla pokolenia służby przeciwlotniczej [Flakhelfergeneration - określenie pokolenia urodzonego około 1930-1935 r., przyp. K. K.]. Póź-

161 O sprawie donosiła ówczesna prasa - Der versöhnliche Ausklang, "Der Spiegel” 1955, nr 11.

162 Manfred Gregor, Most, tłum. E. Werfel, Warszawa 1960 (pseudonimem „Manfred Gregor" posłużył się Gregor Dorfmeister).

${ }_{163}$ W 2008 r. prywatna stacja PRO7 wyprodukowała remake filmu Wickiego (Die Brücke, reż. Wolfgang Panzer). 
niejsze ofiary zostają przedstawione jako pogodni, po części dziecinni i naiwni, zbyt odważni młodzi mężczyźni, którzy dopiero podejmują pierwsze próby miłosne i walczą z problemami okresu dojrzewania ${ }^{164}$.

Akcja filmu rozpoczyna się w kwietniu 1945 r., w małym miasteczku w Bawarii, gdzie siedmiu chłopaków otrzymuje rozkaz stawienia się do wojska. Nauczyciel angielskiego, który stara się zainteresować chłopców Szekspirem, zwraca się z prośbą do dowódcy - okazuje się on jego dawnym kolega, również nauczycielem - by zwolnił nastolatków z walki. Ten przychyla się do prośby i zleca uczniom łatwiejsze, w jego mniemaniu, zadanie ochrony mostu, który ma zostać zniszczony przed przybyciem aliantów (o czym jednak chłopcy nie wiedzą). Potyczkę z Amerykanami przeżywa tylko dwójka, lecz jeden z młodych żołnierzy zdąży jeszcze zginąć od kuli wystrzelonej przez kogoś z niemieckiego oddziału, mającego rozkaz wysadzenia mostu. Wieńczący film napis brzmi: To wydarzyło się 27 kwietnia 1945 roku, i było do tego stopnia nieistotne, że nie zostato wspomniane w żadnym meldunku.

Przez niemal połowę narracji wojna jest wydarzeniem rozgrywającym się "gdzieś daleko", a jej jedynym śladem są słowiańscy robotnicy przymusowi (w dwóch krótkich scenach), racjonowana żywność oraz strach przed tym, co przyniesie przyszłość. $W$ tej części filmu przedstawione zostają przede wszystkim rodziny chłopców, ich społeczne milieu. Sigi to syn owdowiałej praczki, która sama prowadzi gospodarstwo (postać niemal żywcem wyjęta z „proletariackich” filmów z Republiki Weimarskiej), a ponieważ początkowo jest wyśmiewany przez kolegów, z tym większą gorliwością próbuje udowodnić swoje bohaterstwo. Jürgen, pochodzący $\mathrm{z}$ rodziny o tradycjach wojskowych (jak relikwię traktuje pistolet po zmarłym ojcu, $\mathrm{w}$ domu zaś wiszą portrety przedstawiające go w wojskowym rynsztunku), z dumą deklaruje, że wierzy we wszystko, co przykazat mu papa. Ojciec Karla, właściciel salonu fryzjerskiego, jest kaleką (stracił rękę podczas I wojny światowej) i samodzielnie wychowuje syna, który przysparza mu wiele kłopotów. Tata Alberta walczy na froncie, jego żona przygarnęła też Hansa, który (podobnie jak jeszcze jeden chłopak z grupy, Klaus) został przysłany do miasteczka z terenów zagrożonych działaniami wojennymi. Walter zaś jest synem lokalnego aparatczyka, który zdążył jeszcze ewakuować żonę na wieś (nie pozwalając jej nawet pożegnać się $\mathrm{z}$ synem!), a sam wdaje się $\mathrm{w}$ romanse, w czym ułatwia mu dostęp do reglamentowanych dóbr ${ }^{165}$.

${ }^{164}$ Harald Welzer, Materiat, z którego zbudowane sa biografie, tłum. M Saryusz-Wolska, [w:] Pamięć zbiorowa i kulturowa, red. Magdalena Saryusz-Wolska, Kraków 2009, s. 52 (cytowany fragment przekładu został lekko zmodyfikowany przez autora).

165 Wątek dojrzewania bohaterów podkreślają w swych analizach: Klaus Kanzog, „Warten auf das entscheidende Wort": Pubertät und Heldenwahn in Bernhard Wickis "Die Brücke”, 
Już z tej, z konieczności pobieżnej, prezentacji bohaterów wynika, że ich charakterystyka jest $\mathrm{w}$ dramaturgii filmu tak prowadzona, by uwypuklić problem rodziny - niepełnej lub targanej problemami (konflikt Karla i Waltera z ojcami ma charakter pokoleniowego buntu - jak pisze Peter Reichel, „ucieleśniane przez nich [ojców - przyp. K. K.] zło nie ma charakteru politycznego, lecz jest natury ogólnoludzkiej” ${ }^{166}$ ). W to „puste” miejsce wkracza ideologiczna indoktrynacja (nie tyle nazistowska, co nacjonalistyczna, bowiem z Mostu nie można dowiedzieć się wiele o specyfice narodowego socjalizmu!): chłopcy chcą założyć mundury, ponieważ takie wzorce osobowe otrzymali, garną się do wojny - gdyż postrzegają ją jako przygodę. Dopiero gdy stawią się $\mathrm{w}$ punkcie poborowym, gdzie otrzymają za długie mundury i zbyt duże hełmy, okaże się, że przygoda ta nie jest - dosłownie - „szyta na ich miarę". Można powiedzieć, że Most powraca do dyskursu znanego z Rotacji/Brunatnej pajęczyny - zindoktrynowane zostaje młodsze pokolenie, starsi zaś (przynajmniej niektórzy z nich) są bardziej zdystansowani wobec systemu nazistowskiego (to część legendy „,czystego Wehrmachtu"). Gdy kapral próbuje wyjaśnić policji, że stoi na czele oddziału, który ma bronić mostu, zostaje wzięty za dezertera i zastrzelony - wtedy nie ma już nikogo, kto mógłby odwieść chłopców od obrony mostu, i tak przeznaczonego do wysadzenia przez Wehrmacht.

Owszem, do pewnego momentu w filmie zaznaczona jest dystynkcja między „dobrymi Niemcami" i ,złymi nazistami” - efekt ten wytwarzają w stosunkowo prosty sposób (tj. właściwy kinu klasycznemu), dramaturgiczne symetrie i kontrasty. Jeśli więc chłopcy śledzą na szkolnej mapie „postęp" niemieckich wojsk, to mapa u dowódców przedstawia, jak faktycznie sprawy się mają. Skoro w jednej ze scen oficer peroruje o złej sytuacji na froncie, to w kolejnej wygłasza zagrzewającą do boju przemowę dla żołnierzy, którzy mają bronić każdego skrawka niemieckiej ziemi. Zarazem jednak Most odróżnia się od wcześniej wymienionych produkcji tym, iż problem winy nie jest tu ograniczony do „Hitlera i jego kliki”. Właśnie poprzez wyeksponowanie wątku "rodzinnego" dyskurs Mostu sugeruje, że odpowiedzialność za nazizm i wojnę ma szerszy zasięg - i spoczywa na „zwykłych Niemcach" (co wprost wyraża rozmowa nauczyciela z dowódcą).

Jeśli w opracowaniach dotyczących filmu Wickiego często pojawia się opinia o "humanitarnej wymowie” fabuły, to najpewniej z uwagi na sposób przedstawienia wojny jako konfliktu, w którym cierpień doświadcza konkretny człowiek (nie zaś anonimowa „masa ludzka”, jak w sekwencjach

[w:] Der erotische Diskurs: Filmische Zeichen und Argumente, red. Klaus Kanzog, München 1989 oraz Jaimey Fisher, Resisting the war (Film): Wicki's "Die Brücke" and Its Generic Transformations, [w:] Generic Histories of German Cinema. Genre and its Deviations, red. Jaimey Fisher, New York 2013.

166 Peter Reichel, Erfundene Erinnerung..., s. 122. 
batalistycznych wielu wspomnianych produkcji wojennych). Dramaturgia zbudowana jest w ten sposób, by wywołać litość i współczucie nie tylko wobec chłopców, lecz także ich przeciwników. Gdy amerykański żołnierz próbuje zachęcić nastolatków do złożenia broni (Hey, hey, stop shooting, c'mon, give up, we don't fight kids, go home, Kindergarten), Karl zabija go pod wpływem emocji (ponieważ wcześniej żartowano z niego, używając tego samego słowa - „przedszkole”), kamera zaś eksponuje obraz cierpiącego rannego.

Film wywołał olbrzymi rezonans społeczny - i okazał się wielkim przebojem kasowym. To zarazem jeden z nielicznych filmów, o którego recepcji wśród widzów pisała ówczesna prasa. Dysponujemy trzema takimi świadectwami. W „Der Spiegel” napisano, że widzowie wychodzą z kina "milczący, poruszeni, nawet wystraszeni”"167. W Berlinie Zachodnim przeprowadzono po seansie krótki sondaż ${ }^{168}$ - odnotowano wyłącznie entuzjastyczne wypowiedzi (co może nasuwać podejrzenie, czy aby „ankieta” nie była marketingową „ustawką"), zarówno wśród odbiorców starszych (zapewniających, że "tak właśnie było"), jak i młodych (kilkoro z nich twierdziło, że podobne opowieści znali z przekazów ustnych od starszych członków rodziny). I wreszcie trzecie doniesienie, opisujące reakcje młodych widzów (ze szkół średnich), którzy jakoby podczas seansu mieli wznosić okrzyki: „No dalej, strzelaj, zabij ich!” - w scenach, $\mathrm{w}$ których bohaterowie filmu bronią swego posterunku ${ }^{169}$. Z tej ostatniej obserwacji nie należy z pewnością wyprowadzać uogólniających wniosków - potwierdza ona jednak szczególne znaczenie filmu jako doświadczenia niezwykle intensywnie wówczas przeżywanego.

Sposób przedstawienia wojny przez Wickiego powszechnie chwalono już w pierwszych recenzjach. „Za sprawą tego filmu, jednego z najbardziej gorzkich opowieści antywojennych, która pojawiła się na ekranach [...] powtórnie przeżywamy szok, który przed czternastoma laty odczuwaliśmy i o którym zapomnieliśmy" - napisano w "Süddeutsche Zeitung"170. Z kolei we „Frankfurter Allgemeine Zeitung” krytyk wyraził opinię, że Most jest „zasłużonym pomnikiem ku czci nieznanych, niepełnoletnich żołnierzy"171. Autorzy wielu recenzji wyraźnie wahają się, czy pisząc o Moście lepiej posłużyć się terminem „film wojenny” czy „antywojenny”;

167 Die Brücke am Regen, „Der Spiegel” 1959, nr 45.

168 Und was sagen die Berliner? ABEND-Blitzumfrage vor dem Zoo-Palast-Portal, "Der Abend", 14.11.1959.

169 Hans Schwab-Felisch, Hier wird es etwas schief gelaufen und die Kinder lacheln sich fremd, „Frankfurter Allgemeine Zeitung”, 29.10.1959.

${ }^{170}$ Hans-Dieter Roos, Bernhard Wickis Film von der "Brücke”, „Süddeutsche Zeitung”, 25.10.1959.

${ }^{171}$ Hans Schwab-Felisch, Opfergang der Siebzehnjährigen, „Frankfurter Allgemeine Zeitung", 24.10.1959. 
w niemal wszystkich pojawia się jednak opinia, że dzieło Wickiego w znaczący sposób odróżnia się od innych rodzimych produkcji o II wojnie światowej ${ }^{172}$. Rozbudowana argumentacja przedstawiona została w eseju autorstwa Kareny Niehoff. Wyliczyła ona stereotypy niemieckiego filmu wojennego, które udało się Wickiemu ominąć: „honor niemieckiego żołnierza", "zatwardziali naziści okazują się jedynie zwiedzeni na złą stronę przez poczucie obowiązku” i „zachowanie człowieczeństwa w czasach

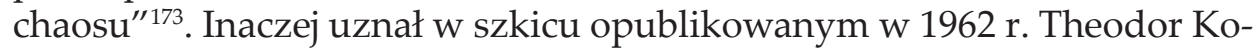
tulla, którego zdaniem mamy do czynienia - ze względu na heroizację śmierci chłopców ${ }^{174}$ - z typowym filmem wojennym, nie zaś antywojennym, jak dystrybutor określał go w materiałach promocyjnych.

Autorem najbardziej chyba wnikliwej recenzji był Enno Patalas, zazwyczaj bardzo surowy wobec erefenowskiego "kina papy”. Recenzent „Filmkritik” uznał Most za jedną z najlepszych realizacji lat 50., zarazem pisał jednak:

Film dotyka tylko powierzchni, nie sięga w głąb uwarunkowań historycznych stanowiących tło wydarzeń. Byłaby to przecież okazja do pokazania, jak pewna liczba Niemców ustosunkowywała się w 1945 roku do wojny, winy z nią związanej, nazizmu, a następnie można byłoby naświetlić przyczyny katastrofy. Zamiast tego film respektuje tabu, które obowiązuje w produkcjach zachodnioniemieckich. Z wyjątkiem naczelnika Volkssturmu, wszyscy dorośli bez wyjątku wydają się niewinnymi ofiarami historii albo przeznaczenia. Nieświadomy niczego zacny profesor gimnazjalny, skonfrontowany z nauczanymi przez siebie patriotycznymi treściami, odpowiada: Ależ wartości te dostały się w ręce fatszerzy! Jednak faktu, że owe "cenne wartości” same sprowadziły nieszczęście na przepojonych duchem narodowym obywateli, nie dostrzega ani on, ani też nie sugeruje tego film, który ukazuje nauczyciela raczej jako tragiczną ofiarę historycznego fatum. Pierwsza część filmu uzmysławia wprawdzie, jakie motywy mogły skłonić tych młodych ludzi do działań na dobrą sprawę samobójczych, ale motywy te mają wyłącznie charakter osobisty i przypadkowy. Ogólne przyczyny fanatyzmu części niemieckiej młodzieży w 1945 roku pozostają poza dyskursem. Nawet mechanizmy panujące w wojsku zostają zdecydowanie uniewinnione. Przełożeni chcą uchronić chłopców przed akcją i tylko przypadkowa śmierć podoficera, który miał się nimi opiekować, udaremnia ten zamiar. Tak więc ostatecznie wojna przedstawiona jest po raz kolejny $\mathrm{w}$ charakterze nieuniknionego fatum, za które nikt nie ponosi winy i któremu nikt nie mógł zapobiec ${ }^{175}$.

172 Zob. na przykład: Helmut Wittkowski, Der beste Nachkriegsfilm gegen den Krieg: der Kriegsfilm "Die Brücke”, „Deutsche Woche”, 4.11.1959.

${ }^{173}$ Karena Niehoff, Blick auf die Leinwand: Die Jungen fressen sich selber auf, „Der Tagesspiegel", 15.11.1959.

174 Theodor Kotulla, Zum Gesellschaftsbild des Films der Bundesrepublik, „Frankfurter Hefte. Zeitschrift für Kultur und Politik” 1962, nr 17, s. 401-402. Autor wspomina, że "pewien południowoamerykański dystrybutor" wprowadził Most na ekrany pod tytułem Bohaterowie umieraja na baczność.

175 Enno Patalas, Die Brücke, „Filmkrtitik” 1959, nr 12 (tłum. za: Obrazy Niemiec 1949_ 1999. Katalog przegladu, red. Grażyna M. Grabowska, Renata Prokurat, Warszawa 1999, 


\subsection{Nowi sojusznicy: NATO}

Helmut Dubiel opisuje lata 50. w RFN jako okres poszukiwania "tożsamości zastępczych"176, które miałyby zapełnić pustkę po upadku koncepcji państwa narodowego rozumianego jako „wspólnota krwi”. Jedną z nich była kształtująca się wówczas idea zjednoczonej Europy - w 1952 r. Niemcy Zachodnie współtworzą Europejską Wspólnotę Węgla i Stali, a sześć lat później wchodzą w życie traktaty rzymskie, ustanawiając m.in. Europejską Wspólnotę Gospodarczą. Podjęto też współpracę na płaszczyźnie militarnej - po podpisaniu tzw. układów paryskich w 1954 r. RFN zgłasza akces do tzw. Unii Zachodnioeuopejskiej (integrującej struktury wojskowe), zaś rok później wstępuje do NATO. Niegdysiejsi przeciwnicy stali się zatem najbliższymi sojusznikami.

Jak wiadomo, kontrowersyjnym aspektem tej współpracy był swoisty „parasol ochronny", jaki na naukowców współpracujących z nazistami, a później gotowych do współpracy z aliantami, nałożyły Stany Zjednoczone. Symbolem tej polityki był Wernher von Braun - w III Rzeszy członek NSDAP i SS, konstruktor rakiet V2, który później został współtwórcą amerykańskiego programu kosmicznego. W koprodukcji pomiędzy RFN i USA powstał film biograficzny Wernher von Braun - sięgam gwiazd (Wernher von Braun - Ich greife nach den Sternen, 1960) w reżyserii J. Lee Thompsona, z Curdem Jürgensem w roli tytułowej. Recenzent „Der Spiegel" trafnie zauważył:

Niczym z dobrze skrojonego programu wyborczego każdy może wyciągnąć z tego filmu to, co go szczególnie zadowala: zarzut wobec bohatera, który skonstruował rakiety V2 - i pochwałę, że zrobił to dla Niemiec; zarzut, że zdradził Niemcy - i pochwałę, że uczynił to na rzecz Zachodu; zarzut, że zmienił barwy narodowe - i pochwałę, że pozostał wierny sobie ${ }^{177}$.

Z jednej strony mamy tu bowiem czynienia z typowym biopic (obejmującym okres od dzieciństwa bohatera, przez stosunkowo krótką sekwencję rozgrywającą się w III Rzeszy, akcentującą "opiekę", jaką Gestapo otoczyło ekipę i rodzinę naukowca, po wiek dojrzały, czyli jego

s. 28). W podobnym tonie pisze - z perspektywy czasu - Peter Reichel; jego zdaniem, Most to przykład „,wynalezionej pamięci o zbrodni wojennej, która spotkała Niemców, nie zaś została przez nich spowodowana. Ostatecznie film ten - czy tego chce, czy nie - jest uwalniającym od winy potwierdzeniem autostereotypu Niemców jako ofiar" (Peter Reichel, Erfundene Erinnerung..., s. 124).

${ }^{176}$ Helmut Dubiel, Niemand ist frei von der Geschichte. Die nationalsozialistische Herrschaft in den Debatten des Deutschen Bundestages, München 1999, s. 75.

177 „Der Spiegel” 1960, nr 36, s. 55. 
współpracę z aliantami), z drugiej zaś - dostrzegalne są pokrewieństwa z preferowanym przez Goebbelsa modelem Genie Film. Dość przytoczyć fragment dialogu z ostatniej sceny:

\begin{abstract}
Amerykański oficer: Choćbym miliony lat próbowat, nie zrozumiem kogoś takiego jak pan. Prosze mi powiedzieć, co w zasadzie naukowiec ma tu, w środku, tam gdzie zwykły człowiek ma serce?

Von Braun: Może odpowiedzialność za przyszłość? Kosmos, cały wszechświat czeka na nas. To właśnie dlatego jesteśmy ludźmi, a nie warzywami.
\end{abstract}

Specyficzny kształt przybrał popularny w zachodnioniemieckim kinie przełomu lat 50. i 60. gatunek, tj. film szpiegowski. Najbardziej znanymi produkcjami tego rodzaju były: Nie zawsze jest kawior (Es muss nicht immer Kaviar sein, reż. Géza von Rádvanyi, RFN 1956) i jej sequel Tym razem musi być kawior (Diesmal muss es Kaviar sein, reż. Géza von Rádvanyi, RFN 1956). Oba filmy zostały nakręcone na podstawie bestsellerowych powieści Johanessa Mario Simmela (ponownie zekranizowanych przez Thomasa Engela w trzynastoodcinkowym serialu dla zachodnioniemieckiej telewizji ZDF w 1977 r.). Pierwszy z filmów wprowadzał postać londyńskiego urzędnika, który podczas podróży służbowej do Berlina zostaje zmuszony do współpracy z Gestapo i wysłany jako szpieg do Paryża (a następnie "przewerbowany" przez brytyjskie Secret Service). W części drugiej (Tym razem musi być kawior) „podwójny agent” uwikłany jest w intrygę na Półwyspie Apenińskim.

Akcja dwóch filmów szpiegowskich rozgrywa się w Stanach Zjednoczonych. Tytułowy Niemiecki szpieg (Spion für Deutschland, reż. Werner Klingler, RFN 1956; scenariusz Herbert Reinecker) to Erich Gimpel, bohater wzorowany na autentycznej postaci o tym samym nazwisku. Rezygnuje on $\mathrm{z}$ powierzonego mu zadania zdobycia informacji o amerykańskim programie atomowym, gdy $\mathrm{w}$ trakcie misji zakochuje się w Amerykance. Ścigany, a następnie aresztowany przez FBI, otrzymuje wyrok śmierci, zamieniony później na karę więzienia (po jedenastu latach bohater wychodzi na wolność, prosto w objęcia czekającej nań Joan). Z kolei w wyprodukowanym przez Artura Braunera filmie Do zobaczenia (Auf Wiedersehn, reż. Harald Philipp, RFN 1961) trzej Amerykanie niemieckiego pochodzenia (wybuch wojny zastał ich w III Rzeszy) mają przedostać się łodzią podwodną do Stanów i wysadzić tam fabrykę; na miejscu wolą jednak spotkać się z rodziną. Ścigani przez FBI, w zakończeniu trafiają do... studia filmowego (nieopodal gra Louis Armstrong!), gdzie - obawiając się, ze zostaną skazani za zdradę - przebierają się w mundury pochodzące $\mathrm{z}$ antyniemieckiej produkcji! (fot. 39). 


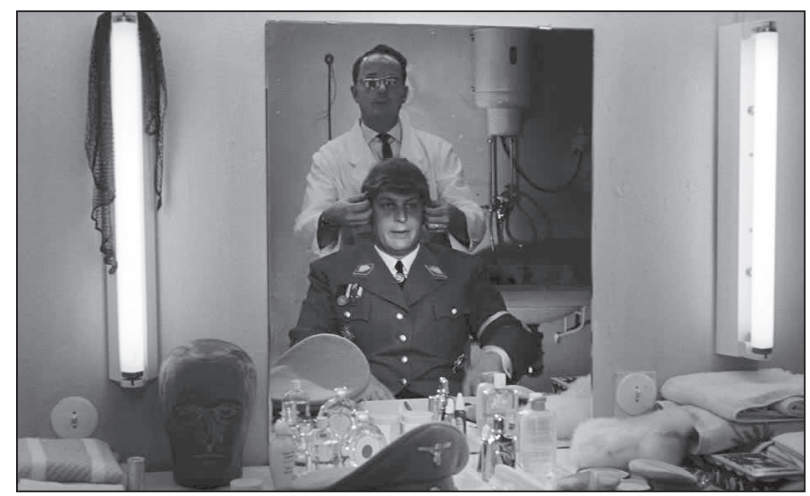

Fot. 39. Do zobaczenia (reż. Harald Philipp, 1961)

Odwrócenie schematu znanego z wielu filmów

o II wojnie światowej - aby uniknąć aresztowania,

Niemcy przebierają się nie w cywilne ubrania, lecz w... mundury Wehrmachtu

Osobliwie na tle zachodnioniemieckiego kina tamtych lat plasuje się Serenada armatnia (Kanonenserenade, reż. Wolfgang Staudte, RFN/Włochy 1958). Bohaterem komedii jest kapitan włoskiego statku przewożącego owoce i warzywa, który pod wpływem propagandy (brytyjska łódź podwodna nie atakuje statku, co zostaje poczytane za odniesione przezeń zwycięstwo) przeistacza się w fanatycznego "militarystę", pragnącego przejść do historii jako bohater wojenny (duch walki jest na pokładzie tak potężny, że jedynym pacyfistą wydaje się niemiecki oficer). Krytyk „Filmforum” z jednej strony zauważał, że film „w wielu aspektach wykracza poza jednostajność (Einerlei) niemieckich produkcji”, z drugiej zaś: przyporządkowywał Serenadę... do gatunku „zabawnej komedyjki”

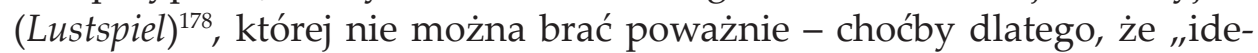
ologiczna przemiana marynarzy, z popleczników Hitlera w antymilitarystów, jest cokolwiek niespodziewana"179. Być może, gdyby reżyserii filmu podjął się Vittorio De Sica (odtwarzający tu główną rolę), powstałaby kolejna udana włoska komedia, wykpiwająca "czyn wojenny" wojsk Duce, a zarazem czyniąca aluzję do nagłej „zmiany frontu” - i przejścia Italii na stronę aliantów.

178 Dieter Krusche, Tomaten und Melonen sind besser als Kanonen, „Filmforum” 1958, nr 9. Krytycznie o filmie wypowiadali się też inni znani krytycy: Karena Niehoff („Der Tagesspiegel”, 2.08.1958) i Enno Patalas („Filmkritik” 1958, nr 9).

${ }^{179}$ Katrin Seybold, Die Welt verbessern mit dem Geld von Leuten, die die Welt in Ordnung finden. Filme in Bundesrepublik 1949-1971, [w:] Wolfgang Staudte, red. Eva Orbanz, Hans Helmut Prinzler, s. 38. 
Fabuły konfrontujące żołnierzy Wehrmachtu z mieszkańcami krajów, które w latach 50. należały do zachodniej strefy wpływów, akcentują „międzyludzką solidarność” i gotowość do przekroczenia wzajemnej wrogości. W filmie Misja Śnieżna Biel (Unternehmen Edelweiss, reż. Heinz Paul, RFN 1954) żołnierz niemieckiego oddziału górskiego i członek norweskiego ruchu oporu muszą zdecydować, czy w sytuacji wspólnego zagrożenia powinni walczyć ze soba, czy razem walczyć o przetrwanie. Z kolei Miłość zawisła na szubienicy (Am Galgen hängt die Liebe, reż. Edwin Zbonek, RFN 1960) opowiada historię małżeństwa Greków, które podczas walk toczonych w Helladzie w 1944 r. najpierw udziela pomocy partyzantowi z greckiego ruchu oporu, a później dwóm żołnierzom Wehrmachtu (w artykule zamieszczonym w "Der Spiegel” dostrzeżono, że scenariusz odwołuje się do mitu o Filemonie i Baucis ${ }^{180}$ - choć nie dopowiedziano już, że taka analogia nakazywałaby widzieć Zeusa i Hermesa w niemieckich żołnierzach). Natomiast w filmie 90 nocy $i$ jeden dzień (90 Nächte und ein Tag, reż. Edgar G. Ulmer, RFN/Włochy 1964), którego akcja rozgrywa się we Włoszech w 1944 r., nadużywający alkoholu brytyjski oficer, kanadyjski lotnik, włoski szeregowiec oraz niemiecki porucznik, zasypani w górach wskutek eksplozji, znajdują schronienie - na tytułowe trzy miesiące $-\mathrm{w}$ jaskini, gdzie fortunnie odkrywają zapasy wody. Zbliżoną historię opowiada nakręcony w tym samym roku film Kryptonim Czapla (Kennwort Reiher, reż. Rudolf Jugert, RFN 1964), do którego scenariusz opracował, na podstawie powieści Charlesa Morgana ${ }^{181}$, wspomniany już kilkakrotnie wcześniej Herbert Reinecker. Akcja rozgrywa się zimą 1944 r. na terytorium Belgii i Francji. Lokalna komórka ruchu oporu ukrywa zestrzelonego amerykańskiego lotnika, Philipa; wkrótce dołącza do niego inny Amerykanin, Frewers, jeszcze później - brytyjski major Barton, który twierdzi, że uciekł z niemieckiego obozu. Cała trójka, z pomocą Francuski Marie, ma zostać przerzucona do Hiszpanii - lecz okazuje się, że jeden z nich jest szpiegiem. Dopiero po wykonaniu wyroku śmierci na domniemanym zdrajcy okazuje się, że popełniono tragiczny błąd.

"Aliancka" tematyka erefenowskich fabuł wojennych z lat 50. wykorzystywała często formuły melodramatu i filmu szpiegowskiego. Program do filmu Lis z Paryża (Der Fuchs von Paris, reż. Paul May, RFN/Francja 1957; scenariusz Herbert Reinecker) zapowiada „opowieść przeciw szaleństwu wojny, której nie można już wygrać”. Tytułowym bohaterem jest generał Quade, który - świadom nadchodzącej inwazji aliantów oraz niemożności skutecznej obrony - konstruuje misterny plan przekazania Brytyjczykom

${ }^{180}$ Maßstäbe gesucht, „Der Spiegel” 1961, nr 19. W artykule jest również mowa o kontrowersjach związanych z decyzją FBW o nieprzyznaniu filmowi predykatu.

181 Charles Morgan, Akcja Spływ, tłum. A. Glinczanka, Warszawa 1960. 
niemieckich strategii defensywnych. W tym celu chce posłużyć się swoim siostrzeńcem, porucznikiem Fürstenwerth; zrządzeniem losu ten zakochuje się $\mathrm{w}$ dziewczynie mającej kontakt $\mathrm{z}$ ruchem oporu. Zdrada zostaje ukarana: Fürstenwerth ginie przed plutonem egzekucyjnym, a Quade popełnia samobójstwo. Akcja filmu Dzień, który nigdy się nie kończy (Ein Tag, der nie zu Ende geht, reż. Franz Peter Wirth, RFN 1959) rozgrywa się natomiast rok wcześniej (1943 r.), w neutralnej wówczas Irlandii. Opowiada o „miłości niemożliwej”: Roberta, niemieckiego kapitana łodzi podwodnej (schodzi on na ląd, by otrzymać pomoc dla załogi swego statku osiadłego na mieliźnie) oraz Irlandki Maureen, wdowy po lotniku służącym w amerykańskiej armii, którego samolot został strącony przez Luftwaffe. Początkowo Robert podaje się za Szwajcara, a gdy prawda wychodzi na jaw, Maureen prosi go, aby pozostał z nią na wyspie. Ponieważ próba ta nie odnosi skutku, kobieta - pragnąc za wszelką cenę nie dopuścić do rozłąki - decyduje się wydać Roberta brytyjskim służbom, uzyskawszy obietnicę, że mężczyzna zostanie internowany; nie wie jednak, że RAF planuje zbombardować statek Roberta.

Niektóre spośród wojennych fabuł szpiegowskich zrealizowanych w owym czasie w RFN wpisywały się w dyskurs o "Niemcach jako oponentach Hitlera” (zob. podrozdział 3.1), być może potwierdzając zarazem formułowane niekiedy przekonanie, iż pokój z Wielką Brytanią mógłby przynieść państwu niemieckiemu istotne korzyści. Przykładowo, w wyprodukowanym przez Artura Braunera filmie Tajna misja: Czarna Kapela (Geheimaktion schwarze Kapelle, reż. Ralph Habib, RFN/ Francja/Włochy 1959) niemieccy oficerowie spiskują przeciw władzy Hitlera już w 1940 r. i przekazują ważne informacje brytyjskiemu wywiadowi (pechowo jeden z nich zakochuje się w agentce SS). Natomiast Radiostacja Calais (Soldatensender Calais, reż. Joe May, RFN 1960) ${ }^{182}$ to rozgrywająca się w Paryżu pod koniec wojny historia dwóch niemieckich braci: Werner jest członkiem francuskiego ruchu oporu, zaś o szpiegowanie dlań zostaje podejrzany służący w Wehrmachcie Jochen, ocalony przez zakochaną w nim Francuzkę.

W każdej z wymienionych fabuł afera szpiegowska rozgrywa się pomiędzy Niemcami i aliantami zachodnimi, zaś jej finałem jest pojednanie. W tym kontekście za nietypowy można uznać film Rotmistrz Wroński (Rittmeister Wronski, reż. Ulrich Erfurth, RFN 1954). Opowiada on, inspirowane autentyczną historia, losy oficera wywiadu II Rzeczpospolitej,

182 Radio Calais - działająca od 1943 r., finansowana przez Brytyjczyków stacja adresowana do niemieckich żołnierzy, nadająca doniesienia z frontu (inne niż te, które można było usłyszeć w stacjach podporządkowanych goebbelsowskiej propagandzie) oraz muzykę jazzową, w III Rzeszy zakazaną. 
porucznika Jerzego Sosnowskiego, który - rozkochując w sobie sekretarki z ministerstwa obrony Rzeszy - wchodzi w posiadanie planów Wehrmachtu (fot. 40). W filmie dalsze sukcesy Polaka uniemożliwione zostają przez złamanie żelaznej zasady szpiega - bohater zakochuje się w swym „obiekcie rozpracowania”.

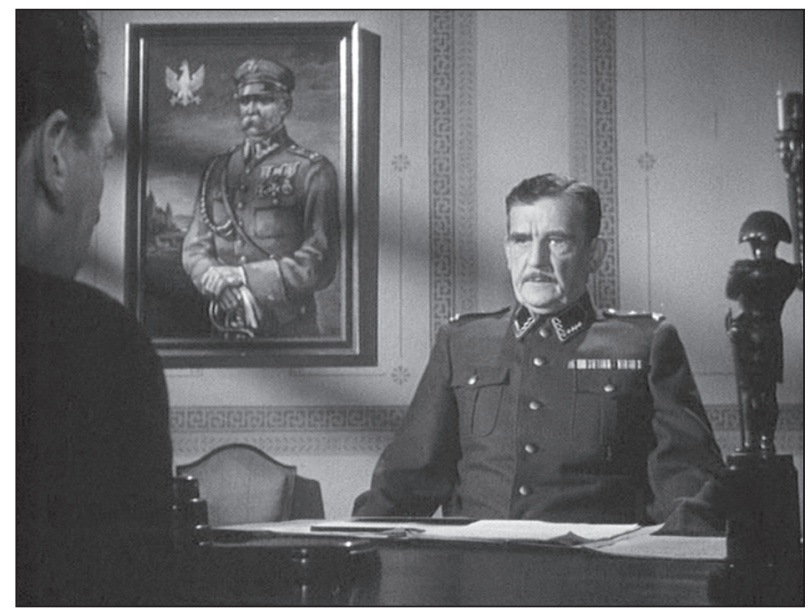

Fot. 40. Rotmistrz Wroński (reż. Ulrich Erfurth, 1954) W gabinecie oficera polskiego wywiadu znajduje się portret Piłudskiego i figurka Napoleona

W połowie lat 50. powstał w RFN film o zupełnie odmiennym schemacie - opowiadał bowiem o komunistycznym agencie działającym $\mathrm{w}$ niemieckim biurze prasowym w Tokio. Prototypem bohatera był autentyczny szpieg, Richard Sorge - jeden z „męczenników” sławionych przez enerdowską propagandę (a później, w 1964 r. pośmiertnie odznaczony tytułem Bohatera Związku Radzieckiego ${ }^{183}$ ). Z uwagi na kontrowersyjny temat oraz padające $\mathrm{w}$ dialogach pochwały pod adresem ZSRR, produkcja ta - zatytułowana Zdrada Niemiec (Verrat an Deutschland, RFN 1954) - początkowo nie otrzymała certyfikatu FSK. Zgodę na dystrybucję uzależniono od wprowadzenia do materiału daleko idących zmian ${ }^{184}$, zaś w prasowych artykułach reżyser został posądzony o prosowieckie sympatie (podejrzenie takie było cokolwiek osobliwe, zważywszy że twórcą tym był Veit Harlan).

183 Także w PRL opublikowano dwa przekłady książek rosyjskich autorów na ten temat: Fiodor D. Wołkow, Richard Sorge, tłum. I. B. Stepowicz, Warszawa 1976; Jurij Korolkow, Operacja "Ramsay": opowieść o Richardzie Sorge, Warszawa 1968.

${ }^{184}$ Erika Müller, Der Fall Sorge oder Harlans „Verrat an Deutschland”, „Die Zeit” 1955, nr 3. 
Wybór miejsc, w jakich rozgrywają się wydarzenia przedstawione w większości wymienionych produkcji nieprzypadkowo pokrywał się ze strefami oddziaływania NATO. Takie polityczne wyjaśnienie nie w każdym wypadku jest wystarczające - kto wie, czy nie należałoby zwrócić uwagi także na "turystyczny" (wizualnie atrakcyjny) wymiar zagranicznych lokacji. Przykładowo, film Młodzieńcy w niebieskich mundurach (Blaue Jungs, reż. Wolfgang Schleif, RFN 1957), którego akcja rozgrywała się na tle wojny na Pacyfiku w 1945 r., reklamowany był wyeksponowanym na plakacie sloganem: „Marynarze, Morze Południowe, dziewczyny”. Wabikiem przyciągającym widzów do kin miała być zatem egzotyka - a może i obietnica erotycznych ćwiczeń, którą mogła zapewnić (sugerowana przez fabułę) koniunkcja „marynarzy” i „dziewczyn”. Z kolei na plakacie do filmu Błyskawiczne dziewczyny na froncie (Blitzmädels an die Front, reż. Werner Klingler, RFN 1958) ${ }^{185}$ znajduje się napis: „O czym nie mówiono w raportach Wehrmachtu" (co bynajmniej nie zapowiadało demaskatorskiego przedstawienia zbrodni popełnianych przez armię - chodziło raczej o zasugerowanie lekko perwersyjnej atmosfery panującej w koszarach, w których stacjonuje trzydziestka młodych kobiet) ${ }^{186}$. Do gatunku „farsy koszarowej” należy z kolei rozgrywająca się w okupowanej Francji komedyjka Frontowy kogut (Der Frontgockel, reż. Ferdinand Dörfler, RFN 1955).

Międzynarodowa intryga (niemiecko-amerykańsko-francusko-polska) pojawia się również w filmie Mokry asfalt (Nasser Asphalt, reż. Frank Wisbar, RFN 1958) ${ }^{187}$. Główny bohater, Greg Bachmann, młody adept

${ }^{185}$ Niezbyt może fortunna propozycja przekładu wynika z polskiego tłumaczenia książki Hansa Hellmuta Kirsta, który napisał scenariusz do filmu (powieść o Blitzmädels - mianem tym określano kobiety pracujące w służbach informacyjnych III Rzeszy - opublikowano później, w 1984 r.). Hans Hellmut Kirst, Błyskawiczne dziewczyny, tłum. S. Marciniak, Warszawa 1996.

186 Ten sam reżyser nakręcił dla wytwórni Artura Braunera film Lebensborn (reż. Werner Klingler, RFN 1960), którego akcja rozgrywa się częściowo w otoczonych niechlubną sławą "ośrodkach hodowli rasowej”. W publikacjach informujących o produkcji Brauner zapowiadał film oparty na skrupulatnych badaniach i relacjach świadków (http://www. spiegel.de/spiegel/print/d-43159321.html, dostęp: 20.01.2014). Dziś film ten, we Francji znany jako Les fiancées d'Hitler (Narzeczone Hitlera), a w krajach anglojęzycznych rozpowszechniany pod tytułem Women ordered to love (Kobiety skazane na miłość), uchodzi za „,kultowy" wśród miłośników sexploitations movies w rodzaju Elsa, wilczyca z SS (Ilsa, She-Wolf of the SS, reż. Don Edmonds, USA 1975).

187 Być może bardziej zasadne byłoby tłumaczenie: Mokry bruk (sformułowanie Asphalt-Journalismus można bowiem przełożyć jako „dziennikarstwo brukowe”). O manipulacjach prasy bulwarowej będzie 16 lat później pisał Heinrich Böll w Utraconej czci Katarzyny Blum, którą w kolejnym roku zekranizuje Volker Schlöndorff (Die verlorene Ehre der Katharina Blum, RFN 1975). 
dziennikarstwa warunkowo zwolniony z więzienia, gdzie przebywał za próbę przeprowadzenia wywiadu ze zbrodniarzami wojennymi w Spandau (!), zostaje asystentem nestora żurnalistyki, Cesarego Boyda, którego teksty chętnie publikowane są w zagranicznej prasie (i którego wpływy sięgają wysoko - z dialogów wynika, że właśnie za jego sprawą skrócono wyrok Bachmanna). Traf chce, że pewnego dnia obaj mężczyźni (pogrążeni w rywalizacji o młodą dziewczynę) zapominają o napisaniu artykułu do francuskiego pisma. Wówczas Boyd na poczekaniu wymyśla historię inspirowaną relacją swego szofera, który pod koniec wojny wraz z innymi żołnierzami odkrył bunkier wypełniony po brzegi konserwami. Artykuł Boyda opisuje losy pięciu żołnierzy Wehrmachtu, którzy nieopodal Gdyni rzekomo przez kilka lat ukrywali się w takim bunkrze; jeden z nich miał nawet przeżyć. Informacja staje się sensacją - aby sprawdzić jej wiarygodność, Amerykanie przysyłają do Polski swojego korespondenta, który jest świadkiem zamknięcia terenu w okolicach bunkra, co tylko utwierdza dziennikarza w przekonaniu o prawdziwości doniesień Boyda. Dochodzi do międzynarodowej afery - na ulicach niemieckich miast rozgrywają się dantejskie sceny z udziałem matek i żon żołnierzy zaginionych na wojnie (protestujący są przekonani, że strona polska przetrzymuje jednego z „zabunkrowanych"). W konsekwencji dochodzi do przepychanki przed polską misją wojskową w Berlinie Zachodnim (tłum zostaje rozproszony dzięki armatkom wodnym, z którymi przyjeżdża policja). Ostatecznie Greg zdaje sobie sprawę z matactw Boyda, który postanawia poświęcić go, by ratować własną skórę.

Scenariusz - stworzony wraz z reżyserem przez Willa Trempera, który wcześniej napisał scenariusz do Chuliganów (Die Halbstarken, reż. Georg Tessler, RFN 1956; dzięki temu filmowi gwiazdą stał się Horst Bucholz, grający w Mokrym asfalcie) - odsyła do autentycznego skandalu z 1951 r. Amerykańska agencja prasowa Associated Press podała wówczas informację o tajemniczym bunkrze, w którym przez kilka lat żyli żołnierze Wehrmachtu (a jeden $\mathrm{z}$ nich, jak w filmie, miał jakoby przeżyć). Doniesienie to nie zostało wprawdzie potwierdzone, ale zaczęło „żyć własnym życiem" - w 1952 r. powstał obszerny poemat Rudolfa Hagelstange Ballada o zasypanym życiu (Ballade vom verschütteten Leben), sztuka Margarete Hohoff Die Legende von Baby Doly (chodziło o Babie Doły w Gdyni), a także kilka innych relacji publikowanych w rozmaitych mediach ${ }^{188}$.

188 Zob. Die Legende von Babie Doly, „Der Spiegel” 1958, nr 5 (http://www.spiegel. de/spiegel/print/d-41760577.html, dostęp: 10.01.2014); także: Der Angeklagte als Richter. In Hamburg entsteht ein giftiger Film: Nasser Asphalt, „Die Zeit”, 20.02.1958 (http://www.zeit. de/1958/08/der-angeklagte-als-richter, dostęp: 10.01.2014). Ponadto, w tych materiałach pojawiają się informacje o obszernym artykule (temat numeru zapowiedziany ilustracją na okładce) w popularnym ilustrowanym czasopiśmie „Kristall” z 1951 r. i słuchowisku radiowym stacji NWR z 1952 r., a także noweli opublikowanej we wschodnioniemieckim 
Na interpretację filmu przez ówczesnych widzów rzutować mogły informacje prasowe, w których scenarzysta wyjaśniał, iż mamy do czynienia z "opowieścią z kluczem": Tremper, podobnie jak filmowy Greg Bachmann, pracował mianowicie jako ghostwriter dla znanego dziennikarza. Pierwowzorem filmowego Boyda miał być Curt Riess, niemiecki dziennikarz żydowskiego pochodzenia, który powróciwszy do ojczyzny po II wojnie światowej, mając już w dorobku kilka książek wydanych na emigracji w USA ${ }^{189}$, zaczął publikować w magazynie "Stern" popularne felietony o gwiazdach i arcydziełach dawnej Ufy. Innymi słowy: człowiek, na którym wzorowana była postać Boyda, mógł należeć raczej do ofiar niż beneficjentów narodowego socjalizmu.

\subsection{Wróg zewnętrzny: opowieści rosyjskie}

Innym ważnym dyskursem kształtującym tożsamość zachodnioniemieckiego społeczeństwa stał się „antytotalitaryzm” - z jednej strony oznaczał on potępienie nazizmu, z drugiej zaś - komunizmu (a zatem ideologii, na której swą autoidentyfikację oparła NRD). Jak stwierdza Kazimierz Wóycicki, w latach 50. wychowanym we wrogości wobec bolszewizmu Niemcom powtarzano, że „należy wciąż przeciwstawiać się temu samemu komunistycznemu zagrożeniu, z którym innymi środkami walczył hitleryzm w latach 30. Tym samym niebezpieczeństwo komunizmu do pewnego stopnia mogło podświadomie usprawiedliwiać nazizm"190.

Dyskurs antykomunistyczny $\mathrm{w}$ kinie zachodnioniemieckim prowadzony był oczywiście również w omówionych już fabułach rozgrywających się na froncie wschodnim (zob. podrozdział 2.2) i - stosunkowo nielicznych - filmach współczesnych dotyczących podziału Niemiec (tematycznie sytuują się one poza zakresem niniejszej książki ${ }^{191}$. O „,długim

\footnotetext{
„Monatsschrift für Schöne Literatur und Kritik” w latach 50. (nie udało mi się ustalić numeru; nowela Pfeiffera została opublikowana jako osobny wolumin: Hans Pfeiffer, Die Höhle von Babie Doly: Erzählung, Leipzig 2004). Co ciekawe, historia ta doczekała się fabularyzacji w Polsce - w wydawnictwie Czytelnik ukazała się w 1959 r. (z dodrukiem w roku kolejnym) powieść na ten sam temat (Zenon Skierski, Gdy słońce gaśnie, Warszawa 1959).

${ }_{189}$ Na przykład popularnonaukową książkę o gwiazdach kina: Curt Riess, Das gab's nur einmal. Das Buch der schönsten Filme unseres Lebens, Hamburg 1956.

${ }^{190}$ Kazimierz Wóycicki, Niemiecki rachunek..., s. 50. Dla powstania i implementacji tej polityki nie bez znaczenia mógł być fakt, iż - jak podaje Norbert Frei - w 1950 r. w Ministerstwie Spraw Zagranicznych RFN na niemal wszystkich kierowniczych stanowiskach zasiadali urzędnicy będący na służbie jeszcze w czasach Ribbentropa, a dwie trzecie z nich było wcześniej członkami NSDAP (Norbert Frei, Polityka wobec przeszłości..., s. 89).

${ }^{191}$ Można także wspomnieć o filmie Dopóki żyjesz (Solange du lebst, reż. Harald Reinl, RFN 1955), rozgrywającym się w Hiszpanii okresu wojny domowej (pielęgniarka, zaręczona
} 
trwaniu" II wojny światowej i jej konsekwencjach w najbardziej spektakularny sposób traktują jednak filmy, których akcja rozgrywa się po 1945 r., w sowieckich obozach na Syberii. Ich wyróżnikiem jest łączenie formuły gatunkowej filmu więziennego (a dokładniej: stanowiących jego istotę motywów nadzoru i woli ucieczki) oraz melodramatu (przepełniająca fabułę wiara w miłość, która - na przekór trudnościom - może przezwyciężyć narodowe i polityczne podziały). Przykładowo, w Tajdze (Taiga, reż. Wolfgang Liebeneiner, RFN 1958) do obozu dla niemieckich jeńców wojennych, bestialsko traktowanych przez sowieckich strażników, trafia nowy transport więźniów, wśród nich lekarka, dr Hanna Dietrich. O jakichkolwiek rozliczeniach z nazizmem nie ma tu mowy - akcję modelują wątki damsko-męskie (jeden z więźniów heroicznie staje w obronie lekarki, gdy dochodzi do próby gwałtu; pomiędzy niedoszłą ofiarą i wybawcą wywiązuje się romans).

Bardziej złożoną intrygą odznaczał się Diabeł grał na bałałajce (Der Teufel spielte Balalaika, reż. Leopold Lahola, RFN 1961), którego patetyczne motto, umieszczone w napisach początkowych, brzmi: Ten film jest apelem do ludzkości - jedynej więzi, która może połaczyć świat podzielony na Wschód i Zachód. Nadzorcą sowieckiego obozu dla internowanych jeńców niemieckich i japońskich, zmuszanych do ciężkiej pracy fizycznej w kamieniołomach, jest sadystyczny porucznik Fusow. Lepiej traktuje więźniów jedynie oficer polityczny Seidenwar (podkreślone jest jego żydowskie pochodzenie) i jego tłumaczka, a prywatnie żona Elena, Żydówka z Austrii, która sama była wcześniej więziona w niemieckim obozie koncentracyjnym. Małżeństwo pomaga uciec głównemu bohaterowi filmu, Peterowi Joostowi - jak się wydaje, z humanitarnych pobudek. Los internowanych w sowieckich obozach jest kilkakrotnie porównywany z sytuacją więźniów niemieckich kacetów - zarówno w dialogach (Śniło mi się, że ten drut kolczasty jest moim drutem kolczastym, i to więzienie jest moim więzieniem - mówi do męża Elena), jak i w warstwie wizualnej (gdy w jednej z ostatnich scen Elena stoi za drutem kolczastym, trudno oprzeć się wrażeniu, że mamy do czynienia z dyskursywnym „przeniesieniem” losu Żydów prześladowanych na terenie zajętym przez Niemcy na obszar ZSRR $)^{192}$. Co więcej, w materiałach promocyjnych i recenzjach podkreślano, iż zarówno reżyser, jak i produ-

\footnotetext{
z żołnierzem walczącym po stronie generała Franco, zakochuje się w rannym niemieckim lotniku, na trop którego wpadają żołnierze komunistycznych brygad). Przykład to tyleż interesujący, co odosobniony: w kulturze politycznej RFN wojna domowa w Hiszpanii nie stanowiła tak ważnego punktu odniesienia, jak w NRD.

192 Zob. także: Robert G. Moeller, Geschichten aus der "Stacheldrahtuniversität": Kriegsgefangene auf Zelluloid in der Bundesrepublik Deutschland, "Amsterdamer Beiträge zur neueren Germanistik" 2001, nr 50.
} 
cent (Peter Bamberger) byli internowani w sowieckich obozach. W ten sposób ekstradiegetyczna "otulina” filmu współgrała z wewnątrztekstową sugestią rzekomej niemiecko-żydowskiej „wspólnoty ofiar”. Wydaje się, że krytyka dostrzegła ten potencjał filmu - choć oceniała go rozmaicie: recenzent „FAZ” uznał Diabła... za „ważny wkład w opisywanie najnowszej historii" ${ }^{193}$, natomiast krytyk z „Der Spiegel” zwracał uwagę, że „Dachau zostało anulowane przez Workutę"194.

Gdy po wizycie Adenauera w ZSRR w 1956 r. sowieci ogłosili wypuszczenie $\mathrm{z}$ więzień wszystkich, tj. ok. 30 tysięcy, pozostających tam jeszcze Niemców (wpływowe zachodnioniemieckie grupy weteranów wojennych uznały, że obietnica nie została spełniona, a ich towarzysze broni nadal przetrzymywani są w łagrach), przez ekrany niemieckich kin „przedefilowali” bohaterowie powracający ze Wschodu. Postaci takie pojawiały się w niektórych heimatfilmach, ale tylko w jednej fabule (główna część jej akcji rozgrywa się w czasie wojny) - w roli pierwszoplanowej. Lekarz ze Stalingradu (Der Arzt von Stalingrad, reż. Géza von Radványi, RFN 1958) ${ }^{195}$ - na podstawie powieści Heinza Konsalika - inspirowany był prawdziwą historią doktora medycyny Ottomara Kohlera, który brał udział $\mathrm{w}$ walkach na froncie wschodnim, a po aresztowaniu przez sowietów „zaliczył” trzynaście obozów, by powrócić do ojczyzny dopiero w $1954 \mathrm{r}$.

Jego przeżycia posłużyły jako materiał opowieści o dr. Fritzu Böhlerze (w tej roli Otto E. Hasse, znany z Canarisa i 08/15), który w pierwszej sekwencji filmu powraca do Niemiec. Jest ona zbudowana $w$ interesujący sposób. Po ujęciach z archiwalnym footage dokumentującym powrót do domu byłych więźniów wojennych (w oknach gapie, na ulicy grupa mężczyzn w zniszczonych ubraniach, jedna z kobiet trzyma w dłoni fotografię przedstawiającą zapewne bliskiego jej człowieka) akcja przenosi się do hotelu, w którym bohater chce wynająć pokój (na ścianie w hallu wisi zdjęcie ruin z napisem: Tyle zostało z hotelu Anker w 1943 roku). Nie widać twarzy tego mężczyzny - kamera wyprzedza aktora, później filmuje tylko jego ręce, na ścieżce dźwiękowej słychać głos z offu, sam bohater wypowiada ledwie jedno zdanie. Taka konstrukcja sceny wykorzystuje właściwe stylowi klasycznemu chwyty ukierunkowane na wzbudzenie zainteresowania protagonistą - a zarazem podkreśla jego osamotnienie, status

193 Anon., „Frankfurter Allgemeine Zeitung”, 22.07.1961.

194 Anon., „Der Spiegel” 1961, nr 14.

195 Film Lekarz ze Stalingradu niekiedy określany jest jako trzecia część „trylogii wojennej" Gézy von Radványi'ego, której dwie pierwsze odsłony (Gdzieś w Europie [Valahol Európában, 1947] i Bezimienna kobieta [Donna senza nome, 1949]) nakręcone zostały, odpowiednio, na Węgrzech i we Włoszech. 
"człowieka znikąd" i stanowi dobre wprowadzenie do rozpoczynającej się chwilę później retrospekcji. Gdy Böhler przypomina sobie moment swego pojmania pod Stalingradem, na ścieżkę dźwiękową nie zostaje wprowadzony jego "monolog wewnętrzny”, lecz archiwalne przemówienie radiowe Hitlera, w którym wyklucza on kapitulację. Obrazy zniszczenia towarzyszące tym słowom (zestrzelone samoloty, palące się budynki, ranni żołnierze) świadczą o czymś dokładnie przeciwnym; doświadczenie osobiste zostaje kontrapunktowo zestawione z propagandą czasu wojny.

Podobnie jak inni protagoniści zachodnioniemieckich filmów wojennych tamtego czasu, Böhler jest przedstawiony jako "zwykły Niemiec" (Nie jestem bohaterem. Jestem Fritz Böhler z Würzburga), pozbawiony przekonań politycznych (nie mówi zresztą o swych przeżyciach wojennych - z ust innych postaci dowiadujemy się, że stracił jedyną córkę podczas bombardowania), w swych działaniach powodowany empatią i pobudkami humanitarnymi (rezygnuje z warunkowego zwolnienia, poświęcając się dla dobra społeczności), które podkreślane są przez symbolikę chrześcijańską. Gdy dr Böhler jest po raz pierwszy pokazany w szpitalu i wraz $\mathrm{z}$ asystentem spiera się ze swymi radzieckimi kolegami o sposób traktowania pacjentów, kamera wyraźnie eksponuje prawosławny krzyż na ścianie (budynek służył niegdyś jako kościół). Do przestrzeni tej wprowadzony zostaje demonicznie przedstawiony rosyjski lekarz, który chce wysłać rannych więźniów wojennych do pracy. Gdy Böhler protestuje, filmowany jest na tle ikon (co nadaje cierpiącym żołnierzom wymiar męczenników, a jemu - status świętego, dokonującego cudów, kiedy leczy ich rany).

Inaczej jednak niż w wielu zachodnioniemieckich filmach wojennych tamtego czasu, fabuła von Radványi'ego akcentuje profesję bohatera, a nie jego stopień wojskowy - nie jest istotny fakt, że Böhler pełni funkcje podoficera, a jedynie to, że ma medyczne wykształcenie ${ }^{196}$. W konsekwencji, brak w Lekarzu ze Stalingradu "kozła ofiarnego", którym w wymienionych filmach stawał się oficer lub członek generalicji. Prawdziwymi czarnymi charakterami są u von Radványi'ego sowieci, utrudniający szlachetne starania Böhlera. Sytuację protagonisty komplikuje także związek jego asystenta, dr. Sellnowa, z rosyjską oficer Alexandrą Kasalinskają (mamy $\mathrm{w}$ filmie i drugi romans: inny niemiecki żołnierz zakochuje się w sowieckiej porucznik) ${ }^{197}$. Rywalem przystojnego Sellnowa jest przełożony Ka-

196 Jennifer M. Kapczynski, The Treatment of the Past: Géza Radvanyi's "Der Arzt von Stalingrad" and the West German War Film, [w:] Take Two. Fifties Cinema in Divided Germany, red. John Davidson, Sabine Hake, Berghahn 2007, s. 142.

197 Inny wariant „niemiecko-sowieckiego” romansu pojawia się w filmie ...jak kiedyś Lili Marleen (...wie einst Lili Marleen, reż. Paul Verhoeven, RFN 1956). Podczas wojny niemiecki żołnierz zakochuje się w robotnicy przymusowej pracującej w fabryce. On trafia 
salinskiej, niejaki Markow (chudy jak szczapa i pozbawiony ręki, którą stracił w czasie wojny). Odkrywa on romans pary chwilę przed planowanym odjazdem Sellnowa (Markow zabija go, zaś Kasalinskaja zostaje aresztowana). W swej analizie filmu Jennifer Kapczynski poświęca temu wątkowi wiele miejsca, dochodząc do wniosku, iż w Lekarzu ze Stalingradu mamy do czynienia $\mathrm{z}$,przedstawieniem frontu wschodniego nie jako terytorialnej agresji, ale romansu, w którym niemieccy mężczyźni są raczej odbiorcami niż inicjatorami"198.

O ile w zasadniczej części narracji Lekarz ze Stalingradu nie odbiega od innych zachodnioniemieckich filmów wojennych tamtego czasu, o tyle jego finałowa sekwencja jest dość osobliwa. Gdy Böhler napotyka, już w powojennych Niemczech, wojskową paradę, pojawia się szereg ujęć w trybie mind-screen, sugerujących wizję możliwej nowej wojny: przed oczami (wyobraźni) bohatera maszerują krasnoarmiejcy, armia koreańska (jeśli właściwie rozpoznałem mundury - $\mathrm{w}$ każdym razie jest to piechota azjatycka), następnie pojawiają się samoloty wojskowe, wystrzeliwane rakiety... Ostatnie ujęcie to stop-klatka, na zbliżeniu ukazująca twarz protagonisty, która wyraża szok i przerażenie; bohater zdaje się myśleć: „tragedia wojny niczego nas nie nauczyła". To zakończenie, być może sugerujące lęk przed kolejnym konfliktem światowym i będące świadectwem pacyfistycznych nastrojów tamtego czasu (II połowie lat 50. to w Europie Zachodniej, także w RFN, czas krystalizacji ruchów antynuklearnych), pozostaje zarazem - w kontekście fabuły Lekarza za Stalingradu - krytyczne wobec ruchu weteranów wojennych, by nie rzec: środowisk „rewanżystowskich”.

A jednak to właśnie w środowisku weteranów (na przykład na łamach periodyku „Der Heimkehrer" ${ }^{199}$ ) film miał najlepszą prasę. Okazał się zresztą sporym sukcesem kasowym (co dla producenta i dystrybutora było szczególnie istotne, gdyż FBW nie przyznała Lekarzowi... predykatu uprawniającego do zniżek podatkowych). Krytycy z wysokonakładowych dzienników chwalili dokumentalny prolog, ale utyskiwali na

najpierw na front, a później do sowieckiego obozu. Gdy po dziesięciu latach zostaje wypuszczony na wolność, wraca do Berlina i szuka ukochanej (w zakończeniu są już razem - korzystają z erefenowskiego Wirtschaftswunder, spacerując aleją handlową Berlina Zachodniego).

198 Jennifer M. Kapczynski, The Treatment of the Past..., s. 146. Tego spostrzeżenia nie należy jednak rozciągać na inne zachodnioniemieckie filmy wojenne tamtego czasu. W Psy, chcecie żyć wiecznie? niemiecki oficer pomaga Rosjance uniknąć deportacji do niemieckiego obozu pracy, ale brak tu wątku romansowego (pomoc udzielona kobiecie opłaci się bohaterowi - ona pomoże mu bowiem, gdy spotkają się po raz drugi na terytorium zajętym przez sowietów). Z kolei w drugiej części 08/15 niemiecki żołnierz, owszem, zakochuje się w Rosjance, ale po spędzonej wspólnie nocy ona okaże się szpiegiem.

199 Peter Reichel, Erfundene Erinnerung..., s. 90. 
„fałszywe tony sentymentalizmu” 200 i „pseudorealistyczne uwznioślenia (Edelreißer)" 201 . Nietrudno się domyślić, że w zajadły sposób zaatakowała Lekarza... prasa enerdowska, określająca tę produkcję jako „film wzywający do nienawiści" (Hetzfilm) ${ }^{202}$. W żadnej z ówczesnych recenzji nie pojawiły się tropy dostrzegane przez komentatorów piszących w XXI w., wskazujące na dyskursywną "podmianę ofiar" (za sprawą scen, w których za drutami kolczastymi stłoczeni są Niemcy - Sonja M. Schultz twierdzi wręcz, że napis Arbeit macht frei został w Lekarzu... zastąpiony przez czerwoną gwiazdę, którą umieszczono nad bramą filmowego obozu ${ }^{203}$ ).

Powyższy przykład - zarówno tekstualna obecność symboli totalitarnych, jak i jej współczesna interpretacja - uświadamia znaczenie zachodnioniemieckich "filmów syberyjskich". Zawarte w nich "zastępcze powidoki" (czyli obrazy sowieckich łagrów - występujące w zachodnioniemieckiej ikonosferze lat 50. z podobną "częstotliwością", co obrazy obozów hitlerowskich) mówią wiele o ówczesnej pamięci o zbrodniach popełnianych w czasie wojny. Pytanie o zasadność takich porównań powróci „rykoszetem” w latach 80. za sprawą tzw. „sporu historyków”, czyli debaty o zrównywaniu nazizmu i komunizmu (zob. zakończenie).

Uwaga ta dotyczy nie tylko filmów kinowych, lecz także dwóch niezwykle popularnych realizacji telewizyjnych z przełomu lat 50. i 60. Jak daleko nogi poniosa (So weit die Füsse tragen, reż. Fritz Umgelter, RFN 1959) to sześcioodcinkowy serial, traktujący o perypetiach niemieckiego jeńca wojennego, który w 1949 r. uciekł z syberyjskiego łagru (dzięki pomocy Igora, armeńskiego Żyda). Materiał fabularny oparto na relacji (jak się okazało, mocno podkoloryzowanej) żołnierza, który na początku lat 50. opowiedział swą historię pod pseudonimem Cornelius Rost. Ośmiogodzinny wywiad posłużył jako kanwa powieści Josefa Bauera, wydanej w 1955 r., a następnie zaadaptowanej na słuchowisko radiowe ${ }^{204}$, finalnie zaś - na wspomniany serial (w opracowaniach niemieckiej kultury audio-

${ }^{200}$ Karl Korn, Heroische Sentimentalität, ein Filmlaster, „Frankfurter Allgemeine Zeitung", 28.02.1958.

${ }^{201}$ Franziska Violet, Der Artz von Stalingrad, "Süddeutsche Zeitung”, 29.04.1958.

202 Der Engel, der keiner ist. Der geistige Vater des Hetzfilms "Arzt von Stalingrad" ein Lügner, "Neues Deutschland” 7.8.1958, Fälschung mit Variationen. Der Hetzfilm "Arzt von Stalingrad” am Pranger, "National Zeitung” 5.8.1958. W języku niemieckim terminem Hetzfilm określane były - i są nadal - m.in. antysemickie filmy powstałe w okresie III Rzeszy.

${ }^{203}$ Sonja M. Schultz, Der Nationalsozialismus im Film: Von „Triumph des Willens' bis "Inglorious Bastards", München 2012, s. 77.

${ }^{204}$ Książka Bauera (So weit die Füße tragen) miała 51 wydań w ciągu 51 lat. W 2010 r. śledztwo dziennikarskie ujawniło, że w opowieści jest wiele przekłamań - zob. http://www. sueddeutsche.de/kultur/falsche-nachkriegserinnerungen-der-schnee-von-gestern-1.12263 (dostęp: 2.01.2014). 
wizualnej określany jako Straßenfeger - co oznacza, iż podczas jego emisji pustoszały ulice zachodnioniemieckich miast ${ }^{205}$. Z kolei punktem wyjścia każdego z pięciu (pełnometrażowych) odcinków nakręconego na podstawie powieści Hansa Scholza dwa lata wcześniej miniserialu $\mathrm{Na}$ zielonej plaży nad Szprewa (Am grünen Strand der Spree, reż. Fritz Umgelter, RFN $1960)^{206}$ jest historia opowiadana przez jednego z byłych żołnierzy, którzy spotykają się w 1954 r. na przyjęciu z okazji późnego powrotu (z sowieckiego obozu) ich majora.

Najciekawszy jest pierwszy odcinek tej serii, Dziennik Jürgena Wilmsa (Das Tagebuch des Jürgen Wilms). Tytułowy pamiętnik - przekazany towarzyszom broni przez autora, nadal przebywającego w sowieckim obozie - zawiera relację $\mathrm{z}$ kampanii $\mathrm{w}$ Polsce i ZSRR, w filmie przedstawioną w obszernej retrospekcji. Niewątpliwie Dziennik... wyróżnia się na tle innych fabuł o Wehrmachcie nakręconych w Niemczech w tamtych latach. Co prawda, także w tym filmie podtrzymany zostaje obraz żołnierzy walczących dla III Rzeszy jako skonfliktowanych z jej politycznym przywództwem: Wilms jest konfrontowany z bezwzględnym oficerem politycznym, Jaletzkim (grozi on wyciagnięciem surowych konsekwencji wobec protagonisty, gdy ten chce podzielić się konserwą z żydowskim dzieckiem; wówczas inni żołnierze biorą Wilmsa w obronę - Wehrmacht to nie szkótka partyjna!). Dziennik... akcentuje przy tym moralne rozterki żołnierzy poprzez (rzadko wówczas stosowany) ponadkadrowy "głos wewnętrzny" bohatera - na przykład w scenie, w której Żydzi ustawiani są w pierwszych szeregach jako żywe tarcze, słychać słowa Wilmsa: Nienawidzę tego. W jakim stopniu można się utożsamiać z działaniami własnego rządu? Czy wystarczy wewnętrzne ich odrzucenie?

Zarazem jednak, jak żaden inny zachodnioniemiecki film tego czasu, Dziennik... pokazuje współudział Wehrmachtu w masowych egzekucjach i pogromach na ludności żydowskiej. Szczególnie wstrząsająca pod tym względem jest - trwająca blisko dwadzieścia minut - przedostatnia

${ }^{205}$ W 2001 r. premierę miał remake serialu Jeniec: jak daleko nogi poniosa (So weit die Füsse tragen, reż. Hardy Martin). Ponadto wydano luksusową edycję DVD oryginalnego serialu - w eleganckim metalowym pudełku można znaleźć m.in. mapę Europy i Azji pokazującą trasę, jaką pokonał bohater. Jest to mapa cokolwiek osobliwa: zachodnie granice Polski oznaczono konturami zgodnymi z mapą polityczną z 1938 r., zaś wschodnie - z 1946 r. (tego rodzaju „,kartograficzna schizofrenia” była stosunkowo rozpowszechniona w podręcznikach drukowanych w RFN w latach 50.).

${ }^{206}$ Lars Koch, Das Fernsehbild der Wehrmacht am Ende der fünfziger Jahre. Zu Fritz Umgelters Fernsehmehrteiler "Am grünen Strand der Spree”, [w:] Der Holocaust im Film. Mediale Inszenierung und kulturelles Gedächtnis, red. Waltraud Wende, Heidelberg 2007, s. 71. Koch zwraca uwagę, że była to kosztowna produkcja - wedle jego ustaleń pochłonęła ona $2 \mathrm{mln}$ marek, wymagała 240 lokacji i 24,5 tys. statystów. 
sekwencja filmu, przedstawiająca mord na ludności cywilnej (fot. 41). Sekwencja ta składa się z trzech części. W pierwszej (gdy bohater zbliża się do posterunku Sonderkommando) pokazana zostaje zabawa mówiących po polsku (!) dzieci, które udają rozstrzeliwanie żydowskiego chłopca (Żydam pagrom - informuje Wilmsa dziewczynka). Następnie bohater jest świadkiem przyjazdu transportu (Żydzi z Polski - powinien pan to wiedzieć - instruuje go oficer). Ponieważ wśród przeznaczonych do rozstrzelania jest Żydówka, w której bohater wcześniej się zakochał, Wilms odciagga jednego ze strażników na stronę i przekonuje go do wypuszczenia kobiety. Ta jednak odmawia ucieczki, nie chcąc opuszczać swej rodziny; na pożegnanie zdąży jeszcze przekazać Wilmsowi swoje zdjęcie. Później zobaczymy ją tylko w jednym ujęciu, tuż przed rozstrzelaniem; po dziewczynie pozostanie zatem jedynie wizualna notacja. Wykorzystanie tego motywu (po raz pierwszy w kinie zachodnioniemieckim) jest warte podkreślenia - rozpoznanie, że faktyczność Zagłady „przemawia językiem pozostałych po niej przedmiotów, zwłaszcza jeśli uszanować ich pojedynczość" ${ }^{207}$, będzie chętniej używane w filmach późniejszych dekad.

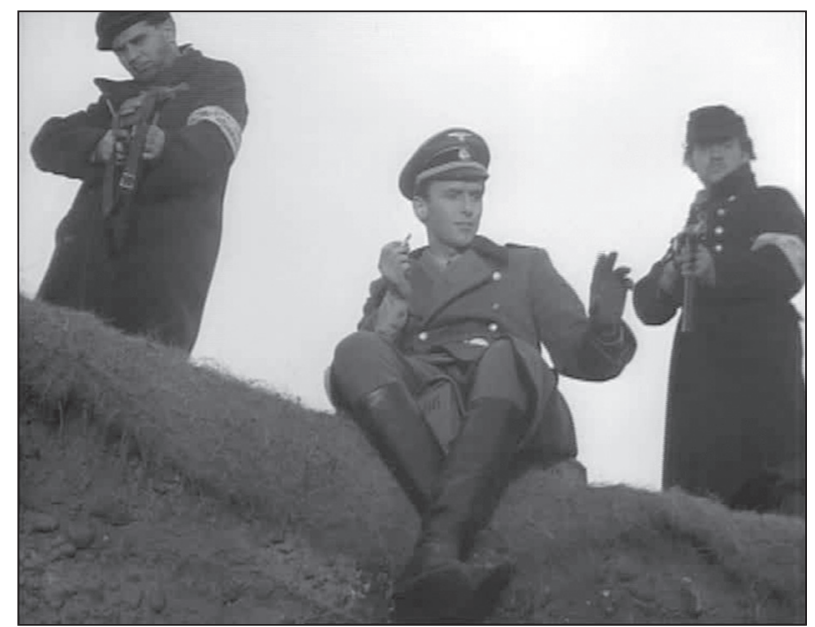

Fot. 41. Na zielonej plaży nad Szprewa - odcinek 1:

Dziennik Jürgena Wilmsa (reż. Fritz Umgelter, 1960)

Sygnałem do likwidacji jeńców jest gest wyrzucenia niedopałka

Ostatnia scena (rozgrywająca się przy dołach, do których wprowadzani są Żydzi) jest świetnie zainscenizowana i przemyślana montażowo

207 Bożena Shallcross, Rzeczy i Zagłada, Kraków 2010, s. 7. 
- zarówno w warstwie wizualnej (kamera dwukrotnie czyni zbliżenie na opaski na mundurach żołnierzy z napisem „W służbie Wehrmachtu”), jak i dźwiękowej (gdy bohater ucieka z miejsca zbrodni, słychać frazę swingującego przeboju Let me explain). Sekwencja zawiera także - jedyne w kinie zachodnioniemieckim tamtego czasu - obrazy sterty butów i martwych nagich ciał leżących $\mathrm{w}$ śniegu ${ }^{208}$ (choć trzeba dodać, że w narracji filmu ujęcie to łączy się z wcześniejszym obrazem dziesiątek niemieckich ofiar po bombardowaniu twierdzy Bresk-Litowsk, która może symbolizować naloty na Hamburg i Drezno). W ostatniej scenie ponownie słyszymy Wilmsa, już awansowanego na podoficera: Wstydze się. Miatem odwage rzucać granaty pod czołgi, ale tam $w$ dolinie byłem zbyt tchórzliwy, aby coś zrobić. Nic nie zrobiłem. Wstydzę się. Ale żyję [...] Jeszcze Niemcy nie zginęły, póki my żyjemy.

\subsection{Kraj po denazyfikacji: mordercy (nadal) są wśród nas}

Jak wspomniałem wcześniej, w pierwszych latach RFN podjęto szereg inicjatyw prawnych, których celem - i efektem - była integracja części niemieckiego społeczeństwa, uwikłanej w nazistowski aparat władzy. W wyniku wzmiankowanych już aktów prawnych - amnestii federalnej z 1949 r. oraz 131er-Gesetz - a także drugiej ustawy o uwolnieniu od kary, uchwalonej latem 1954 r. (odnoszącej się do „czynów popełnionych w okresie załamania państwa" - między 1 października 1944 a 31 lipca 1945 r.), „liczba nowo wszczynanych dochodzeń w sprawach przestępstw nazistowskich spadła w 1954 r. do rekordowo niskiego poziomu - 183 wobec około 2,5 tysiąca jeszcze w 1950 r." ${ }^{209}$, a większość tych, którzy zostali skazani jako przestępcy $\mathrm{w}$ procesach norymberskich lub przez alianckie sądy wojskowe, zdążyła już wyjść na wolność w kolejnych latach. Co więcej, doszło do swoistego odwrócenia pojęć - „znamienne dla ówczesnych nastrojów było częste odnoszenie pojęcia »naprawianie krzywd « (Widergutmachung) także do beneficjentów artykułu 131"210. Na destrukcyjne skutki przepisu, z którego dobrodziejstw korzystali m.in. byli członkowie Gestapo $^{211}$, wskazywał w 1954 r. Eugen Kogon - to on w 1947 r. postulował

${ }^{208}$ Zwraca na to uwagę Knut Hickethier, Die Darstellung des Massenmörders an den Juden im Fernsehen der Bundesrepublik von 1960-1980, [w:] Die Shoah im Bild, red. Sven Kramer, München 2003, s. 125.

${ }^{209}$ Norbert Frei, Polityka wobec przeszłości..., s. 18. Inny autor zwraca uwagę, że w latach 50. systematycznie spadała liczba osób skazywanych przez sądy zachodnioniemieckie za zbrodnie hitlerowskie (w 1951 r. - 259 osób, w 1953 r. - 123 osoby, w 1955 r. - 21 osób).

Zob. Henryk Sołga, Niemcy. Sądzacy i sądzeni, 1939-2000, Kraków 2000, s. 121.

${ }^{210}$ Norbert Frei, Polityka wobec przeszłości..., s. 17.

211 Ibidem, s. 25. 
„prawo do politycznego błędu”, które stało się niejako konstytutywną zasadą RFN: "Nazbyt wielu tych ze 131 definitywnie pokonało już nazbyt wielu z 1945" 212 .

Pierwszym nakręconym w RFN filmem podejmującym temat nierozliczonych zbrodni narodowego socjalizmu był Zagubiony (Der Verlorene, reż. Peter Lorre, RFN 1951). Scenerią współczesnej linii narracyjnej jest obóz dla przesiedleńców ze wschodu (wieżyczki strażnicze, druty kolczaste), w którym retrospektywne narracje (odsyłające do wydarzeń z 1943 i 1944 r.) snują dwaj mężczyźni: Neumeister i Novak. Pierwszy z nich, renomowany mikrobiolog, w rzeczywistości nazywa się Rothe; w Novaku rozpoznaje on Hoescha, swego dawnego asystenta (i współpracownika Gestapo). Podczas wojny zachęcił on Rothego do zamordowania żony podejrzewanej o szpiegostwo i - z uwagi na znaczenie eksperymentów prowadzonych przez doktora - pomógł w zatuszowaniu tego czynu (później okaże się, że Rothe zabił jeszcze jedną kobietę - bohater grany przez Lorrego jest więc, jak w $M$ - morderca Langa, seryjnym mordercą). Ponieważ Hoesch nie rozumie wyrzutów sumienia Rothego, ten zabija swego asystenta, a sam popełnia samobójstwo. Interpretacja filmu może być zależna od tego, którym tropem intertekstualnym podąży jego odczytanie. Jeśli zwrócimy uwagę na podobieństwa do $M$ - mordercy, możemy dojść do wniosku, że postać Rothego jest prowadzona bardzo podobnie; co więcej, protagonista - degenerat zostaje tu w gruncie rzeczy przeciwstawiony „dobrym Niemcom”. Gdyby zaś czytać zakończenie przez pryzmat filmu Mordercy sa wśród nas, wówczas można by dostrzec pewne podobieństwa (dwójka bohaterów, z których jeden cierpi z powodu zdarzeń z przeszłości, drugi zaś uważa, iż jest ona już zamkniętym rozdziałem), ale i znaczącą zmianę: o ile w fabule Staudtego bohater ma nadzieję na skazanie zbrodniarza przez wymiar sprawiedliwości, o tyle protagonista Zagubionego wybiera drogę samosądu i samobójstwa.

Lorre nie nakręcił już w Niemczech kolejnego filmu - w przeciwieństwie do innego z reemigrantów, Roberta Siodmaka, który w RFN zrealizował kilka fabuł utrzymanych w poetyce noir, m.in. Noca, kiedy przychodzit diabet (Nachts, wenn der Teufel kam, RFN 1957). Akcja filmu rozgrywa się w 1944 r., zaś bohaterem jest Axel Kersten - oficer Wehrmachtu, który wskutek ran poniesionych na froncie został zwolniony ze służby i, powróciwszy do Niemiec, podejmuje swą dawną pracę w policji kryminalnej. Protagonista przypadkiem odkrywa, iż Willy Keun, mężczyzna oskarżony o morderstwo, w rzeczywistości jest niewinny, a prawdziwy

${ }^{212}$ Eugen Kogon, Beinahe mit dem Rücken an der Wand, „Frankfurter Hefte” 1954, nr 9, s. 642 (za: Norbert Frei, Polityka wobec przeszłości..., s. 99). 
zabójca, nadal uprawiający swój zbrodniczy proceder, pozostaje na wolności. Poszlaki wskazuja że faktycznym mordercą może być niepełnosprawny umysłowo Bruno Lüdke, co z entuzjazmem przyjmuje przełożony Kerstena, pułkownik SS Rossdorf - taki obrót sprawy potwierdza bowiem nazistowską ideologię czystości rasowej i eugeniki. Kersten liczy na to, że w związku z nowym tropem Keun zostanie zwolniony z aresztu, co dla Rossdorfa jest nie do przyjęcia, ponieważ oznaczałoby to podważenie wiary w skuteczność policji oraz wymiaru sprawiedliwości. Ostatecznie Keun zostaje skazany i zastrzelony podczas rzekomej próby ucieczki, Kersten zaś - zdegradowany i odesłany na front wschodni. Film, nawiązujący do konwencji noir ${ }^{213}$, nie tylko odsłania totalitarny charakter nazistowskiego wymiaru sprawiedliwości, lecz w zakończeniu sugeruje, że prawdziwi mordercy umknęli sprawiedliwości (nie bez znaczenia jest fakt, iż - jak wynika z fabuły - Bruno Lüdke rozpoczął swój zbrodniczy proceder w $1933 \mathrm{r}$. $)^{214}$.

Fakt, że wielu niegdysiejszych członków NSDAP zajmowało w RFN wysokie stanowiska w przemyśle, handlu i bankowości, nie znalazł odzwierciedlenia w znanych mi zachodnioniemieckich filmach doby Wirtschaftswunder. Tematykę tę z powodzeniem eksploatowało kino Defy (zob. podrozdział 3.4), jeśli zaś w kinie RFN była ona w jakikolwiek sposób sygnalizowana, to $\mathrm{w}$ nielicznych, niezbyt zresztą udanych, filmach kryminalnych, w których "ciemne interesy” prowadzone są raczej na małą niż wielką skalę, w przestępczym półświatku. Przykładowo, w filmie Ślad prowadzi do Berlina (Die Spur führt nach Berlin, reż. Franz Cap, RFN 1952)

${ }^{213}$ Tropy estetyki noir analizowane są w: Steffen Hantke, Hollywood Horror Comes to Berlin. A Critical Reasessement of Robert Siodmak's "Nachts, wenn der Teufel kam”, [w:] Caligari's Heirs: The German Cinema of Fear after 1945, red. Steffen Hantke, Lanham 2007.

${ }^{214}$ Formuła gatunkowa - tym razem horroru - została wykorzystana w innym filmie, który można czytać przez pryzmat niedokonanych rozliczeń, w tym przypadku w odniesieniu do eksperymentów medycznych prowadzonych w nazistowskich obozach. Tytułowy Lekarz bez sumienia (Arzt ohne Gewissen, reż. Falk Harnack, RFN 1959), profesor Lund, jest chirurgiem przekonanym o konieczności rozwijania doświadczeń związanych z przeszczepami. Podejmuje je w swej klinice, gdzie pobiera organy od „mniej wartościowych" pacjentów, pochodzących z nizin społecznych, a w procederze tym pomaga mu dawny "lekarz” z obozu koncentracyjnego. Tuż przed aresztowaniem Lund popełnia samobójstwo i zostaje uroczyście pochowany. Tak naszkicowana fabuła kazałaby podejrzewać, iż mamy do czynienia z horrorem klasy B, co byłoby jednak dla filmu Harnacka oceną niesprawiedliwą. Wprawdzie, faktycznie, w Lekarzu bez sumienia pojawiają się elementy ikonografii filmu grozy (zabiegi wykonywane w piwnicach leżącego na uboczu zamczyska - wpływ na taki sposób zaprezentowania transplantacji mógł mieć fakt, iż w czasie powstania filmu nie były one jeszcze akceptowaną procedurą medyczną), ale na pierwszy plan wysuwają się dylematy etyczne, zwieńczone ironicznym zakończeniem (pogrzeb Lunda ma uroczysty charakter). 
amerykański prawnik poszukujący tuż po zakończeniu wojny spadku zaginionego w berlińskich ruinach, trafia na gang zajmujący się dystrybucją fałszywych pieniędzy, w który to proceder zamieszani są naziści. Nieco późniejszy Skarb z jeziora Toplitz (Der Schatz von Toplitzsee, reż. Franz Antel, RFN 1959) to z kolei fabularyzacja „wydarzenia bieżącego", opisywanego w licznych artykułach prasowych kilka miesięcy wcześniej, a dotyczącego odkrycia w austriackim jeziorze Toplitz podrobionych funtów i tajnych archiwów SS. Akcja głównej części filmu rozgrywa się w ówczesnej Republice Federalnej; w krótkim prologu pokazane zostało zatopienie ładunku przez oficera SS, który po latach postanawia odzyskać skarb (lęka się bowiem ujawnienia ",teczek" ukrytych w skrzyniach).

Autorem trzech - o wiele ważniejszych - fabuł o reperkusjach nie do końca rozliczonej nazistowskiej przeszłości w RFN był Wolfgang Staudte. Reżyser pierwszego niemieckiego filmu powojennego, w latach 50. pracował to w NRD, to w RFN. Gdy bońskie ministerstwo spraw wewnętrznych zażądało zobowiązania, że nie będzie tworzył dalej dla Defy - początkowo odmówił, ostatecznie jednak pozostał na Zachodzie ${ }^{215}$.

„Trylogię amnestii” Staudtego otwiera film wysoce oryginalny na tle zachodnioniemieckiej produkcji tamtych lat - Róże dla prokuratora (Rosen für die Staatsanwald, RFN 1959)216. Bohater tej fabuły, Rudi Kleinschmidt, $\mathrm{w}$ ostatnich dniach wojny zostaje aresztowany i werdyktem wydanym przez sąd wojskowy, kierowany przez doktora Schramma, skazany na śmierć za kradzież dwóch opakowań (a dokładniej: puszek) czekolady. Wykonanie wyroku uniemożliwia amerykański nalot bombowy. Od tej pory Rudi zarabia na życie, prowadząc handel obwoźny. Pewnego dnia, wiele lat po zakończeniu wojny, trafia na Schramma, który - jak się okazuje - piastuje wysoką funkcję w urzędzie prokuratorskim. Gdy ten orientuje się, kim jest Rudi, próbuje użyć swych wpływów, by z pomocą policji usunąć jego stoisko z ulicy. Zdesperowany Kleinschmidt kradnie ponownie dwie tabliczki czekolady, wierząc, że przed sądem zwróci uwage na wcześniejszy niesprawiedliwy wyrok. Sprawę prowadzi - ponownie - prokurator Schramm; w trakcie mowy końcowej unosi się gniewem i...

${ }^{215}$ Wolfgang Staudte, red. Eva Orbanz, Hans Helmut Prinzler, s. 32. Zob. także: Magdalena Saryusz-Wolska, Wolfgang Staudte. Sumienie ponad podziałami, [w:] Autorzy kina europejskiego VI, red. Alicja Helman, Andrzej Pitrus, Warszawa 2012.

${ }^{216}$ Tytuł nawiązuje do filmu Georga Wilhelma Pabsta Róże dla Bettiny (Rosen für Bettina, RFN 1956), który dla Staudtego miał być ponoć antywzorem (ilustracją tego, jakie niemieckie kino nie powinno być) - podaję za: Sabine Hake, Politische Satire im Kalten Krieg. "Der Hauptmann von Köln" und "Rosen für Staatsanwalt", [w:] DEFA International. Grenzüberschreitende Filmbeziehungen vor und nach dem Mauerbau, red. Michael Wedel, Barton Byg et al., Wiesbaden 2013, s. 155. 
proponuje skazanie oskarżonego na karę śmierci. Proces zostaje przerwany - Kleinschmidt wychodzi na wolność, Schramm zaś zostaje „urlopowany".

Inspiracją dla scenariusza była informacja prasowa o sędzi, który jeszcze pod koniec wojny wydawał wyroki śmierci w sprawach bagatelnych, a w RFN został prezesem sądu ${ }^{217}$. Tuż przed premierą filmu prasa niemiecka była pełna tego rodzaju rewelacji - za sprawą doniesień płynących z NRD 218, a także wystawy Ungesühnte Nazijustiz (Bezkarny nazistowski wymiar sprawiedliwości) ${ }^{219}$, która pod koniec $1959 \mathrm{r}$. prezentowana była najpierw w Karlruhe, a następnie w innych zachodnioniemieckich miastach. Jednym z celów wystawy było pokazanie, że wielu sędziów, którzy w III Rzeszy wydawali wyroki zgodne nie tyle $z$ literą prawa, ile z duchem polityki narodowosocjalistycznej, nadal piastuje wysokie stanowiska w instytucjach wymiaru sprawiedliwości Republiki Federalnej.

Jak relacjonował Staudte, podczas realizacji Róż dla prokuratora na planie pojawił się urzędnik z Ministerstwa Spraw Wewnętrznych i poprosił o dokonanie zmiany w scenariuszu. Reżyser uległ i wprowadził scenę, która miała pokazać, że w sądach RFN pracują również „uczciwi ludzie" ${ }^{220}$. Wersja bez tego „uzupełnienia” pokazana została na festiwalu w Karlovych Varach, gdzie film uzyskał główną nagrodę; ponoć ingerencja w montaż została tu dokonana bez wiedzy reżysera, który wydarzenia te relacjonował w następujący sposób:

Ktoś wpadł na pomysł, żeby z filmu wyciąć krótką scenę. Nie dowiedziałbym się o tym, gdyby kilka dni wcześniej nie przyszło do mnie kilku zachodnioniemieckich

217 Malte Ludin, Wolfgang Staudte, Hamburg 1996, s. 73.

218 Jak pisze autor opracowania na ten temat, w 1957 r. Albert Norden, czołowy propagandzista wschodnioniemieckiej SED, przedstawił publikację Gestern Hitlers Blutrichter - heute Bonner Justizelite, zawierającą nazwiska 118 prawników. Następnie „Komisja do Spraw Jedności Niemiec [Ausschuß für Deutsche Einheit], centrala enerdowskiej propagandy skierowanej na Zachód, [...] do 1960 roku wydała jeszcze pięć broszur w ogólnym nakładzie 100000 egzemplarzy, demaskując ponad 1000 sędziów i prokuratorów narodowosocjalistycznych sądów specjalnych i doraźnych, Trybunału Ludowego oraz sądów Wehrmachtu" - Marc von Miquel, Prawnicy - sędziowie we własnej sprawie, [w:] Norbert Frei, Kariery w pótmroku. Hitlerowskie elity po 1945 roku, tłum. B. Ostrowska, Warszawa 2011, s. 185.

${ }^{219}$ Wystawa powstała jako inicjatywa studentów uniwersytetu w Berlinie Zachodnim. Była wśród nich także Erika Gregor, która w kolejnych latach, wraz z mężem Ulrichem, współtworzyła stowarzyszenie Freunde der Deutsche Kinemathek oraz kino Arsenal (obie instytucje odegrały istotną rolę w dziejach kina zachodnioniemieckiego). O wystawie zob. Norbert Frei, Kariery w pótmroku..., s. 212-215.

${ }^{220}$ Malte Ludin, Wolfgang Staudte..., s. 76. 
dziennikarzy z minami żałobników składających kondolencje: „Musi Pan zaprotestować!”. Odpowiedziałem spontanicznie: „Jasne. Przeciw czemu?” [...] I dowiedziałem się, co ich tak zdenerwowało. Otóż odważyłem się na słowo sprzeciwu wobec faktu, że w Republice Federalnej przycinano także filmy Chabrola, Wolfa i Leisera, filmy takie jak Kuzyni, Gwiazdy czy Mein Kampf. A jednocześnie twierdziłem, że wycięta scena absolutnie nie zmienia niczego w wymowie mojego filmu [...]. „Ta scena pokazuje, że na wysokich szczeblach panuje wielka troska o kondycję federalnego wymiaru sprawiedliwości i że czynione są wielkie starania, aby tę kondycję zmienić" - pouczył mnie jeden z dziennikarzy na odchodnym. Poddałem się. „Dobrze, będę protestował”. Chwilę później siedzieliśmy znowu przy stole i jeden z nich powiedział: „Na każdym zagranicznym festiwalu musi być niemiecki protest. Taką mamy tradycję"221.

Film Staudtego jest odważną satyrą na zachodnioniemieckie realia lat 50. - buduje ją nie tylko główna linia dramaturgiczna, lecz także scenki epizodyczne (zapytany o drogę policjant radzi, by udać się w stronę Adolf-Hitler-Platz) oraz ścieżka dźwiękowa (gdy prokurator wchodzi do sądu, słychać fragment nazistowskiego hymnu Horst-Wessel-Lied). W jednej ze scen pojawia się odniesienie do głośnej wówczas „sprawy Zinda” (Ludwig Zind, nauczyciel szkoły średniej, który w latach 50. publicznie formułował ostre antysemickie sądy, został skazany na rok więzienia, ale przed rozpoczęciem odsiadki uciekł do Libii, gdzie otrzymał azyl; został aresztowany w RFN w $1970 \mathrm{r}$.) ${ }^{222}$. W filmie prokurator otrzymuje tytułowe róże "od pewnej damy”; gdy żona wyraża zaniepokojenie tym faktem, Schramm uspokaja ją: Daj spokój, ta kobieta nazywa się Zirngiebel / Kłamiesz, przecież prowadzisz postępowanie przeciw jej mężowi, dlaczego miałaby ci przysyłać kwiaty? / Nigdy nie kłamię! Ten nauczyciel uciekt, a róże są znakiem, że przekroczył granice. Czarny charakter grany jest przez Martina Helda - aktora, który wyspecjalizował się w rolach „ludzi sukcesu” mających coś na sumieniu. W taką postać wcielił się także w innym filmie Staudtego, Ostatni świadek (Der letzte Zeuge, RFN 1960) oraz we wspomnianym już Mokrym asfalcie (choć tu - inaczej niż w filmie Wisbara - postać grana przez Helda nie należy do establishmentu wywodzącego się z okresu III Rzeszy).

Sabine Hake określa Róże... jako „odpowiedź na wcześniejszy film Defy"223 - Hauptmanna z Kolonii (zob. podrozdział 2.5). Istotnie, boha-

${ }^{221}$ Wspomnienie Staudtego przedrukowane w: Wolfgang Staudte, red. Eva Orbanz, Hans Helmut Prinzler, s. 87-88. W sformułowaniu o protestach na innych festiwalach chodzi najpewniej o stanowisko erefenowskiego MSZ w związku z canneńską projekcją filmu Alaina Resnais Noc i moła (zob. podrozdział 3.7).

222 O tym, że film Staudtego to „opowieść z kluczem”, pisała wówczas zachodnioniemiecka prasa (Fall Zind, „Der Spiegel” 1959, nr 36).

${ }^{223}$ Sabine Hake, Politische Satire im Kalten Krieg..., s. 149. Warto podkreślić, że Róża... była pokazywana we wschodnioniemieckich kinach, natomiast Hauptmann... nie wszedł do dystrybucji w RFN. 
terami obu fabuł są biedni, szukający pracy mężczyźni, którzy dziełem przypadku zostają uwikłani $\mathrm{w}$ intrygę sięgającą zachodnioniemieckich elit (co oznacza ludzi z nazistowską przeszłością). W obu realizacjach finał rozgrywa się na sali sądowej, a absurdalny przebieg rozprawy sygnalizuje patologie erefenowskiego wymiaru sprawiedliwości. I choć w poszukiwaniu podobieństw pomiędzy filmami najpewniej przecenia Hake instytucjonalne aspekty produkcji224, zarazem słusznie dostrzega użycie podobnych rekwizytów: u Dudowa pojawia się czołg z czekolady, u Staudtego - czołg-zabawka (oraz - można dodać - sama czekolada jako „katalizator” konfliktu). Ponadto, w obu filmach przedstawiciele establishmentu otrzymują bukiety kwiatów, a informacje o wyniku postępowania sądowego zostają podane przez nagłówki gazet ${ }^{225}$. Można wskazać paralele pomiędzy Różami... a filmami Wolfganga Neussa W czepku urodzeni i My, dzieci z piwnicy (o których będzie jeszcze mowa) - w filmie Staudtego Neuss pojawia się ( $w$ tandemie $z$ Wolfgangiem Müllerem) w scenach przypominających running gag - jako kierowca ciężarówki, który komentuje wydarzenia z pozycji „,zwykłych ludzi”.

Róże... otrzymały mieszane recenzje, z przewagą negatywnych. W materiale, który ukazał się we „Frankfurter Allgemeine Zeitung” użyto sformułowań Kleinkunstklamauk (co można przetłumaczyć jako „drobnomieszczańska farsa") i Clownerie. Ponadto napisano, że pokazani w filmie byli naziści są „,karykaturami na wzór Defowski; patrząc na nich nawet sam Staudte nie może wierzyć, że mordercy są wśród nas"226. Z kolei Enno Patalas z jednej strony chwalił Staudtego, który - zdaniem krytyka - przełamał złą passę, z drugiej zaś utyskiwał na sposób rozwiązania intrygi: „o ileż bardziej znaczące byłoby zakończenie, w którym Kleinschmidt musiałby opuścić miasto, a prawnik z krwią na rękach [Blutrichter] pozostał na stanowisku!"'227. Co ciekawe, inaczej widziałby finał także recenzent enerdowskiego pisma "Sonntag” (który generalnie chwalił film, określając jego budowę formalną jako „wzorcową", a aktorstwo jako „ponadprzeciętne"):

${ }^{224}$ Autorka zwraca uwagę, że tytuł filmu Dudowa nawiązuje do popularnej sztuki Carla Zuckmayera Der Hauptmann von Köpenick z 1931 r., zaś scenariusz do Róży... napisał Georg Hurdalek, który wcześniej pracował z Helmutem Käutnerem przy adaptacji innej sztuki Zuckmeyera, Generał diabła. Informacje tego rodzaju stanowią gratkę dla zbieraczy filmowych ciekawostek, ale ich znaczenie dla badań historii kina niemieckiego jest znikome.

${ }^{225}$ Sabine Hake, Politische Satire im Kalten Krieg..., s. 160-162.

226 Martin Ruppert, Flucht nach ̈̈gypten, oder "Rosen für den Staatsanwalt”, „Frankfurter Allgemeine Zeitung", 19.11.1959.

227 Enno Patalas, Mit und ohne Dornen, „Filmkritik” 1959, nr 11. 
Czy w tym miejscu filmu pełna prawda mogła dojść do głosu? Wątpimy w to, gdyż został on zrobiony w państwie Schrammów i tam jest wyświetlany. Staudte doszedł do granic możliwego. W obecnych warunkach panujących w RFN prawdziwszy film nie mógłby zostać zrobiony ${ }^{228}$.

$\mathrm{Na}$ Berlinale niemieccy członkowie jury (wśród nich Frank Wisbar) byli przeciwni nagrodzeniu filmu ${ }^{229}$; ostatecznie nagrodę (Srebrne Lwy) otrzymała grająca w filmie aktorka, Juliette Mayniel. Na ceremonii Niemieckich Nagród Filmowych Staudte, Hurdalek oraz Walter Giller (odtwórca roli Kleinschmidta) otrzymali Srebrne Taśmy (Filmband in Silver; główne nagrody powędrowały do twórców Mostu). Staudte odmówił jednak odebrania nagrody "z rąk dawnego SA-Manna" (ministra spraw wewnętrznych Gerharda Schrödera); przyjął ją producent, zaś sam minister na galę przezornie nie przybył230.

Po nakręceniu Róż..., a przed premierą kolejnego filmu Staudte kilkakrotnie zabierał głos w sprawach publicznych. W NRD ukazał się jego List otwarty do zachodnioniemieckiej prasy, w którym piętnował przejawy społecznej akceptacji dla osób uwikłanych w aparat nazistowskiej represji (reżyser wspomina o telegramie kanclerza Adenauera do Konstantina von Neuratha z okazji jego zwolnienia ze Spandau oraz o przyznaniu Wernerowi Kraussowi wysokiego odznaczenia federalnego), a także akceptację dla pojęcia Vertriebene („wypędzeni”). Pisał m.in.: „Demokracja żyje dzięki przyzwoitości i odwadze obywateli. Tchórzostwo kieruje każde państwo ku dyktaturze. Próbując oddalić od siebie winy z przeszłości, na powrót czynimy siebie winnymi"231. O ile List otwarty... można czytać jako swoisty autorski komentarz do Róż dla prokuratora, o tyle jako zapowiedź kolejnego filmu Staudtego można uznać referat wygłoszony w Berlinie Zachodnim (a później często przywoływany w pracach o historii kina niemieckiego), zatytułowany Bohaterska śmierć napędza wpływy kasowe. Staudte mówił w nim o „filmach wojennych nakrytych celofanem pacyfizmu", w których heroizowana jest „śmierć za ojczyznę, za towarzyszy broni, za ostateczne zwycięstwo", a jednocześnie „obojętne jest, przez kogo owa ojczyzna jest rządzona" ${ }^{232}$.

Kiermasz (Kirmes, reż. Wolfgang Staudte, RFN 1960) został nakręcony na podstawie scenariusza Clausa Hubalka, byłego asystenta Brechta i twórcy kilku filmów telewizyjnych opowiadających o III Rzeszy. Ponie-

228 Alexander Wien, „Rosen für den Staatsanwalt”, „Sonntag” 1959, nr 47.

${ }^{229}$ Wolfgang Staudte, red. Eva Orbanz, Hans Helmut Prinzler, s. 257.

${ }^{230}$ Wolfgang Staudte, red. Eva Orbanz [1977], s. 186.

${ }^{231}$ Wolfgang Staudte, Offener Brief an die westdeutsche Presse, "Neues Deutschland”, 25.02.1960. Przedruk w: Wolfgang Staudte, red. Eva Orbanz, Hans Helmut Prinzler, s. 86-87.

${ }^{232}$ Wolfgang Staudte, Der Heldentod füllt immer noch die Kinokassen, [w:] Wolfgang Staudte, red. Eva Orbanz, Hans Helmut Prinzler, s. 160. 
waż żaden z wiodących zachodnioniemieckich producentów nie był zainteresowany materiałem, został on ostatecznie zrealizowany w spółce Freie Film Produktion, którą Staudte utworzył wraz z Helmutem Käutnerem i Haraldem Braunem, a więc dwoma innymi wyróżniającymi się reżyserami (finalnie inicjatywa ta nie spełniła oczekiwań samych założycieli). Główną intrygę filmu zapowiada następujące wydarzenie: gdy w małym niemieckim miasteczku trwają przygotowania do jarmarku, podczas montażu karuzeli zostaje odnaleziony hełm i karabin z czasów wojny oraz szkielet. Okazuje się, że to szczątki żołnierza Roberta Mertensa (nazwisko odsyła do pierwszego filmu Staudtego!), który - nie mogąc znieść tego, że często otrzymuje rozkazy wykonania wyroków śmierci - w ostatnich tygodniach wojny uciekł w swe rodzinne strony. Wówczas lokalny kacyk NSDAP wzywa Gestapo, które rozpoczyna poszukiwania. Nikt nie chce pomóc dezerterowi, nawet jego rodzice (!); chłopaka odprawia również pastor (obłudnie cytując fragment Listu do Rzymian: „Każdy niech będzie poddany władzom, sprawującym rządy nad innymi", rozdz. 13, 1-14). Gdy dzień przed powrotem bohatera miejscowość zostaje ewakuowana, uznaje on, że reżim upadł, i - wraz z nastoletnią Francuzką robotnicą przymusowa pozostawioną na zgubę (szkoda, że Staudte wprowadza tu dość absurdalny wątek „romansowy”) - zrywa propagandowe plakaty z ulicznych murów. Następnego dnia do miasteczka powracają jego mieszkańcy, w tym nazistowska policja, która rozpoczyna śledztwo. Ponieważ ani rodzina, ani przyjaciele chłopaka nie chcą mu pomóc, popełnia on samobójstwo; ciało zostaje ukryte w kraterze po bombie.

Streszczona powyżej linia narracyjna, opowiadana poprzez retrospekcje, nie obejmuje całej fabuły - rozbudowany jest bowiem także wątek współczesny. Okazuje się, że mentalność lokalnej społeczności niewiele się zmieniła - dawny nazistowski lider nadal piastuje urząd burmistrza, a o zmarłym, w dalszym ciągu traktowanym jako zdrajca, wszyscy chcą jak najszybciej zapomnieć. Jedynie matka Roberta domaga się godnego pochówku, ale już jej mąż (oraz lokalna elita - burmistrz i pastor) odradzają identyfikacji szczątków. Wówczas okazałoby się bowiem, że chłopak, którego nazwisko zamieszczone zostało na pomniku Poległych Podczas Wojny, był faktycznie dezerterem, a rodzina rzekomo okryłaby się hańbą. Krytyczne wobec „zmowy milczenia” przesłanie filmu podkreślane jest przez bezpośrednie odniesienia do ówczesnej polityki - w miejscu, gdzie w czasie wojny rozstrzeliwano dezerterów, wisi plakat z wizerunkiem Adenauera i sloganem wyborczym CDU: Keine Experimente. W finale filmu mieszkańcy miasteczka bawią się na jarmarku; ostatnie zdanie, jakie można usłyszeć w filmie, brzmi: Dzieci i żotnierze Bundeswehry płaca ulgowo (karuzela jest metaforą "cyklicznego powrotu” - podobnie jak maszyna drukarska z Rotacji/Brunatnej pajęczyny). 
FBW odmówiło przyznania predykatu Kiermaszowi, co oznaczało, że szanse na dystrybucję kinową znacząco zmalały - Käutner napisał wówczas protest w obronie filmu: „Niestety, okazuje się, że wielu ludzi w ogóle się nie zmieniło, że przetrwały przesądy [...], że osoby, które piastowały wysokie stanowiska w III Rzeszy, dziś znowu pełnią wysokie funkcje [...]. Ten film nie oskarża, ale stwierdza fakty"233. Polityczne kontrowersje pojawiły się też po projekcji filmu na Berlinale - Georg Anders, urzędnik z ministerstwa spraw wewnętrznych, wyraził wówczas opinię, iż uważa za „niebezpieczne uproszczenie, by wydarzenia z czasów narodowego socjalizmu przedstawiać na przykładzie kryminalnych czynów jednostek, bez pokazania systemu dyktatury jako takiego [...] w taki sposób, iż zdaniem niektórych widzów to wolna demokracja powinna zasiąść na ławie oskarżonych" ${ }^{234}$.

Skutkiem nieotrzymania "predykatu”, w RFN Kiermasz miał ograniczoną dystrybucję i zebrał stosunkowo słabe recenzje. Krytycznie o filmie pisali: Friedrich Luft („film chce być drapieżny - ale jest nijaki [...], chce napominać - ale [...] logika degrengolady nie rozwija się"235), Karena Niehoff („„Film niewiele mówi o nazistach [...] dezerterzy pojawiają się na całym świecie, podczas każdej wojny są ścigani i rozstrzeliwani, to nie jest typowa nazistowska zbrodnia [...]. Świat, który widzi Staudte, jest ograniczony, nie obejmuje całości”236) i Theodor Kotulla („film chybocze się między karykaturą à la Poddany a realizmem à la Rotacja" ${ }^{\prime 237}$ ). Pozytywne recenzje ukazały się w „Frankfurter Allgemeine Zeitung" 238 oraz w "Süddeutsche Zeitung” (krytyk określił dzieło Staudtego „najważniejszym filmem niemieckim od czasu Mostu Wickiego” i „najbardziej przyzwoitym niemieckim filmem współczesnym, który otwiera się na przeszłość ${ }^{\prime 239}$ ). Bardzo pochlebnie o filmie pisano natomiast w NRD 240 - zarówno w głównym dzienniku partyjnym ${ }^{241}$, jak i w periodyku specjalistycznym (gdzie utyskiwano jedynie na „ustępstwa na rzecz potrzeby

${ }^{233}$ Brief an die FBW z 13.08.1960, za: Malte Ludin, Wolfgang Staudte..., s. 82.

${ }^{234}$ Cyt. za: Katrin Seybold, Die Welt verbessern mit dem Geld von Leuten..., s. 47.

${ }^{235}$ Friedrich Luft, Kirmes, „Die Welt”, 4.07,1960.

${ }^{236}$ Karena Niehoff, Kirmes, „Der Tagesspiegel”, 5.07.1960.

237 Theodor Kotulla, Kirmes, „Filmkritik” 1960, nr 8.

${ }^{238}$ Karl Korn, Der entfesselte Krieg. "Kirmes”, ein neuer Film von Wolfgang Staudte, „Frankfurter Allgemeine Zeitung”, 29.08.1960.

${ }^{239}$ Hans-Dieter Roos, Kirmes, "Süddeutsche Zeitung”, 5.09.1960.

${ }^{240}$ Film dystrybuowany był również w Polsce, gdzie na plakacie wyeksponowano napis: „Wybitny film antyhitlerowski”.

${ }^{241}$ Horst Knietzsch, "Kirmes", ein meisterhafter Film von Wolfgang Staudte, "Neues Deutschland", 11.03.1964. 
rozrywki" ${ }^{242}$ ). Co więcej, Kiermasz wyświetlono w enerdowskiej telewizji (w święta Bożego Narodzenia 1960 r.) bez wiedzy zachodnioniemieckiego dystrybutora i bez zapowiedzi w programie, gdzie figurował jedynie anons: „film - niespodzianka" ${ }^{243}$.

„Trylogię amnestii" Staudtego dopełnia Męski piknik (Herrenpartie, RFN/Jugosławia $1964^{244}$ ) - ostatnie istotne dzieło twórcy pierwszego powojennego filmu niemieckiego (później reżyser pracował już wyłącznie dla telewizji). Początek intrygi mógłby być dobrym punktem wyjścia dla komedii: grupka Niemców z towarzystwa śpiewaczego (jest wśród nich tylko jeden młody chłopak), jadąca na urlop nad Adriatyk, wskutek awarii samochodu trafia do jugosłowiańskiej wioski zamieszkałej przez same kobiety (fot. 42). W scenariuszu zrezygnowano jednak z pokusy obrania konwencji komediowej lub romansowej i podążono w zupełnie innym kierunku ${ }^{245}$.

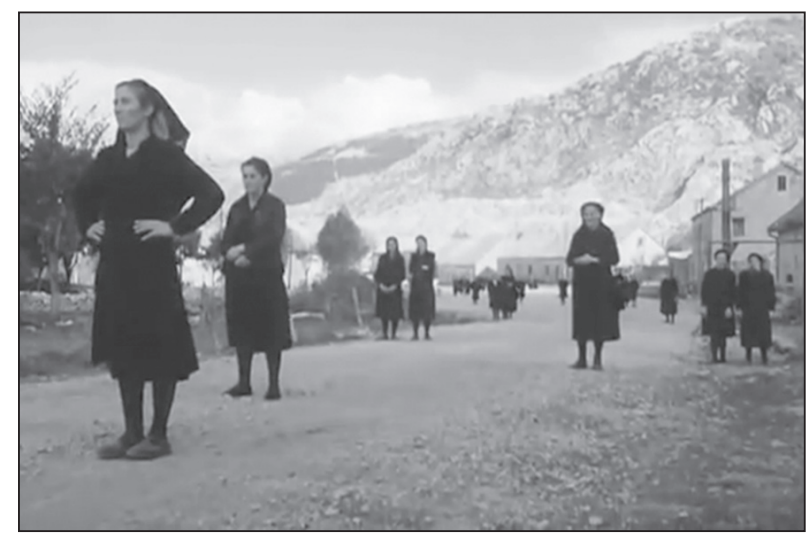

Fot. 42. Męski piknik (reż. Wolfgang Staudte, 1964)

Pogrążone od lat w żałobie mieszkanki jugosłowiańskiej wioski chłodno witają niemieckich turystów

${ }^{242}$ Dieter Wolf, „,Kirmes" - Bekenntnis und Mahnung, „Deutsche Filmkunst” 1960, nr 10.

243 "Kirmes" - Die Räuber, „Der Spiegel” 1961, nr 4.

244 Sformułowanie Męski piknik, przyjęte na potrzeby dystrybucji filmu w PRL, nie oddaje wieloznaczności tytułu oryginalnego, który czytać można jako „męskie głosy” (w chórze), ale też jako „role panów” (w odniesieniu do pojęcia Herrenvolk - „naród panów”).

${ }^{245}$ Staudte wspominał, że podczas przygotowań do filmu w dyskusji z jugosłowiańskimi kolegami wyraził opinię, że „nie tylko sprawcy muszą przezwyciężyć przeszłość, ale także ofiary - niekiedy ofiarom trudniej jest przezwyciężyć przeszłość niż sprawcom" (Ulrich Gregor, Heinz Ungureit, Wie sie filmen. Fünfzehn Gespräche mit Regisseuren der Gegenwart, Gütersloh 1966, s. 51). W innym zaś miejscu relacjonował, że dla strony jugosłowiańskiej szczególnie trudny był „demontaż kultu partyzantki” (Wolfgang Staudte über die Produktionsbedingungen seiner Filme..., s. 77). 
Niemieccy turyści początkowo starają się korzystać z uroków pięknego krajobrazu i zrobić użytek z turystycznego ekwipunku (krótkie spodenki, słomkowe kapelusze, aparaty fotograficzne odbijające się od brzuszków...), ale nie rozumieja czemu są traktowani tak ozięble - i dlaczego wszystkie kobiety ubrane są na czarno. Sądząc, że chodzi o barierę językową lub „różnice kulturowe”, pomysłowi muzycy postanawiają przełamać lody, dając przed lokalną publiką próbkę wokalnych umiejętności (mając wokół siebie westernową scenerię - domów z zamkniętymi okiennicami, jakby mieszkańcy obawiali się przybyszy). Tymczasem okazuje się, że kobiety noszą żałobę, gdyż w czasie wojny w ramach akcji odwetowej hitlerowskie wojska wymordowały wszystkich mężczyzn (pada nawet data: 23 grudnia 1943 r. - niemal jak w filmie Mordercy sa wśród nas)...

Najbardziej interesującą właściwością scenariusza są wysiłki podejmowane przez Niemców, początkowo nierozumiejących przyczyn ostracyzmu, by „udobruchać” wdowy. W jednej ze scen, mając nadzieję na posiłek, mężczyzna wręcza jednej z kobiet plik banknotów (z dumą mówi synowi: widzisz, ten język jest uniwersalny) - ale w słoju, który przynosi im kobieta, nie ma miodu, lecz łuski. Mężczyźni nie mówią też zbyt wiele o tym, co robili w czasie wojny - podejmowane przez nich działania (opracowywanie strategii obronnej, wyszukiwanie punktów obserwacyjnych itd.) nie pozostawiają jednak co do tego wątpliwości (można wręcz odnieść wrażenie, że przybysze nadspodziewanie dobrze orientują się w topografii miasteczka, jak gdyby kiedyś już je odwiedzili...). Śpiewacy stanowią zresztą grupę bardzo subordynowaną - dopiero w zakończeniu, gdy są uwięzieni na wzgórzu, dochodzi między nimi do sporu. Ma on swój aspekt pokoleniowy - koncyliacyjnie nastawiony syn wchodzi w dyskusję z ojcem. Mój chłopcze, to wszystko już przeszłość... My o tym wszystkim nie wiedzieliśmy, to znaczy, jeśli chodzi o szczegóły. Trzeba tym ludziom wyttumaczyć, że my wszyscy wyciagnęliśmy już lekcję z naszej przeszłości - mówi mężczyzna. Syn dopytuje: Jaka? - ale w odpowiedzi usłyszy jedynie zapowiedź redukcji kieszonkowego.

Konflikt generacyjny zaznacza się także w społeczności Jugosłowianek. Ich przywódczynią jest nieprzejednana Miroslava; inna kobieta - oszalała Vlasta - wręcza Niemcom pieniądze, mając nadzieję, ze potraktują je jako łapówkę za uwolnienie jej syna. Do poniechania wendetty (ostatecznie kobietom udaje się ,jedynie” zepchnąć autobusik Niemców w górską przepaść) przekonuje wdowy najmłodsza z kobiet. Zakończenie filmu daje pewne podstawy do nadziei na faktyczne pojednanie między dawnymi sprawcami i ofiarami, ale zarazem przynosi swoistą woltę $\mathrm{w}$ rozumieniu obu pojęć: gdy nadjeżdża milicja, Niemcy nie domagają się odszkodowania za autobus - grany przez Götza George’a chłopak oświadcza, że to on ponosi winę za incydent (a szkodę pokryje ubezpieczenie). 
Oryginalność filmu wiąże się nie tylko z ciekawie wykoncypowaną dramaturgia, lecz także z jego walorami stylistycznymi - sekwencje pokazujące "urlopowe atrakcje” niemieckich turystów zrealizowane są w stylu klasycznym, typowym dla ówczesnych zachodnioniemieckich filmów o tematyce współczesnej, natomiast sceny z życia Jugosłowianek ewidentnie bliższe są poetyce neorealizmu. Walory te nie zostały jednak dostrzeżone przez krytykę - prasowa recepcja filmu była zresztą zaskakująco chłodna. Manfred Delling uznał wprawdzie, że "żaden niemiecki film ostatnich lat nie wymagał równie poważnego namysłu", ale zarazem utyskiwał: „Staudte przesadza nie w samej idei, ale w sposobie jej wyrażenia $[\ldots]$ formułuje nagłówki tam, gdzie powinny się znaleźć dygresje [...] film zaczyna się niczym satyra, potem zbliża się do realizmu, by następnie osunąć się w przeciętny kabaret" ${ }^{246}$. Krytycznie o filmie pisano także w „Filmkritik” - recenzent zarzucił Staudtemu "nierealistyczne ramy opowieści”; sugerował też, że „we wsi powinno być więcej dzieci”, że „nie istnieje miejsce tak przepełnione bólem i gniewem” i że „nieprawdopodobieństwem jest, by istniało miejsce, które nie zmieniło się w istotny sposób od czasu wojny" (sic!). Motywacje niemieckich bohaterów uznał zaś za niewiarygodne - zdaniem krytyka brak im bowiem wystarczających powodów, by „sięgać do wojskowego słownika”. A zresztą - „Wszyscy oni aż nad to [! - przyp. K. K.] przyzwyczaili się do zachowania zgodnego ze standardami demokracji" ${ }^{247}$. W konkluzji recenzent zarzucił Staudtemu wybór niewłaściwej estetyki (za wzór podając filmy Francesco Rosiego) i nie bez racji zauważał:

Ktoś mógłby sądzić, że w dzisiejszych Niemcach tkwi „autorytarna osobowość”, którą Adorno diagnozował w latach 40. - ale wskazać można niewiele dowodów na to, że ów fenotyp jest nadal ten sam. Formy zachowań zmieniły się, zniknął dziarski, wojskowy ton [...]. Autorytarna osobowość dnia dzisiejszego przybiera demokratyczne formy. Ukazanie tego zjawiska byłoby zadaniem społeczno-krytycznego filmu roku $1964^{248}$.

Ponieważ Męskiemu piknikowi nie przyznano predykatu, zarzucając filmowi „niespójność stylistyczną” oraz „negatywne zabarwienie bohaterów"249, dzieło Staudtego nie miało szerokiej dystrybucji. Odmówiono

246 Manfred Delling, Die Lehren der Vergangenheit, „Film” 1964, nr 8.

247 Reinhold E. Thiel, Herrenpartie, „Filmkritik” 1964, nr 4.

248 Ibidem.

${ }^{249}$ Odmowa przyznania predykatu przez FBW, podpisana przez dr. Karla Korna i dr. Gerta Rabanusa z 16 kwietnia 1964 r., przedrukowana w: Werner Jörg Lüddecke, Herrenpartie. Filmerzählung, Berlin (Ost) 1964, s. 96-97. Fragmenty korespondencji Staudtego odpierającego zarzuty zamieszczono w: Wolfgang Staudte, red. Eva Orbanz, Hans Helmut Prinzler, s. 86. 
wysłania filmu do Cannes ${ }^{250}$, natomiast podczas pokazu na Berlinale w 1964 r. na sali rozrzucono ulotki z fałszywymi podziękowaniami od Josipa Broz Tity pod adresem reżysera za wkład w zwycięstwo światowego komunizmu ${ }^{251}$. W odpowiedzi Staudte opublikował - w jednym z numerów festiwalowej gazety - artykuł, w którym odniósł się do zarzutu o „kalanie własnego gniazda”. Pisał m.in.:

Gdy, na szczęście, przegraliśmy wojnę, nasze gniazdo było już beznadziejnie skalane od góry do dołu. A ponieważ nie wykonaliśmy oczyszczenia, brud przykleił się i został [...]. Gniazdo rozpadło się na dwie części, a wraz z nim - odpowiedzialność historyczna. Każda z części miała odtąd okazję oburzać się na brud w drugiej części gniazda - do tego stopnia, że na sprzątanie własnego brakło już czasu. Ci jednak, którzy wykorzystali ten czas, próbując z własnych kątów ten brud wydłubać, musieli zrezygnować z podziękowań od własnej ojczyzny i dowiedzieć się, że ich polityczna wola oczyszczenia kwitowana jest fraza, która stała się okazją do niniejszych uwag: „To kalanie własnego gniazda!" Zarzut taki pojawił się przeciwko mnie wkrótce po premierze filmu Mordercy sa wśród nas. Dziś wiem, że te przepełnione troską zarzuty pochodziły głównie od tych, którzy sami obawiali się, że wylądują między zmiotką a szufelką. A to, że dwadzieścia lat później mordercy nadal są wśród nas, wychodzą spacerkiem z więzień, dostają krzyże zasługi, trafiają na ministerialne stołki, nie świadczy o niczym innym niż to, że we własnym gnieździe nadal jest brud, którego należy się pozbyć. Kto podejmuje się tej pracy [...] jest postrzegany jako obcy ptak z innego gniazda, który z zawistną satysfakcją [schadenfroh] kracze: „Patrzcie, jakie brudne macie gniazdo!" Ale to jego własne gniazdo i jego własny brud ${ }^{252}$.

A skoro mowa o zarzutach dotyczących „kalania własnego gniazda”, trzeba też powiedzieć, że - inaczej niż w kilku innych krajach europejskich - w Republice Federalnej Niemiec lat 50. nie nakręcono filmu, w którym wydarzenia dotyczące nazistowskiej przeszłości ujęte byłyby $\mathrm{w}$ formę komedii. Pewne jej elementy można wskazać w produkcji Artura Braunera Kapitan i jego bohater (Der Hauptmann und sein Held, reż. Max Nosseck, RFN 1955) na podstawie powieści Clausa Hubalka pod tym samym tytu-

${ }^{250}$ Inge Dombrowski, Bonn hat Nein gesagt, „Der Tagesspiegel”, 3.05.1964. Zob. także: Andreas Lenhard, Ohne Prädikat: "Herrenpartie”, [w:] Courage und Eigensinn: zum 100. Geburtstag von Wolfgang Staudte, red. Uschi i Andreas Schmidt-Lenhard, St. Ingbert 2006.

${ }^{251}$ Malte Ludin, Wolfgang Staudte..., s. 85.

${ }^{252}$ Wolfgang Staudte, Das eigene Nest beschmutzen?, „Offizielle Festspielzeitung der XIV. Internationalen Film-Festspiele", 3.07.1964. Przedruk w: Wolfgang Staudte, red. Eva Orbanz, Hans Helmut Prinzler, s. 91. Zob. też: Andreas Wöll, Wolfgang Staudte - „Sicher sind es nicht die Filme, die das eigene Nest beschmutzen", [w:] Engagierte Demokraten: Vergangenheitspolitik in kritischer Absicht, red. Claudia Fröhlich, Michael Kohlstruck, Münster 1999 (zbiór zawiera rozdziały poświęcone wpływowym postaciom życia intelektualnego i kulturalnego RFN, które zabierały głos w sprawie rozliczeń z nazistowską przeszłością - Staudte znalazł się tu w dobrym towarzystwie: m.in. Eugena Kogona, Theodora W. Adorno, Rolfa Hochhutha, Willy'ego Brandta i innych). 
łem. $Z$ jednej strony, w tej fabule można rozpoznać wzorce przewijające się przez wiele późniejszych zachodnioniemieckich filmów wojennych: młody bohater skonfrontowany zostaje $\mathrm{w}$ koszarach z pruskim drylem, ordynowanym przez fanatycznego kapitana. Z drugiej zaś - opowieść korzysta z komediowego schematu "bohatera z przypadku”: nieco ciamajdowaty protagonista jest typem „niebieskiego ptaka” i nie ma „zadatków na bohatera", ale za takiego się podaje. Mianowicie, podczas jednego z nalotów, gdy pomaga w sprzątaniu zbombardowanych kamienic, wchodzi w posiadanie niewypełnionych druków poświadczających nadanie Żelaznego Krzyża (który w przedostatniej scenie, cudem uniknąwszy rozstrzelania, złoży na ręce amerykańskiego żołnierza, domagającego się „,suweniru dla żony") $)^{253}$.

Oprócz wspomnianych Róż dla prokuratora, w kinie RFN II połowy lat 50. pojawiło się kilka innych produkcji, w których brak rozliczeń $\mathrm{z}$ nazistowską przeszłością przedstawiono w satyrycznej formie. $\mathrm{Z}$ taką formułą mamy do czynienia w filmie $W$ czepku urodzeni (Wir Wunderkinder, reż. Kurt Hoffmann, RFN 1958) na podstawie powieści Hugona Hartunga pod tym samym tytułem. Autor tej realizacji w latach 30 . był asystentem Wolfganga Liebeneinera, zaś podczas wojny realizował popularne filmy rozrywkowe, w których specjalizował się także po 1945 r. ${ }^{254}$ Film W czepku urodzeni stał się przebojem kasowym w RFN, zdobył Srebrną Nagrodę Filmową w 1959 r., w kolejnym natomiast - Złoty Glob w kategorii filmu zagranicznego. To także pierwsza produkcja z RFN, która weszła na ekrany kin Izraela ${ }^{255}$. O tym, z jak silnym oddźwiękiem spotkał się film Hoffmanna w ówczesnej RFN, świadczy również fakt, iż jego tytuł przywołał Theodore W. Adorno w znanym eseju Co to znaczy obrachunek z przeszłościa:

To, że co krok natrafia się na postacie, jakie przedstawione zostały w filmie Wir, Wunderkinder, nie ma związku ani z marnością tego świata jako taka, ani z rzekomymi szczególnymi właściwościami niemieckiego charakteru narodowego, lecz ma to związek z tym, że owi konformiści, którzy są w jakichś relacjach z tymi, co kontrolują cały aparat władzy, niczym nie różnią się od potencjalnych sługusów totalitarnego systemu ${ }^{256}$.

${ }^{253}$ Zob. zjadliwą recenzję autorstwa Leona Bukowieckiego, Niemiecki pan kapitan, „Film” 1957, nr 10.

${ }^{254}$ Zob. Ingo Tornow, Piroschka und Wunderkinder oder von der Vereinbarkeit von Idylle und Satire. Der Regisseur Kurt Hoffmann, München 1990.

${ }^{255}$ Christoph Vatter, Gedächtnismedium Film: Holocaust und Kollaboration in deutschen und französischen Spielfilmen seit 1945, Würzburg 2009, s. 153.

256 Theodore W. Adorno, Co to znaczy: obrachunek z przeszłościa, tłum. A. Kaniowski, [w:] O kondycji Niemiec..., s. 126. 
Fabuła, obejmująca okres od końca Cesarstwa Niemieckiego do lat 50., kontrastowo zestawia dwie drogi kariery: Hans Boeckel to typ wrażliwego, nieśmiałego intelektualisty, Bruno Tiches natomiast jest karierowiczem i oportunistą. W latach międzywojennych Boekel zostaje dziennikarzem w dziale kultury monachijskiego dziennika. Po dojściu do władzy nazistów traci przyjaciela Siegfrieda Steina (udaje się on na emigrację do Stanów), a także Verę, swą ukochana, która emigruje wraz z ojcem. Boekel żeni się z Dunką Kirsten i u jej boku udaje mu się przetrwać utratę pracy podczas wojny. Natomiast Tiches pod koniec lat 20. wiąże się z podejrzaną rodziną Meisegeierów ${ }^{257}$ i zostaje wysokim funkcjonariuszem NSDAP, dorabiając się majątku na zajmowaniu pożydowskiego mienia. Po wojnie handluje na czarnym rynku przy aprobacie amerykańskiej administracji, która docenia jego zdolności przywódcze; wreszcie - zostaje szanowanym przemysłowcem. Boekel pracuje na prowincji; dzięki Steinowi, który powraca do Niemiec w mundurze amerykańskiej armii, udaje mu się ponownie znaleźć zatrudnienie w gazecie. Jak łatwo się domyślić, obaj główni bohaterowie spotkają się ponownie - Hans chce napisać artykuł o meandrach kariery Bruna, co ten pragnie udaremnić. Wskutek nieszczęśliwego wypadku, Tiches wpada do szybu windy i ginie. Jego pogrzeb ma charakter podniosłej uroczystości - na nagrobku wyryty zostaje napis Chcemy żyć tak, jak on to sobie wyobrażat. Ironiczny sens tego zapewnienia modelują wieńczące film słowa narratora: Bruno Tiches odszedt. Ale wielu jemu podobnych żyje nadal.

Dyskurs W czepku urodzonych wyróżnia się na tle innych zachodnioniemieckich filmów tamtych lat nie tylko z uwagi na przedstawienie ciagłości pomiędzy III Rzeszą a RFN, lecz także ze względu na „rozciągnięcie” planu historycznego na Niemcy epoki wilhelmińskiej (sama wojna zajmuje w narracji filmu ledwie minutę). Inaczej jednak niż w produkcjach Defy, takich jak Cztery pokolenia czy Poddany, brak tu sugestii, iż III Rzeszę można by uznać za kontynuację Cesarstwa - znaczenie wynikające z pierwszej sekwencji filmu, rozgrywającej się w 1913 r., jest dokładnie odwrotne. Oto dwaj chłopcy próbują wspiąć się na balon poświęcony Kaiserowi. Hans zostaje schwytany i ukarany, Brunowi udaje się uciec; co więcej, ten ostatni chwali się w szkole swoim rzekomym spotkaniem z Kaiserem. Nauczy-

${ }^{257}$ Sceny z rodziną Meisegeierów należą do najbardziej frapujących. Ta cygańska familia (jej członkowie kaleczą język niemiecki; kilkakrotnie mowa jest o niejasnym pochodzeniu i nieślubnych dzieciach, które wcześniej przemieszczały się po kraju w taborze itp.) ukazana jest $\mathrm{w}$ filmie $\mathrm{w}$ wyjątkowo niekorzystnym świetle, w sposób wręcz rasistowski. Wziąwszy pod uwagę politykę rasową III Rzeszy, cokolwiek absurdalne jest powiązanie tych akurat bohaterów z nazistami (Tiches żeni się z jedną z córek Meisegeierów; na jego pogrzeb przybywa „seniora Meisagara z Argentyny”, miejsca azylu wielu nazistów). 
ciel, w uznaniu dla opowieści chłopca, podarowuje mu portret Wilhelma II, ale obraz upada na ziemię i rozbija się na kawałki. Bruno - reprezentujący w dyskursie filmu nazizm - jest jedynie deklaratywnym, w istocie fałszywym „dziedzicem” Kaisera. Tradycja, do której się odwołuje, w sensie dosłownym zostaje, przy jego współudziale, zniszczona.

Oryginalność filmu Hoffmanna wynika w dużej mierze z zastosowanej przez niego formuły „filmu w filmie”. Już podczas napisów początkowych w ścieżce dźwiękowej słychać widzów zasiadających na sali, zaś główna część fabuły zaprezentowana zostaje jako „stary film” - na co wskazują "bruzdy” na taśmie, akompaniament pianina i styl aktorski (przesadna gestykulacja typowa dla kina niemego w scenach, których akcja rozgrywa się przed 1930 r.). Co więcej, na scenie przed ekranem występują artyści kabaretowi (Wolfgang Neuss i Wolfgang Müller) - treść ich piosenek dopowiada lub ironicznie komentuje to, co pokazane jest na ekranie. Rozwiązania takie osłabiają realistyczny tryb odbioru i zachęcają do przyjęcia brechtowskiego krytycznego dystansu wobec wydarzeń, a zatem: oglądania w trybie ukierunkowanym na publicystyczny dyskurs (ostatni napis czołówki brzmi: Fabuła filmu jest zmyślona. Przypadkowe podobieństwa do żyjacych osób sa jednak zamierzone).

Neuss zdyskontował sukces $W$ czepku urodzonych, pisząc scenariusz do fabuły - w oryginale zatytułowanej w zbliżony sposób - My, dzieci z piwnicy (Wir, Kellerkinder, RFN 1960 - choć reżyserem filmu był Jochen Wiedermann, w publikacjach drukowanych i w Internecie produkcja ta często oznaczana jest nazwiskiem Wolfganga Neussa, który zagrał niej główną rolę) $)^{258}$. Akcja filmu rozpoczyna się w 1959 r. w Berlinie. Reporter kroniki filmowej otrzymuje polecenie przygotowania materiału na temat swastyk pojawiających się na murach niemieckich miast ${ }^{259}$. Gdy okazuje się, że w zachodnioniemieckich archiwach nie może odszukać zdjęć dokumentujących ten proceder (pojawia się informacja, że dostępne są one wyłącznie w... zbiorach enerdowskich!), postanawia - wraz z przydzielonym

${ }^{258}$ Decyzją producenta i scenarzysty film został najpierw pokazany w telewizji, a dopiero później miał trafić do kin. Na to z kolei nie zgodzili się dystrybutorzy, którzy zainicjowali bojkot filmu, zakończony interwencją Federalnego Urzędu do spraw Konkurencji (Bundeskartellamt) - zob. http://www.spiegel.de/spiegel/print/d-43067689.html (dostęp: 10.01.2014). Kinowa dystrybucja okazała się bardzo udana, a film znalazł się wśród najchętniej oglądanych w 1960 r. Przywołuję to jako ciekawostkę - ze względu na współczesne strategie dystrybucji filmów, ale także z uwagi na zastrzeżenie poczynione we wstępie, dotyczące trudności z wyróżnianiem tzw. filmów kinowych i telewizyjnych.

${ }^{259}$ Ten koncept fabularny można zapewne czytać przez pryzmat tzw. wydarzenia bieżącego - na przełomie lat 1959 i $1960 \mathrm{w}$ kilku zachodnioniemieckich miastach pojawiły się antysemickie graffiti (media obiegło zwłaszcza zdjęcie przedstawiające napis Juden raus na murach kolońskiej synagogi). 
mu do pomocy operatorem kamery - dopuścić się manipulacji i zainscenizować sytuację. Nikt jednak nie chce podjąć się namalowania swastyki nawet za pieniądze (jeden $\mathrm{z}$ indagowanych sklepikarzy reaguje na prośbę dziennikarza słowami: Aha, jesteście ze Wschodu! Zmiatajcie stą, przeklęci komuniści!). Dopiero trójka zaczepionych na ulicy mężczyzn - Macke (w tej właśnie roli wystąpił Neuss), Artur i Adalbert - zgadza się namalować swastykę na szybie pobliskiego klubu jazzowego, należącego do ojca Mackego. Gdy materiał zostaje nagrany, niespodziewanie pojawia się policja, skutkiem czego towarzystwo musi ukryć się w piwnicy klubu. Jak się okazuje z obszernej retrospekcji (w tamtych czasach nikogo nie trzeba byto zachęcać do malowania swastyk, a policja reagowała nie wówczas, gdy w oknach pojawiaty sie flagi ze swastyka, ale wtedy, gdy było ich za mało), miejsce to jest dobrze znane Mackemu. Przed wojna, jako nastolatek, grał on na bębnie w orkiestrze Hitlerjugend (fot. 43). Ponieważ gorliwość, z jaką ćwiczył werble, przeszkadzała jego rodzinie, chłopak oddawał się swojej pasji właśnie w piwnicy. Gdy pewnego dnia przed nazistowską bojówką (dowodzoną przez kolegę ojca, niejakiego Glaubke) ucieka sąsiad - komunista Knössel, chłopak udziela mu w swej kryjówce schronienia na całe siedem lat. Z kolei po wojnie w piwnicy ukrywa się... ojciec Mackego, poszukiwany przez władze alianckie. Gdy niespodziewanie w lokalu pojawia się Knössel, dochodzi do jego konfrontacji z ojcem Mackego. Obaj mężczyźni uznają chłopaka za zdrajcę, w wyniku czego ląduje on w ośrodku dla psychicznie chorych. Tam poznaje dwóch innych nieszczęśników: Adalberta (który, pracując jako pucybut w monachijskim publicznym szalecie, ze względu na swoje podobieństwo do Führera cieszył się dużą estymą wśród klientów radujących się z faktu, że ich dawny przywódca ocalił życie; zdarzeń tych było tak wiele, że Adalbert w końcu sam uwierzył, iż jest inkarnacją Hitlera) oraz Artura (musiał uciekać z NRD z powodu swego zamiłowania do muzyki jazzowej). Kierownik ośrodka ordynuje trójce pacjentów eksperymentalną terapię: będą zwolnieni do domu, jeśli podczas przepustki do miejsc, w których zostali zatrzymani, uda im się - pod okiem asystenta - udowodnić, że są w stanie zachowywać się jak normalni obywatele. Niestety, zadanie to okazuje się trudne: $w$ teatrze w Cottbus (w NRD!) jako reżyser pracuje... były nazista Glaubke, zaś Adalbert ponownie zostaje wzięty za inkarnację Führera. W Monachium natomiast katalizatorem "przemiany” niegdysiejszego pucybuta w Hitlera jest rozmowa klientów:

- Potrzebujemy tylko jednego człowieka, kogoś takiego jak Hitler. Tym ze Wschodu musimy przeciwstawić się z pomoca kogoś do nich porównywalnego.

- Tak, trzeba tylko odrzucić nienawiść do Żydów i kwestie rasowe - to jesteśmy światu winni. 


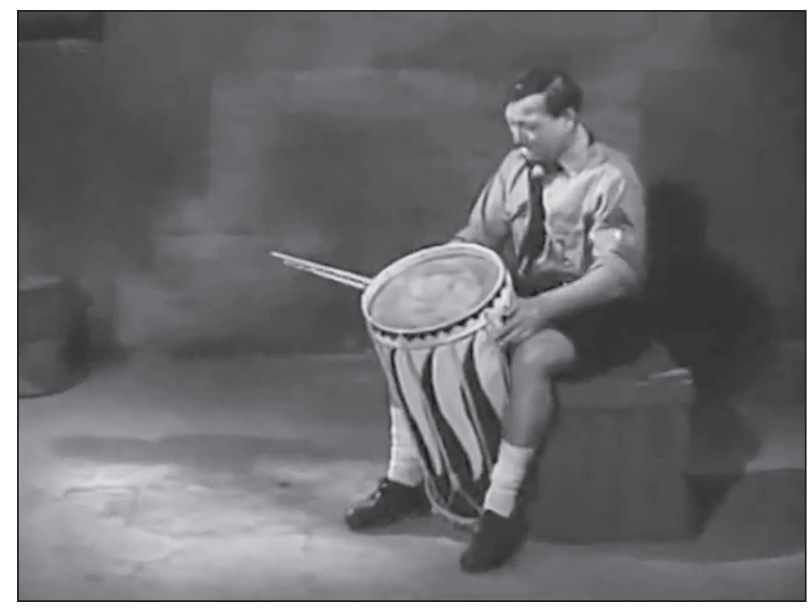

Fot. 43. My, dzieci z piwnicy (reż. Jochen Wiedermann, 1960) Czyżby była to aluzja do wydanego kilka miesięcy wcześniej Blaszanego bębenka?

Z kolei podczas trzeciej przepustki, w Berlinie, bohaterowie dowiadują się, że Knössel w międzyczasie uciekł z NRD do Kolonii, gdzie wydaje książki o „pseudokomuniźmie”. Ostatecznie, udaje im się zdać „egzamin” - i właśnie wtedy napotykają zdesperowanych reporterów... W finale do drzwi piwnicy puka policja, zaś cała trójka trafia z powrotem do domu wariatów (a nakręcony materiał filmowy - do kosza).

Satyryczny obraz kłopotów z dostosowaniem się Niemców do rzeczywistości społecznej trzech ustrojów politycznych wyróżnia się pod wieloma względami na tle zachodnioniemieckich filmów tamtych lat. Po pierwsze, pokazuje niewyplenione przyzwyczajenia („automatyczne" gesty hitlerowskiego pozdrowienia) z okresu III Rzeszy oraz nostalgię wobec symboliki nazistowskiej kultury (tzw. Badenweiler-Marsch ${ }^{260}$, którego odegrania przez muzyków domaga się przyjaciel ojca Mackego). Po drugie, poprzez opowieść ramową akcentuje polityczne zapotrzebowanie na audiowizualne notacje dotyczące rozliczeń z nazizmem (reporterzy są przez ministerialnego urzędnika zachęcani do zajęcia się tematem $w$ stylu Vergangenheitsbewältigung). Przede wszystkim zaś unaocznia - wcale wówczas nierzadkie - ideologiczne konwersje, i to w różnych konfiguracjach: byłych nazistów na stalinistów, stalinistów na "demokratów". Ci

${ }^{260}$ Marsz ten - pod oryginalnym tytułem Badonviller-Marsch - został skomponowany w 1914 r. przez Georga Fürsta dla uczczenia zwycięskiej walki z Francuzami z początku I wojny światowej. W okresie III Rzeszy utwór ten był wykorzystywany przez nazistowską propagandę (rozbrzmiewał na przykład w materiałach promujących igrzyska w Berlinie). 
ostatni - w filmie reprezentowani przez świat medycyny i mediów - sami posługują się manipulacją oraz cokolwiek dyskusyjnymi metodami. Ukazując je w krzywym zwierciadle, Neuss naigrywa się z "denazyfikacji” rozumianej jako pedagogiczno-terapeutyczny projekt, mający "uzdrowić" Niemców i doprowadzić ich do „normalności”.

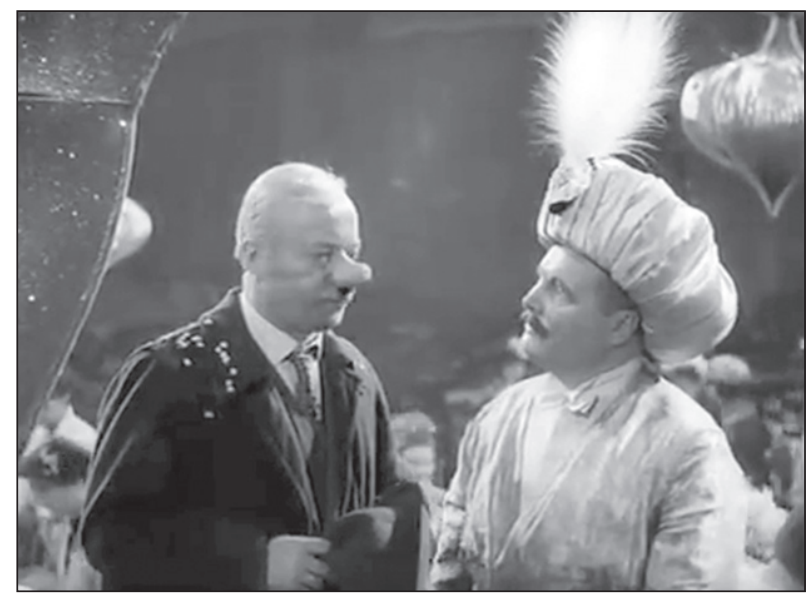

Fot. 44. Kolega ze szkoły (reż. Robert Siodmak, 1960) Na balu kostiumowym można spotkać dawnych znajomych

W formie quasi-komediowej krytyczny obraz skutków nierozliczonej nazistowskiej przeszłości przedstawił również Robert Siodmak w filmie Kolega ze szkoły (Mein Schulfreund, RFN 1960), opartym na wydarzeniach autentycznych, sfabularyzowanych wcześniej w sztuce Johannesa Mario Simmla. Bohater filmu - listonosz Fuchs, którego poznajemy w 1944 r. - jest rozczarowany kondycją państwa i przeciągającą się wojną. Gdy jego córka chce ukryć dezertera (swego narzeczonego), Fuchs początkowo ociąga się z podjęciem decyzji i dokonuje swoistej ekspiacji:

Cóż to za nieludzki reżim... Nikomu nie wolno wam o tym mówić, ale w nocy nie moge spać, bo mam wyrzuty sumienia, że wstapiłem do Partii... [...] „Panie Fuchs, ma pan odpowiedzialna posadę" [Fuchs wspomina rozmowę ze swoim przełożonym]. „Nie moge pozwolić, by pracowat ze mna ktoś, kto nie wie, gdzie wypada należeć. Wszyscy już wstapili, niech pan to sobie przemyśli"... I wstapiłem do partii, z tchórzostwa, z lęku przed utrata pracy.

Ostatecznie Fuchs pisze do swego szkolnego kolegi, Hermanna Göringa, list, w którym prosi go o... podjęcie działań w celu zakończenia wojny. Dzięki wstawiennictwu „kolegi” (Göring nie jest pokazany) wy- 
rok dla bohatera zostaje zamieniony na przymusowy pobyt $\mathrm{w}$ ośrodku dla umysłowo chorych. Po zakończeniu wojny Fuchs nie może odzyskać swej dawnej pracy - w świetle prawa jest bowiem nadal niepoczytalny. Chcąc przekonać sąd do zmiany stanowiska - co ostatecznie, po 15 latach od upadku III Rzeszy, mu się udaje - próbuje pozyskać zeznania od byłych nazistów (w jednej ze scen bohater, by wślizgnąć się na bal kostiumowy, gdzie w zabawnych przebraniach bawią się byli zwolennicy narodowego socjalizmu, zakłada... sztuczny nos - fot. 44). Wymowę filmu podkreśla wybór aktorów: w obsadzie pojawił się Alexander Golling, znany aktor kina III Rzeszy, w czasie jej istnienia niekryjący swych nazistowskich sympatii, zaś główną rolę Siodmak powierzył Heinzowi Rühmannowi - gwiazdorowi filmów rozrywkowych Ufy, który w 1944 r. znalazł się na przygotowanej w resorcie Goebbelsa liście „najbardziej wartościowych artystów niemieckich".

Rühmann zagrał wcześniej w innej "antymilitarystycznej” satyrze - wyreżyserowanej przez Helmuta Käutnera kongenialnej ekranizacji popularnej sztuki Carla Zuckmayera, Kapitan z Köpenick (Der Hauptmann von Köpenick $)^{261}$. To historia osadzona wprawdzie w czasach fryderycjańskich (i bazująca na autentycznych zdarzeniach z 1906 r., gdy pruski szewc, podający się za oficera, przejął ratusz miasta Köpenick), ale dysponująca sporym potencjałem alegorycznych odczytań (z tego powodu sztuka Zuckmeyera była zakazana w III Rzeszy). Film Käutnera okazał się wielkim sukcesem kasowym w RFN; otrzymał Niemiecką Nagrodę Filmową (w kilku kategoriach), był też pierwszym zachodnioniemieckim filmem nominowanym do Oscarów.

Tylko niektóre spośród omówionych w niniejszym podrozdziale fabuł (przede wszystkim dzieła Staudtego) uznawane są w publikacjach poświęconych niemieckiemu kinu za ważne osiągnięcia w jego historii. Większa liczba filmów poruszających problem niedokonanych rozliczeń z nazizmem i ciągłości karier zawodowych osób uwikłanych w działalność NSDAP pojawiła się w latach 70. za sprawą zarówno generacyjnej, jak i politycznej zmiany wywołanej przez pokolenie '68 oraz ruch studencki - i właśnie te późniejsze realizacje uznawane będą za istotny wkład niemieckiego kina w Vergangenheitsbewältigung.

${ }^{261}$ Russel A. Berman, A return to arms: Käutner's "The Captain of Köpenick”, [w:] German film and literature. Adaptations and transformations, red. Eric Rentschler, New York 1986; Edward M. Plater, „The Captain of Koepenick”: a faithful adaptation?, „Film \& History” 1990, nr 20. 


\subsection{Problem antysemityzmu}

Jak zauważa Anna Wolff-Powęska, „,koniec antysemityzmu jako obowiązującej ideologii nie oznaczał bynajmniej radykalnej zmiany postaw społecznych"262. Swiadectwem ich powolnej ewolucji są badania prowadzone przez Institut für Demoskopie w Allensbach: na pytanie „Czy dla Niemców byłoby lepiej, gdyby w kraju nie było żadnych Żydów?", w 1952 r. "tak" odpowiedziało 37 procent ankietowanych (w 1963 r. - 19 procent), odpowiedzi „nie” udzieliło odpowiednio: 20 procent w 1952 r. i 34 procent w 1963 r. ${ }^{263}$

Wśród nakręconych w RFN do 1965 r. filmów można wskazać zaledwie kilka tytułów, które w jakikolwiek sposób przypominały o antysemickiej polityce III Rzeszy. Są wśród nich trzy fabuły przedstawiające prześladowania artystów pochodzenia żydowskiego (lub osób z nimi związanych). Jak zauważa Mark Wolfgram ${ }^{264}$, umieszczenie akcji tych filmów w okresie międzywojennym jest znaczące o tyle, że daje fabularny „placet” na nieuwzględnienie wątku Zagłady.

I tak na przykład, tytułowa bohaterka filmu Friederike von Barring (reż. Rolf Thiele, RFN 1954) zakochuje się w reżyserze żydowskiego pochodzenia i wyjeżdża z nim do Ameryki (by po jego śmierci powrócić jednak do Niemiec) $)^{265}$. Biograficzną formułę - choć tym razem opartą na autentycznej postaci - miał film Pieśń rozbrzmiewa na świat - Historia Josepha Schmidta (Ein Lied geht um die Welt [Die Joseph-Schmidt-Story], reż. Géza von Bolváry, RFN 1958), opowiadający o znanym tenorze, kształconym jako kantor, który - pomimo sukcesów, jakie odnosił na scenie i w kinie (m.in. jako odtwórca głównej roli w filmie Pieśń rozbrzmiewa na świat) wyjechał z Niemiec w 1933 r. (wystąpił jeszcze w kilku filmach zrealizowanych w Austrii przed jej włączeniem do III Rzeszy). Popularną aktorką kina niemieckiego lat 30. była także Renate Müller, której biografię nakręcono w 1960 r. pod tytułem Ukochana bogów (Liebling der Götter, reż. Gottfried

${ }^{262}$ Anna Wolff-Powęska, Pamięć - brzemię i uwolnienie..., s. 479. Pewne znaczenie dla zmiany owych postaw miało zapewne ukazanie się Dziennika Anny Frank (wydane niemieckie 1950 r.), choć nie brakowało publicznie wyrażanych głosów usiłujących przekonać, że jest on fałszerstwem, a sama Anna Frank - postacią fikcyjną.

263 Jahrbuch der öffentlichen Meinung 1955-1967, red. Elisabeth Noelle, Allensbach 1967, s. 96. Zob. także: Werner Bergmann, Rainer Erb, Antisemitismus in der Bundesrepublik Deutschland: Ergebnisse der empirischen Forschung von 1946-1989, Opladen 1991.

${ }^{264}$ Mark A. Wolfgram, West German and Unified German Cinema's Difficult Encounter with the Holocaust, „Film \& History: An Interdisciplinary Journal of Film and Television Studies" 2002, nr 2.

${ }^{265}$ Film był na tyle popularny, że w kolejnym roku ten sam reżyser nakręcił sequel (Barringowie [Die Barrings], RFN 1955). 
Reinhardt). Film akcentuje osobisty dramat bohaterki, wynikający z antysemickiej polityki nazistów: rozłąkę z ukochanym (który zmuszony był wyjechać do Anglii), nadzór przez nazistowską tajną policję, odebranie paszportu, wreszcie - załamanie, skutkujące osadzeniem w ośrodku dla osób chorych psychicznie, a w końcu samobójstwem. Historia ta przypomina losy Gottschalka, sportretowane w Małżeństwie w mroku (tym razem to bohaterka jest Aryjką, a prześladowanym - jej ukochany); pod względem artystycznym Ukochana bogów nie dorównuje jednak poziomem filmowi Maetziga (zob podrozdział 1.3).

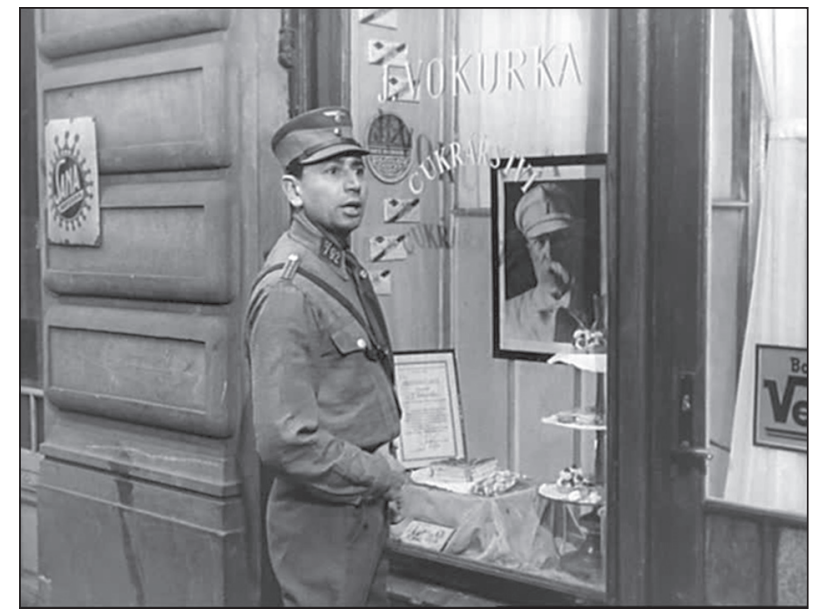

Fot. 45. Dom przy Karpfengasse, część 1

(reż. Kurt Hoffmann, 1965)

Niemiecki oddział dostrzega portret prezydenta

Masaryka umieszczony w sklepowej witrynie

Jeśli w kinie zachodnioniemieckim omawianego okresu temat Zagłady w ogóle pojawia się $\mathrm{w}$ fabule, to najczęściej na zasadzie dramaturgicznego ,alibi" - poprzez wątek drugoplanowy, jak we wspomnianych filmach Generat diabła czy Noc zapadła nad Gotenhafen. Innym przykładem może być film Wiem, po co żyje (Ich weiß, wofür ich lebe, reż. Paul Verhoeven, RFN 1955). Bohaterką filmu jest pielęgniarka Czerwonego Krzyża, która w czasie wojny uratowała dwóch żydowskich chłopców. Wydarzenia te prezentowane są w krótkich retrospekcjach, nad którymi przeważa jednak melodramatyczna opowieść osadzona $\mathrm{w}$ realiach powojennych Niemiec, mianowicie walka kobiety o sądowe uznanie jej prawa do opieki nad chłopcami. Owszem, tłem intrygi są prześladowania Żydów w okresie wojny, ale grawituje ona wyraźnie ku - nośnej w pierwszych latach powojennych (choćby z uwagi na liczne relacje prasowe) - formule opowieści o sierotach. 
Wówczas, gdy temat prześladowań Żydów tworzy główną linię dramaturgiczna, koncentruje się ona na "codziennych" przejawach antysemityzmu, wśród których Zagłada jest jedynie niewypowiedzianą groźbą - jak w filmie Dom przy Karpfengasse (Haus in der Karpfengasse, reż. Kurt Hoffmann, RFN/Czechosłowacja 1965), złożonym z czterech historii o represjonowaniu praskich Żydów, mieszkańców tytułowej kamienicy, po zajęciu Czech przez Niemców w marcu 1939 r. ${ }^{266}$ Wyjątkowość tej realizacji wynika stąd, iż był to pierwszy - od czasu Dluga jest droga (zob. podrozdział 1.6) - zachodnioniemiecki film, w którym wydarzenia rozgrywające się w latach 30. pokazane są z perspektywy żydowskich bohaterów (fot. 45).

Projekt Hoffmanna był początkowo planowany z myślą o kinie, jednak z uwagi na problemy ze znalezieniem dystrybutora ${ }^{267}$, reżyser zwrócił się o wsparcie do telewizji. Gdy okazało się, że film jest udany, został wstępnie rekomendowany do udziału w canneńskim festiwalu. Niemieccy urzędnicy wycofali jednak tytuł z konkursu - oficjalnie władze RFN podały „powody techniczno-estetyczne"268, ale autor literackiego pierwowzoru publicznie twierdził, że zdecydowały względy polityczne ${ }^{269}$. Niejako na pocieszenie film obsypano Niemieckimi Nagrodami Filmowymi - w 1965 r. Dom przy Karpfengasse został uznany za najlepszy film pełnometrażowy, Hoffmann otrzymał nagrodę za reżyserię, a Gerd Angermann - za scenariusz.

Zastanawiając się, co sprawiło, że film napotkał takie przeszkody, Mark Wolfgram podaje dwie prawdopodobne odpowiedzi ${ }^{270}$. Po pierwsze, w fabule nie ma "dobrych Niemców”, zaś „źli” nie są esesmanami, lecz „zwykłymi obywatelami” (jak antysemicki dozorca). Po drugie, film Hoffmanna to zarazem jedna z nielicznych - obok wspomnianej Zdrady Niemiec - produkcji zachodnioniemieckich tamtego okresu, w której pojawia się (w ostatniej nowelce) wątek komunistycznego ruchu oporu. Można się domyślać, że wprowadzenie tego tematu było warunkiem zgody strony czechosłowackiej na realizację zdjęć w Pradze, co zresztą wywołało protesty, zwłaszcza ze strony Niemców Sudeckich (w prasie pytano: „Czy film ten może mówić prawdę o tyranii, skoro tyrani pomagają go zrobić?"271).

${ }^{266}$ Literacki pierwowzór: Moshe Ya'akov Ben-Gavriel, Das Haus in der Karpfengasse, Berlin 1957.

${ }^{267}$ Mark A. Wolfgram, West German and Unified German Cinema's Difficult Encounter..., s. 22-28.

268 Ibidem, s. 28.

${ }^{269}$ Moshe Ya'akov Ben-Gavriel, Die Karpfengasse führt nicht nach Cannes, „Die Zeit”, 28.5.1965.

${ }^{270}$ Mark A. Wolfgram, West German and Unified German Cinema's Difficult Encounter..., s. 29.

271 Tschechische Hilfe für Kurt Hoffmann, „Neue Züricher Zeitung”, 24.02.1962. 
Jak widać z tego skrótowego zestawienia, nazistowska polityka wobec Żydów nie była tematem często podejmowanym przez zachodnioniemieckich twórców. Aż do początku lat 60. gdy na rynku wydawniczym pojawił się Namiestnik Rolfa Hochhutha (o polityce papieża Piusa XII wobec III Rzeszy i jego domniemanej obojętności wobec zbrodni Holocaustu), problematyka ta $\mathrm{w}$ zasadzie nie pojawiała się także $\mathrm{w}$ publicznych debatach prowadzonych w RFN. Zdaniem Norberta Freia "dokumentowanie Zagłady spoczywało w getcie żydowskiej pamięci, było sprawą tych, którzy przeżyli i ich instytucji, głównie zagranicznych"272. Przykładem takiego działania stał się słynny, prowadzony w Jerozolimie w 1961 r., proces Eichmanna, który przykuł uwagę niemieckiej opinii publicznej ${ }^{273}$. Jak pisał Norbert Elias, wydarzenie to z pozoru nie było

niczym więcej, jak tylko indywidualną sprawą toczącą się przy współudziale byłego esesmana, jego izraelskich oskarżycieli, świadków, wśród których znajdowali się uratowani więźniowie obozów koncentracyjnych oraz niewidzialnej międzynarodowej publiczności. Jednak po miesiącach rozchodzenia się po całym świecie doniesień, które przenikały do rozmów, myśli i uczuć wielu ludzi w licznych krajach, proces zaczął się przekształcać w coś więcej [...] powiększył rosnącą masę doświadczeń kwestionujących nasze wyobrażenie o sobie jako społeczeństwie cywilizowanym ${ }^{274}$.

\subsection{Obrazy obozów}

Spośród spraw karnych toczących się przed niemieckimi sądami zainteresowanie porównywalne do tego, z jakim spotkał się proces Eichmanna, wywołały tzw. procesy oświęcimskie (1963-1965) we Frankfurcie nad Menem $^{275}$ (a także inne odbywające się $\mathrm{w}$ tym czasie sprawy karne: sprawców z Treblinki, Bełżca i Sobiboru $)^{276}$. Pierwszym artystycznym świadectwem spowodowanych za ich sprawą zmian było Dochodzenie (1965)

${ }^{272}$ Norbert Frei, Auschwitz und Holocaust. Begriff und Historiographie, [w:] Holocaust - Grenzen des Verstehens. Eine Debatte über die Besetzung der Geschichte, red. Hanno Loewy, Reinbek 1992, s. 101-109.

${ }^{273}$ W 1964, rok po wydaniu angielskim, opublikowano niemiecki przekład Eichmanna w Jerozolimie Hannah Arendt. Swoją droga, w erefenowskim wydawnictwie Piper-Verlag, w którym ukazywały się jej prace, ich redaktorem prowadzącym był Hans Rößner, wcześniej członek kolejno: SA, SS i SD (Arendt ponoć nigdy nie dowiedziała się o wcześniejszej działalności redaktora).

274 Norbert Elias, Rozważania o Niemcach: zmaganie o władze a habitus narodowy i jego przemiany w XIX i XX wieku, tłum. R. Dziergwa, J. Kałążny, I. Sellmer, Poznań 1996, s. 403.

275 Zob. na przykład przejmująca, ekspiacyjną relację Horsta Krügera (W labiryncie winy. Jeden dzień z procesu oświęcimskiego, [w:] O kondycji Niemiec...).

276 Anna Wolff-Powęska, Pamięć - brzemię i uwolnienie..., s. 275. 
Petera Weissa, dramat oparty na dokumentach procesowych. Na filmowe reprezentacje i reinterpretacje znaczenia Auschwitz-Prozesse należało jeszcze nieco poczekać.

Republika Federalna Niemiec doby Adenauera i Erharda nie była przygotowana na konfrontację z ogromem zbrodni popełnionych w obozach zagłady. Zachodnioniemieckie kino tamtych lat dostarcza argumentów na rzecz tej tezy, przede wszystkim ze względu na znikomą liczbę filmów z tym wątkiem (zreszta, gdyby brać pod uwagę kryterium ilościowe, trzeba by powiedzieć, że o ile w erefenowskich filmach $z$ lat 1950-1965 stosunkowo często pojawiały się obozy tymczasowe dla przesiedleńców czy obozy dla jeńców wojennych - przeznaczone dla Niemców, o tyle o obozach przez Niemców zbudowanych możemy co najwyżej usłyszeć w dialogach, i to najczęściej w odniesieniu do obozów koncentracyjnych). Ale wspomnieć można również o decyzjach mających wpływać na politykę repertuarową: wewnętrzna, ale też dotyczącą obiegu festiwalowego. O kwestiach związanych z enerdowskim filmem Gwiazdy była już mowa (zob. podrozdział 2.7). Przy innej okazji, w 1956 r., Ministerstwo Spraw Zagranicznych RFN naciskało na organizatorów festiwalu w Cannes, by wycofali z programu dokument Noc i mgła (Nuit et Brouillard, Francja 1955) Alaina Resnais - argumentując, że to film polityczny, utrudniający międzynarodowe porozumienie ${ }^{277}$ (gdy informacja o tych działaniach przedostała się do opinii publicznej, wielu Niemców z RFN „oprotestowało protest").

O tym, jak trudnym tematem dla zachodnioniemieckiego kina były obozy, świadczyć może film Transport (Der Transport, reż. Roland Jürgen, Herbert Viktor, RFN 1961). Pierwsze sceny, rozgrywające się w obozie właśnie, mogą sugerować opowieść o ofiarach totalitarnego reżimu - ale po kilku minutach narracja weksluje w stronę opowieści zgoła innej. Jej bohater, porucznik Wehrmachtu, w marcu 1945 r. otrzymuje rozkaz przewiezienia więźniów wojennych (również cywilnych) na obszar zagrożony działaniami zbrojnymi i samowolnie postanawia - nie bacząc na nadzorujących go oficerów Gestapo - skierować tytułowy transport na teren zajęty już przez Amerykanów (więźniowie zostają ocaleni, ale dzielny porucznik ginie).

277 Martina Thiele, Publizistische Kontroversen..., s. 189-91; Ewout van der Knaap, Enlightening Procedures: "Nacht und Nebel" in Germany, [w:] Uncovering the Holocaust: The International Reception of "Night and Fog", red. Ewout van der Knaap, London 2006; Walter Euchner, Unterdrückte Vergangenheitsbewältigung..., s. 353-357. Również: Elizabeth M. Ward, Screening out the East: The Playing out of Inter-German Relations at the Cannes Film Festival, „German Life and Letters" 2015, nr 1. 
Przykładem erefenowskiego filmu z wątkiem obozowym może być Ucieczka (w kinach dystrybuowany jako Mensch und Bestie, na DVD jako Die Flucht, reż. Edwin Zbonek, RFN/Jugosławia 1963) - jedna z nielicznych realizacji wspominających o masowych mordach (choć bez przywoływania Zagłady). Schemat dramaturgiczny filmu jest tu pretekstem do przedstawienia historii opartej na podaniu o Kainie i Ablu. Bohaterami są Franz, antynazista osadzony $\mathrm{w}$ obozie $\mathrm{w}$ Mauthausen oraz jego przyrodni brat Willi, podpułkownik SS w oddziale nadzorującym obóz (fot. 46). Gdy Franz dowiaduje się, że wszyscy więźniowie mają zostać zlikwidowani przed nadejściem Armii Czerwonej (akcja rozgrywa się na początku 1945 r.), postanawia uciec, aby sprowadzić jej oddziały przed spodziewaną masakrą. Willi otrzymuje zadanie odszukania zbiega i rozpoczyna polowanie, w wyniku którego zabija brata, zanim ten zdąży przedostać się na zajęty przez sowietów brzeg rzeki. Zakończenie to wzmogło czujność komisji FBW, zdaniem której mogło ono wywołać skojarzenia z murem berlińskim (bratobójczy strzał podczas próby przedostania się „na drugą stronę") $)^{278}$; ostatecznie, filmowi przyznano predykat „wartościowy”.

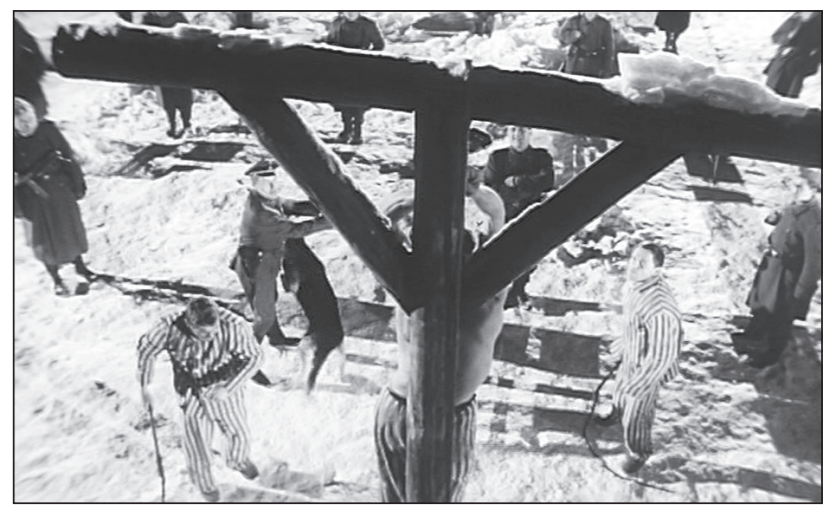

Fot. 46. Ucieczka (reż. Edwin Zbonek, 1963) Więźniowie obozu zmuszani do biczowania ukrzyżowanych współtowarzyszy niewoli

Ucieczka powstała w wytwórni Artura Braunera CCC - i nie zwróciła kosztów produkcji ${ }^{279}$. Brauner postanowił jednak zaryzykować raz jeszcze, korzystając z medialnego zainteresowania wokół rozgrywających się

${ }^{278}$ Zob. http://www.fbw-filmbewertung.com/film/mensch_und_bestie (dostęp: 20.03.2014).

279 Claudia Dillmann, Zu bittere Kräuter: "Zeugin aus der Hölle”. Die Produktion und Rezeption eines "riskanten" Films, [w:] Die Vergangenheit in der Gegenwart..., s. 32. 
w owym czasie procesów przeciw podejrzanym o zbrodnie popełniane w obozach. W efekcie w 1965 r. nakręcono pierwszy zachodnioniemiecki film fabularny traktujący o krematoriach i Zagładzie, będący zarazem krytycznym głosem na temat rozliczeń z nazistowską przeszłością. Świadek z piekła (Zeugin aus der Hölle, reż. Zika Mitrović, RFN/Jugosławia) jest nieco podobny do enerdowskiej Kroniki pewnego morderstwa: akcja obu filmów rozgrywa się w RFN i przybiera formułę thrillera opowiadającego o uratowanej z Zagłady kobiecie, która bezskutecznie domaga się sprawiedliwości.

W zawiązaniu akcji prokurator zatrudniony w Centrali w Ludwigsburgu odwiedza w Belgradzie pisarza Petrovica, który w swej książce opisał losy Lei Weiss, wykorzystywanej w obozie koncentracyjnym do eksperymentów medycznych. Za pośrednictwem literata prokurator dociera do bohaterki, pragnąć zachęcić ją do złożenia zeznań w sprawie przeciwko „lekarzowi” Bergerowi, który po wojnie zrobił karierę w przemyśle farmaceutycznym. Kobieta waha się - nie chce wracać do tragicznych wydarzeń, które stały się jej udziałem. Ostatecznie jednak zgadza się, nie wiedząc, iż decyzja ta przyniesie najpierw cierpienie (będzie musiała zmierzyć się $\mathrm{z}$ oskarżeniami o dobrowolną prostytucję $\mathrm{w}$ obozie, zaś prawnik, który miał ją chronić, okaże się uwikłany w znajomości z byłymi nazistami), a wreszcie śmierć (Lea nie wytrzymuje presji i odbiera sobie życie).

Inaczej niż we wzmiankowanym Lekarzu bez sumienia, również dotykającym procederu eksperymentów medycznych prowadzonych w obozach, fabuła koncentruje się tu na losach ofiary, zaś spora część narracji przybiera postać tzw. filmu sądowego. Choć w scenariuszu nie wykorzystano autentycznych akt z procesów oświęcimskich (jak w dramacie Weissa Dochodzenie), a w filmie nie pada nazwa "Auschwitz”, Ronny Loewy w swym szkicu historycznym poświęconym filmowi pokazuje paralele między bohaterką filmu a rzeczywistą postacią - Dunją Wasserström, która zeznawała we Frankfurcie ${ }^{280}$. Loewy zwraca przy tym uwagę, że w jej zeznaniach nie było mowy o seksualnej przemocy wobec kobiety - tymczasem film wyraźnie eksploatuje ten właśnie wątek. Gatunkowy sztafaż akcentowany jest również przez ",sensacyjny" tytuł (początkowo film miał wejść na ekrany jako Bittere Kräuter - "gorzkie zioła") oraz obsadę (popularni aktorzy Heinz Drache i Werner Peters, znani m.in. z przygodowych adaptacji powieści Edgara Wallace'a). Świadek z piekła na swą premierę czekał aż dwa lata - początkowo FBW odmówiło bowiem przyznania "predykatu” uprawniającego do zniżek podatkowych. Przyczyną decyzji nie był jednak artystyczny poziom filmu, lecz - jak się zdaje - kwestie polityczne, o czym przekonuje wykonana przez Claudię Dill-

${ }^{280}$ Ronny Loewy, "Zeugin aus dem Hölle" und die Wirklichkeit des Auschwitz-Prozesses, [w:] Die Vergangenheit in der Gegenwart. Konfrontationen mit den Folgen des Holocaust im deutschen Nachkriegsfilm, red. Claudia Dillmann, Ronny Loewy, Frankfurt am Main 2001. 
mann kwerenda archiwalna, opisująca „przepychanki” prawne między prawnikami CCC i ekspertami FBW ${ }^{281}$. Ci ostatni, w uzasadnieniu ostatecznie przyznanego predykatu, umieścili takie oto zdanie: „Nie jest jasne, dlaczego bohaterka, która pochodzi z Jugosławii, która była zmuszana w obozie do tak strasznych rzeczy (das Schrecklichste mitmachen), która po wojnie wyszła za francuskiego prawnika - mieszka w Niemczech"282. Zirytowany tym sformułowaniem prawnik CCC dopisał na dokumencie otrzymanym z FBW: „Bo jest Niemką. Można by równie dobrze zapytać: a dlaczego pan Brauner mieszka w Niemczech?"283.

$\mathrm{Z}$ początkiem lat 60 . audiowizualne opowieści o nazistowskiej przeszłości Niemiec zaczęły pojawiać się także w erefenowskiej telewizji ${ }^{284}$. Wyprodukowała ona kilka filmów dokumentalnych na ten temat, wśród nich - nadawany na stacji WDR w czasie, gdy uwagę opinii publicznej zaprzątał proces Eichmanna - czternastoodcinkowy cykl Trzecia Rzesza (Das dritte Reich). Akcentowano w nim wprawdzie rolę antysemityzmu, ale zarazem podtrzymano dyskurs „Niemców jako ofiar Hitlera”. Przemilczano też skalę poparcia dla NSDAP ze strony biznesu i przemysłu oraz wyeksponowano rolę ruchu oporu ${ }^{285}$. Nakręcono też kilkanaście fabularnych teatrów telewizji/filmów telewizyjnych (Fernsehspiel) o narodowym socjalizmie; w większości mówiły one o antynazistowskim ruchu oporu w Niemczech ${ }^{286}$,

${ }^{281}$ Claudia Dillmann, Zu bittere Kräuter...

${ }^{282}$ http://www.fbw-filmbewertung.com/film/die_zeugin_aus_der_hoelle (dostęp: 20.04.2014).

${ }^{283}$ Claudia Dillmann, Zu bittere Kräuter..., s. 34.

${ }^{284}$ Temat ten został nadspodziewanie dobrze opracowany w licznych publikacjach (z nich czerpię informacje, które podaję w kolejnych trzech przypisach). Zob. Christiane Fritsche, Vergangenheitsbewältigung im Fernsehen. Westdeutsche Filme über den Nationalsozialismus in den 1950er und 60er Jahren, München 2003; Christoph Classen, Bilder der Vergangenheit. Die Zeit des Nationalsozialismus im Fernsehen der Bundesrepublik Deutschland 1955-1965, Köln 1999; Knut Hickethier, Kriegserlebnis und Kriegsdeutung im bundesdeutschen Fernsehen der fünfziger Jahren, [w:] Schuld und Sühne? Kriegserlebnis und Kriegsdeutung in deutschen Medien der Nachkriegszeit (1945-1961), red. Ursula Heukenkamp, Amsterdam-Atlanta 2001; idem, Der Zweite Weltkrieg und der Holocaust im Fernsehen der Bundesrepublik der fünfziger und frühen sechziger Jahre, [w:] Der Krieg in der Nachkriegszeit. Der Zweite Weltkrieg in Politik und Gesellschaft der Bundesrepublik, red. Michael Greven, Oliver von Wrochem, Opladen 2000; Michael E. Geisler, The Disposal of Memory: Fascism and the Holocaust on West German Television, [w:] Framing the Past: The Historiography of German Cinema and Television, red. Bruce A. Murray, Christopher J. Wickham, Cardbondale 1992.

${ }^{285}$ Inne filmy dokumentalne wymieniane przez autorów opracowań wskazanych w poprzednim przypisie to: Na tropach kata (Auf den Spuren des Henkers, reż. Peter Schier-Gribowski, Carsten Diercs, 1961), Kto przeżyje, jest winien (Wer überlebt, ist schuldig, reż. Axel Eggebrecht, RFN 1960) i Mury (Mauern, reż. Egon Monk, Günter Lys, RFN 1963).

${ }^{286}$ M.in.: Twierdza (Die Festung, reż. Claus Hubalek, RFN 1957), Niebezpieczny człowiek (Ein gefährlicher Mensch, reż. Claus Hubalek, RFN 1958), Sen sprawiedliwych (Der Schlaf der Gerechten, reż. Oliver Storz, RFN 1962), Obraz człowieka (Das Bild der Menschen, reż. Peter 
a jedynie sporadycznie o prześladowaniach Żydów ${ }^{287}$. Wśród tych ostatnich wyróżnić trzeba, ignorowany w dyskursie akademickim przez kilka dekad, telewizyjny film Dzień. Raport z niemieckiego obozu koncentracyjnego (Ein Tag. Bericht aus einem deutschen Konzentrationslager, reż. Egon Monk, RFN 1965). Jego znaczenie $\mathrm{w}$ historii kina niemieckiego - odkryte na nowo na przełomie wieków - wiąże się z faktem, iż był to jeden z nielicznych w tej kinematografii filmów fabularnych o tematyce obozowej (pomijając enerdowskie Gwiazdy i Nadzy wśród wilków).

Reżyser filmu, Egon Monk, w czasie wojny służył w Luftwaffe, w latach 50. mieszkał w NRD - asystował w filmach Defy, a w Berliner Enseble współpracował z Brechtem (do RFN wyemigrował w 1957 r.). W późniejszych latach dla zachodnioniemieckich stacji kilkakrotnie realizował zresztą teatry telewizji na podstawie sztuk Brechta. W Dniu trudno jednak odnaleźć teatralną proweniencję reżysera, styl filmu przypomina raczej dokument. Zamysł taki przyświecał współscenarzyście (Günther R. Lys), który w latach 1941-1945 był więźniem Sachsenhausen. Jako asystent Monka pracował Klaus Wilderhahn - późniejszy klasyk niemieckiego dokumentu filmowego (w jednej z ról - zdrajcy Mennesa - wystąpił natomiast inny późniejszy dokumentalista, Eberhard Fechner). Obsadę dobrano zaś w taki sposób, by postaci strażników odgrywali byli szeregowcy lub podoficerowie Wehrmachtu ${ }^{288}$. Sam reżyser o swoich zamierzeniach mówił w następujący sposób:

Wszyscy znamy tematy, o których w ciągu pierwszych dziesięciu lat po wojnie mówiono, że jest jeszcze zbyt wcześnie, by je przedstawiać, i o których w kolejnej dekadzie mówiono, że już na to zbyt późno. Obóz koncentracyjny stanowi jeden z takich tematów ${ }^{289}$.

Lotar, RFN 1964), Ulica Leśniczózek 20 (Waldhausstr. 20, reż. Maria Matray, Answald Krüger, RFN 1960), Każdy umiera sam za siebie (Jeder stirbt für sich allein, reż. Falk Harnack, 1962), Paryż musi płonać (Paris muss brennen, reż. Erich Kröhnke, RFN 1965).

287 Do tej grupy autorzy opracowań o historii zachodnioniemieckich mediów elektronicznych zaliczają filmy telewizyjne: Ukochany w Rzymie (Geliebt in Rom, reż. Jürgen Gütt, RFN 1963), Ulica Leśniczówek 20 (wymieniona również w poprzedniej kategorii), Zapytanie (Die Anfrage, reż. Egon Monk, RFN 1962), Akta Wiltau (Akte Wiltau, reż. Ralph Lothar, RFN 1964) oraz Tajny zwiazek przyszłych miłości (Geheimbund Nächstenliebe, reż. Ralph Lothar, RFN 1964).

${ }^{288}$ Karl Prümm, Dokumentation des Unvorstellbares. „Ein Tag. Bericht aus einem deutschen Konzentrarionslager", [w:] Der Holocaust im Film. Mediale Inszenierung und kulturelles Gedächtnis, red. Waltraud Wende, Heidelberg 2007, s. 114.

289 Egon Monk, Parteinahme als Notwendigkeit, „epd-Kirche und Fernsehen” 1966, nr 17, s. 2. W późniejszych latach Monk zrealizował jeszcze kilka telewizyjnych filmów o tematyce związanej z okresem nazizmu. Były to ekranizacje powieści: Hansa Fallady Rolnicy, bonzowie i bomby (Bauern, Bonzen und Bomben, RFN 1973), Liona Feuchtwangera Rodzeństwo Oppermann (Die Geschwister Oppermann, RFN 1983) i Ralpha Giordano Rodzina Bertinich (Die Bertinis, RFN 1988). 
Akcja filmu toczy się na kilka miesięcy przed początkiem wojny w fikcyjnym obozie Altendorf i składa z siedmiu aktów, wprowadzanych planszami tytułowymi:

1) Przyjazd. Ciężarówka zatrzymuje się przed wjazdem do obozu, więźniowie wywoływani są po nazwisku; na drutach kolczastych zwisa ciało martwego mężczyzny.

2) Apel. Kontrolowana jest czystość ubrań; starszy więzień wkłada pod ubranie starą papierową torbę, aby ochronić się przed zimnem.

3) Codzienność. Ciało zostaje przewiezione do krematorium; więźniowie kopią dół z przeznaczeniem na masowe groby; nowo przybyłym golone są głowy i odbierane cywilne ubrania; esesman dopytuje, za co zostali skazani - gdy jeden z zatrzymanych wyjawia, że przyczyną uwięzienia było opowiedzenie politycznego dowcipu, strażnik każe mu ów żart przytoczyć, śmieje się, a potem bije „kawalarza”; weteran walk w Hiszpanii nazwiskiem Springer sprawia wrażenie subordynowanego, jego postawa wzbudza nieufność innych więźniów, którzy obawiają się, że może on być donosicielem.

4) Interesy, trudności, troski. Komendant kacetu dyktuje list z prośbą o przyznanie środków na bardziej wydajne krematoria; w kantynie oficerowie rozmawiają o swych rodzinach i karierze w SS; torturowany więzień Mennes zdradza tajemnice współwięźniów; obozowa starszyzna - więźniowie polityczni: komunista Karl oraz socjaldemokrata Alwin wysyłają do najtrudniejszych zadań tych, którzy i tak mają niewielką szansę na przeżycie.

5) Śmierć adwokata Katza. Żydowski adwokat, który pod ubraniem chował papierową torbę, nie uniknie kary; blokowy rzuca nakrycie głowy Katza na elektryczne ogrodzenie i każe mu je przynieść z powrotem; Katz wie, co go czeka, zdejmuje buty, by inni mogli z nich skorzystać; zanim dojdzie do ogrodzenia, z wieżyczki strażniczej pada seria z karabinu maszynowego; do protokołu zostaje wpisana formuła ",zastrzelony podczas ucieczki”; żołnierz, który oddał strzał, w nagrodę otrzymuje wolny weekend.

6) Apel. Duchowny jest szykanowany - musi mówić: Bóg jest świniq i zostaje ukarany za nieposłuszeństwo; nadzorca oznajmia: Jest sposób na wyjście na wolność. Postuszeństwo, pilność, szczerość, porzadek, czystość, odwaga i miłość do ojczyzny.

7) Wśród zwykłych ludzi. Wartownicy kończą zmianę, idą do restauracji odprężyć się z innymi mieszkańcami miasteczka.

Streszczenie wydarzeń - nieco bardziej niż w wypadku innych tytułów - wydało mi się celowe nie tylko z tego powodu, że Dzień to realizacja mało znana i trudno dostępna, ale przede wszystkim ze względu na to, iż dobrze oddaje epizodyczną narrację filmu. Choć nie sposób wskazać $\mathrm{w}$ nim głównego bohatera, a pojedyncze postaci traci się z oczu, to 
relacje między osadzonymi i strażnikami (oraz więźniami politycznymi i kryminalistami) zostają przedstawione w sposób bardzo klarowny. Powtarzalność sytuacji, sugerowana przez sam tytuł, podkreślana jest przez prosty chwyt dramaturgiczny: repetycję motywu (ciało więźnia zwisające na drutach kolczastych - na początku filmu, i później, gdy podobny los spotka adwokata Katza). Zbliżony efekt wywołują sceny biurokracji obozowej: odczytywanie list więźniów na apelu (dwukrotnie) oraz zbieranie podpisów pod protokołem „ucieczki” Katza.

Unikalną - w porównaniu z innymi niemieckimi filmami tamtych lat - decyzją dramaturgiczną było poświęcenie osobnych scen strażnikom. Nie tylko w finale (gdzie pokazani są jako grupa), lecz także we wcześniejszych scenach, w których dialogi indywidualizują postaci (oficer SS skarży się na przykład na częste rozkazy nakazujące mu zmianę miejsca pracy, w konsekwencji czego, jak domniemywa, jego syn ma problemy z nauką). Wspomniane zakończenie jest $\mathrm{z}$ kolei ciekawe $\mathrm{z}$ uwagi na zastosowane asynchrony wizualno-dźwiękowe: na obrazy przedstawiające gospodę nałożono dźwięki z obozu (kłaść się, powstać [...] to was nauczy). Kontrast jako zasada montażowa został wykorzystany również w sekwencjach, w których materiały archiwalne nakręcone w III Rzeszy są zestawione z rzeczywistością obozową: chwilę po scenie, w której ciało Katza zostaje przewiezione do krematorium, przebitka montażowa pokazuje przyjęcie Führera dla korpusu dyplomatycznego i masy krzyczące „Heil Hitler”.

Dzień miał swą premierę telewizyjną w maju 1965 r. Wśród recenzji przeważały opinie pozytywne, podkreślające wagę podjętej przez film tematyki oraz sugestywność przekazu: „Ogląda się to z poczuciem wstydu, że wówczas się żyło” - napisał recenzent „Der Tagesspiegel”290. Niektórzy krytycy utyskiwali jednakowoż na surowość formy, dając wyraz rozczarowaniu, że nie obejrzeli filmu „w stylu amerykańskim”291 (co szczególnie interesujące w świetle późniejszej - o 14 lat! - debaty o serialu Holocaust). Dostępne są także badania ankietowe widowni Dnia w 1965 r.: na pytanie "Czy to dobrze, że taki temat jest podejmowany przez telewizję?" 60 procent ankietowanych odpowiedziało twierdząco, odpowiedzi „nie” udzieliło aż 39 procent (próba 425 osób). Wskazania były zróżnicowane ze względu na wiek: wśród osób w wieku 14-29 lat "tak" odpowiedziało 74 procent respondentów, wśród osób powyżej 50 lat 45 procent udzieliło odpowiedzi negatywnej ${ }^{292}$. Badania dotyczące kolejnych emisji nie były

290 Wolfgang Paul, Bestiarium „Der Tagesspiegel”, 6.05.1965.

${ }^{291}$ Herbert John, Wie aus Butter Margarine wird. Die deutschen Fernsehunterhalter machen die besten Idee kaputt, „Die Zeit”, 18.04.1975.

${ }^{292}$ Der Dokumentarbericht im Urteil der Zuschauer, München 1965; podaję za: Horst Holzer, Gescheiterte Aufklärung? Politik, Ökonomie und Kommunikation in der Bundesrepublik Deutschland, München 1971, s. 166. 
prowadzone lub ich wyniki nie są znane: do 1990 r. Dzień był przypominany zaledwie trzykrotnie ${ }^{293}$.

Film Monka można odczytywać również przez pryzmat toczącej się w 1965 r. debaty o przedawnieniu karnej odpowiedzialności za zbrodnie nazistowskie (Verjährungsdebatte). W związku z wcześniejszym ustawodawstwem miało ono nastąpić w maju 1965 r. - Bundestag postanowił wówczas odroczyć przedawnienie o cztery lata ${ }^{294}$. Ogólnie rzecz biorąc, w II połowie lat 60. nastąpiła w RFN zmiana w ocenach (nie)dokonanych rozliczeń zbrodni popełnionych w okresie III Rzeszy. Wtedy też wyraźniej niż wcześniej mówiono o konieczności takiego przekierowania polityki publicznej, by Holocaust przestał być li tylko kurtuazyjnym sformułowaniem w okolicznościowych przemówieniach. Symbolem tej zmiany stał się głośny wykład Theodora W. Adorna nadany w 1966 r. przez radio landu Hesji (Hessischer Rundfunk), w którym autor Minima Moralia stwierdził, iż celem edukacji powinno być, aby "Auschwitz się nie powtórzyło" 295 . Ten pedagogiczny wymiar polityki pamięci będzie dominować w kulturze Republiki Federalnej Niemiec kolejnych dekad.

$$
* * *
$$

Jeszcze rok temu milczenie o nazizmie, oporze, wojnie i innych tematach nieodległej przeszłości były częścią umowy pomiędzy producentami oraz widownią [...]. Obywatele Republiki Federalnej, których sumienie zostało dziś wzmocnione prosperita, mogą już sobie pozwolić na pamiętanie - jeśli nawet nie całej, to przynajmniej pół-prawdy 296

${ }^{293}$ Podaję za: Martina Thiele, Publizistische Kontroversen..., s. 284. Dzień... nadano w zachodnioniemieckiej telewizji w 1967 r., następnie dwanaście lat później, zapewne z uwagi na amerykański serial Holocaust (wówczas ukazało się nieco więcej recenzji filmu Monka, przeważnie pozytywnych i utyskujących na emisję filmu w późnych godzinach wieczornych - zob. Ingeborg Müntze, Ein deutsches KZ vor Ausbruch des Krieges. Zur Wiederaufnahme von Monks Film "Ein Tag”, „Hamburger Abendblatt”, 9.11.1979; Dieter Brumm, Der mörderische Alltag der KZ-Opfer, „Süddeutsche Zeitung", 9.11.1979), wreszcie w roku 1989.

${ }^{294}$ Postanowiono, że przedawnienie będzie się liczyć nie od momentu popełnienia zbrodni, ale od 1 stycznia 1950 r. (ponieważ dopiero wtedy zaczął działać autonomiczny niemiecki wymiar sprawiedliwości). W akcie protestu minister sprawiedliwości Ewald Bucher (zreszta, były członek NSDAP i SA, który w wyniku denazyfikacji miał półtoraroczny zakaz wykonywania zawodu) ustąpił ze stanowiska (zob. omówienie debaty w: Karl Jaspers, Wohin treibt die Bundesrepublik?, München 1966, s. 47-121). W czerwcu 1969 r. przesunięto limit przedawnienia na 30 lat od momentu popełnienia przestępstwa. Natomiast dziesięć lat później - także pod wpływem serialu Holocaust - uznano, że zbrodnie nazistowskie nie ulegają przedawnieniu.

295 Theodor W. Adorno, Erziehung nach Auschwitz, [w:] „Ob nach Auschwitz noch sich leben lasse", red. Rolf Tiedemann, Frankfurt am Main 1997, s. 63.

296 Enno Patalas, Der deutsche Film 1955, „Kulturarbeit” 1955, nr 9, s. 163-165. 
- napisał w 1955 r., przy okazji omawiania filmów o Stauffenbergu, przenikliwy Enno Patalas. Opinia ta - akcentująca etyczny wymiar twórczości i społeczne uwarunkowania recepcji - może zostać potraktowana jako swoisty uogólniający osąd o kinie zachodnioniemieckim tamtej epoki. Inny autor piszący na ten temat, Joe Hembus, w 1961 r. wyraził pogląd, iż w latach 50. wytwarzało ono „niebezpieczne zamglenie” (Benebelung) w przedstawieniu nazistowskiej przeszłości, skutkiem czego widz mógł w kinie „delektować się swą deklarowaną niewinnością" ${ }^{297}$. Z kolei Theodor Kotulla - późniejszy reżyser, wówczas krytyk filmowy - sporządził listę najważniejszych, jego zdaniem, stereotypów zachodnioniemieckiego kina powojennego ${ }^{298}$. Lista ta przedstawiała się następująco: 1) narodowy socjalizm i „wojna Hitlera” (Hitler-Krieg) wtargnęły w nieświadomy niemiecki naród z siłą katastrofy naturalnej; 2) niemiecki żołnierz wypełniał jedynie swój obowiązek wobec ojczyzny; należy dokonywać zdecydowanego rozróżnienia pomiędzy nim a przestępstwami narodowego socjalizmu; 3) niemiecki ruch oporu wytworzył się wśród wysokich oficerów wojska; 4) podział Niemiec jest źródłem cierpienia.

Powyższe wyliczenie dotyczyć miało filmowych fabuł - ale zarazem przypomina swoisty elementarz zachodnioniemieckiej polityki historycznej tamtego okresu. Do tego „równania” warto jednak wprowadzić dodatkowy współczynnik: otóż fabuły budujące taki dyskurs zaczęły się pojawiać $\mathrm{w}$ większym natężeniu w połowie lat 50. Odwołując się do dokonanego przez Aleidę Assmann (zob. wprowadzenie) podziału na pamięć kulturową i komunikacyjną, można zaryzykować twierdzenie, że wspominanie lat nazizmu zdominowane było do tego czasu przez drugi z wymienionych typów i związane z nim zasady "komunikacyjnego milczenia” - autocenzury czy zinternalizowanego tabu, zaś rola filmu w budowaniu pamięci kulturowej była jednak dość marginalna. W połowie lat 50 . zachodzi - przynajmniej na polu kinematografii - istotna zmiana ilościowa, która pociąga za sobą przekształcenia o charakterze jakościowym: ukonstytuowanie się reguł topiki, dramaturgicznych syntaks i ikonicznych wzorów w opowiadaniu o narodowym socjalizmie i wojnie.

Niewątpliwie, zachodnioniemiecki film o tematyce wojennej można odczytywać przez pryzmat powołania Bundeswehry ${ }^{299}$, z jednej strony odcinającej się od zbrodni popełnionych ledwie kilkanaście lat wcześniej na rozkaz narodowosocjalistycznej elity, z drugiej zaś - celebrującej żoł-

\footnotetext{
297 Joe Hembus, Der deutsche Film kann gar nicht besser sein, Bremen 1961, s. 134-135.

298 Theodor Kotulla, Zum Gesellschaftsbild des Films in der Bundesrepublik, „Frankfurter Hefte" 1962, nr 6, s. 406.

${ }^{299}$ Niektórzy krytycy pisali więc o "propagandzie wojskowej” - zob. Wilfried von Bredow, Filmpropaganda für Wehrbereitschaft: Kriegsfilme in der Bundesrepublik, [w:] Film und Gesellschaft in Deutschland: Dokumente und Materialien, red. Wilfried von Bredow, Rolf Zurek, Hamburg 1975.
} 
nierskie cnoty "niemieckiego munduru”. Nadużyciem byłoby jednak określanie fabuł nakręconych w tamtych latach jako "militarystycznych" - przeciwnie, wiele filmów ma wymowę jeśli nie pacyfistyczną to z pewnością sceptyczną wobec skuteczności wojny. Mamy w tych realizacjach do czynienia z innym modelem żołnierza - nie jest on postacią aktywna, nie dąży do przejęcia kontroli czy objęcia dowództwa, nie snuje strategicznych planów. Wobec rozkazów jest niechętny, a gdy je wykonuje - czyni to $\mathrm{z}$ poczucia obowiązku ${ }^{300}$. Zarazem $\mathrm{w}$ wielu filmach pojawia się sugestia, że winą za zbrodnie wojenne nie mogą być obarczeni „zwykli żołnierze” - gdyż „szary człowiek” nie może odpowiadać za losy świata.

Przeciw tej łatwości zapominania wystąpiło pokolenie '68 i ruch studencki, którego uczestnicy nie chcieli przejść do porządku dziennego nad przeszłością swoich rodziców, ich ewentualnym zaangażowaniem w system III Rzeszy oraz potencjalnym zagrożeniem nawrotu brunatnej ideologii, której proces denazyfikacji nie zdołał skutecznie wyplenić. Socjologowie zaczęli mówić o tzw. pokoleniu bez ojców (Vaterlosegeneration) - ale już wcześniej Alexander Mitscherlich wskazywał, że zniknięcie z pola widzenia ojca fizycznego powoduje również brak identyfikacji wobec władzy politycznej ${ }^{301}$. Interesującą hipotezę odnoszącą się do tego problemu sformułował Michael Schneider, zdaniem którego pierwsze powojenne pokolenie Niemców musiało zmierzyć się z dylematami Hamleta - odszukać ducha prawdziwego ojca i rozpoznać zbrodniarza w ojcu przybranym ${ }^{302}$.Trudno uwierzyć, że w żadnej (a przynajmniej: żadnej spośród znanych mi i przywoływanych w tej książce) pracy na temat historii kina niemieckiego nie skojarzono tej obserwacji z filmem Reszta jest milczeniem (Der Rest ist Schweigen, RFN 1959) Helmuta Käutnera - uwspółcześnionej adaptacji Hamleta właśnie (przeniesionej w realia fikcyjnej rodziny przemysłowców - właścicieli koncernu Claudius Steel Works - z Zagłębia Ruhry w latach 50.). Jej bohater nie dowierza, że jego ojciec zginął $\mathrm{w}$ nalocie bombowym pod koniec wojny - potęga koncernu jest zatem oparta na przemilczanej "zbrodni założycielskiej”. I choć film nie traktuje wprost o nazistowskich zbrodniach, można potraktować go jako metaforyczne „przepracowanie” dylematów, które rozpoznawali socjologowie. Z prawdziwą moca, nie tylko w trybie przenośni, ujawni się ono w zachodnioniemieckiej kulturze już po 1965 r.

300 Jennifer Kapczynski, Armchair Warriors...

301 Zob. Alexander Mitscherlich, Auf dem Weg zur vaterlosen Gesellschaft. Ideen zur Sozialpsychologie, München 1963. Zob. także: Hermann Glaser, Kultura RFN. Zarys historii 1945-1989, tłum. K. Krzemieniowa, Warszawa 2002, s. 179-183.

${ }^{302}$ Michael Schneider, Väter und Söhne posthum. Das beschädigte Verhältnis zweier Generationen, [w:] idem, Den Kopf verkehrt aufgesetzt oder Die melancholische Linke, NeuwiedLuchterhand 1981. 



\section{Zakończenie}

W pracy poświęconej kulturze filmowej Republiki Federalnej Niemiec lat 70. Thomas Elsaesser wyraził pogląd, iż „,»borykanie się z przeszłością《 stało się typowo niemiecką formą egzystencji" ${ }^{1}$. Spostrzeżenie to można odnieść także do filmów omawianego w tej książce okresu. Były one najczęściej tłem, echem lub kontekstem artykulacji ideologicznych wytycznych lub politycznych debat, rzadko przyczyniając się do ich inicjowania.

Oczywiste różnice, wynikające z funkcjonowania kultur filmowych obu państw w odmiennych warunkach instytucjonalnych i ekonomicznych, nie mogą przysłaniać istotnych podobieństw filmów zrealizowanych w NRD i RFN. Wydają się one ważne choćby z uwagi na podejmowane $\mathrm{w}$ ostatnich latach próby rozpatrywania historii obu kinematografii jako wspólnej przestrzeni kultury niemieckiej - a zatem takiej, w której produkcje Defy stanowią alternatywne spojrzenie na zagadnienia istotne dla społeczeństwa RFN, a kino zachodnioniemieckie uzupełnia, dopowiada lub komentuje dyskursy właściwe filmom enerdowskim.

W książce poświęconej kulturze wizualnej Niemiec lat 1945-1949 Magdalena Saryusz-Wolska pisze o charakteryzującym ten okres dwugłosie pamięci, czyli „dwóch komplementarnych dyskursach wizualnych”. Pierwszy z nich, wytwarzany głównie przez aliantów i wspierany przez środowiska ofiar, koncentrował się na zaświadczaniu o nazistowskich zbrodniach i udowadnianiu niemieckiej winy; drugi zaś budował wizerunek niewinnego społeczeństwa, uwiedzionego przez niewielką grupę zbrodniarzy $^{2}$. I choć zapewne niejakim uproszczeniem byłoby sądzić, że wymieniony wcześniej „porządek obrazów” był narzucany wyłącznie z zewnątrz, a kolejny miał genezę „wewnątrzniemiecką”, podział ten

1 Thomas Elsaesser, Terror und Trauma. Zur Gewalt des Vergangenen in der BRD, Berlin 2007, s. 36.

${ }^{2}$ Magdalena Saryusz-Wolska, Ikony normalizacji. Kultury wizualne Niemiec 1945-1949, w druku (rozdział: Wina i wyparcie). 
wydaje się sensowny przede wszystkim dlatego, iż faktycznie z biegiem czasu niemiecki dyskurs pamięciowy został zdominowany przez drugi z wymienionych "modeli" pamięci (i to zarówno w NRD, jak i w RFN - przy wszystkich różnicach między ich polityką historyczną).

W filmach zrealizowanych w okresie 1946-1949 ewidentne jest profilowanie losów Niemców jako ofiar wojny - poprzez przestrzenie ruin czy charakterystyczne postaci: niepewnego, zagubionego, często pogrążonego $\mathrm{w}$ traumie mężczyzny powracającego $\mathrm{z}$ frontu i kobiety, która musi radzić sobie w sytuacji skrajnego kryzysu. W fabułach tych dominuje „apoteoza szarego człowieka" - i sugestia, że nie można czynić go odpowiedzialnym za losy świata. Zarazem właśnie w filmach z tego okresu często pojawiają się - jak określa je Anke Pinkert - „dziwne momenty” i „tekstualne symptomy” (śmierci i zagłady), na przykład „samoistne” (słabo znarratywizowane) krajobrazy zniszczeń (elusive landscapes), rekwizyty obarczone znaczeniowym "naddatkiem” (wykraczającym poza funkcję fabularną - overdetermined objects) czy "puste spojrzenia” (vacant stares): ujęcia prezentujące bohaterów, którzy "gapią się w dal nieobecnym wzrokiem”3.

Zdaniem Andrzeja Gwoździa zasadnicza funkcja niemieckich filmów z okresu 1946-1949 polegała na przedstawieniu „socjotechnik przetrwania Bogu ducha winnych Niemców w paskudnych czasach"4 oraz legitymizowaniu „odnowy moralnej”. Działo się to zarazem

\begin{abstract}
z pominięciem głębszej albo nawet jakiejkolwiek refleksji na temat powodów wojny, kwestii winy i odpowiedzialności za nią lub dokonywało się wskutek jej uschematyzowania do tego stopnia, że została ona w gruncie rzeczy pozbawiona znamion wydarzenia historycznego na rzecz jakiegoś bliżej nieokreślonego kataklizmu cywilizacyjnego, po którym miasta legły w ruinach ${ }^{5}$.
\end{abstract}

Taka wizja współgrała z dyskusjami na temat przyczyn nazizmu, w których górę wziął pogląd wyrażony po raz pierwszy przez Fredricka Meineckego: „niemiecki naród nie jest z gruntu skażony zbrodniczymi dyspozycjami duszy (Gesinnung), lecz cierpiał na jednorazową infekcję spowodowaną zaaplikowaną mu trucizną" ${ }^{6}$.

W kolejnych dekadach w kinematografiach obu państw niemieckich wyraźnie dochodzą już do głosu wyobrażenia własnych wspólnot, okalanych nowymi granicami. Socjolog Rainer Lepsius zauważył, że o ile RFN z czasem "zinternalizowała” nazistowską przeszłość (akceptując ciągłość państwa i podejmując się odszkodowań finansowych), o tyle w NRD była

\footnotetext{
3 Anke Pinkert, Film and Memory in East Germany, Bloomington 2008, s. 12.

${ }^{4}$ Andrzej Gwóźdź, Obok kanonu. Tropami kina niemieckiego, Wrocław 2011, s. 176.

${ }^{5}$ Ibidem, s. 155.

${ }^{6}$ Friedrich Meinecke, Die deutsche Katastrophe, Wiesbaden 1946, s. 140.
} 
ona w większym stopniu „uniwersalizowana" - nazizm traktowano jako jeden z „odcieni” faszyzmu opierającego się (zgodnie z marksistowsko-leninowskim dogmatem) na kapitalistycznym wyzysku ${ }^{7}$ Pojęcie „,internalizacji" należy tu opatrzyć istotnym zastrzeżeniem - co prawda RFN uznała się za "państwo sukcesyjne” III Rzeszy, ale zarazem zachodnioniemieccy politycy (i historycy) chętnie czytali narodowy socjalizm przez pryzmat refleksji o totalitaryzmie, którego wcieleniem pozostawał ZSRR i jego państwa satelickie. Można więc mówić również o podejmowanej w RFN „eksternalizacji" doświadczeń państwa totalitarnego i przenoszeniu ich na ówczesne NRD - co odpowiada jednej z opisanych przez Aleidę Assmann strategii „wypierania ze świadomości”8. Innymi słowy, na postrzeganie historii $\mathrm{w}$ obu państwach niemieckich wpłynął zimnowojenny kontekst - użyteczny o tyle, iż pozwalał zrzucić odium "faszyzmu” lub "totalitaryzmu" na sąsiednie państwo. W obu wypadkach „złe Niemcy” były „po drugiej stronie": punktami autoidentyfikacji stały się odpowiednio: antyfaszyzm jako doktryna polityczna w NRD oraz antytotalitaryzm (a zatem także antykomunizm) w RFN. Wspólnym zaś celem polityk pamięci wobec nazizmu - zarówno w Niemczech wschodnich, jak i zachodnich - było, jak zauważył Gerhard Paul, „wypracowywanie dystansu” poprzez strategie "kryminalizacji i diabolizacji”" , czyli postrzeganie narodowego socjalizmu jako "zła wcielonego", eksplozji mrocznych emocji i dążeń, której przyczyny nie wynikały ze szczególnych właściwości niemieckiego nacjonalizmu, ale były dyskursywnie wiązane ze wspomnianymi już logikami zimnowojennego konfliktu.

W publikacjach poświęconych historii RFN lata 50. określane są często formułą „zmowa milczenia”. Opinia ta, jeśli miałaby się odnosić do „nazizmu w ogóle”, byłaby uproszczeniem wynikającym z retrospektywnego „nałożenia” na ten okres porównań z dyskursami dominującymi w II połowie lat 60. i kolejnej dekady. Faktycznie bowiem w życiu pu-

7 Rainer Lepsius, Demokratie in Deutschland, Göttingen 1993, s. 229-245 (nadto dodaje Lepsius, że w Austrii nazistowskie zagrożenie zostało „uzewnętrznione” jako niemieckie). Zob. także: Agnes Blänsdorf, Die Einordnung der NS-Zeit in das Bild der eigenen Geschichte. Österreich, die DDR und die Bundesrepublik Deutschland im Vergleich, [w:] Schwieriges Erbe. Der Umgang mit Nationalsozialismus und Antisemitismus in Österreich, der DDR und der Bundesrepublik Deutschland, red. Werner Bergmann, Frankfurt am Main 1995.

${ }^{8}$ Por. Aleida Assmann, Pięć strategii wypierania ze świadomości, tłum. A. Pełka, [w:] Pamięć zbiorowa i kulturowa. Wspótczesna perspektywa niemiecka, red. Magdalena Saryusz-Wolska, Kraków 2009.

${ }^{9}$ Gerhard Paul, Von Psychopathen, Technokraten des Terrors und ganz gewöhnlichen Deutschen. Die Täter der Shoah im Spiegel der Forschung, [w:] Die Täter der Shoah. Fanatische Nationalsozialisten oder ganz normale Deutsche?, red. Gerhard Paul, Göttingen 2002, s. 16. 
blicznym RFN lat 50. silnie zaznaczyły się liczne „rytuały pamięci” - tyle że odnosiły się one najczęściej do niemieckich ofiar wojny. W kinematografii zachodnioniemieckiej tamtych lat można wskazać wiele fabuł dotyczących na przykład żołnierzy powracających z syberyjskich więzień, a także filmów sławiących „dobry Wehrmacht”. Na ten czas przypadają też pierwsze narracje ukazujące Stauffenberga i współpracujących z nim oficerów jako bohaterów narodowych (nie zrealizowano natomiast w tym okresie ani jednego filmu kinowego o Holocauście - choć pojawiały się pierwsze dokumenty i filmy telewizyjne). Do nielicznych - tym bardziej interesujących - wyjątków z końca dekady można zaliczyć produkcje zawierające krytyczny głos na temat braku rozliczeń z nazistowską przeszłością (W czepku urodzeni Hoffmanna, Róże dla prokuratora i Kiermasz Staudtego).

W kinie enerdowskim lat 50. - niezależnie od możliwości gradacji tej dekady na okres stalinowski i „poodwilżowy” - legitymizacja państwowości „lepszych Niemiec" związana była przede wszystkim z heroizacją działaczy komunistycznego ruchu oporu. Wynikająca z marksistowskiej historiozofii hierarchia ofiar wojny spychała natomiast na dalszy plan problem Holocaustu i cierpień osób pochodzenia żydowskiego. Z wyjątkiem filmu Gwiazdy, Holocaust pozostawał nadal tematem drugorzędnym, wprowadzanym bądź jako kontekst narracji o komunistycznym ruchu oporu, bądź jako wątek poboczny w fabułach ukierunkowanych na zdyskredytowanie Republiki Federalnej Niemiec. Charakterystyczne, że bohaterowie żydowscy w kinie Defy to zazwyczaj kobiety (Małżeństwo w mroku, Gwiazdy) lub dzieci (Nadzy wśród wilków), a zatem jednostki „słabsze”, potrzebujące pomocy (ze strony komunistów) ${ }^{10}$. Pomijając nieliczne wyjątki, niemal do końca NRD zachowywał swą ważność - przynajmniej, gdy idzie o filmowe fabuły - dyskurs zapoczątkowany przez Profesora Mamlocka (dramat Friedricha Wolfa z 1933 r.): Żydzi ponoszą część odpowiedzialności za swój los, ponieważ nie rozpoznali w porę źródeł niebezpieczeństwa i nie odważyli się z nim walczyć.

Choć kinematografie obu państw niemieckich funkcjonowały w znacząco odmiennych realiach politycznych i ekonomicznych, nietrudno dostrzec pewne problemowe oraz dyskursywne podobieństwa pomiędzy filmami Defy a fabułami powstałymi w RFN. W erefenowskich filmach wojennych protagonista udowadnia swój heroizm bądź w walce (głównie na froncie wschodnim), bądź dzięki talentom, które pozwoliły mu

10 Thomas Fox, Stated Memory: East Germany and the Holocaust, Rochester 1999, s. 139; Jeffrey Herf, Divided Memory: The Nazi Past in the Two Germanys, Cambridge 1997, s. 83. Zob. też: Frank Stern, Ein Kino subversiver Widersprüche. Juden im Spielfilm der DDR, [w:] apropos: Film 2002. Das Jahrbuch der DEFA-Stiftung, red. Ralf Schenk, Erika Richter, Berlin 2002. 
przeżyć (najczęściej sowiecką niewolę). W filmach Defy bohaterowie walczą z "faszystami” (w Niemczech lub w Hiszpanii) bądź, jeśli akcja rozgrywa się w okresie powojennym, wykazują się cnotami „pionierów ludowej republiki". Zapewne $\mathrm{z}$ uwagi na przedsięwziętą $\mathrm{w}$ obu państwach kampanię na rzecz utworzenia własnych sił zbrojnych, postacią rzadko reprezentowaną $w$ omówionych fabułach był dezerter (w kinie enerdowskim obecny w Królewskich dzieciach i Przygodach Wernera Holta; w RFN zaś - gdzie nakręcono przecież wielokrotnie więcej fabuł wojennych - w Batalionie karnym, Niespokojnej nocy, Koledze ze szkoty oraz - w funkcji bohatera pierwszoplanowego - w Kiermaszu). Natomiast lapidarną opinię Petera Fritzsche, iż „w powojennych fabułach liczba nazistów staje się coraz mniejsza, a odpowiedzialność, jaką ponosza, coraz większa"11 - można z powodzeniem uznać za ogólną (a zatem: uwzględniającą wyjątki) charakterystykę obydwu kinematografii. W obu przypadkach swą ważność zachowuje też obserwacja Dietricha Kuhlbrodta, który w zachodnioniemieckich fabułach dostrzegł chętnie wykorzystywaną figurę „Alibi-Nazi” (odosobniona, wyizolowaną od innych bohaterów, jednostkową postać nazisty, uosabiającego ", (całe zło" $)^{12}$.

Można również mówić o pewnych podobieństwach między konkretnymi filmami z Niemiec Zachodnich oraz produkcjami Defy. Detlef Kannapin $^{13}$ zestawia na przykład Most Wickiego z Przygodami Wernera Holta Kunerta. Nieco mniej przekonującą „parę" stanowi połączenie w jednym rozdziale jego książki filmu 20 lipca Harnacka oraz Kapitana z Kolonii Dudowa (ten ostatni wykazuje więcej podobieństw z Różami dla prokuratora Staudtego, na co wskazała Sabine Hake ${ }^{14}$ ). Potencjalne możliwości komparatystycznych analiz można by uzupełnić, sugerując zestawienie Ucieczki Zbonka z Nagimi wśród wilków Beyera, Kronikę pewnego morderstwa Haslera oraz Świadka z piekła Mitrovića, albo erefenowskich seriali: Jak daleko nogi poniosa i Zielona plaża nad Szprewa - z ich enerdowskim „odpowiednikiem" Niespokojne sumienie.

Przyglądając się niemieckim filmom fabularnym nie w ujęciu chronologicznym, lecz z perspektywy synchronicznej, można dostrzec kilka

11 Peter Fritzsche, What exactly is Vergangenheitsbewältigung? Narrative and Its Unsufficiency in Postwar Germany, [w:] German Memory Contests. The Quest for Identity in Literature, Film, and Discourse since 1990, red. Anne Fuchs, Mary Cosgrove, Georg Grote, Rochester 2006, s. 24.

12 Dietrich Kuhlbrodt, Deutsches Filmwunder: Nazis immer besser, Hamburg 2006, s. 23.

${ }^{13}$ Detlef Kannapin, Dialektik der Bilder: der Nationalsozialismus im deutschen Film; ein Ost-West-Vergleich, Berlin 2005, s. 134-168.

${ }^{14}$ Sabine Hake, Politische Satire im Kalten Krieg. "Der Hauptmann von Köln” und "Rosen für Staatsanwalt", [w:] DEFA International. Grenzüberschreitende Filmbeziehungen vor und nach dem Mauerbau, red. Michael Wedel, Barton Byg et al., Wiesbaden 2013. 
przewijających się - także we współczesnym (pozjednoczeniowym) kinie niemieckim - tematów związanych z pamięcią o latach nazizmu. Pierwszy z obszarów problemowych dotyczy filmowych zapośredniczeń pamięci o ofiarach. Bez wątpienia w kinie lat 1946-1965 (tak zachodnio-, jak i wschodnioniemieckim) akcentowane są przede wszystkim ofiary własne, tj. Niemców (z zastrzeżeniem, że w kinie NRD podkreślano niemal wyłącznie "męczeństwo" członków ruchu robotniczego). Często są to obrazy niezwykle "afektywne", ukazujące ciała cierpiących niemieckich żołnierzy (wycieńczonych musztra, utaplanych $\mathrm{w}$ deszczu, umorusanych błotem). Tylko w nielicznych filmach (na przykład w Profesorze Mamlocku w NRD czy Generale diabła w RFN) pojęcie „cierpiący Niemcy” w wewnętrznej logice świata przedstawionego rozciąga się ponad kryterium etniczne, zgodne z rasistowskimi ustawami III Rzeszy, tj. na rozumienie obywatelstwa czy kulturowej identyfikacji nie-Aryjczyków z „niemieckością”.

Jeśli owi Inni pojawiają się $\mathrm{w}$ kadrze wraz $\mathrm{z}$ bohaterami znakowanymi jako Niemcy, to niemal wyłącznie jako sojusznicy (alianci zachodni w filmach erefenowskich, sowieci w filmach Defy). Gdy zaś przypisana jest im rola przeciwnika (jak w filmach "stalingradzkich" czy "syberyjskich" w RFN) lub ofiary, zazwyczaj oddzielani są od Niemców - bądź przez wewnętrzne ramy w kompozycji kadru (rozmaite naturalne bariery, na przykład druty kolczaste), bądź dzięki montażowi, który rzadko pokazuje postaci $w$ tych samych ujęciach (spektakularnym przykładem byłaby scena aresztowania ukrywającego się Żyda w Noc zapadła nad Gotenhafen, a w kinie enerdowskim - nieliczne sceny z dzieckiem w Nagich wśród wilków). Wyjątków od tej reguły jest niewiele: w kinie enerdowskim byłyby to z pewnością Gwiazdy, zaś w kinematografii RFN - Na zielonej plaży nad Szprewa (odcinek Dziennik Jürgena Wilmsa). W obu filmach pojawiają się zresztą obrazy sugerujące Zagładę (film Wolfa) lub wprost pokazujące mord na zbiorowości (serial Umgeltera). Przedstawienia „śmierci masowej" w niemieckich fabułach opowiadających o wojnie rezerwowane są dla scen batalistycznych - przy czym w kilku filmach erefenowskich powtarza się, w lekko zmodyfikowanych wariantach, ten sam obraz: "las krzyży", po wojnie wykorzystany po raz pierwszy w filmie Staudtego Mordercy sa wśród nas, a później w kilku innych produkcjach (Niespokojna noc, Noc zapadła nad Gotenhafen). Nie były natomiast używane dokumentalne zdjęcia z atrocity films - reedukacyjnych zapisów filmowych rozpowszechnianych przez aliantów w strefach okupowanych. Jeśli sięgano do materiałów archiwalnych, to zwykle po to, by za pomocą kilku ujęć, umieszczanych najczęściej w prologu lub w sekwencjach batalistycznych, wprowadzić informację o rozpoczęciu wojny lub jej przebiegu. 
Drugi z dyskursów, którego modulacje w poszczególnych okresach warto porównać, koncentruje się na sprawcach - współtworzących nazistowski system represji. W obu kinematografiach, co do tego nie ma wątpliwości, przetrwał dyskurs ukształtowany jeszcze w okresie podziału na strefy okupacyjne - tj. zrzucenie winy na przywódców NSDAP. Zasadnicze pytanie dotyczy jednak odpowiedzialności Mitläuferów („,cichych zwolenników”, „zwyczajnych obywateli”, „bezczynnych obserwatorów”). W kinie zachodnioniemieckim omawianego okresu powstało ledwie kilka filmów na ten temat (Kolega ze szkoły, Kiermasz, Męski piknik); prawdziwy zalew fabuł demaskujących faktyczną współodpowiedzialność „zwykłych Niemców" pojawi się dopiero w latach 70. Również kinematografia Defy rzadko podejmowała te zagadnienia - postaci negatywnie znakowane są przede wszystkim według przynależności klasowej (Rada bogów, Hauptmann $z$ Kolonii) lub prezentowane jako „uwiedzione” przez faszystowską ideologię (Lissy, Drugi tor). W tym ostatnim wypadku posługiwano się często schematem „opowieści konwersyjnej”, w której bohater rozpoznaje swe ideologiczne błędy i ochoczo „przemienia się" w admiratora enerdowskiego systemu politycznego.

Trzeci interesujący wątek problemowy dotyczy reprezentacji antynazistowskiego ruchu oporu. $W$ tym wypadku najpełniej ujawniają się różnice pomiędzy historycznymi już „wariantami” niemieckiej pamięci kulturowej. Dla RFN właściwe było pielęgnowanie pamięci o chadeckich grupach antyhitlerowskich (częste są więc sceny modlitwy oraz symbolika chrześcijańska), zaś „mitem założycielskim” NRD stała się działalność komunistycznego ruchu oporu, tematyzowana w rozlicznych filmach fabularnych ${ }^{15}$ (znakiem czasu jest fakt, że tylko niektóre z nich zostały wydane na DVD już w zjednoczonych Niemczech). Jeśli w erefenowskich fabułach wojennych mianem Warburgowskiej "formuły patosu" można by określić ujęcia przedstawiające wspomniany już „las krzyży”, to w filmach Defy z podobną repetycją, obarczoną szczególnym ładunkiem znaczeniowym (często wzmacnianym przez ścieżkę dźwiękową), mamy do czynienia tam, gdzie prezentowany jest "sowiecko-niemiecki sojusz" - gdy niemiecki antyfaszysta i żołnierz Armii Czerwonej (lub współwięzień z ZSRR) padają sobie w objęcia (na przykład w zakończeniach filmów W walce z Hitlerem i Nadzy wśród wilków). Podobne ujęcia pojawiają się również w Królewskich dzieciach (przedostatnia sekwencja w kabinie samolotu,

${ }^{15}$ Jedyny enerdowski film o zamachu z 20 lipca Porucznik Yorck von Wartenburg (Der Leutnant Yorck von Wartenburg, reż. Peter Vogel) powstał w 1981 r. - przy czym Stauffenberg jest tu postacią drugoplanową. Trzy lata później Towarzystwo Historyków NRD i Instytut Historii Akademii Nauk NRD zorganizowały konferencję z okazji czterdziestej rocznicy zamachu Stauffenberga (za: Detlef Kannapin, Dialektik der Bilder..., s. 233). 
w której protagonista słucha lirycznej ballady śpiewanej przez sowieckiego żołnierza) i Pięciu łuskach (wszak bohaterowie spieszą na pomoc rosyjskiemu telegrafiście). W tych scenach mamy do czynienia ze swoistym „naddatkiem braterstwa” (dziś można by doprecyzować - ze szczególnie wyraziście manifestowanymi gestami podległości, wymuszonej wdzięczności lub koniecznego zachwytu wobec politycznego patrona).

Przyrost ilościowy filmów o narodowym socjalizmie, który w obu kinematografiach nastąpił w po 1965 r. (a szczególnie w latach 70.), tylko w Republice Federalnej Niemiec przyniósł zmianę o charakterze jakościowym. Konstatacja ta uświadamia, że opinia o istotniej transformacji, jaka dokonuje się w pamięci kulturowej wraz z upływem lat (i pojawieniem się nowego pokolenia, które nie doświadczyło danych wydarzeń historycznych) może być zakwestionowana w odniesieniu do systemów o znacznym stopniu ograniczenia lub reglamentowania sfery publicznej.

Po 1965 r. kultura filmowa NRD funkcjonowała, podobnie jak w poprzednim okresie, w sinusoidalnym cyklu "odwilży” i "przymrozków” - po zatrzymaniu „filmów króliczych” krótką nadzieję na zmianę wywołała nominacja Ericha Honeckera na stanowisko sekretarza generalnego partii w 1971 r. Sześć lat później symbolem kolejnego „przesilenia” stało się pozbawienie Wolfa Biermanna niemieckiego obywatelstwa (i emigracja wielu enerdowskich twórców).

Istotną zmianą wobec okresu sprzed 1965 r. było częstsze podejmowanie tematyki wojennej - zwłaszcza w popularnych serialach ${ }^{16} . \mathrm{Z}$ produkcji kinowych do klasyki kina enerdowskiego weszły filmy Konrada Wolfa: Miatem 19 lat (Ich war neunzehn, NRD 1968) oraz Mamo, ja żyje (Mama, ich lebe, NRD 1977). Do nielicznych filmów wojennych zaliczyć można Moja godzine zero (Meine Stunde Null, reż. Joachim Hasler, NRD 1970). Blisko dwadzieścia lat na premierę musiał czekać zatrzymany przez cenzurę film Rosjanie nadchodza (Die Russen kommen, reż. Heiner Carow, NRD 1968). W oryginal-

${ }^{16}$ Intensywnie tematyką ,"antyfaszystowską" zajmowała się telewizja, która do rozwiązania NRD wyprodukowała kilkanaście filmów i seriali. Nie sposób wymienić wszystkich; tylko w II połowie lat 60. na małym ekranie pojawiło się kilka miniserii o II wojnie światowej, wśród nich cykl spajany tytułem Tajny oddział... (Geheimkommando...). Wspomnieć można także o dwóch fabułach Joachima Kunerta na podstawie opowiadań Anny Seghers: Wielkiej podróży Agaty Schweigert (Die große Reise der Agathe Schweigert, NRD 1972) oraz Trzcinie (Der Schilfrohr, NRD 1974). Tematyka polska pojawia się zaś w filmie Ocalona (Die Überlebende, reż. Christian Steinke, NRD 1975), którego retrospekcyjny wątek opowiada o romansie niemieckiego dezertera i ukrywającej go Polki z oddziału partyzantów. 
nej wersji realizacja Carowa mogła być pokazana dopiero w 1987 r., kilka miesięcy po innej fabule, również opowiadającej o chłopaku z Hitlerjugend: Stielke, Heinz, lat piętnaście (Stielke, Heinz, fünfzehn, reż. Michael Kann, NRD 1986). O nazistowskiej indoktrynacji młodzieży traktowały też filmy Martwi pozostaja młodzi (Die Toten bleiben jung, reż. Joachim Kunert, NRD 1968) oraz Musisz żyć (Ich zwing dich zu leben, reż. Ralf Kirsten, NRD 1978). Z kolei fabuła dwuczęściowego filmu szpiegowskiego Zamrożone błyskawice (Die gefrorenen Blitze, reż. János Veiczi, NRD 1967) osnuta jest wokół eksperymentów z technologią rakietową w Peenemünde.

Sztafaż historyczny nadal był jednak przede wszystkim okazją do zaprezentowania "ruchu antyfaszystowskiego". Z ważniejszych produkcji na ten temat można wymienić filmy: Flaga z Krzywego Rogu (Die Fahne von Kriwoj Rog, reż. Kurt Maetzig, NRD 1967), Towarzysz Hans Beimler (Hans Beimler, Kamerad, reż. Rudi Kurz, NRD 1969), KLK do PTX - Czerwona orkiestra (KLK an PTX - Die rote Kapelle, reż. Horst E. Brandt, NRD 1970), Między niebem a dniem (Zwischen Nacht und Tag, reż. Horst E. Brandt, NRD 1975), Chcę was zobaczyć (Ich will euch sehen, reż. János Veiczi, NRD 1978), Upomnienie (Die Mahnung, reż. Juan Antonio Bardem, NRD/ZSRR/ Bułgaria 1982) oraz Wengler i synowie (Wengler und Söhne, Eine Legende, reż. Rainer Simon, NRD 1986). Na ich tle wyróżnia się bardziej psychologizujący Twój nieznany brat (Dein unbekannter Bruder, reż. Ulrich Weiß, NRD 1982). Interesującą zmianę, która w latach 80. zaszła w kinie NRD, odnotowała Daniela Berghahn - mianowicie zwróciła ona uwagę, że w tej dekadzie postawy ",antyfaszystowskie” zostały „sfeminizowane"17. Autorka wymienia w tym kontekście filmy: Narzeczona (Die Verlobte, reż. Günther Rücker, Günter Reisch, NRD 1980) i Raport Sonii (Sonjas Rapport, reż. Bernhard Stephan, NRD/Polska/Wietnam/Szwajcaria 1982) - o Ruth Werner, czyli sowieckiej „Macie Hari”, oraz Aktorkę (Die Schauspielerin, reż. Siegfried Kühn, NRD 1988).

Na początku lat 80 . zrealizowano w NRD dwa filmy poruszające temat przemilczeń i prawdy o niedawnej przeszłości: Jadup i Boel (Jadup und Boel, reż. Rainer Simon, NRD 1980/1988) oraz Poszukiwania brandenburskie (Märkische Forschungen, reż. Roland Gräf, NRD 1982) ${ }^{18}$. Tematyka Zagłady nadal była $\mathrm{w}$ fabularnych filmach Defy podejmowana rzadko - poza

17 Daniela Berghahn, Resistance of the Heart: Female Suffering and Victimhood in DEFA's Antifascist Films, [w:] Screening War. Perspectives on German Suffering, red. Paul Cooke, Marc Silberman, Rochester 2010.

${ }^{18}$ W niektórych polskich opracowaniach tytuł filmu Gräfa podawany jest jako Badania marchijskie - tymczasem była to adaptacja powieści wydanej po polsku jako: Günter de Bruyn, Poszukiwania brandenburskie: opowieść dla miłośników historii literatury, tłum. S. Lisiecka, Warszawa 1986. 
głośnym Jakubem kłamca (Jakob der Lügner, reż. Frank Beyer, NRD 1975) ${ }^{19}$ (pierwszym enerdowskim filmem oficjalnie zaprezentowanym na Berlinale i jedynym nominowanym do Oscara w kategorii najlepszego filmu nieanglojęzycznego) można wymienić dwa filmy nawiązujące do Holocaustu: Żywy towar (Lebende Ware, reż. Wolfgang Luderer, NRD 1966) oraz Fariaho (reż. Roland Gräf, NRD 1983) z Franciszkiem Pieczką w roli głównej (wątki polskie pojawiły się też w Pobycie [Der Aufenthalt, reż. Frank Beyer, NRD 1983]). Uroczyste obchody upamiętniające „noc kryształową” po raz pierwszy zorganizowano w NRD w 1988 r. (na tę okoliczność sfinansowano także realizację kilku filmów dokumentalnych). Rok później do produkcji skierowano Dzieci Bronsteina (Bronsteins Kinder, reż. Jerzy Kawalerowicz, NRD 1990), zrealizowane na podstawie powieści Jurka Beckera (zob. podrozdział 2.7), który współsygnował także scenariusz; premiera filmu odbyła się już w zjednoczonych Niemczech.

W odniesieniu do dwóch pierwszych dekad po wojnie istotniejsze zmiany dotyczyły kinematografii - i szerzej: całej kultury - Republiki Federalnej. Posiłkując się dokonanym przez Aleidę Assmann (zob. wprowadzenie) podziałem na pamięć komunikacyjną i kulturową okres po 1965 r. określić można jako czas autonomizacji tej ostatniej - jej uwolnienia od społecznych zasad kształtujących pamięć komunikacyjną (o czym wolno mówić, o czym należy milczeć). Reguły te - stopniowo osłabiane w I połowie lat 60 ., głównie za sprawą medialnych relacji z procesów zbrodniarzy wojennych - uległy gwałtownej erozji za sprawą studenckiej rewolty pod koniec dekady.

Pokolenie kontestatorów, żądające wyrwania kraju ze „zbiorowej amnezji", nie tyle uruchomiło debatę na ten temat, ile zradykalizowało i upowszechniło dyskursy obecne już w ostatnim dziesięcioleciu ${ }^{20}$ - to, co wcześniej było wyrażane przez pojedyncze osoby, teraz stało się zjawiskiem masowym. Często przytaczane stwierdzenie, iż młodzi Niemcy chcieli skonfrontować swych rodziców z ich nazistowską przeszłościa, jest trafne tylko przy dopowiedzeniu, iż konfrontacja ta odbywać się miała w sposób szczególny - jako akt oskarżenia, będący jednocześnie werdyktem skazującym, bez uwzględniania biograficznych niuansów i wysłuchania strony

19 Zob. podrozdział 2.7 oraz: Kalina Kupczyńska, Elżbieta Kapral, O medialności kłamstwa i iluzji: Jakub "Egarz" a Jurek "Pisarz", [w:] Przestrzenie intermedialności. Adaptacje literatury niemieckojęzycznej, red. Kalina Kupczyńska, Magdalena Saryusz-Wolska, Wrocław 2012.

${ }^{20}$ Detlef Siegfried, Zwischen Aufarbeitung und Schlußstrich. Der Umgang mit der NS-Vergangenheit in den beiden deutschen Staaten 1958-1969, [w:] Dynamische Zeiten: die 60er Jahre in den beiden Gesellschaften, red. Axel Schildt, Detlef Siegfried, Karl Christian Lammers, Hamburg 2000, s. 104. 
obwinionej (na to przyjdzie czas dopiero w latach 90.). Gerd Koenen, jeden $\mathrm{z}$ aktywistów ówczesnego ruchu studenckiego w RFN, wspominał, że emocją dominującą $w$ tym środowisku było odcięcie się od każdego, kto z III Rzeszą miał cokolwiek wspólnego ${ }^{21}$ - w myśl zasady: „nie można rozmawiać z ludźmi, którzy stworzyli Auschwitz".

Interesujące jest, że bunt ruchu studenckiego wobec pokolenia rodziców wpisywał się, choć w specyficzny sposób, w dyskurs o niemieckich cierpieniach wojennych. Przedstawiciele pokolenia '68 postrzegali siebie bowiem jako ofiary swych rodziców, symbolizujących nierozliczony - a w skrajnych opiniach: trwający wówczas nadal - „faszyzm”. Pogląd o „niemieckich ofiarach działających nadal faszystów” był do pewnego stopnia podobny z enerdowską propagandą. Zbieżność taka stała się możliwa, ponieważ - jak zauważa Axel Schildt - pokolenie '68 „odrealniło" i „odhistoryczniło” czas III Rzeszy poprzez budowanie abstrakcyjnych analogii pomiędzy państwem, ekonomią kapitalistyczną a faszyzmem właśnie $^{22}$ (na transparentach rewoltującej młodzieży pojawiało się sformułowanie „amerykańscy faszyści” - i slogan „SS - SA - USA”).

„Odhistorycznienie" III Rzeszy i interpretowanie jej w kategoriach „wcielonego zła” przez środowiska kontestatorskie poskutkowało również innym niż w czasach Adenauera i Erharda postrzeganiem Zagłady. Wyraźniej niż wcześniej mówiono o konieczności takiego przekierunkowania polityki, by Zagłada przestała być li tylko kurtuazyjnym sformułowaniem w okolicznościowych przemówieniach. Symbolem tej zmiany stały się: głośny radiowy wykład Theodora W. Adorna nadany w 1966 r., w którym padło stwierdzenie, iż celem edukacji powinno być, aby „Auschwitz się nie powtórzyło" ${ }^{23}$ oraz hołd żydowskim ofiarom nazizmu oddany przez Willy'ego Brandta w Warszawie w grudniu 1970 r. (uklęknięcie pod Pomnikiem Bohaterów Getta - tzw. Kneefall). W tym samym roku zachodnioniemiecki parlament po raz pierwszy oficjalnie upamiętnił koniec II wojny światowej - Brandt wezwał do konfrontacji z przeszłościa ponieważ „nikt nie jest wolny od historii, którą się odziedziczyło" ${ }^{24}$. Świadectwem zmiany $\mathrm{w}$ podejściu do rozliczeń $\mathrm{z}$ nazizmem stały się procesy byłych oprawców z obozów zagłady, toczące się od 1975 do 1981 r.

${ }^{21}$ Gerd Koenen, Das rote Jahrzehnt, Köln 2001, s. 96.

${ }^{22}$ Axel Schildt, Aufarbeitung und Aufbruch. Die NS-Vergangenheit in der bundesdeutschen Öffentlichkeit der 1960er Jahre, „Vorgänge. Zeitschrift für Bürgerrechte und Gesellschaftspolitik" 2002, nr 1, s. 130.

${ }^{23}$ Theodor W. Adorno, Erziehung nach Auschwitz, [w:] "Ob nach Auschwitz noch sich leben lasse", red. Rolf Tiedemann, Frankfurt am Main 1997, s. 63.

${ }^{24}$ Cyt. za: Helmut Dubiel, Niemand ist frei von der Geschichte: Die nationalsozialistische Herrschaft in den Debatten des Deutschen Bundestag, München 1999, s. 133. 
w Düsseldorfie (Majdanek-Prozesse). W 1978 r. - już za czasów rządów Helmuta Schmidta - odbyły się natomiast pierwsze oficjalne uroczystości upamiętniające zajścia „nocy kryształowej”25.

$\mathrm{O}$ ile w połowie lat 60 . symbolem Zagłady było jeszcze Auschwitz, o tyle - zwłaszcza po wyświetleniu w zachodnioniemieckiej telewizji serialu Holocaust - to właśnie ten termin upowszechnił się jako główny problemat zbrodni nazistowskich ${ }^{26}$ (do tego stopnia, iż zdaniem niektórych politologów w dyskursie publicznym doszło do „wymiany II wojny na Holocaust" właśnie) ${ }^{27}$. Z drugiej strony, zachodząca od końca lat 70. uniwersalizacja Holocaustu prowadziła do inflacji jego właściwego znaczenia: dla niektórych stał się on synonimem każdego ludobójstwa. Podejście takie krytykował Alain Finkielkraut, który nie od rzeczy zwracał uwagę, iż status ofiary został odarty z wyjątkowości i stał się otwarty dla każdego, kto zgłosił doń akces ${ }^{28}$.

$\mathrm{W}$ kinie zachodnioniemieckim tematyka rozliczeniowa została podjęta przez twórców kojarzonych z tzw. Nowym Kinem Niemieckim: Alexandra Klugego, Jean-Marie Strauba, Edgara Reitza, Reinera Wernera Fassbindera, Wernera Herzoga, Volkera Schlöndorffa czy Margarethe von Trotty - brak tu miejsca, by wymienić wszystkich autorów i tytuły ich dzieł. Pierwsze ważne pełnometrażowe filmy kinowe autorów zaliczanych do tej grupy - Niepogodzeni, albo Tylko przemoc pomaga tam, gdzie rzadzi przemoc (Nicht versöhnt, oder Es hilft nur Gewalt, wo Gewalt herrscht, reż. Danièle Huillet, Jean-Marie Straub, RFN 1965), Pożegnanie z dniem wczorajszym (Abschied von Gestern, reż. Alexander Kluge, RFN 1966) i Niepokoje wychowanka Törlessa (Der junge Törless, reż. Volker Schlöndorff, RFN 1966), metaforycznie nawiązujące do pedagogiki narodowego socjalizmu ${ }^{29}$ - trafiły na ekrany na przełomie 1965/1966 r.

Pierwszy z wymienionych tytułów - podobnie jak wcześniejszy film duetu Straub-Huillet, krótkometrażowa Machorka-Muff (RFN 1962) o wpływie dawnych oficerów Wehrmachtu na odbudowanie sił zbroj-

${ }^{25}$ Za: Julia Kölsch, Politik und Gedächtnis. Zur Soziologie funktionaler Kultivierung von Erinnerung, Wiesbaden 2000, s. 145.

${ }^{26}$ Dirk van Laak, Der Platz des Holocaust im deutschen Geschichtsbild, [w:] Die historische Meistererzählung. Deutungslinien der deutschen Nationalgeschichte nach 1945, red. Konrad Jarausch, Martin Sabrow, Göttingen 2002.

27 Elisabeth Domansky, A Lost War: World War II in Postwar German Memory, [w:] Thinking About the Holocaust, red. Alvin Rosenfeld, Bloomington 1997, s. 246-258.

${ }_{28}$ Alain Finkielkraut, The Imaginary Jew, trans. Kevin O'Neill, David Suchoff, Lincoln 1994, s. 17.

${ }_{29}$ Zob. Carola Hilmes, Subtelny obserwator jako wspótsprawca: „Niepokoje wychowanka Törlessa" Volkera Schlöndorffa, [w:] Przestrzenie intermedialności... 
nych RFN, również oparta na prozie Heinricha Bölla - podejmuje problemy, które okażą się istotne także dla innych autorów Nowego Kina Niemieckiego: konflikty międzypokoleniowe oraz traumatyczne przeżycia wojenne (doświadczane głównie przez kobiety). Drugim niemieckim pisarzem, którego dzieła były chętnie przenoszone na ekran przez twórców Nowego Kina Niemieckiego, był Günter Grass - dwanaście lat przed sukcesem Blaszanego bębenka (reż. Volker Schlöndorff, RFN 1979), uhonorowanego Złotą Palmą w Cannes i Oscarem za najlepszy film nieanglojęzyczny, nakręcono Kota i mysz (Katz und Maus, reż. Hansjürgen Pohland, RFN 1967) ${ }^{30}$.

Fabuły wielu dzieł Nowego Kina Niemieckiego modelowane są w taki sposób, by uwypuklić relacje pomiędzy nierozliczoną przeszłością a sukcesem ekonomicznym RFN lat 50. Tak dzieje się w Małżeństwie Marii Braun (Die Ehe der Maria Braun, RFN 1979) Fassbindera i Matce (Deutschland, bleiche Mutter, reż. Helma Sanders-Brahms, RFN 1980); natomiast w kilku innych filmach - na przykład w Niemczech jesienia (RFN 1978) oraz Czasie ołowiu (Die bleierne Zeit, reż. Margarethe von Trotta, RFN 1981) - nazizm wskazany jest jako kontekst wydarzeń współczesnych, w szczególności zaś lewackiego terroryzmu spod znaku Rote Armee Fraktion. Niektóre filmy zaliczane do Nowego Kina Niemieckiego współgrały ze światopoglądem studenckiej kontestacji także w tym sensie, iż sugerowały ciaggłość nazistowskiej ideologii z praktykami erefenowskiego („faszystowskiego" - w lewackiej terminologii, powielającej dyskurs rozpowszechniony w NRD) systemu medialnego i „przemocy symbolicznej”. Nic więc dziwnego, że część twórców identyfikowanych z tą formacją starało się obejść dominujące wzory obrazowania - próbując uzupełnić je własnymi „ikonologiami” lub wybierając radykalną estetykę „,antyspektakularną". Jak słusznie zauważył Elsaesser, z tej strategii wyłamał się Fassbinder, właśnie ów spektakl sublimując (na przykład w Lili Marleen - z licznymi odniesieniami do estetyki kina $\mathrm{Ufy}^{31}$ ). O tym, jak silnie skorelowane z dyskursami politycznymi były ówczesne porządki myślenia o estetyce nazizmu, świadczy przypadek filmu dokumentalnego Pamięć sprawiedliwości (Memory of Justice, Wielka Brytania - RFN 1976) Marcela Ophülsa: koproducenci niemieccy domagali się umieszczenia w filmie rozbudowanego porównania Auschwitz do Gułagu, z kolei ekipa brytyjska żądała, by zasugerować zrównanie zbrodni nazistowskich z działaniami armii amerykańskiej w Wietnamie

\footnotetext{
${ }^{30}$ Magdalena Saryusz-Wolska, Sensacja polityczna i nuda filmowa. Adaptacja "Kota i myszy" w reżyserii Hansjürgena Pohlanda, [w:] Przestrzenie intermedialności...

31 Thomas Elsaesser, "Lili Marleene”. Faschism and the Film Industry, "October" 1982, nr 21.
} 
(reżyser ironizował później z tego „komicznego w swej wymowie sojuszu brytyjskich lewaków z niemieckimi rewizjonistami"32).

Podobnie jak w latach 50. i 60., w RFN kolejnej dekady nie powstało wiele filmów fabularnych o nazistowskich zbrodniarzach. Wyjątkiem jest film Śmierć jest moim rzemiosłem (Aus einem deutschen Leben, reż. Theodor Kotulla, RFN 1977) na podstawie powieści Roberta Merlego pod tym samym tytułem, inspirowanej autobiograficznymi notatkami Rudolfa Hössa ${ }^{33}$. O ile w latach 50. postać Führera była objęta przez twórców filmowych dobrowolnym Bildverbot, o tyle w latach 70. przez RFN przetoczyła się fala zainteresowania postacią Hitlera - określana terminem Hitler-Welle ${ }^{34}$. Jej początek wiąże się z nazwiskiem wpływowego historyka, Joachima Festa, szefa działu kultury we „Frankfurter Allgemeine Zeitung” i autora bestsellerowej biografii Führera ${ }^{35}$, która w 1977 r. stała się podstawą kinowego filmu dokumentalnego Hitler - historia pewnej kariery (Hitler - eine Karriere, real. Christian Herrendoerfer, RFN 1977). Film wywołał protesty ze strony lewicowo-liberalnej części zachodnioniemieckiej opinii publicznej (w głośnym eseju, zatytułowanym That's Entertainment, Wim Wenders oskarżał: „Ten film został przepisany od faszystów. Obraz w obraz"36). Nie był to ostatni film o Hitlerze nakręcony w RFN w 1977 r. - mniej więcej w tym samym czasie Ulli Lommel, aktor współpracujący na stałe z Fassbinderem, zrealizował fabułę Adolf i Marlena (Adolf und Marlene), o fascynacji Führera gwiazdą Błękitnego anioła.

Kontrowersje innego rodzaju wywołał Hans Jürgen Syberberg, autor siedmioipółgodzinnego eseju Hitler - film z Niemiec (Hitler, ein Film aus Deutschland, RFN/Francja/Wielka Brytania 1977), już na początku zapewniający: „wszystkie postaci i wydarzenia są fikcyjne ${ }^{\prime 37}$. Zamiast dążenia

32 Zob. Tomasz Majewski, Pamięć, ironia, polityka historyczna. Wokót "Hotelu Terminus" Marcela Ophülsa, [w:] Zagłada. Wspótczesne problemy rozumienia, red. Ewa Domańska, Przemysław Czapliński, Poznań 2009.

${ }^{33}$ Robert Merle, Śmierć jest moim rzemiosłem, tłum. Cz. Przymusiński, Warszawa 1952. Powieść była inspirowana wywiadami, jakie odbył z oskarżonymi w pierwszym procesie norymberskim psycholog Gustave Gilbert (Gustave Gilbert, Dziennik norymberski, tłum. T. Łuczak, Warszawa 2012); zob. też: Rudolf Höss, Autobiografia Rudolfa Hössa, komendanta obozu oświęcimskiego, tłum. W. Grzymski, Warszawa 1989.

${ }^{34}$ Hitlerwelle und historische Fakten, red. Anneliesie Mannzmann, Königstein 1979. Także: Matthias N. Lorenz, Fascinosum Hitler, [w:] Lexikon der "Vergangenheitsbewältigung” in Deutschland, red. Torben Fischer, Matthias N. Lorenz, Bielefeld 2009.

35 Joachim Fest, Hitler, tłum. D. Kucharska, B. Szymańska, W. Jeżewski, t. 1-2, Warszawa 1995-1996.

36 Wim Wenders, That's Entertainment, „Die Zeit”, 5.09.1977 (również w: idem, Emotion Pictures: Essays und Filmkritiken, Frankfurt am Main 1986). Zob. też: Was verschweigt Fest? Analysen und Dokumente zum Hitler-Film, red. Jörg Berlin, Dierk Joachim, Köln 1978.

${ }_{37}$ W języku polskim zob.: Jürgen Müller, „Hitler. Film z Niemiec” Hansa Jürgena Syberberga. Audiowizualne między-gry historii, tłum. Z. Feliszewski, [w:] Kino niemieckie w dialogu pokoleń i kultur, red. Andrzej Gwóźdź, Kraków 2004. 
do realistycznej reprezentacji mamy tu grę z wizerunkami Führera: Hitler jako marionetka, jako Frankenstein, jako Kaligula, jako Napoleon, jako Chaplin z Dyktatora (którego bohater sam już przecież "odgrywał" Führera), jako malarz, Hitler zjadający dywan (Teppichfresser - tak określano napady szału wodza), Hitler z pośladkami zamiast twarzy (i wąsikiem pośrodku), czy wreszcie obraz chyba najbardziej znany, uwieczniony na plakatach filmu Syberberga: owinięty w togę Hitler wynurzający się z grobu Richarda Wagnera.

Nieprawdziwa jest forsowana niekiedy opinia, że zmiana generacyjna w kinematografii RFN oraz już samo zaistnienie Nowego Kina Niemieckiego pociągnęły za sobą wprowadzenie do zachodnioniemieckich filmów fabularnych tematyki Zagłady. Jeśli w ogóle pojawia się ona w filmach z lat 1965-1975, to najczęściej jedynie w tle bądź jako swoisty „intertekst”, ukryty $\mathrm{w}$ pojedynczych obrazach lub motywach dotyczących - pozornie - innych tematów. Pytanie o selektywność reprezentacji historii jest w kontekście Nowego Kina Niemieckiego ważne o tyle, że w niektórych opracowaniach znaleźć można opinię, iż filmy artystów zaliczanych do tej formacji „odkłamały przeszłośćc i „przełamały milczenie”. Otóż wydaje mi się, że tego rodzaju sformułowania wynikają z nazbyt mechanicznego przełożenia opisu dotyczącego życia politycznego na sferę ówczesnej kinematografii bądź rzutowania filmów z końca lat 70. i 80. na wcześniejszy o dekadę okres. Już bowiem rzut oka na parametry ilościowe - tj. wykaz filmów zaliczanych do Nowego Kina Niemieckiego, a nakręconych między 1965 a 1975 rokiem - dowodzi, że ówczesne kino RFN nie było jeszcze gotowe na rzeczywistą konfrontację z nazistowską przeszłością (nieliczne wyjątki potwierdzają regułę). Nurt rozliczeniowy w kinie niemieckim miał się faktycznie pojawić dopiero pod koniec lat $70 .{ }^{38}$ i przybrał na sile na początku kolejnej dekady. Jednocześnie nadal realizowano filmy o niemieckim ruchu oporu ${ }^{39}$ - w 1982 r. doszło do sytuacji rzadko spotykanej (choć podobnej do tej, która stała się udziałem filmów o Stauffenbergu

38 Zob. Krzysztof Stanisławski, Nowe kino niemieckie, Sopot 1998, s. 128. Autor wymienia w tym kontekście Patriotkę Klugego (1979), Małżeństwo Marii Braun Fassbindera (1979), Matkę Sanders-Brahms (1980), Heimat Reitza (1984) oraz oczywiście esej Hitler - film $z$ Niemiec Syberberga (1978).

${ }^{39} \mathrm{Na}$ przełomie lat 60. i 70. zachodnioniemiecka telewizja publiczna sfinansowała i wyemitowała kilka filmów o rodzimym antynazistowskim ruchu oporu w okresie II wojny światowej. Dotyczyły one kolejno: Georga Elsera - Zamachowiec (Der Attentäter, reż. Hans Gottschalk, Rainer Erler, RFN 1969), Białej Róży - Woźny (Der Pedell, reż. Paul Mommertz/Eberhard Itzenplitz, RFN 1971) opowiadający o Jacobie Schmidzie, który schwytał rodzeństwo Schollów chwilę po rozrzuceniu przez nich ulotek na monachijskim uniwersytecie, a także film o spisku Stauffenberga - 21 lipca (Der 21. Juli, reż. Claus Hubalek, RFN 1972). Ponadto zrealizowano siedmioodcinkowy serial Czerwona orkiestra (Die rote Kapelle, reż. Franz-Peter Wirth, RFN/Francja 1972). 
z 1955 r.): nakręcono dwa filmy fabularne opowiadające o Schollach: Biała Róża (Die Weiße Rose, reż. Michael Verhoeven, RFN 1982) oraz Pięć ostatnich dni (Fünfletzte Tage, reż. Percy Adlon, RFN 1982) ${ }^{40}$.

Zresztą, błędem jest utożsamianie kinematografii RFN lat 70. wyłącznie z formacją Nowego Kina Niemieckiego (podobnie jak bezzasadne wydaje się rozpatrywanie jakiejkolwiek kinematografii jedynie przez pryzmat kina autorskiego). Warto zwrócić uwagę, iż w I połowie lat 70. do kin RFN ponownie trafiały filmy $\mathrm{z}$ lat 50.: Kapitan marynarki Prien Reinla oraz Psy, chcecie żyć wiecznie? Wisbara. Z kolei film montażowy z 1961 r. Od 5.45 odpowiadamy ogniem (Seit 5.45 Uhr wird zurückgeschossen, real. Hans Gnamm) w 1975 r. był ponownie dystrybuowany jako Europa wogniu - bohaterstwo na wszystkich frontach (Europa in Flammen - Heldentum an allen Fronten). Największym przebojem kasowym z początku lat 80 . stał się zaś Okręt (Das Boot, reż. Wolfgang Petersen, RFN 1981) na podstawie powieści wydanej w $1973 \mathrm{r}^{41}-\mathrm{w}$ dramaturgii i wymowie przypominający fabuły z przełomu lat 50. i 60. W zachodnioniemieckim box-office z $1981 \mathrm{r}$. Okręt uplasował się na piątym miejscu (na dwudziestym szóstym - Mefisto Istvána Szabó ${ }^{42}$. Przypomnienie tych faktów jest, jak sądzę, istotne dla bardziej zniuansowanego oglądu zachodnioniemieckiej kultury filmowej tamtego okresu.

Objęcie urzędu kanclerskiego przez Helmuta Kohla pod koniec 1982 r. oznaczało z jednej strony kontynuację polityki wschodniej (czego symbolem stała się wizyta Ericha Honeckera w Bonn latem 1987 r.), z drugiej zaś zapowiadało zmianę w oficjalnej polityce pamięci RFN. Na pierwsze lata urzędowania Kohla przypadły ważne symboliczne wydarzenia: w 1983 r. minęło pół wieku od przejęcia władzy przez Hitlera, w 1985 r. odbyły się natomiast obchody 40. rocznicy zakończenia II wojny światowej. Nowe kierunki w myśleniu o wydarzeniach II wojny światowej wyrażało głośne wystąpienie Kohla z marca 1983 r. W swej mowie kanclerz wspomniał o "duchowo-moralnym przełomie" (geistig-moralische Wende) ${ }^{43}$, pomyślanym jako kontra wobec dyskursów narzuconych przez pokolenie '68, które podmyły fundamenty tego, co społecznie wspólne i uniemożliwiają pozytywną identyfikację z kulturą niemiecką. W myśl tej optyki rozumienie historii Niemiec powinno zostać poddane "normalizacji” (termin ten zrobi karierę w latach 90.) w dwojakim rozumieniu. Po pierwsze, nazizm winien być traktowany jako jedna z historycznych epok - nie zaś postrze-

${ }^{40}$ Zob. Konrad Klejsa, Pamięć o rodzeństwie Scholl w filmach Michaela Verhoevena i Percy'ego Adlona-konteksty i interpretacje, "Człowiek i Społeczeństwo” 2012, nr 34.

${ }^{41}$ Lothar-Günther Buchheim, Okręt, tłum. A. Kaska, Warszawa 1987.

42 Za: www.insidekino.com (dostęp: 20.09.2013).

${ }^{43}$ Pełny tekst pod adresem: http://helmut-kohl.kas.de/index.php (dostęp: 30.09.2014). 
gany jako kulminacja niemieckiego „Ordnung” czy kumulacja specyficznych cech niemieckiej kultury; po drugie zaś, doświadczeń „zwykłych Niemców" nie można przywoływać jedynie w charakterze "dowodu sądowego", lecz w sposób podobny do tego, jaki jest udziałem innych narodów (co oznacza z kolei, iż cierpienia wojenne Niemców są równie ważne, jak te, których doznali obywatele innych nacji). Po wielekroć krytykowanym (w RFN, ale i w innych krajach ${ }^{44}$ ) symbolem zmiany zachodnioniemieckiej polityki historycznej stał się "skandal w Bitburgu” ${ }^{45}$ - gdy w 1985 r. Helmut Kohl zaprosił prezydenta Ronalda Reagana do złożenia kwiatów na cmentarzu wojskowym nieopodal miejscowości Bitburg, który był także miejscem pochówku oficerów Waffen SS.

Zainicjowana przez gabinet Kohla zmiana polityki historycznej pozostawała $\mathrm{w}$ kontrze do pedagogiczno-prokuratorskiej polityki pamięci pokolenia 1968 r., które - zdaniem Petera Schneidera - „wymazało ze swej wizji historii wszystkie obrazy Niemców niewpisujące się w ramy pojęcia "pokolenie sprawców «" ${ }^{46}$. Nic więc dziwnego, że wyraźniej słyszalne stały się głosy krytykujące tych historyków, którzy w swych pracach podążali ścieżką wyznaczoną przez dyskursy pokolenia '68. W opublikowanym w 1985 r. eseju ${ }^{47}$ Martin Broszat zarzucił niemieckiej historiografii poddawanie okresu nazizmu „moralnej kwarantannie”, stosowanie dla jego opisu „rutynowych zaklęć” i brak umiejętności takiego budowania narracji, które przedstawiałoby społeczne tło narodowego socjalizmu. Replika, z jaką spotkał się ten esej (zjego tezami polemizował m.in. Saul Friedländer - tzw. Broszat-Friedlander Debatte), była jedną z odsłon szerszej debaty, określanej jako „spór historyków”. Kanwą dyskusji stały się dwie prace opublikowane w 1986 r. W pierwszej z nich - eseju O przeszłości, która nie

${ }^{44}$ Bitburg in Moral and Political Perspective, red. Geoffrey H. Hartmann, Bloomington 1986; Bitburg and Beyond. Encounters in American, German and Jewish History, red. Ilya Levkov, New York 1987; Theo Hallet, Umstrittene Versöhnung. Reagan und Kohl in Bitburg 1985, Sutton-Erfurt 2005; Werner Bergmann, Die Bitburg Affäre in der deutschen Presse. Rechtkonservative und linksliberale Interpretationen, [w:] Schwieriges Erbe. Der Umgang mit Nationalsozialismus und Antisemitismus in Österreich, der DDR und der Bundesrepublik Deutschland, red. Werner Bergmann, Frankfurt am Main 1995.

${ }^{45}$ Historyk Heinrich August Winkler określił Bitburg wprost jako „kontr-gest” wobec Brandtowskiego „Kneefall”. Zob. Heinrich August Winkler, Auf ewig in Hitlers Schatten. Zum Streit über das Geschichtsbild der Deutschen, „Frankfurter Rundschau”, 14.11.1986. Większość komentatorów skłania się ku opinii, iż „skandal” ten nie był dziełem przypad$\mathrm{ku}$, ale został celowo zaaranżowany - ceremonia w Bitburgu była bowiem zapowiedzianym z wyprzedzeniem dużym wydarzeniem medialnym.

${ }^{46}$ Peter Schneider, Deutsche als Opfer. Über ein Tabu der Nachkriegsgeneration, [w:] Ein Volk von Opfern? Die neue Debatte um den Bombenkrieg, red. Lothar Kettenacker, Berlin 2003.

${ }^{47}$ Martin Broszat, Plädoyer für eine Historisierung des Nationalsozialismus, "Merkur" 1985 , nr 5. 
chce odejśćc ${ }^{48}$ - Ernst Nolte podjął polemikę z przekonaniem, że masowa eksterminacja była niemieckim wynalazkiem, dowodząc, iż nazistowskie ludobójstwo na tle rasowym było poprzedzone przez klasowy genocyd prowadzony w ZSRR. Z tego poglądu Nolte wywiódł, iż stalinowskie zbrodnie były zbrodnią „pierwszą", nazistowskie zaś - ich swoistą „,kopią" bądź reakcją na nie. W drugiej pracy, która wywołała gwałtowne i uzasadnione protesty ${ }^{49}$, Andreas Hillgruber zamieścił dwa eseje: o zagładzie Żydów oraz kresie "niemieckiego wschodu”. Kontrowersję wywołało nie tylko zestawienie dwóch społecznych traum: cierpień niemieckich z jednej strony oraz tych spowodowanych przez Niemców z drugiej - w taki sposób, iż obie kategorie mogły jawić się jako równoważne - lecz także zastosowanie de facto kryterium rasowego w ich wyodrębnianiu (autor nie uwzględnił bowiem niemieckich obywateli żydowskiego pochodzenia), co Dan Diner określił jako tworzenie „podwójnej” historii: „niemieckiej” i „żydowskiej”, replikującej nazistowski podział na „Niemców” i „innych" ${ }^{50}$. Obie publikacje podzieliły środowisko historyków i politologów (po stronie obrońców Noltego i Hillgrubera stanęli m.in. Michael Stürmer oraz Klaus Hildebrandt; wśród liczniejszej grupy ich adwersarzy byli zaś Jürgen Habermas i Hans Mommsen). Polemiki dotyczyły głównie zasadności przyznania Holocaustowi centralnego miejsca w analizie nazizmu (czy nie wynika ono z ideologicznej presji pokolenia '68 oraz specjalnego statusu Ocalałych, i czy koncentrowanie się przede wszystkim na Zagładzie nie jest zagrożeniem dla historiografii) oraz kontekstu, w jakim może i powinien być on rozpatrywany (czy eksterminacyjny szał wywołany był przez autorytaryzm niemieckiego społeczeństwa, czy też jego przyczyn należy szukać w traumatycznych doświadczeniach modernizacji). Szczegółowe trajektorie "sporu historyków" nie mogą zostać w tym miejscu szczegółowo omówione; warto natomiast przypomnieć, że w tym samym czasie toczyła się, także w Niemczech, niejako „lustrzana” debata: dotycząca uniwersalizacji i wyjątkowości Zagłady (będzie ona kontynuowana również w kolejnej dekadzie ${ }^{51}$ ).

48 Ernst Nolte, O przeszłości, która nie chce przeminać, tłum. M. Łukasiewicz, [w:] O kondycji Niemiec. Tożsamość niemiecka w debatach intelektualistów po 1945 roku, red. Joanna Jabłkowska, Leszek Żyliński, Poznań 2008.

${ }^{49} \mathrm{~W}$ języku polskim opublikowano fragment jako: Andreas Hillgruber, Dwie katastrofy. Rozbicie Rzeszy Niemieckiej i koniec europejskiego Żydostwa, tłum. M. Łukasiewicz [w:] O kondycji Niemiec...

50 Dan Diner, Between Aporia and Apologia: On the Limits of Historicizing National Socialism, [w:] Reworking the Past: Hitler, the Holocaust and the Historians' Debate, red. Peter Baldwin, Boston 1990, s. 141. Zob. też: Vergangenheit, die nicht vergeht. Die "Historiker-Debatte". Dokumentation, Darstellung und Kritik, red. Reinhard Kühnl, Köln 1987.

${ }^{51}$ Dobre omówienie tych zagadnień znajduje się w artykule: Tomasz Majewski, Dyskurs publiczny po Shoah, [w:] Pamięć Shoah. Kulturowe reprezentacje i praktyki upamiętnienia, 
Wydaje się, iż owe przemiany w dyskursie politycznym RFN nie znalazły bezpośredniego odzwierciedlenia w zachodnioniemieckiej kinematografii lat 80. (w ich kontekście chętnie rozpatrywano Heimat Edgara Reitza; jego Godzina zero [Stunde Null, RFN 1977], opowiadająca o pierwszych miesiącach po zakończeniu wojny, pozwalała z kolei powrócić do czasu, gdy w Niemczech powszechne było poczucie bycia podwójną ofiarą - Hitlera oraz aliantów). Można powiedzieć, że w kinie zachodnioniemieckim tamtego czasu - zwłaszcza autorskim czy artystycznym - nadal przeważały tropy zainicjowane przez pokolenie 1968 r. Generacyjny konflikt znalazł swój wyraz w swoistej psychodramie zrealizowanej przez syna Veita Harlana Kanat rany (Wundkanal, reż. Thomas Harlan, RFN/Francja 1984 ${ }^{52}$ ) - na poły fikcjonalnej, na poły dokumentalnej, bowiem w roli oskarżonego występuje Alfred Filbert, który w czasie wojny był dowódcą jednego z Einsatzkommando. Problem inscenizowania przeszłości tematyzuje Pasażer - witamy w Niemczech (Der Passagier - Welcome to Germany, reż. Thomas Brasch, RFN/Szwajcaria/Wielka Brytania 1988) z Tonym Curtisem w roli amerykańskiego reżysera, który w RFN ma zrealizować fabułę o kulisach produkcji pewnego nazistowskiego filmu.

Producentem (lub koproducentem) kilku filmów o tematyce związanej z okresem nazizmu był Artur Brauner. Wśród jego międzynarodowych koprodukcji mających swe premiery do zjednoczenia Niemiec można wymienić: Ogród Finzi-Continich (Il giardino dei Finzi Contini, reż. Vittorio De Sica, Włochy/RFN 1970), Nieznajoma z Sans Souci (Die Spaziergängerin von Sans Souci, reż. Jacques Rouffio, Francja/RFN 1982) i Hanussena (reż. István Szabó, Węgry/RFN/Austria 1988); dwie fabuły zaś wyreżyserowali Polacy: Jerzy Hoffman (Wedle wyroków Twoich [Blutiger Schnee lub Zu Freiwild verdammt, RFN/Polska 1984]) i Agnieszka Holland (Gorzkie żniwa [Bittere Ernte, RFN 1985), która pięć lat później nakręciła z pomocą Braunera film Europa, Europa (Hitlerjunge Solomon, Francja/Niemcy 1990).

Do oryginalniejszych zachodnioniemieckich fabut, które w latach 80 . konfrontowały widza z okresem nazizmu, należały realizacje Herberta Achternbuscha: Ostatnia dziura (Das letzte Loch, RFN 1981) i Pozdrawiajcie Hitlera! (Heilt Hitler!, RFN 1986), a także David (reż. Peter Liliental, RFN 1979) - pierwszy po Długa jest droga niemiecki film fabularny (nagrodzony

red. Tomasz Majewski, Anna Zeidler-Janiszewska, Łódź 2009. Zob. także: Daniel Levy, Natan Sznaider, Erinnerung im globalen Zeitalter: Der Holocaust, Frankfurt am Main 2001.

52 Tytuł filmu to sformułowanie zaczerpnięte ze słownika medycyny sądowej. W okresie poprzedzającym realizację filmu termin ten pojawiał się w dyskursie publicznym $\mathrm{w}$ odniesieniu do samobójstw liderów RAF w więzieniu Stammheim (twierdzono, że „kanał ran” Andreasa Baadera zaświadcza o tym, że jego domniemane samobójstwo mogło zostać popełnione wyłącznie przy założeniu akrobatycznych wyczynów terrorysty). 
Złotym Niedźwiedziem na Berlinale), w którym wydarzenia pokazane są perspektywy głównego żydowskiego bohatera. Za kontrapunktowe dopełnienie Davida można uznać Gwiazdę bez nieba (Stern ohne Himmel, reż. Ottokar Runze, RFN 1981), film opowiadający o pomocy, jaką żydowskiemu chłopcu udzielają członkowie Hitlerjugend. Dominowały jednak fabuły skrojone według schematu "odkrywania prawdy o bliskich” - zastosowanego na przykład w Niegrzecznej dziewczynie (Das schreckliche Mädchen, reż. Michael Verhoeven, RFN 1989), Złocie Abrahama (Abrahams Gold, reż. Jörg Graser, RFN 1989) czy serialu Kraj ojców, kraj synów (Land der Väter, Land der Söhne, reż. Nico Hofmann, RFN 1988). Formuła sagi rodzinnej była zresztą w telewizji zachodnioniemieckiej lat 80 . wielokrotnie wykorzystywana - by wymienić choćby wieloodcinkową Rodzinę Bertinich (Die Bertinis, reż. Egon Monk, RFN 1988) ${ }^{53}$ na podstawie powieści Ralpha Giordano czy czteroczęściowy cykl Ojcowie i synowie. Niemiecka tragedia (Väter und Söhne. Eine deutsche Tragödie, RFN 1986) - superprodukcję ( $\mathrm{z}$ Burtem Lancasterem $\mathrm{w}$ roli seniora rodu) o koncernie IG Farben (a zatem na temat podjęty przez enerdowską Defę w 1950 r.) na podstawie scenariusza i w reżyserii Bernharda Sinkela ${ }^{54}$.

Podział na wschodnio- i zachodnioniemiecką politykę pamięci - swoisty Ricoeurowski „dyssensus pamięci”, oznaczający antagonizm, ale i konkurencję między pamięcią „własną" i pamięcią „tamtych" 55 - utrzymywał się do zjednoczenia Niemiec. Polityka "normalizacji” - kontynuowana przez gabinety Gerharda Schrödera i Angeli Merkel (niezależnie od głębokich sporów oraz głośnych debat związanych z rozmaitymi kwestiami polityki pamięci, które nie mogą tu zostać przywołane ${ }^{56}$ ) - wyraźnie odnajduje swe odbicie we współczesnym kinie niemieckim. Argumentów na rzecz takiego sądu dostarcza wiele wysokobudżetowych fa-

${ }^{53}$ Monk zrealizował jeszcze dwa telewizyjne filmy o tematyce związanej z okresem nazizmu. Były to ekranizacje powieści: Hansa Fallady Rolnicy, bonzowie i bomby (Bauern, Bonzen und Bomben, RFN 1973) oraz Liona Feuchtwangera Rodzeństwo Oppermann (Die Geschwister Oppermann, RFN 1983).

${ }^{54}$ W wywiadach Sinkel podkreślał osobiste pobudki, które skłoniły go do pracy nad projektem (pradziadek reżysera był jednym z założycieli koncernu, a ojciec - prokurentem spółki). Film Sinkela wywołał krótką debatę (entuzjastyczną recenzję napisał m.in. redaktor naczelny "Der Spiegel”: Rudolf Augstein, Von Teer und Farben zu I.G. Auschwitz, „Der Spiegel" 1986, nr 46), przypominającą - zapomniane już wówczas - uwikłanie IG Farben w nazistowską machinę zbrodni (Wolfgang Heitzeler, Was war mit der IG Farben? Der Nürnberger Prozess und der Fersehfilm „Väter und Söhne”, Herford 1987). Wydano też książkową wersję scenariusza - Bernhard Sinkel, Väter und Söhne. Eine deutsche Tragedie, Frankfurt am Main 1986.

55 Paul Ricoeur, Pamięć, historia, zapomnienie, tłum. J. Margański, Kraków 2012, s. 600.

56 Zob. Wojciech Pięciak, Niemiecka pamięć. Wspótczesne spory w Niemczech o miejsce III Rzeszy w historii, polityce i tożsamości, Kraków 2002. 
buł o cierpieniach niemieckiej ludności cywilnej (w tym - wysiedlonych) oraz przysłowiowych „dobrych Niemcach”, którzy heroicznie przeciwstawiają się nazistowskiej dyktaturze. Ponadto niemieccy reżyserzy sięgają bezpośrednio do repozytorium filmowych reprezentacji nazizmu z lat 50. - by wspomnieć choćby nową wersję emitowanego po raz pierwszy w 1959 r. serialu Jeniec: jak daleko nogi poniosa (So weit die Füsse tragen, reż. Hardy Martin, RFN 2001), czy telewizyjny remake klasycznego filmu Wickiego Most (Die Brücke, reż. Wolfgang Panzer, RFN 2008) ${ }^{57}$.

Jednym $\mathrm{z}$ trendów zauważalnych $\mathrm{w}$ niemieckim kinie historycznym ostatnich lat jest eksponowanie własnych - niemieckich - cierpień doznanych podczas II wojny światowej. Wydaje się, iż na obszarze polityki historycznej doszło do swoistej fuzji dawnych zachodnio- i wschodnioniemieckich dyskursów pamięci o ofiarach. O ile w RFN niechętnie przypominano o alianckich nalotach na niemieckie miasta, o tyle we współczesnej niemieckiej kulturze temat ten jest chętnie podejmowany. Z kolei wspomnienia dotyczące cierpień spowodowanych przez Armię Czerwona, silnie obecne w erefenowskiej sferze publicznej i w oczywisty sposób represjonowane w NRD, dziś zostały włączone do wspólnego już repozytorium pamięci zjednoczonych Niemiec $^{58}$.

Podobną uwagę można sformułować w związku z problematyką antynazistowską. W pierwszych dwóch dekadach po zjednoczeniu dominowała pamięć kulturowa wcześniej ukształtowana w RFN, a więc zogniskowana wokół postaci Stauffenberga i Sophie Scholl (co zaowocowało filmami na ten temat, m.in. Zamach w Wilczym Szańcu [Stauffenberg, reż. Jo Baier, 2004] oraz Sophie Scholl - ostatnie dni [Sophie Scholl - die letzte Tage, reż. Marc Rothemund, 2006]), a także, choć w mniejszym stopniu, pastora Bonhoeffera. $Z$ „panteonu bohaterów” wykluczeni byli natomiast dawni enerdowscy „idole” byłej KPD. Nacisk organizacji lewicowych (we wschodnich landach trafiający na podatny grunt z uwagi na "nostalgię" za NRD) sprawia, że obecnie pojawiają się sygnały świadczące o włączaniu do heroizowanej grupy „oponentów Hitlera” również komunistów

$57 \mathrm{~W}$ porównaniu z pierwowzorem $\mathrm{w}$ tej wersji pojawiły się nowe wątki: ojciec jednego z chłopców chce wysłać do Dachau nauczycielkę, z którą syn ma romans, zaś nawołujący bohaterów do poddania się amerykański żołnierz, w oryginale bezimienny, tu zyskał nazwisko Rosenzweig. Zob. także: Ewa Fiuk, Inicjacje, tożsamość, pamięć. Kino niemieckie na przełomie wieków, Wrocław 2012, s. 60-65.

58 Piśmiennictwo na temat tych przemian jest zbyt bogate, by je w tym miejscu wskazywać, odsyłam więc jedynie do artykułu, w którym podejmuję ów wątek w kontekście dwóch produkcji telewizyjnych z początku XXI w.: Konrad Klejsa, Drezno i Gustloff - miejsca pamięci niemieckich ofiar II wojny światowej $i$ ich reprezentacje w filmach telewizyjnych stacji ARD i ZDF z lat 2006-2008, [w:] Paradygmaty kina wspótczesnego, red. Ryszard W. Kluszczyński, Tomasz Kłys, Łódź 2014. 
(za świadectwo tego procesu może zostać uznany niedawny remake enerdowskiego filmu Nadzy wśród wilków [reż. Philipp Kadelbach, 2015]).

Mnogość powstałych w Niemczech w ostatnich latach fabuł o czasach nazistowskich jest niewątpliwie faktem godnym odnotowania ${ }^{59}$ - choć niekoniecznie specyficznym akurat dla naszych zachodnich sąsiadów, bowiem podobne zjawisko daje się zauważyć w odniesieniu do wielu innych kinematografii narodowych. Jeśli film uznamy za jeden $\mathrm{z}$ instrumentów kreowania polityki pamięci, która uwzględniałaby wielość wariantów narodowego losu, a zarazem ustanawiała pozytywny wizerunek własnej wspólnoty na potrzeby widowni międzynarodowej, wówczas współczesne kino niemieckie dostarczyłoby wielu dowodów skutecznego wykorzystania możliwości, jakie ów instrument oferuje.

Jak przyznał Karsten Visarius, niemieckie narracje o nazizmie podatne są na spekulacje, "czy dają wgląd w zbiorową duszę"60, otwierają się na interpretacje z Kracauerowskiej tradycji socjologicznych odczytań „symptomatycznych”, nakazujących dociekać, czy pod powierzchnią „niewinnych" wydarzeń fabularnych nie kryją się czasem oznaki politycznego Unbehagen, niepokojących pragnień i dążeń. Mowa przecież o kinematografii, w której Macht der Bilder („,potęga obrazów”) była wykorzystywana dla wspierania totalitarnego systemu (jak pisał Wim Wenders w swej druzgocącej krytyce filmu Joachima Festa Hitler - historia pewnej kariery: „nigdy wcześniej i w żadnym innym kraju nie postępowano tak bezmyślnie z obrazami, jak tu; nigdy wcześniej i nigdzie indziej nie zostały zdegradowane do nośnika kłamstw" ${ }^{\prime \prime 61}$ ). Twórców kina niemieckiego obarczono zatem odpowiedzialnością szczególnego rodzaju - choć zarazem perspektywa ta rzadko kiedy była przez nich artykułowana.

Zdaniem Thomasa Elsaessera rozpatrywanie zachodnioniemieckich filmów o historii jest naznaczone dwiema obawami. Pierwsza brzmi: reprezentacje faszyzmu (autor używa tego terminu) mogą być zbyt selektywne; druga zaś wiąże się ze wspomnianą „potęgą obrazów”. Pomni tego dziedzictwa kultury niemieckiej reprezentanci kina autorskiego

59 Zob. Joanna Trajman, Narodowy socjalizm w kinie zjednoczonych Niemiec, Wrocław 2014.

${ }^{60}$ Karsten Visarius, Der Wunsch des Täters nach der Tat. Volker Schlöndorffs „Der neunte Tag", [w:] Das Böse im Blick. Die Gegenwart des Nationalsozialismus im Film, red. Margrit Frölich, Christian Schneider, Karsten Visarius, München 2007, s. 246.

${ }^{61}$ Wim Wenders, Emotion Pictures: Essays und Filmkritiken, Frankfurt am Main 1986, s. 115. 
lat 70., chcąc uniknąć „osunięcia się w spektakl”, wybierali często formy eksperymentalne, brechtowskie, eseistyczne itp. W odniesieniu do pierwszej z obaw Elsaesser przypomina pytania, które pojawiały się w publikacjach krytycznych dotyczących, odpowiednio, serialu Heimat („Gdzie są Żydzi w Schabbach?”) oraz filmowego eseju Hitler - film z Niemiec (,Czy Syberberg uległ mistycyzmowi »Blut und Boden«"?) ${ }^{62}$.

Próbując odeprzeć tego rodzaju zarzuty, Elsaesser wkracza na wyżyny kazuistyki, starając się udowodnić, iż nieobecność Zagłady w wielu zachodnioniemieckich filmach jest świadectwem specyficznej „pracy żałoby" ${ }^{\prime 63}$. Przykładowo, w demonstracyjnym braku tematyzowania Holocaustu przez Klugego widzi Elsaesser - odwołując się m.in. do debaty zainicjowanej przez Claude'a Lanzmanna, a kontynuowanej przez Saula Friedländera, preferujących relację naocznego świadka ponad fikcjonaliza$\mathrm{cje}^{64}$ - stanowisko etyczne polegające na swoistym ikonoklazmie: oddaniu czci poprzez odmowę przedstawienia (,Byłoby to zbyt wiele, w fikcjonalnej formie uczynić widzialnym to, czego znaczenie leży w nieobecności, w fizycznym zniszczeniu [Vernichtung]. Jak pokazać to, czego nie ma?"65). Jest to stanowisko imponujące retorycznie - i skuteczne wówczas, gdy Elsaesser analizuje konkretny film i próbuje wskazać w nim napięcia pomiędzy „pokazanym” i „niepokazywalnym”. Argumentacja Elsaessera chybia jednak w tych punktach, w których stara się on swą interpretację przedstawić jako domniemaną intencję twórczą, charakterystyczną nie tylko dla jednego reżysera, ale wręcz dla całej formacji. Twierdzi nawet - nie wyjaśniając, na jakiej podstawie to czyni - iż niepokazywanie obrazów Holocaustu i brak żydowskich postaci skłania widza do myślenia właśnie o nich.

Warto, jak sądzę, pokusić się o komentarz do takiego poglądu. Otóż wydaje się on klasycznym przykładem diagnozowanej przez Karla Poppera niefalsyfikowalności teorii o psychoanalitycznej proweniencji, w tym również tego trendu w interpretacji, zgodnie z którym „,to, czego nie ma”

${ }^{62}$ Thomas Elsaesser, The New German Cinema's Historical Imaginary, [w:] Framing the Past: The Historiography of German Cinema and Television, red. Bruce A. Murray, Christopher J. Wickham, Cardbondale 1992, s. 290.

${ }^{63}$ Podobnie czyni inny autor: Eric L. Santner, Stranded Objects: Mourning, Memory, and Film in Postwar Germany, London-New York 1990.

${ }^{64}$ Saul Friedländer, Kitch und Tod. Der Widerschein des Nazismus, München 1986; zob. także wstęp jego autorstwa w: Probing the Limits of Representation: Nazism and the "Final Solution", red. Saul Friedländer, Cambridge 1992.

65 Thomas Elsaesser, Die Gegenwärtigkeit des Holocausts im Neuen Deutschen Film - am Beispiel Alexander Kluge, [w:] Die Vergangenheit in der Gegenwart. Konfrontationen mit den Folgen des Holocaust im deutschen Nachkriegsfilm, red. Claudia Dillmann, Ronny Loewy, Frankfurt am Main 2001, s. 55. 
miało by być daleko bardziej istotne niż „to, co jest”. Sposób, w jaki Elsaesser "rozgrzesza” niemieckie filmy o nazizmie jest nadto niezmiernie ważny z czysto pragmatycznego punktu widzenia - modeluje bowiem pozytywny obraz tej kinematografii i demonstrowanych przez nią "sposobów radzenia sobie z przeszłością". Innymi słowy, teoretyczne rozważania mają tu - łatwy do przeoczenia, ale z pewnością wymierny - efekt promocyjny, niewątpliwie wygodny dla wszystkich podmiotów uczestniczących w systemie cyrkulacji komunikatów filmowych (krytyków, dystrybutorów, agentów sprzedaży itp.).

Powyższe spostrzeżenie wieńczy niniejszą książkę nieprzypadkowo. Jak wielokrotnie sygnalizowałem, filmy o tematyce historycznej są bowiem nie tyle "reprezentacjami zdarzeń minionych”, ile przestrzenia, $\mathrm{w}$ jakiej manifestują się przemiany pamiętania o nich, podatne na rozmaite (polityczne czy ekonomiczne) fluktuacje. Mnogość audiowizualnych reprezentacji II wojny światowej i nazizmu sprawia, że przypominają one „wieczny cykl, niekończącą się pętlę"66, odsyłającą już nie tylko do konkretnych wydarzeń, lecz raczej do samych obrazów - repozytoriów pamięci, których przegląd pozwala na rozpoznanie złożonej trajektorii rozmaitych sposobów „radzenia sobie z przeszłością”.

${ }^{66}$ Anton Kaes, From Hitler to Heimat. The Return of German History as Film, Harvard 1989, s. 196. 


\section{Bibliografia}

2 x 20. Juli. Die Doppelverfilmung von 1955, red. Claudia Dillmann, Ronny Loewy, Frankfurt am Main 2004.

50 Jahre FBW - 50 Jahre Filmgeschichte: Filmbewertung 1951-2001, red. Steffen Wolf, Alf Mayer-Ebeling, Gerd Albrecht, Wiesbaden 2001.

A nation of victims? Representations of German wartime suffering from 1945 to the present, ed. Helmut Schmitz, Amsterdam 2007.

Abusch Aleksander, Naród na manowcach. Przyczynek do poznania dziejów Niemiec, tłum. A. Liebfeld, Warszawa 1950.

Adamczyk-Garbowska Monika, Duda Henryk, Terminy "Holokaust”, "Zagłada" i "Szoa" oraz ich konotacje leksykalno-kulturowe w polszczyźnie potocznej i dyskursie naukowym, [w:] Żydzi i judaizm we wspótczesnych badaniach polskich, red. Krzysztof Pilarczyk, Kraków 2003.

Adorno Theodor, Co to znaczy: obrachunek z przeszłościa?, tłum. A. Kaniowski, [w:] O kondycji Niemiec. Tożsamość niemiecka w debatach intelektualistów po 1945 roku, red. Joanna Jabłkowska, Leszek Żyliński, Poznań 2008.

Adorno Theodor, Erziehung nach Auschwitz, [w:] "Ob nach Auschwitz noch sich leben lasse”, red. Rolf Tiedemann, Frankfurt am Main 1997.

Ahbe Thomas, Der DDR-Antifaschismus. Diskurse und Generationen, Kontexte und Identitäten, Sachsen 2007.

Adge Günther, „Mitleid mit den Mördern”? Das „Beil von Wandsbeck” als Film- und Bühnenstoff, [w:] Verwaltete Vergangenheit. Geschichtskultur und Herrschaftslegitimation in der $D D R$, red. Martin Sabrow, Leipzig 1997.

Albrecht Hartmut, Ein neuer DEFA-Film - frei nach Leonard Frank, "Nazionalzeitung”, 2.10.1958.

Albrecht Hartmut, Das Licht der Königskinder, „Nationalzeitung”, 1.06.1962.

Albrecht Hartmut, Die falschen Ideale des Werner Holt. DEFA-Film nach Dieter Nolls Roman, „Nationalzeitung”, 6.02.1965.

Albrecht Hartmut, Fünf Patronenhülsen, „Nationalzeitung”, 30.10.1960.

Albrecht Hartmut, Wahrheit von Buchenwald, "Nationalzeitung”, 5.04.1963.

Allan Seán, "Sagt, wie soll man Stalin danken?" Kurt Maetzig's "Ehe im Schatten”, "Roman einer jungen Ehe" and the Cultural Politics of Post-War Germany, "German Life and Letters" 2011, nr 2.

„Als der Krieg zu Ende war". Literarisch-politische Publizistik 1945-1959, red. Gerhard Hay, Hartmut Rambaldo, Joachim Stork, Marbach 1974.

Anderson Benedict, Wspólnoty wyobrażone: rozważania o źródłach i rozprzestrzenianiu się nacjonalizmu, tłum. S. Amsterdamski, Warszawa 1997.

Ankersmit Frank, Narracja, reprezentacja, doświadczenie: studia z teorii historiografii, red. Ewa Domańska, Kraków 2004. 
Antropologia kultury wizualnej, red. Iwona Kurz, Paulina Kwiatkowska, Łukasz Zaremba, Warszawa 2012.

apropos Film 2004. Das 5. Jahrbuch der DEFA-Stiftung, red. Ralf Schenk, Erika Richter, Claus Löser, Berlin 2004.

Arendt Hannah, Wizyta w Niemczech, tłum. A. i A. Klubowie, „Przegląd Polityczny” 2002, nr 55.

Arendt Hannah, Zorganizowana wina i powszechna odpowiedzialność, tłum. J. Sieradzki, [w:] O kondycji Niemiec. Tożsamość niemiecka w debatach intelektualistów po 1945 roku, red. Joanna Jabłkowska, Leszek Żyliński, Poznań 2008.

Asper Helmut G., Fritz Kortners Rückkehr und sein Film "Der Ruf”, [w:] Wenn wir von gestern reden, sprechen wir über heute und morgen. Festschrift für Marta Mierendorff, red. Helmut G. Asper, Berlin 1991.

Assmann Aleida, 1945 - der blinde Fleck der deutschen Erinnerungsgeschichte, [w:] Aleida Assmann, Ute Frevert, Geschichtsvergessenheit, Geschichtsversessenheit. Vom Umgang mit deutschen Vergangenheiten nach 1945, Stuttgart 1999.

Assmann Aleida, Der lange Schatten der Vergangenheit: Erinnerungskultur und Geschichtspolitik, München 2006.

Assmann Aleida, Między historia a pamięcia, red. Magdalena Saryusz-Wolska, Warszawa 2013.

Assmann Aleida, Persönliche Erinnerung und kollektives Gedächtnis in Deutschland nach 1945, [w:] Erinnerung und Verstehen: Der Völkermord an den Juden im politischen Gedächtnis der Deutschen, red. Hans Erler, Frankfurt am Main 2003.

Assmann Aleida, Pięć strategii wypierania ze świadomości, tłum. A. Pełka, [w:] Pamięć zbiorowa i kulturowa. Wspótczesna perspektywa niemiecka, red. Magdalena Saryusz-Wolska, Kraków 2009.

Assmann Aleida, Frevert Ute, Geschichtsvergessenheit, Geschichtsversessenheit. Vom Umgang mit deutschen Vergangenheiten nach 1945, Stuttgart 1999.

Ast Michaela S., Der alte Film ist tot. Wir glauben an den neuen: die Genese des jungen deutschen Films, Marburg 2013.

Ast Michaela S., Ucieczka $i$ wypędzenie w niemieckim filmie fabularnym lat pięćdziesiątych XX wieku i wspótcześnie, [w:] W drodze do sasiada. Polsko-niemieckie spotkania filmowe, red. Andrzej Dębski, Andrzej Gwóźdź, Wrocław 2013.

Autobiographische Aufarbeitung. Diktatur und Lebensgeschichte im 20. Jahrhundert, red. Martin Sabrow, Helmstedt 2012.

Autorzy kina europejskiego VI, red. Alicja Helman, Andrzej Pitrus, Warszawa 2012.

Axen Hermann, Über die Fragen der fortschrittlichen deutschen Filmkunst, "Neues Deutschland", 18.09.1952.

Bach Steven, Leni. Życie i twórczość Leni Riefenstahl, tłum. T. i P. Grzegorzewscy, Wrocław 2008.

Baczko Bronisław, Wyobrażenia społeczne: szkice o nadziei i pamięci zbiorowej, tłum. M. Kowalska, Warszawa 1994.

Baer Volker, Blick auf die Leinwand: Zwischen Leitartikel und Reportage. "Nacht fiel über Gotenhafen", "Der Tagesspiegel”, 15.05.1960.

Bagemühl Joachim, Thälmann und unsere Nation, „Berliner Zeitung”, 9.10.1955.

Barnert Anne, Die Antifaschismus-Thematik der DEFA. Eine kultur-und filmhistorische Analyse, Marburg 2012.

Barnouw Dagmar, Germany 1945: View of War and Violence, Bloomington 1996.

Barnouw Dagmar, Konfrontation mit dem Grauen. Alliierte Schuldpolitik 1945, „Merkur. Deutsche Zeitschrift für Europäisches Denken" 1995, nr 5. 
Barthel Manfred, Als Opas Kino jung war: Der deutsche Nachkriegsfilm, Frankfurt am Main 1991.

Bathrick David, Billy Wilder's Cold War Berlin, „New German Critique” 2010, nr 110.

Bauer Alfred, Deutscher Spielfilm Almanach, t. 2: 1946-1955, München 1981.

Bausch Ulrich M., Die Kulturpolitik der US-amerikanischen Information Control Division in Württemberg-Baden, Stuttgart 1991.

Beheim-Schwarzbach Martin, Sterne der Sehnsucht, Sterne der Vernichtung, "Die Welt", 30.4.1960.

Becker Frank, Kino und Film im französisch besetzten Württemberg-Hohenzollern, Frankfurt am Main 2007.

Becker Wolfgang, Antifaschismus in den DEFA-Spielfilmen, [w:] Der geteilte Himmel. Höhepunkte des DEFA-Kinos 1946-1992, red. Helmut Pflügl, Wien 2001.

Becker Wolfgang, Schöll Norbert, In jenen Tagen... Wie der deutsche Nachkriegsfilm die Vergangenheit bewältigte, Opladen 1995.

Ben-Gaviel Moshe Ya'akov, Das Haus in der Karpfengasse, Berlin (West) 1957.

Ben-Gavriel Moshe Ya'akov, Die Karpfengasse führt nicht nach Cannes, „Die Zeit”, 28.5.1965.

Benzenhöfer Udo, "Schneidet für Deutschland!". Bemerkungen zu dem Film "Sauerbruch - Das war mein Leben" (1954), [w:] Medizin im Spielfilm der fünfziger Jahre, red. Udo Benzenhöfer, Wolfgang U. Eckhardt, Pfaffenweiler 1993.

Berger John, Which Prosthetic? Mass Media, Narrative, Empathy and Progressive Politics, „Rethinking History" 2007, nr 4.

Berghahn Daniela, Hollywood behind the Wall: the Cinema of East Germany, New York 2005.

Berghahn Daniela, Resistance of the Heart: Female Suffering and Victimhood in DEFA's Antifascist Films, [w:] Screening War. Perspectives on German Suffering, red. Paul Cooke, Marc Silberman, Rochester 2010.

Berghahn Wilfried, Deutschenspiegel für Ost und West. Zu dem DEFA-Film "Der Untertan", „Frankfurter Hefte” 1952, nr 9.

Bergmann Werner, Antisemitismus in öffentlichen Konflikten. Kollektives Lernen in der politischen Kultur der Bundesrepublik, Frankfurt am Main 1997.

Bergmann Werner, Rainer Erb, Antisemitismus in der Bundesrepublik Deutschland: Ergebnisse der empirischen Forschung von 1946-1989, Opladen 1991.

Bergmann Werner, Die Bitburg Affäre in der deutschen Presse. Rechtkonservative und linksliberale Interpretationen, [w:] Schwieriges Erbe. Der Umgang mit Nationalsozialismus und Antisemitismus in Österreich, der DDR und der Bundesrepublik Deutschland, red. Werner Bergmann, Frankfurt am Main 1995.

Berman Russel A., A return to arms: Käutner's „The Captain of Köpenick”, [w:] German film and literature. Adaptations and transformations, red. Eric Rentschler, New York 1986.

Besonders wertvoll: die mit dem Prädikat "Besonders wertvoll” ausgezeichneten Filme, Filmbewertungsstelle Wiesbaden, Wiesbaden 1960.

Beutelschmidt Thomas, Kooperation oder Konkurenz? Das Verhältnis zwischen Film und Fernsehen in der DDR, Berlin 2009.

Beyer Frank, Wenn der Wind sich dreht. Meine Filme, mein Leben, München 2001

Bialas Wolfgang, Antifaschismus als Sinnstiftung. Konturen eines ostdeutsches Konzepts, [w:] Die NS-Diktatur im deutschen Erinnerunggsdiskurs, red. Wolfgang Bergem, Opladen 2003.

Bilder der Holocaust: Literatur - Film - Bildende Kunst, red. Manuel Köppen, Klaus Scherpe, Köln 1997.

Billy Wilder. Mistrz kina z Suchej Beskidzkiej, red. Kamila Żyto, Marcin Pieńkowski, Warszawa 2011. 
Billy Wilders Filme, red. Neil Sinyard, Adrian Turner, Berlin (West) 1980.

Blänsdorf Agnes, Die Einordnung der NS-Zeit in das Bild der eigenen Geschichte. Österreich, die DDR und die Bundesrepublik Deutschland im Vergleich, [w:] Schwieriges Erbe. Der Umgang mit Nationalsozialismus und Antisemitismus in Österreich, der DDR und der Bundesrepublik Deutschland, red. Werner Bergmann, Frankfurt am Main 1995.

Bliersbach Gerhard, So grün war die Heide. Der deutsche Nachkriegsfilm in neuer Sicht, Basel 1985.

Blum Heiko R., 30 Jahre danach. Dokumentation zur Auseinandersetzung mit dem Nationalsozialismus im Film 1945 bis 1975, Köln 1975.

Boa Elisabeth, Rachel Palfreyman, Heimat - a German Dream: Regional Loyalties and National Identity in German Culture, 1890-1990, Oxford 2000.

Bollinger Jörn, Das Lüth-Urteil: Darstellung des (Verfassungs-) Konflikts und eine Analyse seiner Folgen, München 2009.

Bösch Frank, Der Nationalsozialismus im Dokumentarfilm: Geschichtsschreibung im Fernsehen, 1950-1990, [w:] Public History. Darstellungen des Nationalsozialismus jenseits der Geschichtswissenschaft, red. Frank Bösch, Constantin Goschler, Frankfurt am Main 2009.

Brady Martin, Discussion with Kurt Maetzig, [w:] Defa: East German Cinema, 1946-1992, red. Seán Allan, John Sandford, New York 1999.

Brandlmeier Thomas, Kampf ums Nachkriegsprogramm, [w:] Träume in Trümmern. Film - Produktion und Propaganda in Europa 1940-1950, red. Hans-Michael Bock, Jan Distelmeyer, Jörg Schöning, München 2009.

Brandlmeier Thomas, Und wieder Caligari... Deutsche Nachkriegsfilme 1946-1951, [w:] Der deutsche Film. Aspekte seiner Geschichte von den Anfängen bis zur Gegenwart, red. Uli Jung, Trier 1993.

Brandlmeier Thomas, Von Hitler zu Adenauer: Deutsche Trümmerfilme, [w:] Zwischen gestern und morgen: westdeutscher Nachkriegsfilm 1946-1962, red. Hilmar Hoffmann, Walter Schober, Frankfurt am Main 1989.

Brauerhoch Annette, Fräuleins und GIs. Geschichte und Filmgeschichte, Frankfurt am Main 2006.

Brauner Atze, Mich gibt's nur einmal. Rückblende eines Lebens, München 1976.

Breger Claudia, "Kampf gegen den Kampf": Aesthetic Experimentation and Social Satire in "The Ballad of Berlin", [w:] German Postwar Films, red. Wilfried Wilms, William Rasch, New York 2008.

Breitkopf Regina, Das Beil von Wandsbeck, „Beiträge zur Film- und Fernsehwissenschaft” 1984, nr 5.

Briegelb Klaus, Missachtung und Tabu. Eine Streitschrift über die Frage: wie antisemitisch war die Gruppe 47?, Berlin 2002.

Brink Cornelia, Ikonen der Vernichtung. Öffentlicher Gebrauch von Fotografien aus nationalsozialistischen Konzentrationslagern nach 1945, Berlin 1998.

Brumm Dieter, Der mörderische Alltag der KZ-Opfer, "Süddeutsche Zeitung”, 9.11.1979.

Brzóstowicz-Klajn Monika, Śmierci nie ma! (motyw), [w:] Słownik realizmu socjalistycznego, red. Zdzisław Łapiński, Wojciech Tomasik, Kraków 2004.

Buchheim Lothar-Gunther, Okręt, tłum. A. Kaska, Warszawa 1987.

Buchloh Stephan, "Pervers, jugendgefährdend, staatsfeindlich”. Zensur in der Ära Adenauer als Spiegel des gesellschaftlichen Klimas, Frankfurt am Main 2002.

Buck Robert, Die Rezeption des 20. Juli 1944 in der Bundeswehr, [w:] Der 20. Juli: Das "andere Deutschland" in der Vergangenheitspolitik nach 1945, red. Robert Buck, Gerd Ueberschär, Berlin 2008.

Bukowiecki Leon, Film NRD w Polsce, Warszawa 1982. 
Bukowiecki Leon, Niemiecki pan kapitan, „Film” 1957, nr 10.

Bundesrepublikanisches Lesebuch. Drei Jahrzehnte geistiger Auseinandersetzung, red. Hermann Glaser, München 1978.

Burger Hanuš, Der Frühling war es wert. Erinnerungen, München 1977.

Burghardt Kirsten, Moralische Wiederaufrüstung im frühen deutschen Nachkriegsfilm, [w:] Positionen deutscher Filmgeschichte. 100 Jahre Kinematographie: Strukturen, Diskurse, Kontexte, München 1996.

Buruma Ian, Wages of Guilt: Memories of War in Germany and Japan, London 1995.

Caligari's Heirs: The German Cinema of Fear after 1945, red. Steffen Hantke, Lanham 2007.

Carpentier-Tanguy Xavier, Die Maske und der Spiegel. Zum XI. Plenum der SED 1965, [w:] DEFA-Film als nationales Kulturerbe?, red. Klaus Finke, Berlin 2001.

Carruthers Susan, Compulsory Viewing: Concentration Camp Film and German Re-education, „Millennium. Journal of International Studies” 2001, nr 3.

Carter Erica, Men in Cardigans: "Canaris” (1954) and the 1950s West German Good Soldier, [w:] War-Torn Tales: Representing Gender and World War II in Literature and Film, red. Danielle Hipkins, Gill Plain, Oxford 2007.

Caven Hannah, Horror in Our Time. Images of the Concentration Camps in the British Media, 1945, „Historical Journal of Film, Radio and Television” 2001, nr 21.

Chamberlin Brewster S., "Todesmühlen”. Ein früher Versuch zur Massen-Umerziehung im besetzten Deutschland, 1945-1946, „Vierteljahrshefte für Zeitgeschichte” 1981, nr 29.

Chamberlin Brewster S., Kultur auf Trümmern: Berliner Berichte der Information Control Section. Juli-Dezember 1945, München 1979.

Cilek Roman, Kulisy tajnych służb Trzeciej Rzeszy: Alfred Naujocks, tłum. R. Majewski, Warszawa 1998.

Clark David, German Martyrs: Images of Christianity and Resistance to National Socialism in German Cinema, [w:] Screening War. Perspectives on German Suffering, red. Paul Cooke, Marc Silberman, Rochester 2010.

Classen Christoph, Bilder der Vergangenheit. Die Zeit des Nationalsozialismus im Fernsehen der Bundesrepublik Deutschland 1955-1965, Köln 1999.

Claudius Eduard, Zielone oliwki i nagie skały, tłum. J. Rawicz, Warszawa 1958.

Cooke Paul, The GDR and the Memory of the Bombing of Dresden, [w:] Germans as Victims. Remembering the Past in Contemporary Germany, red. Bill Niven, New York 2006.

Courage und Eigensinn: zum 100. Geburtstag von Wolfgang Staudte, red. Uschi und Andreas Schmidt-Lenhard, St. Ingbert 2006.

Cowie Peter, Die Berlinale. Das Festival, Berlin 2010.

Dahlke Birgit, „Frau komm!” Vergewaltigungen 1945: Zur Geschichte eines Diskurses, [w:] LiteraturGesellschaft DDR, red. Birgit Dahlke, Martina Langermann, Thomas Taterka, Stuttgart 2000.

Damit lebe ich bis heute. Ein Gespräch mit Frank Beyer, [w:] Regie: Frank Beyer, red. Ralf Schenk, Berlin 1995.

Danyel Jürgen, Bilder vom "anderen Deutschland". Frühe Widerstandsrezeption nach 1945, "Zeitschrift für Geschichtswissenschaft" 1994, nr 1.

Danyel Jürgen, Die Opfer- und Verfolgtenperspektive als Gründungskonsens? Zum Umgang mit der Widerstandstradition und der Schuldfrage in der DDR, [w:] Die geteilte Vergangenheit. Zum Umgang mit Nationalsozialismus und Widerstand in den beiden deutschen Staaten, red. Jürgen Danyel, Berlin 1995.

Das Böse im Blick. Die Gegenwart des Nationalsozialismus im Film, red. Margrit Frölich, Christian Schneider, Karsten Visarius, München 2007.

Das Thema "Antifaschismus" in Filmen der DDR für Kino und Fernsehen. Auswahlfilmographie 1946-1984, Berlin (Ost) 1985. 
Das zweite Leben der Filmstadt Babelsberg. DEFA-Spielfilme 1946-1992, red. Ralf Schenk, Berlin 1994.

de Bruyn Günter, Poszukiwania brandenburskie: opowieść dla miłośników historii literatury, tłum. S. Lisiecka, Warszawa 1986.

DEFA International. Grenzüberschreitende Filmbeziehungen vor und nach dem Mauerbau, red. Michael Wedel, Barton Byg, Wiesbaden 2013.

DEFA: East German Cinema, 1946-1992, red. Seán Allan, John Sandford, New York 1999.

DEFA-Film als nationales Kulturerbe?, red. Klaus Finke, Berlin 2001.

DEFA-Spielfilm-Regisseure und ihre Kritiker, t. 1-2, red. Rolf Richter, Berlin (Ost) 1981-1983. Delage Christian, Image as Evidence and Mediation: The Experience of the Nuremberg Trials, [w:] Law and Popular Culture, red. Michael Freeman, Oxford 2005.

Delling Manfred, Der Untergang der "Wilhelm Gustloff” - ein Symbol. Frank Wisbars neuer Antikriegsfilm, „Die Welt”, 5.03.1960.

Demokratisierung der Wahrnehmung? Das westeuropäische Nachkriegskino, red. Hermann Kappelhoff, Bernhard Gross, Daniel Illger, Berlin 2010.

Der 20. Juli: Das „andere Deutschland” in der Vergangenheitspolitik nach 1945, red. Robert Buck, Gerd Ueberschär, Berlin 2008.

Der deutsche Film. Aspekte seiner Geschichte von den Anfüngen bis zur Gegenwart, red. Uli Jung, Trier 1993.

Der Deutsche Film. Fragen, Forderungen, Aussichten. Bericht vom Ersten Deutschen Filmautoren-Kongreß, Berlin 1947.

Der Dokumentarbericht im Urteil der Zuschauer, München 1965.

Der erotische Diskurs: Filmische Zeichen und Argumente, red. Klaus Kanzog, München 1989.

Der Filmregisseur Peter Pewas, red. Ulrich Kurowski, Andreas Meyer, Berlin (West) 1981.

Der geteilte Himmel. Höhepunkte des DEFA-Kinos 1946-1992, red. Helmut Pflügl, Wien 2001.

Der Holocaust im Film. Mediale Inszenierung und kulturelles Gedächtnis, red. Waltraud Wende, Heidelberg 2007.

Der Krieg in der Nachkriegszeit. Der Zweite Weltkrieg in Politik und Gesellschaft der Bundesrepublik, red. Michael Greven, Oliver von Wrochem, Opladen 2000.

Der missbrauchte Antifaschismus. DDR-Staatsdoktrin und Lebenslüge der deutschen Linken, red. Manfred Agethen, Freiburg-Basel-Wien 2002.

Der Nationalsozialismus - Die zweite Geschichte. Überwindung - Deutung - Erinnerung, red. Peter Reichel, Harald Schmid, Peter Steinbach, München 2009.

Deutsche Vergangenheiten - eine gemeinsame Herausforderung: Der schwierige Umgang mit der doppelten Nachkriegsgeschichte, red. Christoph Klessmann, Hans Misselwitz, Günther Wichert, Berlin 1999.

Deutschlands Weg in die Diktatur. Internationale Konferenz zur nationalsozialistischen Machtübernahme im Reichstagsgebäude zu Berlin. Referate und Diskussionen, red. Martin Broszat, Berlin (West) 1983.

Deutschland-Trendbuch: Fakten und Orientierungen, red. Karl-Rudolf Korte, Werner Weidenfeld, Opladen 2001.

Die fünfziger Jahre. Beiträge zu Politik und Kultur, red. Dieter Bänsch, Tübingen 1985.

Die geteilte Vergangenheit. Zum Umgang mit Nationalsozialismus und Widerstand in den beiden deutschen Staaten, red. Jürgen Danyel, Berlin 1995.

Die historische Meistererzählung. Deutungslinien der deutschen Nationalgeschichte nach 1945, red. Konrad Jarausch, Martin Sabrow, Göttingen 2002.

Die Mörder sind unter uns, Ehe im Schatten, Die Buntkarierten, Rotation: Vier Filmerzählungen nach den bekannten DEFA-Filmen, red. Ellen Blauert, Berlin (Ost) 1969.

Die NS-Diktatur im deutschen Erinnerungsdiskurs, red. Wolfgang Bergem, Opladen 2003. 
Die Oberhausener. Rekonstruktion einer Gruppe 1962-1985, red. Rainer Lewandowski, Diekholzen 1982.

Die Shoah im Bild, red. Sven Kramer, München 2003.

Die Täter der Shoah. Fanatische Nationalsozialisten oder ganz normale Deutsche?, red. Gerhard Paul, Göttingen 2002.

Die Vergangenheit in der Gegenwart. Konfrontationen mit den Folgen des Holocaust im deutschen Nachkriegsfilm, red. Claudia Dillmann, Ronny Loewy, Frankfurt am Main 2001.

Dietrich Gerd, Politik und Kultur in der SBZ 1945-1949, Frankfurt am Main 1993.

Dillmann Claudia, Zu bittere Kräuter: "Zeugin aus der Hölle”. Die Produktion und Rezeption eines "riskanten" Films, [w:] Die Vergangenheit in der Gegenwart. Konfrontationen mit den Folgen des Holocaust im deutschen Nachkriegsfilm, red. Claudia Dillmann, Ronny Loewy, Frankfurt am Main 2001.

Dillmann-Kühn Claudia, Artur Brauner und die CCC. Filmgeschäft, Produktionsalltag, Studiogeschichte 1946-1990, Frankfurt am Main 1990.

Dobek-Ostrowska Bogusława, Fras Janina, Ociepka Beata, Teoria i praktyka propagandy, Wrocław 1997.

Dobryden Paul, Good Germans, Humane Automobiles: Redeeming Technological Modernity "In Those Days", „Film \& History” 2010, nr 1.

Dokumentarfilm in Dienste der Umerziehung. Amerikanische Filmpolitik 1945-1953, [w:] Lernen Sie diskutieren!: Re-education durch Film. Strategien der westlichen Alliierten nach 1945, red. Heiner Roß, Berlin 2005.

Dokumente zur Kunst-, Literatur-, und Kulturpolitik der SED, red. Elimar Schubbe, Stuttgart 1972.

Domańska Ewa, Historie niekonwencjonalne, Poznań 2010.

Domansky Elisabeth, A Lost War: World War II in Postwar German Memory, [w:] Thinking About the Holocaust, red. Alvin Rosenfeld, Bloomington 1997.

Douglas Lawrence, Film as Witness: Screening "Nazi Concentration Camps" before the Nuremberg Tribunal, „The Yale Law Journal” 1995, nr 2.

Dramat na ekranie, red. Aleksander Jackiewicz, Warszawa 1953.

Drobisch Klaus, Widerstand in Buchenwald, Berlin (Ost) 1989.

Dubiel Helmut, Niemand ist frei von der Geschichte. Die nationalsozialistische Herrschaft in den Debatten des Deutschen Bundestages, München 1999.

Düsterberg Rolf, Soldat und Kriegserlebnis. Deutsche militarische Erinnerungsliteratur (19451961) zum Zweiten Weltkrieg, Osnabrück 1999.

Dynamische Zeiten: die 60er Jahre in den beiden Gesellschaften, red. Axel Schildt, Detlef Siegfried, Karl Christian Lammers, Hamburg 2000.

Dymszyc Aleksander, Warum wir gegen Dekadenz sind, „Tägliche Rundschau”, 21.03.1948;

Dymszyc Aleksander, Über die formalistische Richtung in die Malerei, „Tägliche Rundschau”, 19 i 24.11.1948.

Eberan Barbro, Luther? Friedrich "der Große”? Wagner? Nietzsche? Wer war an Hitler schuld? Die Debatte um die Schuldfrage 1945-1949, München 1983.

Echternkamp Jörg, Mit dem Krieg seinen Frieden schliessen - Wehrmacht und Weltkrieg in der Veteranenkultur (1945-1960), [w:] Von der Kriegskultur zur Friedenskultur. Zum Wandel der politischen Mentalität in Deutschland nach 1945, red. Thomas Kühne, Münster 2000.

Echternkamp Jörg, Von Opfern, Helden und Verbrechern: Anmerkungen zur Bedeutung des Zweiten Weltkriegs in den Erinnerungskulturen der Deutschen 1945-1955, [w:] Kriegsende 1945 in Deutschland, red. Jörg Hillmann, John Zimmermann, München 2002.

Edel Peter, Das Kind vom Ettersberg: Gedanken über ein kleines Bild und einen großen Film, „Die Weltbühne", 8.05.1963. 
Ehlers Wilhelm, Ehe im Schatten, „Der Morgen”, 5.10.1947.

Ein Auto als Hauptperson Helmut Käutner erzählt von seinem Film "In jenen Tagen”, "Hannoversche Presse", 21.01.1947.

Ein Volk von Opfern? Die neue Debatte um den Bombenkrieg, red. Lothar Kettenacker, Berlin 2003.

Eisert Wolfgang, Die Waldheimer Prozesse. Der stalinistische Terror 1950. Ein dunkles Kapitel der DDR-Justiz, München 1993.

Elias Norbert, Rozważania o Niemcach: zmaganie o władzę a habitus narodowy $i$ jego przemiany w XIX i XX wieku, tłum. R. Dziergwa, J. Kałążny, I. Sellmer, Poznań 1996.

Elsaesser Thomas, Der Neue Deutsche Film, München 1994.

Elsaesser Thomas, Die Gegenwärtigkeit des Holocausts im Neuen Deutschen Film - am Beispiel Alexander Kluge, [w:] Die Vergangenheit in der Gegenwart. Konfrontationen mit den Folgen des Holocaust im deutschen Nachkriegsfilm, red. Claudia Dillmann, Ronny Loewy, Frankfurt am Main 2001.

Elsaesser Thomas, New German Cinema: A History, New Jersey 1989.

Elsaesser Thomas, Terror und Trauma. Zur Gewalt des Vergangenen in der BRD, Berlin 2007.

Elsaesser Thomas, The New German Cinema's Historical Imaginary, [w:] Framing the Past: The Historiography of German Cinema and Television, red. Bruce A. Murray, Christopher J. Wickham, Cardbondale 1992.

Elsaesser Thomas, Wedel Michael, Defining DEFAs Historical Imaginary: the Films of Konrad Wolf, „New German Critique” 2001, nr 82.

Entnazifizierung. Politische Säuberung und Rehabilitierung in den vier Besatzungszonen 19451949, red. Clemens Vollnhaus, München 1991.

Erinnerung und Verstehen: Der Völkermord an den Juden im politischen Gedächtnis der Deutschen, red. Hans Erler, Frankfurt am Main 2003.

Ernst Thälmann. Mensch und Mythos, red. Peter Monheath, Amsterdam 2000.

Erwin Leisers Film "Mein Kampf”. Eine Bilddokumentation der Jahre 1914-1945, Frankfurt am Main 1960.

Euchner Walter, Unterdrückte Vergangenheitsbewältigung. Motive der Filmpolitik in der Ära Adenauer, [w:] Gegen Barbarei. Essays Robert Kempner zu Ehren, red. Rainer Eisfeld, Ingo Müller, Frankfurt am Main 1989.

Eylau Hans Ulrich, Fünf Patronenhülsen, „Berliner Zeitung”, 10.11.1960.

Europejskie manifesty kina. Od Matuszewskiego do Dogmy. Antologia, red. Andrzej Gwóźdź, Warszawa 2002.

F. J. R., Vor den Leinwand notiert, „Süddeutsche Zeitung”, 14.04.1960.

Falke Sabine, Soldat der Revolution. Zur Konstruktion des Kaders in Kurt Maetzigs ThälmannFilm, [w:] Politik und Mythos. Kader, Arbeiter und Aktivisten im DEFA-Film, red. Klaus Finke, Oldenburg 2002.

Fay Jennifer, Theaters of Occupation. Hollywood and the Reeducation of Postwar Germany, Minneapolis 2008.

Fehrenbach Heide, Cinema in Democratizing Germany: Reconstructing National Identity After Hitler, Chapel Hill 1995.

Ferro Marc, Film. Kontranaliza społeczeństwa, tłum. A. Karpowicz, [w:] Film i historia, red. Iwona Kurz, Warszawa 2009.

Ferro Marc, Historycy i kino, „Kino” 1989, nr 10.

Fest Joachim, Hitler, tłum. D. Kucharska, B. Szymańska, W. Jeżewski, t. 1-2, Warszawa 1995-1996.

Fiedler Werner, "08/15" mit Ladehemmung. Die Revolte des Gefreiten Asch, "Der Tag”, 10.11.1954. 
Fiedler Werner, Irgendwo in Berlin, "Neue Zeit”, 20.12.1946.

Fiedler Werner, Der Weg durch die Trümmer, „Neue Zeit”, 17.10.1946.

Film i historia, red. Iwona Kurz, Warszawa 2009.

Film in der Bundesrepublik Deutschland, red. Hans Günther Pflaum, Hans Helmut Prinzler, München-Wien 1979.

Film in der DDR, red. Heiko Blum, Hans Blumenberg, München-Wien 1977.

Film und Gesellschaft in Deutschland: Dokumente und Materialien, red. Wilfried von Bredow, Rolf Zurek, Hamburg 1975.

Filmland DDR: ein Reader zu Geschichte, Funktion und Wirkung der DEFA, red. Harry Blunk, Dirk Jungnickel, Köln 1990.

Finkielkraut Alan, The Imaginary Jew, trans. K. O’Neill, D. Suchoff, Lincoln 1994.

Fischer Filmgeschichte, t. 3: 1945-1960, red. Werner Faulstich, Helmut Korte, Frankfurt am Main 1990.

Fisher Jaimey, Resisting the War (Film): Wicki's "Die Brücke” and Its Generic Transformations, [w:] Generic Histories of German Cinema. Genre and its Deviations, red. Jaimey Fisher, New York 2013.

Fisher Jaimey, Who's Watching the Rubble-Kids? Youth, Pedagogy and Politics in Early DEFA Films, „New German Critique” 2001, nr 82.

Fiuk Ewa, Inicjacje, tożsamość, pamięć. Kino niemieckie na przełomie wieków, Wrocław 2012.

Foucault Michel, Archeologia wiedzy, tłum. A. Siemek, Warszawa 2002.

Fox Thomas, Stated Memory: East Germany and the Holocaust, Rochester 1999.

Framing the Past: The Historiography of German Cinema and Television, red. Bruce A. Murray, Christopher J. Wickham, Cardbondale 1992.

Frank Wisbar bei den Dreharbeiten zu "Nacht fiel über Gotenhafen”, „Der Spiegel” 1960, nr 3.

Frei Norbert, 1945 und wir. Das Dritte Reich im Bewußtsein der Deutschen, Beck, München 2005.

Frei Norbert, Auschwitz und Holocaust. Begriff und Historiographie, [w:] Holocaust - Grenzen des Verstehens. Eine Debatte über die Besetzung der Geschichte, red. Hanno Loewy, Reinbek 1992.

Frei Norbert, Kariery w półmroku. Hitlerowskie elity po 1945, tłum. B. Ostrowska, Warszawa 2011.

Frei Norbert, NS-Vergangenheit unter Ulbricht und Adenauer. Geschichtspunkte einer "vergleichenden Bewältigungsforschung", [w:] Die geteilte Vergangenheit. Zum Umgang mit Nationalsozialismus und Widerstand in den beiden deutschen Staaten, red. Jürgen Danyel, Berlin 1995.

Frei Norbert, Polityka wobec przeszłości. Poczatki Republiki Federalnej i przeszłość nazistowska, tłum. B. Ostrowska, Warszawa 1999.

Friedländer Saul, Kitch und Tod. Der Widerschein des Nazismus, München 1986.

Fritsche Christiane, Vergangenheitsbewältigung im Fernsehen. Westdeutsche Filme über den Nationalsozialismus in den 1950er und 60er Jahren, München 2003.

Fritzsche Peter, What exactly is Vergangenheitsbewältigung? Narrative and Its Unsufficiency in Postwar Germany, [w:] German Memory Contests. The Quest for Identity in Literature, Film, and Discourse since 1990, red. Anne Fuchs, Mary Cosgrove, Georg Grote, Rochester 2006.

Fulbrook Mary, German National Identity after the Holocaust, Cambridge 1999.

Funke Christoph, Fünf Patronenhülsen, "Sonntag” 1960, nr 46.

Funke Christoph, Ballade einer Liebe, „Morgen”, 4.09.1962.

Für den Aufschwung der fortschrittlichen deutschen Filmkunst. Resolution des Politbüros des ZK der SED, Juli 1952, [w:] Dokumente zur Kunst-, Literatur-, und Kulturpolitik der SED, red. Elimar Schubbe, Stuttgart 1972. 
Gallwitz Tim, „Was vergangen ist, muss vorbei sein!”. Zur Gegenwärtigkeit des Holocaust im frühen deutschen Nachkriegsfilm 1945-1950, [w:] Die Vergangenheit in der Gegenwart. Konfrontationen mit den Folgen des Holocaust im deutschen Nachkriegsfilm, red. Claudia Dillmann, Ronny Loewy, München 2001.

Gallwitz Tim, „Wir konnten nach all den Jahren nicht darauf losfilmen, als sei nichts geschehen”. Antisemitismus und Judenverfolgung im deutschsprachigen Spielfilm 1946-1950, [w:] Im Bann der Katastrophe. Innovation und Tradition im europäischen Film 1940-1950, red. Johannes Roschlau, München 2010.

Gallwitz Tim, Remigranten und akademische Jugend. Gustav von Wangenheims "Und wieder 48” und Fritz Kortners „Der Ruf”, [w:] Träume in Trümmern. Film - Produktion und Propaganda 1940-1950, München 2009.

Gegen Barbarei. Essays Robert Kempner zu Ehren, red. Rainer Eisfeld, Ingo Müller, Frankfurt am Main 1989.

Gehler Fred, Nackt unter Wölfen, „Filmstudio” 1964, nr 44.

Gehler Fred, Ein Film der künstlerichen Konsequenz, „Deutsche Filmkunst” 1962, nr 2

Geisler Günther, „Berliner Morgenpost”, 19.06.1960.

Geisler Michael E., The Disposal of Memory: Fascism and the Holocaust on West German Television, [w:] Framing the Past: The Historiography of German Cinema and Television, red. Bruce A. Murray, Christopher J. Wickham, Cardbondale 1992.

Gemünden Gerd, In the Ruins of Berlin: "A Foreign Affair", [w:] German Postwar Films, red. Wilfried Wilms, William Rasch, New York 2008.

Generic Histories of German Cinema. Genre and its Deviations, red. Jaimey Fisher, New York 2013.

German Cinema: Texts in Contexts, red. Marc Silberman, Detroit 1995.

German Film and Literature: Adaptations and Transformations, red. Eric Rentschler, New York 1986.

German Memory Contests. The Quest for Identity in Literature, Film, and Discourse since 1990, red. Anne Fuchs, Mary Cosgrove, Georg Grote, Rochester 2006.

German Postwar Films, red. Wilfried Wilms, William Rasch, New York 2008.

Germans as Victims. Remembering the Past in Contemporary Germany, red. Bill Niven, New York 2006.

Geschichte als Herrschaftdiskurs. Der Umgang mit der Vergangenheit in der DDR, red. Martin Sabrow, Köln 2000.

Geschichte des deutschen Films, red. Wolfgang Jacobsen, Anton Kaes, Hans Helmut Prinzler, Stuttgart-Weimar 1993.

Gibas Monika, "Bonner Ultras", "Kriegstreiber" und "Schlotbarone". Die Bundesrepublik als Feindbild der DDR in den fünfziger Jahren, [w:] Unsere Feinde. Konstruktion des Anderen im Sozialismus, red. Silke Satjukow, Rainer Gries, Leipzig 2005.

Gilbert Gustave, Dziennik norymberski, tłum. T. Łuczak, Warszawa 2012.

Gilman Sander L., Jurek Becker, Die Biografie, Berlin 2002.

Giordano Ralph, Die zweite Schuld oder Von der Last Deutscher zu sein, München 1987.

Glaser Hermann, Kultura RFN. Zarys historii 1945-1989, tłum. K. Krzemieniowa, Warszawa 2002.

Glass Peter, Kino ist mehr als Film. Die Jahre 1976-1990, Berlin 1999.

Głowiński Michał, Rytuał i demagogia. Trzynaście szkiców o sztuce zdegradowanej, Warszawa 1992.

Goes Albrecht, Niespokojna noc, tłum. M. Morstin-Górska, G. Mycielska, Warszawa 1955.

Goldstein Cora Sol, Capturing the German Eye: American Visual Propaganda in Occupied Germany, Chicago 2009. 
Gorrish Walter, Za wolność Hiszpanii, tłum. O. i J. Ziemilscy, Warszawa 1951.

Grass Günter, Wolfdietrich Schnurre, Kto milczy, staje się wspótwinny, tłum. L. Żyliński, [w:]

O kondycji Niemiec. Tożsamość niemiecka w debatach intelektualistów po 1945 roku, red. Joanna Jabłkowska, Leszek Żyliński, Poznań 2008.

Greffrath Bettina, Gesellschaftsbilder der Nachkriegszeit. Deutsche Spielfilme 1945-1949, Pfaffenweiler 1995.

Gregor Manfred, Most, tłum. E. Werfel, Warszawa 1960.

Gregor Ulrich, Konrad Wolf. Auf der Suche nach der Heimat, [w:] Film in der DDR, red. Heiko Blum, Hans-Christoph Blumenberg, München-Wien 1977.

Gregor Ulrich, Nackt unter Wölfen, „Filmkritik” 1964, nr 6.

Gregor Ulrich, Sterne, „Filmkritik” 1960, nr 6.

Gregor Ulrich, A Time to Love and a Time to Die, „Filmkritik” 1958, nr 9.

Greiser Katrin, "Die Masse von ihnen stellt kein kampffähiges Element dar”. Deutsche Kommunisten zur Evakuierung in Buchenwald, [w:] Tatort KZ. Neue Beiträge zur Geschichte der Konzentrationslager, red. Ulrich Fritz, Nicole Warmbold, Ulm 2003.

Grindon Leger, Shadows on the Past: Studies in the Historical Fiction Film, Philadelphia 1994.

Grisko Michael, Der Untertan - revisited, Berlin 2007.

Groehler Olaf, Verfolgten- und Opfergruppen im Spannungsfeld der politischen Auseinandersetzungen in der Sowjetischen Besatzungszone und in der DDR, [w:] Die geteilte Vergangenheit: Zum Umgang mit Nationalsozialismus und Widerstand in beiden deutschen Staaten, red. Jürgen Danyel, Berlin 1995.

Groll Gunter, Leise und deutlich: "Unruhige Nacht”, "Süddeutsche Zeitung”, 3.11.1958.

Groll Gunter, Barsch, aber mit Bravour - "Null-Acht Fünfzehn", „Süddeutsche Zeitung”, 2.10.1954.

Groll Gunter, In der Schauburg: „Und über uns der Himmel”, „Süddeutsche Zeitung”, 13.01.1948.

Gröschl Jutta, Die Deutschlandpolitik der vier Großmächte in der Berichterstattung der deutschen Wochenschau 1945-1949, Berlin 1997.

Gross Bernhard, "Stunde Null” und "Liebe 47". Zur ästhetischen Disposition des deutschen Nachkriegsfilm, [w:] Im Bann der Katastrophe. Innovation und Tradition im europäischen Film 1940-1950, red. Johannes Roschlau, München 2010.

Gross Bernhard, Wahrnehmen - Observieren - „Checken”. Geschichtlichkeit als Ästhetische Erfahrung in "Zwischen gestern und Morgen", [w:] Demokratisierung der Wahrnehmung? Das westeuropäische Nachkriegskino, red. Hermann Kappelhoff, Bernhard Gross, Daniel Illger, Berlin 2010.

Grunenberg Antonia, Antitotalitarianism versus Antifascism - Two Legacies of the Past in Germany, "German Politics and Society” 1997, nr 20.

Grzelecki Stanisław, Tajne akta firmy Solvay, „Film” 1954, nr 3.

Gwóźdź Andrzej, Obok kanonu. Tropami kina niemieckiego, Wrocław 2011.

Gwóźdź Andrzej, Powojenne kino niemieckie, [w:] Kino klasyczne. Historia kina, t. II, red. Tadeusz Lubelski, Iwona Sowińska, Rafał Syska, Kraków 2012.

Gwóźdź Andrzej, Zmarnowana szansa, „Kino” 2004, nr 4.

Hage Volker, Hamburg 1943: Literarische Zeugnisse zum Feuersturm, Frankfurt am Main 2003.

Hage Volker, Zeugen der Zerstörung: Die Literaten und der Luftkrieg, Frankfurt am Main 2003.

Hahn Brigitte, Umerziehung durch Dokumentarfilm? Ein Instrument amerikanischer Kulturpolitik im Nachkriegsdeutschland, Münster-Hamburg 1997.

Hake Sabine, Film in Deutschland. Geschichte und Geschichten seit 1985, Reinbek 2002.

Hake Sabine, German National Cinema, New York 2001. 
Hake Sabine, Politische Satire im Kalten Krieg. "Der Hauptmann von Köln" und "Rosen für Staatsanwalt", [w:] DEFA International. Grenzüberschreitende Filmbeziehungen vor und nach dem Mauerbau, red. Michael Wedel, Barton Byg et al., Wiesbaden 2013.

Halbachs Maurice, Społeczne ramy pamięci, tłum. M. Król, Warszawa 1969.

Hanisch Michael, „Um 6 Uhr abends nach Kriegsende” bis "High Noon”: Kino und Film im Berlin der Nachkriegszeit, 1945-1963, Berlin 2004.

Hantke Steffen, Hollywood Horror Comes to Berlin. A Critical Reasessement of Robert Siodmak's "Nachts, wenn der Teufel kam", [w:] Caligari's Heirs: The German Cinema of Fear after 1945, red. Steffen Hantke, Lanham 2007.

Hartenian Larry, Controlling Information in US Occupied Germany 1945-1949: Media Manipulation and Propaganda, New York 2003.

Hartewig Karin, Militarismus und Antifaschismus: Die Wehrmacht im kollektiven Gedächtnis der DDR, [w:] Der Krieg in der Nachkriegszeit: Der Zweite Weltkrieg in Politik und Gesellschaft, red. Michael T. Greven, Oliver von Wrochem, Opladen 2000.

Harych Theo, Morderstwo bez kary: sprawa Jakubowskiego, tłum. I. Sławińska, Katowice 1965.

Hauser Johannes, Neuaufbau der westdeutschen Filmwirtschaft 1945-1955 und der Einfluss der US-amerikanischen Filmpolitik, Pfaffenweiler 1989.

Heimann Thomas, Bilder von Buchenwald. Die Visualisierung des Antifaschismus in der DDR (1945-1990), Köln 2005.

Heimann Thomas, DEFA, Künstler und SED-Kulturpolitik. Zum Verhältnis von Kulturpolitik und Filmproduktion in der SBZ/DDR 1945 bis 1959, Berlin 1994.

Heimann Thomas, Erinnerung als Wandlung. Kriegsbilder im frühen DDR-Film, [w:] Geschichte als Herrschaftsdiskurs. Der Umgang mit der Vergangenheit in der DDR, red. Martin Sabrow, Köln 2000.

Hembus Joe, Der deutsche Film kann gar nicht besser sein, Bremen 1961.

Hendrykowski Marek, Film jako źródło historyczne, Poznań 2000.

Herf Jeffrey, Divided Memory: The Nazi Past in the Two Germanys, Cambridge 1997.

Herf Jeffrey, Germany and the Holocaust since 1945, [w:] Memory and Power in Post-war Europe, red. Jan-Werner Müller, Cambridge 2002.

Hermand Jost, Darstellungen des Zweiten Weltkrieges, [w:] Literatur nach 1945: Politische und Regionale Aspekte, red. Jost Hermand, Wiesbaden 1979.

Hermlin Stephan, O „zróżnicowaniu niemieckiej winy” Karla Jaspersa, tłum. L. Żyliński, [w:] O kondycji Niemiec. Tożsamość niemiecka w debatach intelektualistów po 1945 roku, red. Joanna Jabłkowska, Leszek Żyliński, Poznań 2008.

Hickethier Knut, Der Zweite Weltkrieg und der Holocaust im Fernsehen der Bundesrepublik der fünfziger und frühen sechziger Jahre, [w:] Der Krieg in der Nachkriegszeit. Der Zweite Weltkrieg in Politik und Gesellschaft der Bundesrepublik, red. Michael Greven, Oliver von Wrochem, Opladen 2000.

Hickethier Knut, Die Darstellung des Massenmörders an den Juden im Fernsehen der Bundesrepublik von 1960-1980, [w:] Die Shoah im Bild, red. Sven Kramer, München 2003.

Hickethier Knut, Kriegserlebnis und Kriegsdeutung im bundesdeutschen Fernsehen der fünfziger Jahren [w:] Schuld und Sühne? Kriegserlebnis und Kriegsdeutung in deutschen Medien der Nachkriegszeit (1945-1961), red. Ursula Heukenkamp, Amsterdam/Atlanta 2001.

Hickethier Knut, Militär und Krieg: „08/15”, [w:] Fischer Filmgeschichte, t. 3: 1945-1960, red. Werner Faulstich, Helmut Korte, Frankfurt am Main 1990.

Hillgruber Andreas, Dwie katastrofy. Rozbicie Rzeszy Niemieckiej i koniec europejskiego Żydostwa, tłum. M. Łukasiewicz, [w:] O kondycji Niemiec. Tożsamość niemiecka w debatach intelektualistów po 1945 roku, red. Joanna Jabłkowska, Leszek Żyliński, Poznań 2008. 
Hilmes Carola, Subtelny obserwator jako wspótsprawca: „Niepokoje wychowanka Törlessa” Volkera Schlöndorffa, [w:] Przestrzenie intermedialności. Adaptacje literatury niemieckojęzycznej, red. Kalina Kupczyńska, Magdalena Saryusz-Wolska, Wrocław 2012.

Hirsch Marianne, Pokolenie postpamięci, tłum. M. Borowski, M. Sugiera, „Didaskalia” 2011, nr 105.

Hirsch Marianne, Żałoba i postpamięć, tłum. K. Bojarska, [w:] Teoria wiedzy o przeszłości na tle wspótczesnej humanistyki, red. Ewa Domańska, Poznań 2011.

Hissen Alexandra, Hitler im deutschsprachigen Spielfilm nach 1945, Trier 2010.

Historia w kulturze wspótczesnej. Niekonwencjonalne podejścia do przeszłości, red. Mariusz Mazur, Piotr Witek, Lublin 2011.

Historische DDR-Forschung. Aufsätze und Studien, red. Jürgen Kocka, Berlin 1993.

Hobsbawm Eric, Terence Ranger, Tradycja wynaleziona, tłum. M. Godyń, F. Godyń, Kraków 2008.

Hobsch Manfred, Liebe, Tanz und 1000 Schlagerfilme, Berlin 1998.

Hockerts Hans Günter, Wiedergutmachung in Deutschland 1945-1990. Ein Überblick, "Aus Politik und Zeitgeschichte" 2013, nr 25-26.

Hofmann Heinz, Ein Held unserer Zeit, „Neues Deutschland”, 30.08.1960.

Högerle Daniela, Propaganda oder Verständigung? Instrumente französischer Kulturpolitik in Südbaden, Frankfurt am Main 2013.

Hohenemser Herbert, Übrig bleibt brüllendes Vergnügen, „Münchner Merkur”, 28.05.1955.

Holocaust - Grenzen des Verstehens. Eine Debatte über die Besetzung der Geschichte, red. Hanno Loewy, Reinbek 1992.

Holzer Horst, Gescheiterte Aufklärung? Politik, Ökonomie und Kommunikation in der Bundesrepublik Deutschland, München 1971.

Honecker Erich, Bericht des Politbüros an die 11. Tagung des Zentralkomitees der Sozialistischen Einheitspartei Deutschlands, 15.-18. Dezember 1965. Berlin-Ost 1966.

Horak Jan-Christopher, Postwar Traumas in Klaren's „Wozzeck” (1947), [w:] German Film and Literature: Adaptations and Transformations, red. Eric Rentschler, New York 1986.

Höss Rudolf, Autobiografia Rudolfa Hössa, komendanta obozu oświęcimskiego, tłum. W. Grzymski, Warszawa 1989.

Humberg Michael, Vom Erwachsenenverbot zur Jugendfreigabe. Die Filmbewertungen der FSK als Gradmesser des kulturellen Wertewandels, Münster 2013.

Huyssen Andreas, Present Pasts: Urban Palimpsests and the Politics of Memory, Stanford 2003.

Huyssen Andreas, Rewriting and New Beginnings: W. G. Sebald and the Literature on the Air War, [w:] idem, Present Pasts: Urban Palimsests and the Politics of Memory, Stanford 2003.

"Ich nehm' das alles nicht so ernst..." Gespräch mit Billy Wilder, [w:] Billy Wilders Filme, red. Neil Sinyard, Adrian Turner, Berlin (West) 1980.

Idole des deutsche Films, red. Thomas Koebner, München 1997.

Iggers Georg, Użycia i nadużycia historii, tłum. A. Pantuchowicz, [w:] Pamięć, etyka i historia, red. Ewa Domańska, Poznań 2002.

Im Bann der Katastrophe. Innovation und Tradition im europäischen Film 1940-1950, red. Johannes Roschlau, München 2010.

Inszenierungen des Rechts: Schauprozesse, Medienprozesse und Prozessfilme, red. Klaus Marxen, Annette Weinke, Berlin 2006.

Jabłkowska Joanna, Żyliński Leszek, Rozrachunek z narodowosocjalistyczna przeszłościa a tożsamość niemiecka, [w:] O kondycji Niemiec. Tożsamość niemiecka w debatach intelektualistów po 1945 roku, red. Joanna Jabłkowska, Leszek Żyliński, Poznań 2008.

Jacobsen Wolfgang, Erich Pommer. Ein Produzent macht Filmgeschichte, Berlin (West) 1989.

Jacobson Wolfgang, Rolf Aurich, Der Sonnensucher Konrad Wolf, Berlin 2005. 
Jahrbuch der öffentlichen Meinung 1955-1967, red. Elisabeth Noelle, Allensbach 1967.

Jarausch Konrad, The Failure of East German Anti-Fascism: Some Ironies of History as Politics, "German Studies Review" 1991, nr 1.

Jaskólska Aleksandra, Rodzina Sonnebrucków, [w:] Dramat na ekranie, red. Aleksander Jackiewicz, Warszawa 1953.

Jaspers Karl, Problem winy, tłum. J. Garewicz, Warszawa 1982.

Jaspers Karl, Zróżnicowanie niemieckiej winy, tłum. K. Piesowicz, [w:] O kondycji Niemiec. Tożsamość niemiecka w debatach intelektualistów po 1945 roku, red. Joanna Jabłkowska, Leszek Żyliński, Poznań 2008.

Jaspers Karl, Wohin treibt die Bundesrepublik?, München 1966.

Jeremias Brigitte, Zwei deutsche K-Filme. "Nackt unter Wölfen" und "Mensch und Bestie”, „Frankfurter Allgmeneine Zeitung”, 11.07.1963.

Jockheck Lars, "Rodzina Sonnenbrucków” Georga C. Klarena - pierwszy "niemiecko-polski film wspólnotowy"?, tłum. M. Orepuk, [w:] W drodze do sasiada. Polsko-niemieckie spotkania filmowe, red. Andrzej Dębski, Andrzej Gwóźdź, Wrocław 2013.

Joho Wolfgang, Ein mahnendes Schicksal, „Sonntag”, 9.06.1957.

Joho Wolfgang, Poesie und Wirklichkeit. "Sterne" - ein deutsch-bulgarischer Gemeinschaftsfilm, "Der Sonntag", 12.04 .1959

John Herbert, Wie aus Butter Margarine wird. Die deutschen Fernsehunterhalter machen die besten Idee kaput, „Die Zeit”, 18.04.1975.

Jordan Günter, Der Verrat oder Der Fall Falk Harnack, [w:] apropos Film 2004. Das 5. Jahrbuch der DEFA-Stiftung, red. Ralf Schenk, Erika Richter, Claus Löser, Berlin 2004.

Josselson Michael, German Reactions, „Mills of Death”, „Military Government Weekly Information Bulletin", 23.02.1946.

Jungeblodt Werner, Kriegsfilme - noch und noch, Stuttgart 1960.

Jung Thomas, Jenseits der Erinnerungspolitik: Oder der schwierige Umgang mit dem Holocaust in der DDR, [w:] Kulturelle Repräsentationen des Holocaust in Deutschland und den Vereinigten Staaten, red. Klaus Berghahn, Jürgen Fohrmann, Helmut Schneider, New York 2002.

Jung Thomas, Nicht-Darstellung und Selbst-Darstellung: Der Umgang mit der "Judenfrage" in der SBZ und der frühen DDR und dessen Niederschlag in Literatur und Film, "Monatshefte" 1998, nr 1 .

Kaes Anton, Deutschlandbilder. Die Wiederkehr der Geschichte als Film, München 1987.

Kaes Anton, From Hitler to Heimat. The Return of German History as Film, Harvard 1989.

Kahlschlag. Das 11. Plenum des ZK der SED 1965. Studien und Dokumente, red. Günther Agde, Berlin 1999.

Kannapin Detlef, Antifaschismus im Film der DDR: DEFA-Spielfilme 1945 bis 1955, Köln 1997.

Kannapin Detlef, Dialektik der Bilder: der Nationalsozialismus im deutschen Film. Ein Ost-WestVergleich, Berlin 2005.

Kannapin Detlef, Ernst Thälmann und der DDR-Antifaschismus im Film der fünfziger Jahre, [w:] Ernst Thälmann - Mensch und Mythos, red. Peter Monteath, Amsterdam 2000.

Kanzog Klaus, "Warten auf das entscheidende Wort": Pubertät und Heldenwahn in Bernhard Wickis „Die Brücke”, [w:] Der erotische Diskurs: Filmische Zeichen und Argumente, red. Klaus Kanzog, München 1989.

Kapczynski Jennifer, Armchair Warriors: Heroic Postures in the West German War Film, [w:] Screening War. Perspectives on German Suffering, red. Paul Cooke, Marc Silberman, Rochester 2010.

Kapczynski Jennifer, The Treatment of the Past: Géza Radvanyi's „Der Arzt von Stalingrad" and the West German War Film, [w:] Take Two. Fifties Cinema in Divided Germany, red. John Davidson, Sabine Hake, Berghahn 2007. 
Kappelt Olaf, Braunbuch DDR. Nazis in der DDR, Berlin (West) 1981.

Käppner Joachim, Erstarrte Geschichte. Faschismus und Holocaust im Spiegel der Geschichtswissenschaft und Geschichtspropaganda der DDR, Hamburg 1999.

Käutner, red. Wolfgang Jacobsen, Hans Helmut Prinzler, Berlin 1992.

Kelson John F., Catalogue of Forbidden German Feature and Short Film Productions held in Zonal Film Archives of Film Section, Information Services Division, Westport 1996.

Kershaw Ian, Walkiria. Historia zamachu na Hitlera, tłum. R. Bartołd, Poznań 2009.

Kersten Heinz, Ankläger der Mörder und Untertanen, [w:] Wolfgang Staudte, red. Eva Orbanz, Berlin (West) 1977.

Kersten Heinz, Das Filmwesen in der Sowjetischen Besatzungszone Deutschlands, Bonn 1963.

Kesselring Albert, Żotnierz do końca, tłum. D. Luliński, Warszawa 1996.

Kessler Mario, Zwischen Repression und Toleranz: Die SED-Politik und die Juden (1949-1967), [w:] Historische DDR-Forschung. Aufsätze und Studien, red. Jürgen Kocka, Berlin 1993.

Kino klasyczne. Historia kina, t. II, red. Tadeusz Lubelski, Iwona Sowińska, Rafał Syska, Kraków 2012.

Kino niemieckie w dialogu pokoleń i kultur, red. Andrzej Gwóźdź, Kraków 2004.

Kirschnick Sylke, Anne Frank und die DDR. Politische Deutungen und persönliche Lesearten, Berlin 2009.

Kirst Hans Hellmut, Błyskawiczne dziewczyny, tłum. S. Marciniak, Warszawa 1996.

Kirst Hans Hellmut, Fabryka oficerów, tłum. E. Werfel, Warszawa 1963.

Kirst Hans Hellmut, 08/15, tłum. J. Frühling, t. I-III, Warszawa 1956-1959.

Klaus Udo, „... doch alle Fragen bleiben offen”, "Die Weltbühne”, 10.09.1957.

Klejsa Konrad, Co wydarzyło się 40 lipca? Pierwsze filmowe opowieści o Clausie von Stauffenbergu i ich filmowe konteksty, [w:] Historia w kulturze wspótczesnej. Niekonwencjonalne podejścia do przeszłości, red. Mariusz Mazur, Ewa Solska, Piotr Witek, Lublin 2011.

Klejsa Konrad, Drezno i Gustloff - miejsca pamięci niemieckich ofiar II wojny światowej i ich reprezentacje w filmach telewizyjnych stacji ARD i ZDF z lat 2006-2008, [w:] Paradygmaty kina współczesnego, red. Ryszard W. Kluszczyński, Tomasz Kłys, Łódź 2014.

Klejsa Konrad, Pamięć o rodzeństwie Scholl w filmach Michaela Verhoevena i Percy'ego Adlona - konteksty i interpretacje, "Człowiek i Społeczeństwo” 2012, nr 34.

Klejsa Konrad, Pierwsze filmowe opowieści o Clausie von Stauffenbergu i ich filmowe konteksty, [w:] Historia w kulturze wspótczesnej. Niekonwencjonalne podejścia do przeszłości, red. Mariusz Mazur, Piotr Witek, Lublin 2011.

Klemens Gabriele, Britische Kulturpolitik in Deutschland 1945-1949, Stuttgart 1997.

Klering Hans, Rede, „Tägliche Rundschau”, 18.05.1946.

Klessmann Christoph, Sporne problemy współczesnej historii Niemiec, tłum. J. Kałążny, I. Sellmer, M. Tomczak, Poznań 1999.

Klüger Ruth, Katastrophen. Über deutsche Literatur, Göttingen 2009.

Kłys Tomasz, Od Mabusego do Geobbelsa. Weimarskie filmy Fritza Langa i kino niemieckie do roku 1945, Łódź 2013.

Kniep Jürgen, „Keine Jugendfreigabe!” Filmzensur in Westdeutschland 1949-1990, Göttingen 2010.

Knietzsch Horst, Film gestern und heute. Gedanken und Daten zu sieben Jahrzehnten Geschichte der Filmkunst, Lepizig 1967.

Knietzsch Horst, Ein Lied vom wahren Menschen, „Neues Deutschland”, 11.03.1963.

Knietzsch Horst, Leidensweg und Erkenntnis einer Generation. Der DEFA-Film "Die Abenteuer des Werner Holt", "Neues Deutschland”, 6.02.1965.

Knietzsch Horst, "Kirmes”, ein meisterhafter Film von Wolfgang Staudte, „Neues Deutschland", 11.03.1964. 
Knietzsch Horst, Sie konnten zusammen nicht kommen, „Neues Deutschland”, 11.09.1962.

Knietzsch Horst, Helden unter spanischem Himmel, „Neues Deutschland”, 4.11.1960.Knietzsch Horst, Versuch eines poetischen Films, „Vorwärts”, 29.9.1958.

Knigge Volkhard, Pietsch Jürgen Maria, Seidel Thomas A., Versteinerstes Gedenken. Das Buchenwald Mahnmal von 1958, Spröda 1997.

Knittel Herbert, Der Roman in der deutschen Illustrierten, Berlin (West) 1967.

Knoch Habbo, Die Tat als Bild. Fotografien des Holocaust in der deutschen Erinnerungskultur, Hamburg 2001.

Knop Rosemarie, Ehe im Schatten, „Start”, 10.10.1947.

Kober Anne, Antifaschismus im DDR-Film. Ein Fallbeispiel "Der Rat der Götter", [w:] Der missbrauchte Antifaschismus. DDR-Staatsdoktrin und Lebenslüge der deutschen Linken, Freiburg-Basel-Wien 2002.

Koch Gertrud, On the Disappearance of the Dead Among the Living: The Holocaust and the Confusion of Identities in the Films of Konrad Wolf, "New German Critique” 1993, nr 60.

Koch Lars, Das Fernsehbild der Wehrmacht am Ende der fünfziger Jahre. Zu Fritz Umgelters Fernsehmehrteiler "Am grünen Strand der Spree”, [w:] Der Holocaust im Film. Mediale Inszenierung und kulturelles Gedächtnis, red. Waltraud Wende, Heidelberg 2007.

Kochenrath Hans Peter, Kontinuität im deutschen Film, „Filmstudio” 1966, nr 50 oraz w: Film und Gesellschaft in Deutschland, red. Wilfried von Bredow, Rolf Zurek, Hamburg 1966.

Koegel Gert, Kerls, wollt ihr niemals lernen?, „Vorwärts”, 8.05.1959.

Koenen Gerd, Das rote Jahrzehnt, Köln 2001.

Kogon Eugen, SS-Staat. Das System der deutschen Konzentrationslager, München 1998.

Kohlhaase Wolfgang, Der Fall Gleiwitz, [w:] Spur der Filme. Zeitzeugen über die DEFA, red. Ingrid Poss, Peter Warnecke, Bonn 2006.

Kohlstruck Michael, Zwischen Geschichte und Erinnerung, Berlin 1997.

Kölsch Julia, Politik und Gedächtnis. Zur Soziologie funktionaler Kultivierung von Erinnerung, Wiesbaden 2000.

Konieczny Andrzej, Tajna broń Reinharda Heydricha, Katowice 1984.

König Helmut, Die Zukunft der Vergangenheit: Der Nationalsozialismus im politischen Bewusstsein der Bundesrepublik, Frankfurt am Main 2003.

Konigsberg Ira, Our Children and the Limits of Cinema: Early Jewish Responses to the Holocaust, „Film Quarterly” 1998, nr 1.

Konrad Wolf im Dialog. Künste und Politik, red. Dieter Heinze, Berlin (Ost) 1985.

Konrad Wolf. Direkt im Kopf und Herz. Aufzeichnungen - Reden - Interviews, red. Aune Renk, Berlin (Ost) 1989.

Konrad Wolf. Selbstzeugnisse, Fotos, Dokumente, red. Barbara Köppe, Aune Renk, Klaus Wischnewski, Berlin (Ost) 1985.

Köppen Manuel, The Rhetoric of Victim Narratives in West German Films of the 1950s, [w:] Screening War. Perspectives on German Suffering, red. Paul Cooke, Marc Silberman, Rochester 2010.

Korn Karl, Der entfesselte Krieg. „Kirmes”, ein neuer Film von Wolfgang Staudte, „Frankfurter Allgemeine Zeitung", 29.08.1960.

Korn Karl, Heroische Sentimentalität, ein Filmlaster, „Frankfurter Allgemeine Zeitung”, 28.2.1958.

Korn Karl, Der Pfarrer und der Deserteur, „Frankfurter Allgemeine Zeitung”, 1.12.1958.

Korn Karl, Ordnung? Gehorchen? Ein Nachruf zu "08/15”, „Frankfurter Allgemeine Zeitung", 3.11.1954.

Korzeniewski Bartosz, Filmowe zapośredniczenia niemieckiej pamięci o II wojnie światowej, [w:] Przemiany pamięci społecznej a teoria kultury, red. Bartosz Korzeniewski, Poznań 2007. 
Kosińska-Krippner Beata, Heimatfilm - zarys dziejów gatunku, „Kwartalnik Filmowy” 2009, nr 67-68.

Kotulla Theodor, Nacht fiel am Gotenhafen, „Filmkritik” 1960, nr 4.

Kotulla Theodor, Zum Gesellschaftsbild des Films der Bundesrepublik, „Frankfurter Hefte. Zeitschrift für Kultur und Politik" 1962, nr 17.

Kotulla Theodor, Kirmes, „Filmkritik” 1960, nr 8.

Kötzing Andreas, Zensur von DEFA-Filmen in der Bundesrepublik, "Aus Politik und Geschichte" 2009, nr 1-2.

Kötzing Andreas, Der lange Weg nach Hause. Konstruktionen von Heimat im europäischen Spielfilm, red. Lars Karl, Dietmar Müller, Katharina Seibert, Berlin 2014.

Kracauer Siegfried, Der anständige Deutsche. Ein Filmportrait, [w:] idem, Kleine Schriften zum Film 1932-1961, Frankfurt am Main 2004.

Kracauer Siegfried, Kleine Schriften zum Film 1932-1961, Frankfurt am Main 2004.

Kramer Sven, Widerkehr und Verwandlung der Vergangenheit im deutschen Film, [w:] Der Nationalsozialismus - Die zweite Geschichte. Überwindung - Deutung - Erinnerung, red. Peter Reichel, Harald Schmid, Peter Steinbach, München 2009.

Kranz Erhard, Filmkunst in der Agonie. Eine Untersuchung zu den staatsmonopolistischen Machtverhältnissen in der westdeutschen Filmwirtschaft, Berlin (Ost) 1964.

Krasuski Krzysztof, Realizmu socjalistycznego śmierć i życie pośmiertne, [w:] Słownik realizmu socjalistycznego, red. Zdzisław Łapiński, Wojciech Tomasik, Kraków 2002.

Kraushaar Wolfgang, Der Kampf gegen den "Jud Süß" - Regisseur Veit Harlan. Ein Meilenstein in der Grundrechtssprechung des Bundesverfassungsgerichts, „Mittelweg 36. Zeitschrift des Hamburger Instituts für Sozialforschung" 1995, nr 6.

Kreimeier Klaus, Der westdeutsche Film in der fünfziger Jahren, [w:] Die fünfziger Jahre. Beiträge zu Politik und Kultur, red. Dieter Bänsch, Tübingen 1985.

Kreimeier Klaus, Kino und Filmindustrie in der BRD, Kronberg 1973.

Kreimeier Klaus, The Ufa Story: A History of Germany's Greatest Film Company, 1918-1945, trans. R. Kimber, Berkeley 1999.

Kriegsende 1945 in Deutschland, red. Jörg Hillmann, John Zimmermann, München 2002.

Krisenkino. Filmanalyse als Kulturanalyse: Zur Konstruktion von Normalität und Abweichung im Spielfilm, red. Waltraud Wende, Lars Koch, Bielefeld 2010.

Krusche Dieter, Tomaten und Melonen sind besser als Kanonen, „Filmforum” 1958, nr 9.

Krüger Horst, W labiryncie winy. Jeden dzień z procesu oświęcimskiego, [w:] O kondycji Niemiec. Tożsamość niemiecka w debatach intelektualistów po 1945 roku, red. Joanna Jabłkowska, Leszek Żyliński, Poznań 2008.

Krzemiński Adam, Obrachunek z politycznym zaangażowaniem pisarzy w NRD i RFN, [w:] Literatura i władza, red. Bożena Wojnowska, Warszawa 1996.

Kuby Erich, Mein ärgerliches Vaterland, München 1989.

Kugelmann Cilly, Lang ist der Weg. Eine jüdisch-deutsche Film-Kooperation, „Jahrbuch zur Geschichte und Wirkung des Holocaust" 1996.

Kuhlbrodt Dietrich, Deutsches Filmwunder: Nazis immer besser, Hamburg 2006.

Kühn Günther, Wolfgang Weber, Stärker als die Wölfe. Ein Bericht über die illegal militärische Organisation im ehemaligen Konzentrationslager Buchenwald, Berlin (Ost) 1978.

Kühne Thomas, Zwischen Vernichtungskrieg und Freizeitgesellschaft. Die Veteranenkultur in der Bundesrepublik 1945-1995, [w:] Nachkrieg in Deutschland, red. Klaus Naumann, Hamburg 2002.

Kultur auf Trümmern: Berliner Berichte des amerikanischen Information Control Section, Juli-Dezember 1945, red. Brewster Chamberlin, Stuttgart 1979. 
Kulturelle Repräsentationen des Holocaust in Deutschland und den Vereinigten Staaten, red. Klaus Berghahn, Jürgen Fohrmann, Helmut Schneider, New York 2002.

Kumpfmüller Michael, Die Schlacht von Stalingrad. Metamorphosen eines deutschen Mythos, München 1996.

Kupczyńska Kalina, Elżbieta Kapral, O medialności kłamstwa i iluzji: Jakub „Łgarz” a Jurek "Pisarz", [w:] Przestrzenie intermedialności. Adaptacje literatury niemieckojęzycznej, red. Kalina Kupczyńska, Magdalena Saryusz-Wolska, Wrocław 2012.

Kurt Maetzig: Filmarbeit, Gespräche, Reden, Schriften, red. Günter Agde, Berlin (Ost) 1987.

La Capra Dominick, Pisanie historii, pisanie traumy, [w:] Pamięć Shoah. Kulturowe reprezentacje i praktyki upamiętnienia, red. Tomasz Majewski, Anna Zeidler-Janiszewska, Łódź 2009.

La Capra Dominick, Psychoanaliza, pamięć i zwrot etyczny, tłum. M. Zapędowska, [w:] Pamięć, etyka i historia. Anglo-amerykańska teoria historiografii lat dziewięćdziesiatych. Antologia przekładów, red. Ewa Domańska, Poznań 2006.

Landsberg Alison, Pamięć protetyczna, tłum. M. Szewczyk, [w:] Antropologia kultury wizualnej, red. Iwona Kurz, Paulina Kwiatkowska, Łukasz Zaremba, Warszawa 2012.

Landschaften der Erinnerung: Flucht und Vertreibung aus deutscher, polnischer und tschechischer Sicht, red. Elke Mehnert, Frankfurt 2001.

Langenhahn Sandra, Zur politische Ikonographie des DEFA-Films am Beispiel der Produktionen zu Ernst Thälmann, [w:] Visuelle Politik. Filmpolitik und die visuelle Konstruktion des Politischen, Baden-Baden 1998.

Law and Popular Culture, red. Michael Freeman, Oxford 2005.

Leide Henry, NS-Verbrecher und Staatssicherheit. Die geheime Vergangenheitspolitik der DDR, Göttingen 2007.

Leiser Erwin, Gott hat kein Kleingeld. Errinerungen, Köln 1993.

Lemke Michael, Instrumetalisierter Antifaschismus und SED-Kampagnenpolitik im deutschen Sonderkonflikt 1960-1968, [w:] Die geteilte Vergangenheit. Zum Umgang mit Nationalsozialismus und Widerstand in den beiden deutschen Staaten, red. Jürgen Danyel, Berlin 1995.

Lemmons Russel, "Great Truths and Minor Truths": Kurt Maetzig's "Ernst Thälmann" Films, the Antifascist Myth and the Politics of Biography in the German Democratic Republic, [w:] Take Two. Fifties Cinema in Divided Germany, red. John Davidson, Sabine Hake, Berghahn 2007.

Lenhard Andreas, Ohne Prädikat: "Herrenpartie”, [w:] Courage und Eigensinn: zum 100. Geburtstag von Wolfgang Staudte, red. Uschi und Andreas Schmidt-Lenhard, St. Ingbert 2006.

Lennig Walter, Ein Film der deutschen Wirklichkeit. Zur Uraufführung des Defa-Films "Die Mörder sind unter uns", „Berliner Zeitung”, 17.10 .1946

Lennig Walter, Irgendwo in Berlin, „Berliner Zeitung”, 20.12.1946.

Lepsius Rainer, Demokratie in Deutschland, Göttingen 1993.

Lepsius Rainer, O kulturze politycznej w Niemczech, tłum. A. Żychliński, Poznań 2007.

Lernen Sie diskutieren!: Re-education durch Film. Strategien der westlichen Alliierten nach 1945, red. Heiner Roß, Berlin 2005.

Lerntag über den Holocaust in der politische Kultur seit 1945, red. Herbert Strauss, Norbert Kampe, Berlin (West) 1985.

Leszczyński Władysław, Niemcy o sobie, „Film” 1957, nr 49.

Lexikon der "Vergangenheitsbewältigung" in Deutschland: Debatten- und Diskursgeschichte des Nationalsozialismus nach 1945, red. Torben Fischer, Matthias N. Lorenz, Bielefeld 2007.

Liebe Ulrich, Verehrt, Verfolgt, Vergessen: Schauspieler als Naziopfer, Berlin 1992.

Liebmann Stewart, Cmentarzysko Europy (1944). Pierwszy film o Holokauście?, tłum. G. Dąbkowski, "Zeszyty Majdanka” 2011, t. XXV. 
Liebmann Stewart, Obraz obozu w pierwszych filmach dokumentalnych, tłum. A. Zawrzykraj, „Dialog” 2010, nr 1.

Limburg Guido, Fliegen und Abschießen - Ja, was soll ich da anderes denken? Der "Stern von Afrika" und der bundesdeutsche Nachkriegs-Kriegsfilm, [w:] Zeitmaschine Kino: Darstellungen von Geschichte im Film, red. Hans-Arthur Mariske, Marburg 1992.

Literatur nach 1945: Politische und Regionale Aspekte, red. Jost Hermand, Wiesbaden 1979.

Literaturdidaktik, Lektürekanon, Literaturunterricht, red. Detlef C. Kochan, Amsterdam 1990.

LiteraturGesellschaft DDR. Kanonkämpfe und ihre Geschichte(n), red. Birgit Dahlke, Martina Langermann, Thomas Taterka, Weimar 2000.

Loewy Ronny, Voltaire und die Aufklärung, [w:] 2 x 20. Juli. Die Doppelverfilmung von 1955, red. Claudia Dillmann, Ronny Loewy, Frankfurt am Main 2004.

Loewy Ronny, "Zeugin aus dem Hölle” und die Wirklichkeit des Auschwitz-Prozesses, [w:] Die Vergangenheit in der Gegenart. Konfrontationen mit den Folgen des Holocaust im deutschen Nachkriegsfilm, red. Claudia Dillmann, Ronny Loewy, Frankfurt am Main 2001.

Lorenz Chris, Czy historia może być prawdziwa? O narratywistycznych koncepcjach filozofii historii Haydena White'a i Franka Ankersmita, [w:] idem, Przekraczanie granic. Eseje z filozofii historii i teorii wiedzy historycznej, tłum. M. Bobako, R. Dziergwa, Poznań 2009.

Lorenz Chris, Przekraczanie granic. Eseje z filozofii historii $i$ teorii wiedzy historycznej, tłum. M. Bobako, R. Dziergwa, Poznań 2009.

Löser Claus, Liebe und Schuld im Zeichen des Holocaust. Konrad Wolfs Spielfilm "Sterne", [w:] "Welchen der Steine du hebst". Filmische Erinnerung an den Holocaust, red. Claudia Bruns, Asal Dardan, Anette Dietrich, Berlin 2012.

Lübbe Hermann, Der Nationalsozialismus im deutschen Nachkriegsbewußtsein, „Historische Zeitschrift" 1983, nr 236.

Lübbe Hermann, Verdrängung? Über eine Kategorie zur Kritik des deutschen Vergangenheitsverhältnisses, [w:] Lerntag über den Holocaust in der politische Kultur seit 1945, red. Strauss Herbert, Norbert Kampe, Berlin (West) 1985.

Lüddecke Werner Jörg, Herrenpartie. Filmerzählung, Berlin (Ost) 1964

Ludin Malte, Wolfgang Staudte, Hamburg 1996.

Luft Friedrich, Das Kind von Buchenwald: der DEFA-Film Nackt unter Wölfen läuft jetzt auch im Westen, „Die Welt”, 20.07.1968.

Luft Friedrich, Menetekel wurde zum Kinostück. Wichtiges Thema leider vertan: Falk Harnacks "Unruhige Nacht”, „Die Welt", 1.11.1958.

Luft Friedrich, Kirmes, „Die Welt”, 4.07,1960.

Luft Friedrich, Der erste deutsche Film nach dem Kriege, „Der Tagesspiegel”, 16.10.1946.

Luft Friedrich, Irgendwo in Berlin, „Der Tagesspiegel”, 20.12.1946.

Maetzig Kurt, Filmarbeit. Gespräche, Reden, Schriften, Berlin (Ost) 1987.

Maier Charles, Goraca pamięć, zimna pamięć, tłum. M. Król, „Res Publica” 2001, nr 7.

Majewski Tomasz, Berlin/Wilder - reminiscencje, [w:] Billy Wilder. Mistrz kina z Suchej Beskidzkiej, red. Kamila Żyto, Marcin Pieńkowski, Warszawa 2011.

Majewski Tomasz, Dyskurs publiczny po Shoah, [w:] Pamięć Shoah. Kulturowe reprezentacje i praktyki upamiętnienia, red. Tomasz Majewski, Anna Zeidler-Janiszewska, Łódź 2009.

Majewski Tomasz, Pamięć, ironia, polityka historyczna. Wokół "Hotelu Terminus" Marcela Ophülsa, [w:] Zagłada. Współczesne problemy rozumienia, red. Ewa Domańska, B. Krupa, Poznań 2009

Mann Golo, Niemieckie dzieje w XIX i XX wieku, tłum. A. Kopacki, Olsztyn 2007.

Mann Henryk, Poddany, tłum. M. Wołczacka, J. Marecka, Warszawa 1959.

Margalit Gilad, Der Luftangriff auf Dresden, Seine Bedeutung für die Errinerungspolitik der DDR und für die Herausklistallisierung einer historischen Kriegserinnerung im Westen, [w:] 
Narrative der Shoah. Repräsentationen der Vergangenheit in Historiographie, Kunst und Politik, red. Susanne Düwell, Matthias Schmidt, Padeborn 2002.

Mąka-Malatyńska Katarzyna, Widok z tej strony. Przedstawienia Holocaustu w polskim filmie, Poznań 2012.

Męclewski Edmund, Spadkobiercy Rzeszy, Warszawa 1978-1979.

Mediale Mobilmachung 3. Das Kino der Bundesrepublik Deutschland als Kulturindustrie, 19501962, red. Harro Segeberg, München 2009.

Medien - Politik - Geschichte, red. Moshe Zuckermann, Tel Aviv 2003.

Medizin im Spielfilm der fünfziger Jahre, red. Udo Benzenhöfer, Wolfgang U. Eckhardt, Pfaffenweiler 1993.

Mehnert Elke, Vertriebene versus Umsiedler - der ostdeutsche Blick auf ein Kapitel Nachkriegsgeschichte, [w:] Landschaften der Erinnerung: Flucht und Vertreibung aus deutscher, polnischer und tschechischer Sicht, red. Elke Mehnert, Frankfurt 2001.

Meier Bernhard, "Schultag und Schultag nach vorgegebenen Regeln". Zum Implikazionszusammenhang von didaktischer Theorie, Lektürekanon des Lehrplans und Literaturunterricht in der DDR, [w:] Literaturdidaktik, Lektürekanon, Literaturunterricht, red. Detlef C. Kochan, Amsterdam 1990.

Meier Gustav, Filmstadt Göttingen: Bilder für eine neue Welt? Zur Geschichte er Göttinger Spielfilmproduktion 1945 bis 1961, Hannover 1996.

Meinecke Friedrich, Die deutsche Katastrophe, Wiesbaden 1946.

Memory and Power in Post-war Europe, red Jan-Werner Müller, Cambridge 2002.

Merle Robert, Śmierć jest moim rzemiosłem, tłum. Cz. Przymusiński, Warszawa 1952.

Merz Irena, Niemcy na ekranie, „Kwartalnik Filmowy” 1951, nr 3-4.

Merz Irena, O filmie niemieckim, Warszawa 1954.

Meuschel Sigrid, Legitimationsstrategien in der DDR und in der Bundesrepublik, [w:] Deutsche Vergangenheiten - eine gemeinsame Herausforderung: Der schwierige Umgang mit der doppelten Nachkriegsgeschichte, red. Christoph Klessmann, Hans Misselwitz, Günther Wichert, Berlin 1999.

Meuschel Sigrid, Legitimation und Parteiherrschaft. Zum Paradox von Stabilität und Revolution in der DDR 1945-1989, Frankfurt am Main 1992.

Michałek Bolesław, Humor koszarowo-kaberetowy, „Film” 1958, nr 39.

Michałek Bolesław, Jednostka i mechanizmy historii, „Kino” 1973, nr 10.

Milke Felicitas, "Die Zeit ist für einen solchen Film noch nicht reif”. "Kinder, Mütter und ein General” (1955) als Vermächtnis von Erich Pommer, „Filmblatt” 2011, nr 45.

Miller-Klejsa Anna, Resistenza we włoskim filmie fabularnym, Łódź 2013.

Misterek Susanne, Polnische Dramatik in Bühnen- und Buchverlagen der Bundesrepublik Deutschland und der DDR, Wiesbaden 2002.

Mitscherlich Alexander, Auf dem Weg zur vaterlosen Gesellschaft. Ideen zur Sozialpsychologie, München 1963.

Mitscherlich Alexander, Ödipus und Kaspar Hauser, „Der Monat” 1950, nr 25.

Modi memorandi. Leksykon kultury pamięci, red. Magdalena Saryusz-Wolska, Robert Traba, Warszawa 2014.

Moeller Robert G., Der "Barde des Zweiten Weltkrieges” und der Zusammenbruch des "Deutschen Ostens": Frank Wisbars "Nacht fiel über Gotenhafen", [w:] Mediale Mobilmachung 3. Das Kino der Bundesrepublik Deutschland als Kulturindustrie, 1950-1962, red. Harro Segeberg, München 2009.

Moeller Robert G., Geschichten aus der "Stacheldrahtuniversität": Kriegsgefangene auf Zelluloid in der Bundesrepublik Deutschland, "Amsterdamer Beiträge zur neueren Germanistik" 2001, nr 50. 
Moeller Robert G., Kämpfen für den Frieden: 08/15 und westdeutsche Erinnerungen an den Zweiten Weltkrieg, "Militärgeschichtliche Zeitschrift” 2005, nr 64.

Moeller Robert, Victims in Uniform, 1950s Combat Movies, [w:] Germans as Victims. Remembering the Past in Contemporary Germany, red. Bill Niven, New York 2006.

Moeller Robert G., War Stories: The Search for a Usable Past in the Federal Republic of Germany, Berkeley 2001.

Moeller Robert G., What Did You Do in the War, Mutti? Courageous Women, Compassionate Commanders, and Stories of the Second World War, "German History" 2004, nr 22.

Moeller Robert G., When Liebe Was Just a Five-Letter-Word: Liebeneiner's „Love 47”, [w:] German Postwar Films, red. Wilfried Wilms, William Rasch, New York 2008.

Möller Martina, Vom Expressionismus zum Trümmerfilm? Visueller Stil und Nachkriegskrise im Trümmerfilm, [w:] Krisenkino. Filmanalyse als Kulturanalyse: Zur Konstruktion von Normalität und Abweichung im Spielfilm, red. Waltraud Wende, Lars Koch, Bielefeld 2010.

Moltke von Johannes, Wulff Hans-Jürgen, Trümmer-Diva. Hildegard Knef, [w:] Idole des deutsche Films, red. Thomas Koebner, München 1997.

Monk Egon, Parteinahme als Notwendigkeit, „epd-Kirche und Fernsehen” 1966, nr 17.

Morawski Stefan, Lukácsa krucjata przeciw awangardzie, „Pamiętnik Literacki” 1979, nr 3.

Morgan Charles, Akcja Spływ, tłum. A. Glinczanka, Warszawa 1960.

Morituri in der Neuen Scala, „Neues Deutschland”, 21.11.1948.

Moshe Yael Ben, Hitler konstruieren. Die Darstellung Adolf Hitlers in deutschen und amerikanischen historischen Spielfilmen 1945-2009, Leipzig 2012.

Moving Images of East Germany. Past and Future of DEFA Film, red. Barton Byg, Betheny Moore, Washington 2002

Mückenberger Christiane, Jordan Günter, "Sie sehen selbst, Sie hören selbst...". Eine Geschichte der DEFA von ihren Anfüngen bis 1949, Marburg 1994.

Mückenberger Christiane, Zeit der Hoffnungen 1946 bis 1949, [w:] Das zweite Leben der Filmstadt Babelsberg. DEFA-Spielfilme 1946-1992, red. Ralf Schenk, Berlin 1994.

Müller Erika, Der Fall Sorge oder Harlans „Verrat an Deutschland”, "Die Zeit” 1955, nr 3.

Müller Erika, Morituri Filmerstaufführung in Hamburg, „Die Zeit”, 30.09.1948.

Müller Hermann, Anständige Menschen, „Vorwärts”, 18.06.1947.

Müller Hermann, Ernst Thälmann ist niemals gefallen, "Neues Deutschland”, 8.10.1955.

Müller Hermann, "Der Untertan”. Wolfgang Staudtes Film warnt vor Militarismus und Nationalismus, „Neues Deutschland”, 2.09.1951.

Müller Jürgen, "Hitler. Film z Niemiec” Hansa Jürgena Syberberga. Audiowizualne między-gry historii, tłum. Z. Feliszewski, [w:] Kino niemieckie w dialogu pokoleń i kultur, red. Andrzej Gwóźdź, Kraków 2004.

Müncheberg Hans, Vom Bildschirm ins Kino, [w:] Regie: Frank Beyer, red. Ralf Schenk, Berlin 1995.

Müntze Ingeborg, Ein deutsches KZ vor Ausbruch des Krieges. Zur Wiederaufnahme von Monks Film "Ein Tag", "Hamburger Abendblatt”, 9.11.1979.

Müting Horst, Deutsche Filme bevorzugt, „National Zeitung”, 8.12.1948.

Nachkrieg in Deutschland, red. Klaus Naumann, Hamburg 2002.

Narrative der Shoah. Repräsentationen der Vergangenheit in Historiographie, Kunst und Politik, red. Susanne Düwell, Matthias Schmidt, Padeborn 2002.

Naumann Erich-Peter, Noelle Elisabeth, Jahrbuch der öffentlichen Meinung 1947-1955, Allensbach 1956.

Neumann Thomas W., Der Bombenkrieg: Zur ungeschriebenen Geschichte einer kollektiven Verletzung, [w:] Nachkrieg in Deutschland, red. Klaus Naumann, Hamburg 2002.

Niehoff Karena, Bemühte Unzulänglichkeit, „Der Tagesspiegel”, 25.06.1955. 
Niehoff Karena, Blick auf die Leinwand: Die Jungen fressen sich selber auf, „Der Tagesspiegel”, 15.11.1959.

Niehoff Karena, Kirmes, „Der Tagesspiegel”, 5.07.1960.

„Niemand zeugt für den Zeugen”. Erinnerungskultur nach der Shoah, red. Ulrich Baer, Frankfurt am Main 2000.

Niethammer Lutz, Der gesäuberte Antifaschismus. Die SED und die roten Kapos von Buchenwald, Berlin 1994.

Niethammer Lutz, Deutschland danach. Postfaschistische Gesellschaft und nationales Gedächtnis, Bonn 1999.

Niven Bill, Das Buchenwaldkind. Wahrheit, Fiktion und Propaganda, Halle 2009.

Niven Bill, Der Umgang mit dem Jüdischen in der DDR-Rezeption der Rettung Stefan Jerzy Zweigs, [w:] Umdeuten, verschweigen, erinnern: Die späte Aufarbeitung des Holocaust in Osteuropa, red. Micha Brumlik, Karol Sauerland, Frankfurt am Main 2010.

Niven Bill, On a supposed taboo: flight and refugees from the East in the GDR film and television, "German Life and Letters" 2012, nr 2.

Niven Bill, The Buchenwald Child: Truth, Fiction and Propaganda, Rochester 2007.

Niven Bill, The Good Captain and the Bad Captain: Joseph Vilsmeier's "Die Gustloff" and the Erosion of Complexity, "German Politics and Society" 2008, nr 4.

Noack Frank, Veit Harlan. „Des Teufels Regisseur”, München 2000.

Noll Dieter, Przygody Wernera Holta, tłum. Z. Rybicka, Warszawa 1962.

Nolte Ernst, O przeszłości, która nie chce przeminać, tłum. M. Łukasiewicz, [w:] O kondycji Niemiec. Tożsamość niemiecka w debatach intelektualistów po 1945 roku, red. Joanna Jabłkowska, Leszek Żyliński, Poznań 2008.

Nora Pierre, Czas pamięci, tłum. W. Dłuski, „Res Publica Nowa” 2001, nr 7.

Nora Pierre, Między pamięcia a historia: Les Lieux de Mémoire, „Tytuł roboczy: Archiwum” 2009 , nr 2.

Norden Albert, Czego nas ucza dzieje Niemiec: o roli politycznej kapitału finansowego i junkierstwa, tłum. L. Szybek, Warszawa 1949.

O kondycji Niemiec. Tożsamość niemiecka w debatach intelektualistów po 1945 roku, red. Joanna Jabłkowska, Leszek Żyliński, Poznań 2008.

„Ob nach Auschwitz noch sich leben lasse", red. Rolf Tiedemann, Frankfurt am Main 1997.

Obrazy Niemiec 1949-1999. Katalog przegladu, red. Grażyna M. Grabowska, Renata Prokurat, Warszawa 1999.

Olick Jeffrey, In the House of the Hangman. The Agonies of German Defeat, 1943-1949, Chicago 2005.

Olschowsky Heinrich, Zeitstück und Geschichte. Leon Kruczkowskis Drama "Die Sonnenbrucks" in der DDR, [w:] Verteidigung der Menschheit, red. E. Kowalski, Berlin 1975.

Osten Walter, Der Fall Gleiwitz, „Stuttgarter Zeitung”, 28.11.1963.

Osterland Martin, Gesellschaftbilder in Filmen. Eine soziologische Untersuchung des Filmangebots der Jahre 1949-1964, Stuttgart 1970.

Ott Wolfgang, Rekiny i małe rybki, tłum. R. Stiller, Warszawa 2004.

Overesch Manfred, Buchenwald und die DDR oder die Suche nach Selbstlegitimation, Göttingen 1995.

Paczkowski Andrzej, Od sfatszowanego zwycięstwa do prawdziwej klęski, Warszawa 1999.

Padover Saul, Lügendetektor. Vernehmungen im besiegten Deutschland 1944/45, München 2001.

Padover Saul, The Experiment in Germany. The Story of an American Intelligence Officer, New York 1946.

Pamięć Shoah. Kulturowe reprezentacje i praktyki upamiętnienia, red. Tomasz Majewski, Anna Zeidler-Janiszewska, Łódź 2009. 
Pamięć zbiorowa i kulturowa. Współczesna perspektywa niemiecka, red. Magdalena Saryusz-Wolska, Kraków 2009.

Pamieć, etyka i historia. Anglo-amerykańska teoria historiografii lat dziewięćdziesiatych. Antologia przekładów, red. Ewa Domańska, Poznań 2006.

Panofsky Walter, Liebe 47, „Der neue Film” 1949, nr 8.

Panofsky Walter, München: Festlicher Start der "Neuen Deutschen Filmgesellschaft”. Zwischen gestern und morgen, „Der neue Film”, 21.12.1947.

Paradygmaty kina współczesnego, red. Ryszard W. Kluszczyński, Tomasz Kłys, Łódź 2014.

Patalas Enno, Der deutsche Film 1955, „Kulturarbeit” 1955, nr 9.

Patalas Enno, Die Brücke, „Filmkrtitik” 1959, nr 12.

Patalas Enno, Haie und kleine Fische, „Filmkritik” 1957, nr 11.

Paul Gerhard, Von Psychopathen, Technokraten des Terrors und ganz gewöhnlichen Deutschen. Die Täter der Shoah im Spiegel der Forschung, [w:] Die Täter der Shoah. Fanatische Nationalsozialisten oder ganz normale Deutsche?, red. Gerhard Paul, Göttingen 2002.

Paul Wolfgang, Bestiarium, „Der Tagesspiegel”, 6.05.1965.

Pewas Peter, Über das Gesicht des kommenden Films, [w:] Der Filmregisseur Peter Pewas, red. Ulrich Kurowski, Andreas Meyer, Berlin (West) 1981.

Pfeifer Jochen, Der deutsche Kriegsroman 1945-1960: Ein Versuch zur Vermittlung von Literatur und Sozialgeschichte, Königstein 1981.

Pfeiffer Hans, Die Höhle von Babie Doly: Erzählung, Leipzig 2004.

Pięciak Wojciech, Niemiecka pamięć. Wspótczesne spory w Niemczech o miejsce III Rzeszy w historii, polityce i tożsamości, Kraków 2002.

Pike David, The Politics of Culture in Soviet-Occupied Germany, 1945-1949, Stanford 1992.

Pinkert Anke, Film and Memory in East Germany, Bloomington 2008.

Pitera Zbigniew, Heute Nacht stirbt eine Stadt, „Filmspiegel” 1961, nr 8.

Pitrus Andrzej, Dotykając lustra. Melodramaty Douglasa Sirka, Kraków 2006.

Plater Edward M., "The Captain of Koepenick”: a faithful adaptation?, „Film \& History” 1990, nr 20.

Pleyer Peter, Deutscher Nachkriegsfilm 1946-1948, Münster 1965.

Po upadku Trzeciej Rzeszy, red. Jerzy W. Borejsza, Stefan H. Kaszyński, Warszawa 1981.

Politik und Mythos. Kader, Arbeiter und Aktivisten im DEFA-Film, red. Klaus Finke, Oldenburg 2002.

Politische Gesellschaftsgeschichte im 19. und 20. Jahrhundert. Festgabe für Barbara Vogel, red. Henning Albrecht, Hamburg 2006.

Polnische Dramen in Deutschland. Übersetzung und Aufführungen als deutsch-deutsche Rezeptionsgeschichte 1945-1995, Köln 2011.

Polska i Niemcy: filmowe granice i sąsiedztwa, red. Konrad Klejsa, Wrocław 2012.

Positionen deutscher Filmgeschichte. 100 Jahre Kinematographie: Strukturen, Diskurse, Kontexte, München 1996.

Prädikat: Besonders schädlich. Manfred Bieler/Kurt Maetzig: Das Kaninchen bin ich. Manfred Freitag/Joachim Nestler: Denk bloss nicht, ich heule, red. Christiane Mückenberger, Berlin 1990.

Prinzler Hans Helmut, Die Abenteuer des Werner Holt. Heldenfiguren in der neusten DEFAProduktion, „Stuttgarter Zeitung”, 2.03.1965.

Probing the Limits of Representation: Nazism and the "Final Solution", red. Saul Friedländer, Cambridge 1992.

Prümm Karl, Dokumentation des Unvorstellbares. „Ein Tag. Bericht aus einem deutschen Konzentrarionslager", [w:] Der Holocaust im Film. Mediale Inszenierung und kulturelles Gedächtnis, red. Waltraud Wende, Heidelberg 2007. 
Przemiany pamięci społecznej a teoria kultury, red. Bartosz Korzeniewski, Poznań 2007.

Przemówienie Adolfa Hitlera, wygłoszone 21 lipca 1944 roku, [w:] Ian Kershaw, Walkiria. Historia zamachu na Hitlera, tłum. R. Bartołd, Poznań 2009.

Przestrzenie intermedialności. Adaptacje literatury niemieckojęzycznej, red. Kalina Kupczyńska, Magdalena Saryusz-Wolska, Wrocław 2012.

Public History. Darstellungen des Nationalsozialismus jenseits der Geschichtswissenschaft, red. Frank Bösch, Constantin Goschler, Frankfurt am Main 2009.

Pudowkin Wsiewołod, Smirnowa E., Zwycięstwo prawdy bolszewickiej, tłum. A. Domalewski, „Przegląd Filmowy” 1950, nr 3-4.

Rabinbach Anson, In the Shadow of the Catastrophe. German Intellectuals between Apocalypse and Enlightment, Berkeley 1997.

Reassessing the Nuremberg Military Tribunals, red. Kim Priemel, Alexa Stiller, New York 2012.

Regie: Frank Beyer, red. Ralf Schenk, Berlin 1995.

Reichel Peter, Erfundene Erinnerung: Weltkrieg und Judenmord in Film und Theater, München 2004.

Reichel Peter, Politik mit der Erinnerung. Gedächtnisorte im Streit um die nationalsozialistische Vergangenheit, Wien 1995.

Reichel Peter, Vergangenheitsbewältigung in Deutschland. Die Auseinandersetzung mit der NS-Diktatur von 1945 bis heute, München 2001.

Reimer Robert C., Reimer Carol J., Nazi-retro Film. How German Narrative Cinema Remembers the Past, New York 1992.

Reinecker Herbert, Ein Zeitbericht unter Zuhilfenahme des eigenen Lebenslauf, Wien 1990.

Remarque Erich Maria, Czas życia i czas śmierci, tłum. J. Stroynowski, Poznań 2013.

Reżyser Georg C. Klaren o filmie „Sonnenbruckowie”, „Film” 1951, nr 17.

Richter Erika, Romangestalten auf der Leinwand, „Filmspiegel” 1963, nr 9.

Richter Erika, Zwischen Mauerbau und Kahlschlag, [w:] Das zweite Leben der Filmstadt Babelsberg. DEFA-Spielfilme 1946-1992, red. Ralf Schenk, Berlin 1994.

Ricoeur Paul, Pamięć, historia, zapomnienie, tłum. J. Margański, Kraków 2012.

Ricoeur Paul, Między pamięcia a historia, tłum. M. Frankiewicz, „Znak” 2005, nr 598.

Ricoeur Paul, Nadużycia pamięci naturalnej: pamięć powstrzymana, pamięć manipulowana, pamięć narzucona, tłum. W. Bońkowski, „Konteksty” 2003, nr 1-2.

Ricoeur Paul, Pamięć - zapomnienie - historia, tłum. J. Migasiński, [w:] Tożsamość w czasach zmiany. Rozmowy w Castel Gandolfo, Kraków 1995.

Riefenstahl - ihr Kampf, „Der Spiegel” 1961, nr 3.

Riefenstahl Leni, Pamiętniki, tłum. J. Łaszcz, Warszawa 2003.

Riess Curt, Das gab's nur einmal. Das Buch der schönsten Filme unseres Lebens, Hamburg 1956.

Ritter Gerhard, Europa und die deutsche Frage. Betrachtungen über die geschichtliche Eigenart des deutschen Staatsdenkens, München 1948.

Robnik Drehli, Geschichtsästhetik und Affektpolitik. Stauffenberg und der 20. Juli im Film 19482008, Wien 2009.

Roos Hans-Dieter, Bernhard Wickis Film von der "Brücke”, "Süddeutsche Zeitung”, 25.10.1959.

Roos Hans-Dieter, Kirmes, „Süddeutsche Zeitung”, 5.09.1960.

Rosenstone Robert, Historia w obrazach/historia w słowach: rozważania nad możliwościa przedstawienia historii na taśmie filmowej, [w:] Film i historia, red. Iwona Kurz, Warszawa 2009.

Rosenstone Robert, The Historical Film: Looking at the Past in a Postliterate Age, [w:] The Historical Film: History and Memory in Media, red. Marcia Landy, New Brunswick, New Jersey 2001. 
Roth Wilhelm, 25 Jahre zu spät. Rückblick auf eine "Neue Welle” in der DDR, „epd Film” 1990, nr 7 .

Rücker Günter, Die Verlobte. Der Fall Gleiwitz. Der Dritte. Wolz - Leben und Verklärung eines deutschen Anarchisten. Bis dass der Tod scheidet. Hilde, das Dienstmädchen, Berlin (Ost) 1988.

Rülicke-Weiler Käthe, Weitere Bemerkungen zum Film „Beil von Wandsbeck”, „Beiträge zur Film- und Fernsehwissenschaft" 1984, nr 5.

Rupper Martn, Epilog auf einem Film, „Allgemeine Zeitung”, 20.05.1947.

Rüsen Jörn, Pamięć o Holokauście a tożsamość niemiecka, [w:] Pamięć zbiorowa i kulturowa. Współczesna perspektywa niemiecka, red. Magdalena Saryusz-Wolska, Kraków 2009.

Rüsen Jörn, Friedrich Jaeger, Erinnerungskultur, [w:] Deutschland-Trendbuch: Fakten und Orientierungen, red. Karl-Rudolf Korte, Werner Weidenfeld, Opladen 2001.

Rydel Jan, Polityka historyczna w Republice Federalnej Niemiec. Zaszłości, idee, praktyka, Kraków 2011.

Ryszka Franciszek, Norymberga. Prehistoria i ciag dalszy, Warszawa 1982.

Santner Eric L., Stranded Objects: Mourning, Memory, and Film in Postwar Germany, LondonNew York 1990.

Saryusz-Wolska Magdalena, Ikony normalizacji. Kultury wizualne Niemiec 1945-1949, w druku.

Saryusz-Wolska Magdalena, Pierwsze próby rozrachunku. Kino niemieckie 1945-1949, [w:] Konstelacja Szczecin. Aktorzy szczecińscy i kino okresu międzywojennego, red. Radosław Skrycki, Szczecin 2011.

Saryusz-Wolska Magdalena, Wolfgang Staudte. Sumienie ponad podziatami, [w:] Autorzy kina europejskiego VI, red. Alicja Helman, Andrzej Pitrus, Warszawa 2012.

Sasuly Richard, I.G. Farben: z dziejów jednego kartelu, tłum. M. Marciniak, Warszawa 1949.

Saydewitz Max, Zerstörung und Wideraufbau von Dresden, Berlin (Ost) 1955.

Schallück Paul, „Rotation”. Zehn Jahre verspätet, aber immer noch aktuell, „Filmforum” 1958, nr 3.

Schapow Birgit, Abseits ausgetretener Pfade - Der Fall Gleiwitz, [w:] DEFA International. Grenzüberschreitende Filmbeziehungen vor und nach dem Mauerbau, red. Michael Wedel, Barton Byg et al., Wiesbaden 2013.

Schenk Ralf, Eine kleine Geschichte der DEFA, Berlin 2006.

Schenk Ralf, Mitten im kalten Krieg 1950 bis 1960, [w:] Das zweite Leben der Filmstadt Babelsberg. DEFA-Spielfilme 1946-1992, red. Ralf Schenk, Berlin 1994.

Schieber Elke, "Vergesst es nie - Schuld sind sie!”. Zur Auseinandersetzung mit dem Völkermord an den Juden in Gegenwartsfilmen der DEFA, [w:] Die Vergangenheit in der Gegenwart. Konfrontationen mit den Folgen des Holocaust im deutschen Nachkriegsfilm, red. Claudia Dillmann, Ronny Loewy, Frankfurt am Main 2001.

Schildt Axel, Aufarbeitung und Aufbruch. Die NS-Vergangenheit in der bundesdeutschen Öffentlichkeit der 1960er Jahre, „Vorgänge. Zeitschrift für Bürgerrechte und Gesellschaftspolitik" 2002, nr 1.

Schiller Friedrich, Intryga i miłość. Tragedia mieszczańska w pięciu aktach, tłum. A. M. Swinarski, Gdańsk 2000.

Schittly Dagmar, Zwischen Regie und Regime. Die Filmpolitik der SED im Spiegel der DEFAProduktionen, Berlin 2002.

Schlesinger Hans, Morituri, „Die Weltbühne. Wochenschrift für Politik, Kunst, Wirtschaft”, 30.11.1948.

Schmid Harald, Antifaschismus und Judenverfolgung. Die Reichskristallnacht als politischer Gedenktag in der DDR, Dresden 2004. 
Schmidt Hannes, Werkstatterfahrungen mit Gerhard Klein, "Aus Theorie und Praxis des Films" 1984, nr 2.

Schmidt Josef, Stalingrad für die Kinoleinwand, "Süddeutsche Zeitung”, 24.1.1959.

Schneider Michael, Den Kopf verkehrt aufgesetzt oder Die melancholische Linke, NeuwiedLuchterhand 1981.

Schneider Michael, Väter und Söhne posthum. Das beschädigte Verhältnis zweier Generationen, [w:] idem, Den Kopf verkehrt aufgesetzt oder Die melancholische Linke, NeuwiedLuchterhand 1981.

Schneider Peter, Deutsche als Opfer. Über ein Tabu der Nachkriegsgeneration, [w:] Ein Volk von Opfern? Die neue Debatte um den Bombenkrieg, red. Lothar Kettenacker, Berlin 2003.

Schnurre Wolfdietrich, Film-Rundschau, „Deutsche Rundschau”, 5.11.1946.

Schön Heinz, Tragedia Gustloffa, tłum. M. i J. Zepp, Zakrzów 2006.

Schornstheimer Michael, Die leuchtenden Augen der Frontsoldaten. Nationalsozialismus und Krieg in den Illustriertenromanen der fünfziger Jahre, Berlin 1995.

Schröder Burkhard, Rechte Kerle. Skinheads, Faschos, Hooligans, Reinbek 1992.

Schuld und Sühne? Kriegserlebnis und Kriegsdeutung in deutschen Medien der Nachkriegszeit (1945-1961), red. Ursula Heukenkamp, Amsterdam/Atlanta 2001.

Schultz Sonja M., Der Nationalsozialismus im Film: Von "Triumph des Willens' bis "Inglorious Bastards", München 2012.

Schwab-Felisch Hans, Opfergang der Siebzehnjährigen, „Frankfurter Allgemeine Zeitung”, 24.10.1959.

Schwalbe Konrad, Sterne, „Beiträge zur Film- und Fernsehwissenschaft” 1990, nr 39.

Schwarz Roswita, Vom expressionistischen Aufbruch zur inneren Emigration, Günther Weisenborns weltanschauliche und künstlerische Entwicklung in der Weimarer Republik und im 3. Reich, Frankfurt am Main 1995.

Schwieriges Erbe. Der Umgang mit Nationalsozialismus und Antisemitismus in Österreich, der DDR und der Bundesrepublik Deutschland, red. Werner Bergmann, Frankfurt am Main 1995.

Screening War. Perspectives on German Suffering, red. Paul Cooke, Marc Silberman, Rochester 2010.

Sebald Winfried G., Wojna powietrzna i literatura, tłum. M. Łukasiewicz, Warszawa 2012.

Seeßlen Georg, Das zweite Leben des „Dritten Reichs”, Berlin 2013.

Seeßlen Georg, Faschismus in der populären Kultur, Berlin 1994.

Seeßlen Georg, Faschismus, Krieg und Holocaust im deutschen Nachkriegsfilm, [w:] apropos: Film 2000. Das Jahrbuch der DEFA-Stiftung, red. Ralf Schenk, Erika Richter, Berlin 2000.

Seim Roland, Zwischen Medienfreiheit und Zensureingriffen: Eine medien- und rechtssoziologische Untersuchung zensorischer Einflußnahmen auf bundesdeutsche Populärkultur, Münster 1997.

Sellenthin Hans-Gerd, Sind Heldenflieger Filmhelden? Zum einen neuen Film im UFA-Stil, „Vorwärts”, 13.09.1957.

Seybold Katrin, Die Welt verbessern mit dem Geld von Leuten, die die Welt in Ordnung finden. Filme in Bundesrepublik 1949-1971, [w:] Wolfgang Staudte, red. Eva Orbanz, Berlin (West) 1977.

Shallcross Bożena, Rzeczy i Zagłada, Kraków 2010.

Shandley Robert, Rubble Canyons. "The Murderers Are Among Us" and the Western, "German Quaterly" 2001, nr 2.

Shandley Robert R., Rubble Films: German Cinema in the Shadow of the Third Reich, Philadelphia 2001.

Shandley Robert R., Trümmerfilme. Das deutsche Kino der Nachkriegszeit, Berlin 2010. 
Siegfried Detlef, Zwischen Aufarbeitung und Schlußstrich. Der Umgang mit der NS-Vergangenheit in den beiden deutschen Staaten 1958-1969, [w:] Dynamische Zeiten: die 60er Jahre in den beiden Gesellschaften, red. Axel Schildt, Detlef Siegfried, Karl Christian Lammers, Hamburg 2000.

Siehlohr Ulrike, Heroines without Heroes. Reconstructing Female and National Identities in European Cinema, 1945-1951, Bloomsbury 2000.

Silberman Marc, Remembering History: The Filmmaker Konrad Wolf, „New German Critique” 1990, nr 49.

Silberman Marc, The Discourse of Powerlessness: Wolfgang Staudte's "Rotation", [w:] German Cinema: Texts in Contexts, red. Marc Silberman, Detroit 1995.

Skierski Zenon, Gdy słońce gaśnie, Warszawa 1959.

Skopal Pavel, "It is not enough we have lost the war - now we have to watch it!" Cinemagoer's attitudes in the Soviet occupation zone of Germany - a case study from Leipzig, "Participations. Journal for Audience and Reception Studies" 2011, nr 2.

Skotarczak Dorota, Historia wizualna, Poznań 2012.

Skwara Janusz, Film zachodni a polityka, Warszawa 1970.

Stownik realizmu socjalistycznego, red. Zdzisław Łapiński, Wojciech Tomasik, Kraków 2004.

Sobe Günter, Bis fünf nach zwölf. "Die Abenteuer des Werner Holt”, ein DEFA-Film, „Berliner Zeitung", 10.02.1965.

Sołga Henryk, Niemcy. Sądzacy i sądzeni, 1939-2000, Kraków 2000.

Sorlin Pierre, Klio na ekranie albo historyk w mroku, tłum. J. Galewska, „Film na Świecie” 1980, nr 4.

Spielfilme der Defa im Urteil der Kritik. Ausgewählte Rezensionen 1946-1969, red. Lissi Zilinski, Berlin (Ost) 1970.

Spoden Madina, „Lissy” (1957). Gedanken beim neuerlichen Sehen, „Beiträge zur Film- und Fernsehwissenschaft" 1990, nr 39.

Spur der Filme. Zeitzeugen über die DEFA, red. Ingrid Poss, Peter Warnecke, Bonn 2006.

Stachówna Grażyna, "Drogi pośród nocy” Krzysztofa Zanussiego i inne filmowe romanse polsko-niemieckie, [w:] Polska i Niemcy: filmowe granice i sasiedztwa, red. Konrad Klejsa, Wrocław 2012.

Stanisławski Krzysztof, Nowe kino niemieckie, Sopot 1998.

Staudte Wolfgang, Arbeitstitel: „Die Mörder sind unter uns", „Film und Fernsehen” 1986, nr 9.

Staudte Wolfgang, Das eigene Nest beschmutzen?, „Offizielle Festspielzeitung der XIV. Internationalen Film-Festspiele", 3.07.1964. Przedruk w: Wolfgang Staudte, red. Eva Orbanz, Berlin (West) 1977.

Staudte Wolfgang, Ein Exposé. Arbeitstitel: Die Mörder sind unter uns, [w:] Wolfgang Staudte, red. Eva Orbanz, Hans Helmut Prinzler, Berlin 1991.

Steffen H., In jenen Tagen, „Film-Echo” 1947, nr 5.

Steinbach Peter, Widerstand im Dritten Reich - die Keimzelle der Nachkriegsdemokratie? Die Auseinandersetzung mit dem Widerstand in der historischen politischen Bildungsarbeit, in den Medien und in der öffentlichen Meinung nach 1945, [w:] Der 20. Juli: Das „, andere Deutschland" in der Vergangenheitspolitik nach 1945, red. Robert Buck, Gerd Ueberschär, Berlin 2008.

Steinmetz Rüdiger, Die Film- und Fernseh-Dokumentaristen Walter Heynowski und Gerhard Scheumann, Leipzig 2002.

Steltner Ulrich, Leon Kruczkowski (1900-1962), [w:] Polnische Dramen in Deutschland. Übersetzung und Aufführungen als deutsch-deutsche Rezeptionsgeschichte 1945-1995, Köln 2011. 
Stern Frank, Ein Kino subversiver Widersprüche. Juden im Spielfilm der DDR, „Apropos: Film. Das Jahrbuch der DEFA-Stiftung" 2002, nr 3.

Stern Frank, Im Anfang war Auschwitz. Antisemitismus und Philosemitismus im deutschen Nachkrieg, Gerlingen 1991.

Stern Frank, Real existierende Juden im DEFA-Filme. Ein Kino der subversive Widersprüche, [w:] Zwischen Politik und Kultur. Juden in der DDR, red. Moshe Zuckermann, Göttingen 2002.

Stettner Peter, Der deutsch-deutsche Filmaustausch (1947-1951). Von einer gesamtdeutschen Kooperation zum Kampf um die politische und kulturelle Hegemonie im geteilten Deutschland, [w:] DEFA-Film als nationales Kulturerbe?, red. Klaus Finke, Berlin 2001.

Strahl Rudi, Fünf Patronenhülsen, „Filmspiegel” 1960, nr 24.

Sussex Elisabeth, The Fate of F3080, „Sight and Sound” 1984, nr 53.

Śliwińska Katarzyna, Socrealizm w PRL i NRD, Poznań 2006.

Take Two. Fifties Cinema in Divided Germany, red. John Davidson, Sabine Hake, Berghahn 2007.

Taterka Thomas, „Buchenwald liegt in der DDR”. Grundzüge des Lagerdiskurses der DDR, [w:] LiteraturGesellschaft DDR. Kanonkämpfe und ihre Geschichte(n), red. Birgit Dahlke, Martina Langermann, Thomas Taterka, Weimar 2000.

Tatort KZ. Neue Beiträge zur Geschichte der Konzentrationslager, red. Ulrich Fritz, Nicole Warmbold, Ulm 2003.

Taylor Charles, Nowoczesne imaginaria społeczne, tłum. A. Puchejda, K. Szymaniak, Kraków 2010.

Tempel Ulrich, Wrzesień 1939: „Tu Radio Gliwice!” Gerharda Kleina i „Lotna” Andrzeja Wajdy, tłum. D. Codogni-Łańcucka, [w:] W drodze do sasiada. Polsko-niemieckie spotkania filmowe, red. Andrzej Dębski, Andrzej Gwóźdź, Wrocław 2013.

Teoria wiedzy o przeszłości na tle współczesnej humanistyki, red. Ewa Domańska, Poznań 2011.

Thaisy Laurence, La politique cinématographique de la France en Allemagne occupée: 1945-1949, Villeneuve-d'Ascq 2006.

The BFI Companion to German Cinema, red. Thomas Elsaesser, Michael Wedel, London 1999.

The Historical Film: History and Memory in Media, red. Marcia Landy, New Brunswick 2001.

Theuerkauf Holger, Goebbels' Filmerbe. Das Geschäft mit unveröffentlichen Ufa-Filmen, Berlin 1998.

Thiel Reinhold E., Herrenpartie, „Filmkritik” 1964, nr 4.

Thiele Jens, Die Lehren aus der Vergangenheit: „Rotation” (1949), [w:] Fischer Filmgeschichte, t. 3, red. Werner Faulstich, Helmut Korte, Frankfurt am Main 1990.

Thiele Martina, Publizistische Kontroversen über den Holocaust im Film, Münster 2002.

Thiem Willy H., Drinnen im Zimmer: ein neuer Glaube. Wolfgang Liebeneiner ging neue Wege, "Abendpost", 2.04.1949.

Thinking about the Holocaust, red. Alvin Rosenfeld, Bloomington 1997.

Timm Angelika, Hammer, Zirkel, Davidstern. Das gestörte Verhältnis der DDR zu Zionismus und Staat Israel, Bonn 1997.

Toeplitz Jerzy, Historia sztuki filmowej, t. VI: 1946-1953, Warszawa 1990.

Tok Hans-Dieter, "Sterne”: ein nachhaltiger Film über die Liebe zweier Menschen in einer trostlosen Zeit, ",Leipziger Volkszeitung”, 3.04.1959

Tornow Ingo, Piroschka und Wunderkinder oder von der Vereinbarkeit von Idylle und Satire. Der Regisseur Kurt Hoffmann, München 1990.

Toyka-Seidl Christiane, Gralshüter, Notgemeinschaft oder gesellschaftliche "Pressure-Group"? Die Stiftung "Hilfswerk 20. Juli 1944" im ersten Nachkriegsjahrzehnt, [w:] Der 20. Juli: Das "andere Deutschland" in der Vergangenheitspolitik nach 1945, red. Robert Buck, Gerd Ueberschär, Berlin 2008. 
Trajman Joanna, Narodowy socjalizm w kinie zjednoczonych Niemiec, Wrocław 2014.

Träume in Trümmern. Film - Produktion und Propaganda in Europa 1940-1950, red. HansMichael Bock, Jan Distelmeyer, Jörg Schöning, München 2009.

Trenkner Joachim, Naród z przeszłością. Eseje o Niemczech, Poznań 2004.

Trenkner Joachim, Podmiana ofiar. Jak władze NRD fałszowaty historię obozu koncentracyjnego w Buchenwaldzie, tłum. W. Pięciak, [w:] idem, Naród z przeszłością. Eseje o Niemczech, Poznań 2004.

Trümmer und Träume: Nachkriegszeit und fünfziger Jahre auf Zelluloid: deutsche Spielfilme als Zeugnisse ihrer Zeit, red. Ursula Bessen, Bochum 1989.

Trimborn Jürgen, Riefenstahl: niemiecka kariera, tłum. A. Kowaluk, K. Kuszyk, Warszawa 2008.

Tunnat Frank, Filmsprache als Instrument der Politik. Anmerkungen zu Kurts Maetzigs Thälmann-Film, [w:] Politik und Mythos. Kader, Arbeiter und Aktivisten im DEFA-Film, red. Klaus Finke, Oldenburg 2002.

Ulbricht Walter, O rozwoju socjalistycznej kultury narodowej, [w:] Polityka kulturalna Niemieckiej Republiki Demokratycznej. Wybór dokumentów, red. Teresa Krzemień, Warszawa 1971.

Ulbricht Walter, Warum Nationale Front des demokratischen Deutschlands? Aus dem Referat auf der Parteikonferenz der SED, 17 Mai 1949, [w:] idem, Zur Geschichte der deutschen Arbeiterbewegung. Aus Reden und Aufsätzen, t. 3, 1946-1950, Berlin (Ost) 1954.

Ulbricht Walter, Zur Geschichte der deutschen Arbeiterbewegung. Aus Reden und Aufsätzen, t. 3, 1946-1950, Berlin (Ost) 1954.

Ulrich Helmut, Vom Triumph menschlicher Würde, „Neue Zeit”, 11.04.1963.

Uncovering the Holocaust. The International Reception of "Night and Fog", red. Ewout van der Knaap, London 2006.

Und was sagen die Berliner? ABEND-Blitzumfrage vor dem Zoo-Palast-Portal, "Der Abend", 14.11.1959.

Unsere Feinde. Konstruktion des Anderen im Sozialismus, red. Silke Satjukow, Rainer Gries, Leipzig 2005.

USA und Deutschland: amerikanische Kulturpolitik 1942-1949. Bibliographie-Materialien - Dokumente, red. Michael Hoenisch, Klaus Kämpfe, Karl-Heinz Pütz, Berlin (West) 1980.

van der Knaap Ewout, Enlightment and Process: The Reception of "Nacht und Nebel" in Germany, [w:] Uncovering the Holocaust. The International Reception of "Night and Fog", red. Ewout van der Knaap, London 2006.

van Hoorn Maike, „Das sind keine Menschen...". Zur Darstellung der Nationalsozialisten in Filmen Wolfgang Staudtes, [w:] Courage und Eigensinn. Zum 100. Geburtstag von Wolfgang Staudte, red. Uschi und Andreas Schmidt-Lenhard, St. Ingbert 2006.

van Laak Dirk, Der Platz des Holocaust im deutschen Geschichtsbild, [w:] Die historische Meistererzählung. Deutungslinien der deutschen Nationalgeschichte nach 1945, red. Konrad Jarausch, Martin Sabrow, Göttingen 2002.

Vatter Christoph, Gedächtnismedium Film: Holocaust und Kollaboration in deutschen und französischen Spielfilmen seit 1945, Würzburg 2009.

Verbrecher erinnern: Die Auseinandersetzung mit Holocaust und Völkermord, red. Volkhard Knigge, Norbert Frei, München 2002.

Vergangenheitsbewältigung. Modelle der politischen und sozialem Integration in der bundesdeutschen Nachkriegsgeschichte, red. Andreas Wöll, Gary Schaal, Baden-Baden 1997.

Verner Paul, Der Künstler soll Mitgestalter unserer Gesellschaftsordnung sein, „Neues Deutschland", 20.12.1965.

Verteidigung der Menschheit, red. Edward Kowalski, Berlin (Ost) 1975. 
Verwandlungspolitik. NS-Eliten in der westdeutschen Nachkriegsgesellschaft, red. Wilfried Loth, Bernd A. Rusinek, Frankfurt am Main 1998.

Vielhaber Anna Sarah, Der populäre deutsche Film 1930-1970, Norderstedt 2012.

Vielstimmiges Schweigen. Neue Studien zum DDR-Antifaschismus, red. Annette Leo, Peter Reif-Spirek, Berlin 2001.

Violet Franziska, Der Artz von Stalingrad, „Süddeutsche Zeitung”, 29.4.1958.

Visarius Karsten, Der Wunsch des Täters nach der Tat. Volker Schlöndorffs "Der neunte Tag", [w:] Das Böse im Blick. Die Gegenwart des Nationalsozialismus im Film, red. Margrit Frölich, Christian Schneider, Karsten Visarius, München 2007.

Visuelle Politik. Filmpolitik und die visuelle Konstruktion des Politischen, Baden-Baden 1998.

von Bredow Wilfried, Filmpropaganda für Wehrbereitschaft: Kriegsfilme in der Bundesrepublik, [w:] Von der Kriegskultur zur Friedenskultur. Zum Wandel der politischen Mentalität in Deutschland nach 1945, red. Thomas Kühne, Münster 2000.

von Krockow Christian Graf, Niemcy: ostatnie sto lat, tłum. A. Kopacki, Warszawa 1997.

von Miquel Marc, Prawnicy - sędziowie we własnej sprawie, [w:] Norbert Frei, Kariery w pótmroku. Hitlerowskie elity po 1945 roku, tłum. B. Ostrowska, Warszawa 2011.

von Schilling Klaus, Scheitern an der Vergangenheit, Berlin 2002.

von Salomon Ernst, Der Fragebogen, Hamburg 1951

von Schlabrendorff Fabian, Offiziere gegen Hitler, Zürich 1946.

von Schnitzler Karl-Eduard, Leute mit Flügeln, „Filmspiegel” 1960, nr 18.

von Wrochen Oliver, Deutsche Generalsmemoiren nach 1945 als Grundlage nationaler Opfernarrative, [w:] Autobiographische Aufarbeitung. Diktatur und Lebensgeschichte im 20. Jahrhundert, red. Martin Sabrow, Helmstedt 2012.

W drodze do sasiada. Polsko-niemieckie spotkania filmowe, red. Andrzej Gwóźdź, Andrzej Dębski, Wrocław 2013.

Wagenstein Angel, Ich bin ein balkanischer Europäer, „Neues Deutschland”, 17.04.1999.

Wagner Friedrich A., Die Wolga war ihr Schicksal, "Frankfurter Allgemeine Zeitung”, 23.04.1959.

Wagner Reinhard, „Sonnensucher” (1958/1972), „Beiträge zur Film- und Fernsehwissenschaft" 1990, nr 31.

Wander Fred, Der siebente Brunnen, Frankfurt am Main 1997.

Warburg Aby, Atlas Mnemosyne. Wprowadzenie, tłum. K. Pijarski, „Konteksty” 2011, nr 2-3.

Ward Elisabeth M., Screening out the East: The Playing out of Inter-German Relations at the Cannes Film Festival, "German Life and Letters” 2015, nr 1.

War-Torn Tales: Representing Gender and World War II in Literature and Film, red. Danielle Hipkins, Gill Plain, Oxford 2007.

Weckel Ulrike, Beschämende Bilder. Deutsche Reaktionen auf alliierte Dokumentarfilme über befreite Konzentrationslager, Stuttgart 2012.

Weckel Ulrike, Brutstätte des Antisemitismus und Männerdomäne: Die deutsche Nachkriegsuniversität in der Diagnose des Spielfilms „Der Ruf" von 1949, [w:] Politische Gesell-schaftsgeschichte im 19. und 20. Jahrhundert. Festgabe für Barbara Vogel, red. Henning Albrecht, Hamburg 2006.

Weckel Ulrike, "Die Mörder sind unter uns" oder: Vom Verschwinden der Opfer, „Werkstatt Geschichte" 2000, nr 25.

Weckel Ulrike, Nachsitzen im Kino. Anglo-amerikanische KZ-Filme und deutsche Reaktionen 1945/46 - über Versuche kollektiver Beschämung, „Berliner Debatte Initial” 2006, nr 1-2.

Weckel Ulrike, Spielarten der Vergangenheitsbewältigung - Wolfgang Borcherts Heimkehrer und sein langer Weg durch die westdeutschen Medien, [w:] Medien - Politik - Geschichte, red. Moshe Zuckermann, Tel Aviv 2003. 
Weckel Ulrike, The Mitläufer in Two German Postwar Films: Representation and Critical Reception, "History and Memory. Studies in the Representation of the Past” 2003, nr 2.

Weckel Ulrike, The Power of Images: Real and Fictional Roles of Atrocity Film Footage at Nuremberg, [w:] Reassessing the Nuremberg Military Tribunals, red. Kim Priemel, Alexa Stiller, New York 2012.

Weckel Ulrike, "Wir ahnten, dass uns Abscheuliches vorgeführt wurde”. Alliierte Dokumentarfilme über die Lagerbefreiung und die Reaktionen deutscher Kriegsgefangener, [w:] „Welchen der Steine du hebst". Filmische Erinnerung an den Holocaust, red. Claudia Bruns, Asal Dardan, Anette Dietrich, Berlin 2012.

Wedel Michael, Defining DEFAs Historical Imaginary: the Films of Konrad Wolf, „New German Critique" 2001, nr 82.

Wedel Michael, Filmgeschichte als Krisengeschichte. Schnitte und Spuren durch den deutschen Film, Bielefeld 2011.

Wedel Michael, Thomas Elsaesser, Einblicke von aussen? Die DEFA, Konrad Wolf und die international Filmgeschichte, [w:] Michael Wedel, Filmgeschichte als Krisengeschichte. Schnitte und Spuren durch den deutschen Film, Bielefeld 2011.

Weidauer Walter, Inferno Dresden: über Lügen und Legenden um die Aktion "Donnerschlag”, Berlin (Ost) 1965.

Weiland Mato, Bernhard Wickis großer Regieerfolg: Nur einer kehrt aus der Kriegshölle zurück, "Abendpost", 26.10.1959.

Weingran Katrin, "Des Teufels General” in der Diskussion. Zur Rezeption von Carl Zuckmayers Theaterstück nach 1945, Marburg 2004.

Weiskopf Franz Carl, Lissy: powieść, tłum. S. Kaltman, Warszawa 1963.

„Welchen der Steine du hebst”. Filmische Erinnerung an den Holocaust, red. Claudia Bruns, Asal Dardan, Anette Dietrich, Berlin 2012.

Welzer Harald, Materiat, z którego zbudowane sa biografie, tłum. M. Saryusz-Wolska, [w:] Pamięć zbiorowa i kulturowa. Wspótczesna perspektywa niemiecka, red. Magdalena Saryusz-Wolska, Kraków 2009.

Welzer Harald, Sabine Moller, Karoline Tschuggnall, „Opa war kein Nazi”. Nationalsozialismus und Holocaust im Familiengedächtnis, Frankfurt am Main 2002.

Wenders Wim, Emotion Pictures: Essays und Filmkritiken, Frankfurt am Main 1986.

Wenders Wim, That's Entertainment, "Die Zeit”, 5.09.1977.

Wenn wir von gestern reden, sprechen wir über heute und morgen. Festschrift für Marta Mierendorff, red. Helmut G. Asper, Berlin 1991.

Wenzel Mirjam, Vom Zeugnis zum Tribunal. Zum Status des Dokumentarischen in Filmen, die im Nürnberger Prozess gezeigt oder über diesen gedreht wurden, [w:] „Welchen der Steine du hebst". Filmische Erinnerung an den Holocaust, red. Claudia Bruns, Asal Dardan, Anette Dietrich, Berlin 2012.

Westermann Bärbel, Nationale Identität im Spielfilm der fünfziger Jahre, Frankfurt am Main 1990.

White Hayden, Historiografia i historiofotia, tłum. Ł. Zaremba, [w:] Film i historia, red. Iwona Kurz, Warszawa 2009.

White Hayden, Poetyka pisarstwa historycznego, red. Ewa Domańska, Marek Wilczyński, Kraków 2000.

White Hayden, Tekst historiograficzny jako artefakt literacki, [w:] idem, Poetyka pisarstwa historycznego, red. Ewa Domańska, Marek Wilczyński, Kraków 2000.

Wiedemann Dieter, Der DEFA-Kinderfilm - zwischen pädagogischem Auftrag und künsterischem Anliegen, [w:] Zwischen Marx und Muck: DEFA-Filme für Kinder, red. Ingelore König, Dieter Wiedemann, Lothar Wolf, Berlin 1996.

Wilharm Irmgard, Bewegte Spuren. Studien zur Zeitgeschichte im Film, Hannover 2006. 
Wilharm Irmgard, Filmwirtschaft, Filmpolitik und der "Publikumsgeschmack" im Westdeutschland der Nachkriegszeit, ",Geschichte und Gesellschaft” 2002, nr 28.

Willet Ralph, The Americanization of Germany, 1945-1949, London-New York 1989.

Willy Bleicher. Ein Leben für die Gewerkschaften, red. Georg Benz, Kurt Georgi, Leonhard Mahlein, Frankfurt am Main 1983.

Wischniewski Klaus, Einzelfall oder Verallgemeinerung? "Betrogen bis zum jüngsten Tag", „Deutsche Filmkunst. Zeitschrift für Theorie und Praxis des Filmschaffens” 1957, nr 4.

Witek Piotr, Kultura. Film. Historia. Metodologiczne problemy doświadczenia audiowizualnego, Lublin 2005.

Wittkowski Helmut, Der beste Nachkriegsfilm gegen den Krieg: der Kriegsfilm "Die Brücke”, „Deutsche Woche", 4.11.1959.

Wolf Dieter, "Kirmes" - Bekenntnis und Mahnung, "Deutsche Filmkunst” 1960, nr 10.

Wolf Friedrich, Filip Gecht, Rada bogów, tłum. M. Wirpsza-Kurecka, Warszawa 1951.

Wolf Friedrich, Briefe. Eine Auswahl, Berlin (Ost) 1969.

Wolf Markus, Die Troika. Geschichte eines nichtgedrehten Films, Berlin (Ost) 1989.

Wolfenden Helen, The Representation of Wehrmacht Soldiers as Victims in Post-war West German Film: "Hunde, wollt ihr ewig leben" and "Der Arzt von Stalingrad", [w:] A nation of victims? Representations of German wartime suffering from 1945 to the present, ed. Helmut Schmitz, Amsterdam 2007.

Wolff-Powęska Anna, Pamięć - brzemię i uwolnienie. Niemcy wobec nazistowskiej przeszłości (1945-2010), Poznań 2011.

Wolfgang Staudte, red. Eva Orbanz, Hans Helmut Prinzler, Berlin 1991.

Wolfgang Staudte, red. Eva Orbanz, Berlin (West) 1977.

Wolfgang Staudte. Zur Retrospektive, red. Eva Orbanz, Berlin (West) 1974.

Wolfgang Staudte über die Produktionsbedingungen seiner Filme, [w:] Wolfgang Staudte, red. Eva Orbanz, Berlin (West) 1977.

Wolfgram Mark A., West German and Unified German Cinema's Difficult Encounter with the Holocaust, „Film \& History: An Interdisciplinary Journal of Film and Television Studies" 2002, nr 2.

Wolfrum Edgar, Die beiden Deutschland, [w:] Verbrecher erinnern: Die Auseinandersetzung mit Holocaust und Völkermord, red. Volkhard Knigge, Norbert Frei, München 2002.

Wolfrum Edgar, Geschichtspolitik in der Bundesrepublik Deutschland. Der Weg zur bundesrepublikanischen Erinnerung 1948-1990, Darmstadt 1999.

Wöll Andreas, Vergangenheitsbewältigung in der Gesellschaftsgeschichte der Bundesrepublik. Zur Konfliktlogik eines Streitthemas, [w:] Vergangenheitsbewältigung. Modelle der politischen und sozialem Integration in der bundesdeutschen Nachkriegsgeschichte, red. Andreas Wöll, Gary Schaal, Baden-Baden 1997.

Wöll Andreas, Wolfgang Staudte - „Sicher sind es nicht die Filme, die das eigene Nest beschmutzen", [w:] Engagierte Demokraten: Vergangenheitspolitik in kritischer Absicht, red. Claudia Fröhlich, Michael Kohlstruck, Münster 1999.

Wollenberg Erich, Thälmann - Film und Wirklichkeit, [w:] Ernst Thälmann: Mensch und Mythos, red. Peter Monheath, Amsterdam 2000.

Wóycicki Kazimierz, Niemiecki rachunek sumienia. Niemcy wobec przeszłości 1933-1945, Wrocław 2004.

Würtz Hannes, Lebt der Gilbert Wolzow noch? "Junge Welt" sprach mit Dieter Noll über bundesdeutsche Reaktionen auf Buch und DEFA-Film "Die Abenteuer des Werner Holt", "Junge Welt", 27.09.1966.

Zehm Günter, War alles ganz anders?, „Die Welt”, 14.09.1963.

Zeit zu Leben [sic!] und Zeit zu sterben, „Der Spiegel”, 1.10.1958. 
Zeitmaschine Kino: Darstellungen von Geschichte im Film, red. Hans-Arthur Mariske, Marburg 1992.

Zielinski Siegfried, Faschismusbewältigungen im frühen deutschen Nachkriegsfilm. Staudtes „Mörder sind unter uns" und Käutners „In jenen Tagen”, „Sammlung. Jahrbuch für antifaschistische Literatur und Kunst" 1979, nr 2.

Zielinski Siegfried, Veit Harlan: Analysen und Materialien zur Auseinandersetzung mit einem Film-Regisseur, Frankfurt am Main 1981.

Zilinski Lissy, Spielfilme der Defa im Urteil der Kritik, Berlin (Ost) 1970.

Zimmermann Moshe, Die Erinnerung an Nationalsozialismus und Widerstand im Spannungsfeld deutscher Zweitstaatlichkeit, [w:] Die geteilte Vergangenheit: Zum Umgang mit Nationalsozialismus und Widerstand in beiden deutschen Staaten, red. Jürgen Danyel, Berlin 1995.

Zuckmayer Carl, Geheimreport, Göttingen 2002.

zur Nieden Susanne, ...stärker als Tod. Bruno Apitz' Roman "Nackt unter Wölfen" und die Holocaust-Rezeption in der DDR, [w:] Bilder der Holocaust: Literatur - Film - Bildende Kunst, red. Manuel Köppen, Klaus Scherpe, Köln 1997.

Zweig Arnold, Topór z Wandsbeck, tłum. E. Sicińska, Warszawa 1951.

Zweig Zacharias, "Mein Vater, was machst du hier...?”. Zwischen Buchenwald und Auschwitz. Der Bericht des Zacharias Zweig, Frankfurt am Main 1987.

Zwierzchowski Piotr, Kino nowej pamięci. Obraz II wojny światowej w kinie polskim lat 60., Bydgoszcz 2014.

Zwierzchowski Piotr, Recepcja kinematografii NRD w polskim piśmiennictwie filmowym 19491990, [w:] W drodze do sąsiada. Polsko-niemieckie spotkania filmowe, red. Andrzej Gwóźdź, Andrzej Dębski, Wrocław 2013.

Zwierzchowski Piotr, Spektakl i ideologia. Szkice o filmowych wyobrażeniach śmierci heroicznej, Kraków 2006.

Zwierzchowski Piotr, Pęknięty monolit. Konteksty polskiego kina socrealistycznego, Bydgoszcz 2005.

Zwischen gestern und morgen: westdeutscher Nachkriegsfilm 1946-1962, red. Hilmar Hoffmann, Walter Schober, Frankfurt am Main 1989.

Zwischen Marx und Muck: DEFA-Filme für Kinder, red. Ingelore König, Dieter Wiedemann, Lothar Wolf, Berlin (Ost) 1996.

Zwischen Politik und Kultur - Juden in der DDR, red. Moshe Zimmermann, Göttingen 2002.

Zwischen uns die Mauer: DEFA-Filme auf der Berlinale, red. Jürgen Haase, Berlin 2010. 



\section{Filmografia}

Zestawienie obejmuje tytuły istotnych dla tematu książki pełnometrażowych kinowych filmów fabularnych produkcji niemieckiej (stref okupacyjnych, Niemieckiej Republiki Demokratycznej i Republiki Federalnej Niemiec, również koprodukcji) nakręconych w latach 1946-1965 i mających premiery w tym okresie.

Tytuły zostały uszeregowane latami (a w obrębie lat - alfabetycznie według polskiego tłumaczenia) zgodnie z kryterium roku premiery (w kraju produkcji), który podano za bazą filmportal.de, prowadzoną przez Deutsches Filminstitut we Frankfurcie nad Menem. Dla filmów enerdowskich, których dystrybucja została wstrzymana, w nawiasie podano dodatkowo rok premiery.

Pozostałe tytuły wymienione $\mathrm{w}$ książce (filmy produkcji innej niż niemiecka, filmy dokumentalne i krótkometrażowe, filmy telewizyjne - za wyjątkiem tych, które wprowadzono do dystrybucji kinowej, seriale telewizyjne oraz filmy niemieckie mające premiery przed 1946 lub po 1965 r., a także powstałe w III Rzeszy, a wprowadzone na ekrany po II wojnie światowej) uwzględniono w indeksie filmów, który zawiera też tytuły z niniejszej filmografii.

\section{6}

Gdzieś w Berlinie (Irgendwo in Berlin), reż. Gerhard Lamprecht, Niemcy - sowiecka strefa okupacyjna

Mordercy sa wśród nas (Mörder sind unter uns), reż. Wolfgang Staudte, Niemcy - sowiecka strefa okupacyjna

1947

... a nad nami niebo (Und über uns der Himmel), reż. Josef von Baký, Niemcy - amerykańska strefa okupacyjna

I kiedyś się znowu odnajdziemy (Und finden dereinst wir uns wieder), reż. Hans Müller, Niemcy - brytyjska strefa okupacyjna

Matżeństwo w mroku (Ehe im Schatten), reż. Kurt Maetzig, Niemcy - sowiecka strefa okupacyjna

Między dniem wczorajszym a jutrzejszym (Zwischen gestern und morgen), reż. Harald Braun, Niemcy - amerykańska strefa okupacyjna

W tamtych dniach (In jenen Tagen), reż. Helmut Käutner, Niemcy - brytyjska strefa okupacyjna 
1948

Berlińska ballada (Berliner Ballade), reż. Robert A. Stemmle, Niemcy - amerykańska strefa okupacyjna*

Dtuga jest droga (Lang ist der Weg), reż. Herbert Fredersdorf, Marek Goldstein, Niemcy - amerykańska strefa okupacyjna

Film bez tytułu (Film ohne Titel), reż. Rudolf Jugert, Niemcy - brytyjska strefa okupacyjna

Miłość 47 (Liebe 47), reż. Wolfgang Liebeneiner, Niemcy - brytyjska strefa okupacyjna

Morituri, reż. Eugen York, Niemcy - francuska strefa okupacyjna

Niemcy, rok zerowy (Germania - anno zero), reż. Roberto Rossellini, Włochy/Niemczy

1949

Cztery pokolenia (Die Buntkarrierten), reż. Kurt Maetzig, Niemcy - sowiecka strefa okupacyjna

...Gdyby tylko jeden (...und wenn's nur einer wär'), reż. Wolfgang Schleif, Niemcy - sowiecka strefa okupacyjna

Nasz chleb powszedni (Unser täglich Brot), reż. Slátan Dudow, Niemcy - sowiecka strefa okupacyjna

Ostatnia noc (Die letzte Nacht), reż. Eugen York, Niemcy - francuska strefa okupacyjna

Powołanie (Der Ruf), reż. Josef von Baký, Niemcy - amerykańska strefa okupacyjna

Rotacja/Brunatna pajęczyna (Rotation) reż. Wolfgang Staudte, Niemcy - sowiecka strefa okupacyjna

1950

Rada bogów (Der Rat der Götter), reż. Kurt Maetzig, NRD

1951

Poddany (Der Untertan), reż Wolfgang Staudte, NRD

Rodzina Sonnenbrucków (Die Sonnenbrucks), reż. Georg C. Klaren, NRD

Topór z Wandsbek (Beil von Wandsbek), reż. Falk Harnack, NRD

Zagubiony (Der Verlorene), reż. Peter Lorre, RFN

1952

Kobiece losy (Frauenschicksale) reż. Slátan Dudow, NRD

Matżeństwo aktorki (Roman einer jungen Ehe), reż. Kurt Maetzig, NRD

1953

Tajne akta firmy Solvay (Geheimakten Solvay), reż. Martin Hellberg, NRD

1954

08/15, reż. Paul May, RFN

Canaris, reż. Alfred Weidenmann, RFN

Rotmistrz Wroński (Rittmeister Wronski), reż. Ulrich Erfurth, RFN

Misja Śnieżna Biel (Unternehmen Edelweiss), reż. Heinz Paul, RFN

Silniejsi od nocy (Stärker als die Nacht), reż. Slátan Dudow, NRD

Zdrada Niemiec (Verrat an Deutschland), reż. Veit Harlan, RFN

* Z uwagi na realizację zdjęć w zachodniej części Berlina, film powstał na mocy aż trzech licencji: amerykańskiej, brytyjskiej i francuskiej. Firma producencka - Comedia Filmgesellschaft - miała siedzibę w Monachium, tj. w strefie amerykańskiej. 


\section{5}

08/15 - czesść druga (08/15 - II Teil), reż. Paul May, RFN

08/15 - w ojczyźnie (08/15 - In der Heimat), reż. Paul May, RFN

20 lipca (Der 20. Juli), reż. Falk Harnack, RFN

Bohaterstwo po zamknięciu kramu (Heldentum nach Ladenschuß), reż. Erik Ode, RFN

W diabelskim kręgu (Der Teufelskreis), reż. Carl Ballhaus, NRD

Dzieci, matki i generat (Kinder, Mütter und ein General), reż. Lásló Benedek, RFN

Generat diabła (Des Teufels General), reż. Helmut Käutner, RFN

Kapitan i jego bohater (Der Hauptmann und sein Held), reż. Max Nosseck, RFN

Operacja Śpiwór (Unternehmen Schlafsack), reż. Arthur Maria Rabenalt, RFN

W walce z Hitlerem (Ernst Thälmann - Führer seiner Klasse), reż. Kurt Maetzig, NRD

Wiem, po co żyję (Ich weiß, wofür ich lebe), reż. Paul Verhoeven, RFN

Urlop na słowo honoru (Urlaub auf Ehrenwort), reż. Wolfgang Liebeneiner, RFN

Zdarzyło się 20. lipca (Es geschah am 20. Juli), reż. Georg W. Pabst, RFN

\section{6}

...jak kiedyś Lili Marleen (...wie einst Lili Marleen), reż. Paul Verhoeven, RFN

Hauptmann z Kolonii (Der Hauptmann von Köln), reż. Slátan Dudow, NRD

Nie zawsze jest kawior (Es muss nicht immer Kaviar sein), reż. Géza von Rádvanyi, RFN

Niemiecki szpieg (Spion für Deutschland), reż. Werner Klingler, RFN

Pić mi się chce (Mich dürstet), reż. Karl Paryla, NRD

Róże dla Bettiny (Rosen für Bettina), reż. Georg W. Pabst, RFN

Skandal w Benderath (Zwischenfall in Benderath), reż. János Veiczi, NRD

Tym razem musi być kawior (Diesmal muss es Kaviar sein), reż. Géza von Rádvanyi, RFN

1957

Afrykańska gwiazda (Der Stern von Afrika), reż. Alfred Weidenmann, RFN

Dokądkolwiek pójdziesz... (Wo du hin gehst...), reż. Martin Hellberg, NRD

Lis z Paryża (Der Fuchs von Paris), reż. Paul May, RFN/Francja

Lissy, reż. Konrad Wolf, NRD

Młodzieńcy w niebieskich mundurach (Blaue Jungs), reż. Wolfgang Schleif, RFN

Noca, kiedy przychodził diabeł (Nachts, wenn der Teufel kam), reż. Robert Siodmak, RFN

Oszukani (Betrogen bis zum jüngsten Tag), reż. Kurt Jung-Alsen, NRD

Rekiny i małe rybki (Haie und kleine Fische), reż. Frank Wisbar, RFN

\section{8}

Btyskawiczne dziewczyny na froncie (Blitzmädels an die Front), reż. Werner Klingler, RFN

Lekarz ze Stalingradu (Der Arzt von Stalingrad), reż. Géza von Radványi, RFN

Mokry asfalt (Nasser Asphalt), reż. Frank Wisbar, RFN

Niespokojna noc (Unruhige Nacht), reż. Falk Harnack, RFN

Poszukiwacze słońca (Sonnensucher), reż. Konrad Wolf, NRD (1972)

Prien, kapitan U-47 (U47-Kapitänleutnant Prien), reż. Harald Reinl, RFN

Proces zostat odroczony (Der Prozess wird vertagt), reż. Herbert Ballmann, NRD

Serenada armatnia (Kanonenserenade), reż. Wolfgang Staudte, RFN/Włochy

Tajga (Taiga), reż. Wolfgang Liebeneiner, RFN

W czepku urodzeni (Wir Wunderkinder), reż. Kurt Hoffmann, RFN

Zielone diabły spod Monte Cassino (Die grünen Teufel von Monte Cassino), reż. Harald

Reinl, RFN 
Amigo (Sie nannten ihn Amigo), reż. Heiner Carow, NRD

Batalion karny 999 (Strafbataillon 999), reż. Harald Philipp, RFN

Dzień, który nigdy się nie kończy (Ein Tag, der nie zu Ende geht), reż. Franz Peter Wirth, RFN

Gwiazdy (Sterne), reż. Konrad Wolf, NRD

Misja specjalna (Sonderauftrag), reż. Heinz Thiel, NRD

Most (Die Brücke), reż. Bernhard Wicki, RFN

Noc zapadła nad Gotenhafen (Nacht fiel über Gotenhafen), reż. Frank Wisbar, RFN

Pięć tusek (Fünf Patronenhülsen), reż. Frank Beyer, NRD

Psy, chcecie żyć wiecznie? (Hunde, wollt ihr ewig leben?), reż. Frank Wisbar, RFN

Rommel wzywa Kair (Rommel ruft Kairo), reż. Wolfgang Schleif, RFN

Róże dla prokuratora (Rosen für die Staatsanwald), reż. Wolfgang Staudte, RFN

Sąd wojskowy (Kriegsgericht), reż. Kurt Meisel, RFN

Tajna misja: Czarna Kapela (Geheimaktion schwarze Kapelle), reż. Ralph Habib, RFN/Francja/ Włochy

\section{0}

Dywizja Brandenburg (Division Brandenburg), reż. Harald Philipp, RFN

Fabryka oficerów (Fabrik der Offiziere), reż. Frank Wisbar, RFN

Kiermasz (Kirmes), reż. Wolfgang Staudte, RFN

Kolega ze szkoły (Mein Schulfreund), reż. Robert Siodmak, RFN

Lebensborn, reż. Werner Klingler, RFN

Miłość zawisła na szubienicy (Am Galgen hängt die Liebe), reż. Edwin Zbonek, RFN

My, dzieci z piwnicy (Wir, Kellerkinder), reż. Jochen Wiedermann, RFN

Radiostacja Calais (Soldatensender Calais), reż. Joe May, RFN

Spotkania w mroku (Begegnung im Zwielicht), reż. Wanda Jakubowska, NRD/Polska

Ukochana bogów (Liebling der Götter), reż. Gottfried Reinhardt, RFN

Uskrzydleni (Leute mit Flügel), reż. Konrad Wolf, NRD

\section{1}

Diabeł grał na bałałajce (Der Teufel spielte Balalaika), reż. Leopold Lahola, RFN

Do zobaczenia (Auf Wiedersehn), reż. Harald Philipp, RFN

Ostatnia noc (Die letzte Nacht), reż. Joachim Kunert, NRD

Pięć dni, pięć nocy (Fünf Tage - Fünf Nächte), reż. Lew Arnstam, Heinz Thiel, Anatolij Golowanow, NRD/ZSRR

Profesor Mamlock (Professor Mamlock), reż. Konrad Wolf, NRD

Transport (Der Transport), reż. Jürgen Roland, Herbert Viktor, RFN

Tu Radio Gliwice! (Der Fall Gleiwitz), reż. Gerhard Klein, NRD

\section{2}

Drugi tor (Das zweite Gleis), reż. Hans-Joachim Kunert, NRD

Królewskie dzieci (Königskinder), reż. Frank Beyer, NRD

\section{3}

Atak we mgle (Nebel), reż. Joachim Hasler, NRD

Nadzy wśród wilków (Nackt unter Wölfen), reż. Frank Beyer, NRD

Tajne archiwum nad Łaba (Geheimarchiv an der Elbe), reż. Kurt Jung-Alsen, NRD

Teraz i w godzinę śmierci mojej (Jetzt und in der Stunde meines Todes), reż. Konrad Petzold,

NRD 
Ucieczka (Mensch und Bestie - tytuł kinowy lub Die Flucht - tytuł DVD), reż. Edwin Zbonek, RFN/Jugosławia

1964

90 nocy i jeden dzień (90 Nächte und ein Tag), reż. Edgar G. Ulmer, RFN/Włochy

Kryptonim Czapla (Kennwort Reiher), reż. Rudolf Jugert, RFN

Męski piknik (Herrenpartie), reż. Wolfgang Staudte, RFN/Jugosławia

\section{5}

Dom przy Karpfengasse (Haus in der Karpfengasse), reż. Kurt Hoffmann, RFN/Czechosłowacja Karla, reż. Herrmann Zschoche, NRD (1990)

Kronika pewnego morderstwa (Chronik eines Mordes), reż. Joachim Hasler, NRD

Przygody Wernera Holta (Die Abenteuer des Werner Holt), reż. Joachim Kunert, NRD

Zaginiony anioł (Der verlorene Engel), reż. Ralf Kirsten, NRD (1971) 



\section{Indeks filmów}

... a nad nami niebo (Und über uns der Himmel) $57,60,359,383$

...Gdyby tylko jeden (...und wenn's nur einer wär') 58,384

...i znowu 48 (...und wieder 48) 123

...jak kiedyś Lili Marleen (...wie einst Lili Marleen) 284, 337, 385

...reitet für Deutschland zob. Konnica dla Niemiec

...und wenn's nur einer wär' zob. ...Gdyby tylko jeden

....und wieder 48 zob. ... i znowu 48

...wie einst Lili Marleen zob. ...jak kiedyś Lili Marleen

08/15 248-251, 283, 285, 356, 360, 363, 364, 369,384

08/15 - część druga (08/15 - II Teil) 285, 385

08/15 -wojczyźnie (08/15 - In der Heimat) 385

1 kwietnia 2000 (1. April 2000) 266

1. April 2000 zob. 1 kwietnia 2000

20. Juli, Der zob. 20. lipca

20. lipca (Der 20. Juli) 229, 230, 237, 238$244,329,349,352,354,367,372,375$, 376, 385

21 Juli, Der zob. 21 lipca

21 lipca (Der 21. Juli) 339

3-Groschen-Oper, Die zob. Opera za trzy grosze

90 Nächte und ein Tag zob. 90 nocy $i$ jeden dzień

90 nocy $i$ jeden dzień (90 Nächte und ein Tag) 276, 387

Abrahams Gold zob. Złoto Abrahama

Abschied von Gestern zob. Pożegnanie z dniem wczorajszym

Achtung! Feind hört mit zob. Uwaga! Wróg podstuchuje

Adolf i Marlena (Adolf und Marlene) 338
Adolf und Marlene zob. Adolf i Marlena

Affäre Blum, Die zob. Sprawa Bluma

Afrykańska gwiazda (Der Stern von Afrika) 251, 252, 367, 385

Akcja J (Aktion J) 177

Akrobat Schö-ö-n 61

Akta Wiltau (Akte Wiltau) 318

Akte Wiltau zob. Akta Wiltau

Aktion J zob. Akcja J

Aktorka (Die Schauspielerin) 333

Am Brunnen vor dem Tore zob. Studnia przed brama

Am Galgen hängt die Liebe zob. Miłość zawista na szubienicy

Am grünen Strand der Spree zob. Na zielonej plaży nad Szprewa

Amigo (Sie nannten ihn Amigo) 149, 150, 168, 197, 386

andere Front, Die zob. Inny front

andere Leben, Das zob. Inne życie

andere neben dir, Der zob. Ktoś obok ciebie

Anfrage, Die zob. Zapytanie

Aniot z puzonem (Der Engel mit der Posaune) 91

Arzt ohne Gewissen zob. Lekarz bez sumienia

Arzt von Stalingrad, Der zob. Lekarz ze Stalingradu

Atak we mgle (Nebel) 182, 386

Attentäter, Der zob. Zamachowiec

Auf den Spuren des Henkers zob. Na tropach kata

Auf Wiedersehn zob. Do zobaczenia

Aufenthalt, Der zob. Pobyt

Aus einem deutschen Leben zob. Śmierć jest moim rzemiostem

Badania marchijskie zob. Poszukiwania brandenburskie

Barringowie (Die Barrings) 310 
Barrings, Die zob. Barringowie

Batalion karny 999 (Strafbataillon 999) 264, 329, 386

Bauern, Bonzen und Bomben zob. Rolnicy, bonzowie i bomby

Begegnung im Zwielicht zob. Spotkania w mroku

Beil von Wandsbek zob. Topór z Wandsbek

Berlin - Die Sinfonie der Grosstadt zob. Berlin: Symfonia wielkiego miasta

Berlin: Symfonia wielkiego miasta (Berlin - Die Sinfonie der Grosstadt) 134

Berliner Ballade zob. Berlińska ballada

Berlińska ballada (Berliner Ballade) 30, 58, 352, 384

Bertinis, Die zob. Rodzina Bertinich

Betrogen bis zum jüngsten Tag zob. Oszukani

Bezimienna kobieta (Donna senza nome) 283

Biała Róża (Die Weiße Rose) 340

Białe piekło (Die weisse Hölle vom Piz Palï) 233

Bild der Menschen, Das zob. Obraz człowieka

Bis 5 nach 12 zob. Do za pięć dwunasta

Bittere Ernte zob. Gorzkie żniwa

Blaszany bębenek (Die Blechtrommel) 158, 246

blaue Engel, Der zob. Btękitny aniot

Blaue Jungs zob. Młodzieńcy w niebieskich mundurach

Blechtrommel, Die zob. Blaszany bębenek

bleierne Zeit, Die zob. Czas ołowiu

Blick in die Welt zob. Spojrzenie na świat

Blitzmädels an die Front zob. Btyskawiczne dziewczyny na froncie

Blutiger Schnee zob. Wedle wyroków Twoich

Blutsbrüderschaft zob. Braterstwo krwi

Btękitny aniot (Der blaue Engel) 51, 79, 338

Blyskawiczne dziewczyny na froncie (Blitzmädels an die Front) 279, 385

Bohaterowie pustyni (Тринадиать) 155

Bohaterstwo po zamknięciu kramu (Heldentum nach Ladenschuß) 266, 385

Boot, Das zob. Okręt

Braterstwo krwi (Blutsbrüderschaft) 100

Bronsteins Kinder zob. Dzieci Bronsteina

Brücke, Die (1949) zob. Most (1949)

Brücke, Die (1959) zob. Most (1959)

Brücke, Die (2008) zob. Most (2008)

Brunatna pajęczyna (Rotation) 30, 60, 88, 95-98, 100, 101, 121, 135, 151, 225, 270, 297, 298, 354, 373, 375, 376, 384

Buntkarrierten, Die zob. Cztery pokolenia
Canaris $232,233,247,283,353,384$

Carl Peters 249

Casablanca 201, 223

Chce was zobaczyć (Ich will euch sehen) 333

Chronik eines Mordes zob. Kronika pewnego morderstwa

Chuligani (Die Halbstarken) 280

Cud awiacji (Wunder des Fliegens) 233

Czas miłości i czas śmierci (A Time to Love and a Time to Die) 11, 262, 264, 359

Czas ołowiu (Die bleierne Zeit) 337

Czerwoni kapo z Buchenwaldu (Die roten Kapos von Buchenwald) 206, 370

Człowiek i bestia zob. Ucieczka (1963)

Cztery pokolenia (Die Buntkarrierten) 60, 101, 102, 148, 304, 384

Das war unser Rommel zob. Taki byt nasz Rommel

David 343

Decision Before Dawn zob. Decyzja przed świtem

Decyzja przed świtem (Decision Before Dawn) 231

Dein unbekannter Bruder zob. Twój nieznany brat

Desert Fox zob. Lis pustyni

Deutschland im Herbst zob. Niemcy jesienia

Deutschland, bleiche Mutter zob. Matka

Diabet grat na bałałajce (Der Teufel spielte Balalaika) 282, 386

Diesmal muss es Kaviar sein zob. Tym razem musi być kawior

Division Brandenburg zob. Dywizja Brandenburg

Dtuga jest droga (Lang ist der Weg) 60, 117$121,312,343,365,384$

Do za pięć dwunasta (Bis 5 nach 12) 220

Do zobaczenia (Auf Widersehn) 274, 275, 386

Dokąd jada pociagi (Wohin die Züge fahren) 57

Dokądkolwiek pójdziesz... (Wo du hin gehst...) 154, 385

Doktor Mabuse, gracz (Dr. Mabuse, der Spieler) 64

Doktor Schlüter (Dr. Schlüter) 212

Dom przy Karpfengasse (Haus in der Karpfengasse) 12, 311, 312, 351, 387

Donna senza nome zob. Bezimienna kobieta 
Dopóki żyjesz (Solange du lebst) 281

Dr. Mabuse, der Spieler zob. Doktor Mabuse, gracz

Dr. Schlüter zob. Doktor Schlüter

Draußen vor der Tür (1957) zob. Pod drzwiami (1957)

Draußen vor der Tür (1960) zob. Pod drzwiami (1960)

Drogi w mroku (Wege im Zwielicht) 57

Drugi tor (Das zweite Gleis) 190, 191, 331, 386

Duell mit dem Tod zob. Pojedynek ze śmiercia

Dywizja Brandenburg (Division Brandenburg) 264, 386

Dzieci Bronsteina (Bronsteins Kinder) 334

Dzieci, matki i generat (Kinder, Mütter und ein General) 267, 268, 385

Dzień, który nigdy się nie kończy (Ein Tag, der nie zu Ende geht) 277, 386

Dzień. Raport z niemieckiego obozu koncentracyjnego (Ein Tag. Bericht aus einem deutschen Konzentrationslager) 318-321, 371

Dziewczyna Juanita (Das Mädchen Juanita) 61

Dziś w nocy umrze miasto 127

Ehe der Maria Braun, Die zob. Matżeństwo Marii Braun

Ehe im Schatten zob. Małżeństwo w mroku

Eichmann i Trzecia Rzesza (Eichmann und das Dritte Reich) 221

Eichmann und das Dritte Reich zob. Eichmann i Trzecia Rzesza

Ein Lied geht um die Welt [Die Joseph-SchmidtStory] zob. Pieśń rozbrzmiewa na światHistoria Josepha Schmidta

Elsa, wilczyca z SS (Ilsa, She-Wolf of the SS) 279

Emil i detektywi (Emil und die Detektive) 103

Emil und die Detektive zob. Emil i detektywi

Engel mit der Posaune, Der zob. Anioł z puzonem

Eolomea 201

Ernst Thälmann - Führer seiner Klasse zob. $W$ walce $z$ Hitlerem

Ernst Thälmann - Sohn seiner Klasse zob. Na barykadach Hamburga

Es geschah am 20. Juli zob. Zdarzyto sie 20 lipca

Es muss nicht immer Kaviar sein zob. Nie zawsze jest kawior
Esther 203

Europa in Flammen - Heldentum an allen Fronten zob. Europa w ogniu - bohaterstwo na wszystkich frontach

Europa w ogniu - bohaterstwo na wszystkich frontach (Europa in Flammen - Heldentum an allen Fronten) 340

Fabrik der Offiziere zob. Fabryka oficerów

Fabryka oficerów (Fabrik der Offiziere) 256, 257, 363, 386

Fahne von Kriwoj Rog, Die zob. Flaga z Krzywego $\operatorname{Rog} u$

Fall Gleiwitz, Der zob. Tu Radio Gliwice!

Fariaho 334

Feinde zob. Wrogowie

Festung, Die zob. Twierdza

Film bez tytułu (Film ohne Titel) 58, 93, 120, 384

Film ohne Titel zob. Film bez tytulu

Flaga z Krzywego Rogu (Die Fahne von Kriwoj Rog) 333

Flucht, Die (1963) zob. Ucieczka (1963)

Flucht, Die (2007) zob. Ucieczka (2007)

Foreign Affair, A zob. Sprawy zagraniczne

Frau im Mond zob. Kobieta na księżycu

Frauenschicksale zob. Kobiece losy

Friederike von Barring 310

Frontgocke, Der zob. Frontowy kogut

Frontowy kogut (Der Frontgocke) 279

Fuchs von Paris, Der zob. Lis z Paryża

Fünf letzte Tage zob. Pięć ostatnich dni

Fünf Patronenhülsen zob. Pięć łusek

Fünf Tage - Fünf Nächte zob. Pięć dni, pięć nocy

Gdzieś w Berlinie (Irgendwo in Berlin) 60, 103-105, 120, 357, 366, 367, 383

Gdzieś w Europie (Valahol Európában) 283

gefährlicher Mensch, Ein zob. Niebezpieczny człowiek

Gefrorenen Blitze zob. Zamrożone btyskawice

Geheimakten Solvay zob. Tajne akta firmy Solvay

Geheimaktion schwarze Kapelle zob. Tajna misja: Czarna Kapela

Geheimarchiv an der Elbe zob. Tajne archiwum nad Łaba

Geheimbund Nächstenliebe zob. Tajny zwiazek przyszłych mitości 
Geliebt in Rom zob. Ukochany w Rzymie

Generat diabła (Des Teufels General) 51, 178, $187,233,234,236,295,311,330,379,385$

Germania - anno zero zob. Niemcy, rok zerowy Geschwister Oppermann, Die zob. Rodzeństwo Oppermann

Gewissen in Aufruhr zob. Niespokojne sumienie

Godzina zero (Stunde Null) 94, 343, 359

Gorzkie żniwa (Bittere Ernte) 343

Große Freiheit Nr. 755

große Reise der Agathe Schweigert, Die zob. Wielka podróż Agaty Schweigert

grünen Teufel von Monte Cassino, Die zob. Zielone diabty spod Monte Cassino

Gustloff - rejs ku śmierci (Die Gustloff) 262, $345,363,370,374$

Gustloff, Die zob. Gustloff-rejs ku śmierci

Gwiazda bez nieba (Stern ohne Himmel) 344

Gwiazdy (Sterne) 30, 132, 198, 199, 200, 201, 202, 294, 314, 318, 328, 330, 359, $362,367,374,376,386$

Haie und kleine Fische zob. Rekiny $i$ mate rybki

Halbstarken, Die zob. Chuligani

Hans Beimler, Kamerad zob. Towarzysz Hans Beimler

Hanussen 343

Hauptmann und sein Held, Der zob. Kapitan i jego bohater

Hauptmann von Köln, Der zob. Hauptmann $z$ Kolonii

Hauptmann z Kolonii (Der Hauptmann von Köln) 177-179, 292, 294, 329, 331, 360, 385

Haus in der Karpfengasse zob. Dom przy Karpfengasse

Heilt Hitler! zob. Pozdrawiajcie Hitlera!

Heimat 339, 343, 347

Heimkehr (1929) zob. Powrót do domu

Heimkehr (1941) zob. Powrót do ojczyzny

Heldentum nach Ladenschuß zob. Bohaterstwo po zamknięciu kramu

Herrenpartie zob. Męski piknik

Herzkönig zob. Król kier

Historia jednego fraka (Tales of Manhattan) 83

Hitler - eine Karriere zob. Hitler - historia pewnej kariery
Hitler - film z Niemiec (Hitler, ein Film aus Deutschland) 338, 339, 347

Hitler - historia pewnej kariery (Hitler - eine Karriere) 338, 346

Hitler, ein Film aus Deutschland zob. Hitlerfilm $z$ Niemiec

Holocaust 320, 321, 336

Hunde, wollt ihr ewig leben? zob. Psy, chcecie żyć wiecznie?

I kiedyś się znowu odnajdziemy (Und finden dereinst wir uns wieder) $\quad 60,81,82,383$

Ich klage an zob. Oskarżam

Ich war neunzehn zob. Miałem 19 lat

Ich weiß, wofür ich lebe zob. Wiem, po co żyje

Ich will euch sehen zob. Chce was zobaczyć

Ich zwing dich zu leben zob. Musisz żyć!

Il giardino dei Finzi Contini zob. Ogród Finzi-Continich

Ilsa, She-Wolf of the SS zob. Elsa, wilczyca $z S S$

Immensee 95

Immer am Weg dein Gesicht zob. Zawsze na drodze twej twarzy

In jenen Tagen zob. W tamtych dniach

Inne życie (Das andere Leben) 91

Inny front (Die andere Front) 166

Irgendwo in Berlin zob. Gdzieś w Berlinie

Иван Грозный zob. Iwan Groźny

Iwan Groźny (Иван Грозный) 47

Jadup i Boel (Jadup und Boel) 333

Jadup und Boel zob. Jadup i Boel

Jahrgang 21 zob. Rocznik 1921

Jak daleko nogi poniosa (So weit die Füsse tragen, 1959) 12, 165, 286, 329

Jakob der Lügner (1975) zob. Jakub kłamca

Jakob the Liar (1999) zob. Jakub łgarz

Jakub kłamca (Jakob der Lügner, 1975) 209, 210, 334

Jakub łgarz (Jakob the Liar, 1999) 209, 334, 366

Jeder stirbt für sich allein zob. Każdy umiera sam za siebie

Jeniec: jak daleko nogi poniosa (So weit die Füsse tragen, 2001) 287, 345

Jestem króliczkiem (Das Kaninchen bin ich) 210,371

Jetzt und in der Stunde meines Todes zob. Teraz i w godziné śmierci mojej 
Jud Süss zob. Żyd Süss

Junge Adler zob. Młode orty

junge Törless, Der zob. Niepokoje wychowanka Törlessa

Kameraden zob. Towarzysze

Kanat rany (Wundkanal) 343

Kanat 157

Kaninchen bin ich, Das zob. Jestem króliczkiem

Kanonenserenade zob. Serenada armatnia

Kapitan $i$ jego bohater (Der Hauptmann und sein Held) $\quad 302,385$

Karbid $i$ szczaw (Karbid und Sauerampfer) 170

Karbid und Sauerampfer zob. Karbid i szczaw

Karla 211, 387

Katz und Maus zob. Kot i mysz

Każdy umiera sam za siebie (Jeder stirbt für sich allein) 318

Kennwort Reiher zob. Kryptonim Czapla

Kinder, Mütter und ein General zob. Dzieci, matki $i$ generat

Kлятва zob. Przysięga

KLK an PTX - Die rote Kapelle zob. KLK do PTX - Czerwona orkiestra

KLK do PTX - Czerwona orkiestra (KLK an PTX - Die rote Kapelle) 333, 339

Kobiece losy (Frauenschicksale) 170, 188, 384

Kobieta na księżycu (Frau im Mond) 64

Kolberg 95, 105, 266

Kolega ze szkoty (Mein Schulfreund) 308, 329, 331, 386

Königskinder zob. Królewskie dzieci

Konnica dla Niemiec (...reitet für Deutschland) 108

Kot i mysz (Katz und Maus) 337

Kraj ojców, kraj synów (Land der Väter, Land der Söhne) 344

Kriegsgericht zob. Sad wojskowy

Krok za krokiem (Schritt für Schritt) 154

Kronika pewnego morderstwa (Chronik eines Mordes) 192, 194, 201, 316, 329, 387

Król kier (Herzkönig) 112

Królewskie dzieci (Königskinder) 152, 153, 329, 331, 349, 386

Kryptonim Czapla (Kennwort Reiher) 276, 387

Kto przeżyje, jest winien (Wer überlebt, ist schuldig) 317

Ktoś obok ciebie (Der andere neben dir) 212
Land der Väter, Land der Söhne zob. Kraj ojców, kraj synów

Lang ist der Weg zob. Dtuga jest droga

Leben von Adolf Hitler, Das zob. Życie Adolfa Hitlera

Lebende Ware zob. Żywy towar

Lebensborn 279, 386

Lekarz bez sumienia (Arzt ohne Gewissen) 291, 316

Lekarz ze Stalingradu (Der Arzt von Stalingrad) 247, 316, 256, 283-286, 362, 380, 385

letzte Akt, Der zob. Ostatni akt

letzte Loch, Das zob. Ostatnia dziura

letzte Nacht, Die (1949) zob. Ostatnia noc (1949)

letzte Nacht, Die (1961) zob. Ostatnia noc (1961)

Leute mit Flügeln zob. Uskrzydleni

Leutnant Yorck von Wartenburg, Der zob. Porucznik Yorck von Wartenburg

Liebe 47 zob. Miłość 47

Liebling der Götter zob. Ukochana bogów

Lied der Matrosen zob. Pieśn marynarzy

Lis pustyni (Desert Fox) 231

Lis z Paryża (Der Fuchs von Paris) 276, 385

Lissy 132, 150-152, 331, 375, 379, 385

Ludzie w reckach Boga (Menschen in Gottes Hand) 57

$M-M o r d e r c a(M)$ 62, 64, 107, 115, 152, 290

$M$ zob. $M-$ Morderca

Machorka-Muff 336

Mahnung, Die zob. Upomnienie

Majdanek-cmentarzysko Europy 44

Małżeństwo aktorki (Roman einer jungen Ehe) $186,187,349,384$

Matżeństwo Marii Braun (Die Ehe der Maria Braun) 337, 339

Małżeństwo w mroku (Ehe im Schatten) 30, 60, 87, 88, 89, 91, 121, 178, 186, 196, 235, 328, 349, 354, 356, 364, 383

Mama, ich lebe zob. Mamo, ja żyje

Mamo, ja żyje (Mama, ich lebe) 332

Märkische Forschungen zob. Poszukiwania brandenburskie

Martwi pozostaja młodzi (Die Toten bleiben jung) 333

Matka (Deutschland, bleiche Mutter) 167, 337 
Mauern zob. Mury

Mefisto 340

Mein Kampf 221, 294, 356

Mein Schulfreund zob. Kolega ze szkoty

Memory of Justice zob. Pamięć sprawiedliwości

Mensch und Bestie zob. Ucieczka (1963)

Menschen in Gottes Hand zob. Ludzie w rękach Boga

Męski piknik (Herrenpartie) 299, 301, 302, 331, 366, 367, 376, 387

Miałem 19 lat (Ich war neunzehn) 132, 332

Mich dürstet zob. Pić mi się chce

Między dniem wczorajszym a jutrzejszym (Zwischen gestern und morgen) 50, 60, 91, 108, 109, 121, 359, 383

Między noca a dniem (Zwischen Nacht und Tag) 333

Milczaca gwiazda (Der schweigende Stern) 142, 143

Miłość 47 (Liebe 47) 60, 91-94, 121, 261, 359, 371,384

Miłość zawisła na szubienicy (Am Galgen hängt die Liebe) 276, 386

Misja specjalna (Sonderauftrag) 182, 386

Misja Śnieżna Biel (Unternehmen Edelweiss) 276, 384

Młode orty (Junge Adler) 252

Młodzieńcy w niebieskich mundurach (Blaue Jungs) 279, 385

Mokry asfalt (Nasser Asphalt) 279, 280, 385

Mord in Lwow zob. Mord we Lwowie

Mord we Lwowie (Mord in Lwow) 177

Mörder sind unter uns zob. Mordercy sa wśród nas

Mordercy sa wśród nas (Mörder sind unter uns) $30,49,53,60,61,63-67,70,71$, 74-76, 78-80, 85-88, 92, 94, 95, 168, $170,177,186,255,260,290,300,302$, $330,354,366,375,378,381,383$

Morituri 60, 111-117, 121, 369, 373, 384

Most (Die Brücke, 1949) 93

Most (Die Brücke, 1959) 30, 162, 247, 268, 270-273, 296, 298, 329, 357, 359, 362, $371,372,380,386$

Most (Die Brücke, 2008) 268, 345

Mury (Mauern) 317

Musisz żyć! (Ich zwing dich zu leben) 333

My, dzieci z piwnicy (Wir, Kellerkinder) 295, $305,307,386$
Na barykadach Hamburga (Ernst Thälmann Sohn seiner Klasse) 141

$\mathrm{Na}$ tropach kata (Auf den Spuren des Henkers) 317

$\mathrm{Na}$ zielonej plaży nad Szprewa (Am grünen Strand der Spree) 12, 165, 287, 288, 330, 364

Nachfolger, Der zob. Skrytobójcy

Nacht fiel über Gotenhafen zob. Noc zapadła nad Gotenhafen

Nachts, wenn der Teufel kam zob. Noca, kiedy przychodzi diabet

Nackt unter Wölfen (1963) zob. Nadzy wśród wilków (1963)

Nackt unter Wölfen (2015) zob. Nadzy wśród wilków (2015)

Nadzy wśród wilków (Nackt unter Wölfen, 1963) 169, 180, 202-209, 318, 328331, 358, 359, 362, 367, 381, 386

Nadzy wśród wilków (Nackt unter Wölfen, 2015) 346

Narzeczona (Die Verlobte) 160, 333, 373

Nasser Asphalt zob. Mokry asfalt

Nasz chleb powszedni (Unser täglich Brot) 105, 106, 121, 384

Nebel zob. Atak we mgle

Nibelungen, Die zob. Nibelungi

Nibelungi(Die Nibelungen) 64

Nicht Versöhnt, oder Es hilft nur Gewalt, wo Gewalt herrscht zob. Niepogodzeni, albo: Tylko przemoc pomaga tam, gdzie rzadzi przemoc

Nie zawsze jest kawior (Es muss nicht immer Kaviar sein) 274, 385

Niebezpieczny człowiek (Ein gefährlicher Mensch) 317

Niegrzeczna dziewczyna (Das schreckliche Mädchen) 344

Niemcy - blada ojczyzna zob. Matka

Niemcy jesienia (Deutschland im Herbst) 337

Niemcy, rok zerowy (Germania - anno zero) $10,30,50,56,105,384$

Niemiecki szpieg (Spion für Deutschland) 274, 385

Niepogodzeni, albo: Tylko przemoc pomaga tam, gdzie rzadzi przemoc (Nicht Versöhnt, oder Es hilft nur Gewalt, wo Gewalt herrscht) 30, 336

Niepokoje wychowanka Törlessa (Der junge Törless) 30, 336, 361 
Niespokojna noc (Unruhige Nacht) 254-256, 329, 330, 358, 359, 367, 385

Niespokojne sumienie (Gewissen in Aufruhr) 164, 165, 329

Nieśmiertelna miłość (Unsterbliche Geliebte) 220

Nieznajoma z Sans Souci (Die Spaziergängerin von Sans Souci) 343

Nigdy tego nie zapomnijcie - to oni sa winni (Vergeßt es nie - schuld sind sie!) 43

Niziny (Tiefland) 54, 222

Noc i mgta (Nuit et Brouillard) 197, 198, 294,314

Noc zapadła nad Gotenhafen (Nacht fiel über Gotenhafen) 259-262, 311, 330, 350, $357,365,368,386$

Noca, kiedy przychodzi diabet (Nachts, wenn der Teufel kam) 30, 290, 291, 360, 385

Norymberga i nauki z niej ptynace (Nuremberg: its Lesson for Today / Nürnberg und seine Lehren) 46

Notorious zob. Ostawiona

Nuit et Brouillard, zob. Noc i mgta

Nuremberg: its Lesson for Today zob. Norymberga i nauki z niej płynace

Nürnberg und seine Lehren zob. Norymberga i nauki z niej ptynace

Obóz śmierci Sachsenhaus (Todeslager Sachsenhaus) 44

Obraz człowieka (Das Bild der Menschen) 317

Ocalona (Die Überlebende) 332

Od 5.45 odpowiadamy ogniem (Seit $5.45 \mathrm{Uhr}$ wird zurückgeschossen) 340

Ogniomistrz Kaleń 165

Ogród Finzi-Continich (Il giardino dei Finzi Contini) 343

Ohm Krüger zob. Wuj Krüger

Ojcowie i synowie. Niemiecka tragedia (Väter und Söhne. Eine deutsche Tragödie) 344

Okręt (Das Boot) 253, 254, 340, 352

Olimpiada (Olympia) 100, 222

Olympia zob. Olimpiada

Opera za trzy grosze (3-Groschen-Oper, Die) 96,152

Operacja Himmler 158

Operacja Śpiwór (Unternehmen Schlafsack) 266, 385
Oskarżam (Ich klage an) 62, 92

Ostawiona (Notorious) 224

Ostatni akt (Der letzte Akt) 10, 239, 241

Ostatni etap 44

Ostatni most (Die letzte Brücke) 10, 247

Ostatni świadek (Der letzte Zeuge) 294

Ostatnia dziura (Das letzte Loch) 343

Ostatnia noc (Die letzte Nacht, 1949) 60, 82, 384

Ostatnia noc (Die letzte Nacht, 1961) 165, 386

Oszukani (Betrogen bis zum jüngsten Tag) 156, 380, 385

Pamięć sprawiedliwości (Memory of Justice) 337

Pamiętnik dla Anny Frank (Ein Tagebuch für Anna Frank) 176

Paracelsus 239

Paris muss brennen zob. Paryż musi płonać

Paryż musi płonać (Paris muss brennen) 318

Pasażer - witamy w Niemczech (Der Passagier - Welcome to Germany) 343

Pasażerka 198

Passagier - Welcome to Germany, Der zob. Pasażer - witamy w Niemczech

Patriotin, Die zob. Patriotka

Patriotka (Die Patriotin) 339

Pedell, Der zob. Woźny

Pić mi się chce (Mich dürstet) 154, 155, 385

Pieśń marynarzy (Lied der Matrosen) 142, 167,168

Pieśń rozbrzmiewa na świat - Historia Josepha Schmidta (Ein Lied geht um die Welt [Die Joseph-Schmidt-Story]) 310

Pięć dni, pięć nocy (Fünf Tage - Fünf Nächte) 169, 170, 386

Pięć tusek (Fünf Patronenhülsen) 155, 156, 332, 349, 356, 357, 376, 386

Pięć ostatnich dni (Fünfletzte Tage) 340

Plot to Kill Adolf Hitler, The zob. Zabić Adolfa Hiltera

Pobyt (Der Aufenthalt) 334

Pod drzwiami (Draußen vor der Tür, 1957) 92

Pod drzwiami (Draußen vor der Tür, 1960) 92

Pod mostami (Unter den Brücken) 55

Pojedynek ześmiercia (Duell mit dem Tod) 10

Porträt eines Attentäters zob. Portret zamachowca 
Portret zamachowca (Porträt eines Attentäters) 240

Porucznik Yorck von Wartenburg (Der Leutnant Yorck von Wartenburg) 331

Poszukiwacze słońca (Sonnensucher) 132, 166, 167, 191, 201, 208, 361, 378, 385

Poszukiwania brandenburskie (Märkische Forschungen) 333, 354

Poszukiwanie (The Search) 51

Powiedz prawdę (Sag die Wahrheit) 50

Powołanie (Der Ruf) 60, 110, 121, 350, 358, 378,384

Powrót do domu (Heimkehr, 1929) 57

Powrót do ojczyzny (Heimkehr, 1941) 219

Pozdrawiajcie Hitlera! (Heilt Hitler!) 343

Pożegnanie $z$ dniem wczorajszym (Abschied von Gestern) 30, 191, 336

Prien, kapitan U-47 (U47-Kapitänleutnant Prien) 253, 254, 385

Proces (Der Prozess) 121, 239, 385

Proces zostat odroczony (Der Prozess wird vertagt) 192, 193, 385

Profesor Mamlock (Professor Mamlock, 1961) 132, 195, 196, 330, 386

Professor Mamlock zob. Profesor Mamlock (1961)

Prozess wird vertagt, Der zob. Proces zostaje odroczony

Prozess, Der zob. Proces

Przed nami życie (Vor uns liegt das Leben) 57,60

Przygody Wernera Holta (Die Abenteuer des Werner Holt) 160-164, 329, 363, 371, $375,380,387$

Przysięga (Клятва) 142

Przysiega szeregowca Pooleya (Der Schwur des Soldaten Pooley) 166

Psy, chcecie żyć wiecznie? (Hunde, wollt ihr ewig leben?) 256, 258, 259, 285, 340, 380, 386

Rada bogów (Der Rat der Götter) 163, 172176, 180, 331, 364, 380, 384

Radiostacja Calais (Soldatensender Calais) 277,386

Raport Sonii (Sonjas Rapport) 333

Rat der Götter, Der zob. Rada bogów

Rekiny $i$ małe rybki (Haie und kleine Fische) $252,253,259,370,371,385$
Rest ist Schweigen, Der zob. Reszta jest milczeniem

Reszta jest milczeniem (Der Rest ist Schweigen) 323

Rittmeister Wronski zob. Rotmistrz Wronski

Rocznik 1921 (Jahrgang 21) 181

Rodzeństwo Oppermann (Die Geschwister Oppermann) 318, 344

Rodzina Bertinich (Die Bertinis) 318, 344

Rodzina Sonnenbrucków (Die Sonnenbrucks) 174, 184-186, 362, 370, 372, 384

Rodzina Trappów (Die Trapp-Familie) 226

Rodzina Trappów w Ameryce (Die Trapp-Familie in Amerika) 226

Rolnicy, bonzowie i bomby (Bauern, Bonzen und Bomben) 318, 344

Roma, città aperta zob. Rzym, miasto otwarte

Roman einer jungen Ehe zob. Matżeństwo aktorki

Rommel - Schlachtfeld in der Wüste zob. Taki byt nasz Rommel

Rommel ruft Kairo zob. Rommel wzywa Kair

Rommel wzywa Kair (Rommel ruft Kairo) 231, 386

Rosen für Bettina zob. Róże dla Bettiny

Rosen für die Staatsanwald zob. Róże dla prokuratora

Rosjanie nadchodza (Die Russen kommen) 332

Rotacja zob. Brunatna pajęczyna

Rotation zob. Brunatna pajęczyna

roten Kapos von Buchenwald, Die zob. Czerwoni kapo z Buchenwaldu

Rotmistrz Wroński (Rittmeister Wronski) $277,278,384$

Rotschilds, Die zob. Rotszyldowie

Rotszyldowie (Die Rotschilds) 134, 143, 219

Róże dla Bettiny (Rosen für Bettina) 292, 385

Róże dla prokuratora (Rosen für die Staatsanwald) 30, 292, 293, 296, 303, 328, 329, 386

Russen kommen, Die zob. Rosjanie nadchodza Rzym, miasto otwarte (Roma, città aperta) 244, 266,

SA-Mann Brand 118, 219

Sag die Wahrheit zob. Powiedz prawde

Salonka E 417 (Salonwagen E 417) 83 
Salonwagen E 417 zob. Salonka E 417

Sansibar oder der letzte Grund (1961) zob. Zanzibar, albo ostatnia przyczyna (1961)

Sansibar oder der letzte Grund (1987) zob. Zanzibar, albo ostatnia przyczyna (1987)

Sauerbruch - Das war mein Leben zob. Sauerbruch

Sauerbruch (Sauerbruch - Das war mein Leben) 226,351

Sąd narodów (Суд народов) 46

Sad wojskowy (Kriegsgericht) 266, 386

Schatz von Toplitzsee, Der zob. Skarb z jeziora Toplitz

Schauspielerin, Die zob. Aktorka

Schilfrohr, Der zob. Trzcina

Schlaf der Gerechten, Der zob. Sen sprawiedliwych

schreckliche Mädchen, Das zob. Niegrzeczna dziewczyna

Schritt für Schritt zob. Krok za krokiem

schweigende Stern, Der zob. Milczaca gwiazda

Schwur des Soldaten Pooley, Der zob. Przysięga szeregowca Pooleya

Search, The zob. Poszukiwanie

Seit 5.45 Uhr wird zurückgeschossen zob. Od 5.45 odpowiadamy ogniem

Sen sprawiedliwych (Der Schlaf der Gerechten) 317

Serenada armatnia (Kanonenserenade) 275, 385

Sie nannten ihn Amigo zob. Amigo

Silniejsi od nocy (Stärker als die Nacht) 148, 169,384

Skandal $w$ Benderath (Zwischenfall in Benderath) 192, 385

Skarb z jeziora Toplitz (Der Schatz von Toplitzsee) 292

Skrytobójcy (Der Nachfolger) 212

So weit die Füsse tragen (1959) zob. Jak daleko nogi poniosa

So weit die Füsse tragen (2001) zob. Jeniec: jak daleko nogi poniosa

Solange du lebst zob. Dopóki żyjesz

Soldatensender Calais zob. Radiostacja Calais

Sonderauftrag zob. Misja specjalna

Sonjas Rapport zob. Raport Sonii

Sonnenbrucks, Die zob. Rodzina Sonnenbrucków

Sonnensucher zob. Poszukiwacze słońca

Sonst wären wir verloren zob. W przeciwnym razie bylibyśmy zgubieni
Sophie Scholl - die letzte Tage zob. Sophie Scholl-ostatnie dni

Sophie Scholl-ostatnie dni (Sophie Scholl - die letzte Tage) 345

SOS - Eisberg zob. SOS - góra lodowa

SOS - góra lodowa (SOS - Eisberg) 233

Spaziergängerin von Sans Souci, Die zob. Nieznajoma $z$ Sans Souci

Spion für Deutschland zob. Niemiecki szpieg

Spojrzenie na świat (Blick in die Welt) 43

Spotkania w mroku (Begegnung im Zwielicht) 181, 386

Sprawa Bluma (Die Affäre Blum) 81, 121

Sprawy zagraniczne (A Foreign Affair) 51, 358

Spur der Steine zob. Ślad kamieni

Spur führt nach Berlin, Die zob. Ślad prowadzi do Berlina

Stärker als die Nacht zob. Silniejsi od nocy

Stauffenberg zob. Zamach w Wilczym Szańcu

Stern ohne Himmel zob. Gwiazda bez nieba

Stern von Afrika, Der zob. Afrykańska gwiazda

Sterne zob. Gwiazdy

Stielke, Heinz, fünfzehn zob. Stielke, Heinz, lat piętnaście

Stielke, Heinz, lat piętnaście (Stielke, Heinz, fünfzehn) 333

Strafbataillon 999 zob. Batalion karny 999

Studnia przed brama (Am Brunnen vor dem Tore) 227

Stunde Null zob. Godzina zero

Stürme über dem Montblanc zob. Tragedia na Mont Blanc

Суд народов zob. Sąd narodów

Ślad kamieni (Spur der Steine) 210

Ślad prowadzi do Berlina (Die Spur führt nach Berlin) 291

Śmierć jest moim rzemiosłem (Aus einem deutschen Leben) $\quad 338,368$

Świadek z piekła (Zeugin aus der Hölle) 315, 316, 329, 355

Tag, der nie zu Ende geht, Ein zob. Dzień, który nigdy się nie kończy

Tag, Ein. Bericht aus einem deutschen Konzentrationslager zob. Dzień. Raport z niemieckiego obozu koncentracyjnego 
Tagebuch für Anna Frank, Ein zob. Pamiętnik dla Anny Frank

Taiga zob. Tajga

Tajga (Taiga) 282, 385

Tajna misja: Czarna Kapela (Geheimaktion schwarze Kapelle) 277, 386

Tajne akta firmy Solvay (Geheimakten Solvay) 176, 359, 384

Tajne archiwum nad Łaba (Geheimarchiv an der Elbe) 160, 386

Tajny zwiazek przyszłych miłości (Geheimbund Nächstenliebe) 318

Taki byt nasz Rommel (Das war unser Rommel) 231

Tales of Manhattan zob. Historia jednego fraka

Teraz i w godzinę śmierci mojej (Jetzt und in der Stunde meines Todes) 192, 193, 386

Teufel spielte Balalaika, Der zob. Diabet grat na batałajce

Teufels General, Des zob. Generat diabła

Teufelskreis, Der zob. W diabelskim kręgu

Tiefland zob. Niziny

Time to Love and a Time to Die, A zob. Czas miłości i czas śmierci

Tod hat ein Gesicht, Der zob. Twarz śmierci

Todeslager Sachsenhaus zob. Obóz śmierci Sachsenhaus

Topór z Wandsbek (Beil von Wandsbek) 133, 136, 139, 384

Toten bleiben jung, Die zob. Martwi pozostaja młodzi

Towarzysz Hans Beimler (Hans Beimler, Kamerad) 333

Towarzysze (Kameraden) 108

Tragedia na Mont Blanc (Stürme über dem Montblanc) 233

Transport (Der Transport) 314, 386

Transport, Der zob. Transport

Trapp-Familie in Amerika, Die zob. Rodzina Trappów w Ameryce

Trapp-Familie, Die zob. Rodzina Trappów

Тринадйать zob. Bohaterowie pustyni

Triumf woli (Triumph des Willens) 27, 53, $118,139,221,222,286,374$

Triumph des Willens zob. Triumf woli

Trzcina (Der Schilfrohr) 332

Tu Radio Gliwice (Fall Gleiwit, Der) 158160, 364, 370, 373, 376, 386

Twarz śmierci (Der Tod hat ein Gesicht) 176
Twierdza (Die Festung) 317

Twój nieznany brat (Dein unbekannter Bruder) 333

Tym razem musi być kawior (Diesmal muss es Kaviar sein) 274, 385

U47-Kapitänleutnant Prien zob. Prien, kapi$\tan U-47$

U-Boot westwärts zob. U-Booty na Zachód

U-Booty na Zachód (U-Boot westwärts) 62

Überlebende, Die zob. Ocalona

Ucieczka (Die Flucht, 2007) 261

Ucieczka (Mensch und Bestie / Die Flucht, 1963) 315, 329, 387

Ukochana bogów (Liebling der Götter) 310, 311, 386

Ukochany w Rzymie (Geliebt in Rom) 318

Ulica Graniczna 198

Ulica Leśniczówek 20 (Waldhausstr.20) 318

Und finden dereinst wir uns wieder zob. I kiedyś się znowu odnajdziemy

Und über uns der Himmel zob. ... a nad nami niebo

Unruhige Nacht zob. Niespokojna noc

Unser täglich Brot zob. Nasz chleb powszedni

Unsterbliche Geliebte zob. Nieśmiertelna mitość

Unter den Brücken zob. Pod mostami

Unternehmen Edelweiss zob. Misja Śnieżna Biel

Unternehmen Schlafsack zob. Operacja Śpiwór Upomnienie (Die Mahnung) 333

Urlaub auf Ehrenwort zob. Urlop na stowo honoru

Urlop na stowo honoru (Urlaub auf Ehrenwort) 265,385

Uskrzydleni (Leute mit Flügeln) 132, 167169,386

Utracona cześć Katarzyny Blum (Die verlorene Ehre der Katharina Blum) 279

Uwaga! Wróg podstuchuje (Achtung! Feind hört mit) 176

Valahol Európában zob. Gdzieś w Europie

Valkyrie zob. Walkiria

Väter und Söhne. Eine deutsche Tragödie zob. Ojcowie i synowie. Niemiecka tragedia

Vergeßt es nie - schuld sind sie! zob. Nigdy tego nie zapomnijcie - to oni sa winni 
Verlobte, Die zob. Narzeczona

verlorene Ehre der Katharina Blum, Die zob. Utracona cześć Katarzyny Blum

verlorene Engel, Der zob. Zaginiony aniot

verlorene Gesicht, Das zob. Zapomniana twarz

Verlorene, Der zob. Zagubiony

Verrat an Deutschland zob. Zdrada Niemiec

Vor uns liegt das Leben zob. Przed nami życie

W czepku urodzeni (Wir Wunderkinder) 30, 295, 303-305, 328, 385

W diabelskim kręgu (Der Teufelskreis) 147, 385

$W$ przeciwnym razie bylibyśmy zgubieni (Sonst wären wir verloren) 204

$W$ tamtych dniach (In jenen Tagen) 26, 30, 60, 83-87, 91, 113, 120, 121, 235, 351, $356,375,381,383$

W walce $z$ Hitlerem (Ernst Thälmann - Führer seiner Klasse) 141, 147, 197, 331, 385

Waldhausstr. 20 zob. Ulica Leśniczózvek 20

Walkiria (Valkyrie) 240

Wedle wyroków Twoich (Blutiger Schnee / Zu Freiwild verdammt) 343

Wege im Zwielicht zob. Drogi w mroku

weisse Hölle vom Piz Palü, Die zob. Białe piekło

Weiße Rose, Die zob. Biała Róża

Wengler $i$ synowie (Wengler und Söhne, Eine Legende) 333

Wengler und Söhne, Eine Legende zob. Wengler $i$ synowie

Wer überlebt, ist schuldig zob. Kto przeżyje, jest winien

Wernher von Braun - Ich greife nach den Sternen zob. Wernher von Braun - sięgam gwiazd

Wernher von Braun - sięgam gwiazd (Wernher von Braun - Ich greife nach den Sternen) 273

Wielka podróż Agaty Schweigert (Die große Reise der Agathe Schweigert) 332

Wiem, po co żyje (Ich weiß, wofür ich lebe) 311,385

Wir Wunderkinder zob. W czepku urodzeni

Wir, Kellerkinder zob. My, dzieci z piwnicy

Wo du hin gehst... zob. Dokądkolwiek pójdziesz...

Wohin die Züge fahren zob. Dokad jada pociagi

Wozzeck 80, 81, 361
Woźny (Der Pedell) 339

Wrogowie (Feinde) 108

Wuj Krüger (Ohm Krüger) 62, 105

Wunder des Fliegens zob. Cud awiacji

Wundkanal zob. Kanat rany

Zabić Adolfa Hiltera (The Plot to Kill Adolf Hitler) 240

Zaginiony anioł (Der verlorene Engel) 211, 387

Zagraniczny romans zob. Sprawy zagraniczne

Zagubiony (Der Verlorene) 30, 290, 384

Zamach w Wilczym Szańcu (Stauffenberg) 240,345

Zamachowiec (Der Attentäter) 339

Zamrożone błyskawice (Gefrorenen Blitze) 145, 333

Zanzibar, albo ostatnia przyczyna (Sansibar oder der letzte Grund, 1961) 211

Zanzibar, albo ostatnia przyczyna (Sansibar oder der letzte Grund, 1987) 211

Zapomniana twarz (Das verlorene Gesicht) 57,120

Zapytanie (Die Anfrage) 318

Zawsze na drodze twej twarzy (Immer am Weg dein Gesicht) 165

Zdarzyło się 20. lipca (Es geschah am 20. Juli) 237, 239-244, 385

Zdrada Niemiec (Verrat an Deutschland) 278, $312,369,384$

Zeugin aus der Hölle zob. Świadek z piekła

Zielone diabty spod Monte Cassino (Die grünen Teufel won Monte Cassino) 266, 385

Złoto Abrahama (Abrahams Gold) 344

$\mathrm{Zu}$ Freiwild verdammt zob. Wedle wyroków Twoich

zweite Gleis, Das zob. Drugi tor

Zwischen gestern und morgen zob. Między dniem wczorajszym a jutrzejszym

Zwischen Nacht und Tag zob. Między noca a dniem

Zwischenfall in Benderath zob. Skandal $w$ Benderath

Życie Adolfa Hitlera (Das Leben von Adolf Hitler) 221

Żyd Süss (Jud Süss) 61, 95, 112, 187, 188

Żywy towar (Lebende Ware) 334 



\section{Indeks osób}

Abich Hans 49

Abusch Alexander 40, 130, 192, 349

Achternbusch Herbert 343

Adamczyk-Garbowska Monika 31, 349

Adenauer Konrad 54, 55, 172, 177, 178, $181,183,214,216,218,221,222,224$, $228,245,283,296,297,314,335,352$, 356, 357

Adlon Percy 33, 340, 363

Adorno Theodor 301-303, 321, 335, 349

Agde Günther 29, 50, 141, 210, 362, 366

Agethen Manfred 354

Ahbe Thomas 154, 349

Albers Hans 57

Albrecht Gerd 223, 349

Albrecht Hartmut 34, 153, 155, 164, 193, 208, 254, 349

Albrecht Henning 110, 371, 378

Allan Seán 25, 142, 186, 349, 352, 354

Alten, von Jürgen 219, 319

Andersch Alfred 211

Anderson Benedict 16, 349

Anderson Lindsay 166

Andrijewski Aleksander 102

Angermann Gerd 312

Ankersmit Frank 14, 19, 349, 367

Antel Franz 292

Apitz Bruno 203, 204, 207, 209, 381

Arendt Hannah 36, 43, 67, 108, 122, 182, 313,350

Arndt Ernst Moritz 243

Arnstam Lew 169, 170, 386

Asper Helmut 110, 350, 379

Assmann Aleida 15, 17, 18, 22, 28, 40, 41, $183,214,322,327,334,350$

Ast Michaela 93, 228, 350

Augstein Rudolf 344

Axen Hermann $\quad$ 127, 192, 350
Baader Andreas 343

Baberske Robert 134

Baer Ulrich 46, 370

Baer Volker 262, 350

Bagemühl Joachim 146, 350

Baier Jo 240, 345

Baký, von Josef 52, 57, 60, 383, 384

Balhaus Carl 147, 157, 182

Ballmann Herbert 157, 192, 385

Balthoff Alfred 89

Bamberger Peter 283

Bänsch Dieter 219, 354, 365

Bardem Juan Antonio 333

Barlach Ernst 211

Barlog Boleslaw 48, 57

Barnert Anne 24, 195, 350

Barnouw Dagmar 42, 72, 350

Barthel Manfred 225, 351

Bathrick David 51, 351

Bauer Alfred 52, 227, 351

Bauer Fritz 221, 240

Bauer Josef 286

Bausch Ulrich 47, 351

Becher Walter 225

Beck Ludwig 137, 229, 232

Becker Frank 54, 351

Becker Israel 117

Becker Jurek 209, 334, 358

Becker Wolfgang 26, 113, 351

Beheim-Schwarzbach Martin 202, 351

Behn-Grund Friedl 62

Ben-Gavriel Moshe Ya'akov 312, 351

Benedek Lásló 267, 268, 385

Benz Georg 204, 380

Benzenhöfer Udo 226, 351, 368

Bergem Wolfgang 124, 351, 354

Berger John 14, 351

Berghahn Daniela 25, 72, 131-133, 333, 351 
Berghahn Klaus 125, 362, 366

Berghahn Wilfried 224, 351

Bergmann Karl Hans 48

Bergmann Samuel 235

Bergmann Werner 201, 220, 310, 327, 341, $351,352,374$

Berman Russel A. 309, 351

Berthold Will 264

Bessen Ursula 55, 377

Beutelschmidt Thomas 165, 351

Beyer Frank 131, 132, 152, 153, 155, 156, 169-171, 180, 202, 205, 206, 208-210, $329,334,351,353,369,372,386$

Bialas Wolfgang 124, 351

Bieler Manfred 210, 371

Biermann Wolf 210, 332

Bildt Paul 105

Blank Theodor 228

Blänsdorf Agnes 327, 352

Blauert Ellen 88, 354

Bliersbach Gerhard 226, 352

Bloch Ernst 130

Blum Heiko 24, 26, 132, 352, 357, 359

Blumenberg Hans-Christoph 24, 132, 357,359

Boa Elisabeth 227, 352

Bock Hans-Michael 98, 352, 377

Böll Heinrich $\quad 215,246,279,337$

Bollinger Jörn 220, 352

Bonhoeffer Dietrich 345

Bönnen Ute 206

Borchert Ernst Wilhelm 62

Borchert Wolfgang 92, 378

Borejsza Jerzy W. 22, 371

Bornemann Fritz 92

Borsody, von Eduard 219

Bösch Frank 221, 352, 372

Bossak Jerzy 44

Böttcher Jürgen 131

Brady Martin 142, 352

Brandlmeier Thomas $48,49,52,54,55,98$, 120,352

Brandt Horst E. 143, 333

Brandt Richard 43, 44

Brandt Willy 214, 302, 335

Brasch Thomas 343

Brauerhoch Annette 51, 352

Braun Alfred 219

Braun Ewa 53, 220
Braun Harald 50, 60, 108, 297, 383

Braun Käthe 139

Braun, von Wernher 273

Brauner Artur (Atze) 34, 111, 112, 116, 117, 139, 140, 221, 238-240, 274, 277, $279,302,315,317,343,352,355$

Brecht Bertolt 96, 129, 135, 159, 197, 238, 296, 318

Bredel Willy 141

Bredow, von Wilfried 219, 322, 357, 364, 378

Breger Claudia 58, 352

Breitkopf Regina 139, 352

Briegelb Klaus 217, 352

Brink Cornelia $\quad 42,76,352$

Broszat Martin 341, 354

Brumlik Micha 207, 370

Brumm Dieter 321, 352

Bruns Claudia $\quad 45,198,367,379$

Bruyn, de Günter 333, 354

Brzóstowicz-Klajn Monika 146, 352

Buch Fritz Peter 219

Bucher Ewald 321

Buchheim Lothar-Günther 340, 352

Buchholz Gerhard 219

Buchloh Stephan 224, 352

Büchner Georg 80

Bucholz Horst 280

Buck Robert 229, 230, 352, 354, 375, 376

Bukowiecki Leon 25, 303, 352, 353

Burger Hanuš 45,353

Burghardt Kirsten 60, 120, 353

Buruma Ian 9, 353

Busch Ernst 50

Byg Barton 25, 178, 292, 329, 354, 360, 369, 373

Cap Franz 291

Capra, La Dominick 14, 366

Carow Heiner 149, 150, 332, 333, 386

Carpentier-Tanguy Xavier 29, 210, 353

Carruthers Susan 44, 46, 353

Carter Erica 233, 353

Caven Hannah $\quad 45,353$

Chamberlin Brewster 45-47, 353, 365

Chmielewski Zbigniew 158

Cilek Roman 158, 353

Clark David 256, 353

Classen Christoph 12, 317, 353 
Claudius Eduard $154,155,353$

Cooke Paul 126, 133, 250, 333, 351, 353, $362,364,374$

Cosgrove Mary 329, 357, 358

Cowie Peter 227, 353

Čuř́k Jan 159

Curtis Tony 343

Curtiz Michael 223

Czapliński Przemysław 338

Dahlke Birgit 126, 204, 353, 367, 376

Danyel Jürgen 22, 43, 123, 195, 353, 354, $357,359,366,381$

Dardan Asal 45, 198, 367, 379

Davidson John 141, 284, 362, 366, 376

Dębski Andrzej 35, 93, 158, 184, 350, 362, $376,378,381$

Delage Christian 46, 354

Delling Manfred 262, 301, 354

Deppe Hans 48

Diercs Carsten 317

Dietrich Anette 45, 198, 367, 379

Dietrich Marlena 51

Diez Fritz 145

Dillmann Claudia zob. Dillmann-Kühn Claudia

Dillmann-Kühn Claudia 112, 116, 117, 192, 238, 315-317, 347, 349, 355, 356, $358,367,373$

Dimitrow Georgi 124, 144, 148

Diner Dan 342

Dirhagen Robert 144

Distelmeyer Jan 98, 352, 377

Dobek-Ostrowska Bogusława 16, 355

Dobryden Paul 83, 355

Domańska Ewa 14, 15, 18, 338, 349, 355, $361,366,367,371,376,379$

Domansky Elisabeth 336, 355

Domröse Angelika 164

Dörfler Ferdinand 279

Douglas Lawrence 11, 46, 262, 263, 355, 371

Drache Heinz 316

Drobisch Klaus 206, 355

Dubiel Helmut $18,28,273,335,355$

Dudow Slátan 50, 53, 105-107, 131, 148, $152,177,179-181,188,238,295,329$, 384,385

Düsterberg Rolf 228,355
Duvivier Julien 83

Düwell Susanne 126, 368, 369

Dymszyc Aleksander 47, 128, 355

Eberan Barbro 39, 355

Echternkamp Jörg 215, 228, 355

Eckhardt Wolfgang 226, 351, 368

Edmonds Don 279

Egel Karl 168

Eggebrecht Axel 317

Ehlers Wilhelm 91, 356

Eisenstein Siergiej 47, 224

Eisfeld Rainer 224, 356, 358

Eisler Gerhard 192

Eisler Hans 197

Elias Norbert 313, 356

Elsaesser Thomas $23,25,26,132,223,325$, $337,346-348,356,376,379$

Endres Gerald 206

Engel Erich 81

Engel Thomas 274

Erfurth Ulrich 277, 278, 384

Erler Hans 339, 350, 356

Euchner Walter 221, 224, 314, 356

Eyck, van Peter 61

Eylau Hans Ulrich $\quad 63,155,185$

Fallada Hans $\quad 48,318,344$

Fanck Arnold 53, 233

Fassbinder Rainer Werner 132, 264, 336339

Faulstich Werner 100, 249, 357, 360, 376

Fay Jennifer $42,55,356$

Fechner Eberhard 110, 318

Fehrenbach Heide 23, 51, 356

Felmy Hansjörg 252

Ferro Marc 18, 19, 33, 356

Fest Joachim 338, 346, 356

Feuchtwanger Lion 318,344

Fiedler Werner $78,103,249,356,357$

Finke Klaus 24, 29, 54, 141, 210, 353, 354, $356,371,376,377$

Finkielkraut Alain 336, 357

Fischer Adolf 48

Fischer Torben 22, 338, 366

Fisher Jaimey 56, 104, 270, 357, 358

Fiuk Ewa 20, 27, 345, 357

Fleszarowa-Muskat Stanisława 181

Fohrmann Jürgen 125, 362, 366 
Ford Aleksander 44, 198

Foucault Michel 17, 357

Fox Thomas 89, 328, 357

Frank Leonhard 193, 194

Fredersdorf Herbert $\quad 60,117,384$

Freeman Michael $\quad 46,354,366$

Frei Norbert 16, 22, 28, 39, 42, 123, 183, $217,218,240,245,281,289,290,293$, $313,357,377,378,380$

Freiherr von Gersdorff Rudolf 238

Freund Karl 134, 293

Friedländer Saul 341, 347, 357, 371

Fritsch Wilhelm (Willy) 58

Fritsch Claudia 73

Fritsche Christiane 12, 317, 357

Fritz Ulrich 205, 359, 376

Fritzsche Peter 329, 357

Froelich Carl 219

Fröhlich Claudia $\quad 302,380$

Fröhlich Gustav 57

Frohriep Jürgen 199

Frölich Margrit $\quad 26,346,353,378$

Fuchs Anne 329, 357, 358

Gallwitz Tim 91, 107, 109-111, 121, 358

Gebirtig Mordechaj 198

Gecht Filip 172, 173, 380

Gehler Fred 34, 153, 208, 358

Geisler Günther 202, 358

Geisler Michael E. 317, 358

Gemünden Gerd 51, 358

Georgi Kurt 204, 380

Geschonneck Erwin 139, 155, 165, 208

Gibas Monika 172, 358

Gilbert Gustave 338, 358

Giller Walter 296

Gimpel Erich 274

Giordano Ralph 214, 318, 344, 358

Glaser Hermann 215, 323, 353, 358

Glass Peter 358

Globke Hans 177, 218

Głowiński Michał 129, 358

Gnamm Hans J. 340

Goebbels Joseph $\quad 48,55,88,108,145,177$, $225,239,240,274,309,376$

Goes Albrecht 254, 358

Goldstein Cora Sol 42, 46, 358

Goldstein Marek 60, 117, 384

Golling Alexander 309
Golowanow Anatolij 169, 170, 386

Gomułka Władysław 130

Göring Hermann 147, 233, 234, 308

Gorrish Walter 155, 359

Goschler Constantin 221, 352, 372

Gottschalk Hans 339

Gottschalk Joachim $\quad 88,92,311$

Götz George 300

Gräf Roland 333, 334

Grafe Frieda 34

Graser Jörg 344

Grass Günter 63, 217, 246, 337, 359

Greffrath Bettina 23, 56, 81, 88, 91, 120, 225, 359

Gregor Erika 293

Gregor Manfred 268, 359

Gregor Ulrich $132,180,200,202,209,264$, 299, 359

Greiser Katrin 205, 359

Greven Michael 154, 317, 354, 360

Gries Rainer 172, 358, 377

Grindel Gerhard 220

Grindon Leger 11, 359

Grisko Michael 133, 359

Groehler Olaf 195, 359

Groll Günter 34, 57, 249, 255, 359

Gröschl Jutta 43, 359

Gross Bernhard 94, 109, 354, 359

Grosz Georg 69

Grotewohl Otto 143

Grunenberg Antonia 123, 359

Grzelecki Stanisław 176, 359

Günther Egon 131, 193

Gütt Jürgen 318

Gwóźdź Andrzej $\quad$ 23, 25, 27, 35, 54, 55, 87, 93, 100, 101, 112, 120, 121, 158, 184, $221,226,228,326,338,350,356,359$, $362,363,369,376,378,381$

Haase Jürgen 227, 381

Habermas Jürgen 342

Habib Ralph 277, 386

Hage Volker 215, 359

Hagelstange Rudolf 280

Hahn Brigitte 44, 46, 359

Hake Sabine 23, 140, 141, 164, 172, 178, 224, 284, 292, 294, 295, 329, 359, 360, $362,366,376$

Halbachs Maurice $\quad 14,360$ 
Hanisch Michael 54, 360

Hansen Rolf 226

Hantke Steffen 291, 353, 360

Harich Wolfgang 130

Harlan Thomas 343

Harlan Veit 53, 61, 91, 95, 187, 188, 220, 266, 278, 343, 365, 369, 370, 381, 384

Harnack Arvid 137

Harnack Falk 133, 136, 137, 139, 237, 239 244, 254-256, 291, 318, 329, 362, 367, 384,385

Hartenian Larry $\quad 47,360$

Hartewig Karin 154, 360

Hartl Karl 91

Hartung Hugo 303

Harych Theo 182, 360

Hasler Joachim 176, 182, 192, 329, 332, 386,387

Hasse Hannjo 159

Hasse Otto E. 232, 283

Hathaway Henry 231

Hauser Johannes 49, 360

Hauser Kaspar 214, 368

Häußler Johannes 219

Hay Gerhard 55, 349

Heydrich Reinhard 158, 232, 364

Heimann Thomas 25, 44, 45, 102, 137139, 141, 154, 161, 169, 170, 172, 198, 203, 207-209, 360

Heide Werner 212

Heinze Dieter 132, 364

Heitzeler Wolfgang 344

Held Martin 294

Hellberg Martin 154, 176, 384, 385

Hellwig Joachim 176

Helman Alicja 61, 292, 350, 373

Hembus Joe 322, 360

Hendrykowski Marek 19,360

Herf Jeffrey 22, 40, 125, 328, 360

Hermand Jost 246, 360, 367

Hermann Hugo 63, 120, 166

Hermlin Stephan 41, 360

Herrendoerfer Christian 338

Herzog Werner 336

Heukenkamp Ursula 317, 360, 374

Heuss Theodor 230

Heym Stephan 210

Heynowski Walter 177, 375

Hickethier Knut 249, 289, 317, 360

Hildebrandt Klaus 342
Hillgruber Andreas 342, 360

Hillmann Jörg 215, 355, 365

Hilmes Carola 336, 361

Hindenburg, von Paul 144

Hipkins Danielle 233, 353, 378

Hippler Fritz 52

Hirsch Marianne 14, 361

Hissen Alexandra 145, 361

Hitchcock Alfred 45, 224

Hitler Adolf $\quad 5,23,26,37,39,41,51,53-55$, 59, 66, 84, 95, 96, 100, 102, 110, 136, 138, 141, 144-146, 172-174, 177, 184, 197, 215, 221, 227-233, 239-241, 244, $247,257,265,270,275,277,279,284$, 293, 306, 317, 320, 322, 331, 338-343, $345-348,352,355,356,361-363,369$, $372,378,385$

Hobsbawm Eric 124, 204, 361

Hobsch Manfred 226, 361

Hockerts Hans Günter 126, 361

Hochbaum Werner 48

Hoenisch Michael 47, 377

Hoffman Jerzy 343

Hoffmann Hilmar $\quad 54,223,352,381$

Hoffmann Kurt 12, 30, 57, 303, 305, 311, $312,328,376,385,387$

Hofmann Heinz 169,361

Hofmann Nico 344

Högerle Daniela $\quad 42,361$

Hohenemser Herbert $\quad 249,361$

Hohoff Margarete 280

Holzer Horst $\quad 320,361$

Honecker Erich 210, 332, 340, 361

Hoorn, van Maike 98, 377

Horak Jan-Christopher 81, 361

Höss Rudolf 73, 218, 338, 361

Hubalek Claus 317, 339

Hübner Achim 165, 212

Huillet Danièle 30, 336

Humberg Michael 223, 361

Hurdalek Georg 295, 296

Huyssen Andreas 215, 361

Iggers Georg 15, 361

Ilgner Max 174

Illger Daniel 109, 354, 359

Jabłkowska Joanna 22, 41, 214, 342, 349, $350,359-362,365,370$

Jackiewicz Aleksander 184, 355, 362 
Jacobsen Wolfgang 23, 52, 132, 201, 358, 361,363

Jaeger Friedrich 22, 373

Jakubowska Wanda 44, 181, 386

Janka Walter 130

Jarausch Konrad 125, 197, 336, 354, 362, 377

Jaskólska Aleksandra 184, 362

Jaspers Karl 41, 70, 321, 360, 362

Jeremias Brigitte 209, 362

Jockheck Lars 184-186, 362

John Herbert 320, 362

Joho Wolfgang 135, 152, 201, 362

Jordan Günter 24, 48, 63, 69, 91, 104, 137, 362,369

Josselson Michael 46, 362

Jugert Rudolf $58,276,384,387$

Jung Thomas 125, 194, 362

Jung Uli 48, 352, 354

Jung-Alsen Kurt 156, 160, 166, 385, 386

Jungeblodt Werner 247, 362

Jürgen Roland 314, 386

Kaes Anton 23, 26, 348, 358, 362

Kadelbach Philipp 346

Kampe Norbert 214, 366, 367

Kämpfe Klaus 47, 377

Kann Michael 333

Kannapin Detlef $24,69,135,137,139,141$, $143,162,164,172,175,211,249,329$, 331,362

Kanzog Klaus 269, 270, 354, 362

Kapczynski Jennifer 250, 284, 285, 323, 362

Kappelhoff Hermann 109, 354, 359

Kappelt Olaf 177, 363

Käppner Joachim 124, 192, 363

Kapral Elżbieta 209, 334, 366

Karge Manfred 163, 164

Karmen Roman 46

Kaszyński Stefan H. 22, 371

Käutner Helmut 10, 30, 52, 55, 60, 83-87, 178, 233-236, 247, 295, 297, 298, 309, $323,351,356,363,381,383,385$

Kawalerowicz Jerzy 334

Keisch Henryk 178

Kelson John F. 54, 363

Kershaw Ian 229, 363, 372

Kersten Heinz 24, 67, 70, 225, 290, 291, 363
Kesselring Albert 180, 363

Kessler Mario 125, 192, 363

Kettenacker Lothar 341, 356, 374

Kiesinger Kurt 218

Kirschnick Sylke 176, 363

Kirst Hans Hellmut 246, 248, 249, 256, $262,279,363$

Kirsten Ralf 131, 211, 333, 387

Klaren Georg C. 81, 184-186, 361, 362, 372,384

Klejsa Konrad 33, 34, 181, 237, 262, 340, $345,363,371,375$

Klemens Gabriele $\quad 42,54,363$

Klering Hans 48, 363

Kleßmann Christoph 22, 123, 354, 363, 368

Klingler Werner $\quad 274,279,385,386$

Kluge Alexander 30, 191, 336, 339, 347, 356

Klüger Ruth 207, 363

Kluszczyński Ryszard W. 262, 345, 363, 371

Kłys Tomasz 7, 57, 62, 95, 233, 262, 266, $345,363,371$

Knaap, van der Ewout 198, 314, 377

Kniep Jürgen 223, 363

Knietzsch Horst 34, 136, 153, 155, 156, $164,193,208,298,363,364$

Knigge Volkhard 123, 204, 364, 377, 380

Knoch Habbo $\quad 42,43,364$

Knop Rosemarie 91, 364

Kober Anne 172, 364

Koch Franz 118

Koch Gertrud 196, 364

Koch Horst 147

Koch Lars 55, 287, 364, 365, 369

Kochan Detlef C. 161, 367, 368

Kochenrath Hans-Peter 219, 364

Kocka Jürgen 125, 361, 363

Koebner Thomas 67, 361, 369

Koegel Gert 259, 364

Koenen Gerd 335, 364

Kogon Eugen 41, 42, 203, 289, 290, 302, 364

Kohl Helmut $\quad 28,340,341$

Kohl Paul 219

Kohler Ottomar 283

Kohlhaas Wolfgang 158, 364

Kohlstruck Michael 22, 302, 364, 380

Kölsch Julia 336, 364

Konieczny Andrzej 158, 364 
König Helmut $\quad 28,216,364$

König Ingelore $133,379,381$

Konigsberg Ira 119,364

Konsalik Heinz 246, 264, 283

Köppe Barbara 132, 364

Köppen Manuel 203, 254, 351, 364, 381

Körber Hilde 112

Korte Helmut 100, 249, 357, 360, 376

Korte Karl-Rudolf $\quad 22,354,373$

Kortner Fritz 53, 110, 350, 358

Korzeniewski Bartosz 16, 27, 234, 364, 372

Kosińska-Krippner Beata 226, 365

Kotulla Theodor 261, 262, 272, 298, 322, 338, 365

Kötzing Andreas 92, 224, 365

Kracauer Siegfried 91, 159, 227, 365

Kramer Sven 113, 289, 355, 360, 365

Kranz Erhard 24, 365

Krasuski Krzysztof 129, 365

Krauch Carl 174

Kraushaar Wolfgang $188,220,365$

Kreimeier Klaus 24, 47, 52, 219, 248, 365

Krien Werner 48, 112

Krockow, von Christian Graf 171, 217

Kröhnke Erich 318

Kruczkowski Leon 184-186, 370, 375

Krüger Answald 318

Krüger Horst 313, 365

Krupp von Bohlen und Halbach Alfried 181, 222

Kruscharska Sascha 199

Krzemiński Adam 140, 365

Kuby Erich 259, 365

Kugelmann Cilly 117, 365

Kuhlbrodt Dietrich 26, 224, 252, 329, 365

Kühn Günther 206, 365

Kühn Reinhard 342

Kühn Siegfried 333

Kühnl Reinhard 342

Kühne Thomas 228, 355, 365, 378

Külbe Georg 117

Kumpfmüller Michael 166, 366

Kunert Joachim 131, 161-165, 187, 190, $191,329,332,333,386,387$

Kupczyńska Kalina 209, 334, 361, 366, 372

Kurowski Ulrich 49, 354, 371

Kurz Iwona 14, 18, 350, 356, 366, 372, 379

Kurz Rudi 333

Kwiatkowska Paulina 14, 350, 366
Laak, van Dirk 336, 377

Lahola Leopold 282, 386

Lammers Karl Christian 334, 355, 375

Lamprecht Gerhard 48, 60, 103-105, 383

Lancaster Burt 344

Landsberg Alison 14, 366

Landy Marcia 19, 372, 376

Lang Fritz $62,64,107,115,152,238,239$, 290, 363

Langenhahn Sandra 141, 366

Langermann Martina $\quad$ 126, 204, 353, 367, 376

Langhoff Wolfgang 207, 208

Lanzmann Claude 347

Ledig Gerd 246

Leiser Erwin 221, 222, 255, 294, 356, 366

Lemke Michael 172, 366

Lemmons Russel 141, 366

Lenhard Andreas 98, 302, 353, 366, 377

Lennig Walter 71, 103, 366

Leo Annette 124, 378

Lepsius Rainer 22, 326, 327, 366

Lessing Gotthold 186

Leszczyński Władysław 156, 366

Levkov Ilya 341

Levy Daniel 343

Lewandowski Rainer 228, 355

Liebe Ulrich 88,366

Liebeneiner Wolfgang 52, 60, 62, 91-95, $219,226,261,265,266,282,303,369$, $376,384,385$

Liebmann Stewart $\quad 44,121,366,367$

Liliental Peter 343

Limburg Guido 252, 367

Litvak Anatole 231

Loewy Hanno 313, 357, 361

Loewy Ronny 192, 238, 242, 316, 347, 349, 355-358, 367, 373

Lommel Ulli 338

Lorenz Chris 19, 367

Lorenz Matthias N. 22, 338, 366

Lorre Peter 30, 53, 290, 384

Löser Claus 137, 198, 200, 350, 362, 367

Lotar Peter 318

Loth Wilfried 217, 378

Lothar Ralph 318

Lübbe Hermann 214, 367

Lübbe, van der Marinus 148

Lubelski Tadeusz 25, 359, 363

Lüddecke Werner Jörg 137, 238, 243, 301, 367 
Luderer Wolfgang 334

Luft Friedrich 63, 104, 209, 256, 298, 367

Lukács György 128, 129, 369

Lys Günther 317, 318

Łapiński Zdzisław 129, 146, 352, 365, 375

Maetzig Kurt 30, 48, 50, 53, 60, 87-89, 91, 102, 103, 131, 140-145, 147, 163, 167, 172-175, 178, 186, 197, 210, 311, $333,349,352,356,366,367,371,377$, 383-385

Mahlein Leonhard 204, 380

Maier Charles 15, 367

Maisch Herbert 48

Majewski Ryszard 158, 353

Majewski Tomasz 7, 14, 45, 51, 338, 342, $343,366,367,370$

Mann Golo 215, 367

Mann Heinrich (Henryk) 51, 133-135, 367

Manstein, von Erich 229

Marczinkowsky Günter 152

Margalit Gilad 126, 367

Mariske Hans-Arthur 252, 367, 381

Markus Winnie 108, 112

Martay Oscar 227

Martin Hardy 287, 345

Marxen Klaus 177, 361

Mason James 231

Matray Maria 318

May Joe 57, 277, 386

May Paul 10, 248, 276, 384, 385

Mayer-Ebeling Alf 223, 349

Mayniel Juliette 296

Mazur Mariusz 34, 238, 361, 363

Mąka-Malatyńska Katarzyna 197, 368

Męclewski Edmund 217, 368

Meer, ter Fritz 175

Mehnert Elke 126, 366, 368

Meier Bernhard 161, 368

Meier Gustav 220, 368

Meinecke Friedrich 40, 326, 368

Meisel Kurt 266, 386

Mende Erich 245

Merkel Angela 344

Merker Paul 125

Merle Robert 338, 368

Mertens Lothar 192

Merz Irena 25, 184, 368

Meuschel Sigrid 123, 171, 368
Meyer Andreas 49, 354, 371

Meyer Rolf 57

Michałek Bolesław 11, 177, 368

Milke Felicitas 267, 368

Miller-Klejsa Anna 20, 368

Minetti Bernhard 143

Minetti Hans-Peter 143

Minkin Adolf 195

Misselwitz Hans 123, 354, 368

Misterek Susanne 184, 368

Mitrović Zika 316, 329

Mitscherlich Alexander 213, 214, 323, 368

Moeller Robert G. 94, 215, 251, 261, 267, $282,368,369$

Moholy-Nagy László 159

Möller Martin 55, 369

Möller Robert 257

Möller Sabine 379

Möller Thomas 55, 107

Moltke, von Johannes 67,369

Mommsen Hans 342

Mondi Bruno 95

Monheath Peter 142, 356, 380

Monk Egon 317, 318, 321, 344, 369

Morawski Stefan 128, 369

Morgenthau Henry 37

Moshe Yael Ben 145, 369

Mückenberger Christiane 24, 47, 48, 63, $69,91,104,210,369,371$

Müller Dietmar 92, 365

Müller Erika 116, 278, 369

Müller Hans 60, 82, 383

Müller Hermann 86, 135, 146, 369

Müller Ingo 224, 356, 358

Müller Jan-Werner 125, 360, 368

Müller Jürgen 338, 369

Müller Renate 310

Müller Wolfgang 295, 305

Müller-Stahl Armin 208

Müncheberg Hans 208, 369

Munk Andrzej 198

Müntze Ingeborg 321, 369

Murray Bruce A. 317, 347, 356-358

Müting Horst 55, 369

Nágy Imre 129

Naujocks Alfred 158, 160, 353

Naumann Erich-Peter 229, 369

Naumann Klaus 215, 246, 365, 369

Neumann Günter 58 
Neumann Paul 170

Neumann Thomas W. 215, 369

Neuss Wolfgang 295, 305, 306, 308

Nieden, zur Susanne 203, 381

Niehoff Karena $\quad 34,240,272,275,298,369,370$

Niethammer Lutz 38, 206, 370

Nijakowski Lech 16

Niven Bill 93, 126, 203, 204, 207, 257, 262, $353,358,369,370$

Noack Frank 188, 220, 370

Noelle Elisabeth 229, 310, 362, 369

Noelte Rudolf 92

Noll Dieter $161,164,349,370,380$

Nolte Ernst 342,370

Nora Pierre $14,18,370$

Norden Albert $172,173,177,192,293,370$

Nosseck Max 302, 385

Nussgruber Rudolph 240

Oberländer Teodor 177, 218

Ociepka Beata 16, 355

Ode Erik 266, 385

Oettingen, von Hans 249

Olick Jeffrey 39, 370

Ophüls Marcel 337, 338, 367

Orbanz Eva 50, 61, 67, 74, 96, 101, 137, 224, 225, 275, 292, 294, 296, 301, 302, $363,374,375,380$

Osten Walter 160, 370

Osterland Martin 247, 370

Osterloh Edo 212

Ostrowska Barbara 16, 39, 217, 240, 293, 357, 378

Ostrowski Nikołaj 146

Ott Wolfgang 252, 370

Overesch Manfred 43, 204, 370

Pabst Georg Wilhelm 10, 121, 152, 195, 237, 239-241, 244, 292, 385

Paczkowski Andrzej 15, 370

Padover Saul 37, 370

Palfreyman Rachel 227, 352

Panofsky Walter 92, 108, 371

Panzer Wolfgang 268, 345

Paryla Karl 155, 385

Patalas Enno 34, 87, 252, 272, 275, 295, $321,322,371$

Paul Gerhard 327, 355, 371

Paul Heinz 219, 233, 276

Paul Wolfgang 320, 371
Paulsen Arno 62, 66

Petelska Ewa 165

Petelski Czesław 165

Peters Werner 134, 143, 316

Petersen Wolfgang 253, 254, 340

Petzold Konrad 192, 194, 386

Pewas Peter 48, 49, 53, 354, 371

Pfeifer Jochen 246, 371

Pfeiffer Hans 281, 371

Pferdmenges Robert 181

Pflaum Hans Günther 24, 357

Pflügl Helmut 24, 26, 351, 354

Philipp Harald 264, 274, 275, 386

Pięciak Wojciech 204, 344, 371, 377

Pieck Wilhlem 130, 143

Pieczka Franciszek 334

Pieńkowski Marcin 45, 351, 367

Pietsch Jürgen Maria 204, 364

Pike David 42, 371

Pinkert Anke 25, 68, 81, 99, 104-107, 162, $167,189,326,371$

Pitera Zbigniew 127, 371

Pitrus Andrzej 61, 263, 292, 350, 371, 373

Plain Gill 233, 353, 378

Plater Edward M. 309, 371

Pleyer Peter 23, 52, 54, 371

Pohl Artur 93

Pohland Hansjürgen 337

Pommer Erich 51, 52, 266, 267, 361, 368

Popper Karl 347

Poss Ingrid 61, 138, 364, 375

Prager Willy 89

Preiss Wolfgang 237

Priemel Kim 46, 372, 379

Prinzler Hans Helmut 23, 24, 61, 74, 164, 224, 225, 275, 292, 294, 296, 301, 302, $357,358,363,371,375,380$

Pronin Wassili 141

Prümm Karl 318, 371

Pudowkin Wsiewołod 146, 372

Pütz Karl-Heinz $\quad 47,377$

Rabenalt Arthur Maria 108, 176, 219, 266, 385

Rabinbach Anson 39, 372

Radványi, von Géza 274, 283, 284, 362, 385

Rambaldo Hartmut 55, 349

Rappaport Herbert 195

Rasch William 51, 94, 352, 358, 369 
Rathenau Walther 232, 249

Reagan Ronald 341

Reichel Peter 22, 25, 26, 29, 113, 202, 232, $237,242,250,270,273,285,354,365$, 372

Reif-Spirek Peter 124, 378

Reimer Carol J. 26, 372

Reimer Robert C. 26, 372

Reinecker Herbert $\quad 220,252,267,274,276$, 372

Reinhardt Gottfried 311, 386

Reinl Harald $\quad$ 253, 254, 266, 281, 340, 385

Reisch Günter 142, 168, 333

Reitz Edgar 336, 339, 343

Rejzman Julij 95

Remarque Erich Maria 11, 203, 215, 262, 264,372

Remer Otto 239, 240

Renk Aune 132, 364

Rentschler Eric 81, 309, 351, 358, 361

Resnais Alain 197, 198, 294, 314

Richter Erika 25, 131, 137, 208, 211, 328, $350,362,372,374$

Richter Franz 178

Richter Rolf 24, 354

Richter Walter 112

Ricoeur Paul 14, 344, 372

Riefenstahl Leni $53,54,100,118,139,221$, $222,233,350,372,377$

Riess Curt 117, 281, 372

Rittau Günther 57, 60, 62

Ritter Gerhard $\quad 40,372$

Ritter Karl 219, 265

Robnik Drehli 237, 239, 243, 372

Rocha Peter 204

Romm Michaił 155

Rommel Erwin 231, 247

Rommel Manfred 231

Roos Hans-Dieter 271, 298, 372

Roosevelt Franklin Delano 37

Roschlau Johannes 91, 358, 359, 361

Rosenfeld Alvin 336, 355, 376

Rosenstone Robert 18, 19, 372

Rosi Francesco 301

Roß Heiner 44, 355, 366

Rossellini Roberto 10, 30, 50, 56, 104, 105, 244,384

Rößler Fritz 178

Rößner Hans 313

Rost Cornelius (pseud.) 286
Rothemund Marc 345

Rouffio Jacques 343

Rücker Günter 158, 160, 333, 373

Rühmann Heinz 226, 309

Rülicke-Weiler Käthe 139, 373

Rupper Martn 63, 295, 373

Rüsen Jörn 22, 28, 214, 373

Rusinek Bernd A. 217, 378

Ruttmann Walter 112

Rybkowski Jan 127

Ryszka Franciszek 38, 373

Sabrow Martin 138, 154, 161, 228, 336, $349,350,354,358,360,377,378$

Salomon, von Ernst 217, 249, 378

Sanders-Brahms Helma 167, 337, 339

Sandford John $\quad 25,142,352,354$

Santner Eric L. 26, 347, 373

Saryusz-Wolska Magdalena 7, 15, 23, 27, 28, $43,45,46,52,55,60-62,67,69,70,73$, 76, 78, 87, 92, 99, 209, 214, 247, 269, $292,325,327,334,337,350,361,366$, $368,371-373,379$

Sasuly Richard 173, 373

Satjukow Silke 172, 358, 377

Sauerbruch Ferdynand 184, 226

Sauerland Karol 207, 370

Saydewitz Max 126, 373

Schaal Gary 28, 377, 380

Schapow Birgit 159, 160, 373

Schenk Ralf 24, 25, 47, 48, 127, 130-132, $135,137,138,140,142,143,149,157$, $167,169,176,201,220,328,350,353$, $354,362,369,372-374$

Schenk, von Richard 220

Scherpe Klaus 203, 351, 381

Schieber Elke 192, 196, 373

Schieder Theodore 216

Schier-Gribowski Peter 317

Schildt Axel 334, 335, 355, 373, 375

Schiller Friedrich 89,373

Schiller Lawrence 240

Schiller Willy 48

Schilling, von Klaus 28, 378

Schittly Dagmar 25, 127, 131, 142, 373

Schlabrendorff, von Fabian 230, 378

Schleif Wolfgang 58, 231, 279, 384-386

Schlesinger Hans 116, 373

Schlöndorff Volker 30, 158, 279, 336, 337, $346,361,378$ 
Schmid Harald $\quad$ 113, 195, 354, 365, 373

Schmidt Arno 215

Schmidt Hannes 158, 374

Schmidt Helmut 214, 336

Schmidt Josef 257, 374

Schmidt Matthias 126, 368, 369

Schmidt-Lenhard Uschi 98, 302, 353, 366, 377

Schmitz Helmut $\quad$ 256, 349, 380

Schneider Christian 26, 346, 353, 378

Schneider Hans 178

Schneider Helmut $\quad$ 125, 362, 366

Schneider Michael 323,374

Schneider Peter 341, 374

Schnitzler, von Georg 169, 174, 378

Schnog Karl 44

Schnurre Wolfdietrich $\quad 63,359,374$

Schober Walter 54, 223, 352, 381

Schön Heinz 260, 374

Schöning Jörg 98, 352, 377

Schornstheimer Michael 246, 374

Schröder Burkhard 164, 296, 344, 374

Schroth Karl-Heinz 112

Schubbe Elimar 127, 355, 357

Schulberg Stuart 46

Schultz Sonja M. 27, 286, 374

Schumacher Kurt 245

Schwab-Felisch Hans 271, 374

Schwaen Kurt 150, 159

Schwalbe Konrad 198, 374

Schwarz Roswita 238, 374

Schweikart Hans 108

Schwill Ernst-Georg 150

Sebald Winfried G. 215, 361, 374

Seebohm Hans-Christoph 181

Segeberg Harro 261, 368

Seghers Anna 187, 332

Seidel Thomas A. 204, 364

Seim Roland 224, 374

Seitz Franz (senior) 118, 219

Sellenthin Hans-Gerd $\quad$ 252, 374

Selpin Herbert 249

Shallcross Bożena 288, 374

Shandley Robert 23, 54, 55, 63, 85, 104, 122,374

Sica, De Vittorio $\quad 275,343$

Sieber Josef 112

Siegfried Detlef 334, 355, 375

Siehlohr Ulrike 375

Siemion Wojciech 183
Siemionow Władimir 142

Silberman Marc 95, 132, 133, 250, 333, $351,353,358,362,364,374,375$

Simmel Johaness Mario 274

Simon Günther 142, 143

Simon Rainer 333

Singer Bryan 240

Sinkel Bernhard 344

Sinyard Neil $\quad 46,352,361$

Siodmak Robert $30,53,290,291,308,309$, 360, 385, 386

Sirk Douglas 11, 262-264, 371

Skierski Zenon 281, 375

Skopal Pavel 55, 375

Skotarczak Dorota 19, 375

Skrycki Radosław 23, 373

Skwara Janusz 25, 375

Słaboszowska Zofia 165, 181

Sobe Günter 164, 375

Sohre Rolf 190

Sołga Henryk 38, 289, 375

Sorge Richard 278, 369

Sorlin Pierre 11, 12, 375

Sosnowski Jerzy 278

Sowińska Iwona 25, 359, 363

Spoden Madina 152, 375

Stachówna Grażyna 181, 375

Stanisławski Krzysztof 339, 375

Staudte Wolfgang 30, 32, 47, 49, 50, 52, 60-62, 64-67, 69-77, 80, 86, 87, 94-98, 100, 101, 133, 135-138, 168, 186, 224, 225, 275, 290, 292-299, 301, 302, 309, 328-330, 353, 363, 364, 366, 367, 369, 373-375, 377, 380, 381, 383-387

Steinbach Peter 113, 229, 354, 365, 375

Steinboeck Rudolf 91

Steinhoff Hans 62

Steinmetz Rüdiger $\quad 177,375$

Steltner Ulrich 184, 375

Stephan Bernhard 333

Stern Frank 73, 110, 191, 198, 328, 376

Sternberg, von Josef 51

Stettner Peter 54, 376

Stevens George $\quad 44,46$

Stiller Alexa 46, 372, 379

Stiller Robert $\quad 252,370$

Stork Joachim 55, 349

Storz Oliver 317

Straub Jean-Marie $\quad 30,336$

Strauß Franz Josef $\quad 249,257$ 
Strauss Herbert $\quad 214,366,367$

Stürmer Michael 342

Sussex Elisabeth $\quad 45,376$

Syberberg Hans-Jürgen 338, 339, 347, 369

Syska Rafał 25, 359, 363

Szabó István 340, 343

Sznaider Natan 343

Śląska Aleksandra 184

Śliwińska Katarzyna 129, 130, 186, 376

Taterka Thomas 126, 204, 353, 367, 376

Tempel Ulrich $158,160,376$

Tessler Georg 280

Thaisy Laurence 54, 376

Thate Hilmar 168

Theuerkauf Holger 55, 376

Thiel Heinz $169,170,182,386$

Thiel Reinhold E. 301, 376

Thiele Jens 100, 376

Thiele Martina 117, 196, 204, 210, 221, $314,321,376$

Thiele Rolf 49,310

Thiem Willy H. 92, 376

Thompson J. Lee 273

Tiedemann Rolf $321,335,349,370$

Tillman Friedrich 212

Timm Angelika 125, 376

Toeplitz Jerzy 226, 376

Tomasik Wojciech 129, 146, 352, 365, 375

Tornow Ingo 303, 376

Tourjansky Viktor 108

Toyka-Seidl Christiane 230, 376

Traba Robert 15, 16, 368

Trajman Joanna $27,172,346,377$

Tremper Will 280, 281

Trenker Luis 53

Trenkner Joachim 204, 377

Trepper Leopold 137

Trösch Robert 203

Trotta, von Margarethe 336, 337

Tschesno-Hell Michael 141, 178

Tschuggnall Karoline 379

Tulpanow Siergiej 47,48

Tunnat Frank 141, 377

Turner Adrian $\quad 46,352,361$

Ucicky Gustav 219

Udet Ernst 233

Ueberschär Gerd 229, 352, 354, 375, 376
Uhlen Gisela 193

Ulbricht Walter 124, 129, 130, 142-144, $146,183,184,210,357,377$

Ulmer Edgar G. 218, 276, 387

Ulrich Helmut 208, 377

Umgelter Fritz $\quad$ 12, 286-288, 330, 364

Vatter Christoph 303, 377

Veiczi János 154, 192, 333, 385

Ventzki Werner 216

Verhoeven Michael 33, 340, 344, 363

Verhoeven Paul 83, 284, 311, 385

Verner Paul 210, 377

Viktor Herbert 314, 386

Vilsmaier Joseph 262

Visarius Karsten 26, 346, 353, 378

Vogel Barbara 110, 371

Vogel Peter 331

Vollnhaus Clemens 38, 356

Wagenstein Angel 201, 378

Wagner Friedrich A. 259, 378

Wagner Reinhard 167,378

Wagner Richard 39, 339, 355

Wallace Edgar 226, 316

Wandel Paul 47

Wander Fred 206, 378

Wangenheim, von Gustav 110, 123, 358

Warburg Aby 14, 378

Ward Elisabeth M. 202, 314, 378

Warm Hermann 112

Warmbold Nicole $\quad 205,359,376$

Waschneck Erich 143, 219

Wasserström Dunja 316

Waterstradt Berta 101

Weber Wolfgang 206, 365

Weckel Ulrike 45, 46, 62, 64, 67, 92, 98, $110,378,379$

Wedding Alex 150

Wedel Michael 23, 25, 132, 152, 178, 292, $329,354,356,360,373,376,379$

Weidauer Walter 126, 379

Weidenfeld Werner 22, 354, 373

Weidenmann Alfred 220, 232, 247, 251, 384,385

Weiland Mato 379

Weinke Annette 177, 361

Weisenborn Günther 48, 238, 240, 243, 374

Weiskopf Franz Carl 150, 379

Weiß Helmut 50, 112 
Weiß Ulrich 333

Welzer Harald $\quad$ 234, 268, 269, 379

Wende Waltraud 26, 55, 287, 318, 354, $364,365,369,371$

Wenders Wim 338, 346, 379

Wenzel Mirjam 46, 379

Werner Ruth 333

Wessel Kai 261

Westermann Bärbel 23, 248, 379

White Hayden $18,19,367,379$

Wichert Günther 123, 354, 368

Wickham Christopher J. 317, 347, 356-358

Wicki Bernhard 30, 162, 211, 237, 247, 268-272, 298, 329, 345, 357, 362, 372, 379,386

Wiedermann Jochen $\quad 305,307,386$

Wiens Paul 168

Wiganko Horst 231

Wilczyński Marek 18, 379

Wilder Billy $\quad 45,46,51,351,352,361,367$

Wilderhahn Klaus 318

Wilfried Wilms 51, 94, 352, 358, 369

Wilharm Irmgard 26, 111, 267, 379, 380

Willet Ralph 42, 380

Winkler Heinrich August 245, 341

Wirth Franz Peter 277, 339, 386

Wisbar Frank 252, 253, 256-262, 279, 294, 296, 340, 354, 357, 368, 385, 386

Wischniewski Klaus 156, 380

Witek Piotr 19, 34, 238, 361, 363, 380

Wittkowski Helmut 272, 380

Wolf Dieter 299, 380

Wolf Friedrich 50, 131, 172, 173, 195, 380

Wolf Konrad 25, 30, 132, 150, 151, 166, $167,169,190,196,198,199,201,202$, $332,356,359,361,364,367,375,379$, 385,386

Wolf Lothar 133, 379, 381

Wolf Markus 131, 132, 380

Wolf Steffen 349

Wolfenden Helen $\quad$ 256, 380
Wolff Hans 227

Wolff Meta 88

Wolffhardt Rainer 211

Wolff-Powęska Anna 22, 124, 133, 140, 166, 184, 192, 195, 213, 245, 310, 313, 380

Wolfgram Mark 310, 312, 380

Wolfrum Edgar 22, 123, 230, 380

Wóycicki Kazimierz 22, 38, 214, 218, 281, 380

Woytowicz Monika 164

Wrochem, von Oliver 154, 317, 354, 360

Wulff Hans-Jürgen $\quad 67,369$

Wurster Carl 175

Würtz Hannes 164, 380

Zaremba Łukasz $\quad$ 14, 18, 350, 366, 379

Zbonek Edwin 276, 315, 386, 387

Zehm Günter 160, 380

Zeidler-Janiszewska Anna 14, 343, 366, 367,370

Zeller Wolfgang 112

Zibaso Werner 239

Zielinski Siegfried 87, 220, 381

Ziemann Sonja 264

Zilinski Lissy 24, 208, 375, 381

Zimmermann John $\quad 215,355,365$

Zimmermann Moshe 123, 381

Zind Ludwig 294

Zinnemann Fred 51

Zuckermann Moshe 92, 191, 368, 376, 378

Zuckmayer Carl 50, 51, 187, 233, 234, 236, 295, 309, 379, 381

Zurek Rolf $219,322,357,364$

Zweig Arnold 133, 134, 136, 137, 139, 381

Zweig Stefan Jerzy $\quad 203,204,207,209,370$

Zweig Zachariasz 204, 381

Zwierzchowski Piotr 35, 129, 146, 154, 381

Żyliński Leszek 22, 41, 63, 214, 342, 349, 350, 359-362, 365, 370

Żyto Kamila $\quad 45,351,367$ 



\section{The memory of National Socialism in the German feature films, 1946-1965}

(Summary)

How did German filmmakers of the first two decades after World War II depict the recent past? Which war-related themes were most often explored in feature films and which were avoided? In what way did postwar politics influence audio-visual depictions of both authentic events and fictional narratives set in the time of Nazi Germany? These are some of the questions the author of this book is trying to answer.

In the book's introduction, apart from a discussion of the current state of research, an explanation of the volume's composition and the analytical method applied, various theoretical considerations on the relationships between cultural memory, historical politics and feature films are given. The author emphasises the fact that we should distinguish between the functionalization of historical narratives, i.e. films in which the action is based on actual, historical facts, and the historicization of fictional narratives - tales with historical backgrounds that take place in the past, without significant reference to authentic events.

The main part of the book is divided into three chapters: on the period up to 1949 (films made in occupational zones); on films produced by the German Democratic Republic until the mid-1960s (until the $11^{\text {th }}$ plenary session of the SED Central Committee in the GDR), and on the cinematic output of the Federal Republic of Germany (up to the period of so-called New German Cinema). The adopted thematic criteria mean that the focus lies on the following (in no particular order): films referring to the period of the ideological crystallisation of Nazism and its political domination in the 1930s; films about World War II, including certain very important - although relatively scant - screenplays tackling the death-camps (films about the Holocaust became the central discourse of the work of memory' in the FRG only in the late 1970s), and films about the consequences of the war, including the process of denazification (or the lack of it). The empirical basis for this book consists of the study of over one 
hundred full-length feature films and the most important reviews of their times, published in the mainstream press in both countries.

The advantage of this publication is its comparative integration of deliberations about cinema in the FRG and the GDR dealing with thematic areas such as the myth of the 'good Wehrmacht', the representation of the resistance movement, the image of 'new allies' and 'foreign enemies', national self-presentation from the point of view of denazification, and also the problem of anti-Semitism and the representation of the concentration camps. Some of the obvious differences resulting from the functioning of film cultures in both countries in the different institutional and economic contexts should not conceal the important similarities between the films made in the FRG and GDR. Instead, they should be considered in light of, for example, the attempts made in recent years to consider the cinematographic history of both countries as a mutual sphere of German culture - a sphere in which DEFA's productions are an alternative view of issues important to the FRG's society, while West Germany's cinema complements, adds to, and even comments on the discourses so characteristic of the GDR's films. 


\section{O autorze}

Konrad Klejsa jest adiunktem na Wydziale Filologicznym Uniwersytetu Łódzkiego i wykładowcą Wydziału Organizacji Sztuki Filmowej Państwowej Wyższej Szkoły Filmowej, Telewizyjnej i Teatralnej w Łodzi.

W latach 2007-2009 pracował na Uniwersytecie w Tybindze; współredagował m.in. tomy o polsko-niemieckich relacjach filmowych (Deutschland und Polen: filmische Grenzen und Nachbarschaften - wydanie niemieckie 2011; Polska i Niemcy - filmowe granice i sasiedztwa - wydanie polskie 2012) oraz niemieckojęzyczną historię kina polskiego (Der Polnische Film: von seinen Anfüngen bis zur Gegenwart, 2012). Jest współredaktorem publikacji: Kino polskie: reinterpretacje. Historia - ideologia - polityka (2008), Badanie widowni filmowej. Antologia przekładów (2014), Wokót zagadnień dystrybucji filmowej (2015).

Był stypendystą Fundacji na Rzecz Nauki Polskiej (2007), tygodnika „Polityka” (2008) i Ministra Nauki i Szkolnictwa Wyższego (2009). Jego monografię Filmowe oblicza kontestacji uhonorowano w 2009 r. Nagrodą im. Bolesława Michałka. 
Wydawnictwo Uniwersytetu Łódzkiego

90-131 Łódź, ul. Lindleya 8

www.wydawnictwo.uni.lodz.pl

e-mail: ksiegarnia@uni.lodz.pl

tel. (42) 6655863

Wydawnictwo Biblioteki Państwowej Wyższej Szkoły Filmowej, Telewizyjnej i Teatralnej

90-323 Łódź, ul. Targowa 61/63

www.filmschool.lodz.pl

wydawnictwo@filmschool.lodz.pl

ksiegarnia.filmschool.lodz.pl

tel./faks (42) 6345870 , (42) 2755870

tel. (42) 6655863 